\title{
Városkörnyéki önkormányzati
}

\section{kooperációk az agglomerációs}

\author{
térségekben
}

- PhD. értekezés -

- Konzulens: Prof. Dr. Ágh Attila -

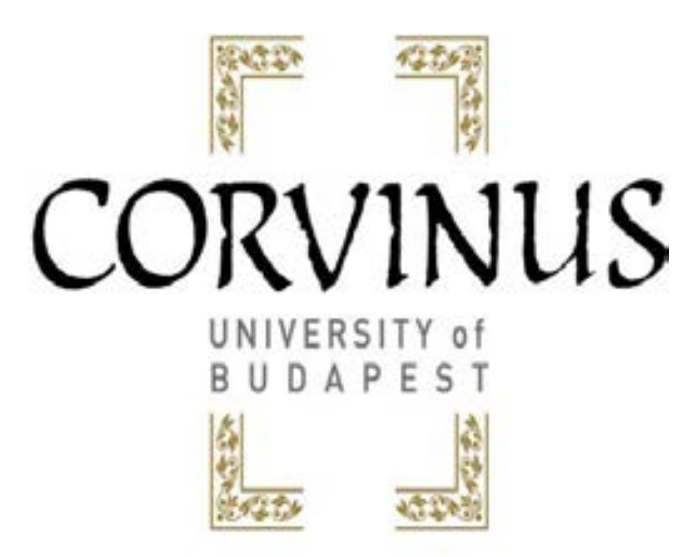

Szabó Tamás

LWBQ9Q

2015 
„A teret ma elsősorban a városhálózatok strukturálják. A földrajzi határok megvonásakor a településhálózati, természetföldrajzi adottságok mellett a területi egységek székhelyeinek mérete, megközelíthetösége alapvetö szempont. Nem a területi egységnek kell keresni a székhelyét, hanem a centrum vonzáskörzetét kell lehatárolni... Különösen kiemelendö azonban az, hogy irreális igény a térbeli folyamatok követése a közigazgatási határokkal. A határok megváltoztatása csak akkor indokolt, ha kifejezetten és hosszútávon akadályozzák a közhatalmi szervek müködését."

Szüleimnek, és kislányomnak Mollikának

${ }^{1}$ Pálné Kovács Ilona: A középszint reformjának nehézségei (in: Magyar Közigazgatás 2006/3-4. tematikus különszám A központi igazgatás és a helyi önkormányzati igazgatás 15 éve) 224. pp. 


\section{Tartalomjegyzék}

I. Előszó

II. Bevezetés és hipotézisállítás

II.1 Kettős „,konfliktuskonténer” a nagyvárosi kormányzásban 8

II.1.1 Stratégiai kormányzás és közpolitikai tervezés a nagyvárosi térségekben.................. 15

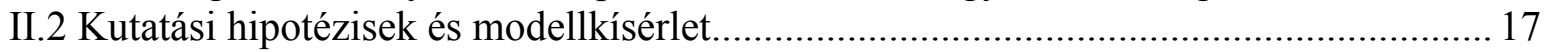

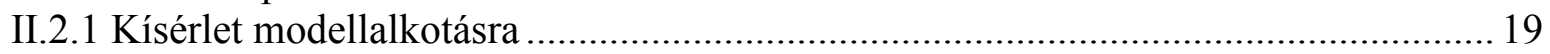

III. A modern nagyvárosi kormányzás elméleti és nemzetközi dimenziói ........................ 24

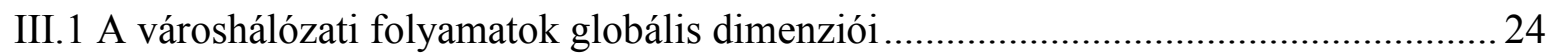

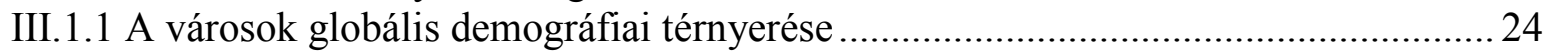

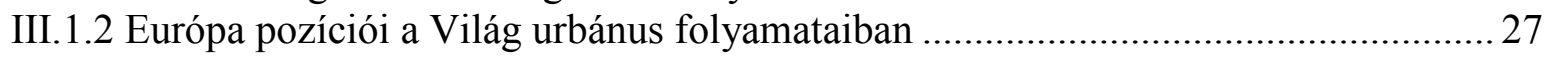

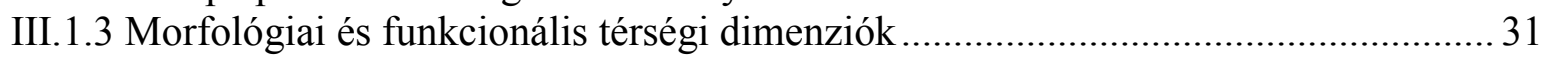

III.2 A nagyvárosi térségek, folyamatok három lehetséges megközelítése ......................... 33

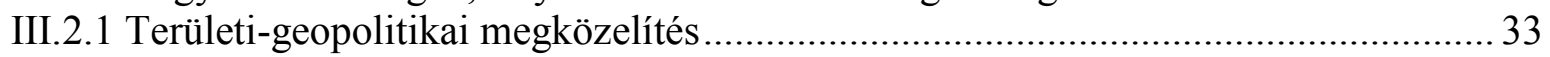

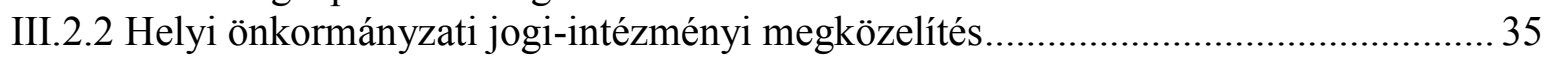

III.2.3 Regionális-térségi funkcionális (közgazdaságtani) megközelítés ............................ 36

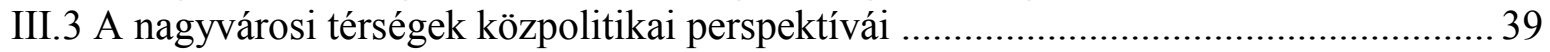

III.3.1 A nagyvárosi térségek helye a modern világgazdaság rendszerében ........................ 40

III.3.2 A fogyasztás hatása a befektetői szándékokra a nagyvárosi térségekben .................. 43

III.3.3 A kreatív gazdaság és közpolitika összefüggései a nagyvárosi térségekben ............ 45

III.4 Közpolitikai stratégia és koordináció a nagyvárosi térségekben............................... 47

III.4.1 OECD alapelvek a nagyvárosi térségi kormányzásról ........................................ 51

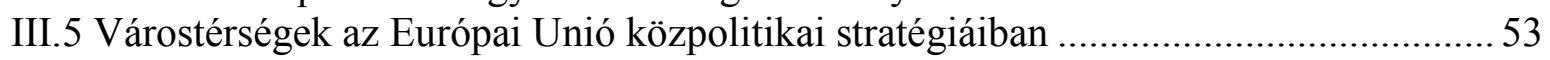

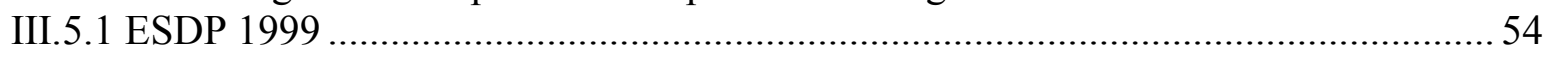

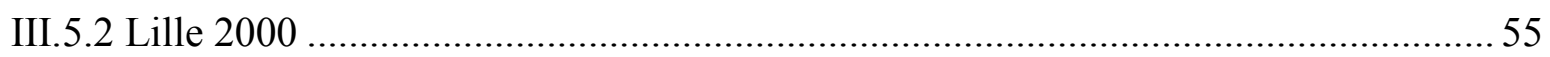

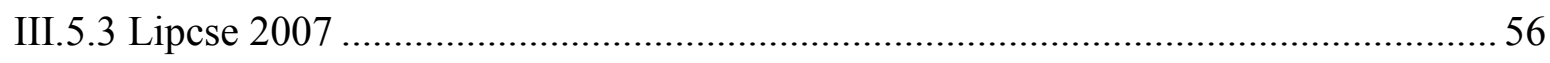

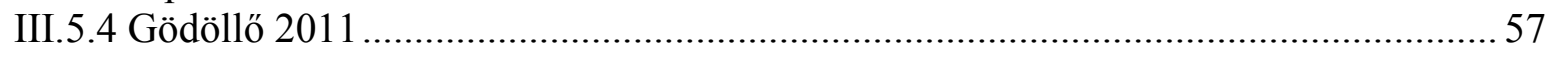

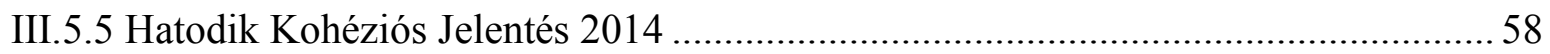

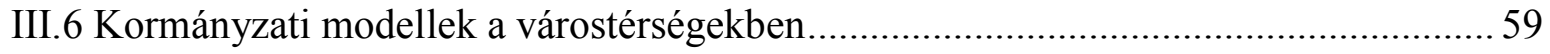

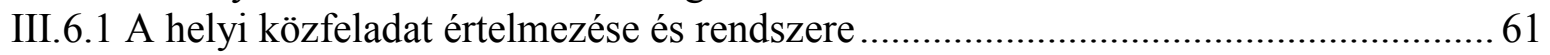

III.6.2 Közpolitikai hatékonyság a várostérségi feladatellátás során ....................................64

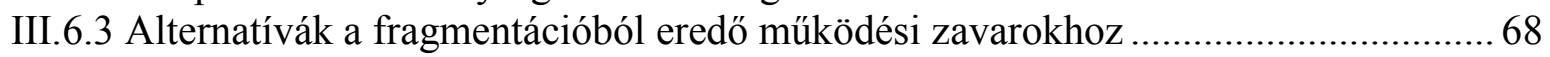

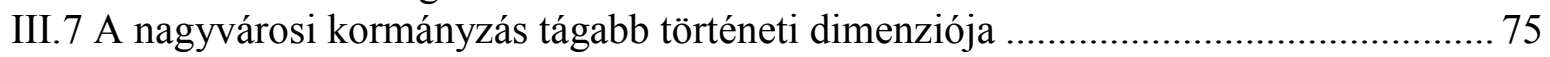

III.7.1 Racionalizálási kísérletek a XIX. századtól a XX. század közepéig......................... 76

III.7.2 Észak-amerikai tapasztalatok a XX. század közepétől napjainkig.......................... 78

III.7.3 Európai várostérségi közpolitikai folyamatok a XX. század második felétől........... 81

III.7.4 Az európai várostérségi folyamatok dinamikája - 1960-1980 évek ........................ 84

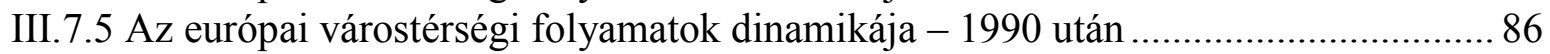

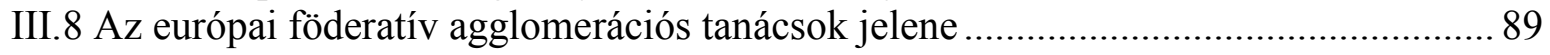

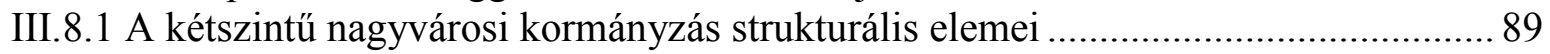

III.9 Várostérségi kapcsolatok a kelet-közép-európai régióban ........................................92

III.9.1 Várostérségi kapcsolatok és közpolitika az államszocialista időszakban .................93

III.9.2 A rendszerváltás hatása a régió várostérségi folyamataira.................................... 96 


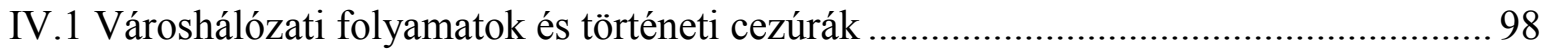

IV.1.1 Trianon hatása a magyarországi városfejlődésre ................................................ 99

IV.1.2 Az államszocializmus hatása a magyarországi városfejlődésre ........................... 100

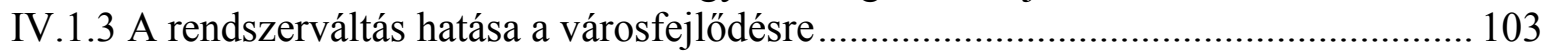

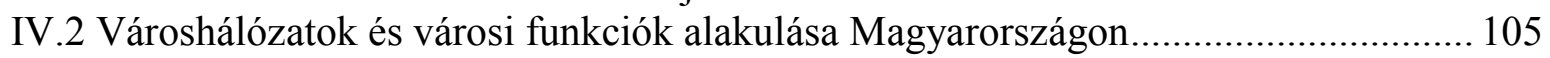

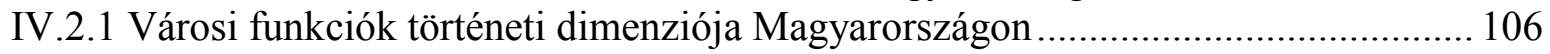

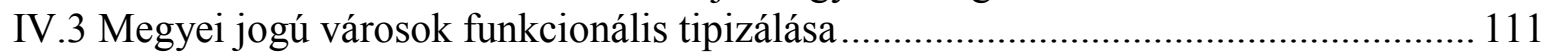

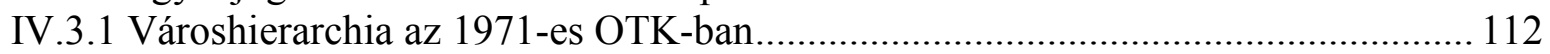

IV.3.2 Az elmúlt másfél évtized megyei jogú városi tipológiái...................................... 114

IV.3.3 Az állami területi dekoncentrált szervek telepítése a vidéki nagyvárosokba.......... 116

IV.3.4 Városhierachia a közigazgatási jogállás és a spill-over hatókör alapján ................ 119

IV.3.5 Magyarországi falvak az urbánus térségekben ................................................... 121

IV.4 A várossá nyilvánítás folyamata a rendszerváltás után........................................... 123

IV.4.1 A funkcionális városi és a közjogi városi kategória elkülönülése 1990 után .......... 123

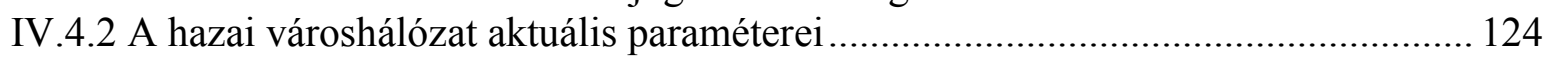

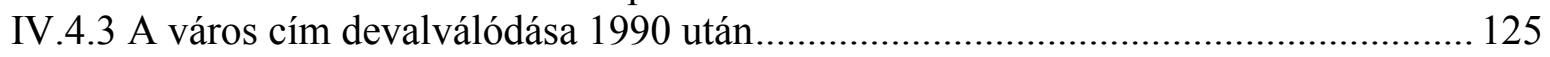

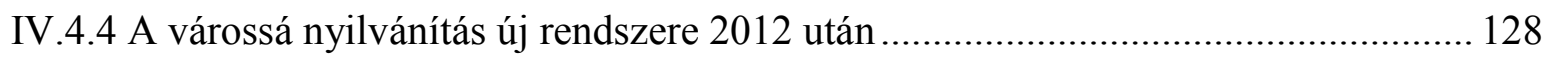

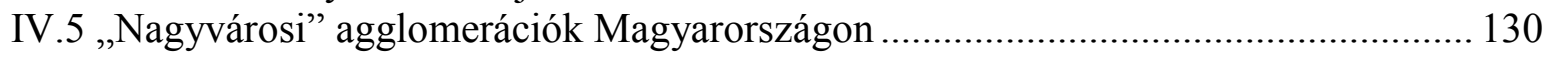

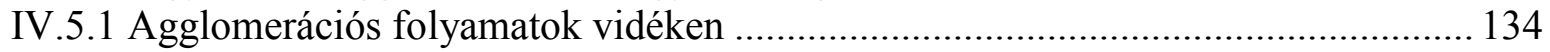

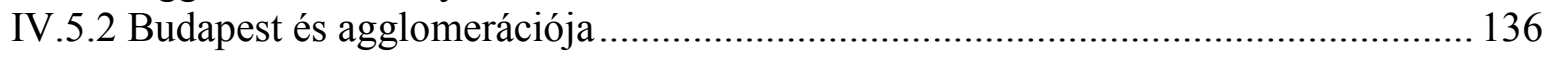

IV.5.3 A fővárosi agglomerációs „konfliktuskonténer”..................................................... 140

\section{Települési önkormányzati kapcsolatok a magyarországi nagyvárosi térségekben ... 143}

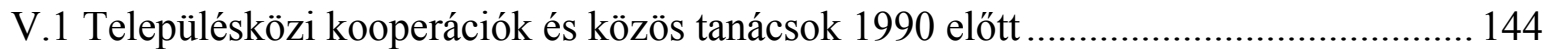

V.1.1 Városkörnyéki igazgatási rendszer a tanácsrendszer időszakában......................... 147

V.2 Polémiák a nagyvárosok szerepéről a rendszerváltás időszakában ............................. 151

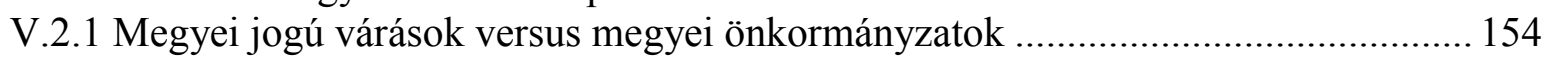

V.2.2 A megye és nagyváros viszonya az új önkormányzati rendszerben 1990 után......... 157

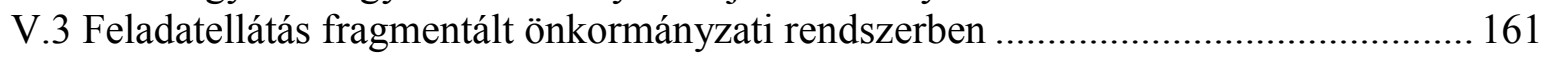

V.3.1 Az ,egy település egy önkormányzat” elv hatása az helyi feladatellátásra ............. 163

V.3.2 Kapacitás- és ellátásbeli problémák a települési önkormányzatok szintjén.............. 165

V.4 Társult és telepített közös önkormányzati feladatellátás 1990 után ........................... 169

V.4.1 Differenciált hatáskör-telepítés az önkormányzati szektorban ............................... 173

V.4.2 Komplex társult feladatellátás a többcélú kistérségi társulásoknál .......................... 176

V.4.3 A finanszírozási ösztönzők hatása a társult feladatellátásban ................................ 178

V.5 Nagyvárosi feladatellátás a városkörnyéki települések irányába .............................. 181

V.5.1 Megyei jogú városok a körjegyzőségeknél és közös intézményfenntartásnál ......... 181

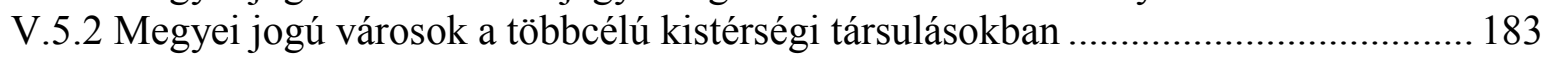

V.5.3 Megyei jogú városok közfeladat-ellátása a városkörnyéki településeken................ 184

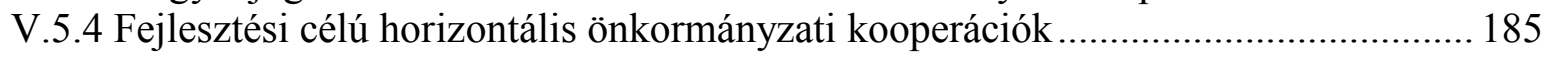

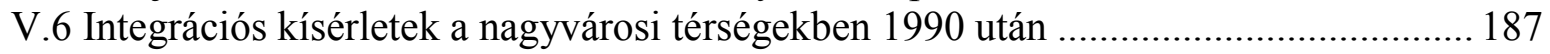

V.6.1 Fővárosi kísérletek - a Budapesti Agglomerációs Fejlesztési Tanács ...................... 188

V.7 Az új jogszabályi és intézményi környezet hatásai 2010 után .................................. 191

V.7.1 2011. évi CLXXXIX. törvény Magyarország helyi önkormányzatairól................... 193

V.7.2 Kötelező önkormányzati társulások az új önkormányzati törvényben..................... 195

V.7.3. Az önkéntes önkormányzati társulásokra vonatkozó jogszabályi változások .......... 196

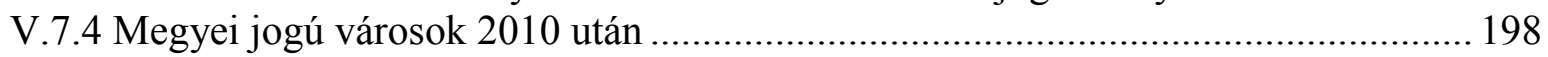


V.7.5 A megyei önkormányzatok teljes ,kiüresítése” 2010 után.......................................2200

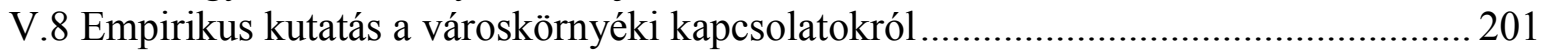

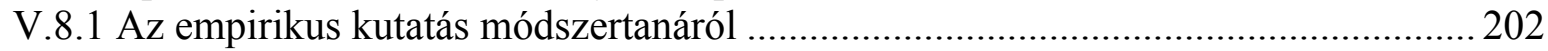

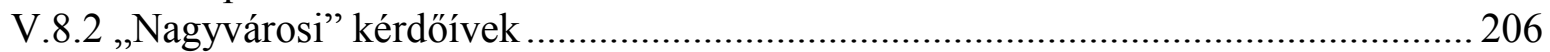

V.8.3 A városkörnyéki települési kérdőívek országos szintézise ….................................. 206

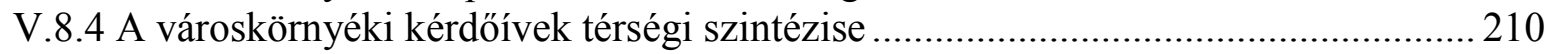

V.8.5 A városkörnyéki kárdőívek jogállás szerinti szintézise ...................................... 213

V.8.6 A városkörnyéki kapcsolatokhoz ajánlott közpolitikai eszközök értékelése ...........216

V.8.7 A szabadon kifejtős kérdéshez érkezett válaszok összesítése ................................. 221

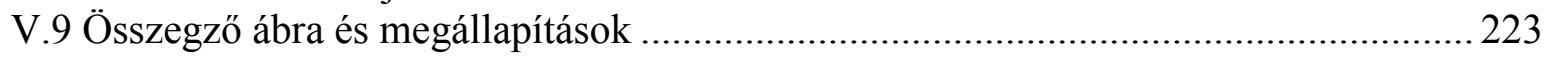

VI.Összefoglalás - hipotézisértékelés és modellkísérlet......................................................225

VI.1 A disszertációs alapdilemma parlamenti, kormányzati környezete ......................... 226

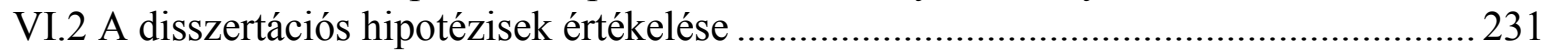

VI.2.1 Disszertációs hipotézis a nem megfelelő szabályozási környezet hatásairól.......... 231

VI.2.2 Disszertációs hipotézis az agglomerációs feladat- és intézményrendszerről .......... 234

VI.3 A modellkísérlet - struktúra és kodifikációs javaslat ............................................ 238

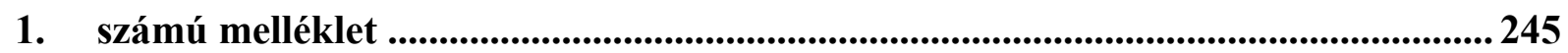

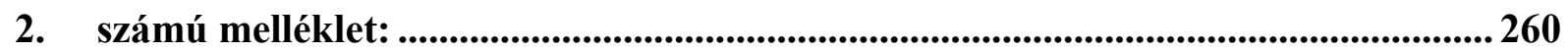

Ábrák, táblázatok jegyzéke ............................................................................................................... 267

Rövidítések jegyzéke .......................................................................................................................... 269

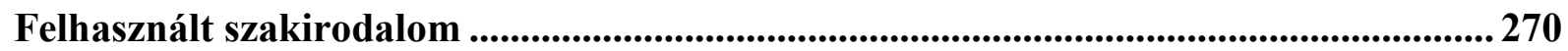




\section{Előszó}

Négy esztendőt töltöttem el a 2000-es évek második felében az Önkormányzati és Területfejlesztési Minisztériumban (2008-2010 között Önkormányzati Minisztérium), ekkor lehetőségem adódott napi szinten foglalkozni a helyi önkormányzatok müködésével. Az elmúlt fél évtizedben tovább erősödött a szakmai kötődésem az önkormányzati igazgatás- és közpolitika nemzetközi és magyarországi dimenzióihoz, különösen a hatékony és racionális feladatellátás valamint az önkormányzati autonómia közötti kapcsolatok kötötték le a figyelmem. A témában való elmélyülést segítette, hogy részt vehettem a Zsigmond Király Főiskola Nemzetközi és Politikai Tanulmányok Intézetében (ZSKF-NPTI) a politológia BA alapszak Önkormányzati szakirány kialakításában 2009-2010-ben. Ezek után nem volt kérdés számomra, hogy doktori disszertációs kutatásom a helyi önkormányzatok valamely aspektusáról fog szólni.

A nagyvárosi agglomerációs résztematika megtalálásában a természetes szakmai érdeklődés mellet egy személyes vonatkozás is szerepet játszott: jómagam Budapest agglomerációs övezetének egyik expanzív (növekvő népességü), közel másfél évtizede városi jogállású szuburbán településén élek, így napi szintű rálátásom van az agglomerációs lét előnyeire és hátrányaira, a munkahelyi ingázás valamint a nagyváros vs. agglomerációs településövezet közötti szolgáltatási spill-over jelenségére. .Az elmúlt fél évtized jelentős jogszabályiintézményi átalakításai érdemben módosították az 1990-2010 között szinte „érintetlen” önkormányzati szektort, így további szakmai motivációt jelentett, hogy a várostérségi problematikán keresztül feltérképezhessem a várostérségi közigazgatás aktuális magyarországi állapotát, benne az időnként hektikusan változó feladatrendszerekkel és intézményi dimenziókkal.

Szeretnék ezúton köszönetet mondani azon személyeknek, akik az elmúlt évek során segítségemre voltak abban, hogy teljesíteni tudjam a vállalásom és elkészüljön a politikatudományi tanulmányaimra pontot tevő doktori disszertációm. Mindenekelőtt Dr. Ágh Attila professzornak, aki vállalva a szakmai konzulens szerepét iránymutatásaival, kritikus, de elöre vivő meglátásaival, pontos tanácsaival segített az elmúlt évek folyamán. Szeretnék köszönetet mondani a disszertációhoz kapcsolódó empirikus kutatás előkészítéséhez nyújtott segítségért Dr. Zongor Gábornak a Települési Önkormányzatok Országos Szövetsége (TÖOSZ) fötitkárának, aki a témához kapcsolódva több évtizedes önkormányzati tapasztalatait is megosztotta velem, jótékonyan formálva a helyi önkormányzati szektorról 
vallott felfogásom, nézeteim. Ugyancsak az empirikus kutatás előkészítésében nyújtott támogatásért mondok köszönetet a Zsigmond Király Föiskola Társadalomtudományi Kutatóintézet (ZSKF-TTK) vezetőjének Dr. Kabai Imre matematikus-szociológus főiskolai tanárnak és ifjú kollégájának Krisztián Viktor szociológusnak, valamint Széman Györgynek a Homo Oecologcius Alapítvány kuratóriumi elnökének. Hálás vagyok továbbá az önkormányzatiság témakörében folytatott rendkívül impulzív beszélgetésekért és szakmai véleményekért Dr. Kökényesi Józsefnek valamint Tétényi Évának. Külön szeretnék köszönetet mondani Dr. Szatmári Péternek a Zsigmond Király Főiskola általános rektorhelyettesének, aki az elmúlt több mint egy évtized során folyamatos lehetőséget biztosított számomra, hogy választott szakmámhoz kapcsolódóan oktassak, szakdolgozókat instruáljak és különböző szakmai projektekben vehessek részt!

Bízom benne, hogy disszertációs értekezésem hasznos lesz a témával foglalkozó hazai szakemberek számára, és munkámmal érdemben hozzájárulhatok a helyi önkormányzati és várostérségi tematikájú közpolitikai- és közigazgatási diskurzus további alakulásához! 


\section{Bevezetés és hipotézisállítás}

\section{II.1 Kettős „konfliktuskonténer” a nagyvárosi kormányzásban}

A modern nagyvárosi kormányzás általános kereteinek valamint fontosabb attribútumainak bemutatására vállalkozott néhány évvel ezelött a Tér és Társadalom területfejlesztési szakmai folyóirat, amikor a 2008/1. számát teljes egészében a témakörnek szentelte. Kiváló hazai urbanisták, városfejlesztéssel és városi szakpolitikákkal foglalkozó szakemberek fejtették ki a nagyvárosoknak a globális illetve a nemzeti gazdasági és társadalmi terekben betöltött posztmodern szerepét és funkcióit. A szerzők a nagyvárosi kormányzás nemzetközi és európai aspektusai mellett foglalkoztak a magyarországi tapasztalatokkal - akár a kettőt összevetve, dacára annak, hogy a magyarországi városfejlődés elmúlt két-három évtizede sok szempontból sajátosan alakult, és nem feltétlenül korrelál a különböző nemzetközi (benne akár az európai) tendenciákkal. Magyarországon közel sem tapasztalható az urbánus népesség és a városi térségek olyan rohamos növekedése, mint például Ázsiában vagy az amerikai kontinensen. Fontos differencia továbbá, hogy Budapest és agglomerációja kivételével a vidéki magyar nagyvárosok (régióközpontok, megyei jogú városok) a modern városfejlődés tekintetében még jobbára csak a szuburbanizációs szakaszban tartanak, így a tartós agglomerálódás utáni dezurbanizációs és/vagy reurbanizációs tendenciák csak a föváros és környéke kapcsán mutathatóak $\mathrm{ki}^{2} \mathrm{~A}$ magyarországi „féloldalas” urbanizálódás fontos attribútuma, hogy a vidéki nagyvárosok és térségeik a demográfiai (alacsony népességszám), illetve gazdasági és társadalmi mutatók alapján egyértelműen alatta maradnak a nemzetközi urbanista szakirodalom és különböző szakmai szervezetek (ENSZ, OECD, Európai Unió) által elfogadott „,nagyvárosi térség” kategória - funkcionális nagyvárosi térség (functional urban area - FUA) - paramétereinek (erről részletesen lásd később!). Budapest és térsége a különböző szóba jöhető indikátorok alapján valódi európai nagyvárosnak számít, és mint a közép-európai régió egyik kiemelt gazdasági központja szervesen kapcsolódik a nemzetközi gazdasági (ipari, pénzügyi, kereskedelmi- és szolgáltató ágazatokban) vérkeringéshez. Ezzel szemben egyetlen hazai vidéki nagyváros sem felel meg a funkcionális nagyvárosi térség nemzetközi statisztikai

\footnotetext{
${ }^{2}$ A budapesti reurbanizációs szakaszra a szakértők még csak következtetni tudnak az elmúlt néhány év bizonyos jeleiből, mint például a belvárosi kerületek rekonstrukciós munkálatai nyomán fellendülő belvárosi ingatlanpiaci felfutásból vagy az agglomerációs övezetből a fővárosba „visszaköltöző” fiatal felnőttek számának növekedéséből.
} 
elvárásainak. Ráadásul az ország méreteihez képest (93 ezer km2) Budapest „kisugárzása” a többi településhez viszonyított roppant méretei folytán is rendkívül jelentős, indirekt módon nehezítheti a vidéki nagyvárosok ${ }^{3}$ valódi régióközponti szerepköreinek kialakulását. Ugyanakkor, ha a magyarországi népesség és a településhálózat összefüggéseit tekintjük, akkor hazánk urbanizáltsága nem marad el az európai átlagtól [Somlyódiné, 2003, 184-186. pp.; Horváth Gyula, 2007, 706. pp.].

A magyarországi városhálózat féloldalas jellegéből fakadóan a hazai szuburbanizációs szakasz - mint a modern városfejlődés második szakasza - területileg eltérő módon mutatható ki: a klasszikus agglomerációs stílusjegyek Budapest mellett direkt módon csak néhány vidéki megyei jogú város környékén jelentkeznek. A Központi Statisztikai Hivatal 2014-es Magyarország településhálózata 1. - Agglomerációk, településegyüttesek címü kiadványa a főváros mellett csak Győr, Miskolc és Pécs térsége kapcsán beszél kifejezett agglomerációs folyamatokról. Eger, Szombathely és Zalaegerszeg megyei jogú városok esetében a KSH kiadvány az ún. agglomerálódó térségek megnevezést használja. További 15 megyei jogú várost és környékét nagyvárosi településegyüttesként definiálja a statisztikai hivatal [KSH, 2014, 5. pp.]. ${ }^{4}$ A városkutatáshoz használt nemzetközi és Európai uniós sztenderdek, a különböző nemzetközi felmérések, kutatások a nagyvárosi agglomerációs térségekre az ún. funkcionális városi térség (FUA) kategóriát alkalmazzák. Ezt az OECD Területfejlesztési Bizottsága és az Európai Bizottság Regionális Főigazgatósága (EC-DG Regio) illetve az EUROSTAT fejlesztette ki a nagyváros térségi folyamatok megértéséhez, leírásához. A funkcionális városi térség alapvető indikátora a legalább 500.000 térségi (város és környéke) lakosságszám. Ez alapján az OECD 275 önálló funkcionális városi térséget azonosított az szervezetet alkotó tagországok területén [OECD, 2013; OECD 2014a; OECD2014b].

\section{A FUA térségek 4 meghatározó kvantitatív paramétere:}

1. A funkcionális városi térség kategóriába meghatározott térségi népsürüség felett lehet bekerülni, amely földrajzilag az alábbiak szerint került meghatározásra:

- Kanada, Egyesült Államok: nagyobb vagy egyenlö, mint 1000 lakos/km2

\footnotetext{
3 A hazai urbanisták és közigazgatási szakértők a nagyváros kategóriát általában 100.000 városi lakostól számítják.

${ }^{4}$ Ennek ellenére a hazai nagyvárosok (Budapest és a népesebb megyei jogú városok) környékén lezajló szuburbán folyamatok kapcsán a szakértők és szakirodalmi müvek sokszor beszélnek általában agglomerációról, dacára a szuburbanizációs szakasz terén egyébként kimutatható akár lényeges különbségeknek. Csapó Tamás: Vidéki nagyvárosaink településmorfológiája (in: Települési környezet szerk.: Orosz Zoltán - Fazekas István Debreceni Egyetem, 2008) 21. pp. www.geogis.detek.unideb.hu/100/talajvedelem/kiadvanyok/TKK1.pdf. ; Bognár Zoltán: „A nagyváros és környéke” összefoglaló tanulmány (in: Kistérségi tanulmányok szerk.: Ágh Attila - Németh Jenő, Belügyminisztérium IDEA Program, Budapest, 2003) 199. pp.
} 
- Európai Unió, Japán, Dél-Korea, Chile, Mexikó: nagyobb vagy egyenlő, mint 1500 lakos/km2

2. A funkcionális városi térség rendelkezzen olyan magas népsürüségü városi klaszterterülettel - értsd: nagyváros, (high-density urban cluster - HDUC) amelynek a lakossága:

- Európai Unió, Egyesült Államok, Chile, Kanada esetén: nagyobb vagy egyenlö, mint 50.000 lakos

- Japán, Korea, Mexikó esetén: nagyobb vagy egyenlö, mint 100.000 lakos.

3. A funkcionális városi térség lakosságának legalább $50 \%$ része magas népsürüségü városi klaszter-területen (min. 50.000 vagy 100.000 lakos) él.

4. A funkcionális nagyvárosi térséget alkotó települések, helyi önkormányzatok lakosságának legalább 15\%-a a központi funkciót ellátó nagyvárosban (mint magas népsürüségü városi klaszterterület) dolgozik. [OECD, 2013, 2-4. pp.].

\section{A FUA kategóriát definiáló szervezetek a következő várostérségi típusokat differenciálnak:}

- Kisebb városi térségek (small urban area) - 200.000 fönél kisebb térségi lakosságszámmal.

- Közepes méretű városi térségek (medium-sized urban area) - 200.000 és 500.000 közötti térségi lakosságszámmal.

- Metropolisz városi térség (metropolitan area) - 500.000 és 1.500 .000 közötti térségi lakosságszámmal.

- Széles metropolisz városi térség (large metropolitan area) - 1.500 .000 lakos vagy afeletti térségi lakosságszám. [OECD, 2013, 4. pp.].

A FUA kategorizálás alapján nagyvárosnak - azon belül is a legnagyobb large metropolitan area-nak csak Budapest minősül a maga közel 1.8 milliós nagyvárosi, illetve a környező agglomerációval együtt 2,5 millió lakosságával. ${ }^{5}$ A magyarországi megyei jogú városok sokkal alacsonyabb lakosságszáma, jelzi az ország városhálózatának rendkívül monocentrikus jellegét. A területben és lakosságban a fővárost követő magyarországi nagyvárosok európai összehasonlításban mindössze az ún. középvárosi kategóriának felelnek meg. ${ }^{6}$ A csökkenő lakosságú és demográfiai veszteséggel küszködő Magyarországon ismeretlenek a Világ más részein az elmúlt évtizedek során tapasztalt roppant mértékü

\footnotetext{
5 A 2014-es agglomerációs KSH kiadvány szerint Budapest lakossága 1.735 .711 fö, az agglomerációs települések lakosságával együtt pedig 2.541 .835 lakos volt - [KSH, 2014 30. pp.]

${ }^{6}$ Söt egyes megyei jogú városok, mint megyeszékhely - pl. Szekszárd - lakossága az egyébként törvényi alapfeltételként meghatározott 50000 fôs városi népességszám alatt marad.
} 
urbanizációs folyamatok és azok volumene. Ennek ellenére hazánkban is kimutathatóak bizonyos városfejlődési trendek és specifikumok, és a kapcsolódó városi, várostérségi kormányzati kísérletek, elgondolások.

A nagyvárosok és a városkörnyéki települések (függetlenül azok önkormányzati jogállásától) sokirányú, komplex szimbiózisban müködnek együtt: a klasszikus gazdasági- és foglalkoztatási munkamegosztás mellett, a különböző köz- és magánszolgáltatások igénybevétele, a munka- és szabadidő eltöltésének módjai, a lakó- és munkahelyek közötti közlekedés kapcsolja össze az érintett településeket. A magas szinten urbanizált térségeknél ${ }^{7}$ egyre általánosabb, hogy a nagyváros és szuburbanizációs településeket valamilyen funkcionális közjogi keret fogja át. Mivel az urbanizáció természetes velejárója a lakosság gyors népességnövekedése a teljes nagyvárosi térségben, ez olyan káros és negatív externáliákhoz vezethet, mint a lakóövezetek kapcsán tapasztalható túlzsúfoltság; a városi szennyvíz és hulladék elhelyezése; a szuburbán települések lakosságszámának, s vele a nagyvárosba napi szinten oda-vissza ingázók radikális megnövekedése, és az abból fakadó közlekedési, tömegközlekedési anomáliák. Mivel az így keletkezett problémák jellege és a lehetséges megoldások eleve meghaladták, meghaladják a települések közigazgatási határait, ezért már a klasszikus ipari forradalom időszakában, a XIX. század első felében jelentkezett az igény, hogy a gazdaságilag funkcionálisan összekapcsolódott, de önkormányzati közigazgatási-joghatósági szempontból egymástól élesen elkülönülő várostérségekben integrált jellegű közös közjogi-szabályozási és technikai megoldások kerüljenek alkalmazásra. A XX. században, különösen a második felétől tapasztalható globális népességrobbanás - s vele a rohamos ütemü urbanizáció (amely mértékéről lásd később!) - folyamatosan napirenden tartotta és tartja a nagyvárosi, várostérségi önkormányzati kooperációk kérdését érintse az a feladatellátás, a területi tervezés vagy a fejlesztéspolitika területeit.

A nemzetközi hírü hazai urbanista Tosics Iván napjainkban az európai nagyvárosi térségek előtt álló kettős kihívást nevesít:

- A globális nagyvállalatok és a nemzetközi kereskedelem által egyre inkább meghatározott globális piacgazdasági környezetben egy egyre növekvő és fokozódó gazdasági verseny tapasztalható a különböző régiók, makrorégiók között. Erre a globális külső gazdasági kihívásra a nagyvárosok hatékonyabban

\footnotetext{
${ }^{7}$ A nagyvárosi térségek lehetnek monocentrikus valamint policentrikus jellegüek attól függően, hogy egy vagy több központi település található az adott metropolisz térségben. A magas fokon urbanizált Egyesült Államokban, de bizonyos sürün lakott európai régiókban (pl. Randstadt régió Hollandiában, több önálló nagyvárosi térséggel) nem ritkák a policentrikus módon felépülő nagyvárosi térségek.
} 
tudnak reagálni, ha a környező szuburbán környezettel (együtt a méretgazdaságosság is erősíthető) közösen keresik és találják meg a válaszokat.

- A szuburbanizációból, s vele a kontrollálatlan területi terjeszkedésböl, társadalmi és környezeti ellentmondásokból fakadó ágazati és horizontális anomáliák kezelése [Tosics, 2008, 4-5.pp.].

Tosics felveti a nagyvárosi térségek problémakezelésének közpolitikai, önkormányzati alapú megoldását, és csomóponti kérdésként a következőt teszi fel: a hatékony nagyváros és térségének problémakezelés formális, felülről szabályozott - lehetőleg kötelező - intézményi keretben vagy csupán a már meglévő szervezeti és eljárási eszközök révén önkéntes formában történjen? Közpolitikai megközelítésben vagy újonnan létrehozó formális intézmény, vagy új intézmény létrehozása nélkül, a már meglévő szervezeti keretek és rendelkezésre álló eszközök, eljárások kreatív alkalmazása közötti választás, mint alkalmazható utak. Ugyanakkor szükséges látni és értékelni a Világ urbanizációs folyamatainak közös halmazát, de a kontinentális, makroregionális, regionális különbségeket is.

A különböző nemzetközi szerzők munkássága nyomán az európai városi kormányzás négy korszaka emelhető ki:

1) A XIX. század utolsó harmadától tapasztalható földrajzi-területi terjeszkedése a városi településeknek.

2) A második világháború után a városi közpolitikák egyre inkább beavatkozó, kiegyenlítő funkciója (humánszolgáltatások, jóléti transzferek).

3) Egyre erősebb tulajdonosi és szabályozási kontroll gyakorlása a különböző infrastrukturális közszolgáltatások területén (víz- és energiaszolgáltatás; tömegközlekedés etc.).

4) A XX. század második felében közvetlen beavatkozási lépések és programok a városi társadalmi egyenlőtlenségek csillapítására, hatékony kezelésére - pl. városrehabilitáció. [Tosics, 2011, 4. pp.].

A XX. század utolsó harmadában az angolszász országokban (Egyesült Államok, Egyesült Királyság, Új-Zéland) elindított közmenedzsment-reformok - különösen a magánszektor fokozottabb szerepvállalását fókuszba állító New Public Management - NPM -, de az összefoglaló nevén ún. „új kormányzás” (new governance) egyéb más 
részirányzatainak $^{8}$ hatásai megjelentek az európai várospolitikákban is. Ezek a hatások a szakértők általános véleménye szerint Európában is a városfejlödés feletti közösségi kontroll gyengülését eredményezték, miközben a helyi társadalmi-civil elvárások éppen az ellenkező irányba („,beavatkozó helyi közpolitikák”) mutatnak. A közösségi kontroll gyengülését olyan lépések és jelenségek határozták meg, mint a személygépkocsi-orientált közlekedési típus még dominánsabbá válása - különösen a napi ingázással terhelt urbánus térségekben; a közösségi (önkormányzati) tulajdonú lakásállomány privatizációja; a korábban szintén közösségi tulajdonban lévő közszolgáltatások teljes vagy részleges „kiszervezése” elsősorban a magánszektornak, de a non-profit (pl. egyház) szektor feladatellátása is fokozódott a közösségi humánszolgáltatói piacon. Az önkormányzati közösségi kontrollt a városokban, nagyvárosokban tovább csökkentette a globális világgazdaság irányait és súlypontjait egyre inkább meghatározó multinacionális termelő- és szolgáltató nagyvállalatoknak a telephelypolitikája, és a helyi politikai döntéshozatal sokszor direkt kiszolgáltatódása a globális nagyvállalati érdekeknek [Tosics, 2011, 4-5. pp.]. Sajátos történeti és geopolitikai jelenségként az 1989-1990-ben politikai és gazdasági rendszert váltó kelet-közép-európai régióban, nagyon gyorsan alig néhány év alatt következett be ez a folyamat - a tanácsi lakásszektor privatizációja; piaci vállalatok megjelenése a közszolgáltatások területén; a multinacionális nagyvállalatok telephelyeiért folytatott városok, agglomerációs települések közötti rivalizáció (pl. adóverseny) és engedmények a befektetői irányba. Az 1990-s évek radikális ,államtalanítási” gyakorlata elsősorban az állami (központi kormányzati) szektort és feladatellátást érintette, de elérte a területi és helyi önkormányzatok, a települések és helyi politika világát is. Ez ma már - különösen a 2008-as pénzügyi és gazdasági világválság tényéből fakadóan - jórészt erőteljes kritika tárgya a közép-európai térség gazdasági és társadalmi közelmúltját kutató szakértők körében - az 1989-1990-es rendszerváltást követő éveket, évtizedet nevezik az ún. Washington-i konszenzus időszakának. A 2008-ban kezdődött gazdasági világválság hatása a helyi település-, benne hangsúlyosan a várospolitikára ismét felértékelni látszik a közösségi kontroll és feladatellátás ethoszát - lásd a neoweberianus államfilozófia térnyerését!

\footnotetext{
${ }^{8}$ New governance - New Public Management; governance without government; Neoweberian State; multi-level governance etc. - [Jenei, 2005; Forgách, 2009; Bevir, 2008 etc.].
} 
Kettős „konfliktuskonténer”9 körvonalazódik a szemünk előtt a nagyváros és térségi kormányzás területén:

I. Területi-joghatósági problémahalmaz: az egyik oldalon a terjeszkedő nagyvárosi térségek (metropolitan area) valóságával - az abból fakadó egyre inkább globalizációs gyökerü gazdasági és társadalmi kihívásokkal -, a másik oldalon pedig sokszor rugalmatlan, és emiatt hatékony közpolitikai válaszokra képtelen önkormányzati igazgatási-joghatósági struktúrákkal.

II. Történeti-politikai problémahalmaz: egyik oldalon a XX. század utolsó harmadában (Kelet-Közép-Európában az 1990-es években) uralkodó NPM-logika ${ }^{10}$ jóvoltából jelentős közösségi pozícióvesztés a közösségi (esetünkben önkormányzati) tulajdon és közfeladat-ellátás területén, a másik oldalon az egyre erősebb igény a civil társadalom és a különböző közpolitikai érdekcsoportok (stakeholderek) részéről a várospolitika, közpolitikai döntéshozók irányába a komplex nagyvárosi és agglomerációs szintű problémák kezelésére - ezáltal erősítve a városi politikák transzparenciáját és legitimitását.

I.1 terjeszkedő nagyváros

(túlnépesedés, szegénység, rossz infrastruktura etc.)

II.1 csökkenő közösségi kontroll

(privatizáció; feladat-kiszervezés; New Public Management)
II.1 rugalmatlan közigazgatásijoghatósági keretek

(funkcionális hátrányok; koordinációs nehézségek)

II.2 növekvő participációs igények

(lakosság és civil szervezetek; legitimációs törekvések)

1. ábra: kettös konfliktuskonténer a nagyvárosi kormányzásban

(saját szerkesztés)

\footnotetext{
${ }^{9}$ A „,konfliktuskonténer” kifejezést az önkormányzati politikával kapcsolatban Ágh Attila vezette be a 2000 -es években - elöször az IDEA kormányzati munkacsoport anyagaiban jelent meg.

${ }^{10}$ New Public Management
} 


\section{II.1.1 Stratégiai kormányzás és közpolitikai tervezés a nagyvárosi térségekben}

A felvázolt nagyvárosi „konfliktuskonténer” sok szempontból kijelöli, determinálja a mozgásteret és cselekvési irányokat a nagyvárosi agglomerációs térségekben a politikai döntéshozók számára. A város és a falu közötti alapvető funkcionális különbség az előbbi valamilyen értelemben vett központi funkciója. A falu általában csak a települési alapfunkciókkal vagy még azzal sem rendelkezik (ivóvíz, közvilágítás, alapszintű közszolgáltatások etc.); a város - eleve nagyobb településként - az alapfunkción túl egyéb speciálisnak tekinthető minőségi, fakultatív funkciókat (különböző szakszolgáltatások - pl. kórház, színház) is ellát, amit az emberek nem feltétlenül napi rendszerességgel vesznek igénybe, „fogyasztják közjószágként.” A városi jelleg másik sarokpontja, hogy az adott szolgáltatást nem csak a székhely település (város) lakossága veszi igénybe, de a környező települések lakossága számára is elérhető. Ezt a helyi feladatellátás, mint szolgáltatási spillover („túlcsordulás”) jelentkezik szükebb, vagy speciális esetben (pl. szakkórházi ellátás) akár a tágabb környezet települései és azok lakossága számára [Tózsa-Jószai-László, 2010, 8-9. pp.]. A nagyvárosi, agglomerációs térségekben a stratégiai kormányzás és közpolitikai tervezés során szóba jöhető módszerek, szabályozási eszközök, közpolitikai akciók kiválasztása, megtervezése és végrehajtása során talán a legfontosabb szempont, hogy milyen önkormányzati igazgatási valamint kompetenciaviszonyok (feladat-, és hatásköri listák) érvényesek. Ezen túl további fontos determináló tényező, hogy a központi kormányzati igazgatás (államigazgatás) milyen pozíciókkal rendelkezik a különböző közfeladatok terén egy centralizált, erösebb döntéskörökkel felvértezett politikai- és igazgatási makroszint akár központi, akár területi dekoncentrált szerveivel képes ellátni olyan közfeladatokat, amelyek a decentralizáltabb országokban az önkormányzati szektorok sajátja - pl. közoktatás, az egészségügy bizonyos szegmensei.

A legegyszerübb tipizálása a nagyváros és környékére vonatkozó önkormányzati struktúráknak az egy- illetve kétszintü metropolisz önkormányzatok, tanácsok típusaira való felosztás. A különbségtétel alapja, hogy a teljes agglomerációs térségre vonatkozólag beszélhetünk-e valamilyen homogén (egységes) joghatóságról vagy sem. Az egyszintü nagyvárosi önkormányzat (one-tier metropolitan government) alapvető attribútuma a nagyváros egységes adminisztratív joghatósága, anélkül, hogy a nagyváros a városkörnyéki szuburbán településekkel valamilyen formális társulást, közös önkormányzati tanácsot alkotna. Az egyszintü nagyvárosi kormányzati modell természetesen alkalmazza a nagyvároson belüli, kisebb területi-igazgatási egységek valamilyen szintü önkormányzati 
autonómiával való felruházását: ebből a szempontból a budapesti kerületek nemzetközi összehasonlításban kiemelkedő önkormányzati jogosítványokkal rendelkeznek már 1990 óta. Az egyszintü nagyvárosi önkormányzati modell kialakulásának megvannak speciális a történeti és földrajzi dimenziói - egyesült vagy összevont önkormányzatok egységes nagyvárosi joghatóság alatt; területi önkormányzati jogokkal felruházott nagyvárosi önkormányzatok [pl. az amerikai város-megye (city-county); a német tartományi joggal felruházott néhány nagyváros; de a magyarországi megyei jogú városokat is ide sorolhatjuk].

A kétszintü nagyvárosi önkormányzati modell (two-tier metropolitan government) alapvető jellegzetessége, hogy a nagyváros és agglomerációját úgy próbálják valamilyen egységes föderatív jellegü önkormányzati igazgatási modellbe rendezni, hogy nem számolják fel fúzióval, egyesüléssel a szuburbán övezet önkormányzatainak önállóságát. Ugyanakkor ez nem zárja ki automatikusan az agglomerációs. szuburbán övezetben különböző racionalizálási, konszolidációs megoldásokat - pl. a németországi Hannover térségi föderatív agglomerációs tanács létrehozásakor, községeket vontak össze a városkörnyéken [Somlyódyné, 2011, 35. pp.]. Rendkívül színes a paletta, hogy a létrejött föderatív jellegü kétszintü nagyváros térségi önkormányzatok, igazgatási rendszerek milyen politikai és jogszabályi felhatalmazás alapján; milyen legitimációval (delegálás vagy közvetlen választás); milyen funkcionális- és szervezeti struktúrával valamint feladat- és hatáskörökkel, kompetencialistákkal bírnak - lásd a témához kapcsolódó OECD jelentéseket!

A nagyvárosi térségi kormányzás története közel sem homogén, tele van intenzív és kevésbé intenzív szakaszokkal, változó trendekkel (struktúrák, eljárások), és az alkalmazott közpolitikai eszközök terén is látványos a sokszínüség. Erre jó példa, hogy amíg az elmúlt évtizedekben a nagyvárosi térségek vonatkozásában éppen a föderatív kétszintü metropolisz/agglomerációs tanácsok megalakítása a jellemző, addig a kanadai Torontóban több évtizednyi kétszintű modellt követően 1998-ban erősítették meg az egyszintű nagyvárosi kormányzati struktúrát korábban önálló települések, városrészek egyesítésével, a városmaghoz való csatolással.

Ugyanakkor Magyarországon a kétszintű városkörnyéki intézményi megoldásokra, kísérletekre alig-alig akadt kezdeményezés. Ilyen volt a Budapesten az 1870-től városrendezési és építésügyi hatóságként müködő Fővárosi Közmunkák Tanácsa, ${ }^{11}$ amely speciális városkörnyéki kompetenciákkal bírt a dualizmus alatt és a Horthy-korszakban [Hencz, 1973; Déry, 1995]. Hasonló kétszintű föderatív intézményi kísérlet volt már a

\footnotetext{
${ }^{11}$ Hasonló müködött a korszakban London és környékére vonatkozólag is - erről részletesen lásd később!
} 
rendszerváltás után a Budapesti Agglomerációs Fejlesztési Tanács (BAFT) rövid néhány éves müködése - ennek müködéséröl részletesen lásd később!

\section{II.2 Kutatási hipotézisek és modellkísérlet}

A disszertáció elméleti alapkérdése a modern nagyváros és agglomerációs térsége közötti együttmüködés, kooperáció intézményi közpolitikai gyakorlata. A nagyvárosi térségben a kormányzás 3 különböző területi szintjét különböztethetjük meg:

i. A közigazgatásilag egységes nagyvároson belüli teljes vagy részleges önálló joghatósággal rendelkező közigazgatási egységekre vonatkozólag - pl. a nagyvárosi kerületi önkormányzatok (Magyarországon a fővárosi kerületi önkormányzatok sorolhatóak ide); de bizonyos szempontból az átruházott, részleges, de önálló hatáskörökkel felruházott részönkormányzati jogintézmény is ide sorolandó.

ii. A közigazgatásilag egységes nagyváros (the core of the city) területére vonatkozólag egyszintü (one-tier government) nagyvárosi kompetenciakör; ez az értelmezés nem érinti a nagyváros és a vele határos agglomerációs területek igazgatási, politikai kapcsolatait. Kortárs hazai példa a Fővárosi Önkormányzat illetve a megyei jogú városi önkormányzatok struktúrája és müködése.

iii. A nagyváros és a vele szomszédos agglomerációs, szuburbanizációs területek (és az ott található településekre) egységesen vonatkozó közpolitikai megoldások - rendkívül széles közpolitikai megoldási eszköztárral a nagyon direkt fúziós és annexiós megoldásoktól (pl. Budapest vonatkozásában az 1873-as fúzió és az 1950-es annexió) kezdve egészen a szuburbán önkormányzatok autonómiáját nem érintő, azt változatlanul hagyó föderatív kétszintủ megoldásokig.

A nagyvárosi igazgatás közpolitikai vizsgálatának mind a három területi szint a természetes része. Közpolitikai megközelítésben ez jelentheti a nagyvároson belüli - az egységes közigazgatási határokon belüli nagyváros - a nagyváros és térségének, városkörnyékének kompetenciaszintézisét: az egyes szintekhez rendelt feladat-, és hatáskörök súlyát; az egyes szintek döntési autonómiájához rendelkezésre álló költségvetési, fiskális eszközök vizsgálatát; de akár az újonnan létrehozott agglomerációs szint formális intézményi feladatellátások lakossági fogadtatását (társadalmi legitimáció). A nagyvárosi feladatellátás kiemelkedő dimenziója a már tárgyalt spill-over hatás, amikor a nagyvárosi intézményrendszer különböző gazdasági és humán közszolgáltatásokkal látja el a szuburbán térség településeinek lakosságát. Észak-Amerikában vagy Nyugat-Európában ma már teljesen 
természetes, hogy a nagyvárosi agglomerációs térségek gazdasági valamint politikaiközigazgatási szereplői, döntéshozói funkcionális egészként értelmezik a nagyvárost és környéki területeket, településeket. Magyarországon illetve a közép-európai régióban azonban jobbára csak bizonyos politikai-, közigazgatási kísérletek akadtak erre vonatkozólag az 19891990-es rendszerváltozást megelőzően (pl. a Fővárosi Közmunkák Tanácsa Magyarországon a háborút megelőzően; városkörnyéki igazgatás a tanácsrendszer időszakában, az 1970-1980as években). A nemzetközi és hazai tapasztalatok szintetizálásakor izgalmas kérdés, hogy Magyarországon milyen történeti előzményei mutathatók ki az integrált nagyvárosi agglomerációs közpolitikai gyakorlatnak, filozófiának. Az elmúlt negyedszázad tapasztalatait rendkívül módon determinálja az 1990-ben létrehozott, kontinentális összehasonlításban jelentősen fragmentált (,,egy település egy önkormányzat” elv), de a települési mikroszinten széles kompetencialistával felruházott magyarországi helyi önkormányzati rendszer. Vizsgálandó alapkérdés, hogy ez miként hatott a hazai várostérségi és nagyváros agglomerációs folyamatokra, valamint a 2010 utáni új szabályozási környezet (2011. évi CLXXXIX. törvény Magyarország helyi önkormányzatairól, valamint egyéb törvények és alsóbb szintü jogszabályok) milyen hatással bírt ebben a tekintetben.

I. hipotézis: Magyarországon az 1990-ben a törvényalkotó által létrehozott helyi önkormányzati rendszer fragmentált és a különböző kooperációkat nem megfelelően ösztönző szabályozás negatív hatással volt az elmúlt negyedszázad különböző nagyvárosi térségi (agglomerációs szintü) közpolitikai folyamatokra. Ezt csak bizonyos fáziskéséssel igyekezett a politika és a jogalkotás különböző eszközökkel orvosolni - pl. negatív forrásszabályozás, differenciált hatáskör-telepítés, az addigiaknál hatékonyabb önkormányzati társulási jogintézmények megteremtése.

A Világ metropolisztérségeiben (különösen Amerikába, Európában) egyre elterjedtebb intézményes gyakorlat a nagyváros és környező agglomerációs, szuburbán övezetben a térségi helyi önkormányzatok kooperációjára épülő - ugyanakkor a résztvevő helyhatóságok autonómiáját tiszteletben tartó - nevesített, lehetőleg több önálló kompetenciával (különböző feladatellátás,- és közszolgáltatások, térségi tervezés és fejlesztéspolitika etc.) bíró föderális kétszintű nagyvárosi tanácsok létrehozása valamint müködtetése. Magyarországon egy ilyen struktúra és közpolitikai gyakorlat leginkább a főváros és agglomerációs térsége tekintetében tünik szükségesnek, de mellette a néhány valódi regionális (nagytérségi spill-over) „kisugárzással” bíró megyei jogú város és környéke esetében is indokolható. Az elmúlt negyedszázad tapasztalatai illetve a politikai realitások egy új és önálló, kifejezetten kötelező 
jellegű agglomerációs társulásos intézményi formát igazolnak - pl. a francia nagyvárosi agglomerációs tanácsok (communaté urbaine) mintájára. A különböző föderatív agglomerációs kétszintü kísérletek eddigi kudarcai is új típusú politikai-jogalkotási választ erősítik, ezt támasztják alá a korlátozott hatáskörü, 2010 után „kimúlt” Budapesti Agglomerációs Fejlesztési Tanács (BAFT), valamint a különböző vidéki modellkísérletek (2005-ben Miskolc és Székesfehérvár) tanulságai. ${ }^{12}$

A nagyvárosi kétszintủ föderatív agglomerációs struktúra határozza meg a disszertáció másik hipotézisét, s vele az önálló modellalkotás kísérletét.

II. hipotézis: a kiemelkedő magyarországi nagyvárosoknál (javasolt lehatárolás: Budapest + a 100.000 fös lakosságot meghaladó megyei jogú városok) meghatározott feladat,hatáskörökkel felruházott föderatív kétszintü agglomerációs önkormányzati tanácsok (mint kötelező önkormányzati társulások) létrehozásával a feladatellátás minőségét tekintve hatékonyabb és gazdaságosabb várostérségi kormányzás volna megvalósítható az önkormányzati szolgáltatási területen, mint a jelenlegi széttagolt illetve eseti kooperációs viszonyok közepette.

\section{II.2.1 Kísérlet modellalkotásra}

Önálló nagyvárosi agglomerációs tanács - mint föderativ jellegü kétszintü nagyvárosi kormányzati intézménytípus kialakitása Magyarországon

Indoklás: az Európai Unió által egységesen megfogalmazott versenyképesség, ugyanakkor az alapelvnek tekintett szubszidiaritás és önkormányzati autonómia (Lisszaboni Szerződés, EU2020, Lipcsei Charta, Helyi Önkormányzatok Európai Chartája etc.) jegyében bizonyos feladatokat, közszolgáltatásokat a nagyvárosi agglomerációs övezetekben érdemes egységesen kezelni a minél hatékonyabb minőségű és gazdaságosabb feladatellátás, közszolgáltatás érdekében.

$\underline{\text { Javaslat a kötelező agglomerációs várostérségi feladat-, hatáskörökre: }}$

- Tömegközlekedés az agglomerációs övezetben.

- Energiapolitika (energia-beszerzés és alternatív energiatermelés).

\footnotetext{
${ }^{12}$ Bár a BAFT „kimúlását” követően, 2011-ben megalakult a Fővárosi Agglomerációs Önkormányzati Társulás (FAÖT), több mint egy tucat érintett agglomerációs önkormányzat részvételével, de a társulásnak nem tagja Budapest (sem kerületi, sem a Fővárosi Önkormányzat révén) -, így nem is tekinthető klasszikus föderatív kétszintű metropolisz önkormányzati tanácsnak, társulásnak.
} 
- Zöldfelület-politika önkormányzati külterületeken (területhasználat).

- Sport- és szabadidő, rekreációs szolgáltatások.

- Zajvédelem- és környezetpolitika.

- Hulladékgazdálkodás.

- Vízszolgáltatás és szennyvízelvezetés.

- Egészségügy - kifejezetten a járóbeteg ellátások területén. ${ }^{13}$

- A teljes várostérséget egységesen kiszolgáló infrastrukturális tervezés, fejlesztéspolitika.

Javaslat az önként vállalt, fakultatív agglomerációs várostérségi feladat-, hatáskörökre:

Lehetőség volna, hogy az érintett települési önkormányzatok más önkormányzati feladat-, és hatáskört egyhangú (az összes érintett önkormányzat támogatásával) döntéssel az agglomerációs tanács saját hatáskörébe utaljanak hatáskör-delegálás révén.

\section{Az agglomerációs tanács létrehozására és müködtetésre javaslat: - vizsgálandó dimenziók}

1. Legitimációs dimenzió - javasolt a delegálás (az érintett helyhatóságok delegáljanak meghatározott számú tagokat): a modell alapjául szolgáló agglomerációs tanácsok ne rendelkezzenek azonos - közvetlen választópolgári - legitimációval, mint a közvetlenül választott települési önkormányzatok.

2. Agglomerációs tanács összetétele - delegált politikusok: javasolt valamilyen elv alapján a meghatározó várostérségi gazdasági és civil stakeholderek számára biztosítani helyeket (hasonló elven, mint a települési önkormányzati bizottságok külsö tagjainak esetében).

3. Saját pénzügyi eszközök - lehetséges forrás: a) az érintett települési önkormányzatok által valamilyen egységes elv alapján átadott müködési forrás; b) önálló várostérségi, agglomerációs adó kivetése; c) központi (parlamenti, kormányzati támogatás), amelynek alapja lehet közvetlen költségvetési törvényben meghatározott feladatellátásra kalkulált normatíva és/vagy pályázati források.

4. Speciális agglomerációs tanács létrehozása Budapest és agglomerációs övezete vonatkozásában, Budapesti Metropolisz Tanács elnevezés alatt - már esett szó arról,

\footnotetext{
13 A modellkísérlet nem kívánja alapjaiban bolygatni a jelenleg hatályos állami és önkormányzati feladatok rendszerét. Ugyanakkor bizonyos korábban önkormányzati, de 2010-2014 között az államhoz került feladatok tekintetében mégis elképzelhetőnek tartom a feladatok beintegrálását, ezzel kvázi „visszatelepítését” az önkormányzati (azon belül pedig kifejezetten az agglomerációs térségi) szintre. Ennek bővebb kifejtése a disszertációt záró Összefoglalás - hipotézisértékelés és modellkisérlet címü fejezetben!
} 
hogy a főváros és agglomerációs térsége, az ország legkiterjedtebb várostérsége a jelentősen kiterjedt több alközpontot (Érd, Gödöllő, Budaörs, Szigetszentmiklós etc.) magába foglaló fővárosi szuburbán térségben, amely a modern városfejlődési folyamatokat tekintve láthatóan elörébb tart, mint a jelenleg még csak a szuburbanizálódás szakaszában járó vidéki nagyvárosi térségek.

5. Agglomerációs tanács néhány meghatározott, 100.000 fős lakosságot meghaladó megyei jogú városok és a környező települések tekintetében kötelező volna. ${ }^{14} \mathrm{~A}$ 100.000 lakos alatti megyei jogú várások és környező települések tekintetében alternatív, az érintett önkormányzatok által választható megoldásként merülhetne fel az agglomerációs tanács létrehozása.

6. Az agglomerációs tanács illetékességi területe - a Központi Statisztikai Hivatal szakértői által meghatározott időnként (javasolt a 2014-től immár 5 éves önkormányzati ciklusokhoz kapcsolódóan) felülvizsgált agglomerációkra, agglomerálódó térségekre, nagyvárosi településegyüttesekre vonatkozólag.

A modellalkotási kísérlet empirikus alátámasztása érdekében került sor egy országos önkormányzati kutatásra még 2014 tavaszán. Ennek alapja egy szakmai kérdőív volt (lásd 1. számú melléklet!), amely keretében polgármesterek véleményezték a magyarországi nagyvárosok (fóváros; megyei jogú városok) és a városkörnyéki települések közötti különböző kapcsolatokat: az általuk ideálisnak tekintett szintről illetve a gyakorlatban tapasztaltakról nyilatkoztak, a válaszokat komparatív szintetizálásnak vetettem alá. Továbbá a településvezetők $6 \mathrm{db}$ - kifejezetten a nagyvárosi térségi, agglomerációs együttmüködéshez kapcsolódó - „kemény” és „puha” közpolitikai eszközt értékeltek a sorrendiség megadásával. A kutatás eredményeit az V.8 fejezet ismerteti!

\footnotetext{
${ }^{14}$ A kötelező vidéki agglomerációs tanácsokra a konkrét javaslatok a disszertációt záró Összefoglalás hipotézisértékelés és modellkisérlet címü fejezetben kerülnek kifejtésre.
} 
Szemléltető ábrák a javasolt modellalkotáshoz:

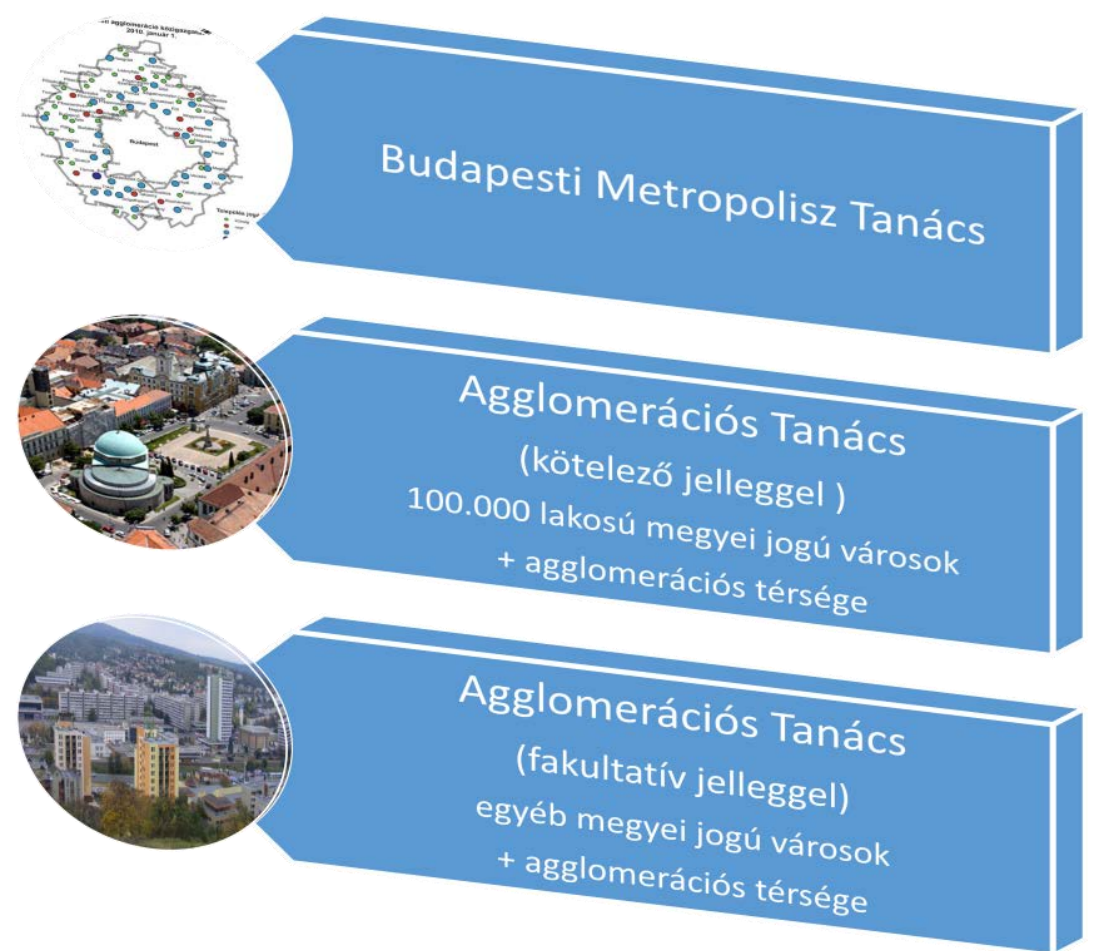

2. ábra: az agglomerációs tanácsok elképzelt rendszere (saját szerkesztés)

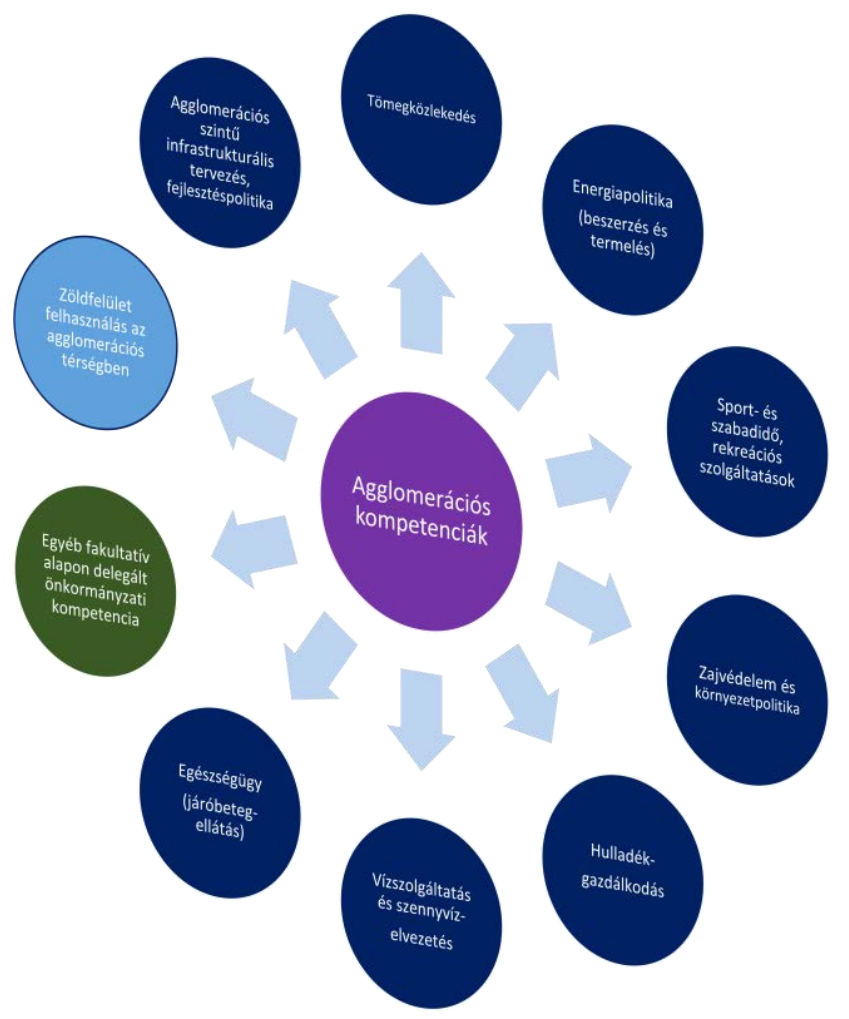

3 ábra: az agglomerációs tanácsok elképzelt feladatköre (saját szerkesztés) 


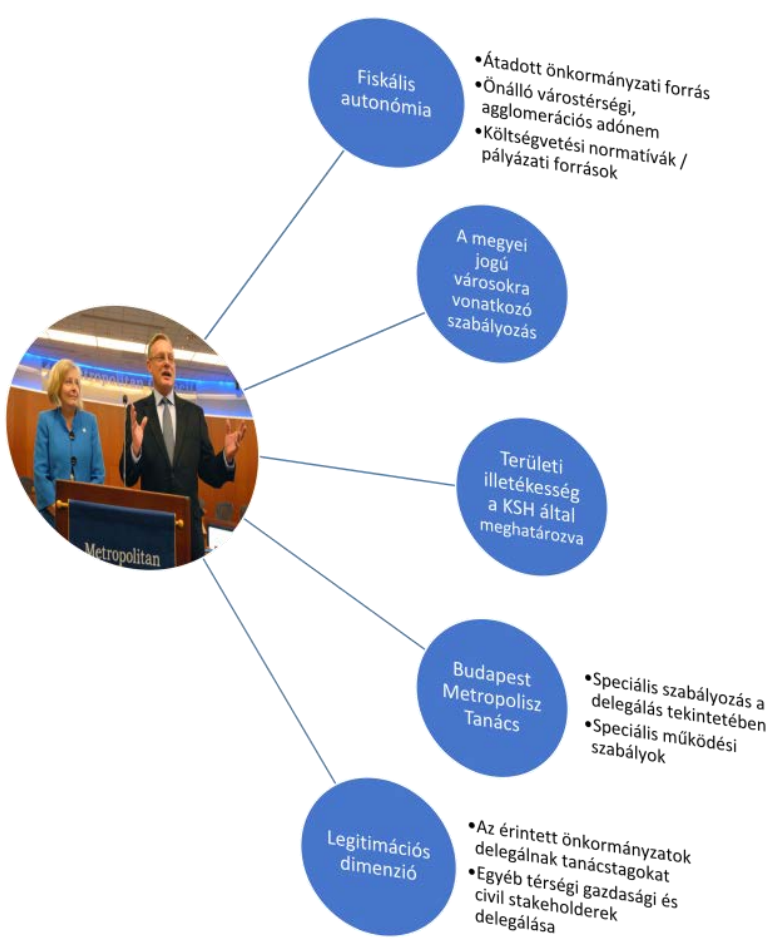

4. ábra: az agglomerációs tanácsok szervezete és müködése (saját szerkesztés) 


\section{A modern nagyvárosi kormányzás elméleti és nemzetközi dimenziói}

\section{III.1 A városhálózati folyamatok globális dimenziói}

Amikor városkörnyéki önkormányzati kapcsolatokról, nagyvárosi-agglomerációs közpolitikai folyamatokról gondolkodunk, akkor a globalizáció korának egyik legdinamikusabb mozzanatáról van szó. Az urbanizáció, s vele a nagyvárosi térségek rohamos térnyerése Amerikától Ázsiáig, Európától Afrikáig és Ausztráliáig egy olyan megállíthatatlan folyamat, amely egyre erőteljesebben dominálja a gazdasági és társadalmi tereket; főirányt szab az emberiség és a történeti modernizáció számára. Ugyanakkor a globális népességrobbanás korábban rendkívül eltérő demográfiai mértékekről beszélünk, $\mathrm{s}$ ezzel párhuzamosan az urbanizációs trendek és a mögöttük lévő tervezési- és egyéb közpolitikai vonatkozások is heterogének, eltérő hatásfokúak. Ahhoz, hogy a magyarországi urbánus térségek önkormányzati kontextusának (önkormányzatok müködése; kooperációk az urbánus térségekben) közelmúltját és jelenét eredményesen feltérképezhessük, szükséges az urbanizáció nemzetközi összefüggéseit, komparatív dimenzióit felvázolnunk - különösen a nagyvárosok és agglomerációs térségeiben alkalmazott közpolitikai government és governance megoldásokat, elhelyezve egy szélesebb (nemzetközi, európai) térben a hazai várostérségi paramétereket és történéseket.

\section{III.1.1 A városok globális demográfiai térnyerése}

A különböző statisztikák illetve az ENSZ, az OECD, az Európai Unió valamint egyéb nemzetközi szervezetek keretében az elmúlt egy-másfél évtizedben született városi, nagyvárosi tendenciákat vizsgáló jelentések szerint a XXI. századra visszavonhatatlanul urbánus jellegüvé vált a világ. 2030-ra a földgolyó népességének már közel 60\%-a városlakó lesz, és ahogy az ENSZ kétévente napvilágot látó összefoglaló kiadványa fogalmaz, a következő 15-20 évben a homo sapiens-t felváltja a homo sapiens urbanus szimbolikus kategóriája. A XX. század hozta az urbánus létforma óriási elterjedését: amíg az 1900-as évek elején a Föld népességének mindössze 13\% volt városlakó, ez a számadat 1950-re már 29\%ra emelkedett; az ezredforduló évtizedében közel kiegyenlítődött, és 15 éven belül várható a 60\%-os arány elérése. [State of the World's Cities 2010/2011, 9-10. pp.] A XXI. század kétség kívül a nagyvárosok, valamint az azokat övező agglomerációs-metropolisz térségek 
évszázada: csak a fejlődő országokban havonta 5 millió fővel gyarapodik a városi lakosság aránya az ENSZ 2008/2009-es jelentése szerint [State of the World's Cities 2008/2009, 11. pp.]. A roppant dinamikus urbanizálódási folyamat hátterében a következő tényezők kombinációja áll: földrajzi lokalizáció; jelentős természetes népszaporulat; falusi - városi irányú migráció; infrastrukturális fejlesztések; a városi térségekre koncentráló nemzeti szakpolitikák; vállalati stratégiák - benne különösen a transznacionális nagyvállalatok tevékenysége; a globalizációs folyamatok által indukált egyéb gazdasági, társadalmi és politikai kényszerek. Ahogy általában a népszaporulat a fejlődő világra - különösen kiemelkedő Ázsia és Afrika aránya - koncentrálódik, ez talán még hatványozottabban jelentkezik a városi, nagyvárosi lakosság esetében.

A fejlett és fejlődő világ urbánus tendenciái között a népszaporulat eltérő dinamikája mellett a másik alapvető differencia a nagyváros-térségi folyamatok minősége, azok spontán vagy tervezett-irányított jellege. Így az afrikai urbanizáció (különösen a szub-szaharai makrorégióban) rendkívül aránytalan képet mutat, mind a lakosságnövekedés, mind a befektetések területi eloszlását illetően a legnagyobb városok (fövárosok) javára: ez a rendkívül monocentrikus folyamat egyúttal koncentrálja a kapcsolódó negatív társadalmi tendenciákat - pl. városi szegénység növekedését. Ehhez képest a fejlett régiókban, ÉszakAmerikában (Kanada, Egyesült Államok) valamint Európában a városfejlődés sokkal tervezettebb keretek között történik egy jellemzően jóval inkább policentrikus (többközpontú) településhálózati, s vele városhálózati térben.

2015-ben már 11. alkalommal adták ki a Demographia World Urban Areas címü szakmai kiadványt, amely a világ lakott területeit, településeit alapvetően urbánus és rurális térségtípusokba sorolja. A kiadvány szerint 2015-ben a rurális (vidéki-falusias) térségekben él a földlakók 46\% része. Az 54\% városi, urbánus népességet további 7 kategóriába sorolják a kiadvány szerkesztői a 100.000 lakos alatti kisvárosi klasztertől egészen a legalább 10 milliós világvárosi metropolisz térségekig. A különböző települési térségek demográfiai megoszlását tartalmazza az alábbi ábra: 


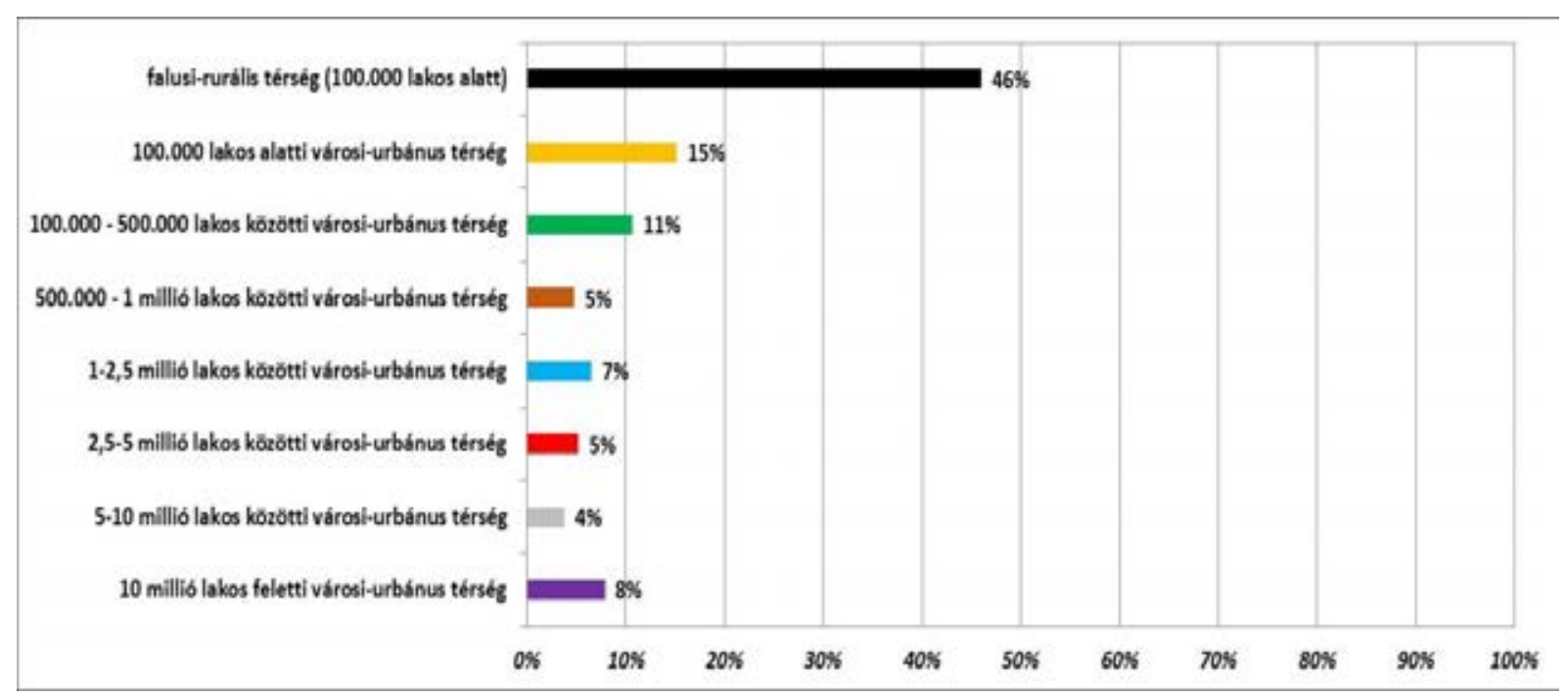

5. ábra: a Világ lakosságának megoszlása városkategóriák szerint 2015-ben (Demographia World Urban Area 11th Annual Edition:2015:01 3. pp)

- $\quad$ saját szerkesztés -

A 2015-ös Demographia World Urban Area kiemelten foglalkozik a legalább 500.000 lakost magában tömörítő nagyvárosi agglomerációkkal, funkcionális nagyvárosi térségekkel amelyekböl 1009 db nagyvárosi térséget (metropolitan area; functional urban area, large urban area - MA/FUA/LUA) azonosítottak a Világon. A metropolisz térségek 2,06 milliárd földlakót érintenek, amely az összes városlakó 53\%-át jelenti. Ázsia roppant méretű nagyvárosi területi és népességnövekedése mögött meghatározó a városok és falvak közötti óriási differencia, ráadásul az elmúlt másfél-két évtized ázsiai gazdasági expanziójának kiemelkedő nyertesei a kontinens metropolisz térségeinek lakosai. A 10 legnépesebb metropolisz térség közül 9 Ázsiában található. Jelenleg 34 olyan metropolisz térség található, ahol a teljes agglomerációs népesség meghaladja a 10 millió lakost, ebből 21 db Ázsiában (amennyiben a törökországi Isztambult is ide számoljuk), 5 db Közép- és Dél-Amerikában, 2 db az Egyesült Államokban, 3 db Afrikában, és 3 metropolisz térség az európai kontinensen (Moszkva, London és Párizs). 2015-ben további 41 olyan nagyvárosi térség van, amely lakossága 5 millió fő felett van - ezekből is mindössze 3 található Európában. A vizsgált metropolisztérségek közül 532 db Ázsiában, 120 db Afrikában, Észak-Amerikában 132 db (benne 34 mexikói nagyvárosi régióval), Dél-Amerikában 74 db, Ausztrália és Óceániában 7 nagyvárosi agglomeráció. Az európai kontinensen 144 db 500.000 várostérségi (város és szuburbán övezete) lakost meghaladó nagyváros és agglomerációja került be a kiadványba [Demographia World Urban Area 11th Annual Edition, 2015, 2. pp., 20-21. pp., 132-133. pp.]. 
Az 1009 metropolisz várostérség kontinentális megoszlását mutatja az alábbi ábra:

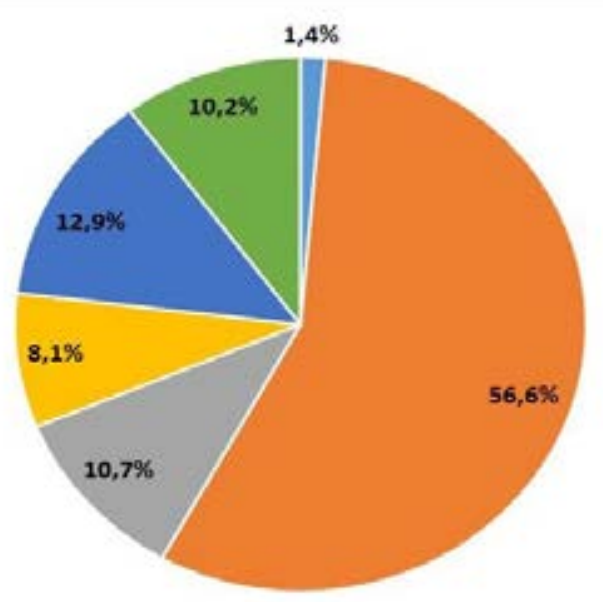

= Ausztrália és Óceánia = Ázsia = Afrika = Dél-Amerika = Észak-Amerika = Európa

6. ábra: a metropolisz várostérségek kontinentális megoszlása (Forrás: Demographia World

Urban Area 11th Annual Edition:2015:01 2.pp.)

- saját szerkesztés -

\section{III.1.2 Európa pozíciói a Világ urbánus folyamataiban}

Település- és városhálózati tekintetben Európa számít a leginkább policentrikus, többközpontú földrésznek. A kontinens az elmúlt három-négy évtizedben sokat veszített a korábban birtokolt urbánus demográfiai pozíciókból; különösen Ázsia és a teljes amerikai kontinens metropolisztérségei értek el roppant demográfiai növekedést az elmúlt néhány évtizedben. Ugyanakkor az ezredforduló utáni Európára az ezredfordulóra rendkívül sürü településhálózat és kiegyensúlyozott, policentrikus városhálózat a jellemző; ez különösen igaz az Európai Unió régebbi tagállamaira (EU-15) - jó példa a sürün urbanizált Hollandia (benne a Randstadt várostérséggel) vagy a több mint tucatnyi német funkcionális metropolisz térség.

A 2015-ös Demographia World Urban Area adatai szerint a világon található 1009 db 500.000 lakost meghaladó nagyvárosi, metropolisz térségből Európa a következő pozíciókkal rendelkezik:

I. Összesen $144 \mathrm{db}$ metropolisz térség, amelybö1

- 91 db található a 28 tagállamot magába foglaló Európai Unió területén;

- 53 db az EU-n kívüli országokban (37 db Oroszországban, 8 Ukrajnában). 
- a 91 EU-s metropolisztérség közül 77 az EU-15 területén (15 db német, 13 db az Egyesült Királyságban, 11-11-11 db francia, spanyol és olasz nagyvárosi térség).

- a 2004 után az Európai Unióhoz csatlakozott 13 új EU tagállam területéről listázott 14 metropolisztérségből 7 db található Lengyelországban.

\section{A $144 \mathrm{db}$ európai metropolisz térség népesség szerinti megoszlása}

- 3 db 10 milliós vagy afeletti világvárosi agglomeráció (Moszkva, London, Párizs);

- 3 db 5 millió - 10 millió lakos közötti agglomeráció (a német Essen-Düssedorf várostérség, Madrid, Milánó);

- $8 \mathrm{db}$ 2,5 millió - 5 millió lakos közötti agglomeráció (Barcelona, Berlin, Róma, Nápoly, Athén, Lisszabon, a hollandiai Rotterdam-Hága várostérség, Manchester, Birmingham);

- Nagyszámú, 130 db európai metropolisztérség az 500.000 - 2,5 millió lakos közötti kategóriában található (Magyarországról egyedül Budapest és térsége minősül a nemzetközi standardok szerint nagyvárosi térségnek) [Demographia World Urban Area 11th Annual Edition, 2015, 132-133. pp.].

Az urbanizációnak természetesen megvannak a maga történeti-földrajzi specifikumai. Már a modern urbanizáció első klasszikus korszakának - a XVIII. század végén kirobbanó ipari forradalomtól számítva közel másfél évszázadig, a XX. század első harmadáig - már megvoltak a maga területi differenciái. Amíg az európai nagyvárosok kialakulását, demográfiai növekedését nagyon sokáig a falu-város irányú migráció táplálta, addig az Egyesült Államokban sokkal inkább a szövetségi állam megszületését követően (1776/1787) folyamatossá vált, és bizonyos történelmi periódusokban ${ }^{15}$ meglóduló nemzetközi bevándorlás mértéke határozta meg az urbanizáció mértékét és ütemét. A második világháború utáni időszakban az Egyesült Államokban a nagyvárosok környékén gomba módra szaporodó agglomerációs elővárosi övezetekbe az amerikai középosztálybeliek milliói költöztek ki új értelmet adva az amerikai álomnak és családmodellnek. Addig ugyanabban az időszakban Nyugat-Európában - különösen látványosan Franciaországban - a külvárosok, elővárosok, nagyvárosokkal határos települések sokkal inkább a városi munkásrétegeket vagy más bizonytalan helyzetű egzisztenciákat vonzották, a nagyvárosi térségekben területileg

\footnotetext{
${ }^{15}$ Nagy bevándorlási hullámok az Egyesült Államokban a XIX-XX. század fordulóján; a második világháború elött és alatt.
} 
„kifelé” koncentrálva a városi szegénységet, a szegregációt és bűnözést. Sajátos paradoxon, hogy az amerikai metropolisztérségekben a hátrányos helyzetủ csoportok, s velük a társadalmi problémák „bent maradtak” a belvárosokban (downtow / the core of the city), az európai nagyvárosokban viszont a magas képzettségü értelmiségi, vezetői rétegek sokkal kevésbé mozdultak a szuburbán övezetek irányába. Sok európai nagyváros éppen az elmúlt időszakban szembesült eme káros folyamatokkal, problémákkal (az európai jóléti szociális modell válságba kerülése; másod- és harmadik generációs bevándorlók valamint az egyre inkább globálissá váló migráns problematika), amelyek az Egyesült Államokban már több évtizedes, akár fél évszázados múltra tekintenek vissza. ${ }^{16}$ Bár a fejlett világ - így Európa - urbánus problémái még mindig jelentősen eltörpülnek a fejlődő országokban tapasztaltaktól, ahol gyakorlatilag kontroll nélkül duzzadnak az afrikai, ázsiai és latin-amerikai metropoliszok, roppant méretü nagyvárosi „konfliktuskonténereket” eredményezve - olykor többmilliós embertelen körülmények között tengődő nyomornegyedek, gettók kialakulása a fejlődő Világ nagyvárosi övezeteiben. Az amerikai és európai agglomerációs tendenciák közötti éles eltérésre másik jellemző példa a nagyváros versus szuburbán övezet lakosságmegoszlás aránya a nagyvárosi térségekben. Az Egyesült Államokban egyértelmüen meghatározóbb a szuburbán övezetek lakossága a szüken vett nagyvárosi populációhoz képest - így New York esetében közel kétszeres, a Los Angeles-i metropolisztérségben már háromszoros az agglomerációs gyürü lakossága. Ehhez képest Európában éppen ellentétes arányokat mutatnak a statisztikák, és kevés kivételtől - Párizs, Koppenhága, Lisszabon, Athén - eltekintve még mindig a nagyvárosok lakossága képezi a látható többséget a szuburbán lakossághoz viszonyítva. Az európai nagyvárosok demográfiai, gazdasági és társadalmi mutatóit rendszerező Urban Audit folyamatosan aktualizált statisztikai adatbázisa ${ }^{17}$ szerint a nagyvárosok lakossága még koncentráltabb az egykori posztkommunista országok fővárosainál - Bukarest vagy Szófia esetében például 85-95\% között alakult az arány az ezredforduló időszakában a szűken vett nagyváros és agglomerációs övezet között az előbbi javára [Szirmai, 2011, 26-30. pp.].

A kontinens várospolitikai szakértői előszeretettel hivatkoznak az ún. holland urbanista iskolára (Dutch school - Klaasen-Paelinck, 1981; van den Berg, 1982), amely az európai városfejlődést a városi lakosság számarányának változása alapján növekvő, stagnáló és csökkenö szakaszokra, s így az azokhoz kapcsolódó meghatározó folyamatokra urbanizáció, szuburbanizáció, dezurbanizáció, reurbanizáció - bontotta. Ezt a már három

\footnotetext{
${ }^{16}$ Elég csak gondolni a párizsi 2005-ös vagy a londoni 2011-es külvárosi zavargásokra.

${ }^{17}$ www.ec.europa.eu/eurostat/web/cities
} 
évtizedes elméleti modellt gondolta tovább a magyar urbanista Enyedi György, aki négy szakaszra tagolódó európai városfejlődést vázolt fel:

1. Gyors népességrobbanás a városokban, ennek fő korszaka Nyugat-Európában az ipari forradalomhoz kapcsolódóan már a XVIII. század végétől megindul; Közép- és KeletEurópában azonban csak egy évszázaddal később indult meg - mint az urbanizáció klasszikus szakasza.

2. A városi népesség relatív dekoncentrációja és „kiáramlása” a városkörnyéki övezetbe, településekre, ez a szakasz Nyugat-Európában az 1960-1970-es évtizedekre fejeződik be - mint a szuburbanizáció szakasza.

3. A nagyvárosi agglomerációk, várostérségek szuburbán települései lépnek át egy erőteljes fejlődési szakaszba (demográfiai növekedés, számottevő helyi gazdaság és foglalkoztatás, a helyi közigazgatás és intézményi kapacitás fejlődése) - mint a dezurbanizáció szakasza.

4. A globalizáció (főleg az elmúlt 2-3 évtized) korának jellemző urbanizációs tendenciája (sokszor párhuzamosan a szuburbán térségek dezurbanizációs folyamataival), hogy a nagyvárosok, illetve azok belső kerületei, belvárosi övezetei ismét a népességkoncentráció - benne döntően a fiatalabb, magas képzettségü, piacképes rétegek - meghatározó színterévé válnak. Ennek általános okai között szerepel a szuburbán övezetek telítődése (agglomerációs közlekedési-ingázási nehézségek megnövekedése), illetve a hagyományos városközpontok, belső kerületek építészetiinfrastrukturális megújulása (pl. Budapest belső kerületei az elmúlt évtizedben) - mint a reurbanizáció szakasza. Enyedi a reurbanizációs folyamatok magyarázatát egészíti ki az ezredfordulót követően a modern urbánus életmódot egyre inkább meghatározó a gazdaság negyedik ún. kvaterner szektorának (ICT - Information and Communication Technologies) térnyerésével, illetve az abból erőteljesen fakadó információs robbanással (lásd Castells és társai!), és annak technológiai dimenzióival (pl. szélessávú internethálózatok és kapcsolódó szolgáltatások kiépülése). Enyedi már az ún. globális metropoliszrégiók koráról beszél, amelyek a korábbi időszakhoz képest még inkább koncentrálják a nemzetközi tökebefektetéseket, $\mathrm{s}$ vele a globális világgazdasági mainstream irányát és uralkodó fogyasztási szokásait [Enyedi, 2011, 47-59. pp; Hünnemeyer, 2012, 56-59. pp.]. 


\section{III.1.3 Morfológiai és funkcionális térségi dimenziók}

Érdemes néhány gondolat erejéig kitérni a várostérségi közpolitikai kormányzás kapcsán az alapvető térségi kategóriákra. A területi-térségi tervezés szempontjából kulcsfontosságú, hogy miként születnek a különböző döntések - különösen a helyi önkormányzati közigazgatási határokon túli területek vonatkozásában:

a) Helyi önkormányzati joghatósági-adminisztratív kategória - a nagyváros és a környező szuburbán települések, helyi önkormányzatok közigazgatási határai.

b) $\mathrm{Az}$ összefüggő épített földterületre kiterjedő morfológiai városi terület (morphological urban area - $M U A$ ), amely általában kisebb területre értelmezhető, mint a funkcionális városi térség kategória.

c) A foglalkoztatási, oktatási valamint egyéb szolgáltatási és szabadidős tevékenységekre valamint kapcsolatokra alapuló, a nagyváros és szuburbán települések közötti ingázásra épülő funkcionális városi terület (functional urban area - FUA) kategória. [Tosics, 2008, 20. pp.; Tosics, 2011, 8-9. pp.].

Az Európai Unió nagy városkutatási projektjének, az ESPON keretében (ESPON 1.4.3 - ESPON, 2007) komparatív jelleggel több tucat funkcionális városi térséget mértek fel az adminisztratív önkormányzati joghatóság, a funkcionális városi illetve a morfológiai városi területek, valamint azok lakosságának komparatív összemérésével. Az adatok tekintetében különösen izgalmas az egyes nagyvárosok adminisztratív határain belüli lakosság viszonyítása a FUA illetve $M U A$ becsült lakosságszámokhoz. A legnagyobb különbség a nagyváros és funkcionális vonzáskörzete lakosságszáma tekintetében a franciaországi Lille esetében 11,3szoros, a lengyel Katowice-nél 9,5-szeres volt. Ezzel szemben szinte alig találtak a kutatók differenciát Bukarest (1,1-szeres) Berlin (1,2-szeres), Róma (1,3-szoros) városoknál - ezek az arányok azt jelentik, hogy magának a nagyvárosnak a közigazgatási-adminisztratív határai lényegében megegyeznek a teljes ingázási vonzáskörzet (FUA) képzeletbeli határaival. Ez egy jóval integráltabb önkormányzati joghatósági szisztémát jelent a fragmentált joghatóságú európai funkcionális városi térségekhez képest. Ugyancsak nagyobb aránybeli eltérést észleltek a kutatók Párizs (5,1-szeres), az angliai Manchester (5,1-szeres) vagy Lisszabon (4,9-szeres) vonzáskörzete valamint az adminisztratív city lakossága között, amiből jó eséllyel következik, hogy nagyobb szuburbán területen nagyobb számú helyi önkormányzat található. Budapest a maga 1,5-szeres $F U A$ vs. Budapest lakosságarányával még a koncentráltabb - a népesség eloszlása szempontjából a rendszerváltás óta tapasztalható erőteljes 
szuburbanizálódás ellenére - még mindig az erőteljesen monocentrikus városrégiók közé tartozik Európában [Tosics, 2011, 9. pp.].

Fontos továbbá a morfológiai városi terület $(M U A)$ - mint a nagyvárossal közvetlenül érintkező, lakó- és egyéb funkciójú építményekkel beépített terület - nagyságának az összehasonlítása a nagyváros adminisztratív-közigazgatási határaival, valamint a funkcionális városi területtel (FUA). A $M U A$-nak a nagyváros adminisztratív határain kívül eső lakott részeken, természetes módon intenzívebbek a városkörnyéki kapcsolatok, mint a funkcionális városi térségnek a $M U A$-n kívül eső övezeteiben, hiszen ezek benépesült lakó- vagy gazdasági övezetek: jó példa erre a nagyvárosok és agglomerációs környékük határszakaszán épült lakóövezetek, bevásárlóközpontok, üzemek (pl. Magyarországon a Budapest vagy több megyei jogú város határainál felépült bevásárlóközpontok). A nagyvárosok adminisztratív határövezeteiben domináns beépítés (mint a $M U A$ értelmezési alapja) előbb-utóbb teljes közművesítést is feltételez, valamint a különböző közszolgáltatások illetve közösségi (egészségügyi, közoktatási etc.) intézmények szervezett megjelenését. A 2007-es felmérésre alapuló ESPON 1.4.3 szerint egyes európai nagyvárosok $M U A$ területe szinte az egy az egyben illeszkedett a nagyváros közigazgatási határaihoz: Róma, Prága, Bécs. Budapest esetében is csak 1,2-szeres volt a $M U A$ terület lakossága, mint a hivatalos adminisztratív határon belüli népesség. Ugyanakkor Katowice (7,1-szeres), Manchester (5-szörös), Lisszabon (4,4-szeres) valamint Párizs esetében szintén 4,4-szeres volt a morfológiai városi térségben élők számának aránya a szüken vett nagyvárosi közigazgatási határok közötti lakosságnak. Az európai nagyvárosokhoz kapcsolódó adminisztratív területi, FUA illetve $M U A$ térségi lakossági adatok egy rendkívül sokszínü európai városi agglomerációs képet rajzolnak elénk, ami sokkal heterogénabb, mint akár az amerikai, akár az ázsiai kontinensek hasonló mutatói.

Példának okáért érdemes összehasonlítani az Európai Unió két paramétereit tekintve globális méretű metropolisz London és Párizs lakossági adatait az adminisztratív városhatáron belül, valamint a kapcsolódó $M U A$ és FUA területen:

\begin{tabular}{|l|c|c|c|}
\hline nagyváros & $\begin{array}{c}\text { adminisztratív terület } \\
\text { lakossága }\end{array}$ & $\begin{array}{c}\text { morfológiai városi } \\
\text { térség területe }\end{array}$ & $\begin{array}{c}\text { funkcionális városi } \\
\text { térség lakossága }\end{array}$ \\
\hline London & 7,43 millió lakos & 8,27 millió lakos & 13,71 millió lakos \\
\hline Párizs & 2,18 millió lakos & 9,59 millió lakos & 11,18 millió lakos \\
\hline
\end{tabular}

1. táblázat: a londoni és párizsi adminisztrativ, MUA és FUA lakossági adatok (2007)

(Forrás: ESPON 1.4.3 - ESPON, 2007 - Tosics, 2011, 9. pp.) 
- London - a MUA lakossága 1,1-szeres, a FUA lakossága 1,8-szoros, mint az adminisztratív londoni lakosság.

- Párizs - a MUA lakossága 4,4-szeres, a FUA lakossága 5,1-szörös, mint az adminisztratív párizsi lakosság.

Az EU két legnépesebb metropolisztérségének lakossági adatai remekül jelzik a várostérségi közigazgatás komplex és heterogén jellegét. London esetében az látható, hogy a 2000-es évek második felében a morfológiai város (a nagyvárossal közvetlenül összefüggő beépített övezet) terület alig haladta meg a nagyváros adminisztratív határait, ugyanakkor közel kétszeres lakosságú ingázási övezet (FUA) van a Nagy-London térségben (Great London Area). Párizsnál már merőben eltérő a területi, épített környezeti szituáció: az adminisztratív határain belül alig éltek többen 2007-ben, mint Budapesten. Viszont több mint 4-szer annyian éltek a nagyvárossal határos beépített $M U A$, valamint 5-ször annyian a teljes párizsi $F U A$ térségben.

\section{III.2 A nagyvárosi térségek, folyamatok három lehetséges megközelítése}

A városi, nagyvárosi térségek közpolitikai-kormányzati dimenzióihoz három alapvető megközelítést alkalmaznak a témával foglalkozó szakértők, ezek a következők: területigeopolitikai megközelítés; helyi önkormányzati jogi-intézményi megközelítés; regionálistérségi funkcionális (közgazdaságtani) megközelítés.

\section{III.2.1 Területi-geopolitikai megközelítés}

A területi-geopolitikai megközelítés a földrajzi elhelyezkedés, a természeti környezet (domborzat, ásványkincsek, termőföld), valamint a fennálló társadalmi tényezők (munkaerőpiac, demográfiai adottságok, jövedelmi-, vagyoni differenciák etc.) összefüggéseiből konvergált területi-térségi értelmezési keret. A XIX. század végén megszülető klasszikus tudományos geopolitika (a német Friedrich Ratzel; a svéd Rudolf Kjellén nyomán) nagyon sokáig kizárólag államközpontú, állam-bázisú elmélet maradt - az állam, amely ,uralja a teret”. Ez tükröződött vissza már a XIX. század nagy hatású nemzetközi geopolitikai elméleteiben, mint a Mackinder-féle „szívtájék” (heartland), a Monroe-elv, vagy a XIX. század közepi amerikai földrajzi terjeszkedést legitimáló „Manifest- 
destiny", majd azt a tengerentúli expanziókra is kiterjesztő Mahan-elv. ${ }^{18}$ Az államközpontú geopolitikai megközelítést a XX. század meghatározó konfliktusai (világháborúk és a hidegháború) konzerválták. Így születettek meg az olyan újabb államközpontú geopolitikai elméletek, mint az egykori amerikai külügyminiszter Brezinski nevéhez köthető eurázsiai sakktábla - ahol az eurázsiai makrotérség, mint az amerikai geostratégia kulcsterületeként került meghatározásra [Brezinski, 1999], vagy a hidegháború után hivatalosra emelt Pax Americana gondolata (,az USA az egyetlen szuperhatalom, globális hegemón, amely a világon bárhol érvényesíteni képes érdekeit"). ${ }^{19}$

Az elmúlt évtizedek modern társadalom- és közgazdaságtudományi elméletei szerint ugyanakkor a globalizáció éppenséggel sok szempontból kikezdte, megkérdőjelezi a korábban domináns államközpontú paradigmát. A kortárs nemzetközi geopolitika fontos teoretikusa a brit-amerikai John Agnew lamentál írásaiban, hogy a hagyományos állam-bázisú világ súlyosan zilálódik, és ez már akár rövidtávon korábban nem tapasztalat minőségü és jellegü rendetlenséget teremthet a glóbuszon [Agnew, 2002]. A hagyományos államközpontú geopolitikai tereket egyre inkább felváltják az alapvetően a globális piaci szereplők által meghatározott új posztmodern geopolitikai terek szupranacionális (makrogégiók - országcsoportok, szubkontinensek) és szubnacionális (központi régiók, nagyvárosi régiók, különleges gazdasági övezetek, határmenti térségek etc.) értelemben is. Ez, a különösen a fejlett várostérségek kiemelt funkcióira alapozó új motivációs koordinátarendszer elsősorban a nemzetközi nagyvállalatok oldaláról generálódik, de egyre inkább átveszik és alkalmazzák az államok és egyéb piaci és non-profit szereplők (pl. KKV szektor; alapítványok; kutatói konzorciumok). Mező Ferenc a geopolitikai terek újrastrukturálódásáról a következőképpen írt egy 2007-es tanulmányban: „Az individuális pénzügyi piacok elveszítik különálló identitásukat. Ebböl következik, hogy az államok már nem tudják kontrollálni saját gazdasági sorsukat” [Mező, 2007, 6. pp.]. Ugyanakkor érdemes utalni arra, hogy a 2008-ban kirobbant

\footnotetext{
${ }^{18}$ Halford J. Mackinder szerint a ,heartland” (szivtájék) Kelet-Európában van, és aki uralja, dominálja KeletEurópát, az dominálja a világpolitikát is 1904-es elmélete szerint. A Monroe-elv 1823-ban, az „Amerika az amerikaiaké" felszólítással igyekezett az európai hatalmakkal (angolok, franciák) tudatosítani az erősödő Egyesült Államok igényét mindenféle külső kolonizációs törekvések elutasítására az észak-amerikai kontinensen. A Manifest-destiny, már az USA hatalmi igényeit legitimálta Észak-Amerikában, majd a Mahan tengernagy nevével fémjelzett Mahan-elv már egyértelmüen megfogalmazta az Egyesült Államok flottaépítési és ezzel, mint általános tengeri hatalom megjelenésének törekvését - Bernek Ágnes: Geopolitika és/vagy geoökonómia - A 21. század világgazdasági és világpolitikai folyamatainak összefüggései (in: Geopolitika a 21. században, Zsigmond Király Főiskola - L'Harmattan, Budapest, 2010) 28-31. pp.

${ }^{19}$ A Pax Americana-nak két eléggé eltérő értelmezése is született a hivatalos amerikai külügy részéről az elmúlt két évtizedben, így az expanziót alapvetően gazdasági eszközökkel fenntartani igyekvő 1995-ös Clintondoktrína, majd annak egy erőteljes katonapolitikai aspektust kölcsönző Bush-doktrína (ez utóbbi, mint a „megelöző csapás” elmélete, lett a 2003-as iraki beavatkozás legitimációs alapja, amely jelentősen megosztotta a nemzetközi közösséget és közvéleményt).
} 
gazdasági-pénzügyi világválság, amely sok szempontból napjainkig érezteti a hatását, újra felértékelte az államok, valamint a kormányközi nemzetközi aktorok szerepét - pl. állami válságkezelő bankmentő csomagok és központi keresletélénkítő akciók; EU-s pénzügyi transzferek az adósságválságba került tagállamok részére. Az új regionális geopolitikai megközelítésnek nagyon fontos aspektusa a nagyvárosi régiókban, övezetekben, térségekben való határozott befektetői gondolkodás, amely hatással van a nemzeti és természetesen a helyi-lokális közpolitikák alakítására. A nagyvárosi térségek gazdasági dinamizmusát biztosítják a központi részek, a szük értelemben vett nagyvárosok, városközpontok, belvárosi övezetek, amelyek egyúttal kiemelkedő igazgatási-adminisztratív központként funkcionálnak. ${ }^{20} \mathrm{~A}$ klasszikus városias részek köré épült - a központi részekkel sokirányú komplex napi szimbiózisban agglomerációs, szuburbán területek képezik a nagyvárosi térségek másik meghatározó területi szegmensét.

\section{III.2.2 Helyi önkormányzati jogi-intézményi megközelítés}

A várostérségekben alkalmazott helyi önkormányzati struktúrákra irányuló jogiintézményi megközelítés (self-government, local government) fókusza az önkormányzás joga, annak gyakorlása - szervezeti és müködési aspektusa. A helyi-lokális önkormányzat kategóriát a szakirodalom helyi alapszintü [Pálné, 2008a] önkormányzatként nevesíti, amelyek az urbánus várostérségekben az állampolgárokhoz legközelebb eső önkormányzati szintet jelenti - a nagyvárosi kerületi helyhatóságok, de az agglomerációs övezetekben található autonóm helyi (települési) önkormányzatok is ebben a körbe tartoznak. Természetesen beszélhetünk a nagyváros teljes közigazgatási területére kiterjedő önkormányzati illetékességgel rendelkező nagyvárosi önkormányzatról - Budapest esetében a Fővárosi Önkormányzat. A városkörnyéki önkormányzati kapcsolatok kiemelkedő szegmensét képezik a kifejezetten a különböző helyhatóságok közötti jogi-intézményi aktusok, mint a nagyváros által a környező önkormányzatok adminisztratív alapú „,bekebelezése”, annexiója, de a szereplők szabad akaratából következő önkormányzati

\footnotetext{
${ }^{20}$ Legyenek azok önkormányzati (nagyvárosi, illetve az egész metropolisz térséghez kapcsolódóan) vagy államigazgatási (területi dekoncentrált intézmények, szakmai háttérintézmények) szervtípusok. A fövárosok pedig általában az országos törvényhozó (parlament), igazságszolgáltatási (legfelsőbb bíróság, etc.) valamint központi kormányzati intézmények (minisztériumok, országos hatáskörú szervek) túlnyomó többségének elhelyezését is biztosítja a föváros adminisztratív centruma (administrative centre). Az elmúlt évszázadban viszont több olyan kísérlet is történt, hogy különbözö okok (szociális-demográfiai, politikai) alapján országok fövárosai megváltoztak kifejezetten az országos adminisztratív (központi állami intézmények) befogadására - pl. Brazíliában a Rio de Janeiro - Brazíliaváros cserét kifejezetten Rio túlnépesedése és szociális problémái generálták.
} 
fúziók, illetve az autonómiájukat érdemben nem érintő együttmüködések, társulások. A nagyvárosi térségek speciális közjogi „terméke” a föderatív kétszintű nagyvárosi önkormányzati tanács - egyúttal, mint a disszertáció meghatározó kutatási kérdése illetve a felvázolt modellkisérlet alapja! -, amely nem összekeverendő az egyszintü nagyvárosi önkormányzattal. A kétszintü agglomerációs tanács a nagyváros és agglomerációs övezetének egy föderatív jellegü, speciális metropolisz (teljes várostérségi, agglomerációra kiterjedő) szintü intézményesített önkormányzati formája, amely érintetlenül hagyja az alsóbb szintü helyhatóságok - nagyváros, azon belül nagyvárosi kerületek, valamint a szuburbán övezet helyi önkormányzatai - autonómiáját, miközben meghatározott feladatokat rendel a metropolisz szintre, és annak különböző intézményeire. ${ }^{21}$ Kifejezetten a nagyvárosokra jellemző speciális közjogi szituáció, hogy a nemzeti törvényalkotó kiemelt, kvázi területi önkormányzati joghatóságot biztosíthat számukra, ami a fővárosok esetében általában kiemelt fővárosi jogállást takar, a nem főváros nagyvárosok esetében lehet a) alsó-középszintü [pl. számos amerikai metropolisz rendelkezik a tagállami szint alatti ottani megyei (city-county)] jogállással, de lehet b) magasabb ún. mezoszintü területi önkormányzati (city-province) joghatóság. Ez utóbbi közjogi megoldást alkalmazzák számos európai országban, elég csak Brüsszel vagy Bécs - mindkettő tartományi jogállásban -, vagy akár a német Hamburg, Berlin és Bréma nagyvárosokra asszociálni. Ez utóbbi a speciális jogállás jellemzi a magyarországi megyei jogú városokat is, amelyek az irányadó szabályozó törvény szerint saját területükön ellátják a megyei önkormányzatok feladat-, és hatáskörét - a megyei jogú várások illetve a megyei önkormányzatok közötti speciális viszonyokról lásd később a magyarországi fejezeteknél!

\section{III.2.3 Regionális-térségi funkcionális (közgazdaságtani) megközelítés}

A nagyvárosi térségekkel kapcsolatban az utóbbi néhány évtizedben egyre inkább előtérbe kerülnek a regionális gazdaságtanból eredeztethető funkcionális, müködési megközelítések. A területi megközelítés mellett - amelynek esetünkben vizsgált alapkategóriája a többé-kevésbé egységes hálózatú városi agglomerációs térség - egyre pregnánsabb a funkcionális specifikáció, ahol a várostérségi jelleg külön meghatározott indikátorokban (statisztikai mutatók, tevékenységtípusok etc.) keresendő. Olyan fogalmakat

\footnotetext{
${ }^{21}$ Ez lehet a meghatározott feladatokat ellátó metropolisz tanács (metropolitan council), vagy speciális egycélú valamely közszolgáltatást koordináló és müködtető - önkormányzati jellegü hatóság (special-purpose type, special district).
} 
használ a közgazdaságtan a várostérségek kapcsán, mint a csomóponti régió; a növekedési pólus (growth pole); az alfa, béta és gamma világvárosok; a policentrikus városhálózatok.

Napjainkra a globális világgazdaság folyamatait magyarázó teoretikusok egyre inkább hangsúlyozzák a térbeli szemlélet, $\mathrm{s}$ vele az egyes földrajzi helyek - mint a globális multinacionális nagyvállalatok potenciális - adottságait, differenciáit, a lehetőségeit és hátrányait, amelyek mentén megszületnek a stratégiai befektetési döntések. Ez a regionálislokális megközelítés alapozott meg olyan közgazdasági irányzatokat, elméleteket, mint az „új gazdaságföldrajz” (new regionalism) [Krugman, 1991] illetve a teljes regionális gazdaságtan [Isard, 1956; Lengyel-Rechnitzer, 2004]. Ez az eredője a regionális gazdasági klaszterelmélet, mint a vállalkozás-gazdaságtan egyik legfrissebb elméleti hajtásának is [Porter, 1990, 1998].

Amíg Krugman a világgazdaság és a nemzetközi kereskedelmi tendenciák vizsgálatából jutott el a földrajzi koncentráció fontosságáig, addig Porter számára a globális vállalati stratégiák elemzése jelentette a kiindulópontot. A gazdasági klaszterek jellegüknél fogva egyszerre kapcsolódnak a globális és lokális dimenziókhoz, mivel a globális vállalatokkal - illetve azok telephelyeivel - a földrajzi kapcsolódás okán együttműködő helyilokális vállalatok és egyéb intézmények (így az államigazgatási szervek és önkormányzatok) dinamikus együttmüködését, közös halmazát tekinthetjük. Európában, s így Magyarországon - köszönhetően az Európai Unió pozitív ösztönzésének és kapcsolódó programjainak is egyre kiterjedtebb irodalma van a klaszter-elméleteknek és a területi gazdasági versenyképesség empirikus megközelítéseinek [Lengyel 2003; Lengyel-Rechnitzer 2002; Hegedűs 2008; Szanyi, 2008]. Mivel a müködő gazdasági klaszterek jellegüknél fogva igénylik a fejlett nagyvárosi és városkörnyéki infrastrukturális környezetet, megkerülhetetlen a helyi közigazgatás és politika támogatása az ilyen típusú kezdeményezésekhez. Így a gyors és hatékony hatósági engedélyezési, szabályozási gyakorlat; befektetőbarát politikai környezet; helyi adómentesség vagy adókedvezmények biztosítása; egyéb technikai- és pénzügyi transzferek. A klaszterfolyamatok egyik legkényesebb eleme a politika, s vele a közszféra jelenléte, katalizátorszerepe: a nemzetközi szakirodalom alapvetően egyetért abban, hogy a közszféra nem sajátíthatja ki és nem pótolhatja a reálszféra jelenlétét. Ezért sokak szerint az első lépést a különböző ágazati-iparági gazdasági szereplőknek szükséges megtenni, és az állam (vagy önkormányzat) lehetőleg csak azt követően lépjen be a maga támogató katalizátorfunkcióival. Kérdéses, hogy a klaszterfolyamatok generálásában és dinamizálásában milyen a központi állami-kormányzati és milyen a helyi (térségi, települési) önkormányzati szint szerepvállalása: egy decentralizált - regionális, föderális államberendezkedési szisztémában jó eséllyel nagyobb szerep jut az önkormányzati 
szereplőknek. A központi kormányzat széles országos áttekintéssel és intézményi koordinációs kapacitással bír, ugyanakkor a helyi szereplök (politikusok, civilek és helyi gazdasági szereplők) a konkrét helyismeret mellett sokkal erősebb személyes érdekeltséggel, motivációkkal bírhatnak az ilyen típusú üzleti innovációs folyamatok esetében. [Szanyi, 2008, 41-42. pp.].

A nagyvárosok közvetlen vonzás-, és ingázási övezeteken túlmutató dinamizáló szerepkörének vizsgálatán alapszik az ún. növekedési póluselmélet, amely alapjait francia közgazdászok tették le az XX. század közepén, második harmadában: Jean-Francois Gravier $^{22}$, J.R. Lausén vagy Francois Perroux [Gravier, 1947; Lausén, 1969; Parr J.B., 1999]. A növekedési póluselmélet a központi régiók túlsúlyos szerepére - benne a fővárosok mármár „nyomasztóan” kiemelkedő demográfiai, gazdasági, társadalmi és politikai-igazgatási pozícióival -, és ezzel területi értelemben monocentrikus „fejnehéz” növekedési modellre kívánt reagálni, illetve azt csillapítani a meghatározó vidéki régióközponti funkciót betöltő nagyvárosok kiemelt központi fejlesztésekkel, közvetlen vagy közvetett dotációval való támogatásával. Ezek a vidéki nagyvárosok, mint potenciális növekedési pólusok már egy új típusú policentrikus (többközpontú) település- és várospolitika alapjait jelölik ki. A policentrikus fejlesztés a modern regionális gazdaságtan egyik kulcsfogalmává vált, amely értelmezhető országos (a vidéki nagyvárosok és térségeik támogatása); de szubnacionális térségi (regionális; metropolisz övezetben) értelemben is. A policentrikus növekedési pólusok fejlesztéspolitikai gyakorlata ma már természetes eleme nemcsak a nemzeti kormányzati területfejlesztési politikáknak, stratégiai alapdokumentumoknak - pl. Magyarországon a jelenleg hatályos Nemzeti Fejlesztés 2030 - Országos Fejlesztési és Területfejlesztési Koncepcióról szóló 1/2014. Ogy. Határozat -, de egyre inkább integráns része a közvetlen nagyvárosi agglomerációs terveknek, közpolitikai stratégiáknak. Ugyanakkor az Európai Unió hivatalos város- és területfejlesztési politikája is egyre erőteljesebben épül a policentrizmus holisztikus alapelvére - ESDP $^{23}$ 1999; Lille Akcióprogram 2000; Lipcsei Charta 2007, Gödöllő 2011.

\footnotetext{
${ }^{22}$ Gravier híres hasonlata a „Párizs és a francia sivatag”, amelynek azonos címen megjelent első kiadása 1947ben éppen a párizsi központi régió gazdasági túlsúlyának központi kormányzati gazdaságfejlesztési és célzott - a vidéki nagyvárosokra koncentráló - területfejlesztési koncepcióját tüzte zászlóra, mint a területi differenciák mérséklésének gyógymódját - J-F. Gravier: Paris and the French Desert [Paris, Portulan 1947]

${ }^{23}$ ESDP - European Spatial Development Perspectives (Európai Területi Fejlesztési Perspektívák)
} 


\section{III.3 A nagyvárosi térségek közpolitikai perspektívái}

Napjainkra az indusztrializált és posztindusztrializált szakaszban tartó országokban a nagyvárosi térségek társadalmi, gazdasági és kulturális szempontból olyan rendkívül dinamikus és komplex entitásokként írhatóak le, amelyek kiterjedt területi és funkcionális belső struktúrákkal - pl. kommunikációs és tömegközlekedési szisztémák - rendelkeznek. Ezek a nagyvárosi térségek szerteágazó társadalmi és gazdasági hálózatokon alapulnak, függetlenül a belső igazgatási-helyhatósági határoktól. A magasan urbanizált várostérségekben az alapvető paradoxon, hogy amíg gazdasági szempontból valódi erőtereknek, csomópontoknak minősülnek, addig sok esetben önkormányzati igazgatási szempontból gyengék, esetlegesek, sok esetben széttartóak [Lefévre, 2010, 623. pp.]. A nemzetközi urbanista szakirodalom alappremisszája (lásd Enyedi már hivatkozott négyes tipologizálását!), hogy a globalizáció kifejezetten serkentőleg hat a többközpontú policentrikus nagyvárosi régiók kialakulására, illetve a nagykiterjedésű urbanizált térségek gazdasági, demográfiai és nem utolsósorban területi növekedésére. A XX. század közepéig, harmadik negyedéig jobbára monocentrikus (egyközpontú) városfejlődési folyamatok többközpontúvá válása nagyban köszönhető a nemzetközi nagyvállalatok transznacionális expanziójának és a kapcsolódó tőkemozgásokhoz (leányvállalatok alapítása és aktivitása) - új befektetési célterületek, s vele új potenciális urbánus központok kerültek fókuszba. Másrészt a sok esetben túlzsúfolt, szociális problémákkal (szlömösödés etc.) küszködő nagyvárosok átesnek a városfejlődés olyan posztmodern folyamatain, mint a dezurbanizáció és reurbanizáció. ${ }^{24}$ Mindezen hatások együttesen kiterjesztik a korábbi nagyvárosi térségek természetes (és nem közigazgatási) határait, egyúttal gazdasági és demográfiai tekintetben dekoncentrálva azok korábban jórészt monocentrikus jellegét. Ez a folyamat a szakértők szerint az Egyesült Államokban már az 1950 és 1960-as években végbement, egy-két évtizedes késéssel Nyugat-Európában jelentkezett, valamint az ezredforduló óta hasonló tendencia figyelhető meg az ázsiai metropoliszok - elsősorban Kelet-, Délkelet-, és DélÁzsiában - térségében. A következőképpen definiálható a folyamat, egymástól fizikailag és közigazgatásilag szeparált (fragmentált) több tucatnyi, akár száz feletti urbánus jellegü település - benne egy vagy akár több nagyvárossal - közötti funkcionális, elsődlegesen

\footnotetext{
${ }^{24}$ A magyarországi városfejlődés makroregionális megkésettségét jelzi, hogy a dezurbanizáció és bizonyos már a reurbanizációra utaló jelek csak Budapest és agglomerációja esetében érzékelhetőek, a vidéki nagyvárosok (meghatározó megyei jogú városok, régióközpontok) általában még csak a második szuburbanizációs szakaszban vannak.
} 
gazdasági kapcsolódások hirtelen dinamizálódnak, térben meghatározott gazdasági ágazati, területi klasztereket és metropolisz térségi szintű egységes munkaerőpiacot eredményezve. Olyan széles, de funkcionális értelemben egységes nagyvárosi régiók, térségek jönnek létre, amelyeket a magas népesség és sürü népsűrüség mellett rendkívül intenzív és fejlett közlekedési és kommunikációs infrastruktúrák (sűrü közút és autópálya-hálózat; kiterjedt tömegközlekedés; telekommunikációs és egyéb vonalas hálózatok) hálóznak be. Az amerikai Lang és Dhavale 2005-ös összefoglaló kötetükben csak az Egyesült Államokban több metropolisztérségből harmonikusan összeérő 10 db ún. megalopolisz övezetet nevesítenek, amelyek 197 millió embert, az ország akkori népességének 68\%-át tömörítették magukban [Hall-Pain, 2006, 3-5. pp.].

\section{III.3.1 A nagyvárosi térségek helye a modern világgazdaság rendszerében}

Az amerikai David Harvey ,új területi vonatkozási pontokként” (new spatial fix) definiálta a globalizált világ metropolisz térségeit. Harvey több közgazdász teoretikusra, így Paul Krugman és Jeffrey Sachs írásaira hivatkozik, akik a korábbi - értsd: globalizáció elötti korszaknak alapvetően a nemzetállami keretek között müködő nemzetgazdasági csomópontok helyett az „új gazdaságföldrajz” (new economical geography) alapegységeként már a nagyvárosokat és a hozzájuk kapcsolódó agglomerációs, szuburbanizációs övezeteket értelmezik. Nagyhatású 1985-ös The Geopolitics in Capitalism címü írásában Harvey a következő néhány alapvető premisszát állította fel: a) a kapitalizmus történeti túlélésének alapja a földrajzi expanzió; b) az innovatív kereskedelmi-szállítási és kommunikációs technológiák, mint az expanzió elengedhetetlen feltételei; c) a gazdasági-termelési környezetet nagyon erősen befolyásolja a rendelkezésre álló nyersanyag, az aktív munkaerő minősége és mennyisége illetve a fennálló piaci viszonyok [Harvey, 1985, 2001]. Az emberi civilizáció, valamint a kapitalista gazdasági- és társadalmi modell földrajzi expanziójának meghatározó dimenziója a városok térnyerése: a központi piaci pozíciót betöltő gazdasági centrumok, koncentrált terek szerepe; hatásuk a szükebb (agglomeráció, szubnacionális régió) és tágabb (állam, szupranacionális makrorégió, szubkontinens) környezetre. A globalizáció s vele az 1970-es évektől a 2008-ban kirobbanó gazdasági világválságig dominánsak számító neoliberális gazdasági modell - kritikusai az állami kontrollfunkciók általános gyengülésével, $\mathrm{s}$ vele a posztmodern gazdasági monopóliumok, oligopóliumok megerösödésével magyarázták az elmúlt négy évtizedben megnövekedett gazdasági és társadalmi különbségeket. Az élenjáró, fejlett régiók, nagyvárosi térségek még inkább elhúztak; a leszakadt térségek versenyhátránya pedig tovább duzzadt a globalizáció korában. 
A világgazdaság térbeli szerveződésével foglalkozó Bernek Ágnes egy a témával foglalkozó tanulmányban 7 premisszában foglalta össze a napjainkra a nemzetközi gazdasági viszonyok által egyre inkább determinált globalizáció vs. lokalizáció témakört [Bernek, 2006, 78-79. pp.]:

1) A meghatározó globális gazdasági rendezőelv a koncentráció (ugyanakkor a tudatos vagy spontán dekoncentráció is tendencia lehet) - pl. telephely koncentrálódás; új növekedési pólusok

2) Erősödő nemzetközi gazdasági függőség: a nemzetgazdaságok illetve a szubnacionális egységek egyre inkább függő helyzetbe kerülnek a multinacionális vállalatok, mint globális gazdasági játékosok által uralt pályán - ennek teoretikus előképe Immanuel Wallerstein világrendszer-elmélete (centrum - félperiféria periféria) tekinthető [Wallerstein, 1983].

3) A földrajzi elhelyezkedés, pozíciók fokozatos relativizálódása: az információs forradalom és általában a globalizáció jelentősen „lecsökkentette” a földrajzi távolságokat (pl. e-business) - ez az ún. „,világfalu” jelensége az amerikai Marshall McLuhan nyomán [McLuhan, 1968].

4) A hagyományos földrajzi-geopolitikai pozíciók mellett a térbeli áramlások legyen az gazdasági, társadalmi, kulturális - és a különböző hálózati jelenségek, dominanciája [Castells, 1996, 1997].

5) Napjaink világgazdasági rendszerének már közel sem a nemzetgazdaságok, hanem sokkal inkább a világvárosok és nagyvárosi térségek jelentik az alapvető elemzési egységeket - lásd Harvey, Krugman vagy Porter munkásságát!

6) Sokkal komplexebb és dinamikusabb a térszerkezet, mint 30-40 évvel ezelőtt, így nagyobb az esélye annak is, hogy egyedi, speciális versenyelőnyökkel rendelkező szubnacionális térségek, nagyvárosi övezetek „kitörhessenek” a tágabb nemzeti, makroregionális közeg determináns kereteiből.

7) A globalizáció a nemzetállamokat új típusú szupranacionális és makroregionális kezdeményezésekre ösztökéli, amelyek köre a szimplán gazdasági szabadkereskedelmi együttmüködésektől (NAFTA, ASEAN, CENTAO etc.) egészen a bonyolult politikai és gazdasági unióig (Európai Unió) terjedhet.

A határokon átnyúló gazdasági folyamatok (tőke- és munkaerő-áramlás; nemzetközi árukereskedelem; globális turizmus) jellege és volumene drámai átalakuláson esett át az 1980as évek óta: az állami- és önkormányzati szektorok felgyorsult privatizációja és a 
közszektorban tapasztalható erőteljes dereguláció; a nemzetgazdaságok korábbi időszakokhoz képest erőteljes megnyitása ${ }^{25}$ a külföldi (globális) multinacionális vállalatok számára; valamint a szabad kereskedelmi övezetek és globális infrastrukturális hálózatok (telekommunikáció, közlekedés, kereskedelem etc.) - mindezek még inkább kiemelték a nagyvárosi térségek szerepét a nemzetközi gazdasági és társadalmi folyamatok során. A külvilág és a nemzetközi közvélemény számára a nagyvárosok, mint az adott régió, tartomány „szubnacionális szimbólumaként” is megjelennek, olyan nemzetközi jelentőségü események házigazdáiként, mint az olimpiai játékok, világkiállítás, nemzetközi konferenciák és vásárok, nemzetközi kulturális rendezvények. ${ }^{26}$ A globális anyacégek külföldi leányvállalatai koncentrálódnak - olyan globális, regionális gazdasági központokat erősítve, mint New York, London, Szingapúr vagy Sao Paolo -, de egyúttal új helyszíneket (régiók, térségek, városok, központi telephelyek) is keresnek, amelyre jó példa a rendszerváltás utáni posztkommunista közép-európai régió olyan központjai, mint Prága, Varsó, Budapest vagy 2000 után Bukarest. A felgyorsult nemzetközi gazdasági koncentráció és diszperzió eme párhuzamos folyamatán alapulnak az új posztmodern globális városok és városhálózatok; a nemzeti és szubnacionális, valamint a nemzetközi piacok fokozatos egymásba integrálódása számára is a nagyvárosi térségek jelentik a fó kapcsolódási pontot [Sassen, 2002, 1-8. pp.]. Ugyanakkor az új termelési- és szolgáltatási mechanizmusok (posztfordista gazdasági modell) újrastrukturálták a vállalati szektor telephely-stratégiáit is, fokozatosan dekoncentrálva a gazdaság korábbi, sokkal inkább a belvárosra összpontosuló térbeli hálózatokat - így váltak, válnak az elővárosok, agglomerációs térségek egyre inkább kedvelt befektetési célpontokká. ${ }^{27} \mathrm{~A}$ meghatározó ipari-, kereskedelmi és egyéb szolgáltató centrumok tudatos kitelepítése a külvárosok, illetve az agglomerációs övezetek (külterület, szuburbán települések) felé, maga után vonta a teljes nagyvárosi önkormányzati policy (reguláció; hatósági-engedélyezési gyakorlat; területpolitika; helyi szakpolitikák) újragondolását - kifejezetten egy vállalkozóbarát és befektetés-orientált proaktív nagyvárosi, várostérségi önkormányzati attitüd irányába. A globalizáció korában a nagyvárosok szubnacionális, de szupranacionális szinteken is egymás gazdasági versenytársaivá váltak, adott esetben rontva ezzel a

\footnotetext{
${ }^{25}$ Ez erőteljes kapcsolatban van a Szovjetunió - s vele a KGST - szétesésével az 1990-es évek elején, s vele a korábbi kommunista országok politikai és gazdasági változásaival (többpártrendszerek és gazdasági kapitalizálódás).

${ }^{26}$ Csak a közelmúltat tekintve az olimpiai rendezővárosok közül Barcelona (1992) Katalónia, Atlanta (1996) az amerikai Georgia állam, Sydney az ausztrál Új-Dél Walles állam számára hozott nagyon jelentős marketingértéket; de említhetnénk Budapest és a Sziget Fesztivál kapcsolatát, utóbbi a magyar fóváros talán legfontosabb nemzetközi brand-jévé vált az elmúlt másfél évtizedben.

27 Magyarországon a fővárosi agglomerációból 1990 után jó példa Budaörs város, amely külföldi cégek leányvállalatai számára kedvelt befektetési telephellyé vált.
} 
metropolisz térségek kölcsönös kooperációs lehetőségeit - pl. kölcsönös fellépés az országos politikai szint ellenében; közös makroregionális közpolitikai kezdeményezések [Kálmán, 2006, 50. pp.].

\section{III.3.2 A fogyasztás hatása a befektetői szándékokra a nagyvárosi térségekben}

A The McKinsey Global Institute 2012-ben napvilágot látott Urban world: Cities and the rise of consuming class összefoglaló tanulmányában az urbánus térségeket a következő tényező szerint vizsgálta: termelés és növekedés; pénzügyi piaci pozíciók; technológia és innováció; urbanizációs folyamatok; munkaerőpiac; természeti erőforrások. A tanulmány alappremisszája, hogy a globális makrogazdasági folyamatok és kényszerek alapjaiban befolyásolják a nagyvárosi térségek önkormányzati stratégiáit és az alkalmazott közpolitikákat. A tanulmány becslése szerint a világ 600 legnagyobb nagyvárosi térsége fogja biztosítani a 2010-2025 közötti globális gazdasági növekedés 65\%-át (évente mintegy 30 trillió dollár). A globális erőtér átalakulását és a feltörekvő országok (Kína, India, Dél-kelet Ázsia, Latin-Amerika) erősödő piaci pozícióit jelzi, hogy a 600 metropolisz térség közül mintegy 440 ezekben a régiókban található. A becslés mögött elsősorban a gazdaságilag feltörekvő országok (különösen Kína és India) egyre növekvő lakossági fogyasztói elvárásai állnak, amelynek eredője a tömeges középosztályosodás jelensége. ${ }^{28}$ [McKinsey Global Institute, 2012, 6-10. pp.]. A posztmodern, globalizációs hatások által meghatározott nagyvárosiasodás egyszerre jelent lakosság- és népsürüség-, gazdasági telephely, munkaeröpiac- és jövedelemkoncentrációt.

A McKinsey tanulmány szerint a világ nagyvárosi térségeiben egy olyan közel 1 milliárdos népességü ún. globális fogyasztói osztály (global consumer class) alakulhat ki 2025-re, amely jövedelmi viszonyaival és vásárlóerejével kiemelkedik a világ népességéből. ${ }^{29}$ Ez a rohamosan növekvő progresszív fogyasztói tömeg a jövedelmi pozíciókhoz hasonlóan magas szintű fogyasztói elvárásokat fogalmaz meg nemcsak a reálszféra (benne különösen a csúcstechnológiai teljesítményeket, termékeket produkáló kvaterner szektorok), de a

\footnotetext{
${ }^{28}$ Az ENSZ a Világ városait és nagyvárosi tendenciáit összefoglaló 2011-es tanulmányában 200 millió lakos felettire becsüli azoknak a számát, aki csak a fejlődő országokban, régiókban és csak a 2000 és 2010 közötti időszakban törtek, törnek ki a mélyszegénység (slum conditions) körülményeiböl - State of the World's Cities 2010/2011 (United Nations Human Settlements Programme - UNHABITAT, London, 2011, 6. pp.)

${ }^{29}$ A McKinsey tanulmány által globális fogyasztói osztály sok szempontból nagyon is rokon a Richard Florida által megalkotott kreativ osztály (creative class) értelmezésével, amennyiben az igényes fogyasztói szokások így a közszolgáltatásokhoz kapcsolódóan is -, a kreatív alkotó munkakörök, a kiegyensúlyozott jövedelmi viszonyok és magas életminőség magas szinten prezentálódnak ezeknél a döntően nagyvárosi rétegek, csoportok esetében.
} 
különböző állami és helyi önkormányzati közösségi szolgáltatások irányába is - legyen az terület- és településfejlesztés, lakás- és ingatlan-fejlesztések, gazdaságfejlesztés. Ugyanakkor már most tapasztalható, hogy a globális vállalati szereplők kitüntetett figyelmet szentelnek eme új globális fogyasztói osztály demográfiai összetétele, kulturális szokás- és attitüdrendszere, illetve jövedelmi viszonyaira - ezek egyre erősebben befolyásolják a nagyvállalatok expanzív üzlet- és telephely-politikáját (befektetés, tökekivonás, struktúraváltás), valamint termék- és szolgáltatásskáláit. Jó példa a globális élelmiszeripari szereplök ázsiai üzletpolitikáját meghatározó olyan tényezők, mint a nagyszámú vegetáriánus indiai háztartás vagy a magas átlagéletkorú Japánban a nagyszámú, de jól szituált időskorú lakosság. [McKinsey Global Institute, 2012, 18-20. pp.].

A 2000-es évekig alapvetően a nemzeti dimenzió és értelmezési keret dominálta a globális vállalati stratégiai döntéseket - melyik országban érdemes befektetni, hol szolgálják ki jobban az állami apparátusok a befektetői érdekeket. Az expanzióra kiszemelt országok (benne természetesen konkrét térségek, települések) gazdasági, társadalmi és politikaiigazgatási viszonyai voltak az elsődleges szelekciós szempontok: így a kedvező adózási viszonyok (adómentesség, adókedvezmények), a befektetések jogi környezete, a helyben megtalálható szakképzett munkaerő, hatékony állami (és önkormányzati) bürokrácia, stabil és kiszámítható politikai viszonyok, kiépített modern hálózatos infrastruktúrák (internet, szennyvíz, csatorna etc.).

Az elmúlt egy-másfél évtizedben érzékelhető roppant gazdasági és társadalmi dinamizálódás következtében a nagyvárosi térségek egyre inkább önálló entitásként, befektetői célpontként jelennek meg a globális piaci szereplők gondolkodásában. A McKinsey olyan várostérségi példákat illusztrált, amelyek önmagukban már sokkal vonzóbb potenciális befektetési célpontként jelennek meg, mint tágabb (régiós és országos) környezetük. Ilyen a nyugat-indiai Surat, amely a szubkontinensi ország textiliparának kétötödét koncentrálja; a jelentős kikötői kapacitásokkal rendelkező Porto Alegre Brazíliában; vagy a kínai high-tech fejlesztési központ, Fosan városa. A McKinsey szakértői következtetése, hogy a globális piaci befektetők ma már inkább vizsgálják a célpont nagyvárosok és a környező övezetek viszonyaiban rejlő fogyasztási, infrastrukturális és egyéb (önkormányzati igazgatási, helyitérségi piaci beszállítói szereplők) lehetőségeket, mint a nemzeti feltételeket. Az új befektetésekért illetve a telephelyek megszerzésért folytatott küzdelem ${ }^{30}$ a korábbi jobbára

\footnotetext{
${ }^{30}$ A multinacionális befektetések telephelyeiért való versenyre regionális példa volt néhány évvel ezelőtt a Mercedes autókat gyártó német Daimler AG közép-európai új gyártóhelyszínéért folytatott küzdelem több
} 
nacionális keretek mellett áttevődik a nagyvárosi térségekre - felértékelve a várostérségi önkormányzati politikai szinteket -, ki és milyen feltételekkel tudja fogadni, menedzselni a nemzetközi befektetői szándékokat. [McKinsey Global Institute, 2012, 21-23. pp.].

\section{III.3.3 A kreatív gazdaság és közpolitika összefüggései a nagyvárosi térségekben}

Az elmúlt közel két évtized egyik legizgalmasabb kortárs társadalomtudományi diskurzusa az ún. kreatív gazdasági tevékenységformák, illetve azok társadalmi- és igazgatási „lecsapódásaira” fókuszál. A globális világgazdaság térbeli sarokpontjai éppen a terjedő, szélesedő, gazdasági és társadalmi szempontból terebélyesedő nagyvárosi térségek - mint „,igazodási pontok” (Harvey). Az ún. kreativ, innovatív ágazatok, tevékenységek abszolút mértékben koncentrálódnak, s ezzel egy masszív, de akár jótékony hatásúnak tekinthető versenyt generálnak az urbánus térségek között a vállalati (különösen a tercier és kvaterner ágazatokban) telephelyekért. Ez a versenyhelyzet leképeződik az alkalmazott nagyvárosi szakpolitikák és politikai-igazgatási eljárások (adórendszer; területhasználat; hatósági engedélyezési gyakorlat; ingatlanpolitika; népjóléti politikák; közösségi közlekedés etc.) szintjére. A magas szintü, fejlett gazdasági tevékenységformák (az ún. kreatív ágazatok ICT, nanotechnológia, kulturális iparágak, tudomány és felsőoktatás etc.) által foglalkozott aktív munkavállalók és családjaik hasonlóan fejlett igazgatási, intézményi és társadalmi szabályozási és végrehajtási közeget igényelnek. A kreatív közpolitikai gyakorlat éppen a kreatív gazdaság nyugodt és kiegyensúlyozott hátterének biztosítására irányul akár klasszikus városközpontokról, nagyvárosokról akár szuburbán településekről van szó. A kreatív gazdaság „kitermelt” egy kifinomult fogyasztói és kulturális igényekkel rendelkező a világ metropoliszaiban folyamatosan növekvő népességü ún. kreatív osztályt (creative class), ${ }^{31}$ amelynek a minőségi közszolgáltatások iránti, valamint különböző szakpolitikai igényei egyre határozottabban artikulálódnak a nagyvárosi közpolitikai döntéshozók, valamint a különböző közpolitikai hálózatokban résztvevő egyéb stakeholder csoportok irányába. A kreatív osztály tagjai számottevő ún. kreatív tőkével rendelkeznek. A kreatív tőke az eredetileg a Putnam által meghatározott klasszikus társadalmi tőkekoncepció (social capital) [Putnam, 1993] mint a modern társadalmak alapvető kötőszövete, kohéziós anyaga - továbbgondolása. Annak elemeit kiegészítve eredményez egy magas szintü kreatív és mindenekelőtt a tehetség és

magyarországi és romániai város között, amit végül Kecskemét nyert meg, és kezdődhetett meg a termelés 2012ben.

${ }^{31}$ A folyamatosan növekvő létszámú és magas intellektusú, tevékenységü és igényủ kreatív osztály természetes része a világ nagyvárosi övezeteiben tömörülö lassan milliárdnyi ún. globális fogyasztói osztálynak, amelyröl szól az idézett McKinsey Global Institute tanulmány. 
technológiai újítások iránt rendkívül nyitott, valamint a különböző kisebbségek (szexuális és etnikai minoritások, fogyatékosok etc.) iránt toleráns társadalmi tudatot, világképet: „3 T”tehetség, technológia, tolerancia (talent, technology, tolerant). Így jutva el a putnami társadalmi tőkétől a Florida-féle kreatív tőke jelenségéig (,,from social capital to creative capital”). Az elsősorban a nagyvárosi térségekre koncentrálódó kreatív osztály elmélet alapjait az amerikai szociológus Richard Florida fektette le nagyhatású írásaiban az ezredforduló utáni években, így vált napjaink egyik meghatározó posztmodern társadalompolitikai diskurzusává - Európában különösen a progressive governance címszó alatt tevékenykedő think-thank, a Demos Institute volt aktív a kreatív tőkeelmélethez kapcsolódó kutatási, kiadói és konferencia területen a 2000-es évtizedben. ${ }^{32}$

Florida 1995-ben - még az internet globális társadalmi robbanásának a hajnalán értekezett az ún. tanuló régiók (learning regions) jelenségéről, ahol a tudásteremtés és az új tudás-intenzív ágazatok, iparágak dominálnak. A tudás illetve a kreatív ötletek összegyüjtése és alkalmazása, egy olyan fenntartható környezeti és társadalmi háttér-infrastruktúrát igényel, amely hatékonyan támogatja és biztosítja az innováció áramlását. Ezeket a térségi fókuszpontokat, térségeket nevezi Florida tanuló régióknak. Így a kaliforniai Silicon Valley, mint az ICT $^{33}$ szektor globális központja; az olyan tőzsdei-pénzügyi központok, mint New York, London vagy Tokió; a globális filmkultúra Los Angelesben (Hollywood); a divatvilág olyan innovatív bástyái, mint az olaszországi Milánó. De már ez az idén két évtizedes tanulmány is megemlíti a fejlődő világ néhány feltörekvő központját, úgy, mint Tajvan, Szingapúr, Bangkok (Thaiföld), Jakarta (Indonézia), Szöul (Dél-Korea), a kínai és indiai nagyvárosok az ázsiai kontinensről, vagy Latin-Amerikából Mexikóváros vagy a brazil Sao Paolo. „Tudásforradalom zajlik”, ahogy Florida fogalmaz, és a globalizált korszak előtti jórészt a Taylor-i (scientific management) és a Henry Ford által lefektetett klasszikus tömegtermelésre épülő kapitalista modellt egy sokkal inkább a fizikai munka dominanciáját kiváltó szellemi munkára és teljesítményre alapozó tudás-intenzív munkaerőpiac és profitmodell váltja fel [Florida, 1995, 527-536. pp.]. Floridához hasonlóan a japán Kenichi Ohmae szintén már az 1990-es években azt hangsúlyozta, hogy a nemzetállamokat

\footnotetext{
32 Florida elméletének legfontosabb hazai propagátora a Demos Magyarország Alapítvány volt a 2000-es években, amely több önálló tanulmányban is foglalkozott a kreatív osztály európai (elsősorban az EU) és magyarországi vonatkozásaival. De emellett évről-évre több hazai tanulmány, írás foglalkozik a Florida-féle elméleti konstrukció magyarországi leképeződésével. Ságvári Bence: A kreatív osztály felemelkedése (Gondolat Kiadó, Budapest, 2008); Ságvári Bence - Lengyel Balázs: A magyarországi kreatív munkaerő területi és időbeli változásáról (Demos Magyarország Alapítvány, Budapest, 2008); Borsi Balázs - Viszt Erzsébet: A kreatív és kulturális ágazatok (CCI) szerepe és növekedési lehetőségei a Budapest Metropolisz Régió gazdaságában (GKI, Budapest, 2010.)

${ }^{33}$ ICT - Information and Communications Technology
} 
világgazdasági szemszögből egyre nehezebb értékelni természetes egységként és helyette sokkal inkább érdemes regionális entitásokról (Ohmae definíciója szerint: regional-state) gondolkodni [Ohmae, 1995].

A brit Patsy Healy a 2004-es Creativity and Urban Governance címü tanulmányában azon governance típusú eszközök, keretek kutatását szorgalmazza, amelyek hatékonyan kiszolgálják a jelentős humán kapacitású kreatív tevékenységeket, folyamatokat; segítenek átvagy kialakítani a modern nagyvárosi kormányzás kultúráját; ezzel képesek mobilizálni és gazdagítani az egész nagyvárosi kormányzás kontextusát. A kulcsmondat „keresni az újat”új szakpolitikák (new policies), új projektek (new projects), új eljárások, (new practises) és új emberek (new people). Healy saját lakóhelyének, az angliai Newcastle példáján keresztül magyarázta a kreatív közpolitika és városi kormányzás pozitív hatásait. Newcastle a klasszikus „rozsdaövezetbeli” angol nagyvárosok megszokott problémáival küszködött az 1980-1990-es években. Komoly szemléletváltás következett be azonban a városvezetés gondolkodásában az ezredfordulóra, amely alapja a 2008. évi Európa Kulturális Fővárosa címnek megszerzése volt -, erről az EU-ban általában 8-10 évvel korábban szoktak dönteni, a minél hatékonyabb komplex felkészülés és megvalósítás érdekében. A Newcastle-i Európa Kulturális Fővárosa projekt nagy hangsúlyt fektetett a kreativitás - mint kulturális tényező megerősítésére és népszerűsítésére (pl. a multifunkcionális Sage Music Centre létrehozása). Healy szerint ahhoz, hogy valóban kreatív kulturális termékek és innovatív produktumok szülessenek egyszerre szükséges a megfelelő patrónus (legyen az köz- vagy magánszereplő) illetve a megfelelő befogadó hallgatóság, közeg, fogyasztó [Healy, 2004]. Nem véletlen, hogy egyre nagyobb jelentősége van a Világon, hogy a kiemelkedő teljesítmények, tevékenységek, események számára mely települések (városok, nagyvárosok) biztosítanak helyszínt, legyen az kiemelkedő nemzetközi sportesemény (olimpiai, világ- és kontinensviadalok), tudományos konferencia, kiterjedt tudományos- és felsőoktatási intézményrendszer, $\mathrm{K}+\mathrm{F}$ beruházások, pezsgő kulturális élet (fesztiválok, színház etc.).

\section{III.4 Közpolitikai stratégia és koordináció a nagyvárosi térségekben}

A kreatív gondolkodás és a megfelelö innovatív közpolitikai eszközök megválasztása, alkalmazása és folyamatos belső minőségi kontrollja akár jelentősen javíthatja egy önkormányzat közpolitikai hatékonyságát (policy efficiency), a helyi kormányzásnak a lakosságra gyakorolt hatásait (policy efficacy) és végső soron a településvezetés újraválasztási esélyeit, mint a közpolitikai eredményesség (policy effectiveness) meghatározó indikátorát. A 
nagyváros térségi, városkörnyéki önkormányzati kooperációk, s vele a nagyvárosok és a környező települések térségi együttmüködéseinek vizsgálatánál a legfontosabb kiindulópont maga a nagyváros. A térségi önkormányzati kapcsolatokat nagymértékben meghatározza a központi magtelepülés társadalmi és gazdasági adottságai, valamint a helyi-lokális közpolitikák (gazdaság- és foglalkoztatáspolitika; oktatás, egészségügyi- és szociálpolitika; ${ }^{34}$ környezetvédelmi és fenntarthatósági szempontok, mint holisztikus horizontális közpolitikai alapelvek etc.) kvantitatív és kvalitatív összetevői. A modern nagyvárosi kormányzás kialakításában, a kölcsönös előnyökre épülő kooperációk megteremtéséhez a nagyvárosok térségi szolgáltató (spill-over) szerepe mellett szükséges a városkörnyéki település, agglomerációs gyürűk szerves és hatékony hozzájárulása. A nagyváros mindenképpen hatással van a környező településekre, ugyanakkor a szuburbán önkormányzatok is pozitívan hozzájárulhatnak a teljes agglomerációs, városkörnyéki térség életminőségéhez, gazdasági és társadalmi munkamegosztásához: a nagyvárosból a lakó- és ipari, kereskedelmi telephelyek „kiköltöztetései” révén a városkörnyéki települések tehermentesítik a nagyvárost és infrastruktúráját; a mezőgazdasági termelés és a ráépülő élelmiszeripar hozzájárulhat a nagyváros élelmezéséhez etc.

Ebben a megváltozott lokális, de egyúttal globálissá is vált miliőben a nagyvárosi térségi kapcsolatok és koordináció szerepe jelentősen felértékelődik. Egy az európai metropolisz politikai-igazgatási modelleket bemutató 2003-as tanulmánykötet a nagyvárosi közpolitikai (policy) koordináció 3 szintjét nevesítette:

a) területi koordináció - az országos, regionális (szubnacionális területi), a nagyvárosi valamint a helyi alapszintü önkormányzati egységek közötti interaktív és integrált közpolitikai koordináció (pl. az egyes szakpolitikák nemzeti, regionális és lokális „összemérése”)

b) funkcionális koordináció - a nagyvárosi térségen belül a föld- és területhasználat (területfejlesztés- és rendezés etc.) illetve a különböző szakpolitikák (környezetpolitika, gazdaságfejlesztés, közlekedés, lakáspolitika etc.) ágazati koordinálása, „egymásra hangolása”

\footnotetext{
${ }^{34}$ A jóléti (egészségügy, oktatás, szociális terület, kultúra és egyéb humánszolgáltatások) politikák területén a különböző települések szerepét a rendelkezésre álló erőforrásokon (saját bevételek, befektetésvonzó képesség etc.), túl az adott közfeladat-, közszolgáltatás területén kialakított kompetenciák, a központi állami és önkormányzati szintek között hatáskör meg- és elosztások determinálhatják. A Magyarországon a 2010-2014-es parlamenti és kormányzati ciklusban elfogadott jogszabályi változásoknak köszönhetően érzékelhetöen csökkent a jóléti politikák esetében az önkormányzati feladatellátás, miközben párhuzamosan növekedett az állami területi dekoncentrált intézmények (megyei/járási kormányhivatalok; egyedi hatáskörökkel ellátott szakigazgatási szervek) munkája.
} 
c) szektorközi koordináció - a köz- (esetünkben az önkormányzati), a privát és a nonprofit szereplök közötti fejlesztési, beruházási és egyéb közpolitikai együttmüködések a stratégiai tervezéstől és közös projektek felmerülésétől (agenda setting) egészen azok megvalósításáig (policy implementation) - pl. nagyvárosi PPP projektek [SaletThornley-Kreukels, 2003, 6-7. pp.].

Kulcskérdés, hogy ez a hármas koordináció milyen intézményi közpolitikai keretek között valósul meg, legyen szó előzetes konzultációról és javaslattételi jogokról illetve a politikum felől a másik két szektor irányába delegált bizonyos döntési pozíciókról - egyszóval melyek az eredményesen alkalmazott közpolitikai eszközök, megoldások a nagyvárosi térségekben, amelyek képesek egységesen kezelni a nagyvárost és agglomerációs övezetét, azok problémáit, válságjelenségeit. A területi koordináció, azon belül is a felsőbb (országos, regionális) szintekkel történő formális és informális szakpolitikai konzultációk talán a legfontosabb kooperációs mechanizmusok: különösen olyan problematikák esetében, amelyek tartalmuknál és jellegüknél fogva éppen a nagyvárosi térségek lakosságát és közintézményi rendszerét sújtják leginkább.

A nemzetközi befektetésekért folytatott küzdelem általános versenyt eredményez a helyi önkormányzatok között: éppen ezért van kiemelkedő fontossága a különböző várostérségi közpolitikai válaszoknak (terület- és ingatlangazdálkodás, helyi adópolitika, munkahelyteremtés, infrastruktúrafejlesztés, klaszterpolitika, városi szegénység kezelése etc.) - legyenek azok közvetlen kezdeményezések, stratégiai növekedési tervek, lokális igazgatásiadminisztratív keretek. Ajánlott továbbá a rövid-, közép és hosszú távú közpolitikai tervek, célok harmonikus „összeillesztése”, valamint függetlenítése az önkormányzati politikai ciklusoktól, aktuálpolitikai „,vonzalmaktól”. Szükséges kiszámíthatóvá alakítani a metropolisz térségek külső (ön)kormányzati kapcsolatait - intergovermental network, ahogy Rhodes azt definiálta [Rhodes, 1992].. Az „okos és vállalkozó város” (smart \& enterpreneur city) címszó jegyében ajánlott a környezetbarát technológiák alkalmazása az önkormányzati ingatlanállomány felújítása, bővítése terén; a teljes nagyvárosi agglomerációs tömegközlekedési szisztémák optimalizálása - ezzel mintegy közvetve formálva a helyitérségi lakossági fogyasztói szokásokat, motivációkat. Mindezek alapja pedig egy fenntartható hatékony és felelősségteljes nagyvárosi fiskális menedzsment (eredmény- és célorientált költségvetés; beruházás és befektetési politikák) működtetése.

A globális világgazdaság kihívásai napjainkra hatványozottan jelennek meg a nagyvárosi stratégiaalkotás: az elsődleges kulcsszó a versenyképes város (competitive city), 
amelynek közpolitikai megalapozása idestova évtizedek óta folyik az OECD, az Európai Unió, egyéb nemzetközi kutatócsoportok és szakértők részvételével. A francia Christian Lefévre is hivatkozik a Harvey-féle „új vonatkozási pont” definícióra - s vele a nagyvárosi térségekre, mint a jelen globális kapitalizmusának fontos sarokköveire. Ugyanakkor Lefévre hangsúlyozza, hogy a nagyváros térségi folyamatok politikai-igazgatási dimenziói sokszor jelentősen elmaradnak a gazdaságitól. Álláspontja szerint ahhoz, hogy ezek a nagyvárosi térségek a gazdaságihoz hasonlóan egységes politikai-igazgatási entitásként is megjelenhessenek, elegendő politikai (állampolgári) legitimációra illetve ahhoz kapcsolódó önálló politikai felelősségre van szükség. Mindehhez pedig olyan önálló metropolisz-szintü koordinált és komplex szakpolitikák, közpolitikák intézményesített szisztémája szükséges, amely rendszerszinten alkalmas az átfogó gazdasági és társadalmi kihívások, problémák kezelésére; regulációs keret, amely hatékony jogi, intézményi, eljárási eszközöket tud rendelni a célokhoz; és különböző kollektív akciókon keresztül megfelelően képes mobilizálni illetve aktivizálni a metropolisz régiók különböző politikai, gazdasági és non-profit szereplöit [Lefévre, 2010, 623-626. pp.].
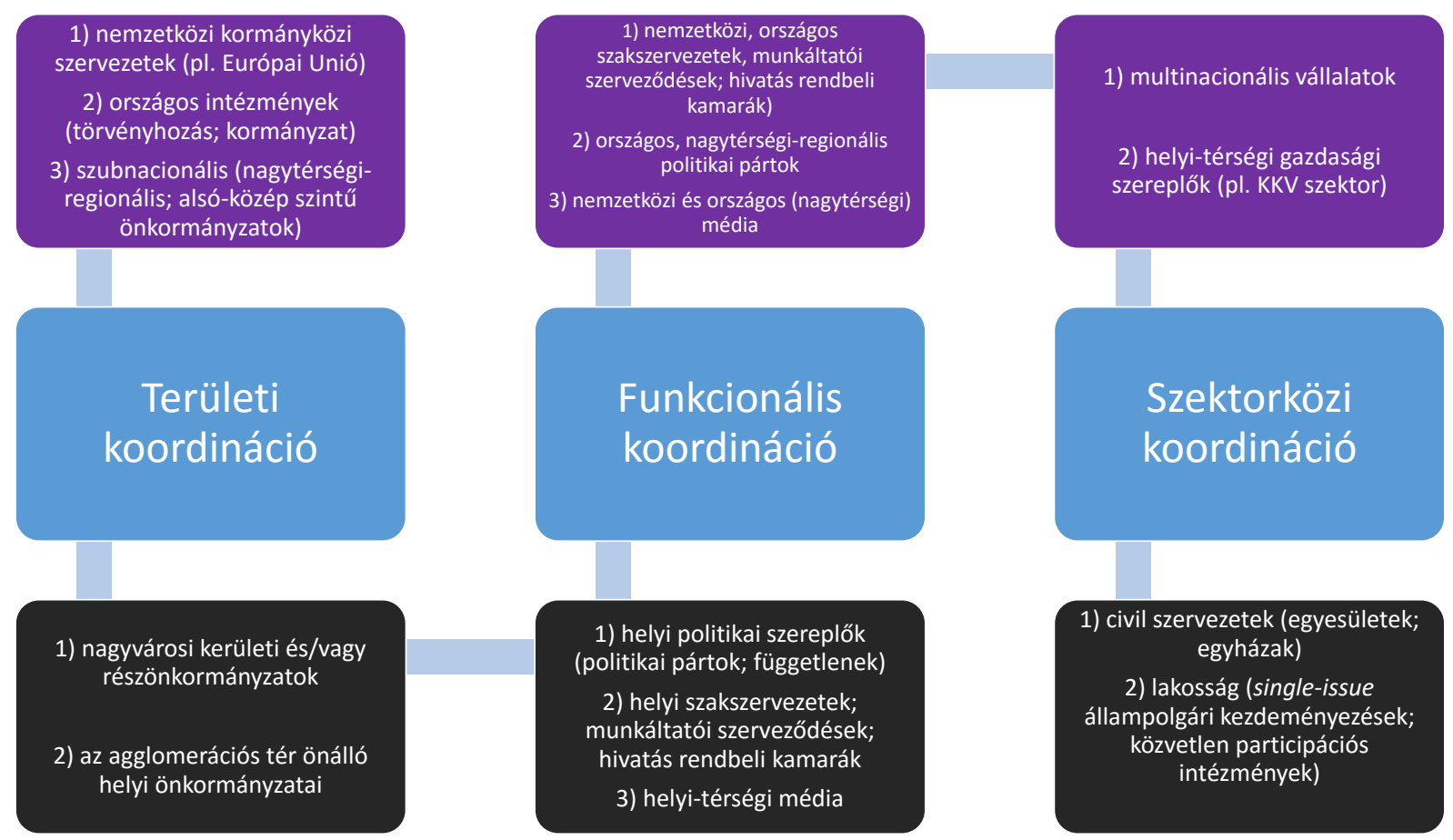

7. ábra: A közpolitikai koordináció egyes szintjei a nagyvárosi térségekben - saját szerkesztés! 


\section{III.4.1 OECD alapelvek a nagyvárosi térségi kormányzásról}

A fejlett ipari államokat tömörítő OECD 2000-ben hozta nyilvánosságra a nagyvárosi kormányzás dimenzióit összegző általános jelentését The reform of metropolitan governance címen. A dokumentum a ,jó kormányzás” (good goverance) bázisát 3 tényezőben nevesítette a nagyvárosi térségekre vonatkozólag:

1) A politikai-önkormányzati és igazgatási joghatóság közötti differenciák, anomáliák eredményes feloldása.

2) Hatékony önkormányzati fiskális-közpénzügyi kondíciók, rendszerek és eljárási módszerek.

3) A transzparens, átlátható döntéshozatali folyamatok kialakítása [OECD, 2000, 2. pp.].

A 2000-es OECD jelentés szerint a nagyvárosi kormányzásnak nincs egyetlen üdvözítő modellje, minden nagyvárosi térség rendelkezik a maga sajátos lokális-térségi, illetve nemzeti-állami politikai, intézményi, kulturális és egyéb kontextusaival. Nagyfokú rugalmasság és adaptációs kényszer szükséges a rapid gazdasági és társadalmi változások, kihívások kezeléséhez a várostérségekben. A progresszív nagyvárosi kormányzás az intézményi és finanszírozási reformok mellett igényli a társadalmi attitüdök és a kormányzás kultúrájának valódi szerves fejlődését (fejlesztését). Egyre inkább alapfeltétel, hogy a hagyományos „top-down” dimenziójú vertikális tagozódású kormányzati rendszerek direkt választási / delegálási legitimációját egészítse ki egy széles társadalmi befogadáson és konzultáción alapuló participatív, horizontális alapú konzultáció, döntés-előkészítő (agenda setting) szisztéma.

A hatékony nagyvárosi kormányzás „kinyitása” érdekében különböző közpolitikai elvek (policy direction) kerültek megfogalmazásra az OECD által. Kiemelten fontos a politikai döntéshozók legitimációjának erősítése; a különböző vezetői kompetenciák fejlesztése illetve a helyi önkormányzati szavazási eljárások modernizációja. Ugyanakkor a szervezet szorgalmazta a teljes politikai döntéshozatal participatív alapú megújítását és megerősítését a különböző stakeholder csoportok aktív bevonásán keresztül, valamint a különböző multiszektoriális megoldások alkalmazását - pl. a köz- és üzleti szféra együttmüködését.

A globalizáció kihívásaihoz leginkább egy flexibilis ún. „vállalkozói nagyváros” (enterpreneurial city), képes hatékonyan alkalmazkodni az alábbi funkcionális adottságokkal: [OECD, 2000, 3-4. pp.]. 
- Üzleti szektor - diverzifikált, nagy hozzáadott értékkel rendelkező ipari- és szolgáltató szektor; az új technológiák alkalmazására fogékony ágazatok jelenléte, kiemelt közpolitikai ösztönzése.

- Vonalas és humán infrastruktúra - modern közlekedési és kommunikációs feltételek; jól képzett humán erőforrás; hatékony köz- és felsőoktatási intézményrendszer; jól funkcionáló nemzetközi gazdasági kapcsolatok.

- Kormányzati-közpolitikai ${ }^{35}$ rendszer - erős és hatékony nagyvárosi kormányzás; valódi stratégiai közpolitikai tervezés; az innováció és a minőségi gazdasági, termelöszolgáltató klaszterek támogatása; a különböző szektoriális politikák összehangolása; a különböző követendő szakpolitikákat megalapozó indikátorok, monitoring és ellenőrző-rendszerek alkalmazása.

- Civil környezet - kiegyensúlyozott társadalmi környezet; pozitív kulturális légkör; jól funkcionáló hálózatias jellegü város és vonzáskörzete kapcsolatok.

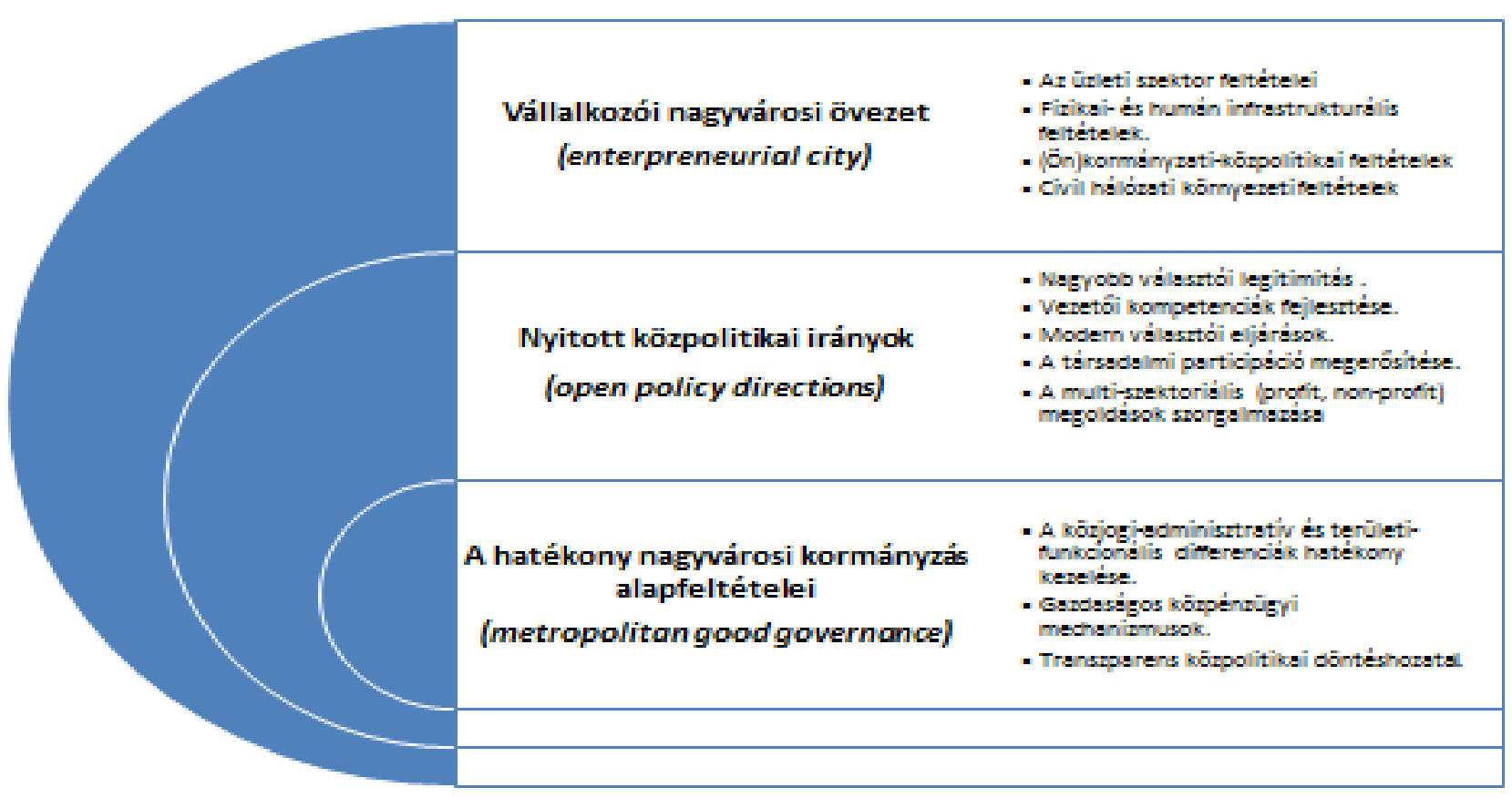

8. ábra: ajánlott OECD közpolitikai alapelvek a várostérségi kormányzáshoz (Forrás: The reform of metropolitan governance, OECD 2000) - saját szerkesztés!

\footnotetext{
${ }^{35}$ Itt egyidejüleg gondolhatunk a helyi (város, városkörnyék) önkormányzati közpolitikákra, de a központi kormányzati közpolitikák ösztönző szabályozási, eljáási és közvetlen támogatási, transzfermegoldásaira - pl. állami szintủ keretjogszabályok; növekedési pólusprogramok; egyéb központi hatáskör- illetve pénzügyi transzferek, akciók. Sőt az Európai Unió tekintetében magára, az EU által alkalmazott direkt és indirekt eszközökre (közösségi jogforrások; közpolitikai jelentések és riportok; Európai Uniós támogatások).
} 
A jelentés kiemelten foglalkozott a várostérségi kormányzás pénzügyi-fiskális kérdéskörével. Az OECD hangsúlyozta a helyi saját bevételek ${ }^{36}$ növelését, egyúttal a központi állami transzferektől, támogatásoktól való függetlenedés motivációját; a nagyváros erőteljesebb megjelenését a tőkepiacokon (közvetlen önkormányzati nyílt értékpapír-piaci müveletek etc.); a korábbiakhoz képest a nagyváros hatékonyabb részvételét a térségi tervezésben; valamint a magánszektor (elsősorban az üzleti, másodsorban a non-profit) további térnyerését a különböző közösségi feladatok- és szolgáltatások terén. A lehetőségekhez mért fiskális önállóság mellett legalább annyira fontos a központi kormányzati és nagyvárosi térségi közpolitikák összevetése, és meghatározott struktúrák mentén való közvetlen tapasztalati koordináció. A 2000-es OECD jelentés nyilvánvalóvá tette, hogy a decentralizáció és a szubszidiaritáson alapuló ajánlott „,nagyvárosi agglomerációs út” napjaink globális gazdasági közegben nagyon is függ bizonyos specifikus tényezőktől. Ilyen többek között a nagyvárosi térségek, városrégiók erősebb megjelenítése a nemzeti jogrendszerekben - pl. magas szintü jogszabályi, törvényi szabályozásokkal. A jelentés további szorgalmazott eleme volt a kreatív - az üzleti szektor szerves bevonására építő - közösségi szolgáltatások, valamint nagyobb transzparencia elérése a lokális politikai döntéshozatalban. Szükséges a lakosság minél szélesebb hozzáférésnek biztosítása a különböző közszolgáltatásokhoz illetve a közérdekű információkhoz; a kormányzás egészét átható teljesítményértékelés; és általában a helyi demokrácia (választás eljárások fejlesztése etc.) erősítése a nagyvárosi régiókban, - ez utóbbiak együtt a nagyvárosi kormányzás kinyitásaként is értelmezhetőek [OECD, 2000, 6. pp.].

\section{III.5 Várostérségek az Európai Unió közpolitikai stratégiáiban}

Amíg az Európai Unió területfejlesztési politikájában az 1980-1990-es évek alapvetően a térségi régiók (NUTS2) kiemelt szerepéről szólt - (kohéziós politika etc.), addig az elmúlt másfél évtizedben a városi kormányzás és annak település-hálózati aspektusai kerültek előtérbe - persze a regionális felzárkóztatás holisztikus törekvése továbbra is megmaradt az EU kiemelt prioritásai között. Az új szemlélet nyitányát az Európai Bizottság által előkészített és a területfejlesztésért felelős uniós szakminiszterek által 1999-ben elfogadott Európai Fejlesztési Területi Perspektívák (European Development Spatial Perspectives - ESDP) jelentette.

\footnotetext{
${ }^{36}$ Ez tartalmazza a helyi szinten generálható összes önkormányzati bevételt, legyen az vállalkozási, intézményi müködési illetve adó- és járulékbevétel.
} 


\section{III.5.1 ESDP 1999}

Az ESDP elfogadásának, $\mathrm{s}$ vele az európai uniós területfejlesztési politika megújításának elsődleges oka az 1993-as Kohéziós Alap felállításával megerősíteni kívánt kohéziós politika relatív sikertelensége volt az ezredfordulóhoz érve: a 25 legalacsonyabb GDP mutatókkal rendelkező NUTS2 régió 1986-1996 között csak az EU-átlag 52\%-ról 59\%re való előrelépést tudta elérni [ESDP, 1999, 9-10. pp.]. Az ESDP a megfogalmazott területi célok eléréséhez 7 beavatkozási területet, közpolitikai eszközt, intézményt nevesített: közösségi versenypolitika; Transzeurópai Hálózatok (TEN); Strukturális Alapok; közös agrárpolitika (CAP); környezetvédelmi politika; kutatási, technológia- és fejlesztéspolitika (RTD); az Európai Befektetési Bank (EIB) hitelnyújtási aktivitása. ${ }^{37}$

A meghatározott beavatkozási területek eltérő mértékben érintették az urbánus és rurális térségeket. Az 1999-es ESDP nevesítve foglalkozott a policentrikus fejlesztés illetve a városfalu kapcsolatokkal. A gyorsabb területi konvergencia kulcsát az ESDP a többközpontú, policentrikus városi szisztémák fejlesztésében, valamint az urbánus és falusi kapcsolatok dinamizálásában és diverzifikálásában (a hagyományos kapcsolódási pontok újszerü kiegészítésével - pl. a vidékfejlesztés szerepe) definiálta. Az ESDP kihangsúlyozta, hogy szükséges közösségi eszközökkel ösztönözni a gazdaságilag versenyképes dinamikus városi gazdasági zónák teljesítményét - benne a gazdasági versenyképesség mellett a humánszolgáltatások (oktatás, a kultúra, a szociális szolgáltatások, a tudás- és innováció területei) fejlesztését. Továbbá a helyi-lokális autonómiák tiszteletben tartása mellett, de erősíteni kell a különböző területi feladatellátás- és fejlesztési kooperációkat. Az ESDP fontos közpolitikai bázist és hivatkozási alapot jelentett a 2000 utáni határmenti település- és térségközi kooperációk számára. Ez magában foglalta a már több évtizedes múltra visszatekintő (euroregionális kapcsolatok) együttmüködéseket, valamint a 2006-ban elfogadott, a tagországok, regionális illetve helyi hatóságok Európai Területi Együttmüködési Csoportosulásairól ${ }^{38}$ szóló 1082/2006/EK rendeletet, amely a korábbiakhoz képest egy jóval integráltabb jogintézményi keretet teremtett a határokon átívelő települési (így a város-falu) együttmüködésekhez [Kaiser szerk., 2006].

Ugyanakkor a dinamikáját vesztett várostérségeknél az ESDP a meglévő gazdasági bázis diverzifikációjához erőteljes közpolitikai beavatkozást szorgalmazott - pl. a gazdasági jelleg funkcióváltása és a potenciálok áthelyezése az elavult strukturális problémákkal terhelt

\footnotetext{
${ }^{37}$ TEN - Trans-European Networks; CAP - Common Agricultural Policy; RTD - Research, Technology and Development; EIB - European Investment Bank.

${ }^{38}$ EGTC - European Grouping of Territorial Coordination
} 
termelő ágazatokról a szolgáltatások irányába. ${ }^{39}$ Nevesítésre kerültek a nagyváros környéki szuburbán agglomerációs területek, mint a versenyképesség területi bázisai a termelés, magán- és közszolgáltatások és a munkaerőpiac számára. Megfogalmazódott a hatékony terület-felhasználás és a fizikai expanzió (urban sprawl) megfelelő kontroll alatt tartása; a közösségi közlekedés fejlesztése; valamint a környezetei fenntarthatóság, mint horizontális közpolitikai alapelv általános integrálása a nagyvárosi és agglomerációs szakpolitikák rendszerében - levegő- és vízvédelem; zajártalmak kiszürése etc.

A praktikus településközi partnerségi kooperációk során szükséges tiszteletben tartani a szereplők autonómiáját. A városok magasabb szintü fizikai és humán infrastruktúrájukból fakadóan bizonyos szolgáltatások (akár a köz-, akár a magánszolgáltatások) esetében egyfajta szolgáltató központ (service pool) funkciót kell, hogy ellássanak a környékbeli települések bizonyos közfunkcióit segítve, bizonyos közfunkcióit pedig akár kiváltva.

Az ESDP kifejezetten a város-falu kapcsolatokhoz ajánlotta a következőket:

1) Fenntartani a városok által fenntartott és müködtetett szolgáltatási és tömegközlekedési szisztémákat a falusi térségekben (különösen a csökkenő lakosságszámú övezetekben).

2) A városi-falusi partnerségi kapcsolatok ösztönzése - ezáltal a valódi funkcionális régiós jelleget erősítve.

3) Integrált fejlesztési stratégiák ${ }^{40}$ megalkotása a nagyváros és környéke viszonylatában - agglomerációs stratégiák etc.

4) Ösztönözni és nemzeti, transznacionális szintekre emelni városi-falusi partnerségi kapcsolatokat - fejlesztési projektekhez való csatlakozás, ,jó gyakorlatok” (best practise) alkalmazása;

5) Klaszterjellegű piaci-vállalkozási jellegü hálózatok támogatása a nagyváros és környéke viszonylatban [ESDP, 1999, 21. pp.; 25-26. pp.].

\section{III.5.2 Lille 2000}

Az akkori francia uniós elnökség időszakában, 2000. október 6.-án az EU területi tervezésért és városi ügyekért felelős szakminisztereinek informális tanácskozásán

\footnotetext{
39 Több európai nagyváros például az Európai Unió által 1985-től egy évre adományozott Európa Kulturális Fővárosa címet igyekezett sikerrel kihasználni a gazdasági hangsúlyok újrafazonírozására illetve a versenyképesség javítására - pl. Glasgow 1990; Liverpool 2008, amely városok a kultúra és a tercier szektor irányába történő elmozdulásra igyekeztek felhasználni a lehetőséget. Valami hasonlóra készült a címet magyar városként első ízben elnyerő Pécs is, az már egy másik kérdés, hogy a projektet folyamatos botrányok - a beruházások befejezésének és átadásának késlekedése etc. - kísérték.

${ }^{40}$ A 2000-es évtized végére az EU nyomására készültek a tagállamokban, így hazánkban is
} 
előterjesztett Lille Akcióprogram (Lille Action Program 2000) többéves szakmai várospolitikai kooperációs programot fogadott el az Európai Unió vonatkozásában (2000-ben még csak EU-15). A Lille Akcióprogram a városi ügyekre kialakított közösségi közpolitikai keret (policy framework) volt. A dokumentum kifejezetten utalt az OECD által megfogalmazott [OECD 2000, 2001] közpolitikai célkitüzésekre, kihangsúlyozva, hogy a globális kihívásokra eredményesen reagáló integrált európai várospolitikának a klasszikus input-orientáció helyett sokkal inkább a közvetlen (output) és közvetett (outcome) hatásokra szükséges koncentrálni.

\section{$\underline{\text { A Lille Akcióprogram a következő várospolitikai célokat tüzte ki: }}$}

1. Szakpolitikai módszertani segítség a tagállamok, de egyúttal az európai városok számára.

2. Egy mindenki számára használható, konszenzusos szakmai referenciakeret.

3. A szakmai dialógus erősítése a különböző érintett szereplők között [Lille Action Programme, 2000, 54-55. pp.].

Közpolitikai módszertani szempontból fontos, hogy a Lille Akcióprogram tervezési eszközként nevesítette az európai várospolitikánál a városi indikátorok egységes benchmarking (összemérés) alkalmazását - az akcióprogram fogalmazta az Urban Audit adatbázis létrehozását. [Lille Action Programme, 2000, 58. pp.]. A Lille-i Akcióprogram már hangsúlyosan szólt a globális migráció helyi-lokális kezelése - pl. a nagyszámú muszlim közösség beilleszkedési nehézségei.

\section{III.5.3 Lipcse 2007}

A következő közpolitikai határkő az Európai Unió várospolitikájában a tagállamok területfejlesztésért felelős miniszterei által szignált 2007-es Lipcsei Charta, mint az Európai Unió területi agendája volt. A 2000-es Lille-i Akcióprogram óta eltelt időszakban fontos változások érték a közösséget. 2004-ben 10 új tagállam csatlakozott az Európai Unióhoz benne hazánk és még 8 másik kommunista múltú közép-európai ország. A bővítés mellett az évtized első felében a másik meghatározó közösségi dimenzió az EU belső működésének strukturális mélyítése volt, amely jegyében a kifejezetten erre a célra összehívott Európai Konvent által előkészített közös alkotmánytervezet (Európai Alkotmány) 2005-ben elbukott előbb a franciaországi majd a hollandiai népszavazáson némiképpen lassítva az integráció folyamatát. Így az alkotmányhoz képest csak egy kevésbé integratív (és föderatív) 
dokumentumot fogadott el az Európai Unió - ez lett a 2009-ben hatályba lépő Lisszaboni Szerződés.

A 2007-es Lipcsei Charta a stratégiai céljait illetően a már ,járt utat” erősítette meg:

- A Charta által meghatározott európai városokról szóló alapelvek nemzeti-tagállami vitáinak kilátásba helyezése.

- Az integrált városfejlesztés, mint általános fejlesztéspolitikai eszköznek a priorizálása a várostervezési folyamatoknál.

- Az európai policentrikus városhálózat, mint elérendő cél ismételt deklarálása.

A Lipcsei Charta hivatkozott az Európai Unió 2000-ben elfogadott 10 éves versenyképességi programjára (Lisszaboni Stratégia 2000-2010), amelynek kiemelt eleme a városok sokszínüsége mellett a társadalmi egyensúly városokon belül és települések között. $\mathrm{Az}$ integrált várospolitika- és városfejlesztésnek része a közigazgatáson kívüli szereplők (gazdasági és civil stakeholderek, közvetlenül az állampolgárok) bevonása a különböző tervezési folyamatokba. A Lipcsei Charta a partneri viszonyt hangsúlyozta a nagyváros és az egyéb közép- és kisvárosok között. A helyi gazdaság, a proaktív oktatás- és innovációs politika, illetve a várostérségi tömegközlekedés mellett már közvetlen célkitüzésként deklarálták a városi energiahatékonyság javítását [Lipcsei Charta, 2007].

\section{III.5.4 Gödöllő 2011}

Az első magyar európai uniós elnökség időszakában, 2011 tavaszán került sor a területfejlesztésért felelős szakminiszterek informális találkozójára Gödöllőn, ahol a jelenlévők elfogadták a 2007-es Lipcsei Charta - mint közösségi területi agenda - értékelő jelentését. ${ }^{41}$ A Gödöllőn elfogadott jelentés a területi kohézió, koherencia valamint a Charta által lefektetett célok megvalósítását vizsgálta. A dokumentum hangulatát és eredményét alapjaiban határozta meg az időközben, 2008-ban kitört pénzügyi- és gazdasági világválság Európára - s benne az Európai Unióra - gyakorolt hatásai, valamint a 2004-2007 közötti bővítési hullám (összesen 12 új tagállam felvétele) szerteágazó tapasztalatai. Továbbá 2009ben lépett életbe a Lisszaboni Szerződés, amely jelentősen megújította a közösségi intézményrendszert (új intézmények; új eljárások etc.), valamint az EU 2010-ben elfogadta a

41 2007-ben a Charta elfogadásakor a német soros elnökség kérte fel a majdani magyar soros elnöki adminisztrációt az értékelésre - Evaluation Report of the Territorial Agenda of the European Union, 2011, 2. pp. 
2000-es Lisszaboni Stratégiát ${ }^{42}$ megújító, azt felváltó EU2020 stratégiát. Ez utóbbi stratégiai dokumentum nem tartalmazott nevesített területfejlesztési feladatokat, helyette sokkal inkább a foglalkoztatás, az energiahatékonyság (alternatív zöldenergia-források) valamint a gazdasági növekedés hármasához kapcsoltak konkrét elérendő output indikátorokat. Ugyanakkor a gödöllői konferencia a területi agenda továbbgondolása mellett foglalkozott az EU2020-ban megfogalmazott célokkal [Evaluation Report of the Territorial Agenda of the European Union, 2011, 1-6. pp.].

A gödöllői dokumentum számba veszi a térség- s vele a városfejlesztéshez leginkább kapcsolódó más EU-s szakpolitikai stratégiákat, akcióterveket - így a fenntartható fejlődést megfogalmazó 2006-os Renewed EU Sustainable Development Strategy vagy a kohéziós politika megújítására irányuló Barca Report. Előtérbe került az Európai Unióban új típusú több tagállamot is érintő ún. makroregionális dimenzió és a kapcsolódó makroregionális programok - Balti Stratégia valamint éppen a magyar soros elnökség idején elfogadott Duna Stratégia. [Evaluation Report of the Territorial Agenda of the European Union, 2011, 6-14. pp.].

Gödöllőn a Lipcsei Charta végrehajtásáról szóló jelentés mellett elfogadtak egy másik stratégiai anyagot is az EU 2020-ig szóló általános területfejlesztési programjáról - Territorial Agenda of the European Union 2020. Ebben további szektoriális célként került megfogalmazásra a különböző adminisztratív közigazgatási határok okozta nehézségek leküzdése, de még inkább az energiahatékonyság, a környezeti kockázatok csökkentése, a biodiverzitás erősítése, a táj- és természeti örökség védelme. A szüken vett település- és térségpolitika kapcsán egyaránt kihangsúlyozásra került a falusi (mint perifériális), a félperiféliális és urbánus térségek integrált fejlesztése. Dicsérték a több mint évtizedes múltra visszatekintő ESPON városfejlesztési programrendszer eredményeit és az alkalmazott módszertan további felhasználását sürgették [Territorial Agenda of the European Union 2020, - 2011, 1-12. pp.].

\section{III.5.5 Hatodik Kohéziós Jelentés 2014}

Az Európai Unióban 3 évente napvilágot látó ún. kohéziós jelentések közül az utolsó 2014-ben jelent meg. A Hatodik Kohéziós jelentés foglalkozik a területi kohézió gazdasági és társadalmi aspektusaival. Mivel most ez tekinthető az európai várostérségekkel foglalkozó

\footnotetext{
42 A 2000-es Lisszaboni Stratégia valamint a 2009-es Lisszaboni Szerződés közötti kapcsolatot csak az aláírás helyszínéül szolgáló portugál főváros kapcsolja össze.
} 
leginkább aktuális közösségi dokumentumnak, érdemes összegezni a kapcsolódó információkat. A Hatodik Kohéziós Jelentés szerint 2011. évben az EU népességének 59\%-át, valamint a foglalkoztatottak 62\%-át érintették az ún. nagyvárosi régiók, amelyekből a jelentést kiadó DG Regio és EUROSTAT 3 csoportot képezett sorolt: fövárosi régiók, második szintü nagyvárosi régió, kisebb szintü nagyvárosi régiók. A rendelkezésre álló statisztikai adatok alapján a Hatodik Kohéziós Jelentés megerősíti a köztudott tényt, hogy a nagyvárosi régiókban tapasztalt 1 főre eső GDP-növekedés minden tagállamban magasabb az átlagosnál. A különbség abban is kimutatható, hogy a nagyobb népességű várostérségek (kiemelten a fővárosi régiók) egyértelmüen jobban teljesítenek. A Hatodik Kohéziós Jelentés hivatkozik a disszertációban később kifejtésre kerülő 2014-es OECD szakértői anyagra [OECD, 2014b], amely különböző gazdasági növekedési adatokat vizsgálva jutott arra, hogy a nagyvárosi térségekben a térségi önkormányzati egységek megduplázódása akár 5-6\%-os termelékenységcsökkenést is eredményezhet. Ez közvetlen fordított arányosságot feltételez a közigazgatási széttagoltság valamint a gazdasági növekedés között. Ugyanakkor valamilyen központi várostérségi intézmény, szerv - mint például a föderatív kétszintű önkormányzati tanácsok -, jelentős eséllyel tudja a hátrányokat csökkenteni megfelelő közpolitikai koordinációval és intézkedésekkel [Hatodik jelentés a gazdasági, társadalmi és területi kohézióról, Európai Bizottság, 2014, 19-20. pp.]. Ugyanakkor a Hatodik Kohéziós Jelentés az a tömegközlekedéshez való hozzáférés, energiafelhasználás valamint a terület-felhasználás tekintetében látja egyértelmủen hatékonyabbnak a városi, nagyvárosi tereket - pl. sorházi lakások alacsonyabb energiafelhasználása [Hatodik jelentés a gazdasági, társadalmi és területi kohézióról, Európai Bizottság, 2014, 110-120. pp.].

\section{III.6 Kormányzati modellek a várostérségekben}

Az amerikai Humes és Martin a helyi önkormányzatokról írott, The Structure of Local Governments Throughout the World [Humes-Martin, 1961] címü nagyhatású müvükben a helyi önkormányzatok négy típusát különböztették meg az általános versus speciális célú, illetve a képviseleti versus nem képviseleti jelleg alapján. Amíg az általános célú helyi önkormányzatok meghatározott területi joghatóságon lehetőleg minél több önkormányzati közhatalmi és közszolgáltatási funkcióval rendelkeznek, addig a speciális célú önkormányzatok már csak egy vagy maximum néhány funkcióval bírnak. A könnyebb lehatárolás végett Humes és Martin a többcélú helyhatóságokat nevezték általános önkormányzatoknak; a speciális (egy vagy néhány) kompetenciával rendelkező szerveket 
pedig funkcionális önkormányzatoknak. A képviseleti versus nem képviseleti jelleg, a helyi választóközösség választói felhatalmazásának lététől (közvetlen választás aktusa) vagy hiányától (ez esetben kinevezés, delegálás útján jöhet létre) függ. Humes és Martin szerint az általános célú közvetlenül választott önkormányzati egységek (general-purpose representative) jelentik az önkormányzás legmagasabb formáját, a másik háromból hiányzik a közvetlen demokratikus felhatalmazás vagy az általános funkcionális jelleg. A következö ábra tartalmazza Humes és Martin féle önkormányzati tipizálást:

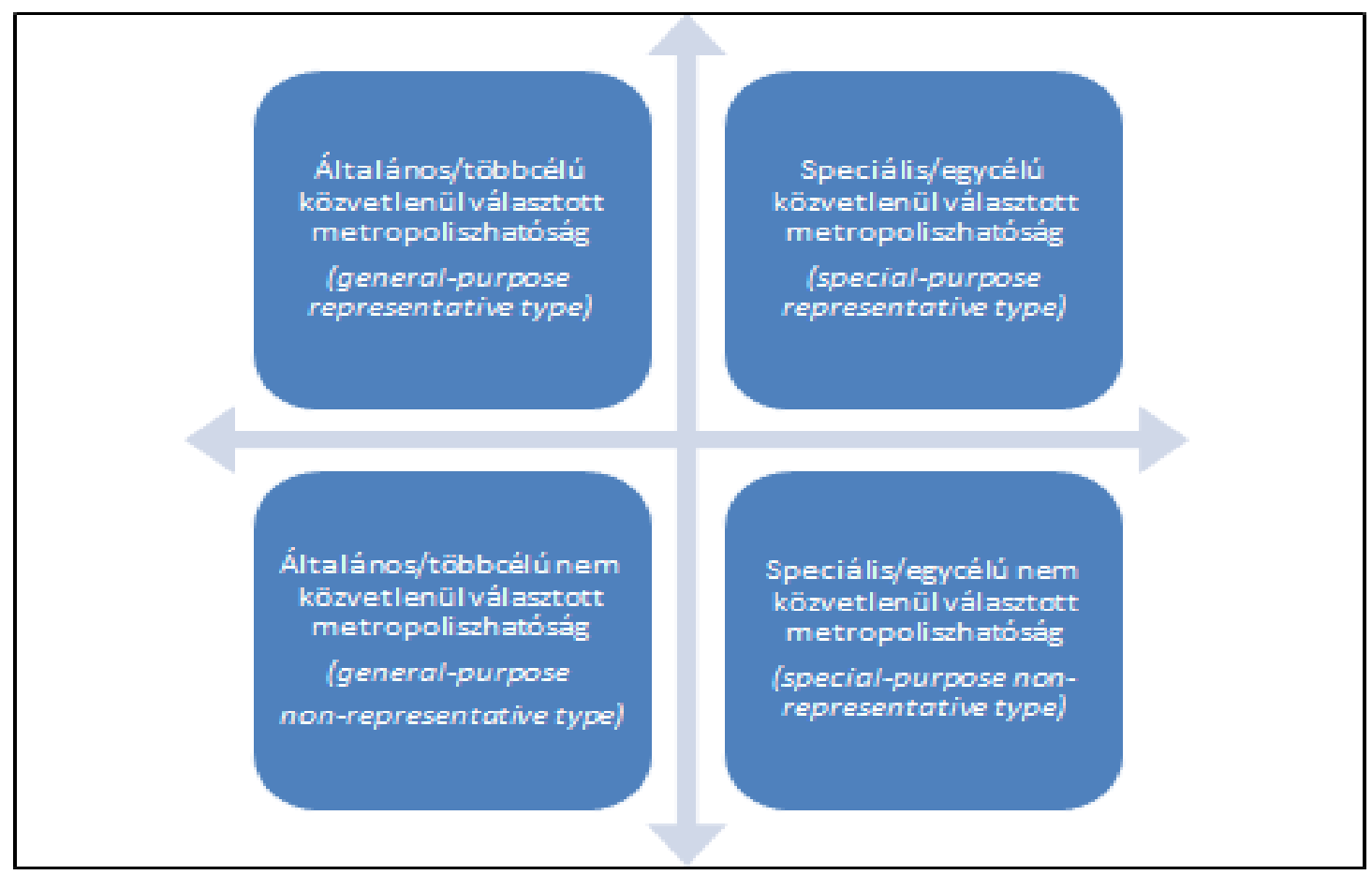

9. ábra: az agglomerációs struktúrák Humes-Martin alapján - saját szerkesztés!

I.M. Barlow 1991-ben megjelent a nagyvárosi kormányzást összefoglaló munkájában a hatékony várostérségi kormányzás és közpolitika alapvető premisszájának az önkormányzati joghatóság valamint a kapcsolódó igazgatási terület koherenciáját, s ezzel a túlzott intézményi elaprózódás elkerülését nevezte meg. A XX. század második felére a tradicionális önkormányzati struktúrák, egyre inkább, mint a modern urbanizációs folyamatok intézményi korlátaiként jelentek meg. Elsőrendű várostérségi kulcskérdéssé vált a területi struktúra illetve a kormányzás területi aspektusa. Barlow a létező önkormányzati modellek két fundamentális gyengeségét emelte ki: az egyik a relatív kisebb önkormányzati terület, fennhatóság; a másik pedig az előzőből fakadó túlzott területi joghatósági fragmentáltság. Ez a müködési zavar akár még fokozható, ha az egyébként is heterogén önkormányzati közegben számos speciális 
egycélú önkormányzati hatóság (pl. tervezési-fejlesztés; vízügy; közlekedési-, egészségügyi körzet) müködik párhuzamosan. Szélsőséges esetben kaotikus szabályozási-, illetve végrehajtási problémák - mint klasszikus közpolitikai zavarok ${ }^{43}$ - alakulhatnak ki a helyitérségi feladatellátásban [Barlow, 1991, 1-3.; 7-8.; 18. pp.].

Az európai nagyvárosi, várostérségi közpolitika kiemelkedő kortárs teoretikusa, a francia Lefévre négy paramétert nevesített, mint a hatékony nagyváros és környéki közpolitika letéteményesei, ezek a következők:

1) Széles, valamilyen tekintetben (legyen az általános vagy speciális egy-, illetve néhány nevesített cél, feladat megvalósítására létrehozott) egységes joghatóság a gazdasági, közlekedési (ingázás) és szolgáltatási értelemben teljes funkcionális nagyvárosi térségre (FUA) vonatkozóan.

2) Erős politikai legitimáció, lehetőség szerint közvetlen választott nagyváros térségi szintü politikai képviselettel, amit a modern várospolitika az ún. kétszintü nagyvárosi kormányzás - benne egy a nagyváros és a környéki önkormányzatokat magága foglaló metropolisztanácsok, hatóságok - intézményi alkalmazásával valósít meg.

3) Világos lehatárolás és önállóság a központi és/vagy szubnacionális (mezoszintü területi önkormányzatok - régiók, tartományok etc.), valamint a helyi-lokális helyhatóságoktól pénzügyi és humán erőforrás területeken.

4) Funkcionális szempontból megfelelő területü önkormányzati joghatóságok kialakítása - „Méret, autonómia, kompetenciák és legitimáció” [Lefévre, 1998 10-12.pp.].

\section{III.6.1 A helyi közfeladat értelmezése és rendszere}

A helyi önkormányzás alapvető kérdése a szubnacionális (mezo és mikroszintü) demokráciagyakorláson túl a különböző helyi közszolgáltatások és közjavak biztosítása, s ezzel egy meghatározott közszolgáltatási struktúra és hierarchia kialakítása. A közfeladatok és közszolgáltatások értelmezéséhez két kapcsolódó feltétel mindenképpen szükséges:

1) Azok a társadalom valós közös szükségleteinek kielégítésére irányuljanak.

\footnotetext{
43 A közpolitikai zavarok két klasszikus típusa a közpolitika-alkotás valamint a közpolitika-végrehajtás szakaszában bekövetkezö kudarcok - Hajnal György: Adalékok a magyarországi közpolitika kudarcaihoz (Központi Személyügyi Központ, Budapest, 2008)
} 
2) A feladatellátás - ha nem is teljes, de valamilyen mértékben - közösségi szervezésben, keretek között valósuljon meg.

Ebből a filozófiai-közpolitikai megközelítésből kiindulva, nem minősülnek valódi közszolgáltatásnak a kizárólag a hatalmi elit kényelmét szolgáló luxusberuházások -, amikor az állam vagy önkormányzat által ellátott feladat nem elégít ki valódi közösségi igényt. Magának a közfeladatnak a megszervezési dimenziója viszont már egy sokkal relatívabb feltétel: a New Public Management és általában a modern közszolgálati menedzsment számára teljesen természetes a szektorközi (közszektor valamint a vállalati és non-profit szektor) mechanizmusok alkalmazása. A közfeladatok rendszerében a helyi közfeladat- és közszolgáltatás alapspecifikuma, hogy olyan közös tevékenységekre korlátozódik, amelyek a települések vagy nagyobb szubnacionális területi (politikai, igazgatási) egységek - kistérség, megye, régió etc. - keretében értelmezhetőek, lehatárolhatóak. Persze ez nem jelent univerzalitást abban az értelemben, hogy adott területi lehatárolásban minden közfeladat egyszersmind helyi közfeladat volna, így egy területi vagy települési (városi, nagyvárosi) önkormányzat természetesen nem váltja ki a területén a központi állam közigazgatási (államigazgatási) tevékenységét, intézményi feladat- és hatásköreit [Horváth M. 2002, 15-16. pp.; Hoffman 2009, 23. pp.].

A közfeladat-ellátás vertikális dimenzióját sokban meghatározza az államberendezkedés (centralizált, föderális, regionális), amely kijelöli, s egyben determinálja a települési- és területi helyhatóságok autonómiáját. Földrajzilag differenciált módon történhet ugyanazon közfeladat ellátása, amíg az egyik államban önkormányzati feladat, addig egy másik országban már minősített állami feladatként kerülhet meghatározásra. A közfeladat-ellátás horizontális dimenziójában történő hangsúlyeltolódások (állami feladat- és hatáskörök, kompetenciák finanszírozása valamint önkormányzati szintekre történő telepítése vagy azok éppenséggel ellentétes irányú transzformációja) jelentik az önkormányzatiság és helyi autonómia tényleges spektrumát adott helyen és időben. ${ }^{44}$ Hoffman István 2009-es önkormányzati közszolgáltatásokkal foglalkozó monográfiájában a nemzetközi tapasztalatok és szakértői leírások alapján az állami és önkormányzati közszolgáltatások, közfeladatok legtágabb, szükebb és legszükebb felfogását nevesítette, az alábbiak szerint:

- A legtágabb megközelítés szerint a közszolgáltatás gyakorlatilag felölel minden olyan szolgáltatást, amit az állam (és önkormányzat) biztosít állampolgárai számára -

\footnotetext{
${ }^{44}$ Persze a helyi önkormányzati autonómia kapcsán született nemzetközi standardok (pl. az Európa Tanács által 1985-ben megalkotott Európai Önkormányzati Charta) jelentenek bizonyos támpontokat a helyi önkormányzatiság egységes értelmezési keretének irányába. A magyar jogban lásd a 1997. évi XV. törvényt!
} 
ezen olvasat szerint még a törvényhozás és az igazságszolgáltatás is egyfajta speciális közjószág; Hoffman ide hivatkozza a német, francia és angolszász közigazgatási irodalom képviselőinek kapcsolódó munkáit.

- A közszolgáltatás szükebb megközelítése már „kirekeszti” az állam közhatalmi funkcióit (törvényhozás, igazságszolgáltatás, közigazgatási hatósági tevékenység).

- A legszükebb megközelítés pedig a közhatalmi funkciókon túl a különböző állami (és önkormányzati) pénzbeli és nem pénzbeli transzfereket (népjóléti támogatások, pályázati források etc.) is kiiktatja az értelmezési tartományból [Hoffman, 2009, 2426. pp.].

A közszolgáltatások speciális európai kategorizálását biztosítja továbbá az általános gazdasági érdekü szolgáltatások (ÁGÉSZ) és az általános érdekü szolgáltatások (ÁÉSZ) definíciók használata. Az ÁGÉSZ az Európai Unió közösségi joggyakorlatában kifejezetten a nagy infrastrukturális hálózatokat müködtető ágazatok - posta, energiaszolgáltatás, közlekedés, távközlés -; a nemzeti jogok tekintetében, pedig minden olyan közszolgáltatást érint, amelynek gazdasági vonatkozásai vannak, és a szolgáltatásért cserébe kért térítési díjak a szolgáltatás jellegéből fakadóan életszerű az állampolgárok számára. Az ÁÉSZ, mint általános érdekü szolgáltatás pedig olyan közszolgáltatásnak fogható fel, amely közérdekü, de nincs ÁGÉSZ jellegü gazdasági vonatkozása - alapvetően a humán közszolgáltatások körét fedi, az ÁÉSZ ritkán alkalmazza a térítés díj intézményét az „egyetemes szolgáltatás elv” alapján [Barna-Haszonicsné-Kiss-Tátrai, 2009, 81. pp.] Ebben a megközelítésben olyan fontos közpolitikai, közmenedzsment kérdések merülhetnek fel, mint a térítésmentes humánszolgáltatások (mint ÁÉSZ) ellátási felelőssége, vagy a térítéses rendszerben működtetett ÁGÉSZ szolgáltatások árszabályozási, működtetési, szervezési jogkörei. ${ }^{45}$

A hagyományosan központosított, centralizált szisztémájú államokban a közfeladatellátásnál a súlypont egyértelmüen a nemzeti-országos szint. A föderális, regionális berendezkedésü államok esetében már jóval hangsúlyosabb a szubnacionális regionálistérségi (tagállamok, régiók, megyék etc.) szint feladatellátása. Amíg a regionális-térségi kompetenciák rendszere nagymértékben az államberendezkedés függvénye, addig a mikroszintü helyi-lokális (települési) feladatok és közjószágok rendszere többé-kevésbé hasonló a demokratikus berendezkedésű államokban legyen az fragmentált (,,egy település

\footnotetext{
45 Adott ÁGÉSZ típusú közszolgáltatást elláthat állami vagy önkormányzati intézmény, illetve azok megbízásából közszektoron kívüli piaci vagy non-profit szereplö; árszabályozó (árak megállapítása, a dífizetés elmaradása esetén szankcionálás) funkciót kaphat állami és önkormányzati intézményi kör - pl. Magyarországon a 2010-ben hivatalba lépett második Orbán-kormány több hatósági árszabályozó kompetenciát (távhő, vízdíj) ruházott át az önkormányzatoktól a központi állami intézményrendszerhez.
} 
egy önkormányzat” elv) vagy integrált (önkormányzati összevonások, fúziók) helyi önkormányzati szisztéma - lásd az 1985-ös Helyi Önkormányzatok Európai Chartájának szövegét! A városi önkormányzatok feladatellátása kapcsán számos klasszifikáció született már, Barlow a brit Stanyer 1976-os besorolását citálta, amely a nagyvárosi önkormányzati közszolgáltatások ötös funkcionális csoportosításán nyugszik:

1) Védelmi jellegü közszolgáltatások - közbiztonság, ${ }^{46}$ tüzvédelem, polgári védelem, engedélyezési és ellenőrzési szolgáltatások (ún. hatósági feladatok).

2) Környezeti jellegü közszolgáltatások - közutak fenntartása, ingatlangazdálkodás, víz- és csatornaszolgáltatás, hulladékgazdálkodás (ún. településüzemeltetési feladatok).

3) Személyes jellegű szolgáltatások - oktatási, jóléti és egyéb szociális szolgáltatások (ún. humán közszolgáltatások)

4) Kulturális és rekreációs (szabadidős) jellegű szolgáltatások - parkok; könyvtárak; rekreációs centrumok és múzeumi szolgáltatások (ezek is humán közszolgáltatásnak minősülnek)

5) Kereskedelmi és közlekedési jellegü müveletek - légi közlekedés, tömegközlekedés, egyéb piaci jellegü értékesítési feladatok (ún. kereskedelmi és közlekedési közszolgáltatások) [Barlow, 1991, 4. pp].

\section{III.6.2 Közpolitikai hatékonyság a várostérségi feladatellátás során}

A nagyvárosi kormányzásról szóló, 2012-ben The Oxford Handbook of Urban Politics címen megjelent összefoglaló tanulmánykötetben Keith Dowding és Richard Feiock közös írásukban elemzik a közpolitikai hatékonyság (policy efficiency) várostérségi összefüggéséit, amelynél a szerzők szerint kétféle dimenzió különíthető el. Az egyik a közpolitikai inputok és outputok közötti technikai hatékonyság, amely szerint a minél magasabb szintü gazdasági (termelési, szolgáltatási) folyamatok, hasonlóan technikai értelemben emelkedő színvonalú közpolitikai szabályozó, feladatellátó szisztémákat (eljárások, szabályok, indikátorok, fejlett technikai infrastruktúrák, hatékony emberi erőforrás és humán közmenedzsment) eredményeznek. A másik az allokációs hatékonyság, amely az elvárt társadalmi igények

\footnotetext{
${ }^{46}$ A közbiztonság és rendvédelem kérdése remekül szimbolizálja a terület eltérő nemzetközi szabályozáát: vannak országok, makrorégiók, ahol ez hagyományosan helyi-lokális önkormányzati kompetenciának minősül (pl. Egyesült Államok), s vannak olyan államok - így az 1989-90-es rendszerváltás utáni Magyarország - ahol a rendőrség a mindenkori kormányzatnak alárendelt államigazgatás része funkcionálisan leválasztva a települési és területi önkormányzati struktúrákról. Bár a hazai helyzetet némileg árnyalja, hogy az önkormányzatok helyzetét újraszabályozó 2011. évi CLXXXIX. törvény lehetővé tette a települési önkormányzatok számára az ún. önkormányzati rendészet szervezeti kialakítását.
} 
(közvetlen és közvetett transzferek, közszolgáltatások etc.) és a tényleges közpolitikai juttatások, támogatások kapcsolatára fókuszál, mondván, minél nagyobb számú állampolgár részesedik a közszolgáltatásokból, annál nagyobb az igény a közösen elosztható források reális és hatékony elosztására - magasabb allokációs, redisztribúciós szint magasabb társadalmi elvárásokat generál [Dowding-Feiock, 2012, 31-32. pp.]. Ma már a különböző kormányzati közpolitikai programok eredményességének, hatékonyságának (amit értelmezhetünk gazdaságossági dimenzióban), illetve hatásosságának vizsgálata, értékelése kiemelt közpolitikai tevékenység. A közpolitikai értékelés (policy evaluation) homlokterében a vizsgálandó közpolitikai terület, folyamat, napirendi pont (policy issue) - nyugodjon az ágazati vagy horizontális (pl. korrupció; környezeti, gazdasági és társadalmi fenntarthatóság) kereteken - mérhető statisztikai mutatókon, ún. input, output és outcome indikátorokon alapuló értékelő vizsgálata áll. A közpolitikai értékelés különböző aspektusairól -, mint az értékelő pozíciói, az értékelés megtervezése, a mérőszámok kidolgozása, az adatgyüjtés, különböző kvantitatív és kvalitatív módszerek - legátfogóbban Carol H. Weiss foglalkozik összefoglaló monográfiájában [Weiss, 2005].

A közpolitikai hatékonyság esetében a gazdasági takarékosság („,olcsóbban, és ha lehet jobb minőséget”) a fö prioritás. A nagyvárosi szakpolitikák müködtetésének társadalmi hatásait (social output) - vagyis a közfeladat- illetve az önkormányzati teljes tevékenység (hatósági ügyintézés, gazdaságfejlesztés, kulturális- és egyéb rendezvények etc.) - már a közpolitikai hatásosság (policy efficacy) vizsgálódási területe, és a különböző gazdasági lobbik és civil stakeholderek mellett az önkormányzati választásokban ölthet konkrét kézzelfogható testet és közvetlen számonkérési esélyt a helyi választópolgárok számára. Alapvető dilemma a nagyvárosi térségek \& közpolitikai hatékonyság esetében a feladatellátás gazdaságosságának kérdése: persze ez nagymértékben függ, hogy az egyes feladatok, közszolgáltatások a feladatellátás tekintetében a leginkább hatékonyan intézhető, kezelhető szinthez, szervezethez legyen rendelve. Nem szabad azonban elfelejteni, hogy a városi kormányzásnak a várostérségi, agglomerációs nexusok mellett legalább annyira fontos integráns része a szük értelemben vett - az agglomerációs szuburbán övezet nélkül - egyszintü nagyvárosi önkormányzásnak (one-tier government) ${ }^{47}$ az elkülönülő szintjei: maga a nagyváros, valamint annak önkormányzati joghatósággal felruházott valamilyen belső

\footnotetext{
${ }^{47} \mathrm{Az}$ egyszintű nagyvárosi önkormányzati modell - benne a nagyvárosi önkormányzattal (élén tanács és közvetlenül vagy közvetett módon választott polgármester) illetve a helyi-lokális kerületi önkormányzatokkal klasszikus kialakulási módozata volt az egyesülés vagy bekebelezés - pl. Budapest/Nagy-Budapest 1873; 1950, New York 1898; Toronto 1998. A kétszintü nagyvárosi önkormányzat (two-tier government) már alapvetően a nagyváros és szuburbán települések önkéntes integrációjából született meg.
} 
tagolódása - hívják azt önkormányzati kerületnek, szomszédságnak vagy akár részönkormányzatnak. A várostérségi kormányzás eme hármas területi modellje (kerületek nagyváros - agglomeráció) tekintetében jelentős differenciák tapasztalhatóak a Világon, így Európában. A kerületi önkormányzati alsószint kompetenciáinak legitimációs forrása lehet a nagyvárosi testület vagy közvetlen országos törvényhozói akarat és szabályozás. Ugyanakkor az is változó, hogy ez a közvetlen feladatellátó szint rendelkezik-e önkormányzati autonómiával, vagy annál csak gyengébb, részleges önálló hatáskörökről beszélhetünk. Ebből a vizsgálati aspektusból például a budapesti kerületek nemzetközi összehasonlításban vonatkozásában jelentős önálló autonómiával, saját feladat,- hatáskörökkel bírnak, amit már az eredeti 1990-es önkormányzati törvény biztosított számukra. Olyannyira kiemelkedő nemzetközi komparatív aspektusban a budapesti kerületek önkormányzati autonómiája, hogy számos európai és észak-amerikai nagyvárosban az ottani lokális kerületek (district / borough) jogállása sokkal inkább a magyarországi szabályozásban részönkormányzatnak nevezett jogintézménynek felelnek csak meg. A budapestihez hasonló erős kerületi autonómia jellemzi az európai nagyvárosok közül Barcelona vagy Amszterdam hasonló szintű igazgatási önkormányzati egységeit [Hegedűs, 2008, 65-66. pp.].

Föderatív kétszintü nagyvárosi önkormányzatról, metropoliszhatóságról (two-tier government) beszélünk azon közpolitikai önkormányzati igazgatási megoldásoknál, amikor a nagyváros valamint az azt övező agglomerációs gyürü szuburbán önkormányzatai közösen alkotnak valamilyen konkrét intézményi tanácsi konstrukciót, amely érintetlenül hagyja a már létező helyi önkormányzati joghatóságokat, határokat. A nagyvárosi kormányzás legfontosabb közpolitikai dimenziói az alkalmazott government és governance eszközök hatékonyság alapú vizsgálata; az alkalmazott konstrukciók legitimációs (közvetlenül választott vagy delegált) aspektusai, valamint egyéb hatásköri (hatáskör-telepítés), ágazatpolitikai illetve horizontális vonatkozások. A feladattelepítés valódi értelme a közpolitikai hatásosság (policy efficacy) kérdésében keresendő: a nagyvárosi térségben történő helyi közfeladat-ellátás milyen hatással van a lakosság és a különböző szervezett csoportjai (stakeholder) életére; az önkormányzati közjavak és redisztribúció eszközével érdemben csökkenthetőek-e a kialakult társadalmi anomáliák (egyenlőtlenségek, szegregációs tendenciák, devianciák). Egy széles kompetenciakörrel rendelkező metropolisz önkormányzati konstrukció eleve magában hordoz egy erősebb beavatkozó - redisztributív, transzfer-allokáló - müködési jelleget. Ugyanakkor a helyi-lokális önkormányzati egységek egészségtelen funkcionális-, hatásköri túlsúlya éppen hogy konzerválhatja a területi, társadalmi differenciákat a metropolisz térségben. Erre jó példa a szélsőségesen sokarcú Los Angeles és agglomerációját magába foglaló 1965-ben alapított 
metropoliszhatóság (Southern California Association of Governments - SCAG), amely 18 millió lakost, 6 megyét (county) és 191 települést (city) foglal magában. A SCAG mindössze a területi tervezés és a közlekedés kapcsán rendelkezik önálló hatáskörökkel, és miközben az USA egyik legnagyobb területü többcélú metropoliszhatósága, kompetenciáit tekintve az egyik leggyengébb; ugyanakkor a Los Angeles-i önálló metropolisz-közlekedési hatósága $(\text { LACMTA })^{48}$ az egyik legnagyobb az USA-ban [OECD, The OECD Metropolitan Governance Survey 2014, 36-45. pp.; www.scag.ca.gov].

A túlzott fragmentáció és az alapszintü helyi önkormányzatok közötti koordináció hiánya nagyban következik a lokális politikai (és sok esetben gazdasági) érdekek alulról származó nyomásából. Ugyanakkor tény, hogy számos nagyvárosi térség esetében folyamatosan bővül a nagyváros közigazgatási határain kívül eső agglomerációs szuburbán településgyürü - pl. a francia főváros Párizs magterülete egyre kisebb területre szorul vissza a teljes agglomerációs övezettel (MUA; FUA) szemben - így egyfajta kényszerként is jelentkezik a szuburbán települések igényeinek fokozottabb akceptálása a magtelepülés irányába [Travers, 2005, 2-3. pp.]. A nagyvárosok tradicionális közigazgatási-adminisztratív határai sokszor már csak, mint a történelmi múlt archaikus lenyomataiként funkcionálnak, miközben teljesen máshová helyeződnek a valódi hangsúlyok - pl. a lakóövezetek és kereskedelmi-szolgáltató valamint a termelő ágazatok telephelyeinek kitolódása az elővárosok irányába; a nagyvárosi infrastrukturális és egyéb közszolgáltatások megjelenése az agglomerációs településeken. Kérdés, hogy az agglomerációs övezetek irányába történő demográfiai, gazdasági - és esetenként politikai - hangsúlyeltolódások miként csapódnak le az egész metropolisz térség igazgatási- és közpolitikai vonatkozásaiban. A nagyváros miként képes hatékonyan ellensúlyozni a nyilvánvaló pozícióvesztést, ${ }^{49}$ illetve az agglomerációs települések - különösen azok gazdasági, adminisztratív policentrikus bástyái térnyerése hogyan és milyen módon jelenik meg az egész nagyvárosi térségre vonatkozó stratégiai tervezési folyamatokban, pénzügyi allokációkban, fejlesztési projektekben.

A funkcionális (speciális) egycélú önkormányzatok elterjedésére a legjobb példa éppen az Egyesült Államok, ahol sokszor egy-egy közmű (vízhálózat, csatornahálózat) üzemeltetése vagy meghatározott közfeladat ellátása áll a speciális helyhatóság tevékenységének fókuszában. Erre jó példa az amerikai iskolai körzetek (school district) vagy

\footnotetext{
${ }^{48}$ Los Angeles County Metropolitan Transportation Authority

${ }_{49} \mathrm{Az}$ agglomerációs folyamatokkal szemben a nagyváros pozícióinak hatékony ellensúlyozására jó példa a nagyvárosi közmücégek közigazgatási határokon túlra a szuburbán települések irányába történő szolgáltatásokért (pl. hulladékszállitás, víz- és csatornaszolgáltatás) cserébe valódi anyagi ellentételezés szerzése a környezö településektől - pl. Budapest Fővárosi Önkormányzat közszolgáltatási szerződései azon főváros környéki településekkel, ahová járnak a Budapesti Közlekedési Vállalat (BKV) járatai.
} 
az egészségügyi körzetek, kerületek (pl. a chicagói egészségügyi-kórházi körzet, amely az egyik legkiterjedtebb funkcionális egészségügyi jellegü önkormányzat az USA-ban) [Osbourne-Hutchinson, 2006, 9-10. pp.]. A funkcionális jelleggel bíró speciális agglomerációs intézmények alkalmazása tipikusan amerikai jelenség: 1952 és 2007 között gyakorlatilag megtriplázódott az ilyen speciális önkormányzati kerületek, hatóságok száma 12 340-ról 37381 db-ra, miközben az általános helyi önkormányzatok száma nagyjából állandósult az időszak egészének tekintetében. Elmondható, hogy a metropolisz szintü problémák kezelésére az Egyesült Államokban az ilyen speciális egycélú önkormányzati hatóságok jelentik a legkézenfekvőbb és a gyakorlatban legkönnyebben megvalósítható megoldást [Mitchell-Weaver - Miller - Deal, 2000, 852. pp.]

Nagyon fontos kérdés a funkcionalitás és a területi joghatóság kapcsolata: meghatározott területü önkormányzathoz funkcionális értelemben hatékony és racionális feladatellátás kapcsolódjon - az optimális méret megválasztása kulcsfontosságú; számos önkormányzati kutatás, hivatalos jelentés foglalkozott már a joghatóság és a hatáskörök összefüggéseit. A politikai illetve a társadalmi-gazdasági szerkezet közötti összhang hiánya ugyanis alapjaiban áshatja alá az önkormányzás funkcionális teljesítőképességeit. [Barlow, 1991, 9. pp; Lefévre, 1998, 12. pp.].

\section{III.6.3 Alternatívák a fragmentációból eredő müködési zavarokhoz}

Konszenzus mutatkozik a várostérségi kormányzás kutatói, az érintett döntéshozó politikusok valamint igazgatási szakemberek részéről, hogy a politikai-igazgatási fragmentáció jelenti még mindig a legnagyobb közpolitikai kihívást a nagyvárosi térségekben. Ugyanakkor az intenzív gazdasági folyamatokból - különösen a globális multinacionális tulajdonú nagyvállalati befektetők - fakadó társadalmi és infrastrukturális (közművek és a kapcsolódó közszolgáltatások; közlekedési hálózatok; lakó- és kereskedelmi, ipari övezetek a szuburbán térségekben) változások folyamatos szabályozási és végrehajtási szükségleteket eredményeznek a várostérségi önkormányzatok (függetlenül, hogy éppen nagy népsürüségü városi klaszter, nagyváros, vagy csak vonzáskörzeti helyhatóság) számára. Az elmúlt 2-3 évtized során jó néhány tipologizálási kísérlet történt ebben a témakörében. A különböző megközelítések a 1) centralizáció versus decentralizáció; 2) az egyesitett vagy társulásos integrációk alkalmazása, és 3) az alkalmazott kooperációs megoldások jellege szerint értelmezhető - ezek közül kerül néhány bemutatásra a következőkben: 
Hamilton - centralizált és decentralizált nagyvárosi közpolitikai eszközök

Az amerikai Hamilton két holisztikus jellegü megoldási metódust javasolt a várostérségi fragmentáció kárainak orvoslásához: 1) egy nagyon határozott centralizált, központosító jellegű válaszcsomag; 2) az előzővel éppen ellentétes irányú decentralizált lépéssorozat. Hamilton a centralizált versus decentralizált megközelítés mellett a government versus governance jelleg alapján tipizálta az urbanizációra adott közpolitikai válaszokat. A government alapú intézkedések a direkt intézményi keretekre korlátozódnak - (pl. annexió, kétszintü föderatív agglomerációs tanácsok) - szabadon kezelve az önkormányzatok területi határait; a governance alapú válaszok, ahogy arról már esett szó, a vizsgált térségben kialakult önkormányzati joghatósági viszonyok tiszteletben tartása mellett egy szélesebb közpolitikai spektrumon alapulnak (pl. privatizáció, koordinációs szektorközi testületek felállítása, közpénzügyi megoldások, közpolitikai transzferek). Alapvető differencia a két megközelítés között, hogy a government megoldás nem tekinti tabunak a meglévő önkormányzati struktúrákat és határokat, addig a governance alternatívák a meglévő helyhatósági intézményi keretek között, és sokkal inkább innovatív közpolitikai eszközök, eljárások alkalmazásával igyekszik a nagyvárosi agglomerációs övezetek problémáit kezelni. A nagyvárosi közpolitikai válaszok négy típusa Hamilton szerint:

1) centralizált government alapú válaszok - területi annexió; önkormányzati egyesülések;

2) centralizált governance alapú válaszok - térségi adóbevételek allokációja a nagyváros és agglomerációs övezetének önkormányzati szereplöi között;

3) decentralizált government alapú válaszok - önkormányzati társulások, intézményi együttmüködések a nagyvárosi térségben;

4) decentralizált governance alapú válaszok - privatizáció, központi vagy regionális transzferek a helyi-lokális önkormányzatok számára, egycélú speciális önkormányzati jellegü hatóságok müködtetése [Hamilton, 1999, 3137. pp.] 


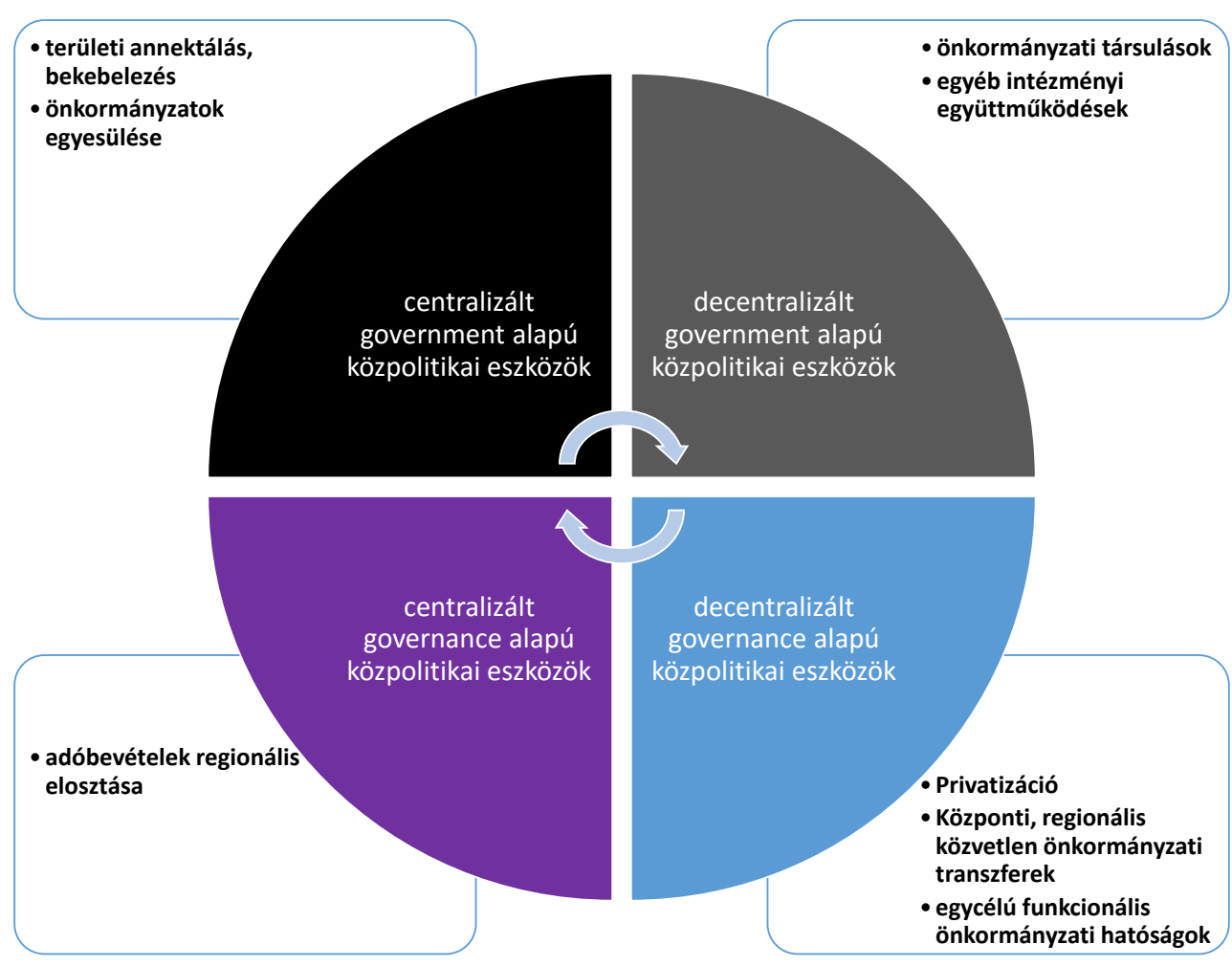

10. ábra: várostérségi eszközök Hamilton alapján - saját szerkesztés!

\section{Lefévre - ,szuper-önkormányzati” és társulásos nagyvárosi modell}

A már többször hivatkozott francia Lefévre két alapvető metropolisz, várostérségi szintü politikai megoldást javasolt: a „szuper-önkormányzati” (supra-municipiality) - mint egyszintű -, illetve az önálló önkormányzatok közötti koordinációra építő társulásos (intermunicipial) modell - mint kétszintủ metropolisz önkormányzati struktúra alkalmazása. Lefévre szerint a ,szuper-önkormányzati” modell 3 legfontosabb kritériuma a következő: közvetlen választói felhatalmazáson alapuló direkt politikai felhatalmazás, legitimáció; határozott pénzügyi-fiskális autonómia; egyértelmű joghatóság és végrehajtó-intézkedési pozíciók. Ehhez képest az önkormányzatok közötti (intermunicipal) modellnél két dologra hívta fel a figyelmet Lefévre. Az egyik a politikai legitimáció, amelyet - a közvetlen választói felhatalmazásra épülő „szuper-önkormányzati” formulától eltérően - az adott intermunicipális modellben résztvevő önkormányzatok szuverén döntésétől függ (alapuljon az közvetlen állampolgári akaraton - népszavazás; vagy önkormányzati testületi döntéseken). A másik pedig a „szuper-önkormányzati” modellhez képest sokkal relatívabb pénzügyi autonómia, amely jóval korlátozottabb, és sokkal inkább kitett az együttműködő alsóbb szintü önkormányzatok akaratának valamint a különböző magasabb szintű (országos vagy regionális-térségi) közvetlen és/vagy pályázati transzfereknek [Lefévre, 1998, 13-15. pp.]. 


\section{Walker - „,könnyü”, „közepes” és „nehéz” közpolitikai eszközök}

Az amerikai David Walker a várostérségi fragmentációra adott közpolitikai válaszokat három csoportba osztotta, megkülönböztetve „könnyü” (easiest), „közepes” (middling) és „,nehéz” (hardest) nagyváros térségi közpolitikai eszközöket. A „könnyü” eszközök között olyan jobbára kooperatív megoldásokat találhatunk, mint az informális alapú koordinációs egyeztetések; az önkormányzatok közötti egyedi közszolgáltatási közmenedzsment jellegü megállapodások és feladatellátás; központi állami-kormányzati fejlesztések, tervek - pl. a fejlesztési pólusok; jobbára csak konzultatív, koordinációs jellegü gyenge föderatív agglomerációs-regionális tanácsok, hatóságok: a „könnyü” eszközök közé Walker alapvetően meghatározott célú, sokszor eseti jellegü governance típusú megoldásokat sorolt.

A „közepes” erősségü policy eszközökhöz Walker többek között az annexiót; a hatáskörtranszfert; néhány meghatározott feladathoz rendelt egy- vagy többcélú várostérségi tanácsot (pl. metropolisz szintű közlekedési hatóság, egészségügyi körzet) létrehozását sorolja.

A „,nehéz” eszközök típusába 3 komplex megoldás tartozik:

a) Egyszintü konszolidációs megoldás: nagyváros és megye/városkörnyék egyesítése.

b) Föderális kétszintü metropolisz struktúrák: intézményesen az agglomerációs szintre telepített közfeladat-ellátások.

c) Az ún. harmadik szintü reformok ${ }^{50}$ - Walker vezette be a regionális koalíciós agenda (The Regional Coalition Agenda) fogalmát. Erre példa az északkeleti Minneapolis St. Paul Regional Economic Development Partnership, valamint az Oregon állambeli Portland's Metropolitan Service District [Walker, 1987, 1999; Mitchell-Weaver - Miller - Deal, 2000, 864-866. pp.].

A Minnesota állambeli Minneapolis és St.Paul nagyvárosok által dominált kétközpontú metropolisz térségben az USA magasan urbanizált övezeteiben megszokott, széles hatáskörü önálló kétszintü modell (Metropolitan Council), ${ }^{51}$ mellett létrehozták a térség meghatározó üzleti szereplőiből álló, saját munkaszervezettel bíró Greater MSP Region non-profit szervezetet, amely a térségi-regionális gazdasági növekedést igyekszik elősegíteni a maga koordinációs eszközeivel. PPP projektek, a helyi KKV szektor támogatása; egyéb

50 One-tier consolidation (város-megye konszolidáció); two-tier restructuring (kétszintű metropolisz önkormányzat); three-tier reforms (regionális koalíciós agenda) [Walker, 1987, 1999]

${ }^{51}$ A Minneapolis - St. Paul régióban müködő MET Councilt, amit mai formájában csak 2013-ban hoztak létre. A MET Council-ra egyrészt rendkívül széles feladatellátást ruháztak át a nagyvárosi és érintett megyei (county) helyhatóságok (közlekedés; területi tervezés; regionális fejlesztés; ivóvízellátás- és tisztítás; csatornahálózat), másrészt egyike azon két amerikai többcélú általános metropoliszhatóságnak, amely rendelkezik saját szabályozási, regulációs hatáskörrel [OECD, 20014; www.metrocouncil.org]. 
speciális célok. ${ }^{52}$ A Portland metropoliszhatóság, pedig mint az egyik első amerikai közvetlen választott általános agglomerációs tanács sokoldalú feladatellátásával, valamint a különböző üzleti és civil stakeholder csoportok irányába kialakított komplex konzultációs mechanizmusaival érdemelte ki Walker figyelmét, mint példa a regionális koalíciós agendára.

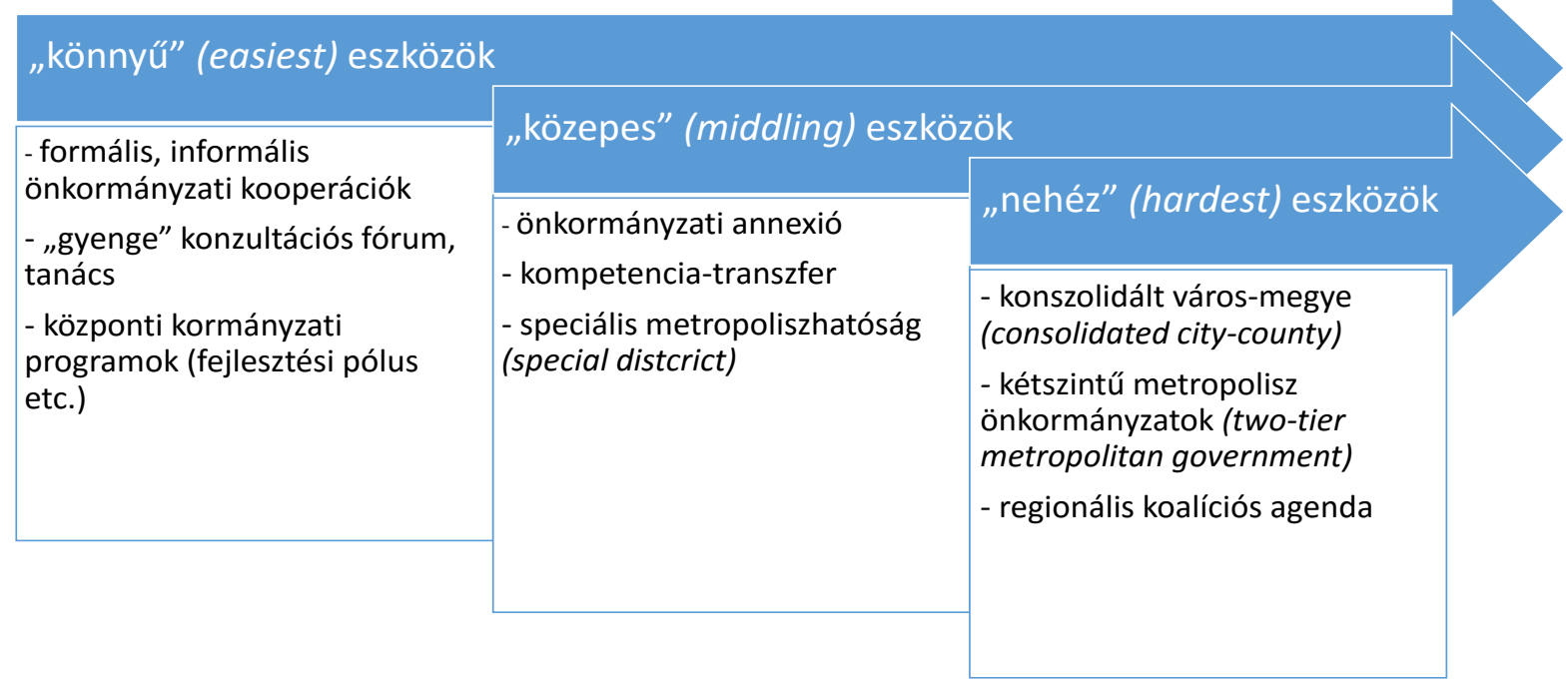

11. ábra: várostérségi eszközök Walker alapján - saját szerkesztés!

Barlow - 6 ajánlott közpolitikai eszköz az urbánus térségekhez

Barlow a nagyvárosi agglomerációs térségekben tapasztalt politikai- és igazgatási fragmentációk feloldására hat megoldási alternatívát kínált 1991-es összefoglaló művében:

1) egyesített (ön)kormányzati keret

2) hatáskör-átruházás

3) központi állami (esetleg szubnacionális) transzferek nyújtása

4) speciális célú igazgatási egységek létrehozása

5) önkormányzati együttmüködések

6) kétszintü föderatív várostérségi önkormányzati struktúra

Az egyesitett önkormányzati keret összevonások révén egy egységes önkormányzat megteremtését eredményezi a várostérségben. Ez a megoldási alternatíva elvileg teljes mértékben képes kiiktatni a politikai fragmentáció problémáját, viszont a megvalósítása hosszabb távon akár komoly müködési deficitet hordozhat magában. A szuburbán (mint

\footnotetext{
${ }^{52}$ A szervezet felépítéséröl és működéséről bővebben a www.greatermsp.org website-on.
} 
vonzáskörzet) területek politikai és igazgatási szereplői teljes mértékben ellenérdekeltek a saját intézményi autonómiájuk leépítésében; továbbá az egyesített metropolisz önkormányzati keret számos funkció és közszolgáltatás esetében túlságosan tág, és a polgárok számára is sokkal hatékonyabb lehet a differenciált többszintü önkormányzati szisztéma, benne a helyi alapszintű helyhatóságok szerepével.

A hatáskör-átruházás keretében a feladattranszfer iránya a magasabb rendü területileg szélesebb - önkormányzati szintek $^{53}$ irányába zajlik. Ennek a megoldásnak két pozitív hatása lehet Barlow szerint. Az egyik, hogy az így csökkenő számú közfeladatok, közszolgáltatások kevésbé fogják terhelni a helyi-lokális önkormányzati költségvetéseket, így eredményezve „kevesebb, de jobb színvonalú szolgáltatást”. A másik, hogy kezelhetővé válhatnak az önkormányzati egységek határain átgyürüző (spill-over), s ezzel hatásköri villongásokat okozó konfliktusok.

A központi pénzügyi transzferek alkalmazása. Barlow szerint az ilyen típusú pénzügyi támogatások segíthetnek mérsékelni az önkormányzatok közötti differenciákat. ${ }^{54}$ A hátrányuk viszont a politikai manipuláció (politikailag vezérelt támogatási döntések) és a sokszor kétséges hatékonyság. Ráadásul a fiskális transzferek önmagukban nem képesek hatékonyan kezelni az olyan típusú problémákat, mint a területi, hatásköri nehézségek a feladatellátásban.

A speciális egycélú igazgatási egységek, hatóságok alkalmazása kifejezetten a közszolgáltatások hatékonysági és eredményességi problémáit kezelhetik sikerrel funkcionális szakmai megközelítésből (pl. agglomerációs közlekedési hatóságok; egészségügyi körzetek az Egyesült Államokban). Ugyanakkor az ilyen típusú hatóságok elburjánzása hihetetlen intézményi komplexitást és ebből fakadó zürzavart okozhat az állampolgárok fejében.

A gyakorlatban az egyik leginkább alkalmazott megoldás a fragmentációs problémák kezelésére az önkormányzati együttmüködések kialakítása és müködtetése. Az együttműködések, társulások révén az önkormányzati autonómiájukat megtartó helyhatóságok önkéntes döntés alapján a feladatellátás közös koordinátarendszerében hatékonyan orvosolhatnak területi, hatásköri nehézségeket. Az eseti kooperáció önkéntes a benne

\footnotetext{
${ }^{53}$ A magasabb szintủ önkormányzati szint a szubnacionális föderális berendezkedés esetében tagállami, illetve regionális, tartományi etc. önkormányzati szintek hatáskörbővülését jelenti Barlow értelmezésében; viszont nem szabad kizárni az önkormányzati hatáskör központi állami szintre történő transzformációját sem, amely az adott közfeladat teljes centralizációját, recentralizációját eredményezheti.

${ }^{54}$ Ugyanakkor komoly belső szubnacionális konfliktusokat is gerjeszthetnek a központi állami transzferek, föként, ha éppen más szubnacionális területi, települési egységek orra elől történik a forrástranszfer - erre remek aktuális példa a németországi Bajorország esete. A bajor tartományi kormányzat a karlsuhe-i szövetségi Alkotmánybíróságon támadta meg az 1949-es alaptörvényben meghatározott, a tartományok eltérő gazdasági teljesítőképességéből eredeztetett tartományi befizetéseken alapuló forrás-átcsoportosítási rendszert, amelynek legnagyobb haszonélvezője, éppen egy tartományi joghatósággal bíró metropolisz, Berlin. A konfliktus közjogi és gazdasági-politikai részleteiről - HVG Besokalltak - Német tartományok vitája, HVG 2012. július 28. szám
} 
résztvevők számára, és szabad a szelekciós lehetőség, hogy mely feladatok, közszolgáltatások körére terjedjen ki a társulás.

A kétszintü agglomerációs tanács a nagyváros és az agglomerációs településgyürü együttes föderatív jellegü önkormányzati struktúrája. Barlow egyértelműen ezt a megoldást preferálta az igazgatási széttagoltság kezelésére: ugyanakkor az alacsonyabb lokális önkormányzati struktúra megtartása révén továbbra is biztosítható a közösségi kontroll és helyi demokrácia. A kétszintü nagyvárosi önkormányzati modell hátrányai a gyakorlati közpolitikai megvalósítás (policy implementation) során ütközhetnek ki, így a két önkormányzati szint közötti feladat- és hatáskörmegosztás anomáliái vagy a papíron igen, de a valóságban egyáltalán nem garantált kiegyensúlyozott munkakapcsolat a két szint között [Barlow, 1991, 21-30. pp.].
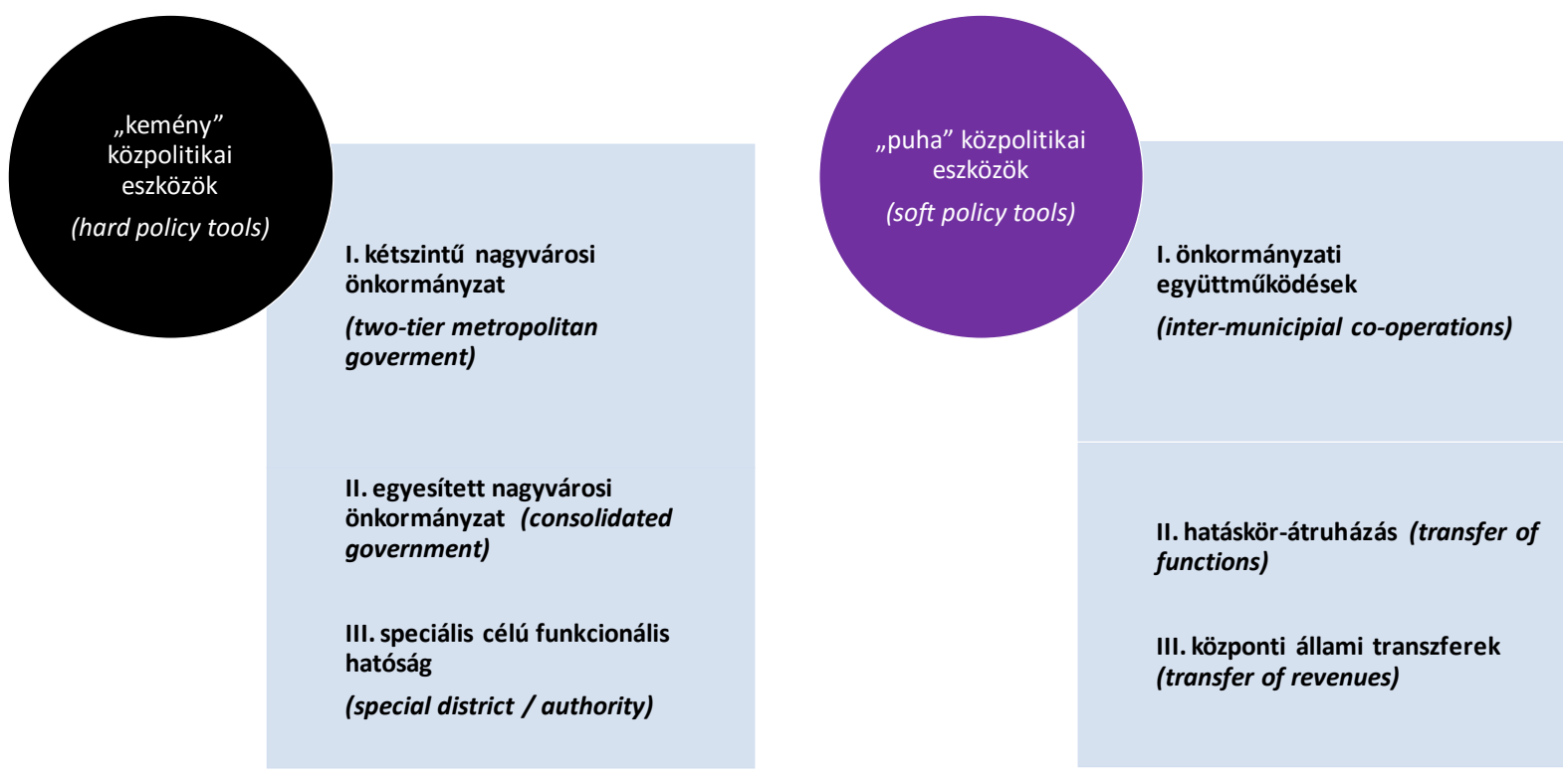

12. ábra: várostérségi eszközök Barlow alapján - saját szerkesztés!

$\underline{\text { Az ismertetett tipológiák szintetizálása: }}$

A különböző bemutatott elméletek szintetizálása során láthatóvá válik, hogy három elemzési egység mentén kategorizálhatóak a helyhatósági fragmentáció oldására alkalmazott, ajánlott közpolitikai módszerek a nagyvárosi övezetekben, ezek a következők:

I. Önálló intézményi keret létrehozásával (egycélú speciális metropoliszhatóság; általános kétszintű nagyvárosi tanács; egyesített város-megye) vagy önálló intézményi keret létrehozása nélkül alkalmazott (formális, informális kooperációk; megosztott regionális-térségi adóalap) megoldások. 
II. Az integrált közös feladatok száma alapján: egycélú funkcionális; csupán néhány kompetenciára koncentráló; nagyszámú hatáskört magába foglaló megoldások;

III. A meglévő önkormányzati fragmentált struktúrát, $\mathrm{s}$ vele a helyi-lokális önkormányzati autonómiát tiszteletben tartó illetve magát a fragmentált helyilokális önkormányzati struktúrát generális intézményi szinten módosító, összevonó, integráló megoldások (annexió, egyesülés, város-megye konszolidáció).

Rendkívül tanulságos a különböző nagyváros térségi igazgatási- és közpolitikai modellek esetében az alkalmazott government és governance típusú megoldások empirikus összevetése. Amíg az angolszász típusú önkormányzatiság, helyi feladatszervezés- és ellátás, gazdagon merít a különböző menedzsmenttudományok gyakorlatából, egyértelműen teret nyitva ezzel a governance megközelítés (gyakorlatok, módszerek, eljárások) számára. Addig a hagyományosan államközpontú kontinentális Európában, a formális intézmények iránti tiszteletből fakadóan sokáig a government alapú szemlélet - s vele a „kemény” intézményi eszközök (hard policy tools) - volt a meghatározó. Az elmúlt harminc év decentralizációs (MLG, regionális reformok és egyéb decentralizációs átalakítások) és/vagy devolúciós (NPM, privatizáció, contracting out etc.) tendenciái azonban már a governance jellegü módszerek, gyakorlatok preferálásának is kedveztek.

\section{III.7 A nagyvárosi kormányzás tágabb történeti dimenziója}

A nagyvárosi kormányzás történetét sajátos dinamizmusok, trendek jellemzik. Az alapvető konfliktusforrás már az ipari forradalom időszakában érzékelhető volt: az egyre inkább egységes gazdasági terekhez fragmentált jogi-közigazgatási struktúrák párosultak. A különböző várostérségi közpolitikai kísérleteknél fontos vizsgálati tényező a történeti szakasz, benne a meghatározó politikai és gazdasági trendekkel, azok földrajzi-geopolitikai vetületével. A periódusokat, korszakhatárokat közel azonos módon írják le a téma szakértői Európában és Észak-Amerikában. Korábban már esett szó arról, hogy a XX. század közepéig a nagyvárosi térségek közpolitikai problémakezeléséhez jórészt a klasszikus intézményi (government) alapú ún. „kemény” közpolitikai megoldások (hard policy tools) kerültek alkalmazásra. A modern kormányzási (governance) filozófiát megjelenítő ún. „puha” közpolitikai eszközök (soft policy tools) az elmúlt évtizedekben kerültek a politikai döntéshozók látóterébe. A nagyvárosi kormányzás empirikus és elméleti tudásanyaga 
exponenciálisan növekszik a társadalmi fejlödés és az urbanizáció előrehaladtával: a leírt tapasztalatok Kanadától Indiáig, Németországtól az Egyesült Államokig, a dél-kelet ázsiai feltörekvő államoktól Latin-Amerikáig érnek. Folyamatosan születnek a különböző statisztikák, komparatív esettanulmányok, nemzetközi konzorciális és nemzeti kutatások.

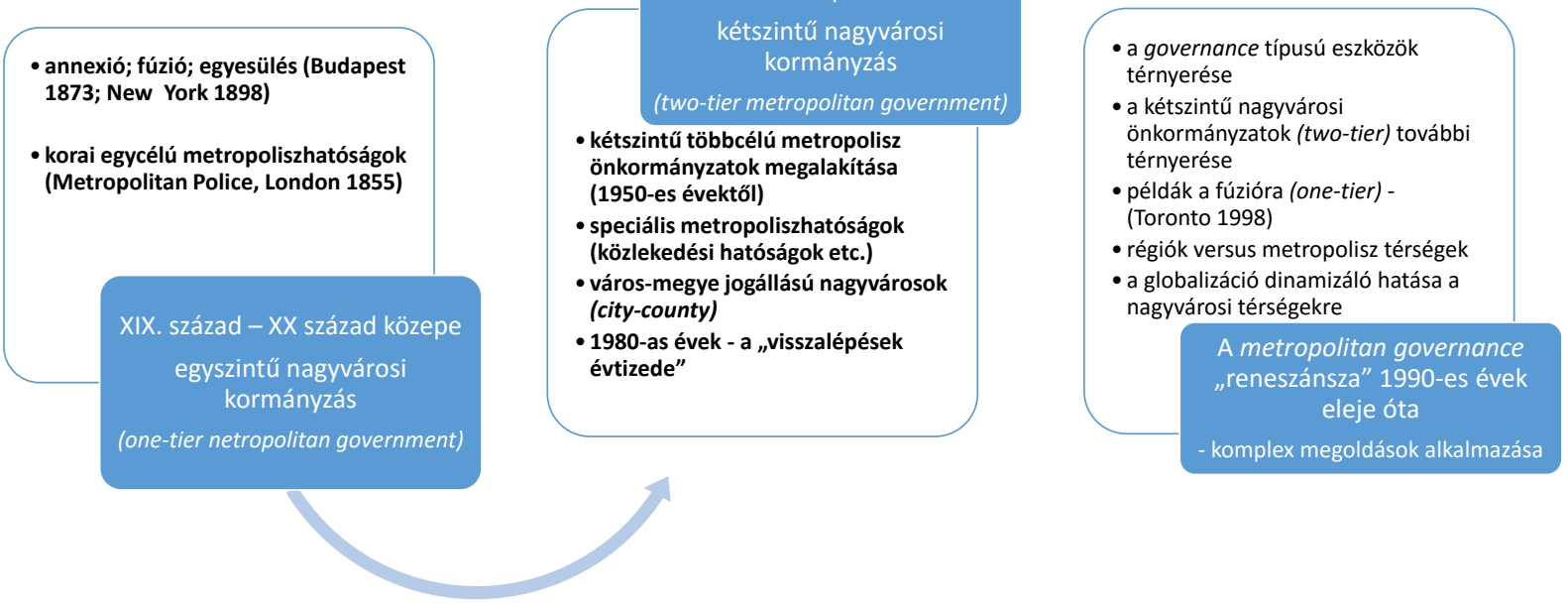

13. ábra: a várostérségi kormányzás idöbeli-történeti dimenziója - saját szerkesztés!

\section{III.7.1 Racionalizálási kísérletek a XIX. századtól a XX. század közepéig}

A XIX. század elejétől a XX. század közepéig a politikai-igazgatási fragmentáció csillapítására alapvetően kétféle kifejezetten „kemény” intézményi módszert alkalmaztak: az önkormányzati egységek önkéntes fúziója, egyesülése a várostérségben, illetve a magtelepülés által dominált - sokszor erőszakos adminisztratív - bekebelezés, annexió. A fúziók és annexiók hátterében a nagyvárosok, városközpontok urbanizációs expanziója állt. Sokszor olyan hétköznapi szükségletek váltották ki a fúziót, az annektálást vagy egyéb racionalizálási intézkedéseket (hatáskörtranszferek etc.), mint például a kolera elleni félelem - így kerültek kialakításra az egységes nagyvárosi víz- és csatornakerületek a XIX. században. Pest, Buda és Óbuda 1873-as fúziója abszolút az uralkodó korszellemet igazolja. Németországban 18701910 között 93 város területe 170 ezer hektárral, s vele a városok népességszáma 14 millió lakossal növekedett a különbözö területi-joghatósági annexiók révén. [Somlyódiné, 2011, 32. pp.]. 
„Ahány ház, annyi szokás” - a helyi önkormányzatiságra sokat adó Egyesült Államokban nagyvárosról nagyvárosra változott, hogy a várostérségi helyhatóságok a fúziót vagy az annektálást preferálták a fragmentáció csökkentésére. Amíg a XIX. században az annektálás volt az alapvető gyakorlat, addig a XX. századra már az önkéntes fúziós megoldások kerültek előtérbe. Az első ipari forradalom (kb. 1780-1850) időszakában az annexió mellett a város-megye konszolidáció (city-county) volt a jellemző területszervezési megoldás az Egyesült Államokban: az amerikai megye, mint alsó-közép szintű területi joghatóság területén található egyéb lokális helyhatóságainak intézményi beolvadásával határozták meg az Egyesült Államok nagyvárosi tendenciáit. Ekkor jöttek létre olyan korai metropolisz nagyvárosi önkormányzatok, mint New Orleans (1805), Boston (1821), Baltimore (1851), Philadelphia (1854), vagy San Francisco (1856). Az annexiós megoldások a második ipari forradalom időszakában (kb. az 1860-as évektől az első világháborúig) is folytatódtak - pl. az egységes Chicago, Detroit illetve Pittsburgh kialakítása. Adminisztrációs és eljárási szempontból az annektálás (bekebelezés) volt a legegyszerübb feloldása a diszfunkcionális fragmentációnak. A XIX. század végétől már inkább jellemzőek a politikailag kifinomultabb eljárásnak tekinthető nagyvárosi egyesülési, fúziós folyamatok pl. az egységes New York-metropolisz önkormányzat létrejötte 1898-ben; Denver 1904-es illetve a hawaii Honolulu 1907-es egyesülési folyamatai [Mitchell-Weaver - Miller - Deal, 2000, 852-853. pp.; Barlow, 1991, 31-34. pp].

Az észak-amerikai döntéshozók már a XX. század elején szükségesnek gondolták a különböző üzleti lobbi- és nyomásgyakorló csoportok aktív támogatását a fragmentációból fakadó nehézségek csillapítása, annak feloldása a napi szintü müködés, operatív ügyintézés fontos előfeltételévé vált. Az 1929-1933-as gazdasági világválság (Great Depression) egyik közpolitikai következményeként az amerikai föderális törvényhozás és kormányzat az erősödő helyi bottom-up metropoliszfolyamatokat felülről (top-down) erősítette meg különböző központi jogalkotási aktusokkal [Mitchell-Weaver-Miller-Deal, 2000, 855-857. pp.]. A XX. század második felében az Egyesült Államokban is meghatározóvá vált a nagyváros és a környezö önkormányzatok kifinomult kooperációjára épülő kétszintű föderatív tanácsok történeti előképei már megjelennek a század első felében - pl. Stuttgart és a vonzáskörzeti települések szövetsége 1931-ben [Somlyódiné, 2011, 33. pp.].

\section{$\underline{\text { London és Toronto - két példa a korai várostérségi kormányzati folyamatokra }}$}

London és a kanadai Torontó - egy európai és egy észak-amerikai nagyváros, amelyek általában az elsők között reflektáltak a modern városfejlődés különböző történéseire, 
folyamataira. A két metropolisz politikai döntéshozói hasonló időben, nagyon hasonló adminisztratív-, közpolitikai válaszokat, reakciókat adtak. Ugyanakkor az előzményekhez képest érdekes, hogy az 1990-es években második felének városigazgatási reformjai alapjaiban tértek el: amíg London és térségében ismét kialakításra került a kétszintü agglomerációs tanács, addig Torontóban éppen a korábbi kétszintű modellt váltotta fel egy integrált - egyesített - egyszintủ nagyvárosi szisztéma (City of Toronto).

Londonban 1829-ben hozták létre a London környéki településekre nézve is hatáskörrel rendelkező rendőri hatóságot Metropolitan Police néven, mint speciális egycélú metropolisz intézményt. Ezt követően hozták létre 1855-ben a Metropolis Management törvény alapján a városkörnyékre kiterjedő területi illetékességgel bíró Metropolitan Board of Works $(M B W)$ intézményt, mint a nagy-londoni közmunkák tanácsát, közel tucatnyi hozzárendelt közfeladattal. 1888-ban az MBW-t a kibővített hatáskörü London City Council (LCC) váltotta fel, majd az 1899-es London Government Act 28 korábban önálló települést annektált a brit fővároshoz [Barlow, 1991, 48-67. pp.].

A kanadai Ontario állambeli Torontó metropolisz-gyökereit még az 1790-es évekre vezetik vissza a helytörténészek. Az 1849-es szövetségi törvény, a Municipal Corporations Act elöírásait követve Torontó és több városkörnyéki helyi-lokális önkormányzati fúziója valósult meg, igazodva a XIX. század urbanizációs és iparosodási folyamataihoz - a háttérben erőteljes népesség- és területi expanzió. Toronto a századfordulóra vált igazi metropolisszá, és amíg a XIX. századi Londonban a direkt „,beavatkozások” (annexiók, fúziók) mellett már alkalmaztak speciális helyhatóságokat (rendőrség, közmunkák tanácsa) a növekvő várostérségi feladatellátáshoz, addig a kanadai nagyváros területi expanziója kimerült a szomszédos települések bekebelezésében - pl. Yorkwille, North Toronto „csatlakozása” [Barlow, 1991, 188-192. pp.].

\section{III.7.2 Észak-amerikai tapasztalatok a XX. század közepétől napjainkig}

A nagyvárosi kormányzás az Egyesült Államok elmúlt 50-60 éves időszakának fontos szubnacionális közpolitikai fejezetét adja. Az európai kontinensen tapasztaltak volumenét jelentősen meghaladó észak-amerikai urbanizációs folyamatok (nagyobb számú megaváros; előrehaladottabb dezurbanizációs és reurbanizációs folyamatok etc.) rendkívül sokszínű képet mutatnak. Már az 1950-es években a különböző kétszintű föderatív agglomerációs megoldások kerültek fókuszba. Erősítette a folyamatot, hogy ebben az időszakban vált igazán látványossá az amerikai nagyvárosi középosztály kiköltözése a szuburbán övezetekbe, 
településekre - pl. New Jersey, Visalia, Orange County korabeli látványos expanziója, megnövekedése. A nagyvárosi problémák integrált területi orvoslására létrehozott új típusú metropolisz politikai-igazgatási keretek között immár nem üresítették ki az alacsonyabb szintek önkormányzati autonómiáját - legyen szó a városmag belső kerületeiről, illetve a szuburbán helyhatóságokról. Ugyanakkor ezt nem jelentett kizárólagos dominanciát, így a XX. század második felében is történtek a kontinens metropolisz térségeiben fúziók, egyesülések és annektálások nagyvárosi térségekben - pl. Indianapolis, Nashville, Toronto 1998.

Az észak-amerikai kontinensen az 1950-es évektől a napjainkig megalakult kétszintű metropolisz tanácsok, önkormányzatok két alapvető típusát ismeri a szakirodalom:

1. Az ún. CGOs (Council of Governments) - mint többcélú föderális kétszintü típusú struktúra -, amely a nagyváros és a városkörnyéki önkormányzatok (városok, községek vagy akár megyék, mint alsó-közép szintü önálló joghatóságok) delegált, vagy ritkább esetben közvetlenül választott döntéshozó testülete. Ezek a $C G O-\mathrm{k}$ több különböző feladatot látnak el a tagok által lefedett területen - területi tervezés, térségi fejlesztési programok, projektek, különböző közszolgáltatások. [Barlow, 1991, 34-36. pp.].

2. Az ún. MPOs (Metropolitan Planning Organizations) - amely kifejezetten egycélú, speciális metropoliszhatóságként funkcionál, a fejlett sürü közlekedési hálózatot müködtető speciális nagyvárosi agglomerációs térségi helyhatóságként. Az MPO-k jogi és finanszírozási alapját egy 1962-es amerikai szövetségi törvény a Federal-Aid Higway Act biztosította, amely az 50.000 fónél nagyobb lakosságszámú városi térségekhez rendelte lehetőségként az érintett tagállam és helyi önkormányzatok kooperációja mellett. ${ }^{55}$

Az Egyesült Államokban az 1950-es években történtek meg az első kísérletek a kétszintű nagyvárosi tanácsok kialakítására: Denver és környéke (Denver Regional Council of Governments), valamint Arkansas állam fővárosaként is funkcionáló Little Rock agglomerációs tanácsa (Metroplan), amely 5 arkansas-i megye (county) alapszintű városi helyhatóságait tömöríti magában - mindkettőt 1955-ben hozták létre. Ezután az északnyugati Seattle térségében 1956-ban (Puget Sound Regional Council) alakult meg, majd 1957-ben

\footnotetext{
${ }^{55}$ Ahogy a modern gyorsforgalmi utak behálózzák az Egyesült Államokat, úgy alakultak meg már az 1960-as években az MPO-k, amelyek komoly érdekérvényesítő szereppel bírnak a szövetségi autópálya politikára (federal highway policy), országos lobbiszervezetük az Association of Metropolitan Planning Organizations (AMPO) - www. ampo.org
} 
hozták létre a Washington D.C.-re nevével fémjelzett agglomerációs szintű közlekedési, területi tervezési és egészségügyi kooperációra épülö Metropolitan Washington Council of Governments várostérségi közlekedési hatóságot, amely a szövetségi fővároson túl közel 30 db Maryland és Virginia állambeli alsószintü önkormányzatot foglalt magában. Kanadában a főváros Ottava térsége (National Capital Comission), illetve a Vancouver-i agglomeráció (Metro Vancouver) területén alakultak meg a két legkorábbi metropoliszhatóság - előbbi 1959-ben, utóbbi 1967-ben.

Jó néhány amerikai kétszintü nagyvárosi önkormányzat alakult meg az 1960-as években, így a massachusetts-i Boston (1963), az arizonai Phoneix (1967), a texasi Dallas (1966), a michigani Detroit (1968), vagy éppen Los Angeles-i (Southern Californian Association of Governments, 1965). Az évtized pezsgését mutatja, hogy a jelenleg is müködő kétszintű metropolisz önkormányzatok több mint egyharmada az 1960-as években jött létre. Ugyanakkor az 1970-es évektől az ezredfordulóig már jóval kevesebb ilyen típusú intézményesedés történt - pl. a texasi Austin (1970), az új-mexikói El Paso várostérségben 1971-ben, Memphis (1974), Portland (METRO, 1979), a Baltimore-i metropolisz önkormányzat 1992-ben. Az ezredfordulót követően alakult meg mai formájában az agglomerációs térségi önkormányzati tanács Chicago térségében (Chicago Metropolitan Agency for Planning, 2005) [OECD, 2014a 26-45. pp.]. Számos amerikai metropolisz térségben azonban nem alakultak meg ilyen típusú kétszintű metropolisz struktúrák - pl. New York vagy a nevadai Las Vegas. Ugyanakkor érdemes megemlíteni, hogy intézményi megoldás tekintetében az Egyesült Államokban Európához képest nagyobb számban jöttek létre a nagyvárosi kormányzásnak az egyesített város-megye típusú megoldása - pl. New York, San Francisco, Virginia állam. Mivel az Egyesült Államok erősen decentralizált és föderális jellegü, nagy szerepe van a helyi-térségi térségi kezdeményezéseknek.

$\underline{\text { Toronto - empirikus példa a többszöri modellváltásra }}$

Torontó 1928-ban hivatalosan is deklarálta, hogy nem kíván élni az annexió lehetőségével a városkörnyék irányába. Egy 1951-es városi statisztika a city összlakosságát 673 ezer, a környező települések, helyhatóságok összlakosságát 347 ezer főben összegezte. A várost körbeövező szuburbán övezet jelentős megduzzadása egyre inkább napi nehézségként ütközött ki az alapvető közszolgáltatások terén, mint a közegészségügy, közbiztonság, víz- és csatornahálózat, vagy a közösségi közlekedés. 1953-ban jött létre a kétszintű metropolisz szintü önkormányzat $(C G O)$ a Metro Toronto, Quebec tartomány törvényalkotása révén. ${ }^{56}$

\footnotetext{
${ }^{56}$ Metropolitan Toronto Act
} 
Igyekeztek egyértelmü feladat- és hatáskör-elhatárolást a lokális (benne Torontó city és a szuburbán önkormányzatok) valamint a kétszintü metropolisz tanács között. Bizonyos kompetenciáknál a részfeladatok mentén többféle illetékességet is meghatároztak. A nagyobb vízi közmüfeladatokat a metropolisz szintre, a kisebb vízügyi kérdések az egyes helyi önkormányzatokhoz telepítették; a gyorsforgalmi utak a teljes várostérséghez, az alacsonyabb rendü utak a lokális szintre kerültek; a hulladékgyüjtés a lokális, addig a hulladékártalmatlanítás már a metropolisz szint, s így CGO reszortja lett. Hasonló lehatárolás érvényesült a helyi adózás tekintetében, az ingatlanadó meghatározása a metropolisz, a beszedése viszont már a lokális önkormányzatok feladata lett. Ugyancsak az 1950-es években speciális egycélú tervezési egységként létrehozzák a Metropolitan Toronto Planning Board (MTPB) hatóságot, a Metro Torontónál nagyobb, de a szubnacionális Ontario tartomány alatti joghatósággal.1967-ben megtörtént a kétszintű Toronto metropolisz önkormányzati rendszer újragondolása a korábbi feladatmegosztás átfazonírozásával. Előbb a lokális szinten történt koncentráció, a 13 önkormányzati egységből 6-ot kialakítva (fúzió). Majd jelentős hatáskörtranszfert valósítottak meg a lokális szintről a metropolisz szint irányába a jóléti szociális- és a víztisztítás területén. Egységes könyvtári szolgáltatást is kialakítottak az egész metropolisz térségre nézve. Ami változatlan maradt, az $M T P B$ egységes tervezési funkciója illetve a metropolisz tanács (COG) delegált jellege. 1975-ben felszámolták még az agglomerációs térségen túlmutató $M T P B$-t felszámolták [Barlow, 1991, 192-198. pp.].

Az 1998-as városi közpolitikai metropolisz „reform” egyesítette az immáron 6 önálló helyi önkormányzatot, és a kétszintü (two-tier) struktúrából egy egyszintü (one-tier) közvetlenül választott föpolgármester és tanács irányította önkormányzati modellt létrehozva: a City of Toronto létrejöttét Ontario állam törvényalkotása elözte meg. A teljességhez hozzátartozik, hogy a 2000-es években a regionális tervezés felelősségét tartományi (szubnacionális) szintre rendelték, valamint 2006-ban egycélú metropolisz intézményként (special district - MPO) létrehozták a Greater Toronto Transportation Authority (METROLINX) elnevezésű metropolisz szintủ közlekedési hatóságot. ${ }^{57}$

\section{III.7.3 Európai várostérségi közpolitikai folyamatok a XX. század második felétől}

Az 1990-es évek eleje óta az európai (elsősorban az Európai Unióban) nagyvárosi kormányzás területén valódi pezsgés tapasztalható. Ezek a történések harmonikusan illeszkednek a globalizáció gazdasági aspektusaihoz. Az 1950-1960-as évek - mint a fordista-

\footnotetext{
${ }^{57}$ A METROLINX hatóságot Ontario állam hozta létre 2006-ban - www.metrolinx.com/en
} 
keynesianus gazdaságtörténeti periódus csúcsidőszaka - alapvetően az adminisztratívigazgatási modernizációról, a területi kiegyenlítésről (pl. növekedési pólusok elmélete és gyakorlata), valamint a közszolgáltatások modernizációjáról szóltak a demokratikus Európában. Ezzel együtt inkább a „kemény” intézményi government megközelítés volt a domináns, és a nagyvárosi közpolitika sokkal kevésbé nyílt ki a szüken vett önkormányzati politikai-igazgatási szektor határain túlra a piaci illetve a non-profit szektorok irányába [Lefévre, 1998, 9-16. pp.]. Fontos, hogy ez az időszak volt az európai jóléti állam „aranykora”, amikor a kontinens állami és önkormányzati feladatellátása rendkívül széles fiskális és közintézményi alapokon nyugodott. Másrészt ez a periódus még sokkal kevésbé szólt a területi tervezés és kiegyensúlyozott policentrikus terület- és településfejlesztésről; így jobbára a korábbi évtizedek, évszázadok során kialakult klasszikus ipari időszak (a két ipari forradalom által lefedett közel két évszázad) gazdasági egyenlőtlenségei által determinált monocentrikus városrendszerek határozták meg az európai városfejlődés képét. ${ }^{58}$

Az 1970-es évek paradigmatikus változásai (a két olajválság 1973, 1979), erőteljesen újrastrukturálták a közgazdasági fókuszok és dimenziók jellegét, irányát. A korábbi széles jóléti (fordista-keynesianus) modell helyét fokozatosan felváltotta már a globális világgazdasági trendek által meghatározott posztfordista modell, a maga radikálisan új vagy újszerü elemeivel, mint a regionális gazdasági koordinációk; a széles térségi (országos, szubnacionális - így metropolisz szintű) tervezési folyamatok; valamint a szuburbanizációs folyamatokhoz erőteljesen kötődő nagyváros - városkörnyék kooperációk. A globális gazdasági verseny a nemzetközi multinacionális befektetésekért, fejlesztésekért globális versenyfutást produkált nemcsak a nemzetgazdaságok, de a szubnacionális területi egységek (régiók és nagyvárosi térségek) között is - lásd Sassen, Harvey és társaik irásait! Egyre fontosabbá vált a funkcionális nagyvárosi térségek egységes entitásként való kezelése a globalizált világgazdaság viszonyai között. A nemzetgazdaságok versenyképesség-központú szemlélete egyre inkább átszivárgott a helyi-lokális gazdasági egységek világába. Miközben tanulva a korábbi jobbára az intézményi government keretekre korlátozódó törekvések politikai- és igazgatási akadályaiból (fragmentált intézményi struktúrák; széttartó önkormányzati politikai törekvések etc.) a nagyvárosi közpolitikát alkotó stratégák, döntéshozók, igazgatási vezetők figyelme egyre inkább a modern governance típusú eszközök felé orientálódott. Ebben persze óriási szerepe volt nemcsak az állam, de az önkormányzati szektorok szintjén is jelentkező hatékonysági (konkrétan fiskális megtakarítási)

\footnotetext{
${ }^{58}$ Lásd Gravier Párizs és „francia sivatag” elméletét Franciaország rendkívül egyenlőtlen gazdasági és területitelepülési (nagyvárosi) viszonyairól.
} 
törekvéseknek. A New Public Management - mint a különböző közfeladatok és közszolgáltatásoknak a szüken értelmezett közszektoron kívülre, a for-profit és civil (egyesületi, alapítványi) világra, történő kiszervezése - legközvetlenebbül éppen az önkormányzati feladatellátásban jelentkezett [Horváth M. 2005; Jenei, 2005; Horváth M., 2013].

A policentrikus területi fejlesztési szemlélet megerősítésében különösen fontos szerepet töltött be az európai integráció keretében megerősödő regionális politika, regionális területi szemlélet - lásd korábban bemutatott különbözö európai uniós stratégiai dokumentumokat! Már az 1957-es Római Szerződés is értekezett az önálló regionális politika fontosságáról, de intézményi és fiskális szempontból csak az 1960-as évek végétől beszélhetünk komoly paradigmaváltásról. Előbb 1968-ban állították fel az önálló Regionális Politikai Főigazgatóságot (DG Regio) - mint ágazatpolitikai intézményi bázis; majd 1975-ben létrehozták az Európai Regionális Fejlesztési Alapot (ERFA) - mint az európai régiók között fennálló gazdasági és társadalmi differenciák mérséklésére hivatott önálló közösségi pénzügyi alap. Ezt követően az 1986-os Luxemburgban elfogadott Európai Egységes Okmány (Single European Act - SEA) keretében érkezett nagyon erős politikai impulzus, amikor a regionális politika deklaráltan is önálló közösségi jelleget kapott. A SEA ,ágyazott meg” a regionális politika radikális reformjának, amit 1988-ban vezettek be, kibővítették az ERFA forrásait, újrastrukturálták az egész allokációs szisztémát ${ }^{59}$ - Strukturális Alapok rendszere; majd 1993tól elindították a speciális jellegü Kohéziós Alapot. Az 1990-2000-es évekre a megújuló Közösség - 1993-tól, mármint Európai Unió -, egyik legfontosabb közösségi politikává vált.

Az európai nagyvárosi térségi közpolitikai folyamatok elemzése kapcsán fontos kiindulópont, hogy a helyi önkormányzatok között milyen együttmüködések, horizontális kooperációs tradíciók figyelhetők meg. Fontos előfeltétel, hogy az adott országban általában milyen struktúrában müködnek a helyhatóságok: fragmentált (,,egy település egy önkormányzat” - elv) vagy integrált (apró települések hozzácsatolása nagyobb, népesebb önkormányzathoz). Utóbbi típus esetében - pl. Egyesült Királyság; skandináv államok értelemszerüen kevésbé jelenik meg az önkormányzatok együttműködése, társulás iránti szükséglet mivel az alsószintü helyi közfeladatok jelentős részét már eleve integrált önkormányzati keretek között látják el. Bár ez természetesen nem zárja ki, hogy más típusú ügyekben az integrált helyhatósági rendszerekben a helyi önkormányzatok még pluszban

\footnotetext{
${ }^{59}$ Az ERFA mellett az önálló regionális politika további eszközei: az Európai Szociális Alap (ESZA 1958); az Európai Mezőgazdasági Garancia és Orientációs Alap (EMOGA) orientációs eszköze; a meghatározott partmenti, halászati területelre koncentráló Halászati Orientációs Pénzügyi Eszközök (HOPE).
} 
kooperálhassanak egymással; a társulási jog egyébként is a nemzetközileg elfogadott fontos része az önkormányzati alapjogoknak - lásd az 1985-ben elfogadott Európai Önkormányzati Chartának a társulásokról szóló passzusát!

Az önkormányzatok közötti kooperációk igénye a fragmentált helyhatósági rendszert alkalmazó országokban sokkal elemibb igényként jelenhet meg, lévén a legapróbb önkormányzati egységek - köszönhetően az alacsonyabb demográfiai és ebből következően gazdasági, intézményi mutatóinak - a helyi közfeladatok kisebb-nagyobb részét (attól is függően, hogy az állami szabályozás mit rendel az önkormányzati szektorhoz) nem képes önerőből ellátni [Pálné, 2008a, 36-37. pp.].

\section{III.7.4 Az európai várostérségi folyamatok dinamikája - 1960-1980 évek}

A nagyvárosi kormányzás témakörben, a XX. század második felének európai történései, kísérletei sajátos dinamizmusról árulkodnak: a) előbb jelentős aktivizálódás az 1960-70'-es években; b) egyértelmü megtorpanás, sőt hátraarc az 1980-as években; c) majd a már sokat emlegetett felívelö, és máig tartó dinamizmus az 1990-es évek elejétől. Az évszázadokig hagyományosan erős centralizált központi kormányzati tradíciókkal rendelkező Franciaországban már 1966-ban ${ }^{60} 4$ nagyvárosi metropolisz közösséget (urban community) hoztak létre törvény által, ezek Bordeaux, Lille, Lyon és Strasbourg nagyvárosokra koncentráltak; habár nem rendelkeztek közvetlen választott testületekkel, de számos feladatot ruháztak a metropolisz (nagyváros és környéke) szintre - tervezés; lakáspolitika. Strassbourg nagyvárosi térségében 1972-ben jött létre föderatív kétszintű struktúra, viszont azt követően egészen az ezredfordulóig megakad az ilyen irányú franciaországi folyamat. [OECD, 2014a 26. pp.; OECD, 2014b 10. pp.].

Az Egyesült Királyságban (Nagy-Britannia és Észak-Írország) 1963-ban került felállításra a Nagy-Londoni Tanács (Great London Council - GLC), mint közvetlenül választott föderatív kétszintű többcélú metropoliszhatóság. Az 1972-es metropolisz megyékről szóló törvény 6 nagyvárosi térségre (köztük Nagy-Manchester - Greater Manchester) terjesztette ki a kétszintű modellt, és így alakultak meg 1974-ben. ${ }^{61}$ Ezeket policentrikus jellegüknél is fogva, funkcionális és igazgatási egységként (pl. egységes helyi adórendszer) kezelte a törvényalkotó, amelyek a londonihoz hasonló intézményi keretet kaptak.

\footnotetext{
${ }^{60}$ Több mint másfél évtizeddel a francia decentralizációs igazgatási reformot nagymértékben megvalósító 1982es törvényhozás elött.

61 Átlagosan 1-3 millió lakos közötti urbánus térségek voltak - Greater Manchester, Merseyside, South Yorkshire, Tyne and Wear, West Midlands, West Yorkshire - ezek a következő nagyvárosokra koncentrálódtak: Manchester, Birmingham, Liverpool, Leeds, Sheffield, Newcastle - [Brenner, 2003].
} 
Hasonló kétszintű kormányzati test volt az 1964-ben létrehozott Rijmond (Greater Rotterdam) Hollandiában. Az akkor még autoriter berendezkedésü Spanyolországban: Madrid Metropolitan Area Planning and Coordinating Comission (MMAPCC) 1963-ban; Metropolitan Corporation of Barcelona (CMB) 1974-ben.

Nyugat-Európa más országaiban is létrejöttek hasonló föderatív agglomerációs intézményi keretek, így Dániában (Greater Coppenhagen Council 1974), valamint az akkori NSZK-ban (Umlandverband Frankfurt 1974; Regionalverband Stuttgart 1972 - bár ezek a későbbiekben átalakultak, megújultak. A leginkább időtálló föderatív struktúrával a német nagyvárosi térségek közül Karlsruhe (Regionalverband Mittlerer Oberheinn), München (Region München) - mindkettő 1973-tól, és Saarbrücken (Regionalverband Saarbrücken) 1974-től számított [Brenner, 2003, 296-303. pp.; Lefévre, 1998 13-15. pp.; OECD, 2014a, 2627. pp.].

Az 1960 és 1970-es évek nekibuzdulását követően az 1980-as évtizedet a megtorpanás évtizedeként aposztrofálja az európai metropolitan governance szakirodalom. Az 1970-es évek világgazdasági struktúraváltása, valamint a klasszikus jóléti állam vívmányainak erőteljes „visszanyesése” keretében indultak nagyon pregnáns ,államtalanítási” kísérletek (pl. Thatcher 1979-től; Reagan 1981-től), amelyek hatása az állami közfeladat-ellátás mellett közvetlenül jelentek meg az önkormányzati szektorban. Már jeleztük több alkalommal is, hogy a közfeladat-ellátás a közszektoron túli szektoraira, elsődlegesen a for-profit piaci, másodlagosan a civil, non-profit szektorok irányába valósult meg. Viszont a közpolitikai hatáskörök, kompetenciák területi-horizontális kinyitását jelentő többszintü kormányzás (MLG), különösen annak nagyvárosi - annak is a kétszintü - változata terén - egyértelmü hátraarc volt tapasztalható az évtizedben: több európai metropolisz szintű közpolitikai kezdeményezés kapott léket kifejezetten a központi kormányzat jóvoltából. Erre eklatáns példa a Nagy-Londoni Tanács (GLC) megszüntetése 1986-ban a Thatcher-kormány jóvoltából, amit majd később az első munkáspárti Blair-kormány (1997-2001) időszakában állítottak vissza eredeti jogköreibe már Great London Authority elnevezés alatt. A Thatcherkormány ideje alatt a London mellett 1974-ben felállított 6 vidéki nagyvárosi agglomerációs helyhatóság (metropolitan county) is megszüntetésre került, hatáskörei pedig visszakerültek az alsóbb szintü helyi-lokális önkormányzatokhoz (nagyváros és városkörnyéki helyhatóságok). Az 1980-aa években megszüntetésre kerültek a korábbi évtizedek kétszintü agglomerációs struktúrái Madridban, Barcelonában, Koppenhágában, Rotterdamban. Habár a kontinensen számos kétszintű agglomerációs tanács ugyan „túléli” az évtizedet, megtartva eredeti intézményi struktúráját, de ezeket is érintette a központi kormányzatok felől érkező 
hatáskörelvonások, valamint indirekt pénzügyi pressziók. Az alkalmazott nagyvárosi közpolitikákon erőteljesen rajta hagyták nyomukat az 1980-as években dominánssá vált deregulációs és neoliberális tendenciák (NPM). Hasonló hatással bírt a nagyvárosok, városközpontok illetve a szuburbán, agglomerációs perifériák közötti verseny a bel- és külföldi befektetésekért, gazdasági telephelyekért (pl. minél kedvezőbb területhasználati policy; lazuló engedélyezési gyakorlatok) [Brenner, 2003, 288-302. pp.].

Lefévre a nyilvánvaló gazdasági nehézségek mellett az 1980-as évek kudarcát két nem fiskális okra vezeti vissza: 1) a legitimitás problémája, mint általában véve a governance alapú kezdeményezések, folyamatok esetében. A másik 2) a túlzottan adminisztratív-hatósági megközelítés, amely során a metropolisz folyamatok jobbára csak erös intézményi (government) aspektust kaptak, háttérbe szorítva a társadalmi, szociológiai szempontból ún. soft megközelítéseket - pl. a helyi-lokális önkormányzatok és stakeholderek meggyőzése a metropolisz szintü funkcionális egység és tervezési keret számára [Lefévre, 1998. 15-16. pp.]. A teljesség kedvéért fontos még szólnunk a speciális kifejezetten egycélú speciális agglomerációs hatóságok európai elterjedéséről. Korábban említettük, hogy ÉszakAmerikában, azon belül is elsősorban az Egyesült Államokban rendkívül elterjedt az ilyen típusú szerveződések felállítása és müködtetése. De tudunk, ismerünk számos európai példát a special district-ekre, így az olasz consorzi társulás, amely intermunicipális jelleggel fog össze víz- és csatornázási társaságokat, közlekedési hatóságokat. Hasonló típusú intézményi szereplők a franciaországi SIVU (single purpose joint authority) hatóságok. Az ilyen típusú speciális helyhatóságok létrehozását indukálható felülről (top-down) - országos szintü jogalkotáson, s így ágazati jogszabályokon (törvények, kormányrendeletek, miniszteri rendeletek) keresztül -, valamint alulról (bottom-up) helyi térségi-lokális kezdeményezések, jogalkotás, szervezési metódusokon keresztül.

\section{III.7.5 Az európai várostérségi folyamatok dinamikája - 1990 után}

Az 1990-es évek nagyvárosi közpolitikai folyamatait sok szempontból a múlt hibáiból való tanulás, valamint az új kihívások (globális verseny a nemzetgazdaságok, makrorégiók és szubnacionális térségek, nagyvárosi övezetek között; fokozódó európai integráció - EU, Maastricht 1992; Amszterdam; Nizza 2000; Lisszabon 2009 etc.) határozták meg - ez a két tényező egyszerre szült kényszereket és lehetőségeket (közpolitikai, intézményi reformok). A múlt hibáiból való tanulás - értsd: a metropolitan governance új típusú értelmezése metódusában radikálisan változtatott a korábbi közpolitikai megközelítésen, a kontinensen. A 
folyamat európai nyitányának az 1990-es olasz törvényi jogszabály tekinthető a metropolisz városokról (citta metropolitane - metropoliotan cities), amely Bologna, Róma, Torinó, Genova és Velence számára teremtett új közjogi intézményi keretet. ${ }^{62}$ Franciaországban már az 1992-es területi igazgatási törvény, valamint az 1995-ben a metropolisz szintű regionális tervezésről született törvények is foglalkoztak a nagyvárosi térségek speciális kezelésével, de az igazi áttörést az 1999-es „Chevenement törvény”63 jelentette, amely az 1966-ban létrehozott négy nagyvárosi helyhatóság mellett további 7 - legalább félmilliós lakosú metropolisz hatóságokat alakított ki 2000-2001-ben (pl. Nantes, Toulouse, Marseille, St. Etienne). Napjainkra 16 franciaországi nagyvárosi térségben található urban community, amely agglomerációs tanácsokba az érintett nagyváros és városkörnyéki helyi-lokális önkormányzatok testületei lakosságszám alapján delegálnak tagokat (council of community), és azok operatív vezetöit - elnök és alelnök - a tanács választja szintén közvetett módon. Mindenképpen külön kezelendő a méreténél és lakosságszám alapján messze-messze kiemelkedő francia főváros, Párizs, amely 8 környező megyével közösen alkotja a közel 12 millió fös Ile-de-France régiót, mint a 22 francia szubnacionális önkormányzati egység egyike. ${ }^{64}$ A világ egyik legurbanizáltabb országában, Hollandiában már az összefüggő nagyvárosi zónaként - a négy legnagyobb holland város, több mint 7 millió lakossal értelmezhető Randstad régión belül is több intermunicipiális együttműködés, kooperáció alakult ki napjainkra. 2006-ban 5 db föderatív kétszintủ agglomerációs tanács jött létre, ebből 4 a Randstad-on belül (Amszterdam, Utrecht, Hága, Rotterdam) valamint Edinhoven térségéhez kapcsolódóan [OECD, 2014a, 29. pp.].

Az Egyesült Királyságban az 1990-es évek végén az első Blair-kormányhoz köthető a brit devolúció (mint decentralizációs államreform) fontos része volt a Thatcher-kormány által megszüntetett Nagy-Londoni Tanácsnak a visszaállítása (32 helyi önkormányzat részvételével) 1999-ben Great London Authority elnevezés alatt. 2008-ban a két skót nagyváros, Glasgow (GCVSDPA) és Edinburg térségében hoztak létre kétszintü agglomerációs tanácsokat a helyhatóságok kezdeményezésére. A brit parlament a helyilokális önkormányzatok integrált nagyvárosi kezdeményezéseinek támogatására 2009-ben

\footnotetext{
${ }^{62}$ Fontos ugyanakkor megjegyezni, hogy az olasz városrégiók/városmegyék (city-county) a metropolisztérség egyéb önálló önkormányzataival mégsem alkotnak föderatív kétszintü metropolisz tanácsot az OECD 2014-es összegző jelentése szerint [OECD, 2014, The OECD Metropolitan Governance Survey 27. pp.].

${ }^{63}$ Jean-Pierre Chevenement francia szocialista politikus, aki a szocialista Jospin-kormányban töltötte be a belügyminiszteri pozíciót 1997-2000 között.

64 Egyedül Párizs metropolisz önmagában több lakost foglal magában, mint a 16 urban communities. A közvetlen Párizs és városkörnyékéhez kapcsolódó föderatív kétszintű intézmény a Paris Metropole ugyanakkor csak 2006-ban állt fel [OECD, 2014 The OECD Metropolitan Governance Survey, 26. pp.; www.parismetropole.fr].
} 
megalkotta a Local Democracy, Economic Development and Constitutional Act-ot, amely lehetővé teszi a nagyvárosi térségekben az integrált funkcionális, de önkéntes együttmüködést. Ez alapján jött létre 2011-ben az egykori Greater Manchester County megújításaként a Greater Manchester Combined Authority - tíz lokális önkormányzat által delegált vezető testülettel. A 2009-es törvény eredetileg kifejezetten az integrált tömegközlekedés és gazdaságfejlesztési funkciókra koncentrált; a két évvel később a Westminster által elfogadott Localism Act 2011 már kilátásba helyezte a müködő és potenciális combined authority-k számára akár közvetlen központi transzfer nyújtását, valamint további hatáskörök kerültek át a törvény révén a központi kormányzattól a NagyLondoni Tanácshoz (GLA). ${ }^{65}$

Az 1990-ben újraegyesült Németországban leginkább a stuttgarti és hannoveri kétszintű agglomerációs tanácsokat emlegeti a szakirodalom. Az 1994-ben létrehozott Verband Region Stuttgart 179 helyi-lokális önkormányzatot tömörít magában, közvetlenül választott metropolisz tanáccsal, meghatározott hatáskörökkel (stratégiai tervezés; közlekedés; hulladékgazdálkodás; gazdaságfejlesztés; turizmus és kulturális igazgatás). Az 1974-ben létrehozott, majd 2001-ben megújított közvetlenül választott Region Hannover agglomerációs tanács szintén rendelkezik egy sor végrehajtó-, adminisztratív kompetenciával (közlekedés, regionális fejlesztés, energiagazdálkodás, turizmus és kulturális igazgatás). Ugyanakkor érdemes megjegyezni, hogy csupán néhány német funkcionális nagyvárosi térség esetében nem alakult meg kétszintü föderatív agglomerációs struktúra, ezek közül éppen a szövetségi főváros Berlin és szuburbán térsége az egyik [Lefévre, 1998, 17-20. pp.; Tosics, 2008, 7. pp.; Somlyódiné, 2011, 33.pp; OECD, 2014a 26-27., 32-33. pp].

Az ezredforduló utáni metropolisz-szintü szerveződési hullám éreztette hatását a posztkommunista közép-európai térségben is, így alakultak meg a lengyel nagyvárosi agglomerációs tanácsok 2006 után - Varsó, Katowice, Lublin, Poznan és Gdansk agglomerációs övezeteiben [OECD, 2014a 29. pp.; OECD 2014b 15. pp]. ${ }^{66} \mathrm{Az}$ elmúlt évtizedben alakítottak/újítottak meg több német metropoliszhatóságot, mint a hamburgi (Metropolregion Hamburg), a frankfurti (Regionalverband FrakfurtRheinMain) vagy a volt kelet-német területről a drezdai agglomerációs hatóság (Region Dresden) 2004-ben [OECD, 2014a 26-45. pp.]. Belgiumban csak a főváros, az egyébként is tartományi jogkörrel

65 Local Demoncray, Economic Development and Construktcion Act 2009 - www. www.legislation.gov.uk/ukpga/2009/20/pdfs/ukpga_20090020_en.pdf; $\quad$ Localism $\quad$ Act 2011 www.legislation.gov.uk/ukpga/2011/20/pdfs/ukpga_20110020_en.pdf

${ }^{66}$ A felsorolt lengyel kétszintű nagyvárosi hatóságokhoz kapcsolódó térségi népesség minden ese3tben meghaladja az 500.000 lakost. 
felruházott Brüsszel és városkörnyéke rendelkezik saját kétszintű agglomerációs intézménnyel - egyedül az energiapolitikát rendelték hozzá, ugyanakkor az összes vizsgált belga nagyvárosi térség rendelkezik saját közlekedési hatósággal [OECD, 2014a 26-45. pp.; OECD 2014b 8-9. pp].

Érdemes felhívni a figyelmet, habár az Európában működő nagyvárosi agglomerációs tanácsok jelentős része a közlekedés, tömegközlekedés területén rendelkezik nevesített kompetenciákkal, de mellette számos funkcionális nagyvárosi térségben önálló agglomerációs közlekedési hatóság (sectoral transport authority) is müködik - a német nagyvárosi övezetekben kivétel nélkül (még Berlinben is); Spanyolországban az OECD jelentés szerint csak Barcelona térségében nincs önálló önkormányzati agglomerációs közlekedési hatóság. Ugyanakkor ez már erősen differenciált a francia és a brit metropolisz-övezetekben. A visegrádi országok közül egyedüliként az OECD által felmért Lengyelországban a 8 funkcionális nagyvárosi térségben csak 5-ben müködik többcélú kétszintű föderatív agglomerációs tanács, viszont az összesben létezik önálló agglomerációs közlekedési hatóság - ez is jelzi számunkra az agglomerációs szintü föderatív intézményi struktúrák európai sokszínüségét [OECD2014a 41-45.pp.].

\section{III.8 Az európai föderatív agglomerációs tanácsok jelene}

Az OECD aktuális összefoglaló tanulmánya a témában a Rudiger Ahrend és Abel Schumann által szerkesztett kiadvány, a The OECD Metropolitan Governance Survey, valamint a kapcsolódó magyarázó tanulmány - Approaches to Metropolitan Area Governance - mindkettő 2014-ből. Ezek révén az olvasó egy kvantitatív és kvalitatív összehasonlítást kap napjaink föderatív kétszintü - a nagyváros és a környező agglomerációs önkormányzatok kooperációjára épülő - kormányzati struktúrákról. A kutatási alapegységeit, az OECD által definiált funkcionális városi térségek, nagyvárosi agglomerációk (FUA) alkották - egy központi nagyvárosra és a környező települések, önkormányzatok funkcionális gazdasági egységére épülő, legalább 500.000 lakossal rendelkező várostérség. A komparatív összehasonlítás intézményi fókusza a nagyvárosi térségi feladatellátás érdekében életre hívott kétszintü várostérségi kormányzati jellegű struktúra [OECD, 2014a; OECD 2014b].

\section{III.8.1 A kétszintű nagyvárosi kormányzás strukturális elemei}

A 2014-es The OECD Metropolitan Governance Survey 263 funkcionális nagyvárosi térségre vonatkozóan tartalmaz adatokat, információkat. A vizsgált 263 nagyvárosi térség 
több mint 90\%-a található közvetlenül OECD tagállamokban; az átlagos lakosságszámuk 2 millió lakos felett van, amelyből a központi magtelepülés (a centrális pozíciójú nagyváros) lakossága átlagosan 1 millió lakos feletti. Ugyanakkor a szélsőértékek szempontjából fontos, hogy a legalacsonyabb lakosságszámú nagyvárosi térség alig haladta meg az 500.000 föt, miközben a legnagyobb lélekszámú agglomerációs övezet a japán föváros Tokió és agglomerációja több mint 35 milliós térségi lakossággal.

21 ország volt érintve magát a felmérésben, ebböl 14 található Európában (13 Európai Uniós tagállam, valamint Svájc; a korábbi kommunista országok közül egyedül Lengyelország került bele a felmérésbe; Németország 24 nagyvárosi térséggel, Franciaország 15 agglomerációs övezettel képviselteti magát). Észak-, Közép-, és Dél-Amerikából 4 állam: Egyesült Államok (kiemelkedik 68 nagyvárosi agglomerációs térséggel); Kanada; Mexikó; Chile. Ázsiát Japán; Ausztrália- és Óceániát Ausztrália és Új-Zéland reprezentálja jelentésében [OECD, 2014a 10. pp.].

Az alábbi ábra tartalmazza az OECD jelentésben a kutatási mintát jelentő nagyvárosi térségek kétszintű agglomerációs kormányzati struktúráinak összemérési komparatív modelljét:

\section{Funkcionális nagyvárosi térség / városi agglomeráció}

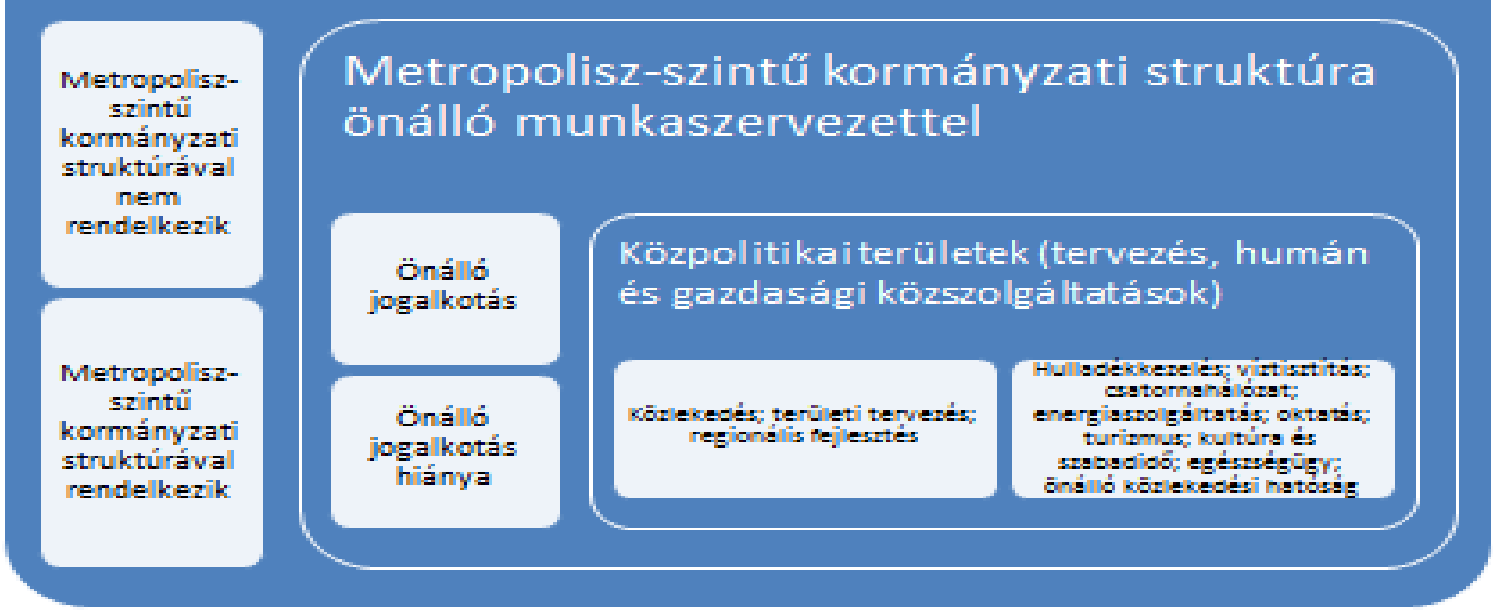

14. ábra: a kétszintü várostérségi kormányzás közpolitikai modellje (Forrás: The OECD Metropolitan Governance Survey, OECD, 2014) - saját szerkesztés! 
Az adatelemzés egy komplex, többrétegü intézményi- és közpolitikai összehasonlítást tesz lehetővé, amely során a jelentést jegyző szakértők a vizsgált metropolisz térségeket egy 3 komponensből álló vizsgálati metóduson futtattak végig:

1. komponens: az adott nagyvárosi térség rendelkezik vagy sem speciális föderatív kétszintű agglomerációs hatósági-intézményi struktúrával.

2. komponens: a vizsgált kétszintű agglomerációs szintű kormányzati hatóságiintézményi struktúra rendelkezik vagy sem önálló jogalkotási, szabályozási kompetenciákkal.

3. komponens: a vizsgált kétszintű agglomerációs kormányzati struktúra - függetlenül attól, hogy rendelkezik vagy sem önálló jogalkotással - milyen konkrét funkcionális (területi tervezés; regionális fejlesztés) és ágazati (közlekedés; ÁÉSZ típusú humán, illetve ÁGÉSZ típusú gazdasági közszolgáltatások) közpolitikai területekre terjed ki.

A 263 analizált nagyvárosi térségben a szakértők 178 esetben (a felmért térségek 68\%ban) találtak olyan kétszintű metropolisz-szintü önkormányzati jellegű struktúrát, amely alkalmas volt a további vizsgálódásra és kategorizálásra. A vizsgált 21 államból mindössze 3 olyan akadt, ahol a statisztikailag kimutatható nagyvárosi térségekben ismeretlen a kétszintü metropoliszhatóság a nagyváros és városkörnyéki településekre kiterjedően, ezek a délamerikai Chile, az EU tagállam Olaszország, valamint Ausztrália volt. További nagyon fontos alapinformáció a teljes jelentés értelmezéséhez, hogy amíg a vizsgált nagyvárosi térségek 68\%-ban volt található 2014-ben metropoliszhatóság, már csak 27\%-uk rendelkezett a közvetlen jogalkotás eszközével (a 178-ból 48 agglomerációs tanács). A 21 vizsgált államból 6 olyan ország került a felmérésbe, ahol ugyan müködnek metropolisz-szintü hatóságok, önkormányzatok, de azok nem alkotnak közvetlenül jogot: Ausztria; Mexikó; Új-Zéland; Lengyelország; Svédország; Svájc [OECD, 2014a 10-12. pp.].

Az Európán és Észak-Amerikán kívül eső OECD országok kapcsán érdemes megemlíteni, hogy a rendkívül sürün lakott japán és koreai metropolisz térségekben változó a föderatív struktúrák alkalmazása. Az európai mértékhez képest szintén nagyon népes mexikói nagyvárosi térségekben az elmúlt 5-6 év közigazgatási „termékeként” alakultak meg a kétszintü tanácsok, kivéve az 1989-es Guadalajara többcélú térségi metropoliszhatóságot [OECD, 2014a; OECD 2014b]. Az alábbi mátrixban kerültek összefoglalásra a jelentés legfontosabb empirikus közpolitikai tapasztalatai: 


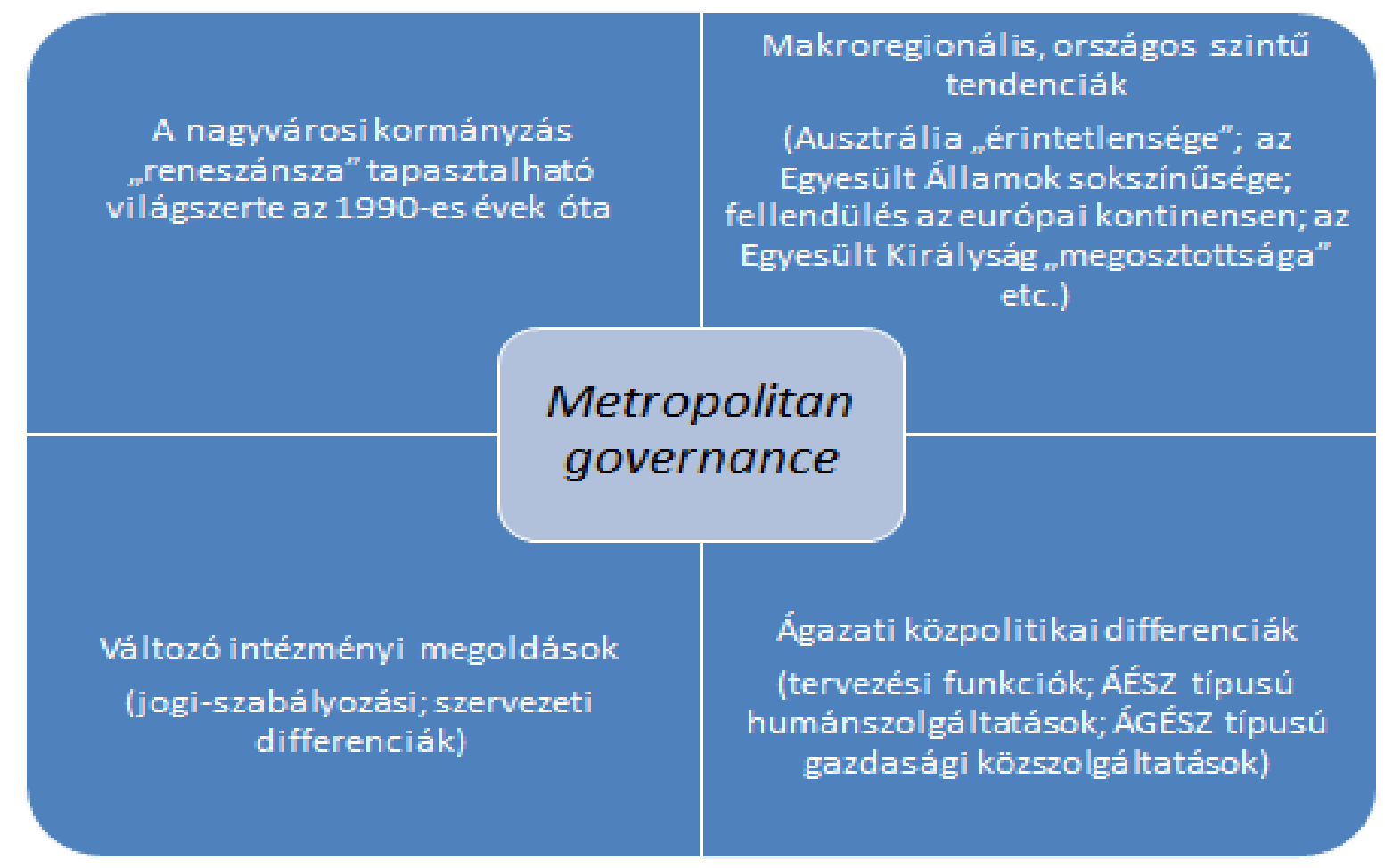

15. ábra: globális és makroregionális tendenciák a várostérségi kormányzásban (Forrás: The OECD Metropolitan Governance Survey, OECD, 2014)

- saját szerkesztés!

Területi (makroregionális, országos) komparatív összevetésben akár azonnal szembeötlő differenciákat, s ezzel specifikációkat láthatunk a nagyvárosi kormányzás történetében és legfrissebb tendenciáiban. A 2 OECD kiadvány országokra és funkcionális nagyvárosi térségekre lebontott adatai ebből a megközelítésből pontos közpolitikai indikátornak minősülnek. Egyes országok esetében eleve visszafogottabb metropolitan governance folyamatokról beszélhetünk, és habár az urbanizációra adott helyi-lokális hatékonysági- és gazdaságossági közpolitikai megoldások megjelenhetnek az önkormányzatok közötti különböző kooperációkban, de anélkül, hogy intézményileg önálló és elkülönült többcélú (delegált vagy választott) kétszintü önkormányzatok, hatóságok alakulnának.

\section{III.9 Várostérségi kapcsolatok a kelet-közép-európai régióban}

A kelet-közép-európai országokban már az 1980-as években különböző mértékben, de megindult gazdasági változások (bizonyos piaci „liberalizációs” lépések - állami vállalati autonómia kiszélesedése; a magántulajdon korlátozott megjelenése) közepette az 1989-1990- 
es radikális politikai változás (az egypárti hegemón pártrendszerekből valódi demokratikus többpártrendszerek kialakulása; a korábbi államszocialista hatalmi elit, a nomenklatúra leváltása részleges vagy teljes politikai elitcserével) bárminemü átmenet, türelmi idő híján „szakadt” ezen országokra. A komplex és holisztikus transzformációs folyamat közvetett hatással volt a terület- és településpolitikai, illetve település-hálózati folyamatokra. A közpolitikai döntéshozatal rendszere szinte az egyik pillanatról a másikra változott meg az országos, a szubnacionális valamint a lokális szinteken. A közszektor tartalma és terjedelme teljesen átalakult, a korábbi jórészt állami illetve közösségi (szövetkezeti) tulajdon helyére a nyugati kaptalista piacgazdaságokat meghatározó magántulajdonra épülő gazdasági modell lépett, valamint decentralizált közigazgatás és sok szempontból „államtalanított” közfeladatellátás vált dominánssá: 1) privatizált, erős közvetlen külföldi, multinacionális tulajdonosi pozíciókkal rendelkező magángazdaság; 2) valódi döntési jogokkal felruházott önkormányzati rendszerek; 3) idővel privatizált közszolgáltatások, ezáltal gyengülő közösségi kontroll. A változások természetesen „lecsapódtak” a városkörnyéki, várostérségi (nagyváros versus szuburbán települések) addig nagyrészt centralizált, központosított kapcsolatrendszeren is. A közigazgatás és közpolitikai döntéshozatal decentralizációja szintén paradigmatikus hatásokkal járt.

\section{III.9.1 Várostérségi kapcsolatok és közpolitika az államszocialista időszakban}

Nemcsak a nyugati tőkés kapitalista államokban merült fel a terjeszkedő nagyvárosok, urbánus térségek igazgatási problémáinak kérdésköre a XX. század második felében. Az államszocialista rendszerek egyoldalú ipar- és városfejlesztési politikájának társadalmi hatásai (a faluról városba való vándorlás megnövekedése; az állami lakásépítkezések városokba, nagyvárosokba koncentrálása etc.) különösen a korábbi Szovjetunió területén eredményeztek egy új típusú társadalmi és igazgatáspolitikai várostérségi „konfliktuskonténert”.

Az államszocialista politikai rendszerek sajátos adottsága volt, hogy a helyi közigazgatás nem ismerte a klasszikus önkormányzati autonómiát, a községi, városi tanácsok többszörösen alárendelt (a felsőbb szintű területi tanácsoknak; az állami-kormányzati intézményeknek; a különböző szint párttestületeknek) hierarchikus viszonyok között müködtek. A tanácsok fejlesztési terveiket illeszteni kellett a különböző szintű gazdasági tervekhez (ötéves tervek rendszere), valamint meg kellett felelni a rendszer alapjául szolgáló ideológiai elvárásoknak, amit időnként sajátosan extrém település-hálózati elképzelések hatottak át - pl. a romániai „falurombolás” kísérlete Ceausescu időszakában; a falus-város természetes vándorlási 
folyamatok adminisztratív korlátozása a két településtípus közötti jelentős gazdasági lehetőségek, paraméterek folytán. Nem meglepő, hogy az egypárti államszocialista országokban a városok életével, igazgatásával foglalkozó korabeli szakirodalom szinte kizárólag müszaki és gazdasági jellegü volt, és adós maradt a kapcsolódó társadalmi aspektusok vizsgálatával [Berényi-Szatmári-Szalai, 1973, 6. pp].

A nagyvárosi térségekre már régóta jellemző közpolitikai paradoxon - a funkcionális várostérség versus közigazgatási fragmentáltság - kezelése során az antidemokratikus államszocialista államokban durván mellőzték a települések lakosságának véleményét, akaratát. Helyette sokkal inkább eröszakos adminisztratív döntéseket hoztak: ez a gyakorlatban szinte kizárólag felső politikai döntésből eredő annexiós (a nagyváros bekebelezi a kisebb szomszédos településeket) lépéseket eredményezett különösen a fővárosi régiókban, amelyek demográfiai és gazdasági mutatói jelentősen kiemelkedtek a nyugati országok policentrikus városhálózataihoz képest. Különösen pregnáns annektálási, egyesítési folyamatok zajlottak le Moszkva, Belgrád, Szófia, Varsó vagy éppen Budapest környékén főleg a szocialista egypártrendszer első időszakában. A nagyvárossal szomszédos önálló elővárosi, külvárosi települések erőszakos bekebelezésének fontos politikai-ideológiai oka volt, hogy ezeken a településeken nagyrészt a városi munkásság - mint a fennálló politikai berendezkedés kiemelt társadalmi bázisa - lakott, és a politikailag megbízhatatlannak vélt városi polgári rétegek, értelmiségiek városon belüli ellensúlyozására megfelelő eszköz volt a munkásság nagyvároson belüli arányának megnövelése. A fővárosokban kettős tanácsi közigazgatási szisztémát alakítottak ki: alul a kerületi tanácsok látták el az alapvető helyi közigazgatási funkciókat, felül pedig a város egészét érintő kérdések, ügyek kezelésére müködtek a fövárosi (nagyvárosi) tanácsok. A nagyváros és agglomerációs térség kontextusban természetesen nem alakultak ki a nyugati demokratikus országokra jellemző a meglévő helyi-települési autonómiákat tiszteletben tartó mechanizmusok [Berényi-SzatmáriSzalay, 1973,11-14. pp.].

A valódi agglomerációval rendelkező nagyvárosok (a fővárosok minden esetben) kiemelt közjogi státuszt kaptak a szocialista országok államigazgatási jogában. Közvetlenül rendelődtek alá a központi intézményeknek kivéve őket mindenféle szubnacionális területi joghatóság alól. Másrészt a nagyvárosok politikai jelentőségét felértékelte, hogy a kommunista nomenklatúra országos vezető pozícióhoz sok esetben éppen a nagyvárosok 
politikai vezetői (tanácselnöki) posztján keresztül vezetett az út. ${ }^{67}$ A nagyvárosok és szuburbán övezetek településeinek kapcsolataihoz igyekeztek valamiféle horizontális koordinációt kiépíteni az államigazgatás folyamatos felügyelete mellett - hasonlóan a nyugati demokratikus rendszerekhez az államszocialista nagypolitika is felismerte a gyorsan urbanizálódó térségek speciális kezelésének szükségét. Ez az együttmüködés lehetett formalizált (valamiféle közös szervezeti keret - tanács, fórum) ${ }^{68}$ illetve informális (vezetői szintű találkozók, konzultációk). A horizontális koordináció keretében egyes államszocialista államokban a fővárosi tanácsok szerezhettek speciális, az agglomerációs települési tanácsok feletti hatásköröket. A Szovjetunióban Moszkva, de akár tagköztársasági központok szereztek ilyen kompetenciákat. Csehszlovákiában az 1967. évi III. törvény rendelte a járási-területi feladatok bizonyos részét közvetlenül a Prága Városi Nemzeti Bizottsághoz (mint fővárosi tanács); a Prága környéki két agglomerációs járási települései felett a fővárosi tanács mellett a szubnacionális Közép-Cseh kerületi Nemzeti Bizottság is gyakorolt jogköröket. Romániában 45 város kapott törvényi úton kompetenciákat ${ }^{69}$ a várostérség helyi tanácsai felett, a fơváros Bukarest jogállása természetesen itt is bővebb volt a többi városhoz viszonyítva. Hasonló hibrid konstrukciók alakultak ki Szófia valamint Belgrád esetében. Lengyelországban az 1980-as évekre a városok - hasonlóan a magyarországi városkörnyéki igazgatási modellhez a környező települések igazgatásában integráns szerepet töltöttek be [Berényi-SzatmáriSzalay, 1973, 167-170. pp.]. A kommunista Német Demokratikus Köztársaság (NDK) történelmi okokból kifolyólag eleve az urbanizáció magasabb fokán állt, mint a közép-európai szocialista országok: a kétségkívül sajátos helyzetü Berlin mellett (csak egy vékony területi korridoron keresztül kapcsolódott az NDK-hoz.) több nagyváros már jóval elörébb haladt a modern városfolyamatok - szuburbanizáció, dezurbanizáció - tekintetében. A helyi városi, községi tanácsok önkéntes kooperációihoz, társulások szabad akaratból való alakításra azonban csak az NDK-ban teremtettek lehetőséget - alapvetően igazgatási tevékenységek összehangolására. Az 1980-as évek hasonló közép-európai gondolkodását jelzi, hogy az ún.

\footnotetext{
${ }^{67}$ Ez a jelenség egyébként megfigyelhető napjainkban demokratikus berendezkedésủ államoknál is - pl. a délamerikai prezidenciális berendezkedésü Kolumbiában megfigyelhető, hogy a fövárosi metropolisz Bogota föpolgármesteri pozíciója egyfajta „politikai ugródeszka” az államelnöki tisztséghez.

${ }^{68}$ Ilyen volt a Varsói Városi Tanács és a Varsói Vajdasági Tanács tagjaiból felállított Varsói Város Együttes Koordinációs Bizottság vagy a szófiai agglomeráció ügyeihez müködtetett hasonló jellegű Szófiai Közös Tervező Igazgatóság. Berényi Lajos - Szatmári Lajos - Szalai Éva: A nagyvárosi agglomerációk és az államigazgatási rendszer a Világ országaiban (ELTE Államigazgatási Jogi Tanszék, Budapest, 1973) 161-165. pp.

${ }_{69}$ Az 1968-as román igazgatási reform a nagyvárosi agglomerációs igazgatási megoldások terén korabeli szakértői vélemények szerint sokat merített a francia agglomerációs tapasztalatokból és szabályozásokból (pl. az 1966-os franciaországi városközösségi törvény).
} 
városkörnyéki igazgatás rendszerét gyakorlatilag azonos időben kodifikálták és vezették be Magyarországon és Lengyelországban 1984-1985-ben.

\section{III.9.2 A rendszerváltás hatása a régió várostérségi folyamataira}

A közép-európai régiót mindig is jellemezte a történelmi lemaradás és fáziskésés Európa nyugati feléhez viszonyítva. Nem meglepő módon ez kimutatható a városfejlődés és szakaszainak tekintetében is. Az eleve később, csak valamikor a XIX. század második felétől urbanizálódott közép-európai régióban később szembesültek olyan jelenségekkel, mint a szuburbanizáció, illetve annak olyan posztmodern vetületeivel, mint az agglomerációs övezeteknek a nagyvárosokkal párhuzamos erőteljes városiasodása (dezurbanizáció), vagy éppen a nagyváros - és különösen annak belső kerületeinek megújítására, reorganizációjára reflektáló visszaköltözési áramlásban testet öltő - reurbanizációs folyamat. A történelmi megkésettség fontos eleme, hogy az államszocialista évtizedek során a kommunista államhatalom erőszakos adminisztratív beavatkozási gyakorlata (pl. állami lakásépítkezés kizárólagossága; ipartelepítési politika; a falvak lakhelyelhagyási tilalma) miatt nem érvényesült a kapitalista rendszerekre jellemző, a településhálózati viszonyokat alakító olyan piaci folyamatok - mint a szabad lakáspiac, a magángazdasági szektor telephely-politikája vagy éppen a demokratikus önkormányzati autonómia. Az irányított centralizált ideologikus várostervezési- és várospolitikai folyamatokról gyakorlatilag átmenet nélkül tértek át a posztkommunista országok 1989-1990-ben a demokratikus decentralizált településpolitikára. Ennek eredményeként ugyan eltünt a korábbi tanácsrendszeri szisztémát átható többirányú hierarchikus alárendeltség, viszont a korábban kiépített tervezés-, igazgatási végrehajtás és kontrollmechanizmusok meggyengültek, miközben jelentős tulajdoni változások (tanácsi bérlakások privatizációja etc.) történtek. Különösen a rendszerváltást követő években volt feltűnő a közép-európai várospolitikában a korábban így-úgy, de müködő térségi koordinációs mechanizmusok eltűnése, és helyettük a jobbára informális, nehezen ellenőrizhető politikai kooperációk, informális alkuk és mechanizmusok érvényesülése [Nedovic-Budic - Tsenkova, 2006, 7-8. pp.].

Az 1989-1990-es politikai és gazdasági változások olyan társadalmi transzformációs sokkszerű folyamatokat (tömeges munkanélküliség az 1990-es évek első felében; térségi „válságövezetek” megjelenése etc.) generáltak, amelyek jelentős hatással voltak az ingázási szokásokra, a lokális viszonyok megváltozott helyzetén keresztül a települési fejlődési pályákra és térségi pozíciókra. A „demokratizálási hevülettől” áthatott települési 
önkormányzati autonómia megteremtése a posztkommunista országokban a helyi önkormányzati kooperációk ellen hatott még a rendszerbe beépített különböző ösztönző társulásos jogintézmények, eszközök mellett is. Nyugat-Európa országai ekkor már túl voltak a helyi alapszintü önkormányzati szektort racionalizáló integrációs (összevonások) valamint a társulásokat ösztönző reformokon. A nagyvárosi agglomerációs együttmüködések tekintetében pedig a megelőző kudarcos évtizedet követően, az 1990-es években kaptak ismét erőre a különböző várostérségi agglomerációs közpolitikai kezdeményezések - lásd az európai nagyvárosi kormányzás tapasztalatait bemutató fejezeteket! Eközben Közép-KeletEurópában a modern nagyváros térségi kormányzás ethosza sokkal inkább a háttérbe szorult. A régió országaiban a nagyvárosi térségekhez kapcsolódóan föderatív kétszintű intézmények kiépülése, kipróbálása már az ezredforduló utáni időszakra maradt - lásd a lengyel kétszintü nagyvárosi önkormányzati tanácsok; Magyarországon a BAFT intézményi története! ${ }^{70}$

\footnotetext{
${ }^{70}$ Budapesti Agglomerációs Fejlesztési Tanács
} 


\section{Városhálózati és agglomerációs folyamatok Magyarországon}

A rendszerváltás utáni várostérségi folyamatok vizsgálatához fontos kapaszkodó az elmúlt évtizedek nemzetközi, európai történéseinek, tendenciáinak ismerete. Segít értelmezni a nagyvárosi kormányzás fontosabb elemzési egységeit, komparatív bázist nyújt a különféle kísérletek, közpolitikai gyakorlatok összehasonlítására - legyenek azok a különböző területszervezési, területpolitikai átalakítások és reformok (az egyszerü annektálásoktól egészen a modern föderatív kétszintű agglomerációs struktúrákig). Azonban amikor a várospolitikát alapvetően befolyásoló okokról, háttérfolyamatokról gondolkodunk, elsődleges fontossága mégis azoknak a belső társadalmi, gazdasági illetve politikai folyamatoknak van, amelyek közvetve vagy közvetlenül determinálják az alkalmazott közigazgatási modelleket, megoldásokat. A rendszerváltás után alkalmazott várospolitikai illetve várostérségi szabályozás és közpolitikai gyakorlat mögötti történelmi, demográfiai folyamatokra koncentrál a következő fejezet: melyek voltak a régmúlt (az elmúlt másfél évszázad) és közelmúlt (az elmúlt negyedszázad) azon determináló tényezői, amelyek mentén a városok közigazgatási pozíciói, valamint az agglomerációs településközi kapcsolatok és közfeladatellátás alakultak Magyarországon.

\section{IV.1 Városhálózati folyamatok és történeti cezúrák}

A XIX. század második felében kialakult modern magyarországi városhálózat fejlődése az 1989-1990-es rendszerváltozásig tanulságos, időnként tragikus mozzanatokat is rejt, mint Trianon vagy a szocialista egypártrendszer durva „beavatkozó” településpolitikája. A dualizmus (1867-1918) ipari-modernizációs hulláma által erősen meghatározott városfejlődést egyoldalú, európai kontextusban is kirívóan monocentrikus, a fővárosra fókuszáló folyamat jellemezte. A korabeli európai nagyvárosi funkciók jelentős részével az akkori Budapest már rendelkezett. Ezzel szemben a korábbi időkből származó regionális - a vármegyéken, mint területi közigazgatási egység - túlmutató szerepkörrel csak nagyon kevés hazai város bírt, ilyen volt Debrecen, mint kézmüves központ és református egyházi székhely; Pozsony, mint Budapest mellett a másik országos politikai központ; az erdélyi Kolozsvár vagy a horvát székhely Zágráb. Ugyanakkor más nagyvárosok (pl. Győr) regionális-térségi pozíciója a dualizmus gazdaságilag felfutó időszakában alapozódott meg. A városok 
demográfiai- és gazdasági térnyerése különösen megmutatkozott a népességszámnál, természetesen kiemelkedett az 1873-ban egyesült Budapest, amelynek lakossága 1840 és 1910 között megötszöröződött és 880 ezer lakosra növekedett; a többi nagyobb város esetében csak a korabeli lakosság átlagos megduplázódásáról tanúskodtak a statisztikák - a második legnépesebb város, Szeged lakossága sem érte el a 100.000 lakost a századfordulón. Ugyanakkor a XX. század elején készült különböző városhierarchia vizsgálatok már tucatnyi regionális szerepkörü várost mutattak: Zágráb, Pozsony, Temesvár, Kolozsvár, Nagyvárad, Debrecen, Szeged, Kassa, Pécs, Győr, Arad, Brassó [Beluszky, 2002, 54. pp.; Filep, 2014, 4445. pp.].

Az elmúlt egy évszázadban azonban olyan paradigmatikus hatású történeti fordulópontok és változások történtek, amelyek alapvető hatással voltak a magyarországi településekre (városok és falvak) illetve a teljes település-hálózati szerkezetre. Ezen történeti cezúrák ismerete nélkül nem lehet szervesen értelmezni akár a közelmúlt, de akár napjaink települési folyamatait. A változások a nyilvánvaló nehézségek mellett ugyanakkor magukban hordozzák a lehetőséget a korábbi hibás elképzelések, stratégiák felülvizsgálatára, s vele új irányok és utak meghatározására, megkezdésére valamint követésére.

\section{IV.1.1 Trianon hatása a magyarországi városfejlődésre}

Hazánkban a XX. század első nagy paradigmatikus történése az első világháborút lezáró Trianoni békeszerződés volt, amely következtében a háborúban győztes nagyhatalmak a történelmi Magyarország területének kétharmad részét csatolták a szomszédos országokhoz. A döntés következtében több, addig regionális központként funkcionáló nagyváros (Kolozsvár, Nagyvárad, Pozsony, Kassa) került a határokon túlra. Ezek a nagyvárosok nemcsak a közvetlen vonzáskörzeti településekre voltak hatással, de müködésük a vármegyék illetve azon túli területekre is kiterjedt a magán- és közszolgáltatási tevékenységük révén. A trianoni döntéssel elszakított regionális központok igazgatási és intézményi funkcióinak elvesztése komoly ürt okozott a korabeli magyar állam és közigazgatás számára, amely különböző adminisztratív intézkedésekkel igyekezett kezelni a helyzetet. Így számos regionális szintü intézményt helyeztek át az új országhatáron belül maradt nagyvárosokhoz pl. egyetemek, állami dekoncentrált intézmények. A dualizmus időszakában már preferált iparosodás hatása rányomta a bélyegét a Horthy-korszak (1920-1944) városfejlődési folyamataira és központi várospolitikai döntéseire. Emellett a hivatalos kormányzati politika igyekezett célzottan foglalkozni a település-hálózatok kérdésével - a Gömbös-kormány 
kormányprogramjának felfogható 95 pontos Nemzeti Munkatervhez különböző nevesített kormányzati stratégiák, intézkedések készültek. A városrendezésröl és az építésügyről szóló 1937. évi VI. törvény minden város számára kötelezővé tette a városfejlesztési terv, az általános és részletes városrendezési terv valamint a teleknyilvántartás vezetését - [1937. évi VI. törvény 1.§ (1)]. Ugyanakkor a városkörnyéki kontextus kizárólag Budapest és környéke kapcsán került nevesítésre az 1937-es törvényben, a Fővárosi Közmunkák Tanácsa (FKT) hatásköreinél: a föváros és környékére az általános és rendezési terv illetve a „városias kialakításra szánt terület" megállapítását [1937. évi VI. tv. 2.§ (3)]; az építésrendészet helyi viszonyok szerint szükséges szabályainak meghatározását Budapest és környékén [1937. évi VI. tv. 22.§ (3)]; építéshatósági ügyekben másodfokon szintén az FKT kapta meg a hatáskört a főváros és környékén [1937. évi VI. tv. 25.§ (1)]. ${ }^{71}$ Habár a második világháborúban az időszakos területnövekedés (I-II. Bécsi döntés) 81-re növelte a magyarországi városok számát, de a második világháborút lezáró 1947-es Párizsi békeszerződés, minimális módosulásokkal, de visszaállította a trianoni határokat és településhálózatot [Csomós, 2011, 102. pp.].

\section{IV.1.2 Az államszocializmus hatása a magyarországi városfejlődésre}

A hazai városfejlödésben az újabb cezúrát a második világháborút követő rövid néhány éves többpárti demokratikus időszakot lezáró kommunista hatalomátvétel jelentette. A direkt politikai irányú „,beavatkozás” keretében az 1940-es évek végén indult meg az ország erőszakos gazdasági és társadalmi átalakítása. ${ }^{72}$ A gazdaságfejlesztésben bekövetkezett ideológiai alapú paradigmaváltás (a nehézipar egyoldalú fejlesztése; a tulajdonviszonyok gyors átalakítása - államosítás és a tanácsrendszer kialakításával a települési autonómiák teljes leépítése) közvetlen hatással volt a magyarországi városfejlődésre. A minden korábbinál erősebben központosított adminisztratív gazdaságpolitikai döntéshozatal, $\mathrm{s}$ vele $\mathrm{a}$ városfejlesztési források az ún. „nehézipari tengelyre”, valamint az ott épült, felfejlesztett „szocialista városokra” (Komló, Ajka, Várpalota, Oroszlány, Kazincbarcika etc.) koncentrálódott. ${ }^{73}$ A nyílt represszióra épülő Rákosi-korszakban 1948-1953 között koherens terület- és településfejlesztési politikáról nem beszélhetünk, a túlideologizált direkt

\footnotetext{
${ }^{71}$ Ezeket a hatásköröket a megyei városok esetében a képviselőtestületek, más törvényhatósági jogú városoknál a törvényhatósági bizottságok gyakorolták - [1937. évi VI. tv.].

72 Ennek legföbb közjogi leképeződése az 1933-as sztálini alkotmánymodellen alapuló népköztársasági alkotmány az 1949. évi XX. törvény volt.

${ }^{73}$ A politikatörténet 11 települést sorol a „szocialista városok” kategóriába: Ajka, Dunaújváros, Kazincbarcika, Komló, Oroszlány, Ózd, Salgótarján, Százhalombatta, Tatabánya, Tiszaújváros, Várpalota - [Germuska, 2002, 50. pp.].
} 
iparosításra koncentráló gazdaságpolitika egyetlen településpolitikai programja a már említett „szocialista iparvárosok” létrehozása és felfejlesztése volt, amelyhez óriási állami invesztíciókat rendelt a pártvezetés [Beluszky, 2002, 54-55. pp.; Germuska, 2002, 49-51. pp]. A hatalom és a döntéshozatal látványos koncentrálódása politikai alapon allokálta az elosztható forrásokat. Történeti dimenzióban ez azt jelentette, hogy előbb a főváros, majd az 1960-as évek derekától a már említett kiemelt „szocialista iparvárosok” mellett a megyeszékhelyek váltak a fő kedvezményezettekké; így a nem megyeszékhely városok egyértelmüen hátrább sorolódtak a szocialista terület- és fejlesztéspolitikában. A Kádárkorszakban a forrásallokáció központi adminisztratív pártállami jellege (Országos Tervhivatal, Pénzügyminisztérium, MSZMP testületek etc.) változatlan maradt, de területi értelemben dekoncentrálódott. A korábbiakhoz képest jelentős források közvetlen szétosztási, felhasználási hatáskörét rendelték a megyei döntéshozatal (elsődlegesen a megyei pártbizottságok és megyei tanácsok) számára: a megyei szinten eldőlő „forrás-továbbosztás” elsődleges kedvezményezettjei ismételten a megyeszékhely városok lettek, tovább szélesítve a városok közötti különbségeket [Beluszky, 2002, 55. pp.]. A tanácsrendszer változó pozícióihoz fontos adalék, hogy a Kádári hatalom számára az 1957-es őszi tanácsi választások eredménye (99\%-os szavazatarány a Hazafias Népfront jelöltjeire) a tanácsok iránti bizalmat erősítette. Ennek eredménye sorozatos politikai döntések révén a tanácsok irányába történő hatalmi dekoncentráció volt meghatározott hatáskörtranszferek (pl. az ipar- és kereskedelmi felügyeleti hatóság), illetve állami vállalatokat átadása a tanácsi kompetencia- és tulajdonosi körbe. Az 1959-1960-ban lezajló „erőszakos” mezőgazdasági szövetkezesítés folyamatában szintén kiemelt végrehajtó szerep jutott elsősorban a megyei és járási tanácsoknak, miközben a korábbiakhoz képest erőteljesebb „fokozatba” kapcsolták a kisközségi tanácsi apparátusok igazgatási koncentrációját valamint 1962-től a közös tanácsok alakítását - a korszak területszervezési vonatkozásairól lásd később! Az 1956-os forradalom utáni megtorlást követő politikai konszolidációs időszakban a tanácsok az új politikai vezetés egyik legfontosabb hatalmi talapzatává váltak. Ugyanakkor az átalakuló hatalmi konstellációban az 1950-es évekhez képest erősebb tanácsi hatalmi legitimáció mellett egyre hangosabbá váltak a különböző kritikus szakmai hangok az ország Budapest-centrikus gazdasági és társadalmi viszonyai miatt. Többek között ezért is adott a politikai vezetés „szabad utat” a Rákosikorszakban teljesen háttérbe szorított regionális gazdasági tervezés hivatalos állami újraindításának, $\mathrm{s}$ vele a várospolitika és település- illetve városhálózat-tervezés megújításának, amely folyamat előbb az 1963-as, majd az 1971-es Országos 
Településhálózat-fejlesztési Koncepció keretében csúcsosodott ki [Feitl, 2011, 369-372. pp.]ennek részleteiröl szintén később!

A direkt ideológiai céloknak (erőltetett iparosítás és tervgazdálkodás; a ,nehézipari tengely” és ,,szocialista városok” valamint az adminisztrativ központok - megyeszékhelyek kiemelt dotációja) alárendelt várospolitika a központi irányítás és centralizált forráselosztás révén mesterségesen alakította, deformálta a városfejlődés különböző aspektusait: voltak kiemelt, „,kivételezett” városok, és voltak az állampárti politikai érdekek által hátrébb sorolt települések. Ez a természetes városfejlődési folyamatokba nemegyszer durván beavatkozó politika (pl. egy időben mesterséges betelepülési tilalom is müködött Budapestre vonatkozólag) sokat enyhült az 1970-es és 1980-as évtizedekre. Ezzel párhuzamosan az államszocialista hatalmi struktúrán belül a hatalmi dekoncentráció erősödött a megyék (megyei tanácsok; az MSZMP megyei párbizottságai és megyei első titkárai) döntési és forráselosztó kompetenciáinak növelésével. Ugyanakkor a településfejlesztés tekintetében a községekhez képest továbbra is sokkal erősebb közvetlen preferenciát kaptak a városok. Ez közvetlenül kimutatható volt a rendszerváltás utáni időszakhoz képest még mindig rendkívül szimpla és sematikus költségvetési elosztási rendszerben, valamint a várossá nyilvánításnak különösen az 1970-1990 között expanzívvá váló folyamatában: 1945-ben 52 db városi jogállású település; 1949-ben 54 db; 1960-ban 63 db; 1970-ben 76 db; 1980-ban 96 db; 1990ben $166 \mathrm{db}$ város volt Magyarországon [Szigeti, 2002, 142-147. pp.].

$\mathrm{Az}$ államszocialista évtizedek a XX. század legintenzívebb hazai belső migrációs vándormozgalmának időszaka is jelentették egyben, különösen a kommunista hatalomátvételtől az 1960-as évek elejéig volt látványos a folyamat. Azt követően a belső területi migrációs folyamatoknál lassuló intenzitást mutatnak a statisztikák egészen a rendszerváltásig. Amíg az 1970-es évekig még hosszabb, több megyét érintő interregionális mozgások dominálták a magyarországi belső migrációt, az 1970-1980-as évtizedekre a kisebb, egyre inkább a megyén belüli mobilizáció vált meghatározóvá. Olyan események befolyásolták a belföldi népességmozgásokat, mint a világháború utáni 1945-ös földreform, a különböző politikai kitelepítések (a háború után a magyarországi németeket; a kommunista hatalomátvétel után az ún. „osztályidegen” csoportokat sújtva), a már említett eröltetett iparosítás, amely az agrárius térségekből indított el tízezreket Budapest és környéke, valamint a „,szocialista iparvárosok” irányába. Ezek a változások közvetlenül „,csapódtak le” az ország település-hálózatában. A szocializmus négy évtizedének belföldi migrációs folyamatainak nyertes települései egyértelműen a városok lettek, a vesztesei pedig a falvak. Az 1980-as évekre azonban némiképp már kiegyensúlyozódtak a korábbi évtizedek egyoldalú vándorlási 
folyamatai - Budapest és a vidéki városok migrációs nyeresége erőteljesen visszaesett, a falvak vesztesége pedig gyakorlatilag minimalizálódott. [Dövényi, 2007, 135-136. pp.].

\section{IV.1.3 A rendszerváltás hatása a városfejlődésre}

A XX. század harmadik paradigmatikus történelmi mozzanata a 1989-1990-es rendszerváltás volt, amely fontos államszervezési elemeként megteremtődött a modern demokratikus helyi önkormányzatiság. A rendszerváltás utáni belső migrációs, népvándorlási folyamatokra, s vele a település-hálózati történésekre alapvető hatással bírt a gazdasági szerkezetváltás - leépülő nehézipar és mezőgazdasági termelőszövetkezetek; az állami tulajdon privatizációja és a külföldi müködő tőke megjelenése. Ennek következtében új válságrégiók, de egyúttal új kitörési pontok, nyertes térségek keletkeztek; települések (pl. Győr és környéke; Közép-Dunántúl; fővárosi agglomerációs települések) helyzete változott meg radikálisan, negatívan vagy éppen pozitívan befolyásolva a vándorlási és településitérségi folyamatokat. Mindközül a leglátványosabb Budapest népességvesztése volt az agglomerációs gyürü szuburbán települései javára. A rendszerváltásra minimalizálódott falusi népességcsökkenés 1991-től elkezdett pozitívba fordulni. Ez különösen a fővárost és vidéki nagyvárosokat övező térségekben volt kimutatható, így a rendszerváltást követő másfél-két évtized migrációs folyamatait nagymértékben határozták meg a szuburbanizációs tendenciák ${ }^{74}$ - a folyamatot remekül példázza, ahogy a KSH 1990 utáni agglomerációs felméréseiben (így a 2003-as és 2014-esben) egyre több települést számítanak bele a nagyváros agglomerációk, településegyüttesek körébe (lásd a KSH 2014-es agglomerációs felmérését!).

A rendszerváltást követően a városok és térségeik (különösen a föváros és a vidéki nagyvárosok) gazdasági pozícióit nagymértékben meghatározták a külföldi nagytőke befektetési-megtérülési igényei. Amíg a rendszerváltás elött a központi pártállami ágazatpolitikai elvek, célkitüzések az esetek nagy többségében felülírták a helyi (tanácsi és egyéb várostérségi lobbik) kezdeményezéseket, addig 1990 után egyrészről a korábbiakhoz képest jóval visszafogottabb állami-kormányzati gazdaságpolitika, másrészről a demokratikus önkormányzatiság megteremtésével a központi közigazgatásról leváló, önállósodó városok agilis vagy kevésbé agilis önálló közpolitikái jellemezték [Filep, 2014, 10-13. pp.]. Ugyanakkor szükséges kimondani, hogy a rendszerváltás utáni években szinte teljesen a margóra került a településhálózat fejlesztésének a kérdése - benne a városhálózat különböző

\footnotetext{
${ }^{74}$ Dövényi Zoltán: A belső vándormozgalom néhány sajátossága Magyarországon (in: A társadalmi földrajz világa Szerk.: Kovács Csaba - Pál Viktor Szegedi Tudományegyetem Gazdaság- és Társadalomföldrajz Tanszék, Szeged, 2007) 136-147. pp.
} 
kérdéseivel (policentrizmus; térségi szerepkörök az alsó-közép szinttől egészen a nagyobb regionális országrészekig). Az 1990-es évek második feléig jobbára csak az önkormányzati címzett- és céltámogatásokon keresztül, közvetlen dotációk formájában történtek „beavatkozások és kiigazítások” a településpolitikában. Központi jogalkotói oldalról a szemléletváltás az évtized második felében következett be, előbb az 1996-os területfejlesztési törvény [1996. évi XXI. törvény a területfejlesztésről és területrendezésről], majd a rendszerváltás utáni első átfogó országos területfejlesztési koncepció [35/1998. (III. 20.) OGY Határozat az Országos Területfejlesztési Koncepcióról] született meg.

Még inkább minőségi változást eredményezett a település- és várospolitika vonatkozásában Magyarország Európai Unióhoz való csatlakozása 2004-ben. Már a megelőző időszakban a különböző ún. EU előcsatlakozási alapok (PHARE, ISPA, SAPARD) forrásai elérhetővé váltak az önkormányzati szektor számára - pl. a környezetvédelmi prioritásra fókuszáló ISPA kiírások keretében önkormányzatok, de önkormányzati társulások is pályázhattak szennyvízkezelés- és csatornázás, ivóvízellátás, hulladékgazdálkodás illetve levegőtisztaság-védelem témákban. 2004. után a teljes jogú tagság soha korábban nem tapasztalt mértékü közvetlen forrásabszorpciós lehetőséget biztosított az önkormányzati szektor számára, különösen a közösségi kohéziós politika jóvoltából (Kohéziós Alap, strukturális alapok). Az Európai Unió másik közvetlen hatása szabályozási illetve szakpolitikai tervezési kontextusban jelentett kihívást és feladatot a települési döntéshozók valamint igazgatási apparátusok számára. A csatlakozás elengedhetetlen feltétele volt a közösségi joganyag (acquis communautaire) harmonizációja, amely roppant közjogi-szakmai feladatot rótt a helyi önkormányzatokra - a teljes hazai hatályos önkormányzati joganyagot (rendeletek és határozatok) átvilágítása történt meg alig néhány év alatt annak érdekében, hogy a magyarországi roppant önkormányzati joganyag ne ütközzön az uniós jogrendbe (elsődleges és másodlagos EU-s joganyagok). A közjogi, szabályozási harmonizáció mellett közpolitikai tekintetben a kapcsolódó európai uniós közösségi stratégiák, jelentések, akciótervek jelentenek egyszerre kapaszkodó és igazodási pontokat a magyarországi városok számára a várostervezés és a különböző városi szakpolitikák terén - (ESDP 1999; Lille 2000; Lipcsei Charta 2007; Gödöllő 2011). Másrészt az ezredfordulót követően a versenyképesség vált az Európai Unió legfontosabb vezérgondolatává - Lisszaboni folyamat 2000-2010; EU2020 -, ez a szemléletmód egyre inkább beépül és tetten érhető az európai városok, 
nagyvárosok gondolkodásában - 1080/2006. ERFA rendelet (lásd az integrált városfejlesztési stratégiák-IVS - megalkotását a 2000-es évek végére!). ${ }^{75}$

\section{IV.2 Városhálózatok és városi funkciók alakulása Magyarországon}

Az időbeli összehasonlító komparatív módszer a magyarországi városfejlődés és várospolitika két fontos dimenziójának megvilágítására mindenképpen alkalmas. Egyrészt a városi jogállású települések helyi funkcióinak, térségi szerepkörének történeti alakulásának körvonalazására, másrészt a helyi feladatellátás, közszolgáltatások fejlődésének demonstrálására.

Beluszky Pál és Sikos T. Tamás közösen írt 2007-es Változó falvaink című monográfiában a rendszerváltást követő másfél évtized települési változásainak gazdasági és társadalmi eredőit a következőkben összegezték [Beluszky-Sikos T., 2007, 8-11. pp.]:

1. A városok és falvak között az államszocialista időszak évtizedeiben még éles szociológiai, foglalkoztatási, életmód- és mentalitásbeli különbségek sokat tompultak 1990 után.

2. A közlekedési infrastruktúra 1990 utáni fejlesztései: az autópálya-hálózat fokozatos kiépülése; a motorizáció felgyorsulása és kiterjedése (a korábbi jórészt KGST közlekedési eszközpark teljes cseréje); a helyközi tömegközlekedési hálózatban bekövetkezett változások. ${ }^{76} \mathrm{~A}$ városkörnyéki közút- és vasúthálózat, valamint a helyközi tömegközlekedési rendszerek által meghatározott ingázási, bejárási lehetőségek közvetlen hatásai a városok és vonzáskörzeti települések közötti gazdasági (foglalkoztatási), illetve köz- és magánszolgáltatási kapcsolatok alakulására.

3. A mezőgazdaság drasztikus méretű termelési, foglalkoztatási visszaesése jelentősen módosította az 1990 előtt a falu = mezőgazdasági tapasztalati kizárólagosságát, a primer szektor a foglalkoztatottak közel hatodát veszítette el negyedszázad alatt. ${ }^{77} \mathrm{~A}$ rendszerváltás utáni gazdasági szerkezetváltás részeként a hagyományos gazdasági ágazatok (mezőgazdaság; élelmiszeripar; hagyományos nehézipar - bányászat etc.) leépülése, illetve az új gazdasági ágak megjelenése (pl. falusi turizmus- és rekreáció;

\footnotetext{
${ }^{75}$ Az elkészült integrált városfejlesztési stratégiákat a VÁTI egy közös internetes oldal keretében gyüjtötte össze - http://www.terport.hu/települesrendezes-fejlesztes/fejlesztesi-dokumentumok

${ }^{76}$ A helyközi tömegközlekedési hálózat fejlesztése tekintetében időnként az alapvetően racionális alapú folyamatokba „,betüremkedtek” politikai motivációk - pl. bizonyos gazdaságtalan vidéki vasúti szárnyvonalak bezárása majd kinyitása része lett különösen a 2000 utáni évek hazai politikai agendájának.

77 A KSH hosszú távú statisztikája szerint, amíg a mezőgazdaság, erdészet, halászalt illetve az élelmiszeripar 1990-ben még 488000 személyt foglalkoztatott, ez a szám 2014-re 410100 före fogyatkozott https://www.ksh.hu/docs/hun/agrar/html/tab11_1_2.html
} 
egyéb tercier szolgáltatások), illetve a gazdaság tulajdonosi szektorában történt átrendeződések (multinacionális cégek hazai leányvállalatainak megjelenése ${ }^{78}$ az új magyar nagytőkési csoportok megjelenése) alapvető hatást gyakoroltak a gazdaságon keresztül a városok és falvak kapcsolatára.

4. Az 1990 utáni településhálózati folyamatok - agglomerációs, szuburbanizációs folyamatok; térségi demográfiai változások (népességnövekedés-, csökkenés, elvándorlás) - sokkal turbulensebb módon jelentkeztek, mint a megelőző évtizedek során. A falvak lakosságának nagy része kvázi „foglalkozást váltott” (az agráriumból a helyi ipari vagy szolgáltató szektorba áramlottak át; sokan ún. kényszervállalkozókká váltak vagy rosszabb esetben kiestek a munkaerőpiacról). Ugyanakkor nagyszámban települtek ki a nagyvárosok magasabban kvalifikált, jobb anyagi helyzetü csoportjai (értelmiségiek, közigazgatási és gazdasági vezetők, vállalkozók) Budapest és jó néhány megyei jogú városkörnyéki településre, elsősorban lakhatás céljából, miközben a munkahely, valamint a különböző köz- és magánszolgáltatásokat (egészségügyi ellátás, oktatás, banki- és más pénzügyi szolgáltatások) továbbra is a központi pozíciót ellátó nagyvárosban vették, veszik igénybe. Ez a kitelepülési folyamat szintén megfigyelhető volt bizonyos közép- és kisváros környéki térségekben.[Beluszky-Sikos T., 2007, 8-11. pp.].

\section{IV.2.1 Városi funkciók történeti dimenziója Magyarországon}

Magyarországon a rendszerváltás után különösen expanzívvá váló várossá nyilvánítási folyamat miatt, napjainkra számos olyan városi jogállású településről beszélhetünk, amelyek funkcionális értelemben (intézményhálózat; valódi vonzáskörzet; gazdasági és demográfiai mutatók) nem teljesítik a városi lét klasszikus értelmezési feltételeit. A tudatosan fellazított jogszabályi környezet (erről részletesen lásd később!), különböző politikai szándékokkal párosulva, 1990 után egy jelentősen felduzzasztott hazai városhálózatot eredményezett, rendkívül differenciált adottságokkal és eltérő fejlődési lehetőségekkel. A magyarországi városoknak a településhierarchiában betöltött szerepéről, azok időbeli mozgásairól Beluszky Pál professzor végez immár több évtizedes empirikus kutatásokat. 2004-ben Győri Róberttel

\footnotetext{
78 Az 1990-es években, majd a 2000-es évtized első felében elsősorban az amerikai és nyugat-európai különösen a német - vállalatok érkeztek meg tőkebefektetőként hazánkba, de a 2000-es évek második felében és a 2010-es években a feltörekvő dél- és kelet-ázsiai szereplök is megjelentek - pl. Hankook, Apollo Tyres).
} 
közösen mérte fel a magyarországi városok aktuális pozícióit, ${ }^{79}$ valamint összehasonlított több, a témában korábban $(1910,1965,1995,2000)$ végzett kutatás eredményeit, keresve az időbeli dimenzió fő specifikumait. Beluszkyék a városi jogállású települések hierarchizálására az ún. leltározó módszert alkalmazták, a városi funkciók- és intézmények előfordulása illetve hiánya alapján sorolták be a városi jogállású településeket egy mesterségesen képzett hierarchiába - 6 féle szolgáltatási intézménytipust és 7 db funkcionális városkategóriát képezve. Fontos leszögezni, hogy a funkciók nem kizárólag csak a közfeladatok és közszolgáltatások körére szükíthetők, hanem a magánjellegü, piaci szolgáltatásokra (pénzügyi szolgáltatások, kereskedelem etc.) is kiterjednek [Beluszky-Győri, 2004, 8. pp.]:

Funkciók, és ahhoz kapcsolódó intézmények - $6 \mathrm{db}$ :

1. Országos hatáskörü intézmények, funkciók

2. Regionális hatáskörü intézmények, funkciók

3. Megyei hatáskörü intézmények, funkciók

4. Középvárosi intézmények, funkciók

5. Kisvárosi (járási hatáskörü) intézmények, funkciók

6. Mikrotérségi szintü, de városi funkciójú intézmények, funkciók

Funkcionális városkategóriák - 7 db: Budapesttel, mint országos központtal Beluszky és szerzőtársa nem foglalkozott a tanulmányban!

a) Regionális központ

b) Megyeközpont

c) Középváros

d) Teljes értékü kisváros

e) Hiányos értékű kisváros

f) Teljes értékü törpeváros

g) Hiányos értékű törpeváros

A tanulmány legfontosabb általános üzenete, hogy az 1910-2000 közötti közel évszázadnyi időszakot vizsgálva, a két kutató a magyarországi városhálózat viszonylagos

\footnotetext{
${ }^{79}$ A várossá nyilvánításról tudósító KSH információk szerint a hivatkozott Beluszky tanulmány óta, 2005-2014 között 72 település nyerte el a városi jogállást - in: Magyarország helynévtára 2014. január 1. (Központi Statisztikai Hivatal, 2014, Budapest)
} 
állandóságát állapították meg: a módszertan során alkalmazott 7 fokozatú városhierarchia csak kissé módosult. Ezzel szemben sokkal inkább kulminálódtak a változások a funkcionális városkategória versus városi funkciók, intézmények dimenzió esetében: fókusza a különböző köz- és magánszolgáltatások, valamint a kapcsolódó intézmények megjelenése, azok időbeli alakulása. A különböző szolgáltatások és funkciók települési (városi, községi) elterjedése egyfajta modernizációs indikátorként is értelmezhető.

\section{A Beluszky-Győri kutatás fontosabb empirikus következtetései (1910-2000):}

- A vidéki regionális központok (Debrecen, Szeged, Pécs, Győr) közé egyedül Miskolc zárkózott fel.

- Jelentősebb mozgások történtek a megyeközpontoknál. Látványos emelkedést Salgótarján és Tatabánya - mint egykori „,szocialista iparvárosok” - produkáltak az államszocialista évtizedek alatt. Ugyanakkor a nógrádi megyeszékhely, Salgótarján rendszerváltás utáni „,vesszőfutása” (a helyi- és térségi nehézipar összeomlása; demográfiai veszteségek) szintén tanulságos.

- Több korábban funkcionális tekintetben megyeváros „lecsúszása” történt a középvárosok közé - Nagykanizsa, Pápa, Baja, Sátoraljaújhely, Gyula. Ennek hátterében, bizonyos esetekben az „ellenérdekelt”80, rivális közeli adminisztratív megyeközpontok (Zalaegerszeg, Miskolc, Veszprém) pozíciójavulása állt.

- A közép- és kisvárosok száma, aránya lényegében nem változott, de a számuk valamivel növekedett 1965 után. Bizonyos középvárosi pozíciói láthatóan javultak (Siófok, Tata, Gödöllő, Kazincbarcika etc.) - a pozíciójavulásnak 3 eredője állapítható meg: 1) iparfejlesztés (,szocialista iparvárosok” az államszocialista évtizedek során); 2) agglomerációs fejlődés (Érd - nagyon látványos expanzió; Dunakeszi; Szigetszentmiklós etc.); 3) idegenforgalom (Balatonboglár; Fonyód etc.).

- Közel tucatnyi, 1910-ben még egyértelműen középvárosi pozícióban lévő város főként egykori „mezővárosok” - jelentős demográfiai, gazdasági és adminisztratív intézményi pozícióromlása. A lokális- és térségi gazdasági hanyatlás ,áldozatává” vált többek között Makó, Jászberény, Mezőtúr, Karcag, Nagykőrös, Kalocsa vagy Mohács.

- A kisvárosok lehetnek teljes vagy hiányos értéküek a településen müködő funkciók (köz- és magánszolgáltatások száma, jellege, minősége) függvényében. Ez alapján

\footnotetext{
${ }^{80}$ Jó példa a regionális-térségi központok magyarországi rivalizálásához az ezredforduló időszakában a DélDunántúlon az akkor kormánypárti vezetésủ Kaposvár (Szita Károly, Fidesz) és ellenzéki, szocialista dominanciájú Pécs (Toller László, MSZP) közötti vetélkedés kormányzati, központi beruházásokért, pólusvárospozícióért.
} 
vannak a romló pozíciójú „elhagyott egykori adminisztratív központok” (Kőszeg, Szentgotthárd etc.) illetve az eleve légüres - más városok által dominált - térségben lévő kisvárosok (Edelény, Füzesabony, Szécsény etc.). Az 1990 utáni általános térségi-regionális „leszakadás” a mai napig negatívan érinti a Tiszántúl egyre inkább hiányos értékủ kisvárosait (pl. Nyírbátor, Vásárosnamény, Berettyóújfalu).

- Ugyanakkor akadnak kisvárosok, amelyek számára éppen a rendszerváltás nyitott új lehetőségeket, kitörési pontokat - pl. a megnyíló határátkelő pozitív hatásai a Zala megyei Lenti kisváros esetében.

- Elsősorban az 1990-2010 (majd a 2014-es évben) meglódult várossá nyilvánítási (számos korábbi nagyközség, község szerzett városi címet) folyamatnak köszönhetően jelentek meg az országban a kutatás szerint teljes és hiányos értékü törpevárosok, ez a folyamat térben viszonylag egyenletesen zajlott le. [Beluszky-Győri, 2004, 12-37. pp.]

A hazai városi folyamatokkal és várospolitikával foglalkozó szakértők közel konszenzusos álláspontja, hogy a valóban városi funkciójú és karakterisztikájú települések száma Magyarországon érdemben nem sokat változott az elmúlt fél évszázad során. Ugyanakkor történtek jelentős belső átrendeződések (városok emelkedése- illetve pozícióvesztése). Érdemes a valós hazai urbanizációs folyamatoktól külön kezelni a rendszerváltás utáni várossá nyilvánítást, amely révén több mint a duplájára nőtt a városi jogállással rendelkező települések száma, miközben a valóságban nem beszélhetünk a valóban városi karakterisztikájú települések számának ilyen mértékű megnövekedéséről.

Legutóbb Szilágyi Dániel és Gerse József 2015-ös közös tanulmányukban hierarchizálták a magyarországi városokat, felhasználva a rendszerváltás utáni hazai várostipológiák tapasztalatait Szilágyi és Gerse 23 indikátort szelektáltak - a népességszámtól kezdve különböző gazdasági, intézményi (pl. humánszolgáltatások és közigazgatás) mutatókig. Az újdonság a korábbi módszertanokhoz képest, hogy a közigazgatási, közszolgáltatási paraméterek esetében nem pusztán az intézmények száma, léte/nemléte, hanem sokkal inkább az intézményi kapacitás (ellátottak száma; a területi illetékesség révén potenciálisan érintett népesség) került a fókuszba, olyan indikátorokat vizsgálva, mint a kórházi ágyszám; működő bölcsődei férőhelyek, színházi előadások száma vagy a városi közoktatási intézmények tanulószáma. Kifejezett vonzáskörzeti mutatóként a városba naponta más településröl bejáró foglalkoztatottak száma mínusz a városból naponta más településre eljáró foglalkoztatottak száma főben (ingázási többlet / hiány). 
A 23-ból 5 indikátor már reflektál a 2010 utáni jogszabályi változásokra - ezekröl később részletesen! - így a 2011-es új önkormányzati törvényre, valamint az időközben kialakításra került államigazgatási járások kialakítása. Talán ez az első városhierarchizálás, amely már méri a járásközpont települések (járásszékhely jogú városok) mutatóit - pl. a járásbíróság által lefedett lakosságszám; a járási építésügyi, valamint földhivatal által területi illetékességben ellátott lakosságszám; járási munkaügyi központ. ${ }^{81}$ A 2013-tól működő államigazgatási járások adminisztratív központjaiként müködő 176 járásszékhely jogú város biztosít helyet a különböző állami területi dekoncentrált szervek, valamint a járásbíróságok épületei számára. Ez a járási adminisztratív-igazgatási centrumpozíció kimutathatóan erösíti az ingázási folyamatokat - pl. ügyintézés miatt ingázók; az állami dekoncentrált intézményekbe a környező településekről ingázó munkavállalók ${ }^{82}$ Szaló Péter, mint a Belügyminisztérium államtitkára, egy 2014 végi szakmai prezentációban a járásszékhely központ önkormányzatokat (mint járásszékhely városi helyhatóságok) 118 kisvárosi és 34 középvárosi járásszékhelyre osztotta az érintett települések funkcionális jellege és objektív paraméterei kapcsán. ${ }^{83}$

Szilágyi és Gerse 4 hierarchikus csoportba sorolta a magyarországi városokat: (ez jóval egyszerübb struktúra Beluszky és Győri tipologizálásához képest, akik Budapestet nem számítva, így is 7 városkategóriát differenciáltak!

1. fỏváros: Budapest - messze kiemelkedve a többi település közül a lakosok számaránya valamint a gazdasági teljesítőképesség tekintetében. Továbbá az országos politikai és kormányzati intézmények otthona. ${ }^{84}$

2. felsőfokú központ: a 100.000 főt meghaladó lakosságú megyei jogú városok (Debrecen, Szeged, Miskolc, Pécs, Győr, Nyíregyháza, Kecskemét), valamint a 100.000 lakos környékén „egyensúlyozó” Székesfehérvár - összesen 8 db felsőfokú

\footnotetext{
${ }^{81}$ Az alkalmazott indikátorok - Szilágyi Dániel - Gerse József: Fokról-fokra a települési lépcsőn - Társadalmigazdasági különbségek a településhierarchia-szintek között Magyarországon (in: Területi Statisztika, 2015/2.) 182. pp.

${ }^{82}$ Ugyanakkor szükséges leszögezni, hogy előfordulhat, nem a járásszékhely város, hanem egy másik település biztosít helyszínt speciális hatáskörü állami dekoncentrált intézmény vagy a járásbíróság számára - pl. a Budakeszi járásbíróság Budaörsön található - ez némiképpen árnyalhatja, ebben az esetben erősítheti az adott nem járásszékhelyként funkcionáló város térségi adminisztratív pozícióját.

${ }^{83}$ Szaló Péter: Integrált településfejlesztési stratégiák a két programozási időszakban (a Magyar Regionális Tudományi Társaság 2014-es vándorgyülése) pp.15. http://www.mrtt.hu/vandorgyulesek/2014/02/szalo_peter.pdf

${ }^{84}$ A 2014-ben hivatalba lépett harmadik Orbán-kormány bizonyos lépései a központi kormányzati szervezeti egységeinek vidékre telepítésével (államtitkárságok áthelyezése megyei jogú városokba) sokkal inkább csak a vidéki Magyarország számára szóló szimbolikus lépésnek tekinthetőek, mintsem a legfelsőbb kormányzati szint valódi területi (helyszíni) dekoncentrációjának.
} 
központi kategóriájú város. Ehhez képest Beluszky és Győri regionális központ kategóriája még csak 5 várost tartalmazott.

3. középfokú központ: 29 város, amely közül a legnépesebb a majd' 80 ezres Vas megyei székhely Szombathely, a legkevesebb lakossal pedig a Balaton parti üdülőcentrum a járásszékhely város, Siófok került ebbe a kategóriába. A középfokú központok közé több más nem megyei jogú város is bekerült, mint például a Borsod megyei Ózd, a Veszprém megyei Pápa, a csongrádi Baja, a Heves megyei Gyöngyös, a Pest megyei Cegléd és Vác, Budapest közvetlen vonzáskörzetéböl Budaörs, Gödöllő, Bélés megyéböl Gyula, Jász-Nagykun-Szolnok megyéből Jászberény.

4. alsófokú központ: 308 település (város, járásszékhely jogú város) került ide a mért indikátorok alapján. ${ }^{85}$ Így például a középfokú központként definiált Siófok lakosságát bőven meghaladó városok, mint a budapesti agglomerációból Dunakeszi vagy Szigetszentmiklós; az alföldi Kiskunfélegyháza, Szentes és Orosháza, a Dunántúlról Ajka [Szilágyi-Gerse, 2015, 183-185. pp.].

Szilágyi és Gerse különböző gazdasági és társadalmi jelenségeket értelmeztek az általuk kialakított új típusú település-hierarchia alapján: a négy funkcionális városkategória mellett további kettő funkcionális falukategóriát alkalmaztak: 500 lakos feletti falvak és 500 lakos alatti aprófalvak. Vizsgálták a városok térségi-, vonzáskörzeti potenciálját, ennek fontos spill-over eredménye, hogy Budapest, a 8 felsőfokú központ, valamint 25 középfokú központi város esetében a munkahely céljából napi szinten bejáró munkavállalók aránya meghaladta az ugyanezen célból „kiingázók” számát. Csak négy olyan középfokú központot sikerült azonosítani, ahol többen járnak más településre dolgozni, mint az oda máshonnét ingázó munkavállalók száma: nem meglepő módon ezek mind Budapest agglomerációjának részei Érd, Gödöllő, Budaörs, Vác [Szilágyi-Gerse, 2015, 192-193. pp.].

\section{IV.3 Megyei jogú városok funkcionális tipizálása}

A magyarországi városok közül nagyságrendjét (demográfia, társadalmi és gazdasági paraméterek, állami és önkormányzati intézményrendszer, magánszektor) tekintve kiemelkedik Budapest főváros valamint a 23 megyei jogú város. Ez utóbbi, mint az 1990-s

\footnotetext{
${ }^{85}$ Szilágyi és Gerse tipologizálását összehasonlítva a KSH 2014-es települési jogállási adataival, azt láthatjuk, hogy a 346 nem községi, hanem valamilyen városi jogállású település (fóváros, megyei jogú város, járásszékhely jogú város, városi önkormányzat) közül csak 336-ot soroltak az általuk definiált 4 típusú funkcionális városkategória közé (főváros, felsőfokú központ, középfokú központ, alsófokú központ).
} 
önkormányzati törvény által létrehozott speciális jogállású települési önkormányzati kategóriába - erről részletesen lásd később! - egymástól jelentősen különböző városokat „tereltek”. Az eltérő adottságokon túl a rendszerváltás utáni gazdasági és politikai berendezkedés (piacgazdaság - külföldi tőkebefektetések és hazai vállalati szektor; demokratikus önkormányzatiság; politikai váltógazdaság) még tovább árnyalták a megyei jogú városok alapvetően heterogén jellegét. Már az 1990-es évek során tapasztalható volt, hogy a nagyobb városok az átlagosnál gyorsabb infrastrukturális és fejlesztési növekedési potenciállal bírnak. ${ }^{86}$ 1990-hez képest már az ezredfordulóra kialakult a megyei jogú városok körében a különböző mutatókat tekintve egy erőteljesen pozíciójavító csoport: Székesfehérvár, Veszprém, Győr, Zalaegerszeg, Nagykanizsa, Pécs, Szekszárd, Debrecen, Nyíregyháza, Szolnok, Szeged és Kecskemét. Voltak továbbá az ún. pozíció-megtartó megyei jogú városok: Békéscsaba, Dunaújváros, Eger, Kaposvár, Sopron és Szombathely. A megyei jogú városok harmadik csoportjába pedig már az 1990-es években jelentős gazdasági, és társadalmi pozíciókat vesztő térségi központok kerültek, mint Salgótarján, Hódmezővásárhely, Tatabánya és Miskolc ${ }^{87}$ [Beluszky-Győri, 1999; Szigeti, 2003, 12-13. pp.]. Nem véletlen, hogy az utóbbi „leszakadó” városcsoport részei voltak a korábbi szocialista nehézipari központok, ezeket különösen hátrányosan érintette a rendszerváltás utáni gazdasági válság és szerkezetváltozás.

Természetes, hogy Budapest és a megyei jogú városok az intézményrendszer és humán erőforrás tekintetében kiemelkednek a többi település közül, alkalmassá válva a szélesebb térségi szintű feladatellátásra - spill-over hatás. A megyei jogú városok feladatellátási kapacitása esetén a valódi különbségtétel a regionális jellegü (a megye közigazgatási területén túlmutató) funkciók, intézmények, vonzáskörzet megléte vagy annak hiánya alapján tehetö. Több szempontból is bizonyított, hogy a megyei jogú városokat az azonos közjogi besoroláson túl nem nagyon tekinthetjük közös halmaznak - ezt jelzik az eltérő statisztikai indikátorok, valamint a kimutatható különbségek a megyei jogú városok gazdasági és társadalmi potenciálja, vonzáskörzeti képességeik között.

\section{IV.3.1 Városhierarchia az 1971-es OTK-ban}

A késő Kádár-korszak fontos településpolitikai és területfejlesztési „vívmánya” volt az önálló és kiterjedt településhálózat-fejlesztési stratégia, amely elfogadása közel azonos időben

\footnotetext{
${ }^{86}$ Budapest vezető gazdasági és politikai-igazgatási szerepe a mai napig megkérdőjelezhetetlen.

${ }^{87}$ Értelemszerúen a csak 2006-ra megyei jogú várossá vált Pest megyei Érd még nem volt része az ezredfordulós vizsgálatoknak.
} 
történt a tanácsrendszer aktuális átalakításával ${ }^{88}$ - az így megszületett 1971-es Országos Településhálózat Fejlesztési Koncepció (1971 OTK) jogszabályi alapja az 1007/1971. (III. 16.) Korm.határozat az Országos Településhálózat fejlesztési koncepcióról volt. A dokumentumot természetes módon átszőtték a szocialista egypártrendszert jellemző ideológiai dogmák, sok szempontból mégis a korszak egyik leginkább racionális, mai szemmel is mérhető jogalkotási, szakpolitikai teljesítménye született meg. Az 1971-es OTK terület- és gazdaságfejlesztési szempontok alapján egy hierarchizált településhálózatot konstruált ugyanakkor a dokumentumnak a tanácsi közigazgatást érdemben módosító relevanciája nem akadt. $^{89}$

Az 1971-es OTK eleve országos központként definiálta Budapestet, amelynek feladata a területileg el nem különíthető országos kormányzati és államigazgatási intézmények számára otthont biztosítani: meghatározott demográfiai célként Budapest és agglomerációja lakosságszámaként maximum a 2,6-2,8 millió lakos fogalmaztak meg - [1007/1971. (III. 16.) Korm.határozat III. 6. a)]. Ezen túlmenően a városi jogállású településeket két további klaszterba sorolta a kormányhatározat: felsöfokú központ valamint középfokú központba. ${ }^{90}$

Az 1971-es OTK a felsőfokú központok definiálásakor a vonzáskörzetre kiható (spill-over) gazdasági, igazgatási, oktatási és egészségügyi megyei szintű szervező-irányító, valamint egymással munkamegosztásban több megyére kiterjedő, akár országos funkciók ellátását írta elő, másrészről a kormányhatározat 3 csoportot különített el a felsőfokú központok tekintetében:

a) Kiemelt felsőfokú központ - Miskolc, Debrecen, Pécs, Szeged, Győr.

b) Felsőfokú központ - Békéscsaba, Kaposvár, Kecskemét, Nyíregyháza, Székesfehérvár, Szombathely, Szolnok.

c) Részleges felsőfokú központ - Baja, Dunaújváros, Eger, Hódmezővásárhely, Nagykanizsa, Salgótarján, Sopron, Szekszárd, Tatabánya, Veszprém, Zalaegerszeg [1007/1971. Korm.határozat III. 6. b)].

\footnotetext{
${ }^{88}$ 1971. évi I. törvény a tanácsokról („harmadik tanácstörvény”)

${ }^{89}$ Ugyanakkor a 6/1971. számú NET határozat nyilvánította ún. megyei várossá a legnagyobb vidéki városokat Debrecen, Györ, Miskolc, Pécs, Szeged

${ }^{90}$ Az 1971-es OTK által meghatározott településhierarchia kapcsán szükséges leszögezni, hogy a jelenlegihez képest sokkal alacsonyabb volt a városi jogállású települések száma, a különböző szakértői vélemények szerint ebben a korszakban még a valóban városi demográfiai és infrastrukturális paraméterekkel, karakterisztikával rendelkező települések számítottak a jog szerint is városnak. Így az 1971-es kormányhatározat szerint meghatározott középfokú központok közé is kerültek be községi jogállású települések, alsófokú központok közé pedig már kizárólag csak azok.
} 
Az 1971-ben elfogadott koncepció a vidéki városokat a felsőfokú központok mellett az ún. középfokú központokba rangsorolta gazdaságfejlesztési szempontból. Kritériumként a megyénél kisebb területrészre kiterjedő gazdasági, igazgatási, oktatási, és egészségügyi szervező-irányító, szolgáltató és ellátó funkciók kerültek meghatározásra. A kormányhatározat $64 \mathrm{db}$ városi illetve községi jogállású települést sorolta fel tételesen (pl. Gyöngyös, Siófok, Kazincbarcika, Gödöllö), valamint az ún. részleges középfokú központként 39 további települést (pl. Balatonfüred, Hajdúszoboszló, Záhony). ${ }^{91}$

Érdemes az 1971-es OTK szövegét összevetni napjaink hazai nagyvárosi (megyei jogú városi) valóságával. Miskolc, Debrecen, Szeged, Győr és Pécs már négy évtizede is kiemelt felsőfokú központként került kiemelésre. Ezek a városok váltak három évtized múltán ún. regionális pólusvárosokká a 2005-ben elfogadott - az 1998-as helyébe lépő - Országos Területfejlesztési Koncepcióban [96/2005. (XII. 25.) OGY Határozat az Országos Területfejlesztési Koncepcióról]. A Közép-Dunántúli statisztikai-tervezési régió ún. társ-pólusközpontjai (Székesfehérvár és Veszprém) már legalább annyira az országos politikai akaratnak - a Közép-Dunántúl jelenjen meg önálló statisztikai-tervezési régióként -, köszönhették a kiemelt fejlesztési-tervezési pozíciót. Fontos látni, hogy a mai megyei jogú városok minimális különbséggel, ${ }^{92}$ de már az 1971-es OTK-ban valamely felsőfokú központi alkategóriába (kiemelt felsőfokú központ; felsőfokú központ; részleges felsőfokú központ) kerültek besorolásra.

Az OTK igyekezett szólni az agglomerációs térségek fejlesztésével és településhálózati kontextusaival kapcsolatban - e szerint szükséges megfelelő alközpontok kialakítása a népesség jobb ellátása érdekében, valamint fontos, hogy az agglomerációs települések egymással illetve a központi településsel összhangban, a természetes jellegének (,,városi, ipari, üdülö” jellegü agglomerációk) megfelelően fejlődjenek.[1007/1971. (III. 16.) Korm.határozat III. 9.].

\section{IV.3.2 Az elmúlt másfél évtized megyei jogú városi tipológiái}

A már bemutatott városhálózat-tipológiák mellett az elmúlt másfél évtizedben születtek egyéb kifejezetten a megyei jogú városokra koncentráló rangsorolások. Csapó

\footnotetext{
${ }^{91}$ Középfokú központoknál 20.000-40.000 fős városi és 50.000-120.000 fős agglomerációs lakosság; részleges középfokú központok esetében 8000-15.000 fös városi és 20.000-25.000 fös agglomerációs lakosság. [1007/1971. Korm.határozat III. 6. c)]

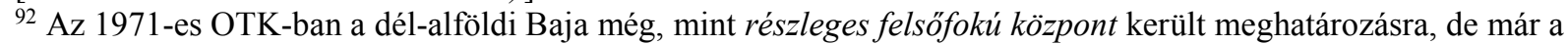
megyei jogot sem kapta meg 1990-ben; ugyanakkor Érd, mint 1971-ben községi jogállású település nem is került külön nevesítésre a kormányhatározatban még a középfokú központok között sem.
} 
Tamás geográfus egy 2002-es összefoglaló kutatás keretében és tanulmányban hierarchizálta a megyei jogú városokat. A komparatív összehasonlítás alapja 80 ún. regionális indikátor volt: 31 állami dekoncentrált intézmény elhelyezése; 16 gazdasági és infrastrukturális mutató; 19 oktatási és kulturális; 14 egészségügyi-, szociális és egyéb intézményi paraméter. Ez alapján Csapó az alábbi csoportokat képezte:

- Egyértelmü regionális központok - Pécs, Debrecen, Szeged

- Bizonyos regionális funkcióval nem rendelkező megyei jogú városok - Miskolc, Győr

- Több regionális funkcióval rendelkező megyei jogú városok - Szombathely, Veszprém, Kecskemét, Szolnok, Székesfehérvár, Kaposvár, Sopron

- Csak néhány regionális funkcióval rendelkező megyei jogú városok - Békéscsaba, Eger, Nyíregyháza, Zalaegerszeg

- Regionális funkcióval nem vagy csak alig rendelkezö megyei jogú városok Dunaújváros, Hódmezővásárhely, Nagykanizsa, Salgótarján, Szekszárd, Tatabánya. ${ }^{93}$ [Csapó, 2002; Szigeti, 2003, 17-24. pp.]

Szigeti Ernő 2002-es Község, város, jogállás címü monográfiában a lakosságszám alapján egy 6 szintből felépülő magyarországi várospiramis-szisztémát modellezett: 1. szint 10.000 lakosnál kisebb népességü városkategória. 2. szint 10.001-20.000 lakosú városkategória. 3. szint 20.001-50.000 lakosú városkategória. 4. szint 50.001-100.000 lakosú városkategória. 5. szint 100.000 lakosnál népesebb városkategória; 6. szint Budapest, mit országos központ - [Szigeti, 2002, 150.pp.]. Látható, hogy a 100.000 városi lakos, mint paraméter Szigetinél is kiemelt fontosságot kapott a nagyvárosok differenciálásában.

Szigeti egy másik 2003-as tanulmányban értékelte a kifejezetten a hazai nagyvárosok (főváros, megyei jogú városok) 1990-2002 közötti változásait, megpróbálva egy belső tipológiát felállítani - [Dövényi, 1992; Tóth, 1993; Beluszky, 1999; Csapó 2002; Szigeti, 2003], a fontosabb megállapítások a következők voltak:

1. Budapest főváros, mint megkérdőjelezhetetlen politikai, közigazgatási és gazdasági országis központ továbbra is, dacára a jelentős agglomerációs irányú kiköltözésnek.

2. Szeged, Pécs, Debrecen - egyértelmüen regionális központ funkciókkal rendelkeznek minden érdemi vizsgálati szempont szerint.

3. Miskolc és Győr - bizonyos tipológiák szerint, ha nem is minősülnek minden tekintetben regionális központnak, adottságaival és különböző mérhető paramétereivel

\footnotetext{
${ }^{93}$ Érd természetesen még nem volt része a 2002-es felmérésnek.
} 
kiemelkednek a 3 regionális (Szeged, Pécs, Debrecen) központ mellett a megyei jogú városok közül.

4. Nagykanizsa, Dunaújváros, Szekszárd, Hódmezővásárhely - a különböző tudományos összehasonlítások szerint ezek a megyei jogú városok „alulról” lógnak ki, Szekszárd méretei (alacsony lakosságszám), a másik 3 város pedig alapvetően az igazgatásiadminisztratív pozíciók hiánya miatt, lévén egyik sem megyeszékhely. ${ }^{94}$

5. A fennmaradó megyei jogú városok többé-kevésbé besorolhatóak közös csoportba - a nem megyeszékhely megyei jogú városok közül Sopron kiemelkedik kedvező geopolitikai adottsága révén - az osztrák-magyar határ rendkívüli közelsége [Szigeti, 2003, 22-23. pp.].

\section{IV.3.3 Az állami területi dekoncentrált szervek telepítése a vidéki nagyvárosokba}

Szükséges tisztázni az ún. regionális központ és a régióközpont terminus technikusok közötti tartalmi különbséget. A régióközpont egyértelmủen hivatalos közigazgatási központ, amely feltételez valamilyen létező politikai-önkormányzati régió meglétét - mint felső-közép szintű területi önkormányzat. A regionális központ (centrum) kifejezést önkormányzati régiók hiányában használatos, és adott területi nagytérség (Európában általában a NUTS2 területi klasztertérség) esetén arra a nagyvárosra, központi centrumtelepülésre alkalmazza a szakirodalom, amely a legnagyobb mértékben ad otthont különböző állami területi dekoncentrált intézmények számára. A hagyományosan monocentrikus Budapest-központú Magyarországon nem meglepő, hogy a minisztériumi szint alatti állami intézmények (kormányhivatalok, központi hivatalok) illetve a területi dekoncentrált intézmények túlnyomó többsége (több mint kétharmaduk) a fövárosban került elhelyezésre. Azonban Budapest mellett számos ilyen típusú szerv található vidéki nagyvárosokban, ez elsősorban az 1998 utáni országos területfejlesztési koncepciókban ún. pólusvárosként (regionális centrumként) definiált vidéki nagyvárosokra érvényes. A különböző vizsgálatok szerint a 2000-es évek második felében Budapest után a dél-dunántúli regionális centrum, Pécs biztosított helyet a legnagyobb számban területi dekoncentrált intézményeknek [Csomós, 2008, 2-3. pp.; Vadál, 2009, 53.p].

Az önkormányzati feladatellátásért felelős intézmények mellett a különböző telepített állami- és közhatalmi területei szervek (közigazgatási intézmények, bíróságok-ügyészségek)

\footnotetext{
${ }^{94}$ A 2006-ban megyei jogú várossá vált Érd is ide tartozik nagy valószínüséggel: nem rendelkezik kiemelkedő igazgatási-adminisztratív funkciókkal; a saját vonzáskörzet pedig rendkívül viszonylagos, mivel maga Érd is része Budapest agglomerációs térségének.
} 
biztosítják az adott nagyváros igazgatási és közszolgáltatási spill-over szerepkörét: Magyarországon a központi kormányzat az államigazgatási szervezettelepítés jegyében közvetett, mégis érdemi hatással bírhat a különböző vidéki regionális központi pozíciókra. Habár az államigazgatás központi és területi dimenziója nem képezi a disszertáció elsődleges fókuszát, érdemes szólni az elmúlt negyedszázad kapcsolódó folyamatairól, politikaiközpolitikai törekvéseiröl. Amíg az önkormányzati szektor átfogó átalakításához „alkotmányerejü” parlamenti 2/3-os akarat szükséges - lásd az irányadó jogszabály (Ötv., majd Mötv.) jellegét! - addig a központi kormányzat és a területi államigazgatás alakításához és szervezéséhez nem kapcsolódik közvetlen 2/3-os parlamenti kompetencia. ${ }^{95}$ A rendszerváltást követő években nem alakult ki koherens kormányzati szemlélet a területi államigazgatási térbeli szervezésének elveiröl. A területi dekoncentrált intézménytípusok nagyobb része megyei szinten müködött - nagyon sok kompetenciát éppen a korábbi megyei tanácsoktól „megörökölve” -, bizonyos intézmények azonban már a kezdettől fogva nem megyei, hanem valamilyen nagyobb (jobb híján nevezzük több megyére kiterjedő regionális jellegünek) ${ }^{96}$ területi szervezésben müködtek - csak néhány példa az utóbbiakra, a bányakapitányságok, a BM bevándorlási és állampolgársági hivatalok, környezetvédelmi felügyelöségek. A megyei szervezésű állami dekoncentrált intézmények túlsúlya miatt a megyeszékhelyek egyszerre voltak önkormányzati és térségi államigazgatási adminisztratív központok. Ez a sok szempontból ad hoc - a belső ágazati szempontok, érdekek és lobbik által meghatározott - szervezetlenség másfél évtizedig volt jellemző, a különböző „,színezetü” (jobb- és baloldali) kormányok átfogóan nem bolygatták az állam területi intézményrendszerét. Persze akadtak változások, racionalizálások - pl. az önkormányzatok törvényességi ellenőrzésére hivatott 1990-ben felállított 8 ún. köztársasági megbízott intézményét az 1994-1998 között 2/3-os országgyülési többségben kormányzó Horn-kabinet megszüntetette, a korábbi kompetenciákat az immáron fővárosi és megyei területi illetékességgel megszervezésre kerülő közigazgatási hivatalok kapták meg. Az ún. államigazgatási regionalizáció lényegében 2002-ig nem kapott hangsúlyos szerepet. ${ }^{97}$

\footnotetext{
95 1⁄2-es parlamenti többség szükséges a minisztériumi struktúra átalakításához, módosításához, valamint a kormányhivatal jogállású közigazgatási szervek létrehozatalához, megszüntetéséhez, módosításához ezzel is a „védve” a mindenkori központi közigazgatást a 2/3-os parlamenti kompetenciával szemben.

${ }^{96}$ Ekkor még jóval az 1998-as Országos Területfejlesztési Koncepció elött voltunk, amely meghatározta a 7 statisztikai-tervezési régiót - [35/1998. (III. 20.) OGY Határozat 5.2]

${ }^{97}$ Sőt bizonyos speciális hatáskörü - nem megyei illetékességü - állami dekoncentrált szervek száma 1992-1998 között csökkent, miközben a legfontosabb „dekók” maradtak megyei szinten (közigazgatási hivatalok, földmüvelésügyi hivatalok, földhivatalok, KSH területi igazgatóságok, munkaügyi központok, ÁNTSZ hivatalok etc.), megyei rendőrkapitányságok - Verebélyi Imre: Válságban a magyar középszintü közigazgatás, quo vadis? (in: Új Magyar Közigazgatás 2009/1. szám 47. pp.)
} 
A direkt politikai-önkormányzati regionalizáció gondolata hangsúlyosan először Medgyessy Péter miniszterelnöksége idején (2002-2004) merült fel, ekkor hozták létre az akkori belügyminiszter kezdeményezésére az IDEA szakértői csoportot Ágh Attila politológus vezetésével - három tematikus munkacsoport keretében éveken át készültek különböző szakmai, szakértői háttéranyagok. Három témakör került kijelölésre: önkormányzati finanszírozás; kistérségi munkacsoport; politikai-önkormányzati regionalizáció. ${ }^{98} 2006$ nyarán az egyszerü feles parlamenti többséggel bíró második Gyurcsány-kormány (3. MSZP-SZDSZ koalíció) benyújtott az Országgyűlésben egy komplex törvényjavaslat-csomagot, benne az önkormányzati régiók létrehozásával. Az Önkormányzati törvény 2/3-os jellege miatt szükség volt a parlamenti ellenzék (elsődlegesen a Fidesz és KDNP frakciók ${ }^{99}$ ) támogatására, de az akkor már jelentős nagypolitikai szembenállás miatt esélye sem volt a csomag parlamenti elfogadásának, a miniszterelnök nyári Balatonöszödön elmondott beszédének őszi nyilvánosságra kerülését követően pedig teljesen lekerült a politikai regionalizálás törekvése a politikai napirendröl. A regionális önkormányzatok megvalósításának kudarca helyett a második Gyurcsány-kormány jobb híján a területi államigazgatás térségi-regionális átalakításába kezdett bele - ezt nevezte Pálné Kovács Ilona az ún. „kiskapus regionalizációnak! [Pálné, 2008, 65. pp.]. A dekoncentrált szervek regionalizálását a 2118/2006. (VI. 30.) kormányhatározat tartalmazta, majd az év végéig számos további kormányzati döntés, kormányhatározat született a konkrét intézménytípusok területi átszervezéséről, ezek nagy része már 2007. január 1.-vel hatályba lépett. ${ }^{100} \mathrm{Az}$ akkori ellenzéki pártok egyöntetű elutasítása mellett a szakma indokolatlanul gyorsnak találta az államigazgatási regionalizáció tempóját. A területi államigazgatás átalakítása az új regionális intézményi székhelyek oldaláról kapcsolható a megyei jogú városok változó pozícióihoz. A témakört kutató Vadál Ildikó egy 2009-es tanulmányában megállapította, hogy a 2007-ben kialakult új területi államigazgatási rendszerben az egyes hivatalok székhelyeinek kiválasztásánál nem érvényesült egységes szakmai-, térszerkezeti logika. Sokkal inkább politikai alkufolyamatok játszottak szerepet a székhely-kijelölő döntések esetében - az egyes megyei jogú városi polgármesterek milyen közvetlen kormányzati lobbipozíciókkal

\footnotetext{
98 Az IDEA munkájáról szóló összefoglaló - Ágh Attila: Az IDEA program a közigazgatási reform szolgálatában (in: IDEA és valóság - Az IDEA közigazgatás-korszerüsítési program négy éve, Közigazgatásfejlesztési Társaság, Budapest, 2008) 9-32. pp.

${ }^{99}$ Habár a 2006 tavaszi országgyülési választáson a két párt közös listán indult, a megválasztott parlamentben már külön Fidesz és külön KDNP frakciókban kezdték meg a népképviseleti munkát.

${ }_{100} \mathrm{Az}$ uniformizálás jegyében nemcsak korábban megyei illetékességü intézmények (ÁNTSZ hivatalok, munkaügyi felügyelőségek, közigazgatási hivatalok. APEH igazgatóságok etc.), hanem más területi szervezésü hivatalok (pl. bányakapitányságok) számára is a statisztikai-tervezési régiók jelentették az új területi szintet.
} 
rendelkeztek. ${ }^{101}$ Nem véletlen, hogy több olyan regionális intézményi példa akadt, ahol nem a pólusváros kapta meg az adott dekoncentrált szerv elhelyezését - pl. Dél-Dunántúlon a regionális ÁNTSZ ${ }^{102}$ igazgatóság Pécs; Észak-Magyarországon Miskolc helyett Eger vált a regionális közigazgatási hivatal székhelyévé [Vadál, 2009, 48-59. pp.]. Látható, hogy az állami területi szervek térségi elhelyezéséről szóló döntésnek nagyon komoly belső regionális tétje van, ezen keresztül közvetlen kormányzati szintröl befolyásolhatók a kialakult vagy éppen formálódó regionális központ (centrum) és betöltött spill-over pozíciók.

A 2010-ben hatalomra került új kormányzat (második Orbán-kormány) szakított elődje állami területpolitikájával ezen a téren is. Az államigazgatási regionalizáció helyett a dekoncentrált intézmények megyei szintü újraszervezése vált a hivatalos kormányzati közpolitikai agenda részévé, másik oldalról viszont a korábbi közigazgatási hivatalok intézményi bázisán hozták létre a megyei kormányhivatalokat (2011. január 1. hatállyal), ${ }^{103}$ amelyekbe közel kéttucat korábban önálló szervtípust olvasztottak be. Területi szinten a dekoncentráció (NUTS2 szintről NUTS3-ra), ágazati tekintetben azonban a közvetlen koncentráció (ágazatközi kormányhivatalok) vált a második Orbán-kormány vezérlőelvévé a területi államigazgatás tekintetében. Természetesen ez fontos intézményi pozíciókat adott vissza azon megyei jogú városoknak, amelyek a 2007-es államigazgatási regionalizáció során pozíciókat veszítettek. A 2013-ban bevezetésre került az államigazgatási járások rendszerében pedig ez azt új típusú szemléletet szervezték tovább alsó-közép területi szinten - a megyei kormányhivatalok járási szintű kirendeltségei, intézményi bázisai lettek a járásszékhely városokban található járási kormányhivatalok, amelyek az államigazgatási kompetenciák mellett számos korábban helyi önkormányzati feladatot (pl. gyámügy) „vettek át”.

\section{IV.3.4 Városhierachia a közigazgatási jogállás és a spill-over hatókör alapján}

Az alábbi összegző diagram a megismert városi tipológiák, szempontok ismeretében hierarchizálja a közigazgatási - immár a Magyarország helyi önkormányzatairól szóló 2011. évi CLXXXIX. törvény szerinti települési önkormányzati - jogállás, valamint a magyarországi városok tényleges városkörnyéki / szélesebb térségi hatókörük szintetizálása alapján a hazai városokat:

\footnotetext{
${ }^{101}$ A 2006 ősz után egyre labilisabb legitimitású kormányzat nem hagyhatta figyelmen kívül a kormánypárti parlamenti padsorokban ülő polgármester honatyák törekvéseit, ehhez képest a 2010 nyarán kényelmes 2/3-os országgyülési hátországgal hivatalba lépő második Orbán-kormány belső mozgásterét nem korlátozták a különbözö fideszes önkormányzati lobbik akár az államigazgatás, de akár az önkormányzati rendszer törvényi átalakítása során.

102 Állami Népi és Tisztiorvosi Szolgálat, mint a népegészség- és járványügy illetékes állami főhatósága.

103 2010. évi CXXVI. törvény a fóvárosi és megyei kormányhivatalokról, valamint a fóvárosi és megyei kormányhivatalok kialakitásával és a területi integrációval összefüggő törvénymódositásokról
} 


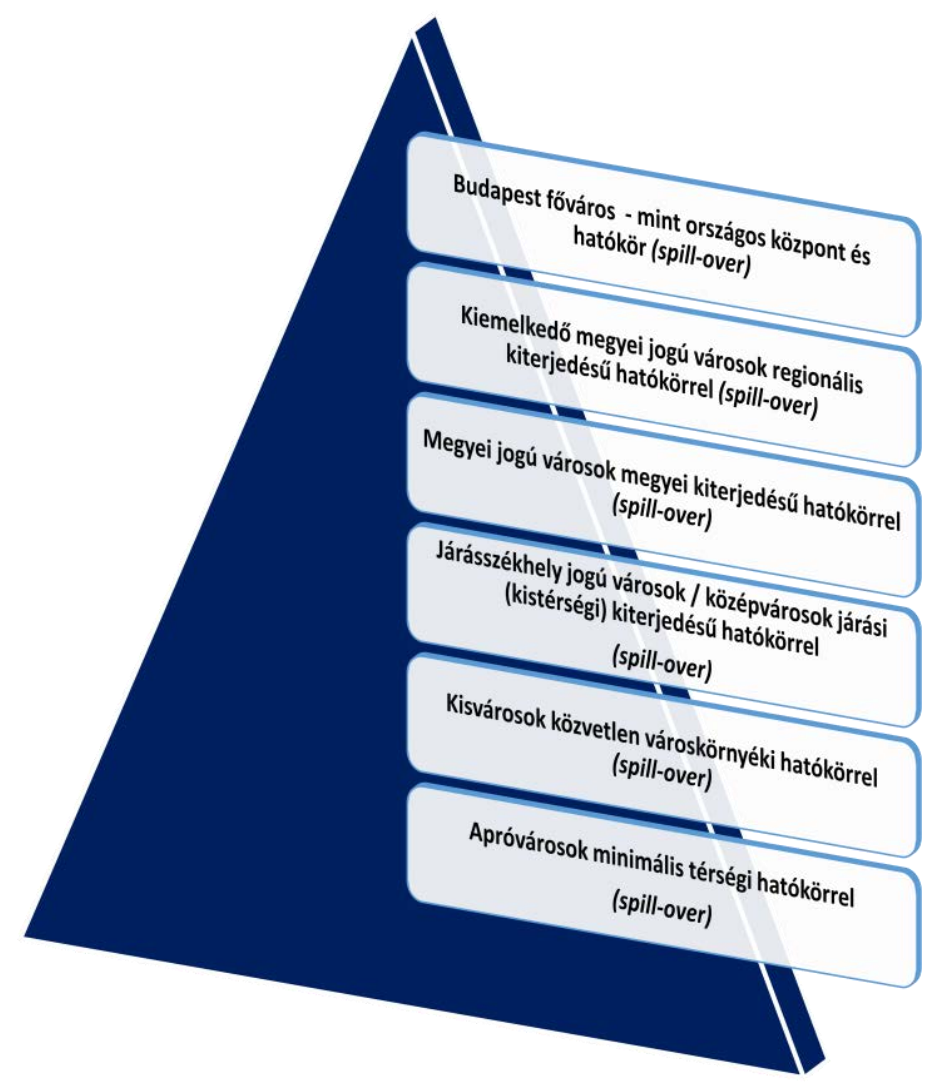

16. ábra: városhierarchia a jogállás és a városkörnyéki spill-over függvényében (saját szerkesztés)

A közel 350 magyarországi város között könnyüszerrel lehet olyan „kakukktojás” településeket találni, amelyek önkormányzati jogállása valamint a tényleges hatókör nem korrelál egymással. A megyei jogú városok közül mindenképpen ilyennek számít Érd a fővárosi agglomerációban, amely egyúttal járási központ (érdi járás), mégis a közvetlen hatása jobbára csak a szük városkörnyéki térségre terjed ki, önálló agglomerációs övezetről nem is beszélhetünk, lévén Érd maga is a Budapest környéki szuburbanizáció része. Hasonlóan kettős helyzet jellemzi a nem megyeszékhely, de megyei joggal felruházott városok helyzetét, amelyek valós hatókörét a mezoszintű megyei adminisztratív funkciók hiánya a megye alatti járásnyi vagy esetleg több járásnyi területre szükíti, ezek: Nagykanizsa, Hódmezővásárhely, Dunaújváros. A megyei jogú városok közül talán Sopron helyzete a leginkább sajátos, amely annak ellenére, hogy nem rendelkezik megyei adminisztratív funkciókkal (azok Győrnél vannak), ellenben geopolitikai adottságainál fogva (határmentiség; relatív nagyobb távolság más hazai nagyvárostól) jelentős térségi hatókört biztosít Sopronnak. Természetesen kisebb városoknál is találhatunk hasonlóan ambivalens különbséget a települési jogállás és a valós 
térségi szerepkör között - pl. Budakeszi járásszékhely jogú város, miközben a közeli Budaörs sokkal inkább számít lakosságszám illetve gazdasági és társadalmi paraméterek tekintetében kistérségi központnak.

\section{IV.3.5 Magyarországi falvak az urbánus térségekben}

A magyarországi kistelepülések rendszerváltás utáni helyzetét erősen befolyásolta a térségi elhelyezkedés (rurális vagy urbánus térségben található), illetve az adott országrészre jellemző településhálózati viszonyok (aprófalvas, óriásfalvas). ${ }^{104}$ Továbbá hatással voltak a falvak helyzetére az elmúlt évtizedek urbanizációs szakaszváltásai - a városokba való vándorlás befejeződése; a nagyvárosok környékén fellendülő szuburbanizációs, elővárosi folyamatok. Az 1971-es Országos Településhálózat-fejlesztési Koncepció a városok mellett foglalkozott a községi tanácsi jogállású településekkel is. Az 1971-es OTK a vidéki városokat felsőfokú és középfokú központ csoportokba sorolta, de az utóbbiak közé bekerültek községi jogállású települések is; alsófokú központok pedig már csak községi tanácsok (önálló vagy közös tanácsok) voltak. Az 1971-es OTK a községek tekintetében a nagy elemszám miatt már nem tartalmazott tételes felsorolást, csak meghatározott nagyságrendi számokat közölt:

- kb. 1000-1100 alsófokú központi szerepkört betöltő község, ebböl 120-150 db kiemelt alsófokú központ; 200-300 db részleges alsófokú központ; a többi egyszerü alsófokú központ. [1007/1971. (III. 16.) Korm.határozat III. 6. d)].

- A semmilyen önálló központi szerepkörrel, karakterisztikával nem rendelkező kistelepüléseket az egyéb települések gyüjtőkategóriába kerültek - [1007/1971. (III. 16.) Korm.határozat II.]

Beluszky Pál és Sikos T. Tamás 2001-es statisztikai adatok alapján végeztek klaszteranalízist a magyarországi falvakról. A nagyvárosi agglomerációs térségek községi jogállású településeit alapvetően 3 fötípusba soroltak (kb. 800 db község) - a rendszerváltás után fellendülö várossá nyilvánítás hullám erôteljesen érintette az nagyvárosi agglomerációs térségek községeit!

I. $\quad$ Az agglomerációk belső övezeteinek községei - az ún. elit szuburbia települései

1. Nagy lélekszámú, jelentősen növekvő községek, 1990 után átlagosan közel 1/3-os arányú demográfiai növekedéssel. Kedvező társadalmi struktúrájú települések, ahol a munkavállalók kétharmada a nagyvárosban dolgozik.

\footnotetext{
${ }^{104}$ Nagy különbségek lehetnek aszerint, hogy az aprófalvas dunántúli, észak-, északkelet-magyarországi térségekben vagy éppen a kevésbé fragmentált óriásfalvas Alföldről van szó.
} 
Rendkívül alacsony a mezőgazdasági foglalkoztatott és magas a szellemi foglalkoztatottak aránya. Közvetlenül Budapest körül a „belső agglomerációs gyürü" települései tartoznak ide, de néhány megyei jogú városok környékén is megtalálhatóak - Miskolc, Pécs, Veszprém etc. ${ }^{105}$

2. Közepes lélekszámú, de gyorsan növekvő népességü kedvező helyzetü agglomerációs községek. Leginkább Budapest, valamint Pécs, Miskolc, Veszprém és Dunaújváros környékén találhatóak ezek a települések.

II. Az agglomerációk külső övezeteinek községei - átlagosan 3000 lakos feletti átlagnépesség; az elit szuburbia településeihez képest kevésbé urbánus községi társadalmi struktúrák - kevesebb szellemi foglalkoztatott, valamivel magasabb agrárius népesség. Előfordulásuk a fővárosi agglomerációs „külső gyürüje”, Győr és Mosonmagyaróvár között vagy a Dunaújváros - Székesfehérvár - Várpalota tengelyen.

III. Az agglomerációs térségekkel határos területek községei - Jó vagy átlagos munkaerőpiaci helyzetü, stagnáló népességü és „magas kiingázású” falvak. 2000 fő vagy az alatti lakosság, községek. Előfordulásuk főleg a Dunántúlon, valamint Heves és Nógrád megyékben, de Békésben, Csongrádban és Tolna megyében is azonosítottak jó néhány falut [Beluszky-Sikos T., 2007, 215-222. pp.].

Beluszky és Sikos T. a 2007-es falukategorizálás során 102 akkor községi jogállású falut soroltak az elit szuburbia települései közé, ezek közül 50 db volt megtalálható Pest megyében, jobbára Budapest szuburbán övezetében. ${ }^{106}$ Ezen túl az elit szuburbia községeit vidéken csak a meghatározó megyei jogú városok környékén mutatták ki (Pécs környékén 7 $\mathrm{db}$, Miskolcnál szintén $7 \mathrm{db}$, Fejér megyében - Székesfehérvár és Dunaújváros - $10 \mathrm{db}$ község) [Beluszky - Sikos T., 2007, 225. pp.]. Ugyanakkor világos a tendencia, hogy amennyiben a kisebb települések minél inkább valamely nagyváros közvetlen közelében, azok szuburbán övezetében találhatók, annál inkább kedvező demográfiai, társadalmi és gazdasági pozíciókkal rendelkeznek, és a belső migrációs folyamatok potenciális haszonélvezői.

\footnotetext{
${ }^{105}$ Elsődlegesen a Beluszkyék által ide sorolt községek köréből vált jó néhány várossá napjainkra.

106 Érdemes megemlíteni, hogy a KSH 2014-es Magyarország közigazgatási helynévkönyve 2014. január 1. kiadvány szerint 2002-2014 között 23 Pest megyei községi jogállású település vált várossá, azok jó része pedig Budapest belső és külső agglomerációs övezetében találhatóak (lásd Beluszky-Sikos T. 2007-es falusi monográfiája!) - [KSH: Magyarország közigazgatási helynévkönyve 2014. január 1. - KSH, Budapest, 2014,
} 


\section{IV.4 A várossá nyilvánítás folyamata a rendszerváltás után}

Amikor a rendszerváltás utáni magyarországi településhálózat változásait vizsgáljuk, szükséges foglalkozni az elmúlt negyedszázad várossá nyilvánítási folyamatáról. A hazai várospolitika történeti dimenzióit tekintve az 1970-es évekig Magyarországon csak a láthatóan jól fejlett, megfelelő infrastruktúrával rendelkező, 15-20 ezer fős minimális lakosú községek válhattak várossá. Az 1980-as években azonban már a 10-15 ezres lakosságszámú településekböl kerültek ki elsősorban az új városok, ez a folyamat főleg az eredetileg városhiányos térségeket érintette; a rendszerváltás évtizedében, az 1990-es években pedig még tovább csökkent az új városok átlagos lakosságszáma az 5-10 ezres szintre [Beluszky, 2002, 55. pp.; Szabó Gábor, 1995, 11-12. pp.].

\section{IV.4.1 A funkcionális városi és a közjogi városi kategória elkülönülése 1990 után}

A rendszerváltást megelőzően a városi jogállás tekintetében a hatályos jogi szabályozás egyértelműen összekötötte a városok jogi és funkcionális meghatározásának kereteit - 11/1971. (III. 31.) Korm. rendelet és 8/1971. (Ép. Ért.) ÉVM-MTTH sz. együttes utasítás $^{107}$-, az Ötv. 115.§ (1) bekezdése 1990. szeptember 30. határidővel azonban hatályon kívül helyezte a várossá nyilvánítás korábbi szabályait. Az 1990-2015 időszakban - beleértve az 1999-ben elfogadott Területszervezési eljárásokról szóló 1999. évi XLI. törvény (Tetv.) várossá nyilvánításról szóló szabályait ${ }^{108}$-, jogszabályi szintű előírás alig rendelkezett a városi cím, mint jogállás és tartalmi mibenlétéről. Ugyan a területszervezési eljárásáról szóló törvény írt a városok kapcsán a településhálózatokban betöltött központi szerepről, de ezen és egy 1999-es Belügyi Közlöny (1999/13. szám) a várossá nyilvánítási eljárást elkészítő szakmai bizottság feladatairól szóló tájékoztatóján túl nem született valódi kvantitatív és kvalitatív mutatókat tartalmazó előírás, mint az említett 1971-es jogi normáknál [Hoffmann, 2009, 58-59. pp.]. A rendszerváltás óta napjainkig érő talán legmeghatározóbb településjogi aspektus a városok számának nagyarányú megnövekedése - gyakorlatilag megduplázódása -,

\footnotetext{
${ }^{107} 1971$ után a tanácsrendszer keretei között ez a két jogi norma határozta meg normatív módon a nagyközségek számára a várossá nyilvánítás feltételeit, meghatározott gazdasági, demográfiai, infrastrukturális és intézményi adatokat rendelve hozzá - pl. belterületi népességszám évi 1\%-os gyarapodása; legalább 300 fős müvelödési ház a nagyközségben.

$108 \mathrm{Az}$ 1999. évi XLI. tv. 15-17.§ (1) szerint a nagyközségi önkormányzat kezdeményezhette várossá nyilvánítását, amit végső soron a köztársasági elnök hagyhat jóvá. Magáról a nagyközség definíciójáról az Ötv. (1990. évi LXV. tv. 108. §) beszélt, amely szerint nagyközség az a községi jogállású település, amely az Ötv. eredeti 1990. szeptember 30. hatálybalépésekor viselte a nagyközségi címet, illetve az a község, amely területén legalább 5000 lakos él.
} 
a várossá nyilvánítás, mint lineáris intenzitású folyamat révén. ${ }^{109} \mathrm{~A}$ KSH Területi Statisztika urbanisztikai és településtani szakfolyóirat 2000-es évtizedét már végigkísérték a funkcionális városfogalom valamint a várossá nyilvánítás jogi szabályozásáról és gyakorlatáról szóló viták. Volt olyan szakértöi vélemény, amely nyíltan megfogalmazta, hogy az akkor már több mint 300 városi jogállású magyarországi település alig egyharmada felel meg a „városok földrajztudományi szempontú kritériumainak” [Németh, 2009, 9. pp.].

\section{IV.4.2 A hazai városhálózat aktuális paraméterei}

Az elmúlt negyedszázad várossá nyilvánítási folyamatának értékeléséhez érdemes a jelen állapotból kiindulnunk: Magyarországon 2014. január 1.-én Budapesten (fővárosi jogállás) és a 23 megyei jogú város mellett további 322 település rendelkezett városi jogállással. Természetesen ennek része az a 176 ún. járásszékhely jogú város, amely települések a 2013. január 1.-vel közel három évtized elteltével létrejött államigazgatási járások központjaiként kerültek kijelölésre a 218/2012. (VIII. 13.) Korm.rendelet a járási (fövárosi) kerületi hivatalokról keretében. A 322 város (járásszékhely jogú és városi jogú települések) összesen 3.225.220 lakost foglalt magába Magyarország össznépességéből. Ezek közül kiemelkedik lakosságszámával a Pest megyei Dunakeszi a 41 ezres lakosságával, Cegléd (36 ezer fö) és Szigetszentmiklós (35 ezer fö) valamint Baja (35 ezer lakos) BácsKiskun megyében. Ennél sokkal érdekesebb statisztika viszont, hogy 25 olyan település is rendelkezett városi jogállással, amelynek lakossága 3000 fő alatt maradt, és ebből 6 db 2000 lakos alatti „apróváros” volt. A legkisebb lélekszámú városi jogállású település az 1060 lakosú Pálháza volt Borsodban [KSH, 2014b, 27-32. pp.]. Még izgalmasabb a 2014-es KSH helynévtár községi, nagyközségi demográfiai adatait vizsgálni: 112 db nagyközséget közöl a kiadvány megyei bontásban. Amíg Vas és Nógrád megyében egyetlen település sem rendelkezett nagyközségi címmel, addig Pest megyében 21 nagyközség, Szabolcs-SzatmárBereg megyében 15 db, Fejér és Hajdú-Bihar megyében 10-10 db ilyen jogállású település volt 2014. január 1.-én. A 112 nagyközség népességi adatai - hasonlóak a városokhoz rendkívül differenciáltak: országosan kiemelkedett a fővárosi agglomerációban található Solymár (10.049 lakos) és Csömör (9.124 lakos) nagyközségek, amelyek lakossága 8-9-szeres a legalacsonyabb népességű városokhoz viszonyítva [KSH, 2014b, 34-99. pp.].

\footnotetext{
${ }^{109}$ A Magyar Tudományos Regionális Kutató Központja (MTA-RKK) egy 2001-es kutatásban az akkor 252 városi jogállású települést vizsgálva mindössze $\mathrm{kb}$. 200 esetében találta megalapozottnak a funkcionális városi jelleget.
} 
Mi a legfontosabb üzenete a KSH települési adatoknak? Leginkább az, hogy az apró vagy törpevárosok esetében mennyire nincs racionális koherencia a települések népességszáma, települési infrastruktúrája és az egyéb mérhető gazdasági, társadalmi paraméterek valamint a városi jogállás között. A 2000 lakos alatti települések várossá nyilvánítása mellett ésszerű szakmai érvek csak nagyon nehezen hozhatóak fel. A KSH Területi Statisztika című folyóiratának 2008/6. tematikus városi számának általános bevezető tanulmányában Csapó Tamás és Kocsis Zsolt a következő mondattal jellemezték a magyarországi városok világát. „Vannak városok, amelyek rendelkeznek térségi szerepkörökkel, vannak, amelyek nem; vannak városok, amelyek infrastrukturális ellátottsága valóban városias, vannak, amelyeknek nem; vannak városok, ahol pontosan lehet tudni, hogy miért volt szükség a cím adományozására, vannak ahol nem (persze, ilyenkor „,magasabb szempontok” érvényesültek).” [Csapó-Kocsis, 2008, 645. pp.]. A „magasabb szempontok” meglétét számos, különösen az 1990-2010 időszakban várossá nyilvánításról szóló döntés bizonyítja. A végső köztársasági elnöki döntést előkészítő szakminisztériumi (1990-2006 között a Belügyminisztérium; 2006-2008 az Önkormányzati és Területfejlesztési Minisztérium, 2008-2010 az Önkormányzati Minisztérium) előterjesztéseknél nagyon sokszor egyszerűen figyelmen kívül hagyták a meglévő demográfiai, intézményi és infrastrukturális adottságokat. Helyette egyéb szakmai (pl. minden statisztikai kistérségre jusson város), vagy közvetlen politikai lobbi-vezérelt (helyi önkormányzati, egyéni parlamenti képviselö) motivációk, szándékok állhattak a folyamatok mögött.

\section{IV.4.3 A város cím devalválódása 1990 után}

A városi cím ilyen értelemben való devalválódása már az 1980-as években megkezdődött, de a településkategória funkcionális „kiürülése” igazán csak a rendszerváltással kezdődött, pontosabban a városi cím elnyerésének szándékosan „laza” jogszabályi meghatározásával. Ugyanakkor ezzel a nyilvánvalóan engedékeny eljárási gyakorlattal hamar orvosolni tudták a városhiányos térségek problémáját, de 2010-re a magyarországi városhálózat telítődött. Az táblázat mutatja számunkra, hogy 1990-től napjainkig 182 községi, nagyközségi jogállású település vált várossá a várossá nyilvánítási eljárás következtében. 
A várossá nyilvánítások száma évente:

\begin{tabular}{|c|c|}
\hline $\begin{array}{l}\text { A várossá nyilvánítás ról szóló } \\
\text { köztársasági elnöki döntés éve }\end{array}$ & $\begin{array}{c}\text { A városi címet kapó település ek } \\
\text { száma }\end{array}$ \\
\hline 1990 & Választási év volt $-0 \mathrm{db}$ \\
\hline 1991 & $8 \mathrm{db}$ \\
\hline 1992 & $8 \mathrm{db}$ \\
\hline 1993 & $14 \mathrm{db}$ \\
\hline 1994 & Választási év volt $-0 \mathrm{db}$ \\
\hline 1995 & $6 \mathrm{db}$ \\
\hline 1996 & $6 \mathrm{db}$ \\
\hline 1997 & $12 \mathrm{db}$ \\
\hline 1998 & Választási év volt $-0 \mathrm{db}$ \\
\hline 1999 & $4 \mathrm{db}$ \\
\hline 2000 & $15 \mathrm{db}$ \\
\hline 2001 & $15 \mathrm{db}$ \\
\hline 2002 & Választási év volt $-0 \mathrm{db}$ \\
\hline 2003 & $4 \mathrm{db}$ \\
\hline 2004 & $18 \mathrm{db}$ \\
\hline 2005 & $15 \mathrm{db}$ \\
\hline 2006 & Választási év volt $-0 \mathrm{db}$ \\
\hline 2007 & $9 \mathrm{db}$ \\
\hline 2008 & $8 \mathrm{db}$ \\
\hline 2009 & $22 \mathrm{db}$ \\
\hline 2010 & Választási év volt $-0 d b$ \\
\hline 2011 & $0 \mathrm{db}$ \\
\hline 2012 & $0 \mathrm{db}$ \\
\hline 2013 & $18 \mathrm{db}$ \\
\hline 2014 & Választási év volt $-0 \mathrm{db}$ \\
\hline
\end{tabular}

2. táblázat: a várossá nyilvánitások száma 1990 után

(saját szerkesztés)

A táblázat jelzi, hogy 1990-től napjainkig 182 községi, nagyközségi jogállású település vált várossá a várossá nyilvánítási eljárás következtében. Világosan látszik, hogy az államfői döntést megalapozó támogató kormányzati előkészítő javaslatok száma az általános választásokat megelőző esztendőkre koncentrálódtak. 1993-ban közel annyi támogató döntés született, mint 1991-1992 években. 1997-ben éppen annyi, mint 1995-1996 években összesen. Az első Orbán-kormány (1998-2002) várossá nyilvánítási gyakorlatát valószínűleg erősen befolyásolta az államalapítás milleniumi évfordulója, 2000-ben és 2001-ben is egyaránt 15-15 település vált várossá. Ez a megélénkült gyakorlat fennmaradt a 2002-2010 között regnáló baloldali kormányok (Medgyessy-, első és második Gyurcsány-, Bajnai-kabinet) időszakában, amikor a 8 év során 76 település nyerte el a városi rangot. Felemásan alakult a 2010-2014 
közötti parlamenti ciklus folyamán: 2011-2012-ben egyetlen község, nagyközség sem szerzett városi jogot, viszont a választást megelőző 2013-as évben 18 db támogató döntés, s vele új város született meg [KSH, 2014b, 101-104. pp.].

\section{$\underline{\text { A városokból „kiszakadó” új községek }}$}

1990-2014 között 96 db új község alakult egy másik településből való kiválással. Ebböl a legspeciálisabb Budapest XXIII. kerületi önkormányzata, Soroksár volt, amely Budapest XX. kerület Pesterzsébetböl alakult - a parlamenti döntés 1994. december 11-én lépett hatályba, és alakult meg a föváros legfiatalabb kerületi önkormányzati egysége. A község alakítások csak roppant csekély mértékben érintették a megyei jogú városokat, mindössze 4 esetet jelez számunkra a 2014-es KSH helynévtár:

- Békéscsaba - 1 új község, Csabaszabadi (1993)

- Eger - 1 új község, Szarvaskő (2002)

- Salgótarján - 1 új község, Somoskőújfalu (2006)

- Szeged - 1 új község. Algyő (1997) [KSH, 2014b, 104-107. pp.].

Jobbára községekből - korábbi településegyesítések megszüntetése révén - alakultak meg az új községek az elmúlt 25 év során, és csak kisebb mértékben „szakadtak ki” városokból. ${ }^{110}$ Érdemes megemlíteni a Borsod megyei kisvárost, Edelényt, amelyből 4 község is kivált 1992-1994 között; a Nógrád megyei Balassagyarmatról 2, a Fejér megyei Bicskéről szintén 2 új község vált le az elmúlt 25 év során.

Az 1990-ben létrejövő demokratikus önkormányzati rendszer sokkal inkább a decentralizáció irányába hatott. Nem történtek a kisebb települések autonómiája ellen irányuló területszervezési döntések, eljárások. A fóváros és a megyei jogú városok nem annektáltak városkörnyéki településeket - pl. Nagy-Budapest létrejötte 1950-ben. Voltak bizonyos félelmek, hogy a megyei jogú városok esetleg „,ráfanyalodnak” a városkörnyéki, agglomerációs kistelepülések „bekebelezésére”"111, ám az elmúlt negyedszázadban semmilyen mértékben nem volt tapasztalható a hazai nagyvárosok (fóváros, megyei jogú városok) részéről erőszakos közjogi expanzió a városkörnyéki települések irányába - egyetlen községegyesítésre vagy városhoz csatolásra sem került sor. Sőt, jó néhány a tanácsrendszer időszakában született településegyesítés (községegyesítés, városhoz való csatolás) által „,bekebelezett” község nyerte vissza önállóságát 1990 után - ezek jó része a korábbi

\footnotetext{
${ }^{110}$ Az új települések létrejöttének kívánt némiképpen korlátot szabni az Önkormányzati törvény 1994-es módosítása, amikor az új község alapítását minimum 300 lakoshoz kapcsolták [1994. évi LXIII. tv. 32.§ (1)].

${ }^{111}$ Erre figyelmeztettek egy 1991-es szakmai tanulmányban: Bércesi-Csefkó-Horváth-Iváncsics-Pálné, 1991, 57.
} 
településegyesítések ellenére a valós fizikai távolságok miatt sosem tudott az annektáló község, város szerves részévé válni [Szigeti, 1996, 520-521. pp.].

\section{IV.4.4 A várossá nyilvánítás új rendszere 2012 után}

A 2011. áprilisban elfogadott és 2012. január 1-vel hatályba lépett Alaptörvény érdemben nem foglalkozott a településkategóriák tipizálásával. A 2011-ben elfogadott Mötv. hatályon kívül helyezte a teljes 1999-es Tetv.-t, valamint kormányrendeletre bízta a területszervezési eljárások konkrét szabályozását. Ez alapján született meg 2012-ben $a$ területszervezési eljárásról szóló 321/2012. (XI. 16.) Korm.rendelet. Fontos információ, hogy a Mötv. nem rendelkezett sem a megyei jogú várossá való, sem a járási jogú várossá nyilvánításról, ezek a kérdések jelenleg nincsenek kielégítően szabályozva.

A 321/2012. (XI. 16.) Korm.rendelet 13-15.§ tartalmazott eljárási újdonságokat - pl. a kormányhivatalok véleményezésének a beépítése -, és az 1999-es Tetv. rendelkezéseihez képest tartalmazott új nézőpontokat, de továbbra sem határozott meg konkrét számszerüsített paramétert, statisztikai indikátort. A legutóbbi parlamenti ciklus során, 2011-2012. években nem történt várossá nyilvánítás, mivel az előkészítésért felelős Belügyminisztérium egyetértve a különböző szakértői érvekkel, megvárta a Mötv. kapcsolódó passzusainak [Mötv. 96-105.§] 2013-as hatálybalépését, így kvázi eljárási moratóriumot hirdetett. 2013-ban ugyanakkor már 18 db támogató politikai döntés született a várossá nyilvánítási ügyekben.

\section{A 61/2015. (III. 24.) Korm.rendelet - mint a legfrissebb irányadó szabályozás}

A közeljövő magyarországi várospolitikai folyamataira meghatározó hatással lesz a 2015. márciusban elfogadott egyes kormányrendeleteknek a helyi önkormányzatok törvényességi felügyeletével és a területszervezési eljárással összefüggő módositásáról szóló 61/2015. (III. 24.) Korm.rendelet, amely érdemben tartalmi szempontból módosította a várossá nyilvánítás feltételeit tartalmazó 2012-es kormányrendeletet. A módosítás révén negyedszázad után először kötötte a jogalkotó objektív mérhető demográfiai, intézményi és infrastrukturális ún. „,kemény” paraméterekhez [14/A§ (1) és (2) $a-k$ )] a községből várossá történő hivatalos várossá nyilvánítási eljárás kezdeményezésének lehetőségét.

Az általános térségi szerepkör keretében meghatározásra került, hogy a városaspiráns községben dolgozók legalább 20\%-a más településről járjon be dolgozni - [321/2012. (XI. 16.) Korm. rendelet 14/A. § (1)]. 
A térségi szerepkört további funkcionális kemény” paraméterekben konkretizálták:

\section{Demográfiai paraméter}

- 5 év folyamatos létszámnövekedést követően a lakosságszám haladja meg a 10.000 föt - [321/2012. (XI. 16.) Korm. rendelet 14./A. § (2) a)].

\section{Infrastrukturális paraméter}

- A csatornázottsági arány minimum 60\%-os - [321/2012. (XI. 16.) Korm. rendelet 14./A. § (2) b)].

- Az OTÉK kormányrendelet ${ }^{112}$ szerinti teljes közmüvesítettség 60\%-os - [321/2012. (XI. 16.) Korm. rendelet 14./A. § (2) c)].

- A belterületi szilárdburkolatú utak aránya legalább 90\%-os - [321/2012. (XI. 16.) Korm. rendelet 14./A. § (2) $d)]$.

\section{Intézményi feltétel}

- Rendelkezik alapfokú és középfokú nevelési-oktatási intézménnyel - [321/2012. (XI. 16.) Korm. rendelet 14./A. § (2)e)].

- Rendelkezik rendőrkapitánysággal vagy helyi rendőrőrssel - [321/2012. (XI. 16.) Korm. rendelet 14./A. § (2)f)].

- Rendelkezik hivatalos tüzoltósággal, katasztrófavédelmi őrssel vagy önkormányzati tüzoltósággal - [321/2012. (XI. 16.) Korm. rendelet 14./A. § (2) g)].

- Rendelkezik egészségügyi alapellátással ${ }^{113}$ - [321/2012. (XI. 16.) Korm. rendelet 14./A. § (2) $i)]$.

- Rendelkezik közfinanszírozott egészségügyi szakellátást nyújtó egészségügyi szolgáltató által fenntartott, illetve müködtetett egészségügyi intézménnyel ${ }^{114}$ [321/2012. (XI. 16.) Korm. rendelet 14./A. § (2) $h$ )].

- Rendelkezik tanuszodával vagy többcélú sportcsarnokkal - [321/2012. (XI. 16.) Korm. rendelet 14./A. § (2) $j$ )].

Speciális adóügyi feltétel:

- Amennyiben a városaspiráns község bevezetett helyi iparüzési adót (HIPA), annak aránya az elbírálást megelöző évben az önkormányzat összes bevételeinek legalább 20\%-a legyen ${ }^{115}$ - [321/2012. (XI. 16.) Korm. rendelet 14./A. § (2) $k$ )].

\footnotetext{
112 253/1997. (XII. 20.) Korm.rendelet

${ }^{113}$ Háziorvosi szolgáltatás.

114 Alapesetben ez az önálló egészségügyi szakrendelést takarja.

115 A ,20\%-os HIPA-arány” teljesülése feltételezi, hogy a városaspiráns községben számottevő helyi társas és egyéni vállalkozói gazdálkodási tevékenység valósul meg.
} 
Ez a viszonylag részletes és szigorú szabályozás mindenképpen éles paradigmaváltást jelez az elmúlt 25 szabályozásához képest, amely sok szempontból „szabad utat” engedett a várossá nyilvánítási folyamatoknak, megszüntetve a funkcionális illetve a jogi városkategóriák egységét. Így válhatott 1990 után számos nagyon alacsony lakosságszámú - olykor 2-3 ezres községi jogállású kistelepülés jogi értelemben várossá. A „várossá nyilvánítás láz” különösen az országgyülési és parlamenti választást megelőző években ${ }^{116}$ tetőzött leginkább, ahogy azt láthattuk az idősoros összehasonlításból. Ugyanakkor a 2015-ös módosítás már erőteljes kritikákat is kapott, a paraméterek túlságosan szigorú meghatározásával. ${ }^{117}$ Nem meglepő, hogy a módosítás idején már hivatalos várossá nyilvánítási kérelmek közül már egy sem tudott átmenni az új feltételek közepette. ${ }^{118}$

\section{IV.5 „Nagyvárosi” agglomerációk Magyarországon}

A várospolitika nemzetközi szabályozása illetve a kapcsolódó szakirodalom természetességgel kezeli, hogy a városi címeknek többszintű rendszere alakult ki a világban. Ez a közjogi szabályozások rendszerére lefordítva azt jelenti, hogy a jogalkotó meghatározott kompetencia-, hatásköri differenciálást alkalmaz a városi jogállású települések tekintetében. Magyarországon 1990-ben a demokratizált Alkotmány valamint az Önkormányzati törvény Budapest főváros mellett megyei jogú valamint városi jogállású településekre bontotta a városokat.

Csapó Tamás a hazai vidéki nagyvárosok településmorfológiájáról szóló tanulmányában leszögezi, hogy a magyar földrajztudomány nagyvárosként kezeli a 100.000 főnél nagyobb lakosú városokat: a KSH 2014-es közigazgatási helynévtára szerint Budapest mellett ebbe a körbe tartozik Debrecen, Szeged, Miskolc, Pécs, Győr, Nyíregyháza, Kecskemét. De gyakorlatilag ehhez a körhöz sorolhatjuk Székesfehérvárt, a maga 99.060 statisztikai lakosságszámával. A következő a sorban a 77 ezres Szombathely, valamint a 73

\footnotetext{
${ }^{116} \mathrm{Az}$ alkotmányos és egyéb törvényi szabályozásoknak, valamint a politikai történéseknek köszönhetően 19902014 között ugyanazon években kerültek megtartásra az országgyülési illetve a helyi önkormányzati választások. Ezt a 2011-ben elfogadott és következö év január 1-én hatályba lépett Alaptörvény, valamint a Magyarország helyi önkormányzatairól szóló 2011. évi CLXXXIX. törvény bővítette 5 évesre a polgármesterek és az önkormányzati képviselők hivatali ciklusát.

${ }^{117}$ A témában készült kritikus hangételủ HVG cikk jelzi, hogy a jelenleg városi jogállású települések közel fele meg sem üti a 10.000 lakos kritériumát, amit immáron előír a rendelet, valamint a 90\%-os belterületi szilárd útburkolatú úthálózatot többek között a megyei jogú város Érd sem tudja jelenleg biztosítani. HVG: Felsültek a városi címben reménykedők 2015. május 31. http://hvg.hu/itthon/201522_megakadt_varossa_nyilvanitasok_varolistak ${ }_{118}$ A várossá nyilvánítás új szabályrendszeréröl szól $A$ várossá nyilvánitás kérdésköre címú tanulmánykéziratom, amely az Új Magyar Közigazgatás szakfolyóirat 2015. decemberi számában (8. évfolyam / 4. szám) fog megjelenni.
} 
ezer lakosú Szolnok. A többi megyei jogú város lakossága 70 ezer fö alatt marad, a legkevesebb lakossal pedig Tolna megye központja Szekszárd bírt a KSH szerint 33.373 fôvel. A magyarországi városszerkezet rendkívül monocentrikus - fővárosközpontú - jellegét mi sem bizonyítja, hogy a 23 kerületből álló Budapest összlakossága 1.744.665fő volt, addig a 23 megyei jogú városnak összesen 1.984.230 lakosa volt [KSH, 2014b 26-27. pp.].

A rendszerváltás időszakában lényeges kérdés volt, hogy hol fogják meghúzni a megyei jogú városi kategória demográfiai határait: volt olyan elképzelés, hogy 60 ezres legyen a limit, de így több város (Eger, Sopron, Veszprém) kimaradt volna, ez indokolta többek között az 50.000 lakos paraméter kitételt a kodifikációkor 1990-ben. [Agg, 1990, 959. pp.]. 21 város kapott megyei jogú városi önkormányzati joghatóságot 1990. december 1.-i hatállyal. Két alacsonyabb lakosságú megyeszékhely, a nógrádi Salgótarján és a Tolna megyei Szekszárd számára csak az 1994-es őszi kétharmados önkormányzati törvénymódosítás biztosított megyei jogú városi pozíciót, azáltal, hogy a megyeszékhely városok automatikusan megyei jogot kaptak. Utolsóként Budapest északnyugati agglomerációjában található Érd vált megyei jogú várossá az Országgyülés 2006-os döntése értelmében.

A rendszerváltás utáni hazai agglomerációs folyamatok bizonyos vonatkozásokban rímelnek az elmúlt évtizedek általános európai várostérségi folyamataira, ugyanakkor akadnak speciálisan Magyarországra jellemző vonások. A közép-kelet európai makroregionális megkésettség természetesen az urbanizációs folyamatoknál is megfigyelhető - a „megkésettség” hazai eszmetörténeti magyarázatának alapja Szűcs Jenő 1983-as „,Vázlat Európa három történeti régiójáról” címü nagyesszéje [Szücs, 1983]. Budapest kiemelt pozíciója mellett, legalább annyira izgalmas elméleti- és módszertani kérdés, hogy a vidéki nagyvárosoknál miként mutathatóak ki az agglomerálódás jelei, annak gazdasági, társadalmi illetve közigazgatási mozzanatai. A szakértők szerint a nyugat-magyarországi Győr környéki településhálózati folyamatok sok szempontból nagyon hasonlóak a budapesti agglomerációban az 1990-es évek első felében tapasztaltakhoz - (erőteljes szuburbanizáció: rekreációs célú kiköltözések; hétvégi telkek vásárlása, mint fontos motiváló tényező). Más városkörnyékeken viszont éppen a nagyvárosi lakásállomány rendszerváltás utáni radikális leromlása és a városi létforma költségeinek megnövekedése állt a kiköltözések mögött - pl. zárkerti ingatlanok állandó lakhellyé alakítása Kecskemét környékén, külterületén. Fontos magyarországi specifikum, hogy közép-európai összehasonlításban a hazai vidéki nagyvárosok népességkoncentrációja alatta maradt más országok mutatóihoz képest, ráadásul a vidéki szuburbanizáció elindulása egy gazdasági értelemben hanyatló időszakra (a rendszerváltás utánra) tehető egy több mint három évtizede egyébként is csökkenő népesség 
mellett. Ugyanakkor szükséges megjegyezni, amennyiben az ország teljes demográfiai folyamatait nézzük, a magyarországi urbánus térségek döntően demográfiai emelkedést mutatnak [Hardi, 2012, 15-17. pp.].

A Központi Statisztikai Hivatal 2014-ben adta ki a „Magyarország településhálózata 1. - Agglomerációk, településegyüttesek” címü kiadványát kifejezetten a hazai nagyvárosok térszervező hatásaira, vonzáskörzeti jellegére fókuszálva. Ebben a nagyváros és környéki településegyüttesek 3 csoportba kerültek a 2011-es népszámlálás adatait felhasználva, ezek a következők: 1) agglomerációk; 2) agglomerálódó térségek; 3) nagyvárosi településegyüttesek. ${ }^{119}$ A lehatárolás alapját a KSH szakértő munkatársai 10 különböző demográfiai, gazdasági, társadalmi és kifejezetten ingázási alapú statisztikai mutatóra számították. Az indikátorok közül hangsúlyosan a városkörnyéki kapcsolatokra irányult a térségi teljes lakónépességhez képest viszonyított ingázók aránya illetve a naponta a központi településre eljárók aránya.

1) Agglomeráció (4 db - Budapest; Győr; Miskolc; Pécs) - a teljes nagyváros és környéki térségre a gyarapodó népességszám a jellemző (a nagyvárosra ez nem feltétlenül igaz - lásd Budapest!), az új lakóépületek erőteljesen koncentrálódnak a vonzáskörzet településeire. A foglalkoztatás (az aktív népesség munkahelyei) alapvetően a centrumtelepülés nagyvárosra koncentrálódik. Sokirányú komplex kapcsolatrendszer müködik a települések között: gazdasági (termelői, kereskedelmi-szolgáltató) kapcsolatok; humán- (oktatás, egészségügy, művelődési, kulturális) és vonalas infrastrukturális (közlekedés, energiaellátás, közüzemi vízellátás) közszolgáltatások. Egyre látványosabb a város és városkörnyéki települések közötti összeépülések (a morfológiai városterület növekedése - $M U A)$.

2) Agglomerálódó térség (3 db - Eger; Szombathely; Zalaegerszeg) - már világosan felismerhetőek az agglomerálódás bizonyos jelei - mezőgazdasági területek átminősítése zöldmezős beruházási vagy lakóépületi területekké; a városkörnyéki települések népsűrüsége és a beépítési intenzitás, beépítési magasság növekszik -, de még nem tekinthető befejezettnek a folyamat. A települések közötti kapcsolatok dinamikusabbak, ahol jelentősebb mértékü a közművesítés.

3) Nagyvárosi településegyüttes (15 db - Békéscsaba; Debrecen; Dunaújváros; Kaposvár; Kecskemét; Nagykanizsa; Nyíregyháza; Salgótarján; Sopron; Szeged; Székesfehérvár; Szekszárd; Szolnok; Tatabánya; Veszprém) - a kimutatható klasszikus agglomerációs

\footnotetext{
${ }^{119}$ A kiadvány jellegéből fakadóan nem foglalkozik a Balaton-parti agglomerálódó térséggel és településeivel, amelyre az irányadó jogszabály a 2000. évi CXII. tv.
} 
jellegű területi összefonódás (morfológiai városterület; ingázási övezet) csekélyebb mértékü. Bizonyos városkörnyéki települések jobban kapcsolódnak a nagyvároshoz, más települések kevésbé [KSH, 2014a 6-12. pp.].

Ezt megelőzően a Központi Statisztikai Hivatal utoljára 2003-ban mérte fel a hazai urbánus térségeket teljes körủen, az akkori adatokra többször is utal a 2014-es kiadvány. A legfontosabb komparatív információhalmazt az egyes nagyvárosi térségek közvetlen vonzáskörzetéhez számított települések számában történt változások mutatják: ez az elmúlt évtized szuburbanizációs dinamizmusait jelzi, hol és hány új település került a nagyvárosok közvetlen vonzáskörzetébe. Több vidéki agglomerációnál jelentős a tapasztalt növekedés: Győr esetében közel 2,5-szeres (2003-ban 29 db; 2014-ben 68 db település), Miskolcnál majd' 3-szoros (2003-ban $13 \mathrm{db}$; 2014-ben 36 db település), de a dél-dunántúli Pécsnél is 2szeres (2003-ban 21 db; 2014-ben 41 db városkörnyéki település) településszám-növekedéssel számolnak a szakértők. ${ }^{120}$ A három agglomerálódó várostérség közül Szombathely és Zalaegerszeg esetében látványos a város és környéki kapcsolatok intenzívebbé válása, s vele a közvetlen városkörnyékhez sorolt települések számának megnövekedése - Szombathely (2003-ban 31 db; 2014-ben 52 db település); Zalaegerszeg (2003-ban 29 db; 2014-ben 51 db település).

A szuburbanizáció legkevésbé integrált szakaszában lévő 15 vizsgált nagyvárosi településegyüttesnél eleve kisebb számú városkörnyéki településről beszélhetünk, mint a másik két kategóriánál. Az elmúlt bő évtizedben a Fejér megyei (és közép-dunántúli regionális társközpont) Székesfehérvár városkörnyéki vonzáskörzetét tartják a leginkább expanzívnak a KSH kutatói - 2003-ban még csak 13 települést, 2014-ben viszont már 35 környező kisebb települést számítottak a székesfehérvári településegyüttes részének. A 2003as felméréshez képest új nagyvárosi településegyüttesként került a kutatásba a Dunaújváros és Nagykanizsa megyei jogú városok (de nem megyeszékhelyek) és környékük vizsgálata. Fontos megjegyezni, hogy Érd és Hódmezővásárhely megyei jogú városok nem kerültek bele a vizsgálatba: a dél-alföldi város térszerkezet (beépítettség; népsürüség; morfológiai szerkezet) szempontjából sokkal inkább, rendelkezik „óriásközségi” sajátosságokkal; Érd pedig, mint egykori agglomerációs ,alvótelepülés” maga is része Budapest vonzáskörzetének.

\footnotetext{
${ }^{120}$ Budapest esetében a már jó ideje 81 agglomerációs övezeti városkörnyéki településszám megmaradt 2003-ról 2014-re - Magyarország településhálózata 1. - Agglomerációk, településegyütesek (Központi Statisztikai Hivatal, Budapest, 2014) 10. pp.
} 


\section{IV.5.1 Agglomerációs folyamatok vidéken}

Amíg a fővárosi agglomerációban az elmúlt negyedszázad leginkább egyedi és nyomon követhető urbanizációs folyamata mutatható ki, a direkt és pregnáns mértékü szuburbanizációtól a lassan már statisztikailag is kimutatható reurbanizációs szakaszig bezárólag, addig a megyei jogú városok térségében jobbára még mindig csak szuburbanizáció meglehetősen eltérő mértékü és intenzitású szakasza mutatható ki. Természetesen szükséges tekintettel lenni az egyes statisztikai-tervezési régiók - mint tágabb szubnacionális környezet migrációs folyamataira, mint például Észak-Magyarország és Észak-Alföld idestova negyedszázada meghatározó népességcsökkenésére; az ezredforduló, de különösen az elmúlt évek pozitív vándorlási egyenlegére a nyugat-dunántúli régióban illetve a korábbi többlet helyett 2009 után népességcsökkenésbe váltó Közép-Dunántúl demográfiai viszonyaira. Budapest és Pest megye migrációs dinamizmusához képest a vidéki régiók vándorlási mutatói mérsékeltebbek maradtak 1990 után. Településtípust tekintve a kistelepüléseken, községekben már az 1990-es évek eleje óta, a megyei jogú városokban - ugyan kisebb mértékben -, de 1998 óta tapasztalható pozitív vándorlási többlet. Bár a vidéki Magyarország belső migrációs folyamatainak ütemét tekintve az elmúlt negyedszázadban végig alatta maradt a budapesti, s vele a központi régió folyamatainak [Bálint-Gödri, 2015, 180. pp.].

A 2014-es agglomerációs KSH kiadványban a szakértők a 21 vidéki nagyvárosi térség közvetlen vonzáskörzetéhez összesen 480 települést, az ország területének $15 \%$-át és megközelítőleg 2,7 millió lakost számítottak. A tanulmány leszögezi, hogy 2003-2014 időszakban a vidéki nagyvárosi térségekhez kapcsolódó települések száma közel megduplázódott, az agglomerációs területek közel másfélszeresére növekedtek, az össznépességszám pedig egytizeddel gyarapodott. A települések számát tekintve 14-szeres különbséget is kimutattak $\mathrm{KSH}$ munkatársai a vizsgált vidéki várostérségek között (Dunaújváros - 5 település; Győr - 68 település). A statisztikai hivatal munkatársai különböző demográfiai, gazdasági és társadalmi mutatók révén igyekeztek megformálni a hazai vidéki agglomerációk sajátos karakterisztikáját, egyben összevetve és differenciálva napjaink átlagos vidéki magyarországi indikátoraival. Bizonyos mutatóknál csak kisebb különbségek tapasztalhatóak. Az alábbiak esetében azonban jóval látványosabb az eltérés:

- a vonzáskörzet településeiről munkaügyben a nagyvárosba ingázók aránya (vidéki nagyvárosi térség 66\% > 40\%-os vidéki átlag); 
- 1000 före jutó vállalkozások száma (vidéki nagyvárosi térség $75 \mathrm{db}>61 \mathrm{db}$ vidéki átlag).

- Egy adófizetőre jutó, SZJA-alapot képező jövedelem (vidéki nagyvárosi térség 1.873.000 Ft $>$ 1.735.000 Ft vidéki átlag). ${ }^{121}$

Ugyanakkor a KSH agglomerációs kiadványa igyekszik érzékletesen bemutatni a hazai nagyvárosi térségek sokszínüségét. A KSH által lehatárolt agglomerációk, településegyüttesek területi különbségei 10-szeres különbségeket is jeleznek: amíg a legnagyobb területü vidéki városkörnyék a békéscsabai 1044 km2-es területi kiterjedéssel, addig a legkisebb a 235 km2-es salgótarjáni településegyüttes. Akár látványos demográfiai különbségek adódhatnak abban a tekintetben, hogy mennyire koncentrálódik a teljes agglomerációs térség a központi településre (megyei jogú város): magasan koncentrált Kecskemét, Nyíregyháza valamint a dél-dunántúli régióközpont Pécs várostérségek, itt a teljes agglomerációs lakosság nyolctizede (80\%) tömörül a megyei jogú városokban, máshol ez az arány $60 \%$ alatt marad. A magas népességkoncentráltság kialakulhat kevés településből álló agglomerációban, településegyüttesben (Nyíregyháza), de ugyanúgy megfigyelhető az aprófalvas pécsi agglomerációban. Az alacsonyabb szinten koncentrált népességű nagyvárosi térség megtalálható széttagolt, de nem aprófalvas agglomerációk esetében, mint amilyen Székesfehérvár vagy Győr, és persze alacsonyabb településszámú térségekben is - ilyen Békéscsaba és környéke. 2001-2013 között csak néhány vizsgált vidéki nagyvárosi térségben növekedett a centrumtelepülés népességszáma (Szeged, Győr, Veszprém, Sopron, Zalaegerszeg, Kaposvár, Kecskemét), tehát általánosságban elmondható, hogy a nagyvárosi térségekben csökken a centrumtelepülésre vonatkozó népességkoncentráció, de ezzel párhuzamosan növekszik a nagyvárosokhoz képest az agglomerációk, városkörnyéki vonzáskörzetek (szuburbán településgyürük) lakossága vidéken és Budapesten is [KSH, 2014a 21-22. pp.].

A demográfiai mutatók mellett a különböző gazdasági indikátoroknál is megfigyelhetőek bizonyos szembeötlő eltérések, mint például az új lakások építése - amíg a soproni településegyüttes 2011-es lakásállományának 18\% épült 2001 után, addig Salgótarján és városkörnyéke esetében ez az arány mindössze 1,8\%. A 15 évnél idősebb foglalkoztatottak agglomerációs térségekben mért arányai erősen igazodnak a magyar gazdaságban egyébként is tapasztalható kelet-nyugati különbségekhez: Sopron, Szombathely, Veszprém,

\footnotetext{
121 Magyarország településhálózata 1. - Agglomerációk, településegyütesek (Központi Statisztikai Hivatal, Budapest, 2014) 15-19. pp.
} 
Zalaegerszeg, Győr foglalkoztatotti rátája átlagosan 8\%-al magasabb, mint a keleti megyei jogú városok (Miskolc, Békéscsaba, Salgótarján). Hasonló a tendencia a jövedelmi viszonyok valamint a vállalkozások száma tekintetében is: az 1 adófizetőre jutó SZJA-alapot képező jövedelem esetében a két agglomerációs szélsőérték különbség 2012-ben 447.000 Ft volt a győri agglomeráció javára a békéscsabai településegyüttes ellenében. A vállalkozói aktivitás terén a leggyengébben a Salgótarján és környéke teljesített (2013-ban évben 1000 före jutó 58 vállalkozás számával, összességében 19\%-val csökkent 2001-hez képest). Nagyon eltérő az egyes nagyváros térségekben, hogy települési szinten hogyan változott az ezredforduló óta a magánvállalkozások száma és aktivitása - pl. Debrecen és vonzáskörzetének valamennyi településén növekedett a vállalkozások száma, addig ez Salgótarján, Békéscsaba vagy Szolnok térségében csak a települések alig 50\%-ra volt ez igaz.

A megyei jogú várásokra jellemző aktuális ingázási adatok terén tapasztalt differenciák szintén erősítik a hazai agglomerációkra, nagyvárosi településegyüttesekre jellemző heterogén összképet. Az alföldi megyékben eleve kisebb mértékü az aktív korú foglalkoztatottak munkahelyi ingázása, mint a tagoltabb településszerkezetü nyugatmagyarországi agglomerációk esetében. Magas 50\% feletti, kifejezetten a megyei jogú városba való munkahelyi alapú ingázás valósult meg az egri, a kaposvári, a zalaegerszegi vagy a szombathelyi várostérségeknél; miközben a többközpontú békéscsabai településegyüttes (Bélés, Gyula, Sarkad) esetében ez csak 18\% volt. Itt fontos tényezö, hogy a központi települések milyen munkaerő-megtartó és generáló képességgel bírnak a várostérségek egészét illetően [KSH, 2014a 23-24. pp.].

\section{IV.5.2 Budapest és agglomerációja}

Kádár János hírhedtté vált mondása: „Ha rend van Budapesten, rend van az országban” [Hajdú, 2007, 173. pp.] - remekül szimbolizálja a magyarországi nagypolitika mondhatni már történelmi viszonyulását az ország fővárosához. Budapest mindig is kiemelt szerepet töltött be az ország település-hálózati rendszerében lakosságának számaránya, a gazdasági teljesítménye valamint a politikai és állami intézményrendszer müködtetésében. A Budapest köré szerveződő agglomerációs településgyürü az ország legkiterjedtebb és legnagyobb népességü szuburbán hálózata - Budapesten kívül további 80 település tartozik a hivatalosan is meghatározott Budapesti agglomerációhoz (így a fóvárossal együtt összesen 81 település alkotja az ország legkiterjedtebb nagyvárosi agglomerációs térségét). 
Budapest területi-történeti expanziójának hátterében sokáig egyoldalú - időnként erőszakosnak is tekinthető - közigazgatási-, helyhatósági terjeszkedés, konkrétan az annexió állt. Kezdődött a kiegyezéskori meghatározó városegyesüléssel - Pest, Buda és Óbuda 1873as fúziója teremtette meg a későbbi világváros alapjait. A következő meghatározó etap már a kommunista hatalomátvétel után, a 23 föváros-környéki település (7 önálló város és 16 falu) „,beolvasztása” volt, így hozva létre a mai értelemben vett Nagy-Budapestet [1949. évi XXVI. tv.]. A rendszerváltás után a fővárost főpolgármesterként vezető Demszky Gábor még egy 1993-as nagyvárosi közigazgatási konferencián a rendszerváltás utáni időszak fővárosi igazgatási problémáit egészen az 1949-es annexiótól eredeztette. Budapest 20 évig hivatalban lévő (1990-2010) főpolgármestere szerint az 1949-ben Budapesthez kerülő korábban autonóm települések problémái - különösen a belső magterületekhez való elmaradott állapot kezelésére nem álltak szükséges eszközök a főváros rendelkezésére. Az 1949-ben erőszakosan „elnyelt” egykori agglomerációs települések jelentős része akár még napjainkig is jobbára kisvárosias, falusias jellegüek, miközben a Budapest környékén 1990 után meghatározó „kivándorlás” (szuburbanizáció) dinamizált egy új agglomerációs folyamatot [Demszky, 1993, 488. pp.].

Bálint Lajos és Gödri Irén már hivatkozott 2015-ben megjelent, a rendszerváltás utáni demográfiai folyamatokat összegző tanulmányuk szerint az 1990-es, de még inkább a 2000-es években a magyarországi belföldi vándorlás a központi régió (a fóváros és Pest megye), azon belül elsősorban Budapest felé irányult - a 2007. év volt a leginkább domináns, amikor a régió egy év alatt 15.000 fős többlettel zárt. Ugyanakkor a közép-magyarországi statisztikaitervezési régión belül Budapestet 1991 és 2008 között egyértelműen negatív vándorlási egyenleg jellemezte (minden évben több volt a főleg az agglomerációs térségbe kiköltöző, mint a fővárosba beköltöző lakos), 2009-től azonban Budapestet ismét vándorlási többlet jellemzi. Szintén a fővároshoz köthető belső migrációs specifikum, hogy a rendszerváltástól jó másfél évtizedig az általános vándorlási távolság mutatója mérsékelten csökkent, azonban 2006 után különösen Budapest és a távolabbi vidéki, kelet-magyarországi megyék közötti aszimmetrikus migrációs kapcsolatok ismét intenzívebbé váltak. A Bálint-Gödri tanulmány szerint a régiók közötti tekintetben a közép-magyarországi régió masszív vándorlási többlete, a régión belül viszont a Budapestről az agglomerációba (annak is elsősorban a belső gyürüjébe) tartó migráció volt a domináns a rendszerváltástól 2008-ig. ${ }^{122}$ A főváros népessége 2000-ben csökkent legnagyobb mértékben, 18.000 fővel, az elvándorlók túlnyomó része a környező agglomerációs településeken jelent meg. A 2010-es években ugyanakkor Budapest

1222008 egyben a pénzügyi- és gazdasági világválság kirobbanásának az éve is volt, és ez a lakáspiac tekintetében éreztette hatását. 
mérsékelt népességnövekedése figyelhető meg, 2014-ben már 5400 fős migrációs nyereséget mutattak a statisztikák - ennek alapját több mint két évtized után az agglomerációs települések fővárosi irányú népesség-kibocsátó tevékenysége biztosította. Amíg ezeknek a településeknek a lakossága a fővárosból történt kiköltözésnek köszönhetően meredeken növekedett a rendszerváltást követően (eklatáns példa Érd), addig a 2010-es évekre Pest megye (s vele Budapest agglomerációja) bevándorlási többletét már nem a főváros, hanem a vidéki megyék biztosítják. Empirikus tapasztalat, hogy egyre más megyéből felköltöző vidéki család vásárol lakóingatlant Budapest környékén, miközben dolgozni Budapestre jár be. A fővárosi agglomerációs települések expanzióját az országos politika is „elismerte”, így Pest megye agglomerációs övezetében a legjelentősebb térségi várossá nyilvánítási folyamat zajlott le a rendszerváltás utáni 20-25 évben. A várossá nyilvánítás területi statisztikái jelzik számunkra, hogy Pest megyében 1990-től napjainkig 41 db várossá nyilvánítási folyamat történt, ebből közvetlen a fővárosi agglomeráció területén 30 olyan település található, amely az elmúlt negyedszázad során szerezte meg a városi címet - bizonyítva Budapest közelségének egyik fontos közjogi hatását [Zongor, 2015, 394-399. pp.].

Napjainkra már a statisztikai mutatók is reurbanizációt jeleznek Budapest, különösen bizonyos belső kerületeknél - így a 2008-ban megtört „szuburbanizációs lendület” még várat magára [Bálint-Gödri, 2015, 171-172.; 178-183. pp.]. A régión kívüli migrációs folyamatok mögötti átfogó gazdasági és társadalmi eredők (gazdasági világválság hatásai; kelet-nyugat irányú migráció etc.) mellett a fővárosi agglomeráció belső konfliktusai, problémagócai állnak. Ilyen az elmúlt évek kibontakozó reurbanizációs trendje mögötti tényezők, mint a vonzáskörzet közlekedési nehézségei (a nagyarányú napi szintű ingázás miatti mindennapos közlekedési dugók Budapest bevezető útjain) vagy a megnövekedett ingatlanárak az elit szuburbán településeken. Másrészt az elmúlt egy-másfél évtized során Budapest Európa egyik legvonzóbb kulturális és szórakoztató centrumává vált, amit különböző városrekonstrukciós beruházások is tovább erősítettek, ezek miatt a fővárosban való visszaköltözés lehetősége egyre vonzóbb a főváros körüli szuburbán térben élő tizenévesek- és fiatal felnőttek számára.

A Budapest és agglomerációjára vonatkozó statisztikák konstans jellegzetessége, hogy jóval az országos átlag feletti kedvező paraméterek jellemzik. Az országos átlagnál magasabb a fővárosi agglomerációban mért iskolázottsági szint, különösen a 25 év feletti felsőfokú végzettségűek (diplomások) tekintetében: országos átlag 19\%; fővárosi agglomerációs átlag 24\%; Budapest 34\%. Természetesen a foglalkoztatottsági és munkanélküliségi adatok is az országosnál kedvezőbben alakultak. Az országban működő vállalkozások 37\%-a koncentrálódott a főváros és agglomerációs térségére. A gazdasági szempontból kivételezett 
térségi pozíciót talán az egy adófizetőre jutó, SZJA-alapot képező 2012. évi jövedelem szimbolizálja leginkább: Budapesten 2,5 millió Ft, az agglomerációban átlagosan 2,3 millió Ft volt a vizsgált esztendőben - csak emlékeztető gyanánt, ez az adat a vidéki nagyvárosi térségeknél átlagosan 1.873.000 Ft/fö volt. A közlekedéshálózat tekintetében a vidéki urbánus térségekhez képest szintén kedvezőbb adottságokkal rendelkezik Budapest szuburbán térsége - ennek legfontosabb eleme a Budapestet sugarasan körbeölelő M0 autóút, amely az agglomerációs települések bekapcsolása mellett az ország autópályáiról érkező átmenő forgalom nagy részét is sikeresen kezelni képes a föváros tehermentesítésével. A közösségi közlekedés agglomerációs aspektusait figyelembe véve mindössze 8 olyan település volt, amelyre a Budapesti Közlekedési Vállalat (BKV) jármüvei nem közlekedtek a 2014-es KSH agglomerációs kiadvány szerint [KSH, 2014a 32-39. pp.].

Ugyanakkor bizonyos indikátorok esetében látványos a differencia adódik Budapest és a szuburbán övezet között: a népesség korösszetétele jóval kedvezőbb az agglomerációban (a fövárosban másfélszer annyi 65 évesnél idősebb lakos van, mint gyermekkorú; az agglomerációban pedig egyértelmüen magasabb volt a gyermekek aránya az időskorúaknál igazolva a fiatal gyermekes családok nagyarányú kitelepülését Budapest környékére). Szintén árulkodóak az ezredforduló utáni lakásépítési adatok - az országos átlag felett Budapesten 2001-2011 között egytizedével (kb. 10\%), az agglomerációban egynegyedével (kb. 25\%) bővült a lakásállomány [KSH, 2014a 34-39. pp.].

Rendkívül tanulságosak a szuburbán települések saját intézményrendszeréről szóló információk - KSH által vizsgált köz- és magánszolgáltatás agglomerációs intézményi elhelyezése terén, 3 csoportot képezhetünk:

1) Az agglomerációs települések túlnyomó többségében megtalálható intézményi szolgáltatás: óvoda; általános iskola; postai szolgáltatás; egészségügyi alapellátás (házirorvos / gyermek háziorvos / fogászat); banki szolgáltatás az agglomerációs települések háromnegyedében.

2) A fővárosi agglomeráció bizonyos típusú - elsősorban városok, járásszékhely városok - településein megtalálható intézményi szolgáltatás: bölcsőde - ezek 3/4 része a fővárosban található; középiskola - a települések négytizedének területén található, de az agglomerációban élő középiskolások 84\%-a budapesti intézménybe járt; okmányirodai szolgáltatás kizárólag a 10 járásközpontban müködött). 
3) Túlnyomórészt csak a fővárosban megtalálható szolgáltatás: felsőoktatás - ugyanakkor 4 olyan agglomerációs település (Gödöllö, Piliscsaba, Pécel, Vác) is van, ahol felsőoktatási BA vagy MA képzés folyt 2014-ben [KSH, 2014a 39. pp.]. ${ }^{123}$

\section{IV.5.3 A fővárosi agglomerációs „konfliktuskonténer”}

Perger Éva a nagyvárosi agglomerációs közigazgatás hazai kutatója az 1990-es évek közepén Budapest és agglomerációjának állapotát az 1960-1970-es évek fejlett nyugati országok agglomerációs övezeteihez hasonlította, ahol már egyre feszítőbbé vált az ellentmondás a szuburbanizációs szakasz városszerkezete (morfológiai és funkcionálisingázási övezet) és a széttagolt önkormányzati-igazgatási struktúra között. Már a főváros belső kettős önkormányzati rendszere (Fővárosi Önkormányzat, kerületi önkormányzatok) is némiképp anakronisztikusnak számított a nemzetközi összehasonlításban „szupererős” alsószintű kerületekkel valamint a gyengébb kompetenciákkal bíró fővárosi szinttel. Eközben megmaradt a városkörnyéki agglomerációs települések éles elkülönülése. Már a rendszerváltás előtt elkezdődő, de 1990-től felgyorsuló fővárosi szuburbanizáció némiképp más társadalmi előjelekkel zajlott le, mint Nyugat-Európában: a késő Kádár-korszakban a magas jövedelmü fővárosi értelmiségi és vállalkozó rétegek nem a közigazgatásilag elkülönülő városkörnyéki településekre, hanem sokkal inkább a budai illetve külső-pesti „elővárosi” zöldövezeti kerületekbe áramlottak ki, így a szuburbán települések új lakosai sokkal inkább a vidékről a főváros irányába törekvő családok lettek, akik kisebb érdekérvényesítő képességgel bírtak. Így az agglomerációban jobbára alacsony szolgáltatási színvonalú és infrastruktúrájú „alvóvárosok” rendszere alakult ki. Eme folyamat jelentősen árnyalódott 1990 után, mivel a fővárosi elitek ,kitelepülése” egyrészt kiterjedt most már bizonyos agglomerációs településekre, másrészt a főváros (s vele a központi régió) gazdasági struktúrája is jelentősen átalakult - az agglomeráció Budapesthez közeli településgyürüje vált a különböző multinacionális nagyvállalatok kedvelt telephelyévé (lásd Budaörs példáját!), javult a városkörnyék települési infrastruktúrája és közszolgáltatási színvonala. Mindezzel párhuzamosan bizonyos belső kerületek (VII., VIII., IX. kerület) épületállománya, infrastruktúrája jelentősen leromlott - szlömösödés etc. - különösen az 1990-es években, amely folyamatot jelentős társadalmi szegregáció kísért. Budapest és agglomerációja

${ }^{123}$ A különböző szolgáltatások vizsgálatánál nem a feladatot ellátó (köz- vagy magánszféra; állam vagy önkormányzat) intézmény, hanem az adott szolgáltatás megvalósulásának a helyszíne volt a meghatározó. Továbbá jól láthatóak a szolgáltatási spill-over tekintetében kialakult különbségek, agglomerációs jellegzetességek. 
tekintetében egyszerre érvényesült az elmúlt negyedszázad folyamán a szuburbanizáció, valamint bizonyos belső szuburbán területeken a dezurbanizáció városfejlődési folyamata. Ráadásul a fővárosi agglomeráció fejlődését belső ellentmondások és területi egyenlőtlenségek kísérték - kedvezőbb helyzetü nyugati, és kedvezőtlenebb keleti agglomerációs települések, térségek [Perger, 1994, 746-748. pp.].

A meglehetősen heterogén fővárosi gazdasági és társadalmi folyamatokat egy rendkívül diffúz és széttagolt közigazgatási szisztéma nehezítette 1990 után. Amíg nyugaton a nagyvárosi kormányzás fókusza már évtizedek óta a budapestihez képest jóval egységesebb és hatékonyabb belső önkormányzati-igazgatási struktúrával bíró nagyváros és szuburbán települések közötti harmonikus együttmüködés, elsősorban kétszintü föderatív típusú kooperációk (agglomerációs tanácsok) irányába fejlődött. Addig a magyar főváros esetében a nagyváros versus agglomeráció viszonyrendszert pluszban megterhelte a föváros versus fövárosi kerületek „konfliktuskonténer”. A települési önkormányzatok (községektől a nagyvárosokig) az 1990-ben megszerzett autonómiájukat sokszor éppen egymás ellen igyekeztek használni, ez különösen a rendszerváltás évtizedében jelentősen gyengítette a helyi önkormányzatok közötti kooperációs attitüdöket és motivációkat - ennek részleteiről lásd később!

Ez a tendencia a kisközségek mellett tetten érhető volt a nagyvárosi térségekben, így a főváros agglomerációs övezetében. Az ambivalens viszonyt jelzi, hogy Budapest vezetői többször nyilvánosan is hivatkoztak, hogy a főváros a saját közigazgatási területén úgy biztosított közszolgáltatásokat (oktatás, egészségügyügy, kultúra) az agglomeráció lakossága számára, hogy ahhoz érdemben az agglomerációs önkormányzatok arányosan hozzájárulnának. A szuburbán települések ugyanakkor azt rótták fel, hogy a főváros visszaél előnyös helyzetével valamint hatalmi nyomásgyakorló pozícióival az országos politikai döntéshozók irányába. A helyzetet tovább árnyalta, hogy az agglomerációs települések lakossága számára bizonyos törvény által meghatározott térségi intézményi szolgáltatásokat (középfokú oktatás, kórházak, szociális és kulturális intézetek) a fővárostól de iure egyértelműen elkülönített Pest megyei önkormányzat biztosította, miközben számos szolgáltatást („,közjószágot”) a szuburbán térség lakói a fővárosi intézményeken keresztül vették igénybe - pl. könyvtári szolgáltatás. Amíg Európában az ezredfordulóra az európai nagyvárosok többsége igyekezett strukturált együttmüködést (kétszintü föderatív tanácsok etc.) kialakítani az agglomerációs településekkel való együttmüködéshez, addig Budapest és a környező települések között ez mesterséges és szervetlen maradt: habár az agglomerációs települések funkcionálisan (gazdasági, ingázási, magán- és közszolgáltatási spill-over) 
egyértelműen a fövároshoz kötődnek már hosszú évtizedek óta, közigazgatásilag hangsúlyosan Pest megye részei maradtak. Már az 1990-es években nyilvánvalóvá vált, hogy a Budapest agglomerációjában tapasztalt fejlettségbeli különbségek láthatóan nagyobbak, széttartóbbak, mint Közép-Európa más kiemelkedő nagyvárosai, országos központjai (Bécs, Prága, Pozsony) esetében. Rendkívül tanulságos az agglomerációs gyürü belső fejlettségbeli megoszlása, a Budapesthez közelebb eső agglomerációs belső gyürüs települések folyamatosan zárkóznak fel (sőt bizonyos települések - Budaörs, Budakeszi, Telki etc. - már Budapestet is meghaladják), addig a külső gyürü önkormányzatainál ez már közel sincs így [Ágh, 2005, 5-15. pp; Perger 2004, 220-231. pp.].

A fővárosi agglomerációban a különböző integrációs kooperatív önkormányzati kezdeményezések, kísérletek, sikerek vagy kudarcok bemutatását lásd „Az intergrációs kisérletek a nagyvárosi térségekben 1990 után” címü fejezetben! 


\section{Települési önkormányzati kapcsolatok a magyarországi nagyvárosi térségekben}

A magyarországi városhálózati folyamatok kapcsán láthatóvá vált, hogy az egyébként már három és fél évtizede csökkenő lakosságú Magyarországon a nagyvárosok (Budapest és a néhány valóban regionális centrumként funkcionáló megyei jogú város) illetve közvetlen városkörnyéki térségeik gazdasági és társadalmi paraméterek tekintetében látványosan kiemelkednek az országos átlagból. Habár az elmúlt negyedszázad tekintetében akár számottevőnek is tekinthetjük a Budapestről valamint közvetlenül a nagyvárosokból való kiköltözés mértékét, de ha a teljes nagyvárosi agglomerációs térségeket (nagyvárosok és városkörnyékük) nézzük, akkor a népességmozgás mindenképpen pozitív: a szuburbán térségek még mindig vonzzák a nagyvárosok, de a rurális térségek mobilis családjait. A világban megfigyelhető közgazdasági jelenség, hogy a nagyvárosok kiemelkedve környezetükből, egy sor a saját közigazgatási, de a közvetlen vonzáskörzet (nagyvárosi kistérségen) határain akár lényegesen túlmutató szerepkörrel, funkciókkal - vagyis spill-over hatással és területi kiterjedéssel rendelkeznek. Ezeket a hatásokat széles körben, a klasszikus helyi közfeladatokon túl olyan speciális posztmodern funkciókra is kiterjeszthetjük, mint a gazdaságfejlesztés, a munkahelyteremtés, az innováció-politika valamint általában a versenyképesség-növelés.

A hatékony nagyváros térségi kormányzás fontos elméleti kérdése, hogy a települési alapfeladatok milyen mértékben telepíthetők egyáltalán a településnél szélesebb, esetünkben az agglomerációs térségi szintre - példának okáért a már említett IDEA munkacsoport egy 2003-as szakértői anyaga a települési önkormányzati alapfeladatok rendszerét nem kívánta megbolygatni ilyen értelemben. [Bekényi-Bércesi-Németh, 2003, 200-203. pp.]. Az urbánus várostérségek esetében fontos vizsgálati szempont, hogy a helyi alapfeladatok ellátása a gyakorlatban milyen mértékben koncentrálódik a települési vagy a területi alsó-közép szinthez (kistérség/járás), és milyen feladatok kerülnek kifejezetten a teljes nagyvárosi agglomerációs feladatellátáshoz. Az urbanisták közmegegyezése szerint mára a várostérségi közlekedés, tömegközlekedés vagy a térségi területfejlesztés kifejezetten agglomerációs térségi feladattá vált. Ugyanakkor a helyi közfeladatoknak, közszolgáltatásoknak kialakult egy láthatóan alakulóban lévő szegmense, amely intézményi elhelyezése vitatható, pro és kontra felhozható érvekkel - pl. ingatlangazdálkodás, energia-beszerzés (távhőellátás). A 
következő fejezetek éppen arról fognak szólni, hogy Magyarországon milyen hagyományai, előképei vannak a nagyváros térségi agglomerációs szintủ települési kooperációknak, és egyáltalán elképzelhető, $\mathrm{s}$ ha igen milyen elméleti alapokon az egységes agglomerációs szintü köz-feladatellátás az érintett helyi önkormányzatok intézményi együttmüködésén.

\section{V.1 Településközi kooperációk és közös tanácsok 1990 előtt}

A rendszerváltás utáni települési és városkörnyéki kapcsolatok elemzésénél érdemes számba venni a tanácsrendszer időszakának fontosabb területszervezési folyamatait. Ennek különösen két dimenziója fontos, az 1) a települések sorsát - s így a települések számát alapjaiban befolyásoló területszervezési döntések, mint az új község kialakítása; a községegyesítés; község városhoz való csatolása (annektálás) és a várossá nyilvánítás. Szigeti Ernő 1996-os tanulmányában összegezte a tanácsrendszer időszakának ilyen irányú intézkedéseit, különböző időszakokra bontva a fontosabb statisztikai mutatókat:

- 1945-1960 között: 169 új község (köztük sok ún. tanyaközség az Alföldön) alakult; 136 községegyesítés és városhoz csatolás történt.

- 1960-1990: több mint 1700 községegyesítés és városhoz csatolás, amely eredményeként az önálló települések száma 230-al csökkent, és mindössze 19 új község alakult a három évtized során.

A Kádár-korszak meghatározó területszervezési folyamatának a településegyesítések (községegyesítések, községek városokhoz való csatolása) számítottak, amelynek fontos oka volt, hogy a „harmadik tanácstörvény” [1971. évi I. törvény], valamint annak végrehajtási rendelete [11/1971. (III. 31.) Korm.rendelet] a közös tanácsok létrehozásának ösztönzése mellett a községegyesítés feltételeit jelentősen könnyítette [Szigeti, 1996, 517-520. pp.].

A másik 2) dimenzió kifejezetten a tanácsszervezési döntésekre koncentrált, nevezetesen, hogy az egyébként önálló települések milyen tanácsi szisztémában (önálló tanács, közös tanács) müködtek a szocialista egypártrendszer időszakában. A tanácsrendszer bevezetésének évében 1950-ben - hasonlóan az 1990-es logikához - gyakorlatilag a települési szintre méretezett tanácsrendszert alakítottak ki Magyarországon. Az „egy település egy tanács" elv keretében integrációs jellegü tanácsszervezést csak a 300 lakosnál kisebb törpefalvak esetében valósítottak meg - ezeket átcsatolták népesebb tanácsokhoz. A fragmentált helyi tanácsszervezés logikája a gazdaság, a közigazgatás és a társadalom eröszakos államszocialista átalakításának törekvéséből fakadt: a változásokat biztosítani a 
legapróbb településekig bezárólag. Az 1960-as évek elején elindított tanácsi összevonások (közös tanácsok) hátterében viszont már az 1959-1960-ban végrehajtott erőszakos „szövetkezesítési” folyamat állt: a magánkézen maradt földtulajdonok mezőgazdasági termelőszövetkezetekbe való bevonása, és a falvanként addig jobbára tagolt agrárüzemek egyesítésének hatékony igazgatási hátterét igyekeztek biztosítani a kistelepülési tanácsok összevonása révén, ugyanakkor ezt a közvetlen politikai okot az 1960-as évek végére már előszeretettel magyarázták - az időközben nyugaton is divatossá - vált üzemgazdaságossági indokkal.

\section{$\underline{\text { A folyamat a következő statisztikai adatokkal értékelhető: }}$}

- A tanácsrendszer bevezetésének időszakában [1950. évi I. tv.] Magyarországon 2857 önálló községi tanács és 170 községi közös tanács volt - ez utóbbi 360 községet tömörített magában.

- Érdemben a tanácsrendszer első évtizedében ezek a számarányok alig változtak: a községi tanácsok száma 1960-ban 3024 volt - ebből 2857 önálló községi tanács és 167 közös tanács.

- 1970-ben összesen már csak 1875 községi tanács - 1249 önálló és 626 községi közös tanács.

- 1986-ban már csak 1363 községi tanács müködött, amelyböl már 701 közös tanács volt, 2271 kisebb-nagyobb települést foglalva magába.

- Közvetlenül az 1990-es önkormányzati választást megelőzően az egypártrendszer utolsó éveiben köszönhetően a dekoncentrációs folyamatnak már 1627 tanács volt, amelyből 632 közös tanács, ebből következően a községek kétharmada volt már része valamilyen közös tanácsnak. Ebböl a koncentrált tanácsi szisztémából alakult ki 1990 végére egy sokkal decentralizáltabb demokratikus önkormányzati rendszer (3092 önálló települési önkormányzat, amelyből 2915 községi helyhatóság) [Verebélyi, 1993, 193. pp.; Hencz, 1973, 568. pp.; Szigeti 1994, 610-611. pp.; Fürcht, 2009, 44. pp.].

Korábban már esett szó arról, hogy a tanácsrendszer időszakában a településpolitika illeszkedve a szocialista tervgazdaság és az egyoldalú igazgatáspolitika elvárásaihoz, mesterségesen differenciált a különböző települések között - így kaptak egyértelmű politikai alapú preferenciát a megyeközpont, megyeszékhely városok a többi városhoz; valamint általában a városok a községekhez képest. Ez a mesterséges diszkrimináció megmutatkozott a 
közös tanácsok esetében - fontos leszögezni, hogy a közös tanácsok túlnyomó többsége ún. községi közös tanács volt, amelyek nem érintettek városi jogállású településeket. Az államigazgatási feladat- és intézményszervezés jegyében a községi közös tanácsok adminisztratív módon kijelölt székhelytelepüléseihez összpontosították a tanácsi és egyéb állami hivatali feladatokat, intézményi erőforrásokat így alapvetően ide koncentrálták az alapfokú oktatást vagy a kulturális közszolgáltatásokat. A községi közös tanácsokban érintett, társított kisebb községeket a különböző állami tervek (pl. az 1971-es OTK) az ún. „,szerepkör nélküli község” kategóriába sorolták, kategorikusan elvonva tőlük a fejlesztési forrásokból való részesedés komolyabb lehetőségét. Ugyanakkor le kell szögezni, hogy az extenzív iparfejlesztés (azon belül különösen a szocialista nehézipar mesterséges „felpörgetése”) jegyében megvalósított erőltetett és egyoldalú városfejlesztés miatt a községi közös tanácsok székhelyközségei hasonló alárendelt viszonyba kerültek a városokhoz képest az állami fejlesztéspolitikai prioritások és forrásallokáció (pl. az állami lakásépítkezések egyértelmüen a városokba koncentrálásával) tekintetében, mint a községi közös tanácsban a társközségek [Verebélyi, 1993, 193-195. pp.]. Az államszocialista gazdaság- és településpolitika a települések demográfiai, gazdasági és igazgatási pozícióival egyenes arányosságban - sokszor a reális szükségletekhez képest torzított módon - preferálták a nagyobb településeket politikai- és adminisztratív alapon torzítva a valós szükségleteket.

Összesen a közös tanácsok (városi és községi közös tanácsok) 1990-ben 2116 magyarországi települést érintettek. A közös tanácsokban müködő, de nem székhely társközségek száma 1484 db volt. Közvetlenül az 1990-es első önkormányzati választást megelőzően 632 községi közös tanács, valamint 17 olyan városi tanács volt, amely közös tanácsként funkcionált, ez utóbbiak mintegy 50 községet kapcsoltak magukhoz. Ezek alapján kimondhatjuk, hogy az államszocialista időszak kötelező tanácsi kooperációi jórészt a községekre illetve a helyi tanácsi alapfeladatokra (intézményfenntartás és hatósági hatáskörök) koncentráltak. [Fürcht, 1994, 196. pp.]. Ugyanakkor a rendszerváltás előtti években a magyarországi kistelepülések oldaláról már elindult az állampárti politika által is megtámogatott függetlenedési folyamat, amely a közös tanácsokból való kilépésben és önálló községi tanácsi jövő választásában öltött testet. Az 1985-ös tanácsi statisztikákhoz képest 1990-re 10\%-al csökkent a közös tanácsok száma (638 db), valamint a fél évtized alatt 7\%-al kevesebb lett a közös tanácsokhoz tartozó települések száma. Csak 1988-ban 51 közös tanácsból való községi kiválási kérelmet hagyott jóvá a területszervezési kérdésekben akkor döntéshozó kompetenciával bíró Népköztársaság Elnöki Tanács [Szigeti, 1994, 611. pp.; Somlyódiné, 1990, 23. pp.]. 


\section{V.1.1 Városkörnyéki igazgatási rendszer a tanácsrendszer időszakában}

Az 1968-ban megindult gazdaságpolitikai indíttatású változások (Új Gazdasági Mechanizmus), sajátos helyi közigazgatási dimenziója volt a tanácsrendszer racionalizálásának jegyében az ún. városkörnyéki igazgatás gyakorlat gondolatának a megjelenése. Ennek szakmapolitikai alapja a természetes városi vonzáskörzet, mint igazgatási kategória ekkor még „lopakodó” felbukkanása a tanácsi feladatellátás- és igazgatás rendszerében. A városkörnyéki igazgatás meghatározott községi tanácsi hatáskörök első fokú területi koncentrálását jelentette a városi tanácsok és intézményrendszer irányába. Mivel föszabályként a helyi közigazgatás strukturális alapját továbbra is a tanácsrendszer [benne a megyei tanácsok és 1971-ig a járási tanácsok, mint területi tanácsok; valamint a helyi (önálló és közös tanácsok] jelentette, a városkörnyéki igazgatás egyfajta kiegészítő elemeként funkcionált. Az ún. „harmadik” tanácstörvény a járási tanácsok megszüntetése (de a járási hivatalok meghagyásával) a következőképpen rendelkezett. Az 1971. évi I. törvény 66.§ (2) szerint a „Városkörnyéki község tekintetében a járási hivatalt vagy annak elnökét megillető hatáskört a városi tanács végrehajtó bizottságának titkára, illetöleg szakigazgatási szervei gyakorolják" - ez a passzus teremtett lehetőséget, hogy az addig kizárólagos járási hivatal alternatívájaként megjelenjenek a városi tanács és szakigazgatási szervei a városkörnyéki községek számára a helyi feladatellátó szerepkörben. Az 1971-es tanácstörvény végrehajtási rendelete a 11/1971. (III. 31.) Korm.rendelet a következöket tartalmazta a városkörnyéki község kapcsán: „,Községi tanácsot városkörnyéki községi tanáccsá akkor lehet nyilvánítani (a Népköztársaság Elnöki Tanácsa hozott döntéseket területszervezési kérdésekben a rendszerváltás elött), ha a város és község között kölcsönösen szoros társadalmi, gazdasági, ellátási, munkaerö-foglalkoztatási, földrajzi és közlekedési kapcsolatok vannak, továbbá a község és város összehangolt fejlesztése különösen indokolt” - [11/1971. (III. 31.) 12.§ (4)].

A városkörnyéki igazgatás 1968-as elvi lehetőségének megteremtésétől számított 15 éven belül néhány tucat esetben került kialakításra. A járási hivatalok megszüntetésének időpontjában ${ }^{124}$ (1983. december 31.) a városkörnyéki igazgatás keretében 61 városhoz mindössze 207 városkörnyéki település, község tartozott, ami csak korlátozott empirikus keresztmetszetet jelentett a városkörnyéki igazgatási gyakorlat számára [Bartke, 1985, 22. pp.]. A járási hivatalok - s vele a teljes járási szisztéma immáron végleges - megszüntetésével párhuzamosan született meg az állami döntés a korábban csak alternatívnak tekinthető városkörnyéki szisztéma általános bevezetéséről Magyarország területén. Az 1971. évi I.

\footnotetext{
${ }^{124}$ A járási rendszer kialakításakor 1950-ben 140 járást alakítottak ki, ezek száma később 150-re növekedett, viszont a megszünés időszakában mindössze már csak 83 járás volt Magyarországon.
} 
törvény 75.§ 8) bekezdésének 1983-as módosítása - [1983. évi 26. tvr. 18.§ (8)] szüntette meg a járási hivatalokat, ${ }^{125}$ az alsó-középszintü területi államigazgatásban kizárólagossá téve a városkörnyéki igazgatási szintet. Az újonnan bevezetendő kötelező városkörnyéki igazgatási rendszer területi lehatárolásait és települések szerinti besorolását a Népköztársaság Elnöki Tanácsának 23/1983. számú határozata rögzítette, meghatározva ezzel a konkrét városkörnyéki igazgatási egységeket. Az 1983-as tanácsi „reform” döntően a hatósági ügyintézés területére koncentrálta a városkörnyéki igazgatás hatókörét, ellenben a településközi tervezési-, gazdálkodási és közszolgáltatási területeken a városkörnyéki egységek nem váltak automatikusan az egykori járási tanácsok és járási hivatali ügyintézés örökösévé. Párhuzamosan erősítették a helyi alapszintü tanácsok (benne a községi közös és önálló községi tanácsok) önállóságát, saját hatásköreit - egyfajta tanácsi kompetenciadekoncentrációt eredményezve, valamint bővítették a közvetlen megyei tanács - helyi tanács kapcsolatok körét [Beluszky, 1985, 18. pp.]. A városkörnyéki igazgatás általánossá tételének kísérlete az 1980-as években a hazai településközi kooperációk, együttmüködések korábbi tradícióit tekintve meredek vállalásnak bizonyult. Az alsó-közép szintű területi közigazgatás ilyen módon való átszervezésének keretében 139 városkörnyéki igazgatási egység jött létre, ezek többé-kevésbé a rendszerváltozásig működtek. A városkörnyéki igazgatási egységek központi településeinek tanácsi szervezeteit ruházták fel a városkörnyéki térségi igazgatási funkciók gyakorlásával, végrehajtásával. Az akkori városhiányos települési joghatósági viszonyok miatt 34 esetben községi jogállású település kapta a körzetközponti szerepkört, ezért ezen kiemelt községek megkapták az ún. városi jogú nagyközség - kissé már „nyakratekert” jogállást, amit majd egészen a rendszerváltásig viseltek, feltéve, ha addig nem szereztek városi címet. A disszertációs téma szempontjából érdemes az 1983-s NET határozatot megvizsgálni, különösen a mai megyei jogú városok akkori városkörnyéki igazgatási egységeit:

1. Pécs - 1971-től megyei város: 9 községi tanács, amelyből 8 községi közös tanács. Érdekes, hogy a szintén aprófalvas Baranyából Siklós városhoz már 18 községi közös tanácsot - számtalan kistelepüléssel - rendelt az 1983-as NET határozat.

2. Kecskemét - 12 önálló községi közös tanács a városkörnyéki igazgatási egységben.

\footnotetext{
125 A járási szint „kivezetése” a tanácsrendszer időszakában, egy lassabb többlépcsős folyamat volt: előbb az 1971-es „harmadik” tanácstörvény szüntette meg a járási tanácsokat, miközben a járási hivatalok (élükön a járási VB titkárok) igazgatási feladatellátása megmaradt még közel másfél évtizedig. Az 1971. évi I. tanácsokról szóló törvény 75.§ 8) bekezdését 1983-ban a következőképpen módosította az Országgyülés: „Ha feladatot és hatáskört megállapító jogszabály eltéröen nem rendelkezik, a járási hivatal és elnöke helyett, a városi (városi jogú nagyközségi) tanács végrehajtó bizottságának megfelelö szakigazgatási szervét kell érteni. A járás, mint jogszabályi megjelölés hatályát veszti” - www.jaras.info.hu/jogszabalyi-hatter/torvenycikkek-es-rendeletek1536-1983
} 
3. Miskolc - 1971-től megyei város; 27 kapcsolódó községi tanáccsal, amelyek nagyobb része önálló tanácsi jogállású volt.

4. Szeged - 1971-től megyei város; 10 kapcsolódó községi tanáccsal, nagyobbrészt önálló tanácsi jogállásban.

5. Hódmezővásárhely - 3 önálló községet rendeltek hozzá (2 önálló és 1 nagyközségi jogú tanács).

6. Dunaújváros - 15 önálló tanáccsal közösen a városkörnyéki igazgatásban.

7. Székesfehérvár - 14 községi tanáccsal együtt, azok közel fele volt községi közös tanács.

8. Győr - 1971-től megyei város; 23 kapcsolódó községi tanács, amely közel fele-fele volt önálló vagy közös tanács.

9. Debrecen - 1971-től megyei város; 12 kapcsolódó - nagyrészt önálló - községi tanácsokkal.

10. Eger - 29 kapcsolódó községi tanács, amelynek valamivel több, mint a fele közös tanács volt.

11. Tatabánya - 5 kapcsolódó tanács (4 községi közös, 1 önálló jogállásban).

12. Salgótarján - 10 kapcsolódó, nagyrészt községi közös tanáccsal.

13. Kaposvár - 18 kapcsolódó községi közös tanáccsal.

14. Nyíregyháza - 27 kapcsolódó tanács, amelyben voltak nagyközségi és községi közös, valamint községi önálló tanácsok.

15. Szolnok - 11 kapcsolódó nagyrészt községi közös tanáccsal.

16. Szekszárd - 16 községi tanács, amelyek közel fele-fele községi és önálló jogállású.

17. Szombathely - 15 kapcsolódó községi tanács, amelyek túlnyomó része közös jogállású.

18. Veszprém - 5 kapcsolódó tanács a városkörnyéki rendszerben (4 közös, 1 önálló).

19. Zalaegerszeg - kb. 90 kistelepülést (köztük nagyon sok aprófalu) magába foglaló 20 db községi közös tanács a városkörnyéki igazgatási egységben.

20. Sopron - 13 kapcsolódó községi tanács, amelyek nagy többsége több települést tömörítő közös tanácsi jogállású volt

21. Nagykanizsa - 13 községi tanács, amelyből csak 1 db volt önálló, a többi közös jogállású.

22. Békéscsaba - 10 községi tanács, amelyböl 8 db önálló jogállású.

Budapesthez a városkörnyéki rendszerben nem rendeltek szomszédos, környező településeket (tanácsokat). Ugyanakkor Pest megyében a többi megyéhez képest nem meglepő módon nagyobb számban hoztak létre önálló városkörnyéki igazgatási egységeket. Fontos adalék, hogy a 12 adminisztratív Pest megyei városkörnyékből több olyan is akadt, aminek a központja speciális városi jogú nagyközség lett (pl. Monor, Ráckeve, Szigetszentmiklós). ${ }^{126}$ Széttagolt városkörnyéki egységek jöttek létre Gödöllő, Vác és Szentendre székhelyekkel (18-15-13 kapcsolódó tanáccsal). A 2006-ban megyei jogot kapott Érdhez 1983-ban a diósdi, a sóskúti (amely tanács magába foglalta Pusztazámor községet) és tárnoki tanácsokat rendelték, mint városkörnyéki igazgatási egység.

\footnotetext{
${ }^{126}$ Ezek természetesen ma már városi jogállású fővárosi agglomerációs települések.
} 
Az 1983-as politikai döntés egyértelmü volt abból a szempontból, hogy az összes város (plusz az igazgatási körzetközponti szerepkörre kijelölt községek) rendelkezzen saját városkörnyéki igazgatási rendszerrel, ez viszont az ország eleve rendkívül heterogén településhálózati szerkezetéből fakadóan kirívó aránytalanságokat eredményezett. Ezt remekül demonstrálja a két városkörnyéki igazgatási „végpont”, az egyik a mindössze 1 városkörnyéki településsel már önálló városkörnyéki igazgatást müködtető alföldi Karcag városa, a másik pedig az aprófalvas baranyai térségben 92 kisebb-nagyobb községet a saját városkörnyéki rendszerében integráló egyébként kisvárosnak számító Siklós volt [Kara, 1996, 93-94. pp.]. A járások fokozatos leépítésével (a járási tanácsok 1971-es, a járási hivatalok 1984-es megszüntetése) a térségi-körzeti közigazgatás a városi tanácsi szervekhez került, és a városi szakigazgatás városkörnyéki, agglomerációs feladatellátása 3 elkülöníthető tevékenységtípust ölelt át:

- Városok és községek együttmüködése mellérendeltségi alapokon.

- A megyei irányításban szerepet vállaló városok a városkörnyéki települések felett felügyeleti jogokkal,- hatáskörökkel rendelkeztek.

- Meghatározott ügyekben másodfokú hatósági jogkörök az első fokot gyakorló községek felett [Bércesi, 2002, 524. pp.].

A rendszerváltás után több olyan szakértői vélemény is született, ami a késő tanácsrendszeri keretek között megvalósult városkörnyéki igazgatási modellt Magyarország addigi történetének legkorszerübb igazgatástechnikai kísérleteként értékelte, amelynek fontos kritériuma volt az üzemgazdaságosság. A városkörnyéki igazgatási körzetekhez rendelt ún. városkörnyéki koordinációs bizottságok (benne a város és városkörnyéki tanácsok képviselete; egyéb intézményvezetők) a kor antidemokratikus viszonyaihoz képest a partnerség és együttmüködés alapján müködve a demokratikus önkormányzatiság egyik közvetlen előfutár-gyakorlatának is tekinthető. Ugyanakkor az 1980-as évek közepére Magyarországon általánossá tett városkörnyéki igazgatás, mégsem tudta érdemben felülírni a szocialista egypártrendszer időszakában meghatározó városok (megyeközpontok, „szocialista” iparvárosok) által uralt központi tervezési szemléletet, így az ország településhálózatában domináns diszharmonikus érdekviszonyok megmaradtak a rendszerváltásig [Balázs, 1996, 107. pp.].

A városkörnyéki központokba szervezett térségi feladatokat a várostérségi referensek - afféle kvázi hivatali végrehajtó szervként - látták el a környező érintett települések, elsősorban községek számára. Voltak városkörnyékek, ahol közösen és hatékonyan szervezték 
meg feladatellátást (szemétszállítás etc.), voltak városkörnyékek, ahol a résztvevő tanácsok közös városkörnyéki pénzalapot alapítottak illetve közös beruházásokat (pl. Tokaj és Rakamaz közösen létesített autóskempinget a Tisza parton) eszközöltek. A városkörnyéki modell a város-község kapcsolatok széles tárházát tette lehetővé: közös tanácsi vállalat vagy közintézmény létrehozása; meghatározott hatósági hatáskörök közös ellátása a városi intézményrendszer, apparátus által. 1988-1989-re azonban rohamos ütemben épültek le a városkörnyéki igazgatási egységek, 1990-re már gyakorlatilag csak két megyében maradt belőlük hírmondó [Iváncsics, 1985, 278-282. pp.; Frücht, 2003, 129. pp.; Bekényi-BércesiNémet, 2003, 195. pp.].

A városkörnyéki igazgatási kísérletekkel párhuzamosan történtek egyéb kooperációs kísérletek a helyi tanácsok (benne városi és községi tanácsok) közös részvételével, ilyen volt még az 1970-es évek végén létrehozott Velence-tó környéki építésügyi hatósági igazgatási társulás reflektálva az üdülöövezet kiépülésére, majd az 1980-as években létrejött nagyszámú, több száz tanácsi igazgatási társulás (adóügyek, szabálysértés, gyámügy, kisajátítás, ipar- és kereskedelmi igazgatás). Az 1980-as évek elejétől pedig elsősorban a városokban valamint a fővárosi kerületekben jöttek létre az ún. GAMESZ ${ }^{127}$ típusú tanácsi vállalatok intézményfenntartás- és müködtetési feladatokra. Ezek jelentős része megmaradt az önkormányzati rendszer kialakítását követően is - ma is számos városban, fővárosi kerületben müködnek GAMESZ vagy GESZ (gazdasági ellátó szolgálat) elnevezés alatt. Ennek révén szintén lehetővé vált, hogy egyedi megállapodások során a városi GAMESZ szervezetek feladatellátása kiterjedjen a városkörnyéki községek irányába a tanácsrendszer utolsó évtizedében.

\section{V.2 Polémiák a nagyvárosok szerepéről a rendszerváltás időszakában}

Boross Péter a rendszerváltás utáni első demokratikusan megválasztott kormányzat MDF-FKgP-KDNP kormánykoalíció - második belügyminisztere (Antall József 1993. decemberi halála után rövid ideig miniszterelnök), 1992-ben a következőképpen nyilatkozott az 1990 végén életre hívott helyi önkormányzati rendszer kapcsán: „Magyarországon jelenleg a széttagolódás korszakát éljük - ez válasz a múltra. Tudjuk azt, hogy nyugaton már sokkal nagyobb agglomerációk alakulnak ki, a község fogalom sem az, ami régen volt, de meg vagyok róla győződve, hogy egy ideig azoknak az impulzusoknak kell engedni, amelyek a széttagolódás irányába mutatnak... Annyit lehet mondani jelenleg, hogy a széttagolódás nem

\footnotetext{
${ }^{127}$ GAMESZ - gazdasági, müszaki ellátó és szolgáltató szervezet
} 
felel meg bizonyos racionális követelményeknek, de megfelel egy lelki igénynek, és egyik szempont szélsőséges érvényesülésére sincs szükség." [Zongor-Agg, 1994, 371. pp.] - az akkori belügyminiszter szavai tartalmilag az akkor még nagyon fiatal önkormányzati rendszer kritikusait erősítette meg alig másfél évvel a helyi önkormányzatokról szóló 1990. évi LXV. törvény (Ötv.) megszületését követően. A települési közösségek „lelki igényére” történő hivatkozás az önkormányzati törvény 1990-es kodifikációja óta talán a legerősebb legitim politikai érv a helyi alapszinten kialakított fragmentált önkormányzati szisztéma (,egy település egy önkormányzat” elv) következetes fenntartása mellett.

Az Ötv. 1990-es vitája során az akkor legnagyobb parlamenti ellenzéki párt, a liberális Szabad Demokraták Szövetsége a törvényben életre hívott megyei önkormányzati kompetenciakörhöz képest is jóval gyengébb megyei területi autonóm igazgatási szint kialakítását szorgalmazta - olyannyira, hogy a kodifikáció parlamenti vitája során a végül a megyei önkormányzatokhoz rendelt térségi feladatok ellátását is eredetileg pusztán csak a települési önkormányzatok önkéntes társulására bízták volna a liberálisok. Az SZDSZ önkormányzati ügyekben meghatározó „erős embere” 1990-2010 között Wekler Ferenc volt, aki a parlamenti képviselőség (1990-2006) mellett a Baranya megyei Mecseknádasd település polgármestereként, valamint a Községek, Kistelepülések és Kistérségek Országos Önkormányzati Szövetségének (KÖSZ) elnökeként közvetlenül is megtapasztalhatta az 1990ben létrehozott önkormányzati rendszer előnyeit-hátrányait. Wekler szintén még az 1990-es évek első felében a következőket mondta a megyerendszer, a város és környéke valamint a természetes térségi vonzáskörzetek kapcsán. „Én nem gondolnám, hogy át kell alakítani (mármint a megyerendszert - a szerző kiegészítése), de rá kell bizni a településekre, hogy a természetes vonzáskörzet mentén ök formálhatnák régiójuk. De a város és a környéke közötti együttmüködés - ami a korábbi rendszerben kényszerként müködött (értsd: az 1950-1990 közötti szovjet típusú tanácsrendszer, benne a városkörnyéki igazgatási modellel - a szerző kiegészítése) - egy lépés abba az irányba, amit én jónak gondolok." - majd folytatta a gondolatmenetet a városok és a különösen a megyei jogú városok kapcsán: „Vannak nyolcezres községek, s vannak 3500 lakosú városok. Ezek magyar sajátosságok. Az biztos, hogy az ötvenezres határ politikai kérdés volt (mármint az Ötv. azon passzusa, hogy az 50 ezer lakos feletti város kezdeményezheti a megyei jogú városi cím megszerzését az Országgyüléstől). Néhány képviselőnek az volt az érdeke, hogy a városa bekerüljön ebbe a státusba, s így ez sikerült is.” [Agg, 1994, 385-386. pp.].

Bihari Mihály jogász-politológus, az 1990-es években MSZP-s parlamenti képviselő, majd később alkotmánybíró, még 1993-ban a következő szavakkal lamentált a megyei 
önkormányzati szint valamint a városok és községek közötti kapcsolatokról. „Nyilván nem kívánja senki vissza azt az erös megyét, amely rátelepült a községekre és a városokra (itt Bihari a tanácsrendszer időszakára és a megyei tanácsok városi és községi tanácsok feletti erőteljes „gyámkodására” utalt - a szerző kiegészítése), viszont ez a teljesen súlytalan megye is hiba." - sőt Bihari a középszint szervezése kapcsán visszanyúlt egészen a XX. század első felének ún. „városmegye” Bibó István és Erdei Ferenc nevével fémjelzett koncepcióig: „A megyerendszert illetöen persze el lehetett gondolni a 19 plusz fóváros megyéje helyett mást is, azt az eredeti Bibó-Erdei féle városmegye koncepciót, amely 100-150 városmegyére osztotta volna fel az országot. Ennek a meglépésére jó alkalom lett volna a rendszerváltás... Én azt gondolom, hogy a 19 nagy megyével szemben kisebb területü, valódi települési integrációs funkciót ellátó, a lakossághoz még elég közel lévö talán 80-100 városmegyére kellett volna átalakitani a magyar települési rendszert” [Agg-Navracsics-Oláh, 1994, 392. pp.] - Bihari azonban még ugyanabban az interjúban kérdezői felvetésre módosította álláspontját, kifejezetten csak a nagyvárosokra korlátozva egy speciális városkörnyéki igazgatás lehetőségét, a közép- és kisvárosok önkormányzati igazgatási pozícióit nem bolygatva. „Azt gondolom, hogy az eredeti Erdei-Bibó féle javaslat túlhaladott, és azt semmiképpen nem lehetne megvalósitani és én is azt mondom egyébként, hogy a megyerendszer megváltoztathatatlan, illetve alakitható, változtatható, de nem szüntethetö meg. Azt el tudom gondolni, hogy mivel 6-8 ilyen nagyságrendü városunk ${ }^{128}$ van, a 6-8 város körül, ahol a települések valóban szerves egységet alkotnak a várossal, ott valamilyen, az általánostól kismértékben eltérö, tehát nem gyökeresen más igazgatási struktúrát, illetve viszonyt lehetne kialakitani. A homogén igazgatási rendszerrel szemben tehát én egy heterogén igazgatási rendszerben gondolkodnék, amelyben a föváros az egyik különleges helyzetü, státusú és megoldást igénylö közigazgatási rendszer, csakúgy, mint a nagy megyei városok és az erös, városi és községi, városkörnyéki funkciót ellátó települések és egyebek. És ebben az egyebekben nyilván egy sürü, kis lélekszámú, sok település dunántúli régió és egy ritka települést felmutató nagyobb települési számú alföldi közigazgatási rendszer között lehetne jogi-igazgatási, szervezeti, gazdasági szempontból is különbség. Tehát a homogén közigazgatással szemben én egy heterogén, legalább háromelvü közigazgatásnak lennék a hive”[Agg-Navracsics-Oláh, 1994, 394. pp.]. Bihari több mint két évtizedes megállapítások mögött nagyon is koherens kép rajzolódik ki: azon nagyvárosok esetében, ahol a nagyváros és környéke kapcsolatában előrehaladott agglomerálódás és szuburbanizáció figyelhető meg, ott

\footnotetext{
${ }^{128}$ Itt Bihari nagy valószínűséggel a megyei jogú városok sorából kiemelkedő regionális kiterjedésủ központok csoportjára gondolhatott - lásd bövebben a magyarországi városhierarchia változásait bemutató fejezeteknél!
} 
a jog- és politikatudós már a rendszerváltás után közvetlenül kialakíthatónak gondolt egy speciális jogi szabályozásra és intézményrendszerre alapuló demokratikus városkörnyéki igazgatási modellt.

A megyei jogú városkategória 1990-es kodifikációs kialakításának módja, a hatáskörtelepítés logikája nem elsődlegesen a hazai nagyvárosok igazgatásának hatékony méretbeli kezelése, sokkal inkább a területi (megyei) önkormányzati szinttől való elkülönülés és függetlenség biztosítása volt. Ezért rendelkezett az 1990-es Önkormányzati törvény, hogy a megyei jogú városok, mint települési önkormányzatok a területükön a települési önkormányzati kompetenciák mellett lássák el - „megfelelő eltérésekkel” (sic!) - a megyei önkormányzatok feladat-, és hatásköreit is - [1990. évi LXV. törvény 61.§ (1)]. Mindeközben olyan teoretikus kérdések merültek fel már az 1990-es évek elején, hogy egyáltalán a megyei érdekképviselet kiterjedhet-e az adott megye területén található megyei jogú városra vagy városokra.

\section{V.2.1 Megyei jogú várások versus megyei önkormányzatok}

1990-ben a rendszerváltó parlament az új önkormányzati rendszer megalkotásakor egy tudatosan gyenge középszintü területi önkormányzati szintet (megyei önkormányzatok) alkotott meg. A tanácsrendszer időszakában egészen az 1990-es önkormányzati választásokig a helyi tanácsok (önálló tanácsok és községi közös tanácsok) területi illetékességét meghaladó térségi feladatok zömét a megyei önkormányzatok jogelődjének számító megyei tanácsok és a kapcsolódó intézményrendszer (megyei tanácsi hivatalok; megyei tanácsi vállalatok) látták el - a tanácsi feladatkörökröl gazdag korabeli szakirodalom található! [Verebélyi, 1987]. Ugyanakkor az új közjogi környezetben a térségi feladatellátás oroszlánrészét a kormányzat helyi végrehajtó területi dekoncentrált intézmények szerezték meg, és csak kisebb rész került az újonnan létrejövő megyei önkormányzatokhoz. Érdemes visszatekinteni a korábbi korok történéseire, hogy megértsük a megye és a városok, nagyvárosok sokszor rendkívül ambivalens viszonyát (a korábbi évszázadokban a vármegye és a különböző jogállású városok - szabad királyi városok, mezővárosok). A középkori majd koraújkori magyar városok története nem más, mint a függetlenség és a közvetlen környezettől való autonómia 
biztosításának küzdelme - a mezővárosok a helyi földesúrtól, a szabad királyi városok a nemesi vármegyétôl. ${ }^{129}$

A modern városi szabályozást Magyarországon az 1867-es Kiegyezés utáni reformer törvényhozás teremtette meg. A főváros vonatkozásában külön döntés született a korabeli Országgyülés által: az 1872. évi XXXVI. törvény mondta ki „Buda és Pest szabad királyi fövárosok, valamint Ó-buda (sic!) mezöváros és a Margit-sziget (sic!), ez utóbbiak Pest vármegyéböl kikebeleztetvén, Buda-Pest (sic!) fơváros név alatt egy törvényhatósággá egyesittetnek" - ezzel megteremtve a mai egységes Budapest jogi alapját. Már az 1872-es törvény megteremtette a budapesti kerületi elöljáróságok rendszerét, igaz csak nagyon szük önálló hatáskörökkel. Ugyanakkor a fövárosi törvény rendelkezett arról is, hogy a főváros és valamely egyéb község későbbi fúziójához külön törvény szükséges [Hencz, 1973, 111-112. pp.].

Újraszabályozták a teljes magyar közigazgatást, benne a különböző településtípusokkal:

- 1870. évi XLII. törvény a köztörvényhatóságok rendezéséről - ez meghatározta az általános és speciális önkormányzattal rendelkező területi és települési egységeket, úgymint a vármegyék, a szabad királyi városok illetve az önálló törvényhatósági jogú városok, egyéb speciális helyhatóságok (székelyszékek, Jász-Kun és Hajdú kerület; a délvidéki határőrvidék etc.).

- 1886. évi XXI. törvény a törvényhatóságokról - 63 vármegye illetve 24 törvényhatósági joggal felruházott város ${ }^{130}$, Budapest föváros - erröl külön törvény is született 1872-ben!-, valamint a különleges jogállású Fiume városa.

- Az 1876. évi XX. törvény ugyanakkor 47 korábban szabad királyi város illetve törvényhatóságú joggal felruházott város címmel rendelkező városi települést fosztott meg a címétől, közvetlen vármegyei fennhatóság alá rendelve azokat. ${ }^{131}$

Trianon közvetlen hatásaként a régi anyaország 27 törvényhatósági jogú városából $11 \mathrm{db}$; a 112 rendezett tanácsú városból pedig mindössze 36 maradt az új országhatárokon belül. A Horthy-korszakban speciális „nagyvárosi mozgalmak” alakultak ki, amely keretében egyes vidéki térségi központok agilis területi terjeszkedési célokat fogalmaztak meg a

\footnotetext{
${ }^{129}$ A korabeli város versus vármegye komplex viszonyrendszer megjelent Mikszáth Kálmán híres történelmi regényében „A fekete város”-ban, ahol a szabad királyi város felvidéki Löcse és Szepes vármegye konfliktusa szimbolizálódott a bíróját gyászoló Lőcse és a szepesi alispán konfliktusában.

${ }^{130} \mathrm{Az}$ 1886. évi XXI. törvényben felsorolt 24 törvényhatóságú joggal felruházott város közül 10 található a mai Magyarország területén $-[1886$. évi XXI. tv.] http://www.1000ev.hu/index.php?a=3\&param=6214

${ }^{131}$ Iggy került vármegyei fennhatóság alá Esztergom, Székelyudvarhely vagy Csíkszereda - [1876. évi XX. tv. némely városi törvényhatóságok megszüntetéséről] http://www.1000ev.hu/index.php?a=3\&param=5733
} 
városkörnyékre vonatkozólag, ilyen volt Nagy-Miskolc és Nagy-Szeged megteremtésére irányuló törekvések, amelyek azonban csak apró annexiókban testesültek meg a vármegyék ellenállása miatt. A Nagy-Budapestre vonatkozó koncepciók is felbukkantak már a két világháború közötti évek során [Hencz, 1973, 461-515. pp.].

A második világháborút követő rövid demokratikus időszak államreformelképzeléseinek fontos szeletét jelentette az ún. városmegye koncepció megjelenése alig titkoltan a vármegyék - mint a területi közigazgatás addig megingathatatlan bástyái rovására. A Nemzeti Parasztpárt 1946-ban Erdei Ferenc városmegye koncepcióját fogadta el, amely az akkori 25 vármegyére és 151 járásra épülő közigazgatási rendszer helyett egy 70-80 kiemelt város vagy még éppen városiasodó település térségi irányító szerepkörén alapuló, közvetlen városkörnyéki igazgatási szervezőelvet fogalmazott meg. A városmegyék megteremtése mellett az önkormányzatok ellenörzése, illetve a központi államigazgatás dekoncentrációja érdekében $7 \mathrm{db}$ kerületi központ gondolatát fogalmazta meg Erdei a következő térségi kerületi székhelyekkel - Budapest, Miskolc, Debrecen, Szeged, Pécs, Szombathely és Győr. Erdei reformjavaslatát alapvetően a kisebb hivatali intézményrendszer és apparátus megteremtésével indokolta [Hencz, 1973, 518-521. pp,; Erdei, 1977b, 369-380. pp.].

Erdei Ferenc városmegye koncepciójához hasonló közigazgatási elképzelései voltak a XX. század egyik legnagyobb hazai politikai gondolkodójának, Bibó Istvánnak, aki 1946-ban önálló közigazgatási területi reformtervezetet készített. Ez az ország térszerkezeti, morfológiai paraméterein alapulva a területi közigazgatás bázisaként egy kb. 600-1000 km2 és megközelítőleg 60-90 ezer lakosú önkormányzati egységet tartott alkalmasnak, amely középpontjában egy városi funkciókkal rendelkező centrumtelepülés illetve közvetlen vonzáskörzete állt. Ennek gyakorlati megvalósulása egy kb. 80-100 városmegyéböl felépülő területi önkormányzati konstrukciót jelentett volna [Vass, 1993, 537. pp.]. Az 1947-1948-as államszocialista politikai fordulat, $\mathrm{s}$ vele a gyorsan kiépülő egypártrendszer területi közigazgatási keretei azonban a megyék - igaz már az 1950-től kiépülő tanácsrendszeri keretek között - újbóli megerősítését eredményezték.

A megye és a városok kapcsolata a történelmi előzményekhez hasonlóan, ambivalens módon alakult az államszocialista évtizedek során is. Az 1950. évi I. törvény a helyi tanácsokról („első tanácstörvény”) egyértelmüen alárendelte a megyének (sőt a járásnak) igazgatási, s vele politikai szempontból a városokat: Budapest fóváros szervezett tanácsát a megyei tanácsokkal azonos szintre állította, viszont minden más várost a területileg illetékes járási tanács fennhatósága alá vont [1950. évi I. tv. 4.§ (2) és 5.§]. Ezt a kettős, a megyéknek 
és a járásoknak való területi „,alávetettséget” a vidéki nagyvárosok erőteljesen sérelmezték, és követelésük hamar célba ért. Az 1954. évi X. törvény a tanácsokról („második tanácstörvény”) 3.§ a) értelmében a fővárosi tanács, a megyei tanácsok illetve a megyei jogú városok tanácsai közvetlenül az Országgyülésnek valamint a Népköztársaság Elnöki Tanácsának (NET) ,, vannak alárendelve, és azok irányitása alatt áll”. Ugyanakkor az ún. járási jogú városok a megyei tanácsnak rendelődtek alá a továbbiakban [1954. évi X. tv. 3.§ b)] - ezzel a városok teljesen kikerültek a járási fennhatóság alól a „második tanácstörvény” rendelkezése által.

\section{V.2.2 A megye és nagyváros viszonya az új önkormányzati rendszerben 1990 után}

A politikai átmenet (1989-1990) kevésbé látványos, de fontos eleme volt az új demokratikus politikai osztály (azon belül kifejezetten az új politikai pártok - MDF, SZDSZ, Fidesz, FKgP, KDNP etc.) valamint a helyi közigazgatást az 1990 végi első szabad demokratikus önkormányzati választásokig meghatározó megyei és helyi tanácsok közötti koordinált együttműködés. Ennek keretében a hivatalos kapcsolatfelvételek, konzultációk 1989 nyári hónapjaitól váltak rendszeressé, elsősorban a megyékben illetve megyeszékhelyeken volt ennek jelentősége, ahol ún. Politikai Érdekegyeztető Bizottságok alakultak - ezek elnöki pozícióját választott tanácstagok töltötték be, de képviselöiket delegálták az újonnan megalakult politikai pártok. Ezek a bizottságok a még funkcionáló tanácsok mellett egyfajta döntés-előkészítő, véleményezö-konzultatív szerepkört láttak el, és alapvető funkciójuk a készülődő új politikai osztály felkészítése volt a helyi politika megismerésére [Bozsó, 1990, 648-653. pp.].

A megyei jogú városok szükszavú törvényi szabályozásának - két kritérium: a megyeszékhely pozíció és/vagy az 50 ezres lakosságszám - szakmai kritikája már az önkormányzati rendszer megteremtésének időszakában megjelent. A kritikusok szerint az Önkormányzati törvény semmilyen további társadalmi, gazdasági illetve vonzáskörzeti kritériumot nem határozott meg, miközben a korszak hazai empirikus nagyvárosi kutatásai bizonyították, hogy regionális vagy akár csak ténylegesen megyei léptékű feladatellátásra a megyei jogú városoknak csak egy szükebb köre képes, alkalmas. A kizárólag a lakossági kritérium (50.000 lakos) miatt a korábbi megyei városokhoz képest „fellazított” városcsoportnál a megyéhez, megyei önkormányzathoz való viszony, pozíciók jelentősen determinálódtak az adott megyei jogú város valós társadalmi és gazdasági ereje, a rendelkezésre álló erőforrások ismeretében - „, a megyétöl való függés vagy függetlenség 
kérdése” [Bércesi-Csefkó-Horváth-Iváncsis-Pálné, 1991, 54-56. pp.]. A megyei jogú városok törvényi meghatározását alkotmányjogászok, közigazgatási szakemberek kritizálták - köztük az első Alkotmánybíróság tagja, a jogtudós Ádám Antal, aki egyrészt hiányolta a megyei jogú városok körzeti szerepkörének korrekt meghatározását, másrészt valódi hatáskör-elkülönítést - s vele egyértelmü intézményfenntartói definiálást - sürgetett a megyei önkormányzatokhoz képest [Ádám, 1994, 9. pp.].

A két önkormányzati típus közötti sajátos viszonyrendszert (a kompetenciák nem egyértelmü lehatárolása) tovább bonyolította a tény, hogy a megyei jogú városok lakosságát törvényi úton „kizárták” a megyei önkormányzatok képviseleti szervének, a megyei közgyülések megválasztásából, amely helyzet mind a mai napig fennáll. Ehhez kapcsolódóan komoly alkotmányos aggályok merültek fel már az 1990-es években, és így született meg egy 1995-ös alkotmánybírósági határozat, amely helyben hagyta az eredeti törvényi rendelkezést [63/B/1995. AB határozat]. Ugyan az Ötv. 1994-es módosítása [1990. évi LXV. tv. 61.§ (1)] igyekezett tompítani a megyei jogú városok versus megyei önkormányzatok konfliktusos viszonyrendszert azzal, hogy ún. egyeztetö bizottságok létrehozására kötelezte az azonos megye területén müködő megyei és megyei jogú városi helyhatóságokat (ahol 2 megyei jogú város van, ott $2 \mathrm{db}$ egyeztető bizottság életre hívásával), de adós maradt az egyeztető bizottságok konkrét kompetenciáinak meghatározásával. ${ }^{132}$

Szükséges leszögezni, hogy a tanácsrendszer időszakában tapasztaltakhoz képest megszűnt a megyék és települések közötti alárendelt függőségi viszony, a korábban „fejnehéz” megyei tanácsok újraelosztó funkcióját nem örökölték meg a „lebegő” megyei önkormányzatok. Ugyanakkor ez nem zárta ki a két önkormányzati típus közötti együttmüködést, amelyre az alkotmányos jogként biztosított önkormányzati társulási lehetőség kínálkozott elsődlegesen. Az Önkormányzati törvény által már 1990-ben meghatározott társulásos formák közül az intézményirányító társulás [1990. évi LXV. tv. 43.§] jöhetett racionális alapon szóba a megyei önkormányzatok és megyei jogú városok között. A kooperáció azonban jobbára kimerült különböző formális gesztusokban - pl. tanácskozási jog keretében kölcsönös „,megfigyelő státusz” biztosítása a megyei illetve megyei jogú városi közgyülési üléseken. Viszonylag kevés esetben fordult elö, hogy meghatározott keretjellegü eseti együttmüködési

\footnotetext{
${ }^{132}$ Az 1994. évi LIII. tv. 37. § (2) pontja egészítette ki a 61./A §-sal az Önkormányzati törvényt (1990. évi LXV. tv.), hogy a „közös feladatokban való együttmüködés elökészítésére és összehangolására” egy 10 tagú egyeztető bizottságot állít fel, a tagok egyik felét a megyei, a másik felét a megyei jogú város önkormányzata delegálja. Az egyeztető bizottság a törvény szerint saját maga határozza meg a szervezeti és működési szabályait, az elnöki pozíciót pedig felváltva tölti be a megyei közgyülés elnöke valamint a megyei jogú város polgármestere. A paragrafus lehetővé tette továbbá, hogy más megyék képviselöit is bevonhassák az egyeztető bizottság munkájába - a változásról bővebben: Szabó Lajos: A középszint az önkormányzati törvény módosítása tükrében (in: Magyar Közigazgatás 1994/12. szám) 724. pp.
} 
megállapodásokat kötöttek egymással különböző szakigazgatási koordinációra vagy még ritkább esetben konkrét integrált feladatellátásra - pl. beiskolázásban való együttmüködés a megye és a megyei jogú város között [Csefkó, 1992, 690-693. pp.].

Az 1990-ben a megyei jogot kérelmező 21 városból az Országgyülés egyedül Esztergom kérelmét utasította el, mondván a Komárom-Esztergom megyei történelmi város nem teljesíti az Önkormányzati törvény eredeti kodifikált változatában meghatározott 50.000 lakos kitételt. Wekler Ferenc az akkor legnagyobb ellenzéki párt, az SZDSZ önkormányzati ügyekben meghatározó szereplője ezért a megyei jogú várossá nyilvánításhoz kettős alternatívát vázolt fel: a) minden 50.000 föt meghaladó népességü város automatikusan kapjon megyei jogot, illetve b) maradjon meg az Országgyűlés mérlegelési jogköre, de kerüljön kidolgozásra egy objektív kritériumrendszer is az ilyen esetekre. Az Ötv. 61. § (1) pontja megtartotta az 50.000 fös kritériumot, de a parlament mérlegelési jogkörét is, anélkül, hogy érdemben részletezte volna a mérlegelés alapjául szolgáló kritériumokat, egyéb objektív társadalmi, igazgatási vagy akár infrastrukturális feltételeket. ${ }^{133}$ Az 1990-es illetékes parlamenti bizottsági vitában a Belügyminisztériumot képviselő Kara Pál - későbbi helyettes, majd közigazgatási államtitkár - érdemi vizsgálat helyett „ténykérdésnek minösitette, hogy a megyei jogú városi kérelmet a parlamentnek benyújtó 20 város rendelkezik saját kórházzal, középiskolával, müvelödési házzal, könyvtárral és így tovább. Rendelkeznek az alapvetö középfokú intézményhálózattal a saját és vonzáskörzetük tekintetében” [Tóth Tamara, 2010, 227-230. pp.].

Az 1990-es megyei jogú várossá nyilvánítási országgyülési határozatok esetében még kritérium volt az előírt 50 ezres lakosságszám - [82/1990. (XII. 7.) OGY határozat egyes városok megyei jogú várossá nyilvánításáról] -, de az 1994-es Ötv. módosítás ${ }^{134}$ automatikusan minden megyeszékhely számára biztosította a megyei jogú városi jogállást, így vált azzá Szekszárd és Salgótarján. A 2000-es évekre a rohamosan növekvő, 50.000 lakost is meghaladó Pest megyei Érd város önkormányzatának megyei jogú várossá válásáról szóló kérelmét az Országgyülés a 82/2005. (XI. 10.) OGY határozattal ${ }^{135}$ támogatta, kialakítva ezzel a megyei jogú városok mai napig meghatározott körét.

\footnotetext{
133 Ugyanakkor Wekler a Magyar Közigazgatás 1993-as a helyi önkormányzati törvény lehetséges továbbfejlesztéséről szóló tematikus különszámba írt cikkében már a megyei jogú várossá nyilvánítás feltételeinek a szigorítását és részletesebb kidolgozását szorgalmazta - Wekler Ferenc: Az önkormányzás fejlesztési irányai (in: Magyar Közigazgatás 1993/11. szám) 660. pp.

${ }^{134}$ Az 1994. évi LXIII. törvény 37./1§ úgy módosította az Ötv. 1990. évi LXV. tv. 61. (1) bekezdését, hogy „a megyeszékhely város megyei jogú".

${ }^{135}$ Érd megyei jogúvá válása igazodva az akkor hatályos területszervezési eljárásról szóló 1999. évi XLI. törvényhez - mint a parlament területszervezési döntéseinél - a következö általános önkormányzati választás napján 2006. októberben valósult meg.
} 
Az Önkormányzati törvény ugyan 1990 óta egységes közjogi blokkban kezelte a megyei jogú városokat, de láthatóan egy nagyon heterogén városcsoport került kialakításra a kodifikációval. Néhány megyei jogú várost ${ }^{136}$ leszámítva, ezt a településcsoportot is folyamatosan sújtja az ország egészét általánosan érintő népességcsökkenés, viszont ahogy arról már esett szó a nagyvárosi agglomerációs térségek (benne a szuburbán kisebb településekkel) lakosságszáma alapvetően növekszik. A disszertációs téma szempontjából a megyei jogú városok közötti legfontosabb érdemi differenciák a következők:

1. A kapcsolódó természetes vonzáskörzet (agglomerációs térség) nagysága; a vonzáskörzethez kapcsolódó városkörnyéki települések száma (azok jogállása; gazdasági, társadalmi és intézményi paraméterek).

2. Az adott megyei jogú város településszerkezetének jellemzői (morfológiai terület; funkcionális - „ingázási” - várostérség nagysága; a vonzáskörzet településeinek elhelyezkedése).

3. Közigazgatási intézményi hálózat - saját önkormányzati intézményi hálózat; az adott megyei jogú városba telepített állami területi dekoncentrált intézmények (regionális központ dilemma).

Már az elsődleges kodifikációját megalapozó 1990-es parlamenti vita során megfogalmazódtak aggodalmak a megyei jogú városok és megyei önkormányzatok esetleges hatásköri,- és illetékességi vitáiról, potenciális konfliktusairól, ennek ellenére komolyabb előzetes hatásvizsgálat illetve intézményes „,biztonsági fék” (mint amilyen az 1994-ben bevezetett egyeztető bizottság is lett) mellőzésével került az eredeti Önkormányzati törvény elfogadásra. Ugyanakkor a megyei jogú városok és a megyei önkormányzatok differenciálásakor fontos szakmai érv volt, hogy az átlagosnál fejlettebb, nagyobb lakosságszámú, kiterjedtebb gazdasági- és munkaerőpiaccal bíró, a magán- és a közszolgáltatások által sokkal inkább lefedett városok lakossága ne legyen automatikusan rászorulva a megyei önkormányzati feladatellátásra. Ezzel viszont egy speciális müködési anomáliákkal megterhelt szabályozási és intézményi müködési közeg magvai kerültek elvetésre: az alapvetően települési helyhatóságként müködő megyei jogú városok a törvény értelmében területén ellátják a megyei önkormányzati feladatokat, valamint a saját vonzáskörzetének vonatkozásában bizonyos önkormányzati feladatellátást a városkörnyéki települési önkormányzatok számára - pl. szemétszállítás, tömegközlekedés.

${ }^{136}$ Érd, Veszprém, Sopron, Szeged - Nagyvárosi térségek - kistérségek, Nagyvárosi funkciók - kistérségi szerepek, Helyi Obszervatórium LRMI Local Monitoring, Készítette: Perger Éva, 2008 http://www.terport.hu/webfm_send/4010) 7.pp. 
A megyei jogú városi jogállás megteremtése már a rendszerváltás időszakában kapott szakmai kritikákat - eme lamentálás alapja volt, hogy ugyan a megyei jogú városok a törvény erejénél fogva megkapták a jogot, hogy területükön ellássák - „megfelelö eltérésekkel” - a megyei önkormányzati kompetenciákat [1990. évi LXV. tv. 61.§ (1)], de sajátos helyzetük miatt a települési, városi érdekeltség természetszerüleg felül fogja írni a térségi (s vele a szűkebb illetve tágabb városkörnyéki települési) érdekeket. [Zongor, 1991, 552. pp.].

\section{Az 1990 utáni területu feladatellátás konfliktusos elemeivé a következök váltak:}

- Bizonytalanságok a területi feladatellátás tekintetében - a megyei jogú városok illetve a megyei önkormányzatok feladatellátása közötti pontos határvonalak hiánya. ${ }^{137}$

- Koordinációs bizonytalanságok és deficit a megyei jogú városok és a megyei önkormányzatok között - az egyeztető bizottságok „felemás” müködése.

- Esetleges együttműködések az önkormányzati feladatellátás- és közszolgáltatások területén a megyei jogú városok valamint a városkörnyéki települési önkormányzatok között.

\section{V.3 Feladatellátás fragmentált önkormányzati rendszerben}

Magyarországon a szovjet típusú hierarchizált és antidemokratikus tanácsrendszer négy évtizedes korszakát követően a törvényalkotó 1990-ben egy a feladat,- és hatásköreit tekintve decentralizált, a települési egységek kifejezett önkormányzati autonómiájára épülő helyi önkormányzati alapszintet - mint települési önkormányzatok - hozott létre. A hatásköreiben erős települési helyhatóságok mellett egy gyenge megyei önkormányzati szint mint területi helyhatósági szint - került kialakításra. A megyék hatásköre elsősorban az intézményfenntartásban merült ki, így nem kapták meg a helyi adókivetési jogát sem - lásd 1990. évi C. törvény a helyi adókról!138 A rendszerváltás után az 1949-es keltezésű, de 19891990-ben demokratizált 2012. január 1.-ig hatályban lévő Alkotmány (1949. évi XX. tv. 42.§), ${ }^{139}$ az Önkormányzati törvény (1990. évi LXV. tv.), valamint a kormányzat által

\footnotetext{
137 Érdekes módon kevésbé került elő a különböző szakmapolitikai vitákban, írásokban, hogy a megyei önkormányzati, megyei jogú városi térségi feladatkörök alsóbb szintre, a települési önkormányzatokhoz kerüljenek - erre egyébként differenciált hatáskör-telepítés révén a városi önkormányzatokra lehetett volna a legkézenfekvőbb a kompetencia-transzfer - Somlyódiné Pfeil Edit: A városok helye és szerepe a kistérségi közigazgatás rendszer kialakulásában (in: Magyar Közigazgatás 2003/7. 414. pp.)

${ }^{138}$ A megyei önkormányzatok tudatosan legyengített modelljét nevezte „lebegő megyének” Zongor Gábor önkormányzati szakértő és a Települési Önkormányzatok Országos Szövetségének a főtitkára az 1990-es évek elején; a kifejezés azt követően beépült a magyarországi önkormányzati diskurzusba.

${ }^{139} \mathrm{Az}$ eredetileg az 1933-as szovjet alaptörvény mintájára készült sztálinista magyar Alkotmányt (1949. évi XX. tv.) „demokratizálták” 1989-90'-ben (1989. évi XXXI. tv, majd 1990. évi XL. tv.). A régi Alkotmányt a 2011
} 
elfogadott, de a magyar jogban csak az 1997. évi XV. törvénnyel megerősített Helyi Önkormányzatok Európai Chartája által megfogalmazott önkormányzati alapjogok (autonómia) a törvények erejénél fogva illették meg az összes hazai, immáron közel 3200 települési önkormányzatot. ${ }^{140}$

1990-ben a korábbi megyei tanácsok - mint a legjelentősebb területi, térségi feladatellátó- és közszolgáltatásokat szervező igazgatási egységek -, szakigazgatási, szakhatósági feladatainak jó részét nem a tanácsi vagyon és más szempontok alapján jogutódnak minősülő megyei önkormányzatok, hanem a már meglévő vagy az újonnan létrejövő állami területi államigazgatási (dekoncentrált) „örökölték meg”, jelentősen erősítve ezzel a mindenkori központi kormányzati igazgatási, végrehajtási intézményrendszert. A III. Magyar Köztársaság 1990-ben kialakult közigazgatása ebben a kontextusban a helyi közfeladatok-, és közszolgáltatások szempontjából decentralizált (lásd a települési önkormányzati kompetenciák széles körét!); a térségi-területi hatáskörök tekintetében viszont sokkal inkább centralizált modellként jött létre (lásd a megyei önkormányzatok szük, valamint a kormányzati igazgatás - minisztériumi, kormányhivatali, központi hivatali - és a területi dekoncentrált államigazgatás széles kompetencialistáit!). A rendszerváltás után egy kétszintü önkormányzati rendszer (mikroszinten a települési önkormányzatok, a területi mezoszinten a megyei önkormányzatok) vált általánossá, így nem került sor sem a Kádár-korszakban megszüntetett járási szint önkormányzati típusú újraszervezésére - mint járási alsó-közép szintü önkormányzatok - amelyre számos nyugat-európai példát tudunk (pl. Egyesült Királyság), sem az 1984 után általánossá tett városkörnyéki igazgatás bárminemü141 továbbgondolására. Ez a közigazgatási szisztéma a meghatározó kompetenciaviszonyokkal (települési feladatok és intézmények; megyei önkormányzati feladatok és intézmények) időnkénti hangsúlyeltolódások mellett ${ }^{142}$ - rendkívül stabilnak bizonyult az 1990-2010 között. A 2010-2014 közötti törvényalkotási időszakban azonban jelentős változások történtek az állami és önkormányzati feladatellátás rendszereiben - erröl részletesen lásd később!

áprilisában a Magyar Országgyülés által elfogadott, 2012. január 2-vel hatályba lépő Magyarország Alaptörvénye váltotta.

140 A 2011. áprilisban a Fidesz-KDNP 2/3-os kormánypárti többsége által a parlamentben elfogadott új Alkotmány (Alaptörvény) viszont már nem nevesíti közvetlen a települési (község, város, főváros és kerületei) választópolgárok közösségének a helyi önkormányzáshoz való jogát.

141 A később tárgyalandó differenciált hatáskör-telepítés eszközével csak minimális mértékben delegáltak önkormányzati hatásköröket városokra, és még kevesebbet megyei jogú városokra.

${ }^{142}$ A megyei önkormányzatok forráselosztó pozícióinak erősítése az 1996-os területfejlesztési törvényt követően, majd 2006 után hatáskörveszítés (illeték-beszedés joga); számos államigazgatási hatáskör végrehajtási kompetenciájának áttelepítése a települési önkormányzatokra (jegyzői hatáskörbe adás). 
Az 1990-es „demokratikus hevület” legdirektebb, a helyi politikát és közigazgatást érintő történése az erős települési önkormányzatiság megteremtésének aktusa volt. Szakértői javaslatként még az is felmerült, hogy az idők folyamán a városokhoz csatolt egykori városok, községek önkormányzatiságát is vissza lehetne adni - pl. a Nagy-Budapestbe 1946-ban annektált korábban önálló településeknél [Kovacsics, 1990, 832. pp.] - bér ez semmiféle politikai támogatást nem kapott. Ugyanakkor megjelent a hatékonysági érv, hogy a települési (így községi) autonómia elvszerü megteremtése mellett tekintettel kell lenni a méretgazdaságossági szempontokra. A szakértők számára már az 1990-es évek elején világos volt, hogy Magyarországon az 1989-1990-es demokratizálódás jegyében a helyi és területi közigazgatás-szervezésnél a nemzetközi (elsődlegesen nyugat-európai) tendenciákkal ellentétes folyamatok játszódnak le, és a települési közösségek „öntudatra ébredése” (a széles települési önkormányzati autonómiával a hátuk mögött) a közigazgatási egységek elaprózódását fogja eredményezni [Somlyódiné, 1991, 750-752. pp.].

\section{V.3.1 Az „egy település egy önkormányzat” elv hatása az helyi feladatellátásra}

Államszervezési szempontból a demokratikus országok két lehetséges utat követnek a helyi önkormányzati feladatellátás megszervezése során. Az egyik megoldás a fragmentált önkormányzati rendszer, amely a helyi közösségek és feladatellátás dominanciájára épít, kiegészülve a települési önkormányzás együttmüködési, társulásos jogintézményeivel - a vezérlöelv, hogy a helyi önkormányzás alapegységei követik a településstruktúrát (,,egy település egy önkormányzat” elv). A másik megoldás esetében a településhálózat és települési struktúra elválik az önkormányzati közigazgatás szerkezetétől, létrehozva egy többé-kevésbé integrált helyi önkormányzati alapszintet, bizonyos paraméterek (általában a népességszám) alatt a „,öbb település egy önkormányzat” elvet érvényre juttatva - lásd a XX. század második felének nyugat-európai önkormányzati reformjait! ${ }^{143}$ Európában a fragmentált vagy integrált helyi alapszintü önkormányzati struktúraszervezést egészíti ki a nagyvárosi agglomerációs térségekben az utóbbi másfél-két évtizedben előtérbe került posztmodern városi kormányzás (lásd az ESDP vagy a Lipcsei Karta rendelkezéseit!), amelynek fontos attribútuma a nagyvárosokat és agglomerációs vonzáskörzetüket összefogó valamilyen közös jogi- és intézményi keretek - leggyakrabban a kétszintü föderatív agglomerációs tanácsok.

\footnotetext{
143 Önkormányzati integrációs reformok révén Belgiumban 78\%-al, Angliában 76\%-al, Svédországban 87\%-al, Németországban 67\%-al, Ausztriában 42\%-al csökkent a helyi alapszintü önkormányzatok száma 1950-1992 között M.R. Martins 1995-ös összehasonlító vizsgálata szerint (Pálné Kovács Ilona: Helyi kormányzás Magyarországon Pécs Dialóg Campus Kiadó, Budapest - Pécs, 2008) 37. pp
} 
Magyarországon az 1990-es önkormányzati kodifikáció elsődlegesen a települési autonómia alkotmányos-törvényi biztosítására fókuszált, ugyanakkor a hosszútávon fenntartható hatékony önkormányzati gazdálkodás intézményi keretfeltételei hamar devalválódtak nemegyszer éppen az országos politika jóvoltából - pl. a helyben befizetett SZJA visszaosztási arányának radikális csökkenése, elvonása az állam irányába már az 1990es évek folyamán. ${ }^{144}$ A települési önkormányzatok strukturális müködési problémái különösen a kistelepülések intézményi (humán- és anyagi erőforrások) kapacitáshiányában öltöttek testet. A törvényalkotó 1990-ben széles kompetenciakörben határozta meg a minden település számára kötelező jelleggel ellátandó feladat- és hatásköröket, függetlenül a kisebb települések valós a feladatellátó képességétől, kapacitásától - a települési önkormányzatok kötelezö feladatait tartalmazta az 1990. évi LXV. törvény 8.§ (1) pont. Gazdálkodási szempontból szektoriális nehézséget jelentett, hogy az Ötv. finanszírozási rendszere nem kezelte megfelelően a települési önkormányzatok határain túlnyúló közszolgáltatások (spillover) problematikáját. Ez az ellentmondás kiütközött mind a vonalas infrastrukturális, ún. ÁGÉSZ típusú (tömegközlekedés, energiaszolgáltatás, hulladékkezelés etc.), illetve a humán ún. ÁÉSZ típusú közszolgáltatások (egészségügyi, szociális, kulturális) területén. A magyarországi nagyvárosok (Budapest és a szélesebb, akár regionális vonzáskörzettel rendelkező megyei jogú városok) müködése során a saját nagyvárosi közintézményei révén ellátták a nem helyben lakó (értsd: bejelentett lakóhelyük nem a városban, hanem a városkörnyéki településeken vagy esetleg még távolabb található), de az ellátást igénybevevő lakosokat, anélkül hogy az így keletkezett többletfeladat finanszírozása egységesen megoldott lett volna [Péteri, 2007, 53. pp.]. Az ilyen jellegü nagyváros - városkörnyéki község kapcsolódásokat a gyakorlatban különféle egyedi közszolgáltató szerződésekkel (pl. a fővárosi agglomerációban a Budapesti Közlekedési Vállalat konkrét megállapodásai az agglomerációs településekkel a BKV Budapest közigazgatási határain túli szolgáltatásokról) valamint kapcsolódó pénzügyi megállapodásokkal igyekeztek kezelni, annak érdekében, hogy az érintett kistelepülések valamilyen módon és mértékben járuljanak hozzá a nagyváros megnövekedett müködési költségeihez. Azonban ezek a kooperációk esetleges jelleggel alakultak ki, a korábbi városkörnyéki igazgatási egységek megszüntek a rendszerváltás időszakára, az Ötv. pedig a kötelező társulások helyett csak önkéntes társulásos jogintézményeket határozott meg 1990-ben.

144 1990-ben a helyben befizetett SZJA 100\%-át kapták vissza az önkormányzatok a parlamenttől a központi költségvetési törvényen keresztül, ez már 1992-re 50\%-ra, 2000-re 40\%-ra-forrás: éves költségvetési törvények 


\section{V.3.2 Kapacitás- és ellátásbeli problémák a települési önkormányzatok szintjén}

Magyarországon az 1990-ben létrehozott helyi önkormányzati rendszer a települések választópolgáraira, mint helyi közösségekre bízta a helyi alapszintü önkormányzás jogát, ezzel létrehozva a fragmentált helyi (települési) önkormányzati alapszintet. Ez a modell a települési egységek afféle „közösségi önkormányzási lelki igények” kielégítésére épülve, sok szempontból figyelmen kívül hagyta a településközi kapcsolatok, a körzeti-térségi közös feladatellátás valamint kifejezetten a nagyvárosi agglomeráció és szuburbanizáció folyamatait a helyi közigazgatás és közfeladat-ellátás tekintetében. Nemzetközi példák bizonyítják, hogy az elaprózott helyi önkormányzati rendszereknél az apró önkormányzati egységek kapacitásbeli nehézségeit a települési szinthez közel eső területi decentralizált (önkormányzati járás, megye etc.) és/vagy a dekoncentrált (állami területi végrehajtó hatóságok) intézményi hatáskörök kiterjesztésével orvosolhatják.

Magyarországon hamar az önkormányzati rendszer alapkonfliktusává vált a kistelepülések (községek, kisvárosok) kapacitásbeli hiánya. Fontos leszögezni, hogy az elmúlt 50-60 év önkormányzati integrációs trendje (kistelepülési önkormányzatok összevonása) ellenére több régi EU-tagállam (pl. Franciaország) helyhatósági szisztémája a fragmentált települési önkormányzatiságon nyugszik továbbra is, mégis kiszámíthatóbb gazdálkodás és müködés jellemzi ezeket, ahol nem terhelik a rendszert súlyos finanszírozási és ellátási anomáliák. A kiadási oldal nyers mutatószámai ráadásul nem is jellemzik tökéletesen egy ország önkormányzati szektorának valós hatékonyságát. Külön nemzeti szabályozás kérdése, hogy adott államban mit sorolnak az önkormányzati feladatellátáshoz- és költségvetési rendszerhez - pl. a dán önkormányzati szektor kiadásait jelentősen megnöveli, hogy a társadalombiztosítási kiadások döntő hányadát a helyhatóságokhoz rendelték; a cseh önkormányzati rendszerben az önkormányzati fenntartású közoktatási intézmények pedagógusainak fizetését a több mint két évtizede magyarországi gyakorlattal (1990-2013) ellentétben közvetlen a központi költségvetés fedezte a helyhatóságok helyett [Illés, 2005, 2627. pp.]. ${ }^{145}$

A probléma az egyes településtípusok közötti jelentős kapacitásbeli differenciákban gyökerezett. Magyarországon az egy helyi (települési) önkormányzatra jutó átlagos lakosságszám átlagosan 3100 fő körül alakult. Ez a szám a leginkább integrált európai

\footnotetext{
${ }^{145} 1990$-től a pedagógusfizetések az állami költségvetésen keresztül, de az önkormányzatoktól érkeztek, 2013 -tól azonban a Klebelsberg Iskolafenntartó Intézet (KLIK) a munkáltató.
} 
helyhatósági szisztémát müködtető Nagy-Britanniában 120 ezer fő, de a skandináv államoknál is több tízezer lakos. Bár ez a 3100 fö/település mutatószám regionális értelemben nem kirívó - Szlovákiában 1700 fö/település; Csehországban 1500 fö/település - viszont a kapacitásbeli, és az abból következő müködési problémák is hasonlóan alakultak ezekben az országokban. Horváth M. Tamásnak az önkormányzatok gazdasági kapacitásképességét vizsgáló 2007-es tanulmányában szerepelt egy szerzői számítás a 2005. évi Pénzügyminisztérium és KSH statisztikák alapján - a mutatószám alapja az 1 lakosra jutó önkormányzati bevétel, ez a következők szerint alakult 2005-ben [Horváth M., 2007, 23. pp.]:

\begin{tabular}{|l|l|l|l|l|}
\hline & Községekben & Városokban & $\begin{array}{l}\text { Vidéken } \\
\text { (megyével } \\
\text { együtt) }\end{array}$ & Fövárosban \\
\hline $\begin{array}{l}1 \quad \text { lakosra jutó } \\
\text { átlagos bevétel }\end{array}$ & $171874 \mathrm{Ft} /$ fö & $273705 \mathrm{Ft} / \mathrm{fö}^{\prime \prime}$ & $281165 \mathrm{Ft} / \mathrm{fö}$ & $382070 \mathrm{Ft} / \mathrm{fö}$ \\
\hline
\end{tabular}

3. táblázat: 2005. évben az 1 lakosra jutó átlagos önkormányzati bevétel (Horváth M., 2007, 23.pp.)

A táblázat magában foglalja a legfontosabb kapacitásbeli összefüggést: minél nagyobb egy település, annál nagyobb bevétel-generáló képességekkel rendelkezik az adott önkormányzat, ezért fajlagosan jóval több forrás jut a saját bevételekből az önkormányzat által ellátott önkormányzati- és államigazgatási feladatokra, közszolgáltatásokra - különösen igaz volt ez Budapest kerületei esetében. Nagyobb önkormányzati bevételek, magasabb szintü közszolgáltatások, nagyobb mozgástér a települési fejlesztésekhez, átgondolt vagyongazdálkodás és kreatív gazdálkodás kihasználva az önkormányzatok számára a költségvetési intézményekhez képest jóval szabadabb gazdálkodási lehetőségeket - az önkormányzat részvétele gazdasági társaságokban; hitelfelvétel és kötvénykibocsátás; kiterjedt vagyongazdálkodás; privatizáció, contracting out, koncessziós, PPP (Public Private Partnership). ${ }^{146}$ Másrészt a nagyobb településeken az önkormányzatok eleve szélesebb és magasabb színvonalú emberi erőforrás-állománnyal rendelkeznek: sűrün specializált önkormányzati hivatali és intézményrendszer (vagyonkezelő holdingok, fejlesztési projektcégek etc.) és akár a magánszektorral is versenyképes jövedelmek. Ez önmagában is jelentős versenyelőny a városok, nagyvárosok számára a csak néhány munkatárssal vagy saját hivatali szervezettel nem is rendelkező kistelepülésekkel szemben (lásd a körjegyzöségek

\footnotetext{
146 Ugyanakkor a 2000-es évek végi nagy önkormányzati eladósodási „hullámnak” az egyik oka éppen a nagyobb önkormányzatok által kihasznált - akkor még szabályozatlan - kötvénykibocsátás volt, amivel anyagi és megfelelő humán erőforrás hiányában a kisebb települések (községek) nem tudtak/kívántak élni.
} 
önálló önkormányzati hivatallal nem rendelkezö településeit!). Az 1996-ban megalkotott önkormányzati adósságrendezés [1996. évi XXV. tv] gyakorlata is csak kistelepüléseket érintett. Egy 2009-es tanulmány összegezte az 1996-2008 között lezajlott önkormányzati adósságrendezéseket, és az érintett települések közül a Pest megyei (fővárosi agglomerációs) Páty volt a legnépesebb közel 5000 fös lakossággal, a többi közel kéttucat település egy-két kivételtől eltekintve mind 3000 lakos alatti község volt. Ugyanakkor az önkormányzatok 2010-re radikálisan megnövekedett adósságállomány miatt 2013-ban már 14 település került adósságrendezési eljárás alá - a 2012-2013-as adósságkonszolidációról lásd a fejezetben később! [Kovács-Vigvári, 2009, 28. pp.; Lentner, 2014, 336. pp.].

Zongor Gábor a Települési Önkormányzatok Országos Szövetségének (TÖOSZ) a főtitkára, a következőképpen értékelte a 2011-es önkormányzati kodifikációt: amíg az 1990-es évek elején még az ,egyedül mindenre képesek vagyunk” szemlélet jellemezte a polgármestereket és a képviselőtestületeket, addig különösen az 1996-os területfejlesztési törvény hatálybalépése után már ,,az egyedül nem megy igazsága” vált a meghatározóvá. A fragmentált településszerkezet problémáit tetézte a mindenkori parlament és kormányzat azon káros gyakorlata, hogy valódi differenciálás nélkül egységesen „zúdította rá” a különböző hangsúlyozottan államigazgatási feladatok ellátást az önkormányzati szektorra (jegyzőkre és önkormányzati apparátusokra), miközben a feladatellátáshoz szükséges forrást nem biztosította elégséges mértékben a központi szint [Zongor, 2012, 1. pp.]. Egyre inkább kinyílt a feladattelepítés illetve a finanszírozás közötti olló.

\section{ÖNHIKI és a „6/3.” - kiegészítő támogatások az önkormányzatok napi müködéséhez}

Az önkormányzati kapacitáshiány korai megnyilvánulása volt, hogy sok település képtelen volt a müködési költségeket kigazdálkodni - ez különösen az érdemi saját bevétellel nem rendelkező községeket érintette. A központi költségvetési politika ezért hamar rákényszerült az ún. müködési célú kiegészitő pénzügyi támogatási rendszerek alkalmazására. 1993-ban került bevezetésre az ún. ÖNHIKI ${ }^{147}$ alap, amit eredetileg a valóban korlátozott bevételi lehetőségekkel rendelkező kistelepülések, községek megsegítésére rendelték, így a bevezetés évében már közel 200 önkormányzat részesült belöle. Ez az arány 2008-ra már 2000 település felett volt, 2010-ben az önkormányzatok kétharmada volt ÖNHIKI-s a 2012. költségvetésre évben pedig 1216 település volt érintve. ${ }^{148}$ Az ÖNHIKI rendszerét egészítették ki a 2000-es évek közepén a leginkább kiszolgáltatott települések kvázi kormányzati azonnali

\footnotetext{
147 ÖNHIKI - önhibáján kívül hátrányos helyzetben lévő önkormányzatok

148 Forrás: 1216 önkormányzat kapott ÖNHIKI-s támogatás - in: Magyar Polgármester online folyóirat (http://www.magyarpolgarmester.hu?site $=104 \& \mathrm{c}=615 \& \mathrm{menu}=\mathrm{c02}$ )
} 
„gyorssegélyével” az ún. „müködésképtelen önkormányzatok egyéb támogatása” címszó alatt az önkormányzatokért felelős miniszteri keretösszeggel. A 2000-es évtized végére roppant méretűre terebélyesedő önkormányzati „konfliktuskonténer” sokatmondó indikátorává vált a városok érintettsége az ÖNHIKI-s keretből: 2010-ben 51 db, 2011-ben már 156 városi önkormányzat részesült belőle. Az elmúlt években olyan megyei jogú városok kaptak támogatást az ÖNHIKI-ből, mint Miskolc vagy Salgótarján [Domokos, 2012, 167. pp.; Ivády, 2010].]. 2014-től megváltozott a költségvetés kapcsolódó struktúrája, és az ÖNHIKI helyett az ún. Helyi önkormányzatok müködési célú költségvetési támogatásai melléklet rendelkezik 9 előirányzat keretében - pl. gyermekszegénység; lakossági víz, ivóvíz- és csatornaszolgáltatás támogatása [2014. évi C. tv. Magyarország 2015. évi központi költségvetéséről 3. melléklet I. 1-9.].

Önkormányzati adósságválság- és konszolidáció 2010 után

A 2000-es évtized második felében a korábbi - sokak szerint a felelőtlen szektoriális deviza-eladósodás, majd a 2008 végén kirobbanó pénzügyi- és gazdasági világválság hatásaként is - jelentősen megduzzadt az önkormányzati adósságállomány (hitelek, kötvények ${ }^{149}$, amely éppen a hitelintézetek szemében sokkal inkább megbízhatónak tartott nagyobb helyi önkormányzatokat - különösen a fővárosi kerületeket és a megyei jogú városokat - érintette. A témáról bővebben az Állami Számvevőszék Kutató Intézetének 2009. márciusi „Pénzügyi kockázatok az önkormányzati rendszerben” beszámolója értekezik. Ebben egy összefoglaló táblázat jelzi, hogy 2007 végére az egy lakosra jutó önkormányzati adósság a Fővárosi Önkormányzat, valamint a megyei jogú városok körében duzzadt meg radikálisan [ÁSZ, 2009, 21. pp.].

Az eladósodás realitásából kiindulva a 2011-ben elfogadott Magyarország helyi önkormányzatairól szóló 2011. évi CLXXXIX. törvény (Mötv.) a korábbi jogi szabályozáson jelentősen szigorítva állami-kormányzati engedélyhez kötötte a helyhatóságok kölcsönfelvételét. Továbbá a korábbi költségvetési finanszírozás helyett egy új típusú szigorúbb logika („feladatfinanszírozás”), valamint 2011 előtthöz láthatóan szűkebb kompetencialista - erről részletesen lásd késöbb! - került meghatározásra. A törvényi szigorítás mellett a helyi önkormányzatok gazdasági stabilizálásához és a meglévő adósságállomány újratermelődésének megakadályozására (az önkormányzati rendszer

\footnotetext{
149 Az önkormányzati adósság megnövekedésében a pontatlan szabályozás is szerepet játszott, mivel a kötvénykibocsátásról - mint speciális hitelfelvétel - nem rendelkezett az Ötv., így nagyobb önkormányzatok (föváros, kerületek, megyei jogú városok, megyei önkormányzatok) bocsátottak ki akár fejenként többmilliárd $\mathrm{Ft}$ értékben 5-8 éves lejáratú kötvényeket.
} 
adósságállománya 2010 végén 1247 milliárd Ft volt) a második Orbán-kormány az önkormányzatok adósságkonszolidációját, egészen pontosan az önkormányzati adósságállomány állami átvállalását választotta. Ennek nyitánya a megyei önkormányzatok mintegy 170 milliárd Ft-os adósságának átvállalása volt - ennek részleteiről lásd később „A megyei önkormányzatok 2010 után” címü részfejezetben! Az önkormányzati adósságrendezés azonban elsődlegesen a települési önkormányzatok felhalmozódott tartozásainak átvállalására irányult. Ezt a miniszterelnök 2012 őszén jelentette be: az 5000 lakos alatti települések teljes körü, 100\%-os konszolidációban, az 5000 lakosnál népesebb települések (városok, megyei jogú városok, fővárosi kerületek és a Fővárosi Önkormányzat) arányosan részleges átvállalásban részesültek. A települési önkormányzati szektor eladósodásának mértékét jelzi, hogy csak az 5000 lakos alatti településeknél 1710 községi, nagyközségi önkormányzat volt érintve. A 2014 tavaszán befejeződő önkormányzati adósságkonszolidáció során az állam által átvállalt teljes adósságállomány értéke 1344,4 milliárd Ft volt [Lentner, 2014, 334-340. pp.].

\section{V.4 Társult és telepített közös önkormányzati feladatellátás 1990 után}

Magyarországon a helyi közigazgatásban (önkormányzatok, tanácsok) komoly múltra tekintenek vissza a különböző társulásos megoldások. Már az 1870-es és 1886-os községi törvények tartalmaztak rendelkezéseket, így a vármegyék „körökbe” szervezhették a feladataikat önmaguktól ellátni képtelen községeket különböző hatósági és egyéb tevékenységek ellátására - pl. a körgyám vagy a körorvos, előbbi bizonyos gyámügyi, utóbbi az orvosi alapellátásokért volt felelős. A dualizmus alatt majd a két világháború közötti időszakban a kötelező társulások mellett az önkéntes társulás is kedvelt alkalmazott forma volt a helyi közfeladatok ellátása során (pl. vízszabályozási társulások). A tanácsrendszer időszakában sokáig nem hagytak választási lehetőséget a helyi tanácsok számára a társulásokban való részvételről. A közös tanácsok szervezéséről felső szintű jogszabályokkal döntöttek, és jelentős integráció zajlott le, különösen 1971 után - ekkor történt egyértelmü elmozdulás az egy település egy tanács elvröl a több település egy tanács elv irányába. Igazán az 1970-1980-as években kezdett megjelenni a megyei és települési tanácsok körében az önkéntes együttműködés gyakorlata, nem meglepő módon elsősorban a fragmentált településszerkezetü térségekben, megyékben (pl. Baranya) [Hoffman, 2011, 29. pp.].

A rendszerváltó parlament már az 1990-es Ötv. kodifikációja során tisztában volt a széttagolt településszerkezeti viszonyokkal, valamint az új települési önkormányzati szisztéma fragmentált jellegével. Ezért nem meglepő módon, igyekezett megkönnyíteni a 
lehetőséget az önkéntes önkormányzati társulások számára: egyrészt az 1989-1990 során több ütemben is demokratizált Alkotmányban megerősítették az önkormányzati társulás alkotmányos alapjogát - [1949. évi XX. tv. 44/A. § (1) h)], valamint az Önkormányzati törvény kodifikálta az önkéntes önkormányzati társulások létrehozásának jogát - benne önkormányzati hatósági társulás, a közös intézményfenntartó társulás, a közös képviselötestület, ${ }^{150}$ valamint a körjegyzöségek ${ }^{151}$ társulásos jogintézményeivel - [1990. évi LXV. tv. 39-44.§]. Azonban a tanácsrendszer negatív emlékezete, valamint az 1990-ben „kivívott” települési önkormányzati autonómia és a társulások önkéntes jellege sokáig visszafogta a települések „kedvét” a társulásoktól, s vele a közös feladatellátástól. Az 1990-es sokak szerint túlzottan decentralizált és a települési autonómiát támogató önkormányzati szabályozás egyértelműen nem kedvezett a fragmentált település-hálózattal és térszerkezettel bíró Magyarországon a településközi önkormányzati kooperációk számára. Különösen nem az eltérő jogállással (városok, községek) rendelkező települések között, aminek talán érthető történeti oka volt, hogy a tanácsrendszer időszakában nagyon hosszú ideig kizárólag csak az azonos szintü tanácsok köthettek egymással együttmüködési megállapodást vagy erősebb esetben közös községi tanácsot alkottak [Somlyódiné, 1991, 1007. pp.].

A rendszerváltó parlament már az 1990-es törvényi kodifikáció során felismerte a közjogilag immáron függetlenné vált települések önállóságából fakadó működési veszélyeket. Habár a települési autonómia szellemében leépítette a tanácsrendszer kötelező jellegü településközi intézményi kooperációit, de a már felsorolt önkormányzati társulási jogintézmények révén igyekezett mégis valamilyen módon az elejét venni az önállósodott kistelepülések várható müködési kapacitáshiányának. Érdemi különbség volt, hogy a korábbi kötelező kooperációs intézményi lehetőség (közös tanácsok) helyébe lépő új társulásokat az Önkormányzati törvény csak önkéntes alapon határozta meg [1990. évi LXV. tv. 39-44.§]. ${ }^{152}$ Az Ötv. társulásos intézményei közül a jegyzői - s vele a viszonylag kisszámú jegyzői önkormányzati feladatok mellett a helyhatóságokhoz rendelt államigazgatási kompetenciák feladatok közös megszervezésére irányuló körjegyzöség volt a leginkább megfeleltethető a

\footnotetext{
150 A közös képviselötestület társulási megnevezést az egykori községi közös tanácsokra hajazó negatív konnotáció miatt módosították az ún. társult képviselötestület társulási jogintézményre az 1997-es Ötv. módosítás során. [1997. évi CXXXV. tv.]

${ }^{151}$ Az Ötv. 1990-es önkormányzati társult jogintézményei közül egyedül a körjegyzőségek rendelkeztek az egypártrendszer elötti intézményi hagyományokkal, a körjegyzőségek nagyszámban müködtek már a Horthykorszakban.

${ }^{152}$ Kötelező jelleggel egyedül az 1000 lakos alatti aprófalvakat rendelte a törvény körjegyzöségbe -1990 . évi LXV. tv. 39.§ (1) - ugyanakkor az első években az 1000 fönél kisebb lakosú települések 34,6\% mégis önálló polgármesteri hivatalt hozott létre. - Frücht Pál: A körjegyzöségek müködésének föbb tapasztalatai (in: Magyar Közigazgatás 1992/12. szám) 730. pp.
} 
korábbi községi közös tanácsok hivatali tevékenységének. Már ekkor sok kistelepülés felismerte az „egy település egy önkormányzat” elvböl fakadó üzemgazdaságossági problémákat, és a körjegyzőségi jogintézmény hatékony munkaszervezési lehetőségeit: az 1990 decemberében megválasztott első települési képviselőtestületek közül 1526 db már 1991 elejére 529 körjegyzőséget hozott létre - nem meglepő módon az érintett települések túlnyomó többsége a tanácsrendszer idöszakában már érintve volt a községi közös tanácsi szervezésben, müködésben. Ugyanakkor élve a jogszabályi lehetőségekkel 1992 elején 23 körjegyzőség szünt meg az alkotó települések testületeinek döntései alapján, ezzel mintegy 87 önkormányzat „kényszerült rá” a hivatali teendők saját hatáskörben való ellátására (önálló polgármesteri hivatal felállítása). ${ }^{153}$ Nagyon elenyésző számban, de 17 városi önkormányzat vállalta a rendszerváltás utáni időszakban, hogy a városi jegyző körjegyzőként ellátja a vonzáskörzetbe tartozó községek igazgatási teendőit. A körjegyzöségi formában müködö város - városkörnyéki községi igazgatási kapcsolatok túlnyomó része az ún. város-község közös tanács keretében már funkcionáltak a tanácsrendszer utolsó időszakában. 1993-ban már 23 olyan körjegyzőség volt, amelynek igazgatási központja városi jogállású településen található, ezen városok néhány kivételtől eltekintve mind 1983 után szereztek városi címet [Fürcht, 1992, 725. pp.; Szigeti, 1994, 615. pp.]. Az Önkormányzati törvény átfogó 1994-es módosításának része volt, hogy amennyiben a körjegyzőség székhelye nagyközség vagy városi jogállású település, akkor a körjegyzői feladatokat mindenképpen a székhelyközpont település polgármesteri hivatala látja el [1994. évi LXIII. 25.§ (3)] - [Fürcht, 1994, 719. pp.].

A települési önkormányzatiság törvényi megteremtése mögött a rendszerváltó új parlamenti elit politikai konszenzusa (,adjuk meg az emberek számára helyben a demokráciagyakorlás - saját önkormányzathoz való jog - lehetöségét”) állt, amely csakhamar kvázi „örök politikai igazsággá” transzformálódott. Az „,egy település egy önkormányzat” egyszersmind vonatkozási pont és politikai tabu mind a mai napig a meghatározó politikai erők programjaiban, így nem meglepő, hogy az elmúlt negyedszázadban a kormányzásra esélyes politikai pártok közül még csak meg sem kérdőjelezték a települési önkormányzatiság gondolatát, a jelenleginél integráltabb önkormányzati rendszert (önkormányzatok

\footnotetext{
${ }^{153}$ Egy rövid megjegyzést megér, hogy az 1990-es, de a 2000-es években több alkalommal felmerült az ún. csatlakozó község intézményének a bevezetése. Ez azt jelentette volna, hogy egy község amennyiben képtelen nem képes megteremteni a működési minimális elemeit sem, akkor a település nevének és jelképeinek megtartása mellett úgy csatlakozhatna egy nagyobb önálló települési önkormányzathoz, hogy az gyakorlatilag minden önkormányzati müködési formát (a képviselettől a végrehajtásig) gyakorolna a csatlakozó község helyett, de a jogintézmény csak koncepció maradt, sosem jutott el a parlamenti kodifikációig.
} 
összevonása) ajánlva a választópolgárok számára. ${ }^{154}$ Miközben a kis versus nagyobb helyi önkormányzat polémia folyamatosan jelen volt a helyi közigazgatással foglalkozó szakértői körökben.

Az alábbiakban összegezhetjük az önkormányzati kooperációkat az 1990-1995 időszakban:

1. Az Ötv. által szabályozott önkormányzati társulások (az Ötv. által meghatározott négy típus): 499 körjegyzőség 1388 tagönkormányzattal (1994); nagyszámú hatósági igazgatási társulások, amely kooperációk többsége még a tanácsrendszer időszakából eredeztethető; meglehetősen kevés intézményfenntartó társulás (1992-ben kb. 120 db); nagyon ritka közös képviselőtestület - ezek száma 1992-ben alig 20 db. ${ }^{155}$

2. Egyéb - nem az Önkormányzati törvényen alapuló - önkormányzati társulások: általában 2-nél több helyhatóságot tömörítettek magukba vagy közös feladatellátás (pl. szemétszállítás) vagy fejlesztési célok (telefon-bekötés, úthálózat fejlesztése) alapján.

3. Kistérségi fejlesztési társulások: a bizonytalan jogi-szervezeti paraméterek (ekkor még nem volt lehetőség jogi személyiség nélküli társulási megoldásra) ellenére az MTA RKK $^{156} 1994$-es felmérése szerint már 140 kistérségi fejlesztési társulás mintegy 1800 települési önkormányzatot érintve. Ezek létrejöttében kiemelt szerepet játszottak a különböző elnyerhető fejlesztési források, elkülönített állami pénzalapok (az 1990-es években Területfejlesztési Alap, Foglalkoztatási Alap, az Európai Uniós PHAREprogram etc.). ${ }^{157}$

4. Egyéb speciális gazdasági alapú kooperációk: több önkormányzat közös tulajdonában lévő közszolgáltató gazdasági társaság (erős gazdasági érdekelteltség a tulajdonos helyhatóságok részéröl; általában városi önkormányzati szolgáltató vállalat (pl. szemétszállítás) megállapodás alapján szolgáltat más önkormányzatok területén. Ezekben a cégekben a kizárólagos önkormányzati tulajdon nem feltétel, így klasszikus

\footnotetext{
${ }^{154}$ Az egyetlen kivétel a 2010-es parlamenti választási kampányban a Magyar Demokrata Fórum volt, amely választási gazdasági programját a Horn-kormány egykori pénzügyminisztere Bokros Lajos jegyezte: a Munka és méltóság = Modern Magyarország című választási programban felvetették a 3200 települési önkormányzat helyébe állítandó 240-280 számú járási önkormányzatot vizionált. A kistelepüléseket csak elöljárók képviselték volna, egy sokkal integráltabb helyi önkormányzati alapszintet létrehozva (,, több település egy önkormányzat” elv) http://www.origo.hu/itthon/valasztas2010/kampanynaplo/20100124-valasztas-2010-az-mdf-valasztasiprogramja.html

${ }_{155}$ Az 1997-es Ötv. módosítás során a közös képviselőtestület jogintézménye ún. társult képviselőtestületre változott, de ez érdemben nem tette népszerủvé ezt a nagyon erős társulásos formát, így 2005 -re 4 db, 2006-ra pedig 3 db társult képviselőtestület maradt Magyarországon - [Hoffman, 2011, 29. pp.].

${ }^{156}$ MTA Regionális Kutatások Központja

$157 \mathrm{Az}$ 1996. évi XXI. tv. a területfejlesztésröl és területrendezésről adott először lehetőséget az ún. területfejlesztési társulások számára, amelyek különböző hatásfokkal kezdtek el müködni, majd szerepüket a 2004 után elterjedő többcélú kistérségi társulások vették át.
} 
gazdasági társaságok, akár magánszemélyek is megjelenhetnek tulajdonosként, feladatellátóként [Horváth M., 1995, 570-573. pp.; Hoffman, 2011, 29-30. pp.].

Az eredeti társulásos jogintézmények közül az intézményi társulások (mint közös intézményfenntartás) váltak a leginkább alkalmazott társulási eszköz. Ezek száma 1992-ben még csak $120 \mathrm{db}$, addig 2003-ra már 1274, a 2005. évre 1586 db-ra emelkedett - utána viszont a meredek emelkedése erősen mérséklődött a többcélú kistérségi társulások térnyerésével - ezekröl részletesen lásd később! [Hoffman, 2011, 30-31. pp.].

\section{V.4.1 Differenciált hatáskör-telepítés az önkormányzati szektorban}

Az Önkormányzati törvény 1990-es kodifikálásakor a kötelező települési önkormányzati feladatok-, és hatáskörök egységesen kerültek meghatározásra függetlenül az adott helyhatóság méretétől, gazdasági és társadalmi paramétereitől, valamint települési önkormányzati típusától - [1990. évi LXV. tv. 8.§]. Ugyanakkor a törvényalkotó felismerve a realitásokat, egyrészt már az eredeti kodifikáció során lehetővé tette az önkormányzatoknak, hogy különböző önkéntes társulási formákat hozzanak létre, másrészt az Ötv.-be a 6 . § (2) bekezdés útján beépítette az ún. differenciált hatáskör-telepités jogi eszközének lehetőségét, ami szerint: „törvény a nagyobb lakosságszámú és teljesitöképességü önkormányzatoknak más helyi önkormányzatokhoz képest - több kötelezö feladat-és hatáskört állapithat meg..."

Az 1990-es Önkormányzati törvény mellett szükséges szólni az 1991. évi XX. a helyi önkormányzatok és szerveik, a köztársasági megbizottak valamint egyes centrális alárendeltségü szervek feladat- és hatásköréröl szóló törvényröl, amit általában ,hatásköri törvényként” ismer a közigazgatás és a közvélemény. Ez tovább pontosítja az önkormányzati kompetenciákat, benne néhány kifejezetten a főváros és megyei jogú városi önkormányzatokhoz rendelt jelenleg hatályos feladatkörökkel, ezek a következők:

a) Nevesített kompetenciák hozzárendelése a Fővárosi Önkormányzathoz (köztemetőkhöz, települési folyékony hulladék, közterület-tisztaság és lomtalanítási akciók [1991. évi XX. törvény 18-20.§].

b) Az ipar- és kereskedelmi igazgatás terén nevesített fővárosi és megyei jogú városi hatáskörök: energiaellátási tanulmány. Csak a főváros kapott feladatokat az idegenforgalmi területhez kapcsolódóan [1991. évi XX. törvény 65-66.§].

A meghatározott típusú önkormányzatok irányába történő differenciált önkormányzati (és persze államigazgatási) hatáskör-telepítés révén lehetőség teremtődött az önkormányzatok 
közötti valós különbségek - adottságok, pénzügyi paraméterek, a rendelkezésre álló dologi és humán eszközök, erőforrások - kezelésére a feladattelepítés tekintetében. Ennek alkalmazása révén meghatározott közfeladatot csak bizonyos típusú (legalább városi) helyhatóság számára lehetett delegálni. Ugyanakkor a központi jogalkotás, különösen a rendszerváltás utáni évtized során rendkívül visszafogottan bánt az eszköz alkalmazásával [Somlyódiné, 2001, 147. pp.]. Csak az 1990-es évek közepétől-végétől kezdik alkalmazni a differenciált hatáskör-telepítést bonyolultabb szakigazgatási feladatoknál, mint például az építéshatósági ügyek. Csefkó Ferenc egy 2000-es tanulmányban számszakilag összegezte szakigazgatási ágazatonként a községi, városi, megyei jogú városok feladatkatasztereit. Az ágazatok többségénél mindössze 1-2 konkrét differenciált hatáskör volt kimutatható. A legtöbb ilyen példa a belügyi, a közoktatás és a munkaügyi területeken adódott, de sehol sem haladta meg a 4-5 hatáskört. Jellemző a jogintézmény alacsony kihasználtságára, hogy a speciálisnak mondható egészségügy, az ipar- és kereskedelmi vagy a környezetvédelmi ágazatokban semmilyen különbség nem adódott az önkormányzatokhoz rendelt hatáskörök tekintetében. A témával foglalkozó több szakértő felvetette, hogy a differenciált hatáskör-telepítés egy tagoltabb (a község - város - megyei jogú város felosztást tovább strukturáló) települési önkormányzati hierarchiában volna igazán hatékony eszköz. Így maga Csefkó is 7 db község- és 4 db városkategóriát (3000-50.000 lakos között) javasolt; a megyei jogú városokat pedig a regionális (megyén túlmutató spill-over hatások) szerepkör megléte vagy nem léte alapján különböztette volna meg [Csefkó, 2000, 72-78. pp.].

Véleményem szerint egy hatékonyan alkalmazott differenciált hatáskör-telepítés fogékony jogalkotási közeg és gyakorlat mellett eredményes eszköz lehetett volna a hatékonyabb önkormányzati feladattelepítés és feladatellátás irányába. Ennek révén a valós települési demográfiai, társadalmi és gazdasági paraméterekhez jobban igazodó hatáskörtelepítés, s vele önkormányzati kompetencia-rendszer és igazgatás valósulhatott volna meg. A differenciált hatáskör-telepítés lépcsőzetes inkrementális folyamata révén az agglomerációs térségekben akár néhány parlamenti ciklus folyamán kiépülhetett volna egy speciális nagyváros-térségi igazgatás keretei. Kéki Zoltán - az ezredforduló időszakában Kaposvár Megyei Jogú város jegyzője -, egy kiterjedt differenciált hatáskör-telepítési rendszerhez tételes javaslatcsomagot adott: lakásgazdálkodás; helyi tömegközlekedés; helyi tűzvédelem; az óvodai nevelés; az általános iskolai oktatás és az egészségügyi alap- és járóbeteg ellátás területén. Valamint kifejezetten a megyei önkormányzatoktól átvállalt feladatok-, intézmények fenntartása (pl. középfokú, térségi oktatási intézmények; fekvőbeteg egészségügyi ellátók - kórházak) [Kéki, 2000, 157-161. pp.]. Összességében elmondható 
tehát, hogy törvényalkotó a differenciált hatáskör-telepítés eszközét kifejezetten a főváros/megyei jogú város irányába nagyon ritkán alkalmazta. Helyette sokkal inkább az alsóközépszintü térségi -, s vele a városok környező településeket is kiszolgáló feladatellátását erősítette ezzel a speciális jogalkotási eszközzel, amint az a következő néhány példa is bizonyítja:

\section{Építésügyi igazgatás}

Sajátos megosztott feladatstruktúra alakult ki az építésügyi igazgatásban, az állami szervek mellett a települési jegyzők is szereztek hatásköröket 1990-ben (engedélyezés, szankcionálás). Már az 1990-es években jelentkezett a probléma, hogy számos önkormányzati építéshatósági ügyintéző szakmai felkészültsége nem megfelelő - a jelenségről bővebben! [Imre, 1994, 140-141. pp.; Szép-Klonkay, 1996, 101, pp.]. A helyi építésügyi hatósági igazgatás még hatékonyabbá tétele érdekében az 1997-es „építésügyi” törvényben ${ }^{158}$ élve a differenciált hatáskör-telepítés eszközével az ún. kiemelt épitésügyi hatósági ügyekben való első fokú eljárást a városi (Budapesten a fővárosi kerületi) önkormányzat jegyzőjére szignálta a törvényalkotó.

\section{Okmányirodai ügyintézés}

Az okmányirodai feladatokat ellátó ún. körzetközponti (értsd: városi) önkormányzatok körét és illetékességi területét a 143/1999. (IX. 15.) Korm. rendelet jelölte ki első ízben. Az okmányirodákhoz rendelték a különböző hivatalos hatósági igazolványok kiadását és a közlekedéshatósági jogköröket - gyakorlatilag az önkormányzati hatósági ügyintézés jelentős szelete kapott ezzel városkörnyéki/körzetközponti igazgatási jelleget. Az okmányirodai területi beosztás eltért a statisztikai kistérségi struktúrától - 2002. január 1.-től 252 (önkormányzati) okmányiroda és gyámhivatal intézte a legnagyobb forgalmú hatóság állampolgár közvetlen ügyfélforgalmat. [Farkas, 2001, 626-630.]. A 2010 utáni roppant önkormányzat-állam irányú hatáskörtranszfernek az okmányirodai ügyintézés is a részévé vált, a járási kormányhivatalok szervezeti rendszerébe került beillesztésre [2012. évi XCIII. tv].

\section{Gyermekvédelmi szakellátások}

A gyermekek védelméröl és a gyámügyi igazgatásról szóló 1997. évi XXXI. törvény strukturálta újra a gyermekvédelmi igazgatási rendszert, aminek fókuszában az ún. területi

\footnotetext{
158 1997. évi LXXVIII. törvény az épített környezet alakításáról és védelméröl
} 
gyermekvédelmi szakszolgálat került, amely kialakítását és müködtetését a törvény kifejezetten a megyei illetve a megyei jogú városi önkormányzatokhoz rendelte [Rétiné-Rigó, 2001, 699-700.]. A területi gyermekvédelmi szakszolgálatok fenntartói jogosítványai megváltoztak 2010 után - így Budapest és a megyei jogú városi gyermek- (és mellette az egyéb szociális jellegü) szakellátó intézményeit a 2012. évi CXCII. törvény ${ }^{159}$ keretében vette át az állam.

A 2011-es új önkormányzati törvény természetesen fenntartotta a differenciált hatáskör-telepítés lehetőségét az önkormányzati szektor kapcsán - [Mötv. 11. § (1)].

\section{V.4.2 Komplex társult feladatellátás a többcélú kistérségi társulásoknál}

Az Önkormányzati törvény 1997-es módosítása [1997. évi CXXXIV. törvény], valamint kifejezetten az önkormányzati társulások jogi helyzetét racionalizálni igyekvő 1997. évi CXXXV. a helyi önkormányzatok társulásairól és együttmüködéseiröl szóló törvény - nem hoztak létre érdemben új társulási jogintézményt, hanem a már létezők számára biztosítottak jogtechnikai és müködési könnyítéseket. Ez tette lehetővé a jogi személyiség nélküli önkormányzati társulások létrehozását, ami korábban sok kooperáció megvalósulását akadályozta [ÁSZ 0817, 2008, 7. pp.]. ${ }^{160}$ Az Ötv. és Önkormányzati választási törvény [1990. évi LXIV. törvény] 1994 őszi módosítása ${ }^{161}$ után nagypolitikai (értsd: 2/3-os parlamenti) konszenzus nem mutatkozott a kötelező társulások megvalósítására, így eszközként a közvetett kormányzati fiskális „ráhatás” (normatív többlettámogatások és pályázati források) maradt a különböző társulások ösztönzésére. Ez elsősorban a körjegyzőségek számának - és a körjegyzőségekhez kapcsolódó kistelepülések - 1998 utáni növekedésében nyilvánult meg [Szigeti, 2010].

A magyarországi önkormányzati társulások életében minőségi ugrást jelentett a 2004. évi CVII. a többcélú kistérségi társulásokról szóló törvény (Ttv.) elfogadása, amely a korábbiakhoz képest jóval komplexebb [a törvényben 18 nevesített feladattípus - Ttv. 2.§

\footnotetext{
159 2012. évi CXCII. törvény egyes szakosított szociális és gyermekvédelmi szakellátási intézmények állami átvételéről és egyes törvények módosításáról

${ }^{160}$ A különbözö önkormányzati társulások dinamikájáról több értékelő szakmai tanulmány és kutatás értekezett az elmúlt 15 évben. Ezek közül különösen tartalmas: Dudás Ferenc - Sárosi Magdolna - Virág Rudolf: Önkormányzati együttmüködés és társulás (Közgazdasági és Jogi Könyvkiadó, Bp. 1998), Torba Nándor: Kistérségi társulások föbb jellemzői (In: Közigazgatási Szemle, 2008/1. szám), Szigeti Ernő: A körjegyzőségi rendszer térszerkezeti jellemzői (In: Közigazgatástudományi Közlöny, 2010/1. szám).

${ }^{161} \mathrm{Az}$ 1994-es módosításokat az Országgyülésben akkor 2/3-os többséggel rendelkezö MSZP-SZDSZ koalíció (a Horn-kormány parlamenti „hátországaként”) az akkori jobboldali ellenzék tiltakozása ellenére vitte végig. Azt követően 1994 vége és 2010 között csak rendkívül eseti jelleggel tudott a parlament módosítani az Ötv.-n (lásd az 1997-es módositást!).
} 
(1) $]^{162}$ jogi- és szervezeti, intézményi alapokon tette lehetővé, igaz továbbra is önkéntes alapon a települési önkormányzatok társult közös feladatellátását - legyen az hatósági feladatok, humán közszolgáltatások (elsősorban oktatás és szociális feladatok), területfejlesztés, hulladékgazdálkodás. A többcélú kistérségi társulások számára közvetlen nevesített költségvetési valamint egyéb hazai pályázati forrásokat igyekezett biztosítani meg a központi politika (Országgyülés, Kormány). A területileg a statisztikai kistérségi besoroláshoz kapcsolt (a törvény szerint ezek a társulások nem metszhették keresztbe a statisztikai kistérségi határokat) többcélú kistérségi társulások rendszere alig néhány év alatt lefedte az egész ország területét: a kodifikáció évében, 2004-ben 118 db, 2006-ban 163 db, 2008. január 1.-én pedig már 173 többcélú kistérségi társulás müködött hazánkban - a dinamizmus kétségtelen volt. ${ }^{163}$

A törvény értelmében a területi keretté a statisztikai kistérség vált: a kategóriát még egy 1994-es KSH elnöki közlemény hozta létre [9006/1994. (S.K.3)], majd az eredeti 138 statisztikai kistérségből a folyamatos módosításoknak köszönhetően 2011-re már 175 db volt. A 2004-es Ttv. alapján létrejött többcélú társulások az évtized végére már az összes statisztikai kistérségben megtalálhatóak voltak. Budapesten kívül csak a debreceni kistérség volt az, amely mindössze a nagyvárost (1 településes statisztikai kistérség) foglalta magában, azonban 2007-ben a szomszédos néhány ezer lakosú község, Mikepércs a DerecskeLétavértes kistérségből átkerült a debrecenihez, így 2008. január 1.-től Debrecen megyei jogú város és Mikepércs község részvételével megalakult a Debrecen-Mikepércs Többcélú Kistérségi Társulás is. A Ttv. révén egy olyan jogi együttműködési keretrendszert teremtődött a települések számára, amelybe a korábbiakhoz képest jóval hatékonyabban lehetett beilleszteni az elsősorban az alapszintű helyhatósági feladatokat összekapcsoló térségi közös feladatellátást. A többcélú kistérségi társulások keretében lehetőség volt továbbá az érintett települések között már működő különböző társulásos kooperációkat (jegyzői feladatok, intézményi társulások, hatósági igazgatási társulások) „beintegrálni” az új komplex intézményi keretbe (Ttv.). Nem meglepő, hogy a többcélú kistérségi társulások elterjedése visszafogta az egyéb formális intézményes önkormányzati társulásokat (persze a növekedés így is megmaradt a körjegyzőségek, ${ }^{164}$ valamint intézményi és hatósági társulások esetében).

\footnotetext{
162 A klasszikus humánigazgatási feladatok mellett érintette a vonalas infrastrukturális szolgáltatásokat, gazdaság- és turizmusfejlesztést, agrárigazgatási feladatokat, környezetvédelmet, belső ellenőrzést, területfejlesztést - 2004. évi CVII. tv. 2.§ (1)

${ }^{163}$ A forrás helye: Önkormányzati Minisztérium, Önkormányzati és Lakásügyi Államtitkárság 2008. június

${ }^{164}$ A körjegyzőségek száma: 2003-ban 605 db; 205-ben 634 db; 2006-ban 633 db; 2007-ben 718 db. [Hoffman, 2011, 31. pp.].
} 
Azonban a kistérségi társulásoknak is megvoltak a területi korlátjai (a statisztikai kistérségi határok), ami nem számolt a statisztikai kistérségi, megye- vagy akár országhatárokon átívelő gazdasági, társadalmi és igazgatási kapcsolatokkal. Ugyanakkor pozitív hatásuk a különböző közszolgáltatásokra tagadhatatlan volt, a kistérségi társulásokon keresztül olyan feladatok is elláthatóvá váltak széles körben különösen a kistelepülési szektorban, mint az önkormányzati belső ellenőrzés, vagy a házi segítségnyújtás. ${ }^{165}$

\section{V.4.3 A finanszírozási ösztönzők hatása a társult feladatellátásban}

Érdemes megvizsgálni a többcélú kistérségi társulások - annak ellenére, hogy csak önkéntes társulási jogintézmény volt - néhány év alatt történő országos méretű elterjedésének az okait, miközben a hagyományos (1990-es Ötv.-ben kodifikált) társulások elterjedéséhez jóval több idő volt szükséges. A titok nyitja a megfelelő központi (országos) financiális ösztönzés kialakítása volt az Országgyülés és a kormányzat részéröl. Az 1990-es törvényi szabályozás elsősorban a települési autonómia védelmére irányult, valamint az önkéntesség elvén maradva nem alakítottak ki kötelező, úgymond „kényszertársulásos” formákat. Így a közvetlen közjogi kényszerek helyett csak indirekt anyagi ösztönzök maradtak a településközi kooperációkhoz a kormányzat kezében. Mivel a helyi adók aránya elhanyagolhatóan alakult a központi adóbevételekhez viszonyítva, így a finanszírozás formái kizárólag a központi szintről származó rendes (normatív támogatás; átengedett központi adók) és speciális (önkormányzati címzett- és céltámogatások; 1996-tól területi decentralizált források és az Európai Uniós előcsatlakozási alapok; 2004-től közvetlen EU-s források) pénzügyi eszközök maradtak. A rendszerváltás utáni évek „demokratikus hevületében” égő települési önkormányzatok nagyon kevés kooperációs célt fogalmaztak meg, így az együttmüködési motiváció és hajlandóság még az előzetesen vártakhoz képest is elmaradt, és habár a településeknek lehetőségük közösen benyújtani pályázatot az önkormányzati címzett és céltámogatásokra - előbbi odaítélése a parlament, utóbbié a kormány kompetenciája volt -, de a pályázás lehetőségét nem kötötték semmilyen társulás kialakításához. Hasonló volt a helyzet a megyei önkormányzatok saját település- és területfejlesztési támogatásainál, ezek kialakított jogi mechanizmusai szintén nem segítették érdemben a településközi kooperációk megszületését [Somlyódiné, 1994, 117. pp.].

\footnotetext{
${ }^{165}$ A 2000-es évek második felében több értékelö-összegző statisztikai alapú tanulmány született a többcélú kistérségi társulásokról - így az önkormányzatokért felelős szaktárcák (Önkormányzati és Területfejlesztési Minisztérium; Belügyminisztérium), valamint különböző szakmai háttér- és érdekszervezetek (Magyar Közigazgatási Intézet; Települési Önkormányzatok Országos Szövetsége)
} 
A rendszerváltás évtizedében az önkormányzati finanszírozás kapcsán született tanulmányok meglévő közpolitikai problémaként azonosították a társulásokhoz kapcsolódó közgazdasági ösztönző-rendszer hiányosságát. Született szakmai javaslat a várostérségi önkormányzati együttmüködésnél nagyobb összegü normatív támogatásáról vagy valamilyen nevesített helyi várostérségi adó bevezetéséröl is. Ráadásul több olyan parlamenti, kormányzati döntés is született, amelyek az önállósodási törekvéseket erősítették. Jó példa volt erre az 1990-es években az önálló kistelepülési iskolák létrehozásának és müködtetésének kiemelt költségvetési támogatása illetve az, hogy a társulási keretben ellátni kívánt közoktatási feladatokra szánt közvetlen normatíva alatta maradt az önálló feladatellátáshoz kapcsolódó normatíva összegének [Szabó Lajos, 1994, 147-148. pp.; Balázs, 1996, 117. pp.; Sió, 1998, 664-665. pp.].

Több szakértő már az rendszerváltás utáni években javasolta az ún. negatív forrásszabályozás eszközének ${ }^{166}$ széles körben való alkalmazását: meghatározott feladatminimum alatt csak csökkentett központi anyagi támogatás legyen adható. Tehát amennyiben adott önkormányzati feladatot egy meghatározott lakosságszám alatti település önerőből - a rendelkezésre álló társulási lehetőségeket ki nem használván - kívánja megvalósítani, akkor a kapcsolódó állami normatíva is alacsonyabb összegű legyen. A negatív forrásszabályozás adta lehetőségeket az országos politika (s benne a központi költségvetési tervezés) csak valamikor az 1990-es évek közepén kezdte el tudatosan alkalmazni. Így külön nevesített költségvetési támogatást kaptak a körjegyzőségeket létrehozni kívánó helyhatóságokat, valamint pénzügyi transzferben részesítették azon önkormányzatokat, amelyek közös beruházásra kértek önkormányzati céltámogatást [Verebélyi, 1995, 69. pp.].

A második parlamenti ciklus (1994-1998) végére a nagypolitika felismerte, hogy a központi anyagi ösztönzéssel nemcsak lehetőség, de szükséges az önkormányzati társult kooperatív feladatellátás ösztönzése - így a kistelepülések már átlagosan 5-15\%-os plusztámogatást kaptak az egyes normatívák után közös feladatellátás esetén [Kara, 1998, 581. pp.]. Még erőteljesebb önkéntes társulási hullám indult el a harmadik parlamenti, kormányzati ciklusban (1998-2002). A társult feladatellátást ugyanis egyre inkább támogatta a központi költségvetés, illetve az 1997-es önkormányzati társulási törvény adta lehetőségek is sikeresnek bizonyultak, így 1998-1999 időszakban az összes önkormányzati társulások száma 20\%-al, a társulásban résztvevő települések száma pedig 8\%-al növekedett [Fürcht, 2000, 534-535. pp.].

\footnotetext{
${ }^{166}$ A fogalomról bővebben - Kökényesi József: A városkörnyéki igazgatás gazdasági alapkérdései (in: KÖOSZMJVSZ-MKI: Város és vonzáskörzete Szerk.: Szabó Gábor ÖNKORKÉP, Budapest, 1996) 176. pp.
} 
Kifejezetten a koordinált városkörnyéki együttmüködések finanszírozási strukturális nehézsége volt, hogy a nagyobb települések (különösen a fỏváros és a megyei jogú városok) intézményei a vonzáskörzeti települések lakossága számára a nélkül biztosítottak - akár még a mai napig is - különböző közszolgáltatásokat, hogy a környező agglomerációs települési önkormányzatok anyagilag megfelelően ellentételeznék azt. A nagyvárosok által szolgáltatott „feladat-túlcsordulás” (spill-over) számos gazdasági- és vele politikai természetű vitát generált az elmúlt negyedszázadban a nagyváros és városkörnyéki önkormányzatok közötti alkumechanizmusok során. A városkörnyéki különböző önkéntes önkormányzati társulások száma is alacsonyabb volt a szükségesnél, sokáig csak a körjegyzőségek központi támogatása növekedett olyan mértékben, hogy az érdemben motiválja a várostérségek önkormányzatait a kooperációkra [Lóránt, 1999, 494. pp.; Lóránt-Somogyiné-Bukva, 2002, 368-369. pp.].

Mivel az önkormányzati finanszírozás és gazdálkodás kérdéseinek csak bizonyos elemei kerültek kétharmados parlamenti szabályozás alá (Alkotmány, Ötv.) ezért sokkal inkább a minden évben feles parlamenti többséggel elfogadott költségvetési törvény helyi önkormányzatokról szóló fejezete - s vele a mindenkori költségvetési mozgástér ${ }^{167}$ - volt az irányadó a települési önkormányzatok számára. A jobbára csak az előző esztendő forrásait szem előtt tartó bázisalapú költségvetési tervezési gyakorlat közepette alig volt lehetőség érdemi módszertani fordulatra. Ráadásul a várossá nyilvánítás mesterséges „felpörgetése” szintén relativizálta a város-falu viszonyrendszert. Pitti Zoltán a 2000-es évek első felében az önkormányzati reformot előkészíteni hivatott IDEA munkacsoport finanszírozási kabinetvezetője ${ }^{168}$ kifejezetten a főváros és a nagyvárosok (regionális szerepkörü megyei jogú városok) speciális feladatellátáshoz igazított finanszírozási modellt, megoldásokat javasolt. A városkörnyéki spill-over hatások kezeléséhez növelni a támogatásokat; végiggondolni, hogy bizonyos speciális középfokú megyei önkormányzati feladatok müködtetése átkerüljön a nagyvárosokhoz; a piaci és agglomerációs körülményekhez igazított szolgáltatási, hatósági díjszabás és egyéb jóváhagyási technikák alkalmazása - címkézett önkormányzati pénzeszközök átadása agglomerációs övezeteken belül). [Pitti, 2005, 65-66. pp.]. Azonban csak szakértői felvetések szintjén maradt a nagyvárosi térségekre vonatkozó szabályozott módon történő helyi adóteher-kiegyenlítés gondolata, amely nemzetközi gyakorlata szerint a

\footnotetext{
167 Az eredeti 1990-es költségvetési mozgástér folyamatosan csökkent, amely testet öltött többek között a helyben maradó SZJA-alap radikális „,megnyesésében”, roppant méretű államigazgatási kompetenciatömeg megfelelő finanszírozást mellőző átruházása az önkormányzatokra, az állami normatívák inflációalatti növekedésében, de az időröl-időre jelentkezö központi megszoritásokból fakadó szektoriális forráskivonásokban is.

168 Pitti a 2000-es években, szociálliberális kormányzati időszakban az akkori adóhivatal, az APEH országos elnöki pozícióját is betöltötte.
} 
nevesített agglomerációs adót a térség adott településén élő lakosok a lakóhelyükön befizetik, de a szolgáltatási spill-over mértékének figyelembevételével osztják újra a több szolgáltatást nyújtó nagyváros valamint az egyéb térségi alközponti funkciót ellátó települések javára [Somlyódiné, 2003, 422. pp.].

\section{V.5 Nagyvárosi feladatellátás a városkörnyéki települések irányába}

Verebélyi Imre egyetemi tanár, 1994-1998 között a Horn-kormány közigazgatás korszerüsítésért felelős kormánybiztosa, még egy 1993-as tanulmányában különböző alternatívákat ajánlott a decentralizált és fragmentált magyarországi helyi önkormányzati alapszint problémáihoz. Ezek a különböző típusú települések önkéntes vagy kötelező társulásaitól egészen a törpefalvak törvényi kényszer alatt történő adminisztratív integrálásáig, összevonásáig terjedtek. Az alternatívák közül Verebélyi három esetben érintette a városi, nagyvárosi önkormányzatokat, ezek a következők voltak [Verebélyi, 1993, 204. pp.]. :

- Ún. városkörnyéki bizottságok felállítása, ahol kötelező a megalakítás és a konzultáció, egyeztetés, viszont nincs megállapodási kényszer. Nagyobb térségekre nézve Verebélyi a megyei közgyülés és a városi közgyülések, települési testületek közötti koordinációs bizottságot ajánlotta - ennek bevezetése az 1994-es átfogó Ötv. módositás elemét képezte, de nem jelentett valódi áttörést a két önkormányzati típus közötti kooperációkban!

- Bizonyos államigazgatási (jegyzői) feladatkörök ellátása tekintetében a városi önkormányzatok hatáskörének kiterjesztése a környező községekre - ez a jegyzői államigazgatási feladatok speciális hatáskör-delegálását jelentette volna a városi apparátusokhoz!

- Lehetőséget kell biztosítani a város és a városkörnyéki települések számára, amennyiben van igény a városi közfeladat-ellátás és közszolgáltatások kiterjesztésére a környező településeken, akkor önkéntes és szerződéses alapon (a felek meghatározott anyagi hozzájárulása mellett) megállapodhassanak egymással. Ennek az alternativának a gyakorlati megvalósulása leginkább a többcélú kistérségi társulásokban öltött testet!

\section{V.5.1 Megyei jogú városok a körjegyzőségeknél és közös intézményfenntartásnál}

Az elmúlt negyedszázad önkormányzati kooperációk jellegét és a rendelkezésre álló statisztikai adatokat szemügyre véve látható, hogy mely együttműködési formák alapvetően 
mely típusú településekre, helyi önkormányzatokra voltak jellemzőek. Ebből a szempontból a körjegyzőségek, valamint az intézményfenntartó önkormányzati társulások alapvetően a kisközségi helyhatóságok közötti „kényszerkapcsolatok” termékei voltak, nem véletlen, hogy az önkormányzati rendszer első időszakában megszülető önkormányzati társulási kapcsolatok jó része már a rendszerváltás is léteztek a községi közös tanácsok keretében. A hatósági igazgatási társulásokban - pl. szakhatósági ügyintéző közös alkalmazása - már nagyobb arányban tudtak megjelenni városi önkormányzatok (általában a társulási apparátus, humán erőforrás biztosítása révén). ${ }^{169} 2008$ tavaszán az Önkormányzati Minisztérium - mint az akkor a helyhatóságokért felelős szaktárca - készített összefoglaló tanulmányt $A$ helyi önkormányzati rendszer helyzetértékelése és továbbfejlesztésének irányai címen, ${ }^{170}$ ennek szakmai melléklete tartalmazta a körjegyzőségek székhely szerinti megoszlását 2008. márciusi állapot szerint. Ez alapján az összesen 758 müködő körjegyzőség közül mindössze 2 $\mathrm{db}$ érintett megyei jogú várost, amelyek természetesen egyúttal körjegyzőségi székhelytelepülések is voltak: Eger és Szekszárd megyei jogú városok. Ezen túlmenően pedig 58 városi jogállású település szerepelt körjegyzőségi székhelyként. Nagyközség 36 esetben, községi székhely viszont már 667 db (87\%) esetben volt [Önkormányzati Minisztérium, 2008, 3. sz. melléklet]. Ha a müködő körjegyzőségek lakosságszám alapján való megoszlását tekintjük: mindössze 18 db olyan körjegyzőség volt, ahol a körjegyzőséghez tartozó települések összlakossága meghaladta a 10.000 lakost, és $36 \mathrm{db}$, ahol 5000-10.000 lakos között volt [Önkormányzati Minisztérium, 2008, 4. sz. melléklet]. A rendszerváltás után az intézményfenntartó önkormányzati társulások alapvetően a közoktatásra - ott is elsősorban az óvoda, általános iskola intézményekre - terjedtek ki: a 2007/2008. valamint a 2008/2009.-es tanévre szóló támogatási igények szerint kb. 700 ilyen típusú intézményi társulás volt az országban, amely mintegy 2150-2330 települési önkormányzatot érintett valamilyen módon. Ugyanis eltérőek az adatok aszerint, hogy óvodai, 1-4. évfolyamos általános iskolai vagy 5-8. évfolyamos általános iskolai oktatásról volt szó. A kb. 700 intézményfenntartó közoktatási önkormányzati társulásból megközelítőleg 550-600 társulás székhelye volt község vagy nagyközség. ${ }^{171}$ Vagyis a körjegyzőségekhez képest mindenképpen nagyobb arányban voltak

\footnotetext{
169 A differenciált hatáskör-telepítés során a városkörnyéki községek lakosság számára szolgáltató városi, körzetközponti feladatellátás (pl. okmányirodák) habár nem jelent klasszikus társulást, de jellegénél fogva a hatósági igazgatási társuláshoz áll legközelebb.

170 Jómagam 2006-2010 között a minisztérium Államtitkárságán dolgoztam, így szereztem szakmai rálátást az önkormányzati rendszerhez kapcsolódó minisztériumi stratégiai elképzelésekről.

171 A pontos számok: 2007/2008. tanév: 709 óvodai társulás - 599 községi/nagyközségi székhelyü társulás; 709 1-4. évfolyam ált.isk. társulás - 558 községi/nagyközségi székhelyü társulás; 700 1-8. évfolyam ált.isk. társulás 547 községi/nagyközségi székhelyü társulás. 2008/2009. tanév - 706 óvodai társulás - 596 községi/nagyközségi
} 
érintve a feladatellátásban a legalább városi önkormányzatok [Önkormányzati Minisztérium, 2008, 10. sz. melléklet].

\section{V.5.2 Megyei jogú városok a többcélú kistérségi társulásokban}

A városok szerepe az önkormányzati társulások területén igazán majd csak a többcélú kistérségi társulásokban - [2004. évi CVII. törvény - Tkt.] -, értékelődött fel igazán - ez sok szempontból univerzális szerepkörbe helyezte a többcélú társulási központtelepüléseit (gyakorlatilag kivétel nélkül városi jogállású településeket), ezt bizonyítják a 2004 után létrejövő többcélú kistérségi társulások keretébe utalt közös feladatok széles (hatósági feladatok; gazdasági- és humán közszolgáltatások egész sora) köre. ${ }^{172}$ Már korábban esett szó a többcélú kistérségi társulások megalakulásának rendkívül expanzív üteméről, 4-5 év alatt gyakorlatilag keresztül-kasul behálózták az országot, és megalakultak minden statisztikai kistérségben. Budapest természetesen kimaradt, viszont Pest megyében, s vele a fővárost övező belső és külső szuburbán településgyürükben szintén megalakultak a kistérségi társulások. Vidéken, különösen a rurális térségekben nagyon sok települési önkormányzat tekintett bizakodva a kistérségi társulások adta lehetőségekre, aminek felismerésében „segítettek” a folyamatosan növekvő központi költségvetési és pályázati források. A vidéki nagyvárosok - és most ezt a kategóriát azonosítsuk a megyei jogú városokkal - és a többcélú kistérségi társulások kapcsán a következő volt a szabályozási alaphelyzet: a Tkt. nem tett érdemi különbséget a megyei jogú illetve nem megyei jogú városok köré szerveződött többcélú társulások között sem a megalakítás, sem az igénybe vehető normatív és kiegészítő források szempontjából. Ugyanakkor már egy 2004-es tanulmány felhívta a figyelmet a Tkt. bizonyos ellentmondásaira, amely paradox módon éppen a megyei jogú városokat tette bizonyos szempontok szerint ellenérdekeltté vagy legalábbis szkeptikussá az akkor új típusú komplex önkormányzati társulásban való részvétel kapcsán. Itt rögtön vissza is kanyarodhatunk a rendkívül eltérő kapacitásbeli differenciákra. Eleve egyenlőtlen pozíciókról beszélünk: nagyságrendekkel jelentősebb saját intézményrendszer, pénzügyi mozgástér és humán erőforrás a megyei jogú városoknál; másrészről a rosszabb minőségü és/vagy hiányos intézményrendszer, a közös feladatellátásra való „,rászorultság”, de a társulási tanács döntési

székhelyü társulás; 703 1-4. évfolyam ált.isk. társulás - 552 községi/nagyközségi székhelyü társulás; 698 5-8. évfolyam ált.isk. társulás - 546 községi/nagyközségi székhelyű társulás.

172 Ugyanakkor a többcélú kistérségi társulásokon belül egyfajta területi munkamegosztás is érvényesült az intézmények és közfeladatok koncentrálása terén a társulási központ valamint az azon kívül álló maximum 2-3 mikroszékhely település. 
mechanizmusai sokkal inkább a városkörnyéki kistelepüléseket érdekeltségét erősítette a törvény biztosította komplex kooperációban [Lábadyné, 2004, 13-15. pp.].

\section{V.5.3 Megyei jogú városok közfeladat-ellátása a városkörnyéki településeken}

Önkormányzati feladatellátás gyakori megvalósulása közös önkormányzati tulajdonú gazdasági társaságokon keresztül - ennek alapja még az Önkormányzati törvényből ered [1990. évi LXV. tv. 1.§ (6) b)]. Az önkormányzati tulajdonú gazdasági társaságok rendkívül széles köre alakult ki, közülük sok nem is kapcsolódott a szük értelemben vett önkormányzati feladatellátáshoz és közte vegyes tulajdonú - gazdasági társaságok, akár magánszemélyek részvételével müködő - társaság is akadt. Szükséges leszögezni, hogy gazdasági társaságokat önállóan vagy más szereplőkkel közösen sokkal inkább a nagyobbtelepülések (városok, megyei jogú városok, fôváros, fóvárosi kerületek) voltak képesek működtetni a tapasztalatok szerint. Városi, nagyvárosi önkormányzati vállalatok a városhatárokon túlra - így a városkörnyéki településekre - irányuló feladatellátása általában az érintett települések (városi önkormányzat, mint feladatellátó / városkörnyéki önkormányzatok, mint a szolgáltatást igénybevevő) közötti közszolgáltatási szerződéses kontraktus útján realizálhatóak. ${ }^{173}$ Kifejezetten a megyei jogú városi tulajdonban lévő önkormányzati vállalati szektor költségvetésen kívüli közfeladat-ellátását vizsgálta az évtized elején (2011-2012) Szabó István okleveles közgazdász, aki a doktori disszertációját szentelte a témának: ${ }^{174}$ kutatása során az érintett településkör 25\%-nál magasabb önkormányzati tulajdonhányaddal rendelkező közszolgáltató vállalati körét mérte fel, az ellátott kötelező és fakultatív (önként vállalt) feladatellátásán keresztül. A vizsgált önkormányzati gazdasági társaságok 14 ÁGÉSZ (általános gazdasági érdekü szolgáltatást) típusú közfeladatot láttak el. Az önkormányzati humánszolgáltatások (ÁÉSZ - általános érdekü szolgáltatások) ellátása Magyarországon hagyományosan a saját költségvetési körbe tartozó közintézmények vagy ritkább esetben civil non-profit, főleg egyházi intézmények reszortja volt, ezért a humánszolgáltatások önkormányzati társulásban való ellátása elsődlegesen önkormányzati hivatalokon, közintézményeken keresztül történhet. Városkörnyéki relációban a településüzemeltetési feladatok illetve a gazdasági infrastrukturális-hálózatos közszolgáltatások (különösen a főváros és a megyei jogú városok környékén, agglomerációs övezetében) a legegyszerübb

\footnotetext{
173 Ezek konkrét közmenedzsment típusú polgári jogi sokféle lehet: koncessziós szerződés, közszolgáltatási szerződés, közbeszerzési eljárás és kapcsolódó megállapodás, közüzemi üzemeltetési szerződés - Horváth M. Tamás: Közmenedzsment (Dialóg-Campus Kiadó, Budapest-Pécs, 2005) 126-127. pp.

174 Szabó István doktori értekezésének tézisei -

http://rgdi.sze.hu/images/RGDI/honlapelemei/fokozatszerzesi_anyagok/szabo_istvan_tezisfüzet40.pdf
} 
módon a nagyváros saját gazdasági társaságain keresztül a nagyváros és a városkörnyéki önkormányzatok közötti közszolgáltatási, közüzemi szerződésen keresztül valósultak meg.

Szabó István kutatása a következő ÁGÉSZ közszolgáltatásokra terjedt ki: kéményseprés; helyi tömegközlekedés; fürdöüzemeltetés; szennyvizelvezetés- és tisztitás; vizhálózat-üzemeltetés; helyiség- és lakásgazdálkodás; köztemetö-fenntartás; temetkezési szolgáltatás; park és zöldterület-fenntartás; közterületek tisztán tartása; távhőszolgáltatás; távhötermelés; kommunális hulladék elhelyezése; kommunális hulladékgyüjtés. A 14 ÁGÉSZ közszolgáltatásból mindössze 3 olyan akadt, amely csak a megyei jogú város területét érintette: fürdőüzemeltetés; helyiség- és lakásgazdálkodás; távhőtermelés. Bizonyos közszolgáltatásoknál csak néhány (1-4) megyei jogú városi vállalat szolgáltatott a városkörnyék településeire - pl. temetkezési szolgáltatások, távhőszolgáltatás, közterület és parkfenntartás, helyi tömegközlekedés, kéményseprés. Bizonyos közszolgáltatásoknál, amelyek viszont túlnyomórészt éppen a vizsgált nagyvárosi vállalatok szolgáltatnak az agglomerációs térségben, ezek a következők:

- szennyvízelvezetés- és tisztítás;

- vízhálózat-üzemeltetés;

- kommunális hulladék elhelyezése;

- kommunális hulladékgyüjtés [Szabó István, 2014].

\section{V.5.4 Fejlesztési célú horizontális önkormányzati kooperációk}

Az 1990-ben elfogadott Önkormányzati törvény az önkéntes társulások 4 típusát teremtette meg (körjegyzőség, hatósági igazgatási társulás, közös intézményfenntartás, közös képviselőtestület) - ezek a jogintézmények jellegükből fakadóan elsődlegesen a napi működtetési feladatok közös ellátására irányult. A településközi - s így a városkörnyéki kooperációnak további fontos dimenzióját képezik a fejlesztési típusú együttmüködések. Az önkormányzati fejlesztési kooperációk többféle motivációval jöhettek létre gazdaságfejlesztő, vállalkozáserősítő-, élénkítő illetve munkahelyteremtő szándékok. Amíg a müködtetési célú társulások intézményi, közjogi paramétereire az Önkormányzati törvény és egyéb jogszabályok pontos leírást biztosítottak, addig a fejlesztési célú társulási kezdeményezések sokáig bizonytalan és kialakulatlan szervezeti-jogi struktúrákban müködtek - ennek ellenére 1994-re országosan 140 db kistérségi fejlesztési társulás működött különböző célokból [Verebélyi, 1995, 71. pp.]. A bizonytalan területfejlesztési jogi keretek és a 
fejlesztéspolitika akkori komolytalan léptéke ${ }^{175}$ miatt az Önkormányzati törvény 1994-es módosítása kimondva azt is, hogy a későbbiekben önálló törvényben szükséges szabályozni a területfejlesztés szervezeti kérdéseit [1994. évi LXIII. tv. 40.§ (3)]. A törvényi felhatalmazásnak tett eleget a Magyar Országgyülés két évvel később, amikor megalkotta a területfejlesztésröl és területrendezésről szóló 1996. évi XXI. törvény (Tftv.). Ez hívta életre a különböző fejlesztési tanácsokat: Országos Területfejlesztési Tanács (OTT); megyei területfejlesztési tanácsok (mft); kistérségi fejlesztési tanácsok - ezek mind sajátos összetételü vegyesen delegált (önkormányzati és kormányzati delegáltak, civilek) konzultatív, érdemi döntéshozatallal kevésbé rendelkező tanácsok voltak. A térségi fejlesztési tanácsok rendszerét egészítette ki a Tftv. 1999-es módosítása [1999. évi XCII. tv. 6.§], amely létrehozta a 7 statisztikai tervezési régiónak megfelelő regionális fejlesztési tanácsot (rft). Az ezredforduló után, de különösen a 2002-es kormányváltást követően az rft-k lettek a bizonyos mértékben decentralizált területfejlesztési politika (hazai területi decentralizált források elosztása CÉDE, TEKI, TEUT, TFC etc.) intézményi bástyái. ${ }^{176}$ A 2004-es EU csatlakozást követően még fontosabbá váltak a regionális fejlesztési tanácsok, a 2007-2013 hétéves uniós költségvetésben a 13 strukturális alap 7 ún. regionális operatív program (ROP) forrásainak odaítéléséröl már közvetlenül az rft-k dönthettek. A vegyes delegált összetételü regionális fejlesztési tanácsokban a kormányzati (minisztériumi) tagok száma egyébként egy 2000. környéki módosításnak köszönhetően több lett, mint az önkormányzati delegáltak (az érintett megyei közgyülési elnökök és megyei jogú városok polgármesterei; az ún. kistérségi fórumok polgármester). Kifejezetten fejlesztéspolitikai területen az rft-k lehetőséget teremtettek intézményesített közpolitikai koordinációra a különböző szintü önkormányzati szereplők között. Kistérségi szinten a regionális fejlesztési tanácsok révén alakultak meg az ún. kistérségi fórumok, amelyek a kistérségi polgármesterek gyüléseit jelentette, kiegészítve sok helyen a kistérségi jegyzői kollégiumok konzultatív fórumával [Szaló, 1999, 8-13. pp.]. A területfejlesztési tanácsok rendszerének 2010 utáni átalakitásáról lásd a „Fövárosi kísérletek - a Budapesti Agglomerációs Fejlesztési Tanács" címü alfejezetben!

\footnotetext{
175 Az 1996 előtt a központi területfejlesztési politikát finanszírozni hivatott Területfejlesztési Alap (mint elkülönített állami pénzalap) forrása az akkori Budapesti Közlekedési Vállalat (BKV) Fővárosi Önkormányzattól kapott támogatásának alig 60\%-át tette ki - Enyedi György: Regionális folyamatok Magyarországon (MTA VITA Alapítvány, Budapest, 1996) 130. pp.

176 A különböző decentralizált pályázati alapok rendszere évröl-évre változott, miközben országosan néhány tucat tízmilliárd Ft fejlesztési támogatásokat allokáltak elsődlegesen önkormányzatok és társulásaik számára.
} 


\section{V.6 Integrációs kísérletek a nagyvárosi térségekben 1990 után}

A „széttartás” évtizedeként értelmezhető 1990-es években is akadtak már speciális, térségi - a város és városkörnyéki települési önkormányzatokra kiterjedő meghatározott feladat vagy feladatok közös ellátására irányuló kooperációs kezdeményezések. Ezek között akadtak kis- vagy középvárosokra fókuszáló kooperációk. Ilyen volt például a szétaprózódott településszerkezetü Vas megyében, az 1991-ben létrejött Vas Megyei Elmaradott Térségi Önkormányzatok Szövetsége (VETÖSZ), amely saját fejlesztési irodát müködtetett Vasvár városban; vagy az ugyancsak dél-dunántúli Ormánsági Társulás; a Veszprém megyei valamikori pápai járás területén, az 1993 elején létrehozott önálló vonzáskörzeti szövetség, közös ellenőrzési irodával Pápán. Hasonló kistérségi kezdeményezés volt városi jogállású településekkel a fókuszban a Tisza-tavi Önkormányzatok Szövetsége, a Velencei-tavi Önkormányzatok Szövetsége vagy a Fürdővárosok Szövetsége; Esztergom és környékén pedig kifejezetten térség- és településfejlesztési jelleggel városkörnyéki önkormányzati tanácsot hoztak létre. Ugyanakkor tudunk olyan önkéntes önkormányzati kooperációkról - és ezek a disszertációs téma szempontjából fontosabbak - amelyek már kifejezetten valamely megyei jogú város vezetésével, anyagi gesztorságával jöttek létre. Ilyen korai az 1990-es évek első feléhez köthető kísérlet volt Székesfehérvár megyei jogú város körzetében 14 helyi önkormányzat szövetsége, amely a szemétgyüjtés, a hulladékkezelés, bizonyos infrastrukturális fejlesztések, középfokú oktatás és kollégiumi elhelyezés illetve közös önkormányzati hatósági ármegállapítás (vízdíj, szemétszállítási díj, tömegközlekedési tarifák) közös ellátására törekedett. Ilyen volt továbbá Nyíregyháza és a környező települések önkéntes kooperációs kísérlete térségi beruházási konzultációs jelleggel. [Németh, 1994, 482488. pp.; Kemenszky, 1993, 481-487. pp; Szabó Lajos, 1994, 151. pp.]. Az önkormányzati társulási „fősodor” (körjegyzőség, hatósági igazgatási társulás, intézményfenntartás, társult képviselőtestület) funkciókon túli egyéb kooperációra jó példa volt a Zalaegerszeg Megyei Jogú Város és a környező települések közötti együttmüködési megállapodás közös testnevelési és sportfeladatokra - Zalaegerszeg sportrendezvényeket szervezett a környező települési sportegyesületek számára, illetve gondoskodni próbált a térségi sportszakemberképzésről [Hódir-Varga, 2002, 35. pp.].

A 36/2005. (III.1.) Korm.rendelet a 2004-es Ttv. alapján frissen megalakult többcélú kistérségi társulások támogatásáról $6 \mathrm{db}$ ún. kistérségi modellkísérlet helyszínét jelölte ki, amelyből kettő kifejezetten nagyvárosi kistérségre koncentrált - Miskolc és Zalaegerszeg, ebből a miskolci volt az átfogóbb, komplex agglomerációs feladatellátásra irányuló 
$\operatorname{program}^{177}$ [Gazsó-Kovács-Perger-Schneider-Szegvári-Vigvári-Zsugyel, 2008, 528-530- pp.; Delbó, 2013, 205-220. pp.]. Különösen motivált együttmüködési kezdeményezések jellemezték a dél-dunántúli statisztikai-tervezési régió (benne hangsúlyosan Pécs) önkormányzati valamint civil szereplöit - ennek kutatására külön tanulmánykötet szentelt a Pécsi Tudományegyetem Interdiszciplináris Doktori Iskolája 2009-ben! ${ }^{178}$

\section{V.6.1 Fővárosi kísérletek - a Budapesti Agglomerációs Fejlesztési Tanács}

A Budapest közigazgatási határain túlmutató térségi-agglomerációs szintű tervezési és hatósági kooperációs folyamatokra tudunk már háború előtti történeti példát - a városkörnyéki területi illetékességgel felruházott Fővárosi Közmunkák Tanácsa. Az egypártrendszer időszakában a 1005/1971. (II. 16.) Korm.határozat rendelkezett a főváros környéke általános rendezési tervének jóváhagyásáról. A határozat, mint általános rendezési terv Budapestre valamint akkor még további 44 agglomerációs településre vonatkozott, benne 2 db járási jogú várossal (Százhalombatta / Szentendre) valamint 42 község - köztük a ma már megyei jogú város Érd, valamint számos, azóta városi illetve járásszékhely városi címet kapott településsel (pl. Budaörs, Dunaharaszti, Szigetszentmiklós, Dunakeszi). Az 1005/1971. (II. 16.) Korm.határozat különböző agglomerációs (tehát Budapest határain túlmutató, a főváros és a környező települések kapcsolatára koncentráló) célokat fogalmazott meg, mint a mennyiségi lakáshiány felszámolása a „Bp. környékén városias jellegü lakásépités szorgalmazásával”; az elővárosi HÉV-hálózat gyorsvasúttá fejlesztése; közlekedés és közmühálózat-fejlesztés a városkörnyéken; Budapest környékére üzemek telepítése vagy éppenséggel más települések üdülő jellegü fejlesztése.

Szóltunk már korábban az ún. fővárosi önkormányzati „konfliktuskonténerről”, amelynek csak az egyik síkja a fóváros versus fóvárosi kerületek kontextus. Habár az elmúlt negyedszázad során születtek bizonyos jogszabályi-, strukturális változások ${ }^{179}$ valamint a főváros és kerületek viszonyát olykor közvetlen rivalizálások tarkították (pl. az ún. megosztott bevételek aránya), ennek ellenére a szisztéma alapvetően stabilnak bizonyult. Időnként azért

\footnotetext{
177 A miskolci „A nagyváros és térsége modellprogram”; a Zalaegerszeg-Gellénháza-Bak egységes integrált kistérségi önkormányzati költségvetési gazdálkodási modellprogram - 36/2005. (III. 1.) Korm.rendelet 2 . sz. melléklet 1.d) és f)

${ }^{178}$ A politika új szintere a régió Szerk.: Pálné Kovács Ilona (Pécsi Tudományegyetem Interdiszciplináris Doktoris Iskola, Budapest-Pécs, 2009)

179 1990-1994, valamint 2014 óta a Fővárosi Közgyülésnek automatikusan tagjai a kerületi polgármesterek. 1991-1994 között a fővárost és kerületeit külön 1/2 többséget igénylő törvény szabályozta [1991. évi XXIV. tv.], de 1994-ben a kisebb koalíciós partner az SZDSZ javaslatára a föváros önkormányzati rendszeréről szóló rendelkezések is bekerültek az Ötv.-be.
} 
felbukkantak eltérő szerkezeti koncepciók, mint például a belső kerületeket egyesítő egyetlen magkerület létrehozása - ún. city-koncepció, amely már az 1990-es évek során, de a 2011-es Mötv. kodifikálás előtt is megjelent a lehetséges alternatívák között [Szegvári, 2015, 354-362. pp.]. A „konfliktuskonténer” másik síkja, a kevésbé látványos - a média által kevésbé taglalt Budapest és agglomerációs települések közötti nézetkülönbségek, a Magyarországon talán a leglátványosabban kimutatható spill-over hatásokból fakadóan. A rendszerváltás után már a Fővárosi Önkormányzat politikai megrendelésére az első önkormányzati ciklusban kidolgozásra került egy agglomerációs közpolitikai stratégiai tervezet, amely első ütemben a főváros és agglomerációs települések közötti önkéntes társulások megalakítását tüzte ki célul, ez alapja lehetett volna egy későbbi önálló ún. városmegyének, amely Budapest és az agglomerációs településeknek a Pest megyéből való kiválását is jelentette volna Budapest városmegye elnevezés alatt, hasonlóan Párizs régióhoz. A koncepció során felvetették az ún. Budapesti Agglomerációs Szövetség megalakítását, amely keretében Budapest városmegye társulhatott volna a külső - már nem agglomerációs - Pest megyei önkormányzatokkal [Barabás-Tiba, 1995, 193-200. pp.]. Az 1996-os területfejlesztési törvény 15/B § hozta létre a Budapesti Agglomerációs Fejlesztési Tanácsot (BAFT), amely mint a Tftv. által meghatározott térségi tanács korlátozott kompetenciákkal (fejlesztési koncepció, stratégia). ${ }^{180}$ 1999-ben fogadta el a BAFT a saját stratégiai programját, amelynek középpontjában a dinamikus várostérség valamint egy országos kelet-nyugati transzferpozíció kialakítása állt. A BAFT feladatait 2002-ben a Közép-Magyarországi Regionális Fejlesztési Tanács (KMRFT) vette át, majd a Tftv. 2004-es módosítása [Tftv. 15/B.§ (1)] visszaállította a BAFT intézményét, ehhez kapcsolódóan 2005-ben önálló törvény is született a Budapest Agglomeráció Területrendezési Tervről [2005. évi LXIV. tv.] - benne az agglomeráció szerkezeti és övezeti tervéről. A BAFT-ot a Tftv. 2004-es módosítása szerint a Fővárosi Közgyülés illetve a KMRFT közösen hozza létre, és tagja a föpolgármester; az érintett regionális fejlesztési tanács elnöke; 3 fővárosi kerületi polgármester; az agglomeráció által érintett kistérségi fejlesztési tanácsok által delegált 3 polgármester, valamint a Kormány képviselője - így adva egy speciális föderatív jelleget a BAFT-nak.

A fővárosi agglomerációs „,konfliktuskonténer”elemei 1990 után:

1) Budapest és agglomerációja a fejlesztéspolitikában nem jelenik meg funkcionális egységként, helyette Budapest és egész Pest megye alkot közös tervezési-statisztikai

\footnotetext{
${ }^{180}$ A BAFT mellett ilyen kiemelt térségi területfejlesztési tanács volt a Balaton Fejlesztési Tanács; majd a 2000es években a törvény adta lehetőségek szerint létrejöttek saját kezdeményezésre hasonló térségi tanácsok, mint a Tisza-tó Térségi Fejlesztési Tanács
} 
régiót (Közép-Magyarország NUTS2 statisztikai-tervezési régió, valamint korábban a Közép-Magyarországi Regionális Fejlesztési Tanács intézménye).

2) Budapest Főváros és a Pest Megyei Önkormányzat egészségtelen rivalizálása - utóbbi több alkalommal is kifejezte a Budapesttől való elszakadási óhaját, mivel a főváros pozitív gazdasági és társadalmi mutatói miatt Közép-Magyarország - mint NUTS2 térség - az Európai Unió kohéziós politikája tekintetében ún. versenyképességi régiónak számít. Addig a többi hazai vidéki NUTS2 térség konvergencia-régiónak, $\mathrm{s}$ vele jogosultak olyan felzárkóztató közösségi forrásokra (strukturális alapok etc.), amelyre a Pest megyei települések nem.

3) A fővárosi agglomerációs települések számos tekintetben ambivalens helyzetben vannak, mivel funkcionálisan a budapesti agglomerációs tér szereplői, de adminisztratív-közigazgatási szempontból Pest megye részei, miközben az agglomerációs jellegüknél fogva élesen elkülönülnek a megye agglomeráción kívüli részeitől. 2011 előtt a megyei önkormányzatok jelentős intézményfenntartó közigazgatási szereplők voltak, így számos agglomerációs településen található közintézmény megyei fenntartásban voltak, ugyanakkor mára a megyék elveszítették intézményfenntartó szerepkörüket.

4) A BAFT a hangzatos célok ellenére nem tudott valódi „,agglomeráció zászlóshajóintézménnyé" válni, feladatköre megmaradt pusztán tervezési jellegünek, bárminemü érdemi feladatellátás nélkül. Jelenleg nem látható komoly integrációs elképzelés a fővárosi agglomerációs térség kapcsán.

2011-ben a közigazgatási átalakítások részeként - erröl bővebben lásd a következö fejezetben! - radikálisan átszabták a területfejlesztési intézményrendszert: a Tftv.-t módosító 2011. évi CXCVIII. törvény 39. § (1) a) pontja 2012. január 1. határidővel megszüntette a regionális valamint a kistérségi fejlesztési tanácsokat, illetve a Budapest Agglomerációs Fejlesztési Tanácsot - így egyedül a Balaton Fejlesztési Tanács maradt meg a korábbi másfél évtized területfejlesztési intézményrendszeréből. Mindezzel párhuzamosan a területfejlesztést kizárólagosan és kifejezetten a megyei önkormányzatokhoz rendelte a Mötv. [2011. évi CLXXXIX. tv. 27.§ (19)]. A regionális területfejlesztési konzultáció ür „kitöltésére” a Tftv. keretében mégis beillesztettek egy a megyei határokon átívelő térségi fejlesztési kérdésekre kiterjedő konzultációs jellegü ún. regionális területfejlesztési fórum intézményt, anélkül, hogy saját hivatali szervezetet rendeltek volna hozzá ${ }^{181}$ - ha egy adott kérdés érinti Budapestet,

\footnotetext{
181 Összehasonlíthatatlanul gyengébb intézményi legitimáció, mint a regionális fejlesztési tanácsok esetében.
} 
akkor a föpolgármester és a Pest megyei közgyülés elnöke közötti kommunikációval [1996. évi XXI. tv. 14/A §.].

A főváros agglomerációs településekben azonban továbbra is létező az igény, hogy valamiféle koordinált és intézményesített együttműködés mégiscsak müködjön Budapest és az érintett települések között. Ezért hozták létre 2011 júniusában az agglomerációs Gyál városában 17 Budapest környéki szuburbán település részvételével a Fővárosi Agglomerációs Önkormányzati Társulást (FAÖT) - mint önkéntes önkormányzati kooperációs társulást. Az alapító önkormányzatok a FAÖT számára széles ágazati feladatkörben (közlekedés, közbiztonság, gazdaságfejlesztés, környezet- és természetvédelem etc.) fogalmaztak meg együttműködési célokat, mégis a résztvevő agglomerációs települések viszonylag kis száma, a társulás önkéntes jellege valamint Budapest távolmaradása miatt eleve korlátozott cselekvési keret, müködési hatékonyság és gyenge legitimáció jellemzi a FAÖT jelen helyzetét. ${ }^{182}$ Miközben a Fővárosi Önkormányzat intézményi tekintetben láthatóan kevésbé partner az agglomerációs integrációs törekvésekben, a közelmúlt stratégiai természetü fővárosi dokumentumaiban azért megjelent az agglomerációs tematika: így a 2013-ban elfogadott Budapest 2030 Hosszú távú városfejlesztési koncepció elsődlegesen Pest megyét említi, mint térségi együttmüködési partner. Ugyanakkor nagytérségi együttmüködési korrelációban a Pest megyével érintkező összes szomszédos megye (Fejér, Komárom-Esztergom, Heves, JászNagykun, Bács-Kiskun, Nógrád), illetve az ott található megyei jogú városok nevesítésre kerültek. Városkörnyéki tekintetben pedig egy teljesen megújított Budapest - Pest megye koordinációs mechanizmusrendszer szükségességét (benne a Budapesti Agglomeráció határainak újratervezésével) vetette fel a dokumentum [Budapest 2030, 80-87. pp.].

\section{V.7 Az új jogszabályi és intézményi környezet hatásai 2010 után}

Somlyódiné Pfeil Mária a hazai kistérségi és városi önkormányzás témakörében sokat publikáló szakértő 2009-es tanulmányban - mintegy két évvel az új önkormányzati törvény előtt - az önkormányzatok általános kapacitáshiányából fakadó ellátási nehézségekre adandó lehetséges - egymást nem feltétlenül kizáró - megoldási alternatívák főbb típusait összegezte, ezek a következők voltak:

- Önkormányzatok fúziója - „az egy település egy önkormányzat” elv meghaladása, amely radikális önkormányzati reformot jelent.

\footnotetext{
182 Bővebben a FAÖT hivatalos internetes oldalán - www.faot.hu
} 
- Önkormányzatok társulása - továbbra is alkalmas lehetőség, bár hatása korlátozottabb annak függvényében, hogy önkéntes vagy kötelező társulásokról van szó.

- A város és vonzáskörzete valamilyen nevesített közös igazgatási egységben való kezelése. Ez nem feleltethető meg egy az egyben a társulásos megoldással, mivel kell, hogy tartalmazzon valamilyen speciális városkörnyéki, agglomerációs specifikumot.

- Differenciált hatáskör-telepítés - meghatározott önkormányzati népességkategóriákhoz meghatározott helyi önkormányzati kompetenciák kötése.

- Közvetett közigazgatás - közszolgáltatások, közfeladatok kiszervezése („privatizációja”) a piaci és non-profit szereplők számára.

- Az önkormányzati szintek közötti feladatmegosztás - a kifejezetten fragmentált helyi önkormányzati alapszint tehermentesítése a felfelé az önkormányzati középszint vagy középszintek (amennyiben alsó és felső középszintű területi önkormányzati szintek is müködnek - pl. Németország) irányába [Somlyódiné, 2009, 34. pp.]. ${ }^{183}$

A 2010-2014-es parlamenti ciklusban érdemi változások történtek az állami- és önkormányzati feladatellátás rendszereiben, amelynek politikai legitimációs alapját a 2010-es parlamenti választásokon a Fidesz-KDNP pártszövetség elsöprő választási sikere, valamint az abból következő 2/3-os országgyülési választási többség jelentette, amely Orbán Viktor második kormányának (2010-2014) parlamenti hátországát biztosította. A 2010 előtti időszakhoz képest gyökeresen megváltozott országos, s majd önkormányzati politikai környezetben ${ }^{184}$ megnyílt a lehetőség arra, hogy a kormányzat saját elképzelései és akarat szerint alakítsa a különböző központi jogszabályokat (törvények, rendeletek), anélkül, hogy bármilyen politikai kompromisszumra szorult volna a parlamenti ellenzékkel - a parlamenti alkotmányozó többség jóvoltából! A 2010 óta tapasztalt roppant jogszabályi változások Alaptörvény, mint új alkotmány 2012-töl; a 2/3-os ún. sarkalatos törvények körének teljes megújítása; számos 1/2-es parlamenti többséget igénylő fontos ágazati törvényalkotás (köz- és felsőoktatás, szociális- és egészségügyi rendszer, Munka törvénykönyve etc.) - alapvető

\footnotetext{
183 Önkormányzati feladatok áttelepítésének gondolata a központi államigazgatás (valamely központi szerv kormányhivatal, központi hivatal) vagy az alárendelt területi államigazgatási intézményi szektorhoz nem jelent meg a felsorolt alternatívák között, mégis ez vált a 2010 utáni közigazgatási reformok egyik meghatározó irányává.

${ }^{184}$ A 2010-es tavaszi országgyűlési választást követően, a már új 2/3-os kormánypárti parlamenti átalakította az önkormányzati választási rendszert, majd 2010 októberében 1990 óta nem látott politikai sikert arattak a kormányerők (Fidesz-KDNP) az önkormányzati választásokon. Budapest első alkalommal került egyértelmü jobboldali dominancia alá (Fővárosi Közgyülés; főpolgármester; a kerületi önkormányzatok és polgármesteri pozíciók nagy többsége). A 23 megyei jogú város Szeged kivételével a Fidesz-KDNP irányítása alá került; az összes megyei közgyülés is a kormányerők többségi befolyása alá került.
} 
tartalmi indikátorává az állam (s vele a kormányzat) felelősségének, feladatellátásának, közjogi illetve gazdasági pozícióinak a korábbi időszakhoz képest jelentős megerősítése vált. A központi állami pozíciók erősítése természetszerüleg érintette a helyi önkormányzati szektor feladat-, hatásköri rendszert, de a kapcsolódó vagyoni-tulajdonosi funkciókat is. Az átalakítás támogatói (a kormányzat és a hozzá közelálló intézmények, szakértők) az önkormányzati kompetenciák szükséges ,áramvonalasítása” mögötti egyik legfontosabb indoknak a 2000-es évek végére elszabaduló önkormányzati adósságállományt hangsúlyozták, aminek kezelése az ún. önkormányzati adósságkonszolidációban öltött testet 2012 vége és 2014 tavasza között. Az adósságkonszolidáció érintette a megyei önkormányzatok valamint a települések által felhalmozott különböző forint és deviza-kintlévőségeket. A konszolidáció mértékéröl és fontosabb elemeiről már szóltunk az önkormányzatok kapacitáshiányáról szóló fejezetben! - a következökben az átalakítás közjogi (önkormányzati rendszer és önkormányzati feladatok, - és hatáskörök) aspektusairól lesz szó.

\section{V.7.1 2011. évi CLXXXIX. törvény Magyarország helyi önkormányzatairól}

Az új önkormányzati törvény (2011. évi CLXXXIX. törvény Magyarország helyi önkormányzatairól - Mötv.) mellett számos egyéb, a helyi feladatellátáshoz és közszolgáltatásokhoz kapcsolódó ágazati törvény-, valamint alsóbb szintű jogszabályalkotás történt a 2010-2014 parlamenti, kormányzati ciklusban. A 2011-ben elfogadott új önkormányzati törvény az 1990-es Ötv.-hez képest direktebb különbséget tesz az egyes települési önkormányzati jogállások között. A törvény egyrészt kimondja, hogy a különböző települési és területi (megyei) önkormányzatoknak egymástól eltérő feladat- és hatáskörei lehetnek [2011. évi CLXXXIX. tv. 11.§ (1)], másrészt a törvény a kötelező feladat- és hatáskörök meghatározásánál köteles differenciálni a különböző jogállású önkormányzatok között a gazdasági teljesítőképesség, a lakosságszám valamint a közigazgatási terület nagyságának figyelembevételével [2011. évi CLXXXIX. tv 11.§ (2)]. ${ }^{185}$ Fontos rögzíteni, hogy a Mötv. kibővítette a települési önkormányzatok körét a járásszékhely városi önkormányzat típusával, mint korábban nem létező önálló önkormányzati jogállással - [2011. évi CLXXXIX. tv 3.§ (2)]. Az új önkormányzati törvény mellett a helyi közfeladat-ellátás szempontjából nagyon fontosak azon egyéb jogszabályok, amelyek szintén hozzájárultak az állam (kormányzat) és az önkormányzati szektor közötti hatáskör-transzferhez. Így többek

\footnotetext{
${ }^{185}$ Az 1990-es Ötv. nem fogalmazott meg ilyen összefüggést a kötelező önkormányzati feladatok illetve az önkormányzati jogállás között, ami a helyhatóságok fontos kritikája volt.
} 
között a megyei önkormányzati intézmények (középiskolák, szociális intézmények, megyei fekvőbeteg intézmények) átvétele, valamint a Fővárosi Önkormányzat intézményi „profiltisztása” - benne a fővárosi kórházakkal. Megtörtént a korábban városi, megyei jogú városi tulajdonban lévő kórházak állami átvétele is; a több ezer köznevelési (közoktatási) intézmények fenntartói joga pedig kifejezetten a célra létrehozott központi hivatal Klebelsberg Iskolafenntartó Központra (KLIK) szállt, napjainkig érő komoly szakmai vitákat generálva ezzel. A kormányzat területi feladatellátásért felelős megyei kormányhivatalok közvetlen térségi feladatellátásának segítésére megtörtént az államigazgatási járások kialakítása (járási kormányhivatalok). ${ }^{186}$ Viszont az önkormányzati feladatellátás része maradt a bölcsőde- és óvodai feladatok, az egészségügyi alap- és járóbetegellátás, illetve a helyi szociális feladatok nagyobb része. A tevékenységüket a 2013. január 1. határidővel ellátó járási kormányhivatalokhoz nagyszámú önkormányzati feladat került át immáron, mint saját államigazgatási hatáskörök, amelyeket korábban a települési önkormányzatok, a gyakorlatban sokszor éppen többcélú kistérségi társulások láttak el.

A 2011. évi CLXXXIX. törvény hozta létre a járásszékhely városi önkormányzatot, mint önálló önkormányzati jogállást - [Mötv. 3.§ (2)]. Ezek kiemelt kistérségi szerepköre közvetlenül fakad a 2013. január 1-vel életbe lépő államigazgatási járásrendszerből. A járásszékhely városok biztosítanak otthont a járási szintű területi dekoncentrált intézményeknek (elsődlegesen a járási kormányhivatal, de egyéb speciális állami szakhatósági intézményeknek is - NAV kirendeltségek etc.). Ennek nagy valószínüséggel további közvetetett pozitív reálgazdasági és társadalmi hatásai lesznek akár már rövid- és középtávon: kistérségi szinten vonzó befektetési célpont; várható magasabb foglalkoztatottság; ingatlanárak potenciális növekedése.

A főváros és a megyei jogú városok lakosságszámuknál, igazgatási intézményrendszerüknél, gazdasági és társadalmi paramétereivel jelentősen különböznek a járásszékhely városok, egyszerü városi önkormányzatok és falvak világától. A Budapest mellett NUTS2 szinten értelmezett kiemelt nagytérségi városi központok - Szeged, Pécs, Debrecen, Miskolc - [ezek a 2005-ös Országos Területfejlesztési Koncepcióban, mint külön fejlesztési célok pólusvárosok, majd a jelenleg hatályos OFTK-ban (1/2014. Ogy. határozat a Nemzeti Fejlesztés 2030 - Országos Fejlesztési és Területfejlesztési Koncepcióról), már ún.

\footnotetext{
186 2011. évi CLIV. törvény a megyei önkormányzatok konszolidációjáról, a megyei önkormányzati intézmények és a Fővárosi Önkormányzat egyes egészségügyi intézményeinek átvételéröl. 2012. évi XXXVIII. törvény a települési önkormányzatok fekvőbeteg-szakellátó intézményeinek átvételéröl és az átvételhez kapcsolódó egyes törvények módosításáról. 2011. évi CXC. törvény a nemzeti köznevelésröl. 2012. évi XCIII. törvény a járások kialakításáról, valamint egyes ezzel összefüggő törvények módosításáról.
} 
regionális központok elnevezés alatt kerültek nevesítette] - pedig eleve eltérő gazdaságfejlesztési, állami területi térségszervezési, valamint egyéb közpolitikai dimenzióban mozognak a különböző stratégiai dokumentumokban, szakpolitikai tervezésben továbbá a politikai döntéshozók, államigazgatási vezetők, és fejlesztési szakemberek gondolkodásában.

\section{V.7.2 Kötelező önkormányzati társulások az új önkormányzati törvényben}

A 2012-ben hatályba lépett Alaptörvény helyi önkormányzatokról szóló fejezete kifejezetten lehetőséget biztosított a kötelező önkormányzati társulásokhoz: „törvény elrendelheti a helyi önkormányzat kötelező feladatának társulásban történő ellátását” [Alaptörvény, 34. cikk, (2)] ${ }^{187}$ Ugyanakkor az önkéntes önkormányzati társulás lehetősége továbbra is fennáll az Alaptörvény olvasatában - [Alaptörvény, 32. cikk (1)].

A Mötv. 85.§ (1) pontja szerint a 2000 lakos vagy az alatti települések számára kötelezö, 2000 lakos felett pedig lehetöség az ún. közös önkormányzati hivatalba történö tömörülés - ez tulajdonképpen a korábbi körjegyzőség karakterisztikájú, de immáron kötelező társulásos jogintézmény. A Mötv. által életre hívott közös önkormányzati hivatalok váltották fel a korábban önkéntes alapon létrejött körjegyzőségeket - a föszabály a 2012. december 31. megszünési időpont volt [Bekényi-Gyergyák, 2013, 39-40. pp.]. A 2014-ben kiadott Magyarország közigazgatási helynévkönyve 2014. január 1. KSH kiadvány tartalmazza a 2014. január 1-én müködő közös önkormányzati hivatalok területi és települési adatait. A törvény $85 . \S$ (3) pontja értelmében a közös önkormányzati hivatalok alapításáról szóló önkormányzati megállapodások az általános önkormányzati választásokat követő év január 1.vel lépnek hatályba, így a KSH kiadvány pontosan tartalmazta a magyarországi közös önkormányzati hivatalok számát - ez 2014-ben Magyarországon 749 db ${ }^{188}$ a következő NUST2 térségi-regionális megoszlásban:

- Közép-Magyarország 28 közös önkormányzati hivatal

- Közép-Dunántúl 100 közös önkormányzati hivatal

- Nyugat-Dunántúl 138 közös önkormányzati hivatal

- Dél-Dunántúl 143 közös önkormányzati hivatal

- Észak-Magyarország 165 közös önkormányzati hivatal

\footnotetext{
187 Eme passzus révén az Alaptörvény tulajdonképpen biztosítja a lehetőséget, hogy akár a nyugat-európai nagyvárosi szövetségek, agglomerációs tanácsok mintájára kötelező nagyvárosi önkormányzati társulásos jogintézményt hozhasson létre törvény.

${ }^{188}$ A 2014-es KSH helynévtár szerint a 2014. január 1-én 3177 magyarországi település közül 545 település tartott fenn önállóan önkormányzati (polgármesteri) hivatalt; 749 város vagy község, mint közös önkormányzati hivatal székhelytelepülése volt, és 1883 községi önkormányzat nem rendelkezett saját hivatallal, de része volt természetesen közös önkormányzati hivatalnak, amelynek más településen volt a székhelye [KSH, $2014,23$. pp.].
} 
- Észak-Alföld 103 közös önkormányzati hivatal

- Dél-Alföld 72 közös önkormányzati hivatal [KSH, 2014, 24. pp.].

A 2014-es KSH helynévtár külön táblázatban elemzi a közös önkormányzati hivatalok székhelytelepüléseit, ebből látható, hogy a 2014. január 1.-én müködő 749 közös önkormányzati hivatalból mindössze $3 \mathrm{db}$-nak volt a székhelytelepülése megyei jogú város 1 db Veszprém; 1 db Szeged és 1 db Szekszárd. Ez az indikátor jelzi, hogy a megyei jogú városok érdemben továbbra sem kívánnak komolyabb szerepet vállalni a városkörnyéki települések jegyzői hivatali feladatok ellátásában [KSH, 2014b 24. pp.].

\section{V.7.3. Az önkéntes önkormányzati társulásokra vonatkozó jogszabályi változások}

2013. január 1-vel hatályát vesztette a helyi önkormányzatok társulásairól és együttműködéséről szóló 1997. évi CXXXV. törvény, valamint a többcélú kistérségi társulásokról szóló 2004. évi CVII. törvény (Tktv.). Ugyanakkor ez nem jelentette az ominózus jogszabályok mentén korábban kialakított önkéntes társulások automatikus megszünését. A Mötv. 87-95.§ alapján továbbra is fennmaradt az önkéntes önkormányzati társulások lehetősége - ugyancsak 2013. január 1. hatályba lépéssel. A Mötv. 87. § a következő generális szabályban rögzítette az önkéntes társulások fogalmát: „A helyi önkormányzatok képviselö-testületei megállapodhatnak abban, hogy egy vagy több önkormányzati feladat- és hatáskör, valamint a polgármester és a jegyzö államigazgatási feladat- és hatáskörének hatékonyabb, célszerübb ellátására jogi személyiséggel rendelkezö társulást hoznak létre." Tartalmi szempontból az önkormányzati kompetenciák kiegészítése a polgármester és a jegyző államigazgatási feladataival mindenképpen racionális szabályozási elemnek tekinthető. A már létrehozott önkéntes önkormányzati társulások teljes felülvizsgálatára irányuló jogalkotói szándékot jelzi, hogy a Mötv. 146.§ (1) átmeneti rendelkezése minden 2013. január 1. elött megkötött önkormányzati társulás felülvizsgálatát tủzte ki 2013. június 30.-ig - az érintett képviselőtestületek határozatban foglalt nyilatkozatával, amely dönt a megszüntetésről vagy a további fenntartásról meghatározva, hogy a korábbi együttmüködés, társult feladatellátás mely területeken, kompetenciákban marad fent. A Mötv. ezzel lehetőséget adott a korábbi többcélú kistérségi társulások közös akaratból történő megszüntetésére, s vele a kistérségi munkaszervezet feloszlatására. A korábbi többcélú kistérségi társulások új típusú önkormányzati társulási keretben való „továbbélését” nehezítette, hogy kizárólag jogi személyiségü társulási keretet támogat a törvény. A 6 hónapos memorandum keretében viszonylag szoros időbeli kötelezettséget róttak 
a többcélú kistérségi társulások számára, nyilvános összefoglaló tanulmány az eltelt idő rövidsége folytán nem nagyon készült. Mindenképpen említésre méltó azonban az Állami Számvevőszék 2014-es őszi tanulmánya, amely kifejezetten a települési önkormányzatok társulásait és azok feladatellátását vizsgálta. A különböző társulások gazdasági (de a jogi aspektusok is szóba kerültek) működését górcső alá vevő ÁSZ vizsgálat 17 többcélú kistérségi társulásra és 49 intézményfenntartó önkormányzati társulást érintett: előbbiek közül 15 társulás résztvevői döntöttek a kooperáció fenntartásáról és mindössze $2 \mathrm{db}$ mondta ki a megszűnését - a 17 vizsgált többcélú társulás közül 2 kapcsolódott megyei jogú városhoz, amelyből a kecskeméti megszünt, a szekszárdi viszont fenntartotta továbbműködését. A 49 intézményfenntartó társulás közül csak 19 alakult át a Mötv.-nek megfelelően, 30 társulás azonban megszünt a törvényben elöírt határidőn belül. Az intézményfenntartó társulások kapcsán fontos információ, hogy itt is csak Kecskemét és Szekszárd megyei jogú városok kerültek be a vizsgálatba, és amíg Kecskeméten mindkét intézményi társulás ( 1 egészségügyi, 1 szociális) megszünt, addig a 8 Tolna megyei székhelyt érintő intézményfenntartó társulásból 5 maradt fent és 3 esetben mondták ki a társulást alkotó tagönkormányzatok a megszűnést [ÁSZ, 2014, 52-55. pp.].

\section{Új jogi környezet és perspektívák a várostérségi tervezéshez:}

Az államszervezet- és közigazgatás területén az elmúlt évek centralizációs átalakítása mellett a kormányzat láthatóan továbbra is tisztában van az egységes, integrált várostérségi szemlélet fontosságával. Ennek jegyében került elfogadásra a településfejlesztési koncepcióról, az integrált településfejlesztési stratégiáról és a településrendezési eszközökröl, valamint egyes településrendezési sajátos jogintézményekröl szóló 314/2012. (XI. 8.) Korm.rendelet. Ez jelentősen megújította a településfejlesztés általános kereteit: a hosszútávra szóló településfejlesztési koncepció; valamint a középtávra szóló integrált településfejlesztési stratégia (4 évenkénti kötelező felülvizsgálat) - [314/2012. (XI. 8.) Korm.rendelet 5-7.§]. A területrendezési eszközök kapcsán a 10 évente felülvizsgálandó településszerkezeti terv valamint az ugyancsak 4 évre szóló helyi építési szabályzat lett nevesítve [314/2012. (XI. 8.) Korm.rendelet 9-16.§]. Ami igazán lényeges az önkormányzati kooperációk szempontjából, hogy mind a településfejlesztési [314/2012. (XI. 8.) Korm.rendelet 8.§]., mind a településrendezési [314/2012. (XI. 8.) Korm.rendelet 17.§] dokumentumok elkészítésénél a jogszabály engedi az önkormányzati társulásban való elkészítést és elfogadást Önkormányzatok közös tervezése címszó alatt. 
A 1181/2013. (IV. 5.) Korm.határozat a várostérségi integrált programok tervezési térségeinek lehatárolásával kapcsolatos irányelvekről rövid, de fontos intenciókat tartalmaz a várostérségi fejlesztési irányelvekre vonatkozólag kifejezetten a 2014-2020 EU költségvetési források hasznosulása szempontjából. A kormányhatározatban a terület- és településfejlesztési tervek összhangját erősíteni hivatott térségi és helyi egyeztető partnerségi mechanizmusok majdani kialakítása mellett ún. várostérségi fejlesztési dokumentumok készítését fogalmazta meg jövőbeli célként. A kormányhatározat javasolja Budapest és agglomerációja tekintetében az integrált városfejlesztési program kidolgozását [1181/2013. (IV. 5.) Korm.határozat 2. a)]; megyei jogú városoknál a vonzáskörzetekre kiterjesztett integrált várostérségi programokat, amelyek elkészítésébe a városkörnyéki településeket illetve a megyei jogú városokat is szükséges bevonni [1181/2013. (IV. 5.) Korm.határozat 2. b)]. A megyék esetében pedig a megyei jogú városokkal való egyeztetést, a járási székhelyek megerősítését valamint a kiegyensúlyozott településstruktúra irányába tett tervezést helyezett kilátásba [1181/2013. (IV. 5.) Korm.határozat 2. c)]. Az 1181-es kormányhatározat alapján jelenleg is készülnek a várostérségi stratégiák, amelyek másik nagyon fontos vonatkozása, hogy az 1831/2013. (XI. 14.) Korm.határozat a 2014-2020 tervezési időszak decentralizált forrásait tartalmazó a Terület- és Településfejlesztési Operatív Program (TOP) ${ }^{189} 3$ tervezési szintben gondolkodik: megyei szint; megyei jogú város szintje; várostérség és a megyei jogú város térségének a szintje. A kormányzat 2015 nyarán fogadta el a 18 megye és 22 megyei jogú város által benyújtott integrált területi programokat, amelyekhez kapcsolódó konkrét pályázati források 2015 őszén kerülnek kíŕrásra. ${ }^{190}$ A 2010 óta elkelt jogszabályi változások ismeretében említésre méltó, hogy amíg a közfeladat-rendszer tekintetében egyértelmüen csökkent az önkormányzati feladat- és intézménykataszter, s ezzel közvetve a nagyváros-térségi helyi alapfeladatok közös ellátására irányuló integrációs kezdeményezések lehetősége, addig a területi jellegü EU-s forrásfelhasználás tervezése kapcsán fontos, akár elsődleges prioritást kaphatnak akár már néhány éves távlatban a nagyvárosok.

\section{V.7.4 Megyei jogú városok 2010 után}

Már a Fidesz-KDNP elsöprő 2010-es választási sikerét és az új Országgyülés megalakulását követően került sor júniusban az $\mathrm{MJVSZ}^{191}$ soros féléves közgyülésére

\footnotetext{
189 A TOP Budapest és a közép-magyarországi régió (Pest megye) kivételével az összes egyéb statisztikaitervezési régióra (18 megye és megyei jogú városaik) vonatkozó ágazati operatív program.

190 Elfogadta a kormány az integrált területi programokat - http://hirlevel.egov.hu/2015/08/16/elfogadta-akormany-az-integralt-teruleti-programokat/

${ }^{191}$ Megyei Jogú Városok Szövetsége
} 
Győrben. Kósa Lajos (Debrecen fideszes polgármestere 1998-2014 között), felszólalásában már jelezte, újra kell rögzíteni az állami és önkormányzati feladatok teljes körét a méretgazdaságosság és hatékony feladatellátás jegyében. Pintér Sándor a „régi-új” belügyminiszter ${ }^{192}$ habár beszédében a települési önkormányzatok négy tervezett szintjéről beszélt, de a megyei jogú városok differenciálásásáról már nem szólt. A megyei jogú városvezetők közül az országosan akkor már ellenzékbe szorult szocialista párti Botka László, Szeged első embere hangsúlyozta leginkább a városok közigazgatási határon túli feladatait illetve a megyei jogú városok közötti nagy differenciákat [Csörgits, 2010, 98-105. pp.].

A rákövetkező évben, 2011-ben Szekeres Antal Debrecen Megyei Jogú Város jegyzője még a Mötv. elfogadása előtt a nyári XIX. Országos Jegyzői Konferencián fejtette ki véleményét a megyei jogú városokról: sérelmezte, hogy továbbra is megoldatlan a megyei jogú városok politikai képviseletének a megoldása a megyei közgyülésekben, amin egyébként a Mötv. sem változtatott érdemben. Felvetette, hogy a megyei jogú város jegyzője lehessen tagja a megyei államigazgatási kollégiumnak, illetve a már 1994-es Ötv. módosítás által életre hívott egyeztető bizottságok kapjanak végre érdemi hatásköröket. Szervezeti javaslatként elhangzott, hogy a kialakításra kerülő járási államigazgatási hatáskörök megállapodás alapján beintegrálódhassanak a megyei jogú város önkormányzati hivatali (az érintett kompetenciák államigazgatási jellege persze nem változna) rendszerébe. Mivel ekkor már napirenden volt az új állami dominanciájú közoktatási-köznevelési modell előkészítése, a jövőben (értsd: 2013tól) átadásra kerülő önkormányzati iskolák lehetséges „,visszaszerződése” - s így a fenntartói jogok önkormányzatoknál tartásának gondolata is megjelent a debreceni főjegyzőnél [Szekeres, 2011, 34-35. pp.]. Ez a téma különösen érzékennyé vált a Klebelsberg Iskolafenntartó Központ (KLIK) létrehozását követően. Egyes fideszes kormánypárti képviselők (Kósa Lajos, akkor még, mint Debrecen első embere; Pokorni Zoltán egykori oktatási miniszter, 2006 óta Budapest XII. kerületének vezetője) informális tiltakozásainak ellenére az egységes állami közoktatási rendszer koncepciója valósult meg 2013-tól.

Röviden summázva a 2011-es új önkormányzati törvény változatlanul hagyta a nagyvárosok (Budapest főváros és a megyei jogú városok) törvényi pozícióit: bár az új önkormányzati törvény Budapest önkormányzati jogállását tekintve egyszerre minősíti települési és területi önkormányzatnak - [Mötv. 21.§ (2)], ugyanakkor a megyei jogú városoknál lényegében megmaradt az 1990-es megfogalmazás: , azokat a közszolgáltatásokat is biztosítja, melyek saját területén túl a megye egészére vagy nagy részére kiterjednek”. 192 Pintér Sándor az első (1998-2002), a második (2010-2014), de harmadik (2014 óta) Orbán Viktor vezette
kabinetekben is ellátta, ellátja a belügyminiszteri pozíciót. 
Alkotmányosan ugyanakkor kétséges, hogy a Mötv. (de az Alaptörvény sem) nem rendelkezik a megyei jogú várossá nyilvánításról, mivel csak annyit mond, hogy „,Megyei jogú város a megyeszékhely város és az Országgyülés által e törvény hatálybalépése elött megyei jogúvá nyilvánított város” [Mötv. 21.§ (3)], a szimpla várossá nyilvánítás új szabályrendszere 321/2012. (XI. 16.) Korm.rendelet csak a községből várossá nyilvánítást rendezi - lásd a várossá nyilvánitásról szóló fejezetet!

\section{V.7.5 A megyei önkormányzatok teljes „kiüresítése” 2010 után}

A megyei önkormányzatok ún. konszolidációja keretében a 2000-es évek végére felhalmozódott adósság az állami átvállalás ellenében a megyei önkormányzati fenntartásban lévő különböző közfeladatot ellátó intézmények állami fenntartásba kerültek - kivéve a korábbi megyei önkormányzati múzeumokat, amelyeket az állam felajánlott a múzeum szerint illetékes települési, amely általában megyei jogú város önkormányzatoknak. A központi és önkormányzati kormányzás 2010 utáni térbeli átalakítását túlzás nélkül minősített drámainak Pálné Kovács Ilona egy 2012-es tanulmányban [Pálné, 2012, 20-24. pp.] Az 1990-es önkormányzati kodifikáció során létrejött „lebegő megye” gyengeségeit (főleg a korlátozott bevételi lehetőségek) az 1996-os területfejlesztési törvény igyekezett ellensúlyozni a decentralizált források kiemelt térségi allokációs funkciójával, de különösen az ezredforduló utáni különböző indirekt kormányzati eszközökkel és döntésekkel ismét gyengítették a megyei önkormányzatok felelősségi körét. Forrásallokáció tekintetében a megyei önkormányzatok helyett a közvetlen demokratikus legitimitással nem rendelkező megyei területfejlesztési tanácsok (mft), de sokkal inkább a regionális területfejlesztési tanácsok (rft) kerültek fókuszba. A megyék fejlesztéspolitikai térvesztése már az 1998-2002 parlamenti ciklusban elindult, a negyedik ciklus során (2002-2006) pedig egyértelműen a régió került a kormányzati államreform-elképzelések centrumába lásd az IDEA munkacsoport tevékenységét!), a 2006-2010 időszakban a nagyfokú politikai szembenállás - Heves kivételével minden megyei önkormányzatban Fidesz-KDNP többség „harcos szembenállása” a balliberális Gyurcsány-kabinettel - miatt került le a politikai regionalizálás kérdése a napirendröl. ${ }^{193}$ A korszak sajátos intézményi „,csataterepe” volt a Kormány-Önkormányzatok Egyeztető Fórum, ahol a kormányzat a jobbára ellenzéki irányítású (a megyei jogú városok nagy többsége; 18 megyei közgyülés) önkormányzati szektorral a meghatározó

\footnotetext{
${ }^{193}$ Nagypolitikai konszenzus híján a második Gyurcsány-kormány az államigazgatás regionális átalakításába fogott bele 2006 végén, erről részletesen lásd „Az állami területi dekoncentrált szervek telepitése a vidéki nagyvárosokba" címủ alfejezetben!
} 
önkormányzati érdekszövetségeken keresztül igyekezett formális intézményi kommunikációban maradni a parlamenti kapcsolatok mélypontra kerülése mellett [Pálné, 2012, 21-22.pp.; Szabó Tamás, 2009].

A megyei önkormányzatokat 2010 után érintő törvényi kodifikációk a helyi önkormányzati rendszer átalakításainak a nyitányát jelentették. A megyei önkormányzatokat érintő adósságkonszolidáció időben megelőzte a települések adósság-elengedését. A megyei önkormányzatok konszolidációjáról, a megyei önkormányzati intézmények és a Fövárosi Önkormányzat egyes egészségügyi intézményeinek átvételéröl szóló 2011. évi CLIV. törvénynek már az elnevezése is jelzi az ,adósságátvállalásért cserébe intézmény-fenntartási jogot és vagyonátvételt" alapelvet, amit az állam érvényesített: mintegy 170 milliárd forint megyei önkormányzati adósságállomány ${ }^{194}$ állami átvállalásáért cserébe közel 1000 milliárd forint értékü vagyon (intézményrendszer) került a központi közigazgatáshoz. Ugyanakkor ezzel a lépéssel a megyei helyhatóságok intézményfenntartó szerepe teljesen eltünt, pedig 1990 óta ez jelentette az érdemi intézményi befolyásuk alapját. A jelenlegi helyzetben a szinte teljes mértékben „kiüresített” megyék elveszítették az esélyt, hogy az államnak rövid- és középtávon bármilyen konkurens szintjévé léphessenek elö, de egyúttal a nagyvárosokkal (főváros / megyei jogú város) szembeni intézményi pozícióik is látványosan romlottak.

\section{V.8 Empirikus kutatás a városkörnyéki kapcsolatokról}

A bevezetésben felállított modellkísérlet - mint egy új típusú magyarországi kétszintü föderatív agglomerációs tanács intézményi kialakítása - adta az ötletet, hogy készüljön egy kiegészítő empirikus kutatás, amely „A hatékony nagyvárosi kormányzás lehetőségei Magyarországon az új Önkormányzati törvény elfogadását követően” elnevezés alatt valósult meg. A reprezentativitás biztosításához operativv szervezeti segítséget nyújtott a Települési Önkormányzatok Országos Szövetsége (TÖOSZ), mint a legtöbb települési helyhatóságot magában tömörítő önkormányzati érdekszövetség. A kutatáshoz szakmai módszertani segítséget biztosított - a kérdőív online változatának előállítása; az adatfeldolgozásában való részvétel; a mintavétel magyarázata és statisztikai súlyozás - a Zsigmond Király Főiskola Társadalomtudományi Kutatóintézetének (ZSKF TTK) munkatársai, Dr. Kabai Imre matematikus-szociológus, főiskolai tanár, valamint Krisztián Viktor szociológus.

194 A forrás helye - Magyar Nemzeti Bank: Jelentés a pénzügyi stabilitásról 2012. április 61. pp. https://www.mnb.hu/letoltes/jelentes-penzugyi-stabilitas-201204-hu.pdf 


\section{V.8.1 Az empirikus kutatás módszertanáról}

Napjainkra a különböző társadalomtudományi kutatási adatfelvételek egyre nagyobb része készül online formában. Az internetes penetráció (kapcsolat, elérhetőség) a közigazgatásban - így az önkormányzatok körében - ma már gyakorlatilag 100\%-osnak tekinthető. A helyhatóságok rendelkeznek önálló webes felülettel, a vezetők és munkatársaik pedig e-mailes elérhetőséggel. A kutatási adatbázist a TÖOSZ biztosította, amely révén több ezer közvetlen polgármesteri e-mail címre került kiküldésre a figyelemfelhívó elektronikus levél Zongor Gábor TÖOSZ fötitkár aláírásával, benne a kutatás rövid felvezetésével illetve a kérdőívet tartalmazó weboldal (http://www.hoec.hu/kutatas-varosikormanyzas) elérésének megadásával - a figyelemfelhívó levelet, illetve magát a kérdőívet az 1. számú melléklet tartalmazza.

A kutatási kérdőív alapváltozata 2013. szeptemberben készült el, majd többkörös szakmai egyeztetést követően a végleges változat 2014. március elején került fel a társadalomtudományi kutatásokkal foglalkozó Homo Oecologicus Alapítvány internetes honlapjára (www.hoec.hu/kutatas_varosikormanyzas). A kutatási adatfelvételre az előzetes felhívás szerint 2014. március 3. és 2014. április 3. között került sor.

A kutatás témája: a nagyváros (főváros/megyei jogú város és városkörnyéki önkormányzatok) térségi településközi kapcsolatok, valamint a hatékony várostérségi kormányzáshoz ajánlott közpolitikai eszközök értékelése polgármesterek percepciós véleménye alapján.

\section{A kutatási kérdőív szerkezete:}

I. kérdéscsoport (I.1-I.8) - tájékoztató kérdések: nem, életkor, iskolai végzettség, az önkormányzat helye (megye/járás), önkormányzati jogállás, lakosságszám, az adatfelvétel idején betöltött hivatali ciklus száma.

II. kérdéscsoport (II.1-II.10) - $10 \mathrm{db}$ állítás, kontextus, mint vizsgálati paraméter szükségességének értékelése 1-5 skálán a nagyváros (fơváros / megyei jogú város) és városkörnyéki települések közötti kapcsolatok tekintetében - „szükséges dimenzió”.

III. kérdéscsoport (III.1-III.10) - a II. kérdéscsoportban vizsgált 10 db vizsgálati paraméter napi tapasztalati, percepcionális értékelése 1-5 skálán a nagyváros (fơváros / megyei jogú város) és városkörnyéki települések közötti kapcsolatok tekintetében „tapasztalati dimenzió”. 
IV.Települési kooperációk vizsgálata - az önkormányzatok közötti együttmüködések tipizálása.

V. kérdés: ajánlott „kemény” és ,puha” közpolitikai eszközök rangsorolása a nagyváros és városkörnyéki kapcsolatok erősítéséhez, javításához - 6 db ajánlott közpolitikai eszköz rangsorolása 1-6. pozíciók alkalmazásával.

VI. kérdés: egyéb javasolt beavatkozások, problémák megnevezése a nagyváros és városkörnyéki települési kapcsolatok témakörben - szabadon kifejtös válasz lehetösége!

A kutatási populáció, mint célcsoport:

A KSH már többször hivatkozott 2014-es agglomerációs kiadványában a statisztikai hivatal szakértői 561 települést nevesítettek, amelyek a főváros, valamint 21 megyei jogú 195 város szuburbán térségeit alkotják [Magyarország településhálózata 1. - KSH, 2014]. Ez az összes magyarországi települése (a KSH által 2013-ban regisztrált 3176 településszámmal kalkulálva) 17\%-át foglalja magában. Mivel a disszertáció az önkormányzati alapfeladatok várostérségi vizsgálatán túl kiterjedt a nagyvárosok önkormányzati, államigazgatási és egyéb ágazati közszolgáltatási pozíciók városhatáron túli tényleges hatókörére, ezért fontosnak gondoltuk megismerni, hogy a közvetlen agglomerációs térségi polgármesterek mellett mit gondolnak a nagyváros versus városkörnyéki települési önkormányzati kapcsolatokról a távolabbi települések első emberei. Ezért a kutatási célcsoportot ezért tudatosan az összes magyarországi települési önkormányzatra, pontosabban a települési polgármesterekre terveztük. A kutatásnak különös aktualitást adtak a már ismertetett a 2010 utáni jogszabályi változások.

\section{$\underline{\text { A kutatási minta paraméterei }}$}

A 30 napig tartó kutatási adatfelvétel során 241 db kitöltött értékelhetö polgármesteri kérdöivet kaptunk, amely a 3176 magyarországi települési önkormányzat - mint teljes országos teljes populáció (a KSH 2013-as települési statisztikái szerint) vonatkozásában 7,59\%-os kutatási (országos) mintavételt eredményezett. A megfelelő reprezentativitás érdekében elvégeztük a térségi adatok szociológiai súlyozását, a következő módon:

\footnotetext{
${ }^{195}$ Már esett szó korábban arról, hogy Hódmezővásárhely és a fővárosi agglomerációban található Érd megyei jogú városok esetében a KSH kiadvány nem beszél kimutatható agglomerálódásról.
} 


\begin{tabular}{|c|c|c|c|c|c|c|c|c|}
\hline $\begin{array}{l}\text { statisztikai-tervezési régióc } \\
\text { (NUTS2) }\end{array}$ & \multicolumn{4}{|c|}{10.000 lakos alatti település } & \multicolumn{4}{|c|}{10.000 lakos feletti település } \\
\hline & $\begin{array}{c}\text { teljes } \\
\text { populáció } \\
\text { (település) }\end{array}$ & $\begin{array}{c}\text { kutatási } \\
\text { minta } \\
(\%)\end{array}$ & $\begin{array}{c}\text { kutatási } \\
\text { minta } \\
\text { (db) }\end{array}$ & $\begin{array}{c}\text { alkalmazott } \\
\text { súly }\end{array}$ & $\begin{array}{c}\text { teljes } \\
\text { populáció } \\
\text { (település) }\end{array}$ & $\begin{array}{c}\text { kutatási } \\
\text { minta } \\
(\%)\end{array}$ & $\begin{array}{c}\text { kutatási } \\
\text { minta (db) }\end{array}$ & $\begin{array}{c}\text { alkalmazott } \\
\text { súly }\end{array}$ \\
\hline Észak-Magyarország & 567 & 43,02 & 45 & 0,96 & 43 & 3,26 & 1 & 3,26 \\
\hline Közép-Dunántúl & 359 & 27,24 & 40 & 0,68 & 41 & 3,11 & 3 & 1,04 \\
\hline Közép-Magyarország & 139 & 10,55 & 5 & 2,11 & 71 & 5,39 & 13 & 0,41 \\
\hline Nyugat-Dunántúl & 624 & 47.35 & 50 & 0,95 & 33 & 2,5 & 1 & 2,5 \\
\hline Dél-Alföld & 201 & 15,25 & 25 & 0,61 & 53 & 4,02 & 3 & 1,34 \\
\hline Dél-Dunántúl & 615 & 46,67 & 27 & 1,73 & 41 & 3,11 & 1 & 3,11 \\
\hline Észak-Alföld & 321 & 24,36 & 23 & 1,06 & 68 & 5,16 & 4 & 1,29 \\
\hline Összesen: & 2826 & & 215 & & 350 & & 26 & \\
\hline
\end{tabular}

4. táblázat: a kutatási mintában az egyes NUTS2 régióknál alkalmazott statisztikai súlyok

Az országos minta (241 db kérdöív) meghatározott paraméterek szerinti megoszlása:

A polgármesterek által reprezentált települések lakosságszáma

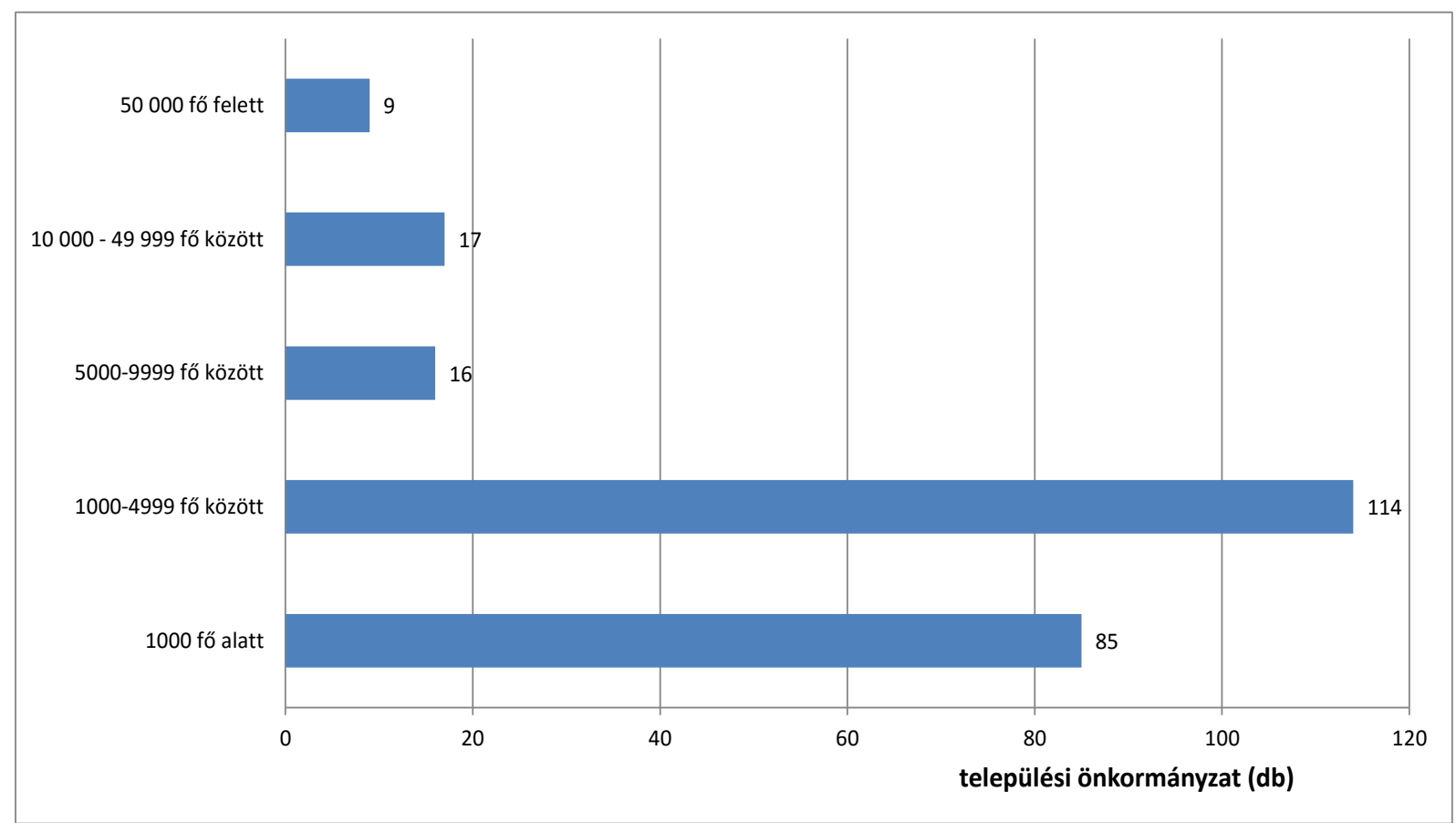

17. ábra: kutatási minta a települések lakosságszáma szerint (elemszám: 241) 
A polgármesterek által reprezentált települések önkormányzati jogállása

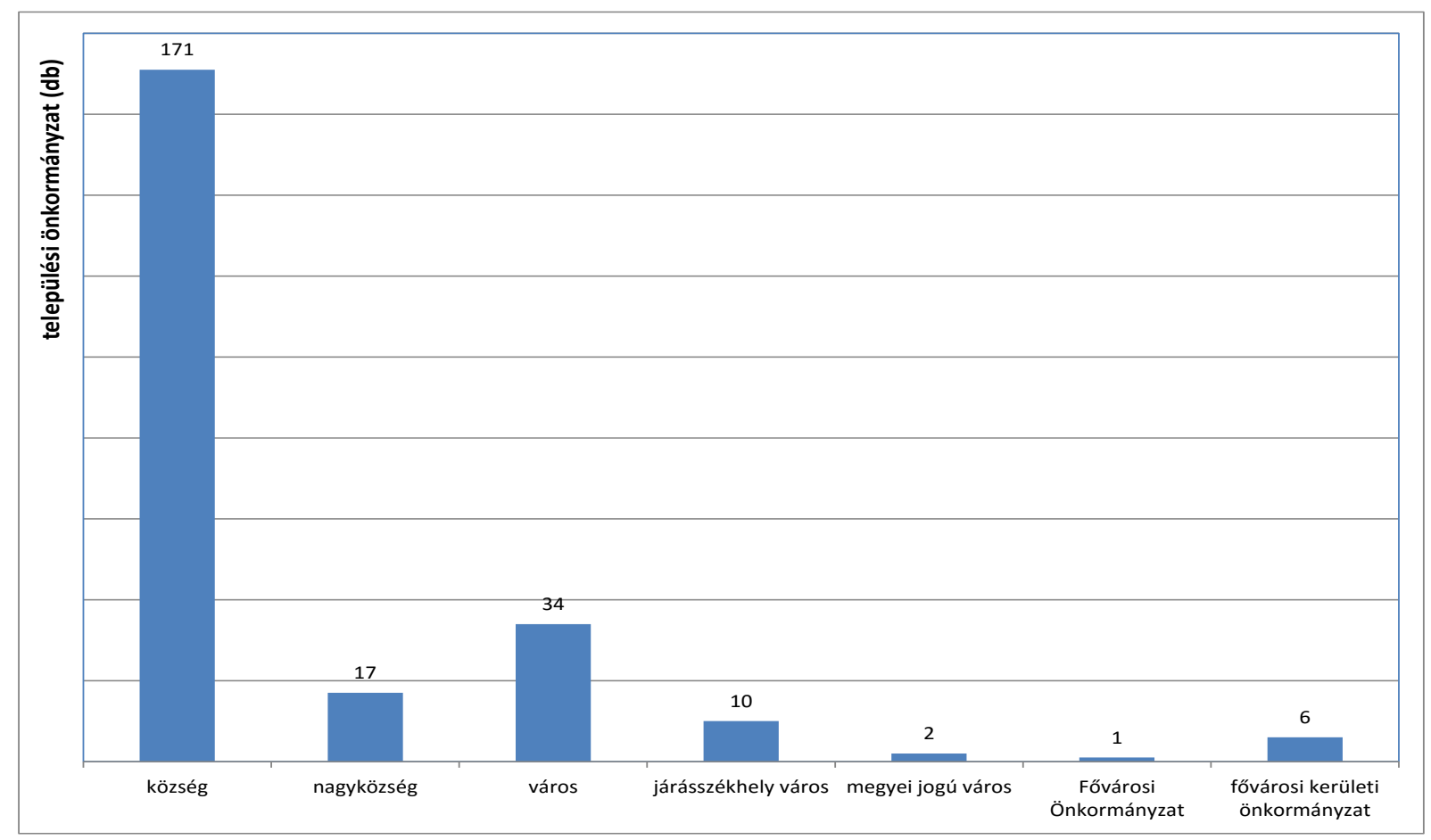

18. ábra: kutatási minta a települések jogállása szerint (elemszám: 241)

\section{A „,nagyvárosi” és városkörnyéki települési kutatási csoportok:}

A 241 db kérdőív települési önkormányzat típus szerinti megoszlását illetően a „nagyvárosi” kategóriába ${ }^{196}$ (esetünkben: fővárosi önkormányzat / megyei jogú városi önkormányzat) mindösszesen 3 kitöltött értékelhető polgármesteri kérdőívet kaptunk. Ezért a kutatást a nagyvárosi oldalról az alacsony elemszám miatt nem reprezentatív. Mivel a disszertációt, s vele a kutatási kérdőívet, alapjaiban meghatározó vizsgálati kontextus a nagyváros versus városkörnyéki települések (esetünkben: ide csoportosítottuk a minta összes egyéb jogállású települését) ${ }^{197}$ viszonyrendszer. Ezért a kutatási kérdőívek feldolgozása során alkalmazott alapvető lehatárolást az adott várostérség centrumtelepülése (föváros/megyei jogú

\footnotetext{
${ }^{196} \mathrm{Az}$ empirikus kutatásunk esetében a nagyváros kategória nem egyezik meg az 500.000 lakos/nagyvárosi térség nemzetközi standarddal - funkcionális nagyvárosi térség (Functional Urban Area - FUA) -, ugyanis ezen az alapon csak Budapest és agglomerációja került volna szóba. De a hazai geográfusok között egyezményesnek tekinthető legalább 100.000 lakosú nagyvárosi lakosságszám sem vált kutatási paraméterré. Mivel elsődlegesen a várostérségek közigazgatási dimenziójával foglalkozik a disszertáció, ezért magyarországi vonatkozásban - s így a kutatási kérdőívben is - önkényesen a nagyváros kategóriát a fóváros /megyei jogú város önkormányzati jogálláshoz kötöttük.

${ }^{197}$ A kérdőívet kitöltötte 6 fővárosi kerületi polgármester is, ugyan a kerületi helyhatóságok az ország egyik legspeciálisabb önkormányzati jogállást jelentik és a helyzetük sok szempontból nem lehet összevetni a települési önkormányzatokkal (pl. lakosságszámuknál fogva vannak kerületi önkormányzatok, amelyek meghaladják a 100.000 lakost). Mégis bent maradtak a városkörnyéki nem nagyvárosi mintában ezek a kérdöívek - miközben a kerületi polgármesterek véleményei több esetben radikálisan eltértek a vidéki községi, városi polgármesterek percepcióitól.
} 
város) és az összes többi (mint városkörnyéki település) közé helyeztük. Ezen a tartalmilogikai alapon a 238 városkörnyéki települési önkormányzati kérdöív közös halmazban került értelmezésre.

\section{V.8.2 „Nagyvárosi” kérdőívek}

Az adatfelvétel során a nagyváros kategóriához 3 értékelhető kérdőívet kaptunk: $1 \mathrm{db}$ fővárosi önkormányzat; $1 \mathrm{db}$ nyugat-magyarországi megyei jogú város; $1 \mathrm{db}$ keletmagyarországi megyei jogú város. Nagyvárosi vonatkozásban a minta nem reprezentatív, de illusztrációként érdemes a 3 db kérdőív fontosabb eredményeit, üzeneteit számba venni.

\section{A nagyváros és városkörnyéki települések kapcsolatrendszere:}

A nagyváros és városkörnyéki települések közötti kapcsolatok tekintetében a három nagyvárosi polgármester az 1-5 skálán leginkább szükségesnek az átlátható és egyértelmü jogszabályi kereteket (II.1) valamint a térségi önkormányzati politikai kapcsolatokat (II.2), a legkevésbé szükségesnek a nagyváros és városkörnyéki települések civil szervezetei közötti kapcsolatok, együttmüködéseket (II.6) illetve az Európai uniós és egyéb nemzetközi kapcsolatokat (II.7) vélte. A napi hivatali gyakorlatban megélt percepciós tapasztalati élmények alapján a leginkább pozitív megítélést az országos politikai (kormányzati, parlamenti) kapcsolatok (III.3) paraméter kapta. A legalacsonyabb tapasztalati percepciók az agglomerációs civil (III.6), valamint az Európai Uniós és egyéb nemzetközi kapcsolatokat (III.7) érték. A többi vizsgált paraméter megítélései különböző mértékben alakult.

A többi IV-V-VI. kérdéscsoportok ${ }^{198}$ sajnos rendkívül hiányosan kerültek kitöltésre a 3 nagyvárosi kérdőívben. Szakmai törekvésem, hogy valamilyen formában akár a kutatás során alkalmazott kérdőívet, akár már annak valamilyen módosított, továbbfejlesztett változatát közvetlenül tesztelhessem a későbbiekben kvalitatív mélyinterjúk keretében nagyvárosi polgármesterek között.

\section{V.8.3 A városkörnyéki települési kérdőívek országos szintézise}

Az adatfelvétel során 238 db községi, nagyközségi, városi, járásszékhely városi, valamint fövárosi kerületi polgármester által kitöltött értékelhető kérdőívet találtunk. A két

\footnotetext{
${ }^{198}$ IV. kérdéscsoport: a különböző már létező településközi önkormányzati kooperációkról; az V. kérdés a nagyváros és városkörnyéki településekhez ajánlott különbözö közpolitikai eszközök értékelését; a VI. kérdés a témakörhöz kapcsolódó további fontos beavatkozásról illetve megoldandó problémákról szóló szabadon kifejtős véleményt rögzítette.
} 
községi települési önkormányzati típusból (171 db községi és 17 db nagyközségi önkormányzat) összesen 188 db kérdöív volt a mintában, ami 78,99\%-os reprezentációt jelent a teljes minta esetében. Ugyanakkor, ha lakosságszám alapján (I.7 kérdés) csak az 5000 lakos alatti településeket számítjuk, abból 199 db található (85db 1000 lakos alatti település; 114 db 1000 - 4999 lakosú települése) - a két ábra komparatív összehasonlítása jelzi számunkra, hogy valószínüleg legalább 10 olyan település található a mintában, amely 5000 lakos alatti, de nagy valószínüséggel nem községi, hanem városi jogállású település.

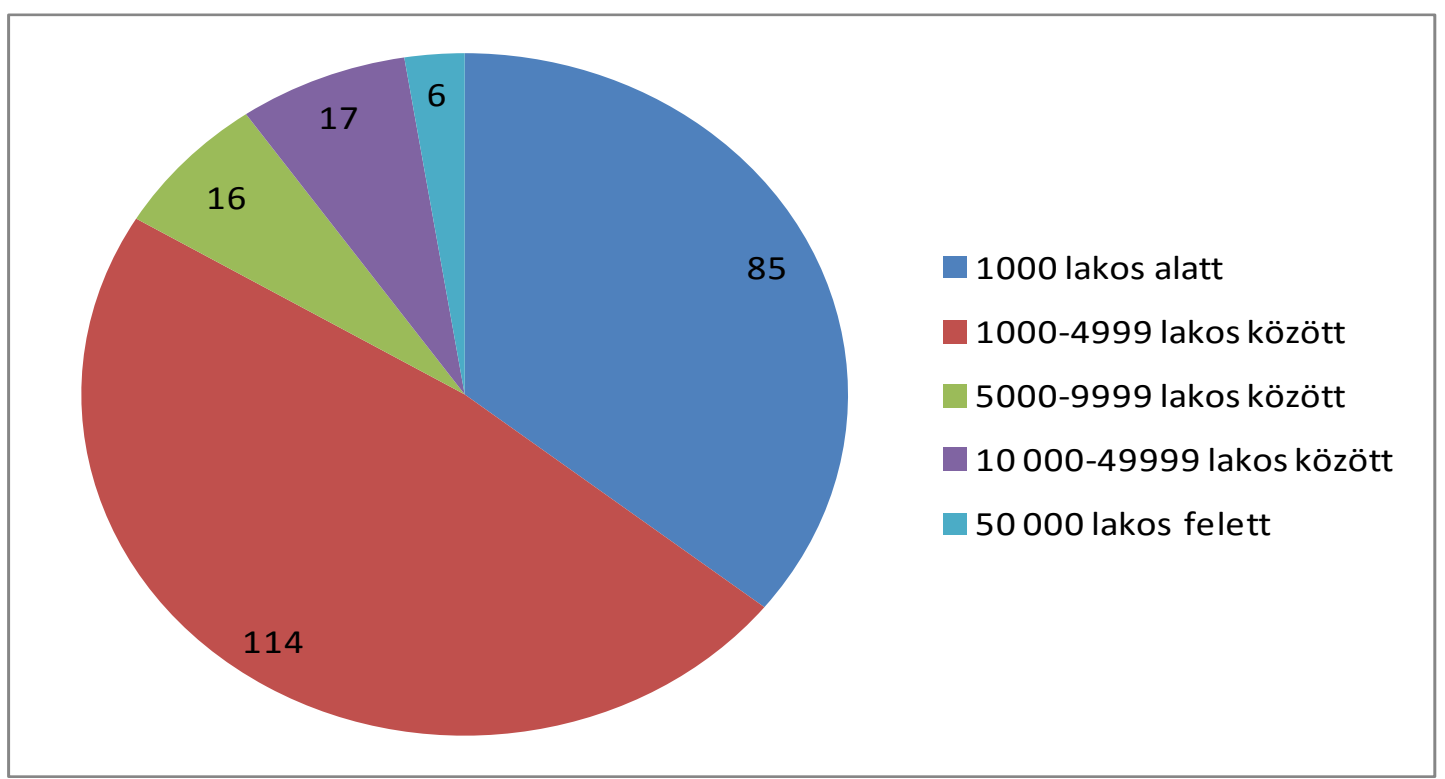

19. ábra: a városkörnyéki kérdőivek megoszlása a települések lakosságszáma szerint (elemszám: 238)

A „,szükségességi” dimenzió vizsgálata országos összevetésben:

Az 1-5-ig terjedő szükségességi skálán (1 egyáltalán nem szükséges; 2 inkább nem szükséges; 3 közepesen szükséges; 4 inkább szükséges; 5 nagyon szükséges) országos összevetésben a következő átlagértékek születtek a 238 db városkörnyéki települési polgármesteri kérdőív tekintetében. 


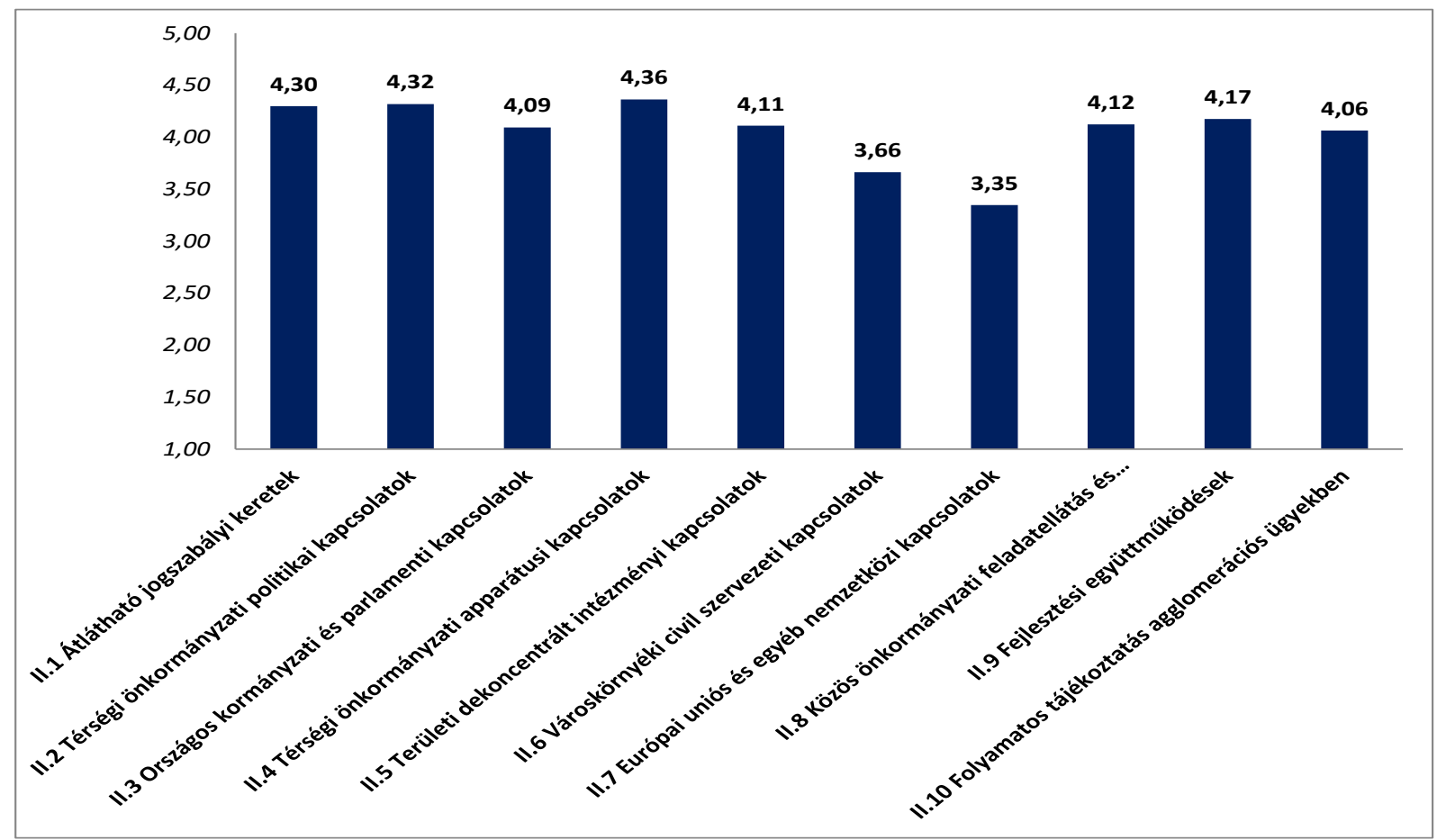

20. ábra: országos ,,szükségességi” dimenzió a városkörnyéki településeknél (elemszám: 238)

A leginkább szükségesnek a II.4 a térségi önkormányzati apparátusi kapcsolatokat (4,36 átlagpont) ítélték meg országosan, alig megelözve a II.2 Térségi önkormányzati politikai kapcsolatokat (4,32 átlagpont), valamint az I.1 Átlátható jogszabályi kereteket (4,30 átlagpont). Közel azonos mértékben gondolkodtak a kérdöívet kitöltő nem nagyvárosi településvezetök a II.9 a nagyvárosok és városkörnyéki települések közötti fejlesztési együttmüködések (4,17 átlagpont); a II.8 a nagyváros és városkörnyéki települések együttmüködésén alapuló önkormányzati feladatellátás és közszolgáltatások (4,12 átlagpont); illetve a II.5 a térségi önkormányzatoknak az államigazgatás területi szerveivel (kormányhivatalok, egyéb szakigazgatási szervek) kialakitott kapcsolatokról (4,11 pontos átlagpont). 4,09 pontos átlagot ért el a II.3 Országos kormányzati és politikai kapcsolatok kérdés. A II.10 az agglomerációs ügyekben a nagyváros és városkörnyéki települések lakosságának folyamatos tájékoztatása paraméter szükségességét 4,06 pontra értékelték átlagosan. Az előzetes kutatói feltevésekre leginkább talán az országos kormányzati és politikai kapcsolatok szükségességét értékelő válaszok cáfoltak rá, mivel a 10 állításból csak a 7.-ik legszükségesebbnek gondolták ezt a kérdőívet kitöltő nem nagyvárosi (községi, városi, járásszékhely jogú városi) településvezetők. Ha jobban megvizsgáljuk az egyes paraméterek szükségességére adott válaszokat, láthatjuk, hogy a legtöbben - szám szerint 126 polgármester - a leginkább szükséges kategóriát jelentő 5 ponttal az II.1 Átlátható jogszabályi kereteket illették, míg a legkevesebb 5 pontos értékelést a II.7 Európai uniós és egyéb 
nemzetközi kapcsolatok kérdés kapta 21 kérdőívben. Ugyancsak nagyszámú - 100 feletti kérdőív - 5 pontos értékelést kapott a II.2 Térségi önkormányzati politikai kapcsolatok, valamint a II.4 a térségi önkormányzati apparátusi kapcsolatok kérdés. Nem meglepö, hogy a nemzetközi kapcsolatok mellett a II.6. A nagyváros és városkörnyéki települések civil szervezetei közötti kapcsolatok, együttmüködések kérdésre érkezett még látványosan kisszámú (39 db) 5 pontos értékelés. Ugyanakkor az egyáltalán nem szükséges 1 pontos értékelést nagyon kevés esetben találtunk a vizsgált paramétereknél - ahol akadt, ott is bőven $10 \mathrm{db}$ alatt: a legnagyobb számban 3 polgármester adott egyáltalán nem szükséges (1 pontos) értékelést a II.7 Európai uniós és egyéb nemzetközi kapcsolatokra.

\section{A ,tapasztalati dimenzió” vizsgálata országos összevetésben:}

A 238 városkörnyéki nem nagyvárosi kérdőíven az 1-5-ig terjedő tapasztalati skálán (1 egyáltalán nem segit; 2 inkább nem segit; 3 valamiben segit, valamiben nem segít; 4 inkább segít; 5 teljes mértékben segíti) a következő átlagértékeket kapták a vizsgált paraméterek.

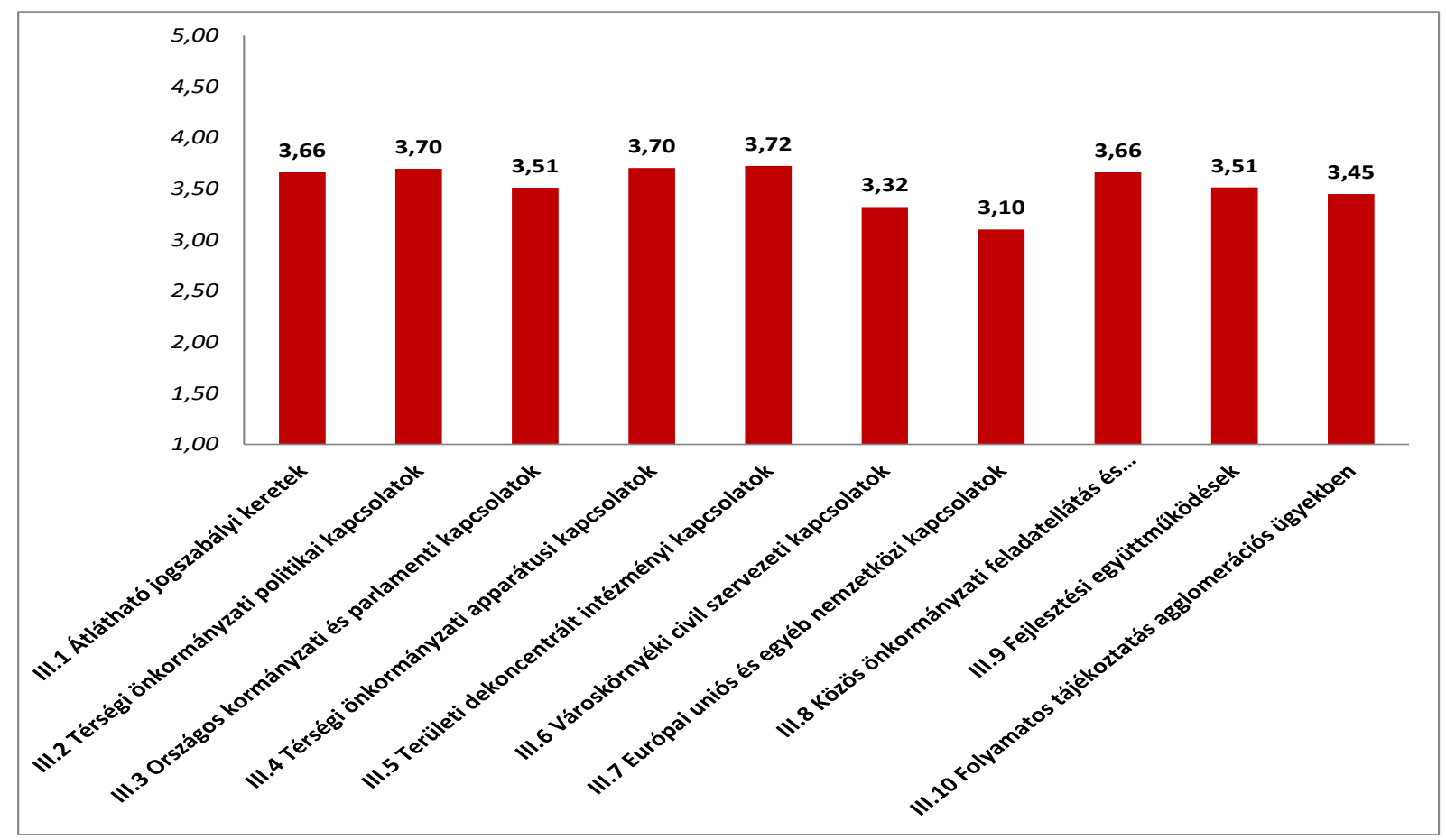

21. ábra: országos ,tapasztalati” dimenzió a városkörnyéki településeknél (elemszám: 238)

A „szükséges” versus „tapasztal” típusú társadalomtudományi komparatív kérdéspárokhoz hasonlóan, a tapasztalati dimenzióhoz érkezett válaszok szignifikánsan alacsonyabb átlagértékűnek bizonyultak az összes vizsgált paraméter tekintetében. A napi gyakorlatban legmagasabb átlagos értékünek tapasztalt paraméternek a III.5 a térségi önkormányzatoknak az államigazgatás területi szerveivel (kormányhivatalok, egyéb 
szakigazgatási szervek) kialakított kapcsolatokat (3,72 átlagpont) bizonyult a polgármesterek körében. Ettől alig maradt el a III.2 Térségi önkormányzati politikai kapcsolatok (3,70 átlagpont), illetve a III.2 Térségi önkormányzati apparátusi kapcsolatok (3,70 átlagpont) tapasztalatok alapján való átlagos megítélése. Hasonlóan vélekedtek a III.1 Átlátható jogszabályi keretek (3,66 átlagpont); a III.8 közös önkormányzati feladatellátás és közszolgáltatások (3,66 átlagpont); a III.9 a közös fejlesztési együttmüködések (3,51 átlagpont); a III.3 Országos kormányzati és politikai kapcsolatok (3,51 átlagpont) valamint a III.10 az agglomerációs ügyekben való folyamatos tájékoztatás (3,45 átlagpont) kérdésekben. A polgármesterek ugyanakkor a legalacsonyabb pontszámmal a III.6. A nagyváros és városkörnyéki települések civil szervezetei közötti kapcsolatok, együttmüködések (3,32 átlagpont), valamint a III.7 Európai uniós és egyéb nemzetközi kapcsolatok (testvérvárosi kooperációk; euroregionális együttmüködések; közvetlen brüsszeli, európai uniós kapcsolatok) (3,10 átlagpont) paramétereket értékelték. A felmérés bizonyította, hogy a polgármesterek gondolkodásában - mind a „szükséges”, mind és „tapasztalati” dimenziókban -, a legkevésbé a nemzetközi illetve a várostérségi civil kapcsolatok jelennek meg - ez jelenti a kutatás egyik legfőbb üzenetét. A legtöbben - szám szerint 45 kitöltő - a teljes mértékben segíti kategóriát jelentő 5 ponttal illette a III.1 Átlátható jogszabályi kereteket - ezzel kihangsúlyozva a szabályozási környezet fontosságát. Ugyanakkor az egyáltalán nem segíti (1 pontos) szélsőséges értékelést nagyon kevés esetben találtunk a kérdöíveken. $11 \mathrm{db}$ ilyen értékelés született mindössze. A „tapasztalati” dimenzióban az értékelések közel 2/3 része vagy a valamiben segíti, valamiben nem segíti (3 pont) vagy az inkább segíti (4 pont) kategóriába esett.

\section{V.8.4 A városkörnyéki kérdőívek térségi szintézise}

Elvégeztük a 238 városkörnyéki (község, nagyközség, város, járásszékhely jogú város) polgármesteri kérdőív statisztikai-tervezési régiók szerinti feldolgozását, amelynek alapja a következő NUTS2 térségi megoszlás lett: 


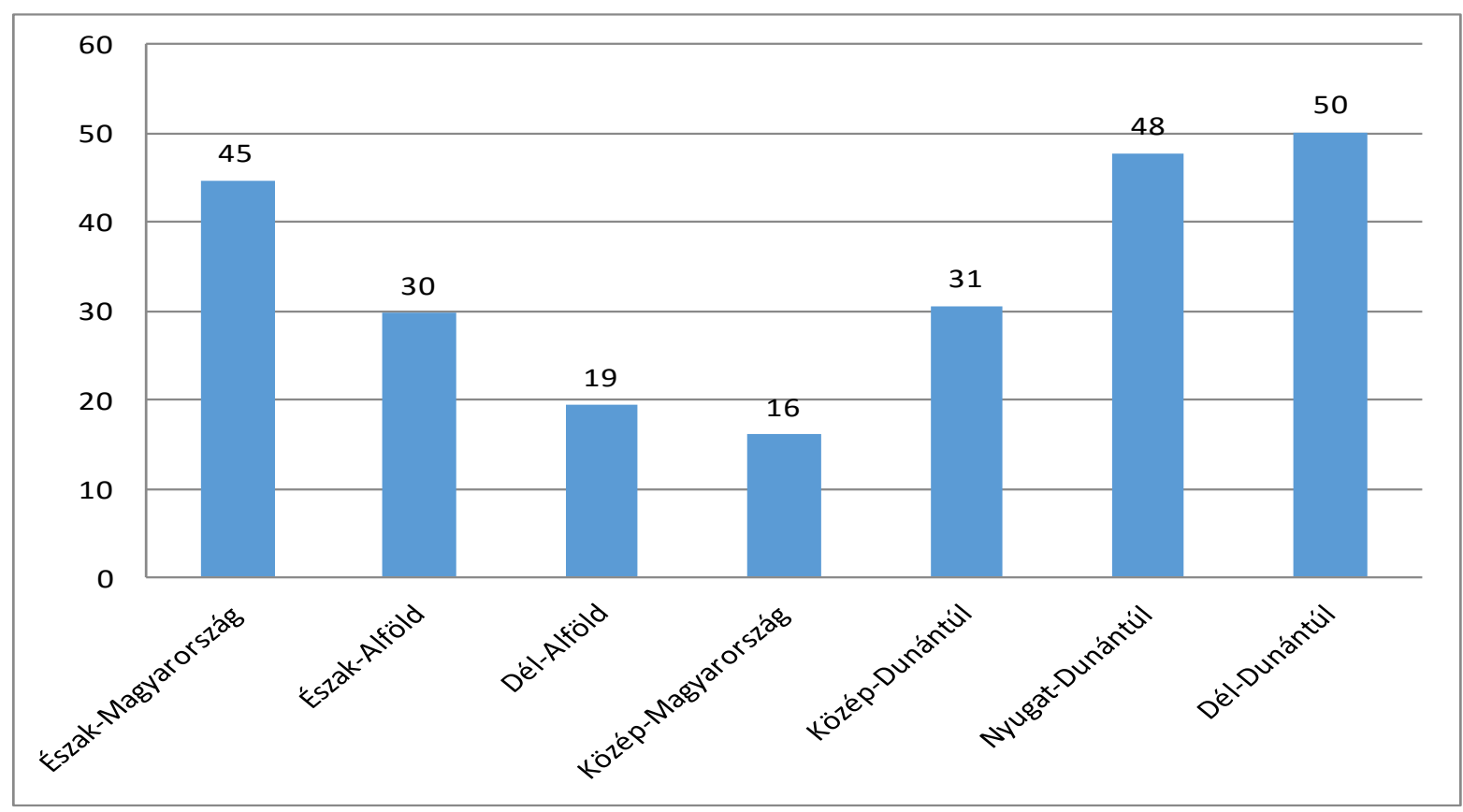

22. ábra: a városkörnyéki kérdőivek megoszlása NUTS2 régiók szerint (elemszám: 238)

Az így kapott eredmények jelzik, hogy habár a magyarországi településszerkezeti differenciákból ${ }^{199}$ fakadó közpolitikai determinációk (társulási és egyéb együttmüködési kényszerek) széles körben ismertek, a polgármesterek mégis hasonló arányban értékelték a vizsgált paraméterek szükségességét és azok megélt tapasztalati szintjét. A regionális településszerkezeti differenciák jóval kevésbé mutatkoztak meg, mint amire előzetesen akár számítani lehetett. Érdemes külön kitérni az országos kormányzati és parlamenti kapcsolatok (II.3-III.3) paraméter településvezetői megítélésére. Már az országos adatoknál is látható volt, hogy a polgármesterek a szükséges és tapasztalati percepcióknál a vizsgált paraméterek alsó szegmensébe értékelték az országos nagypolitikai kapcsolatokat: 7. legszükségesebb (4,09 átlagpont); 6. tapasztalati besorolás (3,51 átlagpont). A „nagypolitikai paraméter” térségiregionális eredményeit tekintve a leginkább szükségesnek a Dél-Dunántúlon illetve ÉszakAlföldön gondolták a polgármesterek - [4-4. pozíció]. A legkevésbé szükségesnek pedig a dél-alföldi és közép-dunántúli térségekben - [8. pozíció]. A tapasztalati percepciók a legmagasabb értéket Dél-Alföldön eredményezték, ahol a 2. legmagasabb átlagértéket adták a térségi polgármesterek; a legalacsonyabb térségi átlagpontszámot pedig a nyugat-dunántúli településvezetők adták a városkörnyéki kapcsolatok szempontjából az országos kormányzati és politikai kapcsolatoknak - [9. pozíció]. A közeljövőre nézve érdekes dilemma lehet, hogy a helyhatóságok életére - benne a településközi kapcsolatokkal - milyen hatással lesznek az

199 Aprófalvas szétaprózódott térségek a Dunántúlon, Észak- és Kelet-Magyarországon; jóval kevésbé fragmentált, óriásfalvak és városok dominálta alföldi területek; speciális szuburbanizált viszonyok KözépMagyarországon és néhány vidéki nagyváros térségében. 
elmúlt időszak jelentős szabályozási és közpolitikai változásai: parlamenti képviselőség és választott települési önkormányzati pozíciók (polgármester, képviselő) összeférhetetlensége 2014 ősztől. Továbbá az önkormányzati kompetenciák- és források átcsoportosítása az állami költségvetési szektorhoz; önkormányzati adósságkonszolidáció és megszigorított önkormányzati gazdálkodási szabályok (hitelfelvétel kormányzati engedélyhez kötése etc.).

A térségi „,szükséges” és ,tapasztalati” dimenziókat tartalmazó ábrákat a disszertáció 2. számú melléklete tartalmazza, az alábbiakban a legfontosabb térségi tapasztalatok kerültek összegzésre.

A ,szükségességi” dimenzió térségi-regionális eredményeinek szintetizálása:

A vizsgált kompetenciák szükségességének regionális-térségi kontextusa esetében látható, hogy a térségi önkormányzati politikai (II.2) valamint az önkormányzati hivataliapparátusi kapcsolatokat (II.4) az összes statisztikai-tervezési régióban a legszükségesebbnek vélt négy paraméter közé sorolták. Ez különösebben nem meglepő ismerve az 1990 óta fragmentált helyi önkormányzati szisztémát (,egy település egy önkormányzat” elv) és az abból fakadó intézményi együttmüködési - társulások etc. - közpolitikai determináltságot.

Ugyancsak magas szükségességet állapítottak meg a térségekben az átlátható jogszabályi kereteknek (II.1) - pl. nagyon magas 4,85 pontos átlagot eredményezve KözépMagyarországon. Általában a paraméterek felső szegmensébe sorolták az egyes régiókban a polgármesterek a kooperáció olyan eseteit, mint a közös önkormányzati feladatellátás és közszolgáltatás (II.8) illetve a különbözö konkrét fejlesztési együttmüködések (II.9).

A legalacsonyabb szükségességet - visszaigazolva az országos átlagokat - mind a 7 régióban a nemzetközi és Európai Uniós (II.7) valamint a városkörnyéki civil szervezeti kapcsolatok (II.6) paraméterek kapták a polgármesterektől. A térségi empirikus adatok is arról árulkodnak, hogy a hazai polgármesterek nem tulajdonítanak komolyabb jelentőséget a nemzetközi illetve a helyi-térségi civil kooperációknak, miközben napjaink posztmodern globális politikai és gazdasági, valamint a helyi governance alapú közpolitikai folyamatainak egyre erösebb dinamizáló forrása a két említett paraméter. A túlzottan forrásorientált attitüd illetve a direkt politikai formális és informális kapcsolatok „hajszolása” határozza meg leginkább a településvezetők gondolkodását és mozgásterét, így rendkívül háttérbe szorulnak az azokon kívül eső egyéb stratégiai „kitörési pontok”. Ez a felismerés egyszersmind egy alternatív helyi politikai attitűd kijelölésére is alkalmas lehet a jövőre nézve a sok szempontból „,beszűkült” helyzetbe hozott helyhatóságok életében - átalakult önkormányzati feladatrendszer (új 
önkormányzati törvény és ágazati jogszabályok 2010 után); új finanszírozási és vállalkozási környezet.

\section{A „tapasztalati” dimenzió térségi-regionális eredményeinek szintetizálása:}

A térségi tapasztalati eredmények követték az országos tendenciát, minden térségben az összes paraméternél a szükségeshez képest alacsonyabb tapasztalati értékek születettek. Több régióban a területi dekoncentrált intézményekkel kialakitott kapcsolatok (III.5) került a paraméterlista élére - kiemelkedik Észak-Magyarország, ahol 4,01 átlagos pontértékkel egyedüliként érte el a településvezetői megítélés a 4-es pontátlagot. Persze voltak speciális térségi eredmények, így Közép-Magyarországon, ahol a térségek közül a legmagasabb szükségességet tulajdonítottak az átlátható jogszabályi kereteknek (III.1). A közös önkormányzati feladatellátás és közszolgáltatások (III.8) a Közép-Dunántúlon valamint DélDunántúlon is a legmagasabb értékeket kapták a 10 paraméter közül - ismerve a két régió erősen aprófalvas, szétaprózódott településszerkezetét valamint az abból fakadó aktívabb társulási tapasztalatokat, nem meglepő, hogy az érintett polgármesterek véleményében erősebben tükröződött ez vissza. A „szükségességi” dimenzióhoz hasonlóan a térségi önkormányzati politikai (III.2) és apparátusi kapcsolatok (III.4) is általában magasabb tapasztalati besorolást kaptak a válaszoló polgármesterektől.

Alig meglepő módon összes az statisztikai-tervezési régióban a nemzetközi, Európai Uniós kapcsolatok (III.7), illetve a nagyváros-városkörnyéki civil kapcsolatok (III.6) tapasztalati értékelése kapta a legalacsonyabb pontokat. Az alacsony elvárásokhoz hasonlóan alacsony szintủ tapasztalatokról árulkodnak a polgármesteri percepciók. Láthatóan a két paraméter fontossága alig-alig jelenik meg a településvezetők stratégiai gondolkodásában. A legrosszabb empirikus értékelés Dél-Dunántúlon született, ahol a városkörnyéki civil kapcsolatok átlagos pontértéke 3,08 pont; a nemzetközi, EU-s kapcsolatoknál pedig mindössze 2,77 pont körül alakult az 1-5 skálán. Az egyes statisztikai-tervezési térségekben a felmérés eredményeként tapasztalható, az egyes vizsgált paraméterek kapcsán mért „hiányérzetek” vonatkozólag érdemben nem tértek el sehol sem az országos hiányérzeti adatoktól.

\section{V.8.5 A városkörnyéki kérdő́vek jogállás szerinti szintézise}

A városkörnyéki kapcsolatokat értékelő polgármesteri percepciók összevetése a települési önkormányzati jogállással hasonlóan fontos vizsgálati aspektus. Kérdés, hogy a településvezetői gondolkodást és attitüdöket mennyiben befolyásolja a települési 
önkormányzati jogállás az önkormányzati stratégiaalkotás és várostérségi helyhatósági kapcsolatok alakítása során.

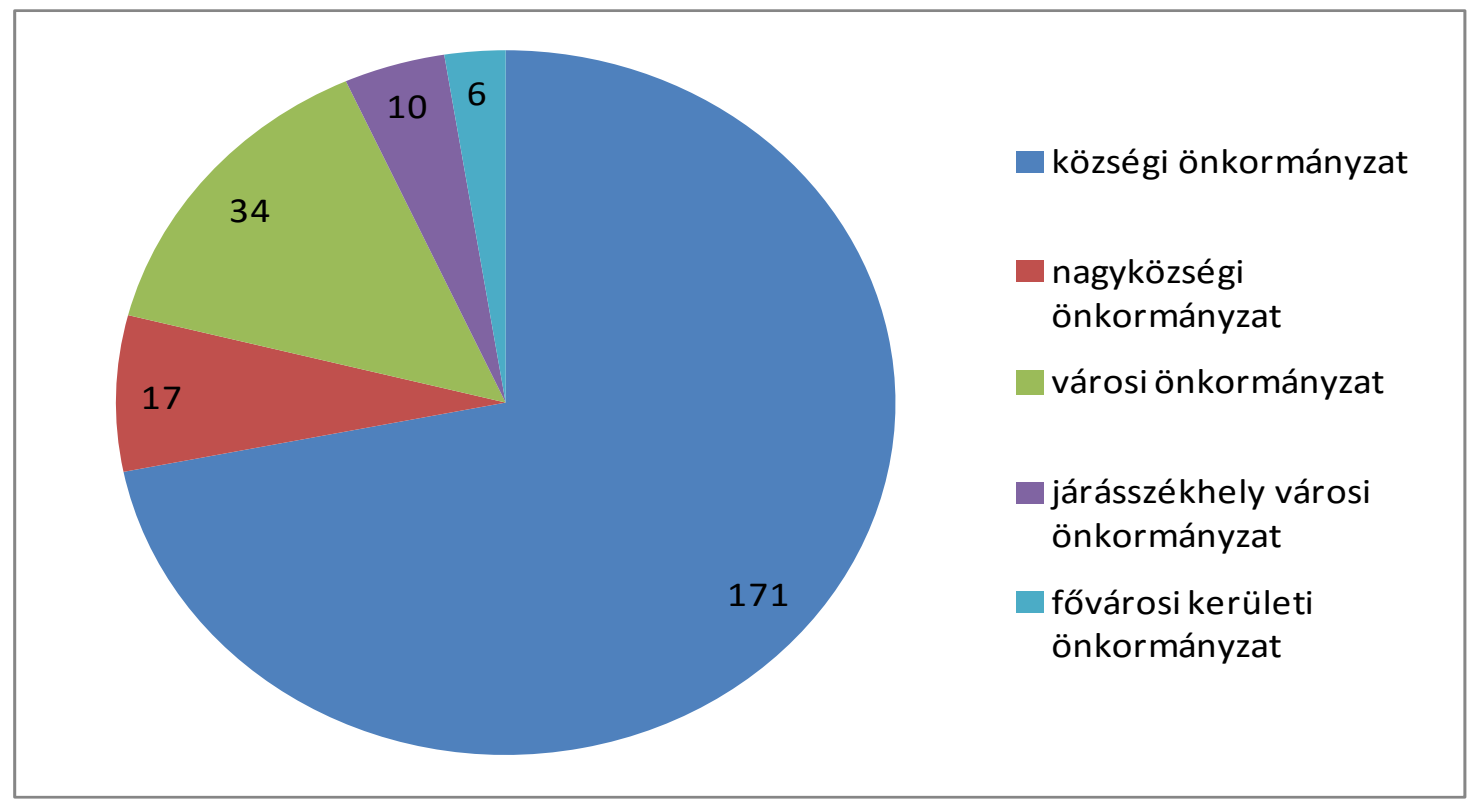

23. ábra: a városkörnyéki kérdőivek a települési jogállás szerint (elemszám: 238)

A ,szükségességi” dimenzió önkormányzati jogállás szerinti szintetizálása:

A községek, nagyközségek száma jelentősen felülprezentált nemcsak általában a magyarországi települési önkormányzatok (mint teljes kutatási populáció) között, de a kutatási mintában is, ezért a kistelepülési adataink nem meglepő módon rendkívül hasonlóan alakultak az országos „szükségleti” ábrához. Egy csoportban kerültek feldolgozásra a kitöltött községi és nagyközségi kérdőívek - 188 db kérdőív, amely a teljes nem nagyvárosi kutatási minta 78\% részét képezi. A községi, nagyközségi polgármesterek leginkább szükségesnek $a$ térségi önkormányzati politikai (II.2), az önkormányzati apparátusi (II.4), valamint az átlátható jogszabályi kereteket (II.1) gondolták. A legkevésbé szükséges paraméter pedig az Európai uniós és egyéb nemzetközi (II.7), illetve a városkörnyéki civil kooperációk (II.6) lett a községi, nagyközségi településvezetők szemében.

A városi jogállású önkormányzatok polgármesterek (34 db kérdőív) leginkább az önkormányzati közös fejlesztési kooperációk (II.9), az átlátható jogszabályi keretek (II.1), illetve a közös önkormányzati feladatellátás és közszolgáltatások (II.8) fontosságát hangsúlyozták ki. A civil (II.6) és a nemzetközi kapcsolatok (II.7) itt is a lista aljára kerültek. A kutatási mintába bekerült kisszámú $(10 \mathrm{db})$ járásszékhely városi polgármesterek az átlátható jogszabályi kereteket (II.1) látványosan felül-, addig az országos kormányzati és parlamenti (II.3) és az EU-s, egyéb nemzetközi (II.7) kapcsolatokat alulértékelték. A fővárosi kerületi 
polgármesterek jelentősen máshogy értékelték a paramétereket (pl. a városkörnyéki civil kapcsolatok jelentős felülértékelése). Ennek oka a fővárosi kerületeknél jelentős eltérő objektív léptékek - magasabb lakosságszám; fejlettebb gazdasági és társadalmi mutatók.

A jelentős reprezentáltság okán közlésre kerül a községi/nagyközségi polgármesterek kérdőíveket tükröző ,,szükségességi” ábra:

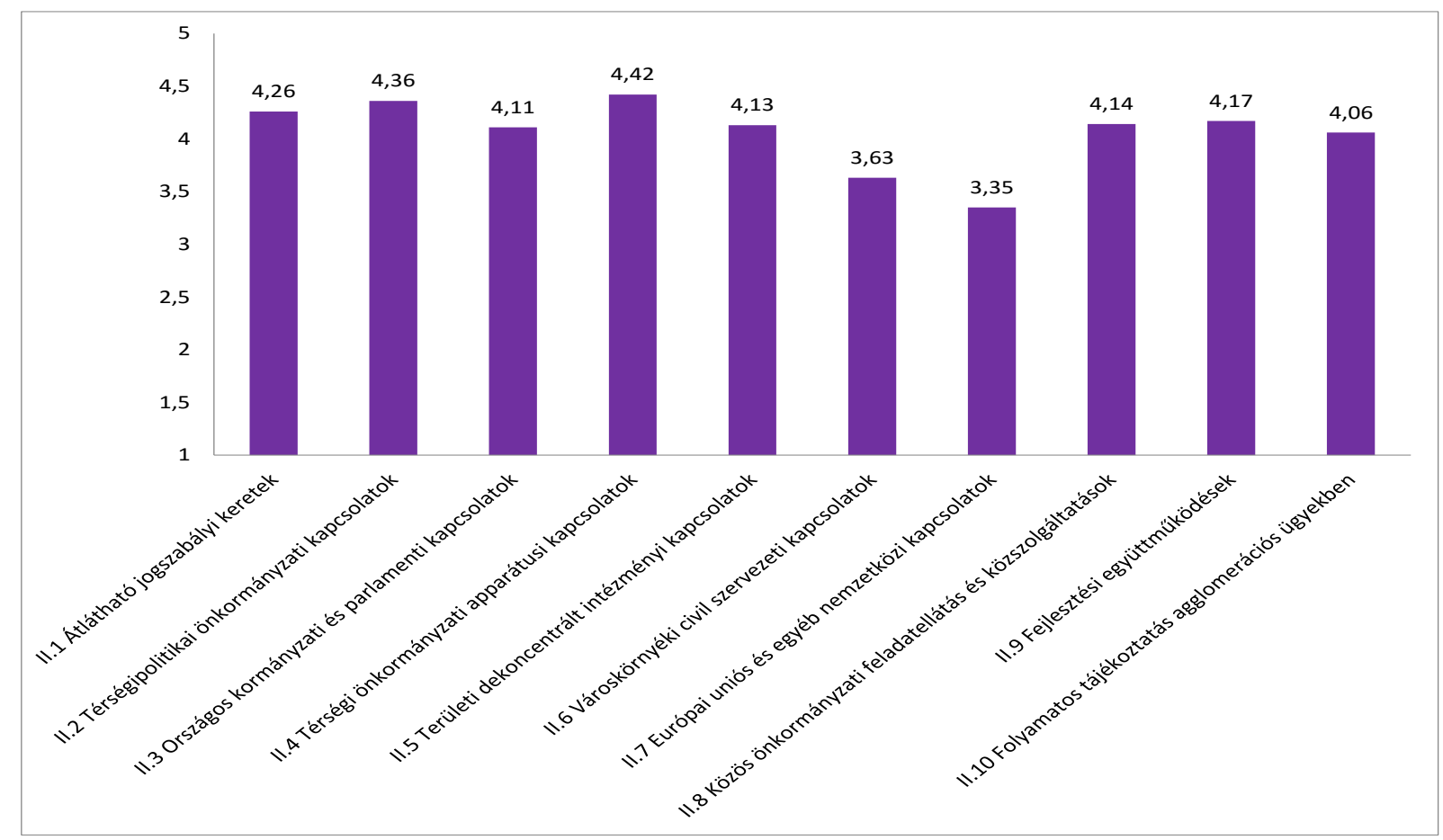

24. ábra: „szükséges” dimenzió a községek, nagyközségek csoportban (elemszám: 188)

\section{A „tapasztalati” dimenzió önkormányzati jogállás szerinti szintetizálása:}

A községi, nagyközségi településvezetői vélemények a „tapasztalati” dimenzióban rendkívül hasonlóan alakultak az országos adatokhoz: kiemelten értékelték a területi dekoncentrált intézményekkel való (III.5), valamint a térségi önkormányzati politikai (III.2) és apparátusi (III.4) kapcsolatok fontosságát. A városi polgármestereknél minden paraméternél magasabb átlagpontok születtek, mint a községi, nagyközségi szegmensben. Különösen $a z$ országos kormányzati és parlamenti kapcsolatok (III.3) esetében érvényesült ez a tendencia: 3,9 pontos átlaggal a legmagasabb elégedettséget kapta ez a paraméter. A járásszékhely városi településvezetőknél a legmeglepőbb az állami területi dekoncentrált intézményekkel kialakitott kapcsolatok (III.5) viszonylagos alulértékelése volt. A fővárosi kerületi polgármestereknél a tapasztalati vélemények is látványosan máshogy alakultak. A legmagasabb átlagpontszámot a városkörnyéki civil kapcsolatok (III.6) paraméter kapta, amely országosan az egyik legalulértékeltebb volt. A térségi politikai önkormányzati 
kapcsolatok (III.2) a tapasztalati paraméterlista alsó szegmensébe kerülése speciálisan csak a kerületi önkormányzati polgármesterek válaszainál érvényesült.

A községi/nagyközségi kérdöívek felülprezentált jellege folytán közlésre kerül a kistelepülési polgármesterek véleményét tükröző „tapasztalati” ábra:

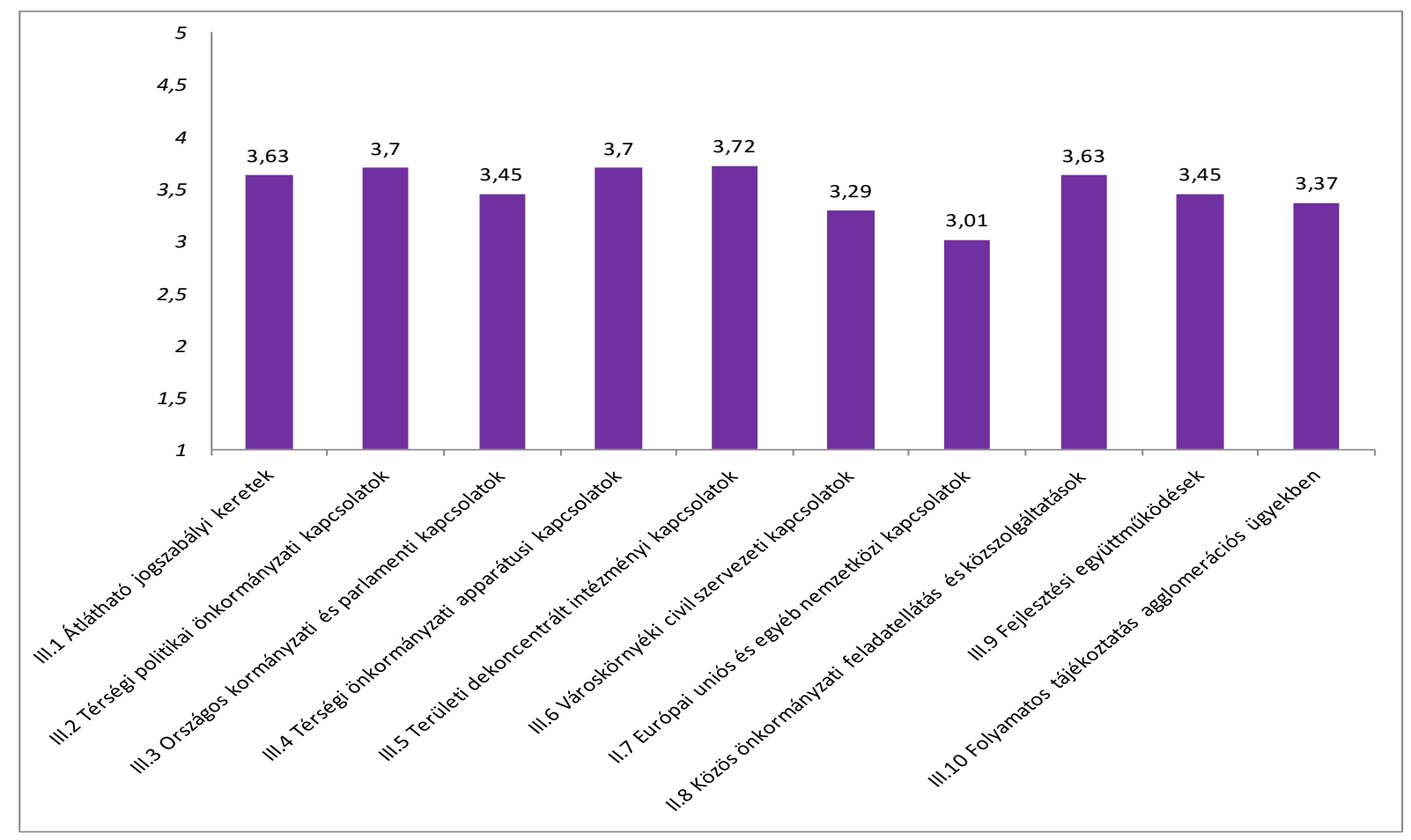

25. ábra: „,tapasztalati” dimenzió a községek, nagyközségek csoportban (elemszám: 188)

\section{V.8.6 A városkörnyéki kapcsolatokhoz ajánlott közpolitikai eszközök értékelése}

A kutatási kérdőív V. kérdése a nagyvárosok és városkörnyéki települések kapcsolatainak javításához, azok hatékonyságnöveléséhez ajánlott különböző közpolitikai eszközök polgármesteri percepciós értékelésének megismerésére irányult: $V$. Kérjük, alkosson sorrendet a nagyváros és városkörnyéki települések közötti kapcsolatok erösitéséhez ajánlott alábbi közpolitikai eszközökröl? (Kérjük, válaszait 1-6-ig terjedö fontossági sorrendben jelezze! Az 1. mint a legfontosabb, leghatékonyabbnak vélt eszköz; a 6. a legkevésbé fontos és legkevésbé hatékony eszköz, a két végpont között pedig szabadon alakítható a sorrend. Itt a településvezetők gondolkodásmódját vizsgáltuk, hogy milyen intézkedéstípusokat preferálnak: „kemény” vagy „puha” intézményi megoldásokat. A kérdéshez kapcsolódó közpolitikai eszközök (policy tools) a következők voltak: 
A. Agglomerációs / Városkörnyéki Önkormányzati Tanács: ${ }^{200}$ a nagyváros és városkörnyéki települési önkormányzatok közös részvételével létrehozott, önálló föderatív döntési feladat- és hatáskörökkel bíró önkormányzati jellegü szerveződés. „kemény” közpolitikai eszköz (196 kérdőíven értékelték).

B. Nevesitett agglomerációs, városkörnyéki pénzügyi alap: kifejezetten agglomerációs, városkörnyéki célokhoz rendelve - (forrása lehet az állami költségvetés elkülönített fejezete; átengedett központi adó; területi decentralizált forrás; közvetlen agglomerációs / városkörnyéki helyi adó). - „kemény” közpolitikai eszköz (196 kérdőíven értékelték).

C. Az Önkormányzatok Nemzeti Együttmüködési Tanácsának (ÖNET) ${ }^{201}$ mint a központi kormányzat és a helyi önkormányzatok közpolitikai konzultációs intézményének regionális, nagytérségi szintű kiterjesztése, ahol konkrét nagyvárosi-agglomerációs és városkörnyéki ügyek terítékre kerülnek. - „kemény” közpolitikai eszköz (195 kérdőíven értékelték).

D. Speciális közigazgatási, gazdasági és társadalmi agglomerációs, városkörnyéki tudásanyag, mint önálló modul (jegyzetek, tankönyvek, multimédiás kiadványok, önálló képzési tematika) a működő köztisztviselői és kormánytisztviselői képzés, továbbképzés rendszerében. - „puha” közpolitikai eszköz (195 kérdőíven értékelték).

E. A nagyváros és városkörnyéki települések gazdasági szereplöi közötti kapcsolatok intézményesitett erősitése: a gazdasági klaszterek és klaszterszerü kezdeményezések támogatása; a minőségbiztosítás hatékonyabb hatósági érvényesítése a beszállítói és egyéb gazdasági jellegü kapcsolatok terén. - „puha” közpolitikai eszköz (196 kérdőíven értékelték).

F. Speciális, valamilyen közszolgáltatás vagy egyéb profitcélú gazdasági tevékenység biztositására irányuló: a nagyváros és városkörnyéki önkormányzatokat tömörítő önálló jogi személyiséggel felruházott konzorciális együttműködés. - „puha” közpolitikai eszköz (192 kérdőíven értékelték).

\footnotetext{
${ }^{200}$ Gyakorlatilag a kétszintű agglomerációs önkormányzat (two-tier government) alapjának felelne meg egy ilyen típusú testület, bár az erősen függne a lehetséges hatásköröktöl, de erre már nem terjedt ki a kérdés.

${ }^{201}$ Az 1128/2013. (IV.26.) Korm. határozat az Önkormányzatok Nemzeti Együttmüködési Tanácsáról, amely az ÖNET-et, mint a Kormány mellett működő javaslattevő, tanácsadó, konzultatív testületként határozta meg. A kormányzati szereplök mellett az önkormányzati szektort az ÖNET-ben az országos önkormányzati érdekszövetségek képviselők a kormányhatározat szerint.
} 
Az ajánlott közpolitikai eszközök átlagos besorolása az 1-6 skálán:

Az 1-es besorolás jelenti a legmagasabb (leginkább hatékony) osztályzatot, és a 6-os a legalacsonyabb (legkevésbé hatékony) a vizsgált közpolitikai eszközök tekintetében!

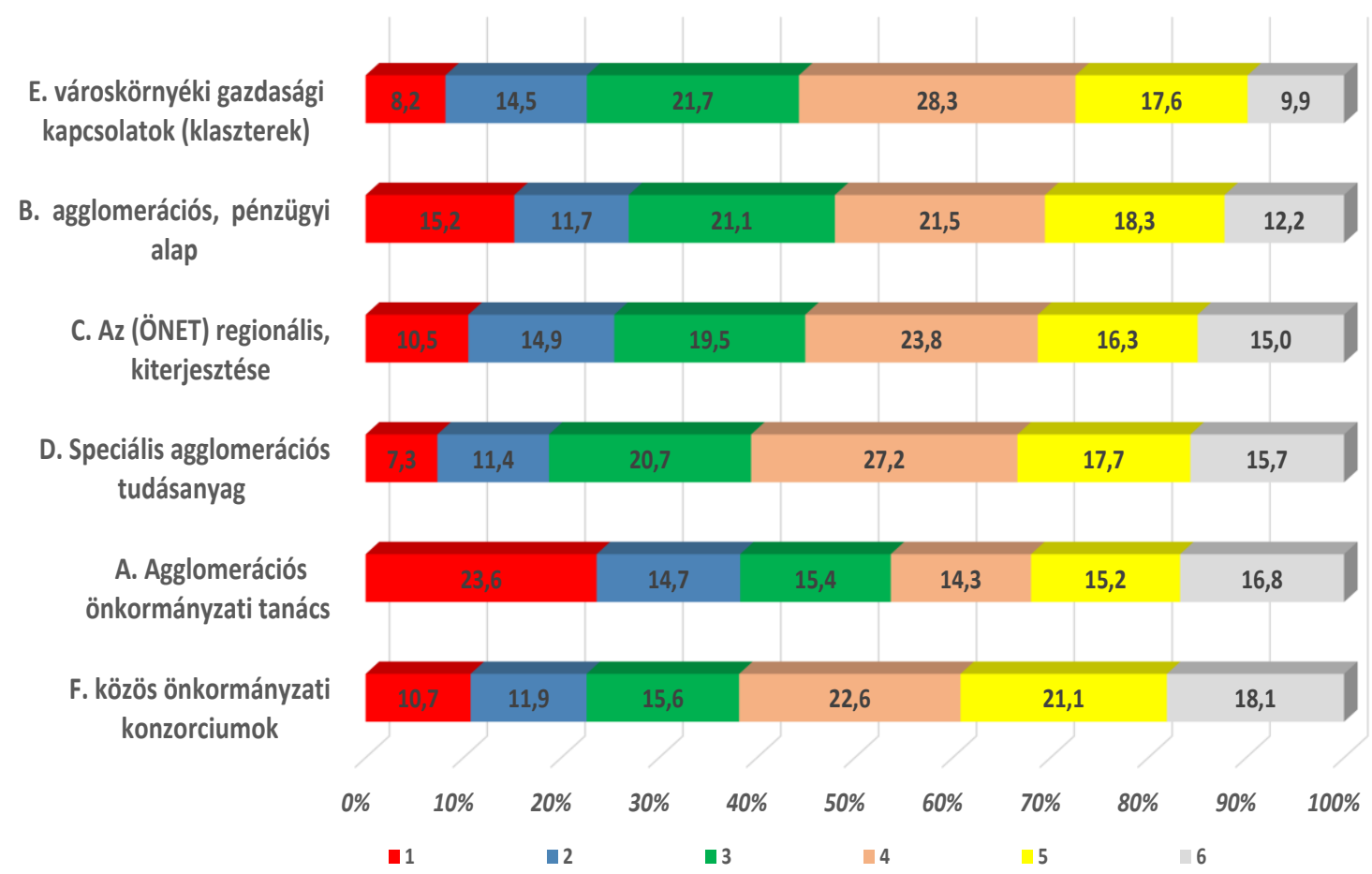

26. ábra: az ajánlott közpolitikai eszközök értékelésének komplex ábrázolása (elemszám: 192-

195-196)

\section{Agglomerációs önkormányzati tanács}

Az önálló hatáskörökkel felruházott kétszintü föderatív agglomerációs tanács a fejlett országokban széles körben alkalmazott eszköz Magyarországon gyakorlatilag ismeretlen. A válaszoló településvezetők közül a legtöbben (46 polgármester; 23,6\%), mégis ezt vélték a leghatékonyabb eszköznek az agglomerációs települési kapcsolatokhoz: viszont ez is csak alig minden 5.-ik válaszadót jelentette. A 2-6. pozíciókra való besorolás nagyon kiegyenlített volt.

\section{Agglomerációs pénzügyi alap}

„Kemény” közpolitikai eszköz az agglomerációs, városkörnyéki pénzalap, amely a várostérségi szintre delegált feladatok, kooperációk egyik finanszírozási alapját jelentené. 30 polgármester (15,2\%) jelölte meg az önálló agglomerációs pénzügyi alapot a leghatékonyabb közpolitikai eszköznek. A legjellemzőbb pozícionálást mégis a 3-4. helyre való besorolás jellemezte: előbbire 41-en, utóbbira 42-en gondoltak. A legrosszabb 6. pozícióba viszont kevesebben (24 válaszoló) helyezték az önálló agglomerációs, városkörnyéki pénzügyi alap gondolatát, mint az agglomerációs tanácsot. 


\section{Az ÖNET nagytérségi, regionális szintű kiterjesztése}

A már létező ágazatpolitikai konzultatív fórumként hivatalosan funkcionáló Önkormányzatok Nemzeti Tanácsának egy szubnacionális (regionális, nagytérségi) szintre való kiterjesztését, s vele az ÖNET tartalmi kérdéseinek nagyvárosi-agglomerációs, városkörnyéki vonatkozásainak intézményi „kemény” közpolitikai dekoncentrációs javaslata jelentősen megosztotta a polgármestereket. 20 polgármester $(10,5 \%)$ vélte a leghatékonyabbnak a városkörnyéki ügyekhez. A 2.-ik helyre 29 településvezető; a 3. helyre 38-an; 46 válaszoló a 4.-ik helyre; 32 válaszoló az 5.-ik helyre. Az utolsó 6. helyre 29-en pozícionálták a regionális ÖNET gyülések gondolatát.

\section{Speciális agglomerációs tudásanyag}

A kifejezetten az agglomerációs közpolitikai tematikára fókuszáló önálló speciális tudásanyag, mint „puha” közpolitikai eszköz szintén megosztotta a településvezetőket. Mindössze 14 polgármester (7,3\%) vélte, hogy ez lehetne a leghatékonyabb agglomerációs szintü eszköz. A legtöbben a középső pozíciókhoz sorolták be a speciális agglomerációs, városkörnyéki tudásanyag (jegyzetek, tankönyv, multimédiás oktató anyagok etc.) ötletét: 40 válaszoló a 3. helyre; 53 válaszoló a 4.-ik helyre; 34 válaszoló az 5.-ik helyre. Az utolsó 6. helyre 31 válaszoló pozícionálta a javasolt eszközt.

\section{Városkörnyéki gazdasági kapcsolatok (klaszterek)}

Szintén „puha” közpolitikai eszközként ajánlottuk a nagyváros és városkörnyéki települések gazdasági szereplői (vállalkozások) közötti üzleti kapcsolatok intézményesített erősítését kifejezetten a helyi önkormányzati közpolitikai stratégiák és eljárások (vállalkozásfejlesztés és klaszterpolitika, hatósági ügyintézés, minőségpolitika etc.) vonatkozásában. Ennek értékelése hasonlóan alakult az agglomerációs tudásanyag paraméterhez: 16 településvezető ajánlottaz 1 . helyre $(8,2 \%)$; 22-en a 2 . helyre; 40 fö a 3. helyre; 53 fő a 4. pozícióhoz; 34-en az 5. és 31-en az utolsó 6. helyre tették.

\section{Közös önkormányzati konzorciumok}

A közszolgáltatás, fejlesztési- vagy egyéb profitcélú (értsd: jövedelemteremtö) vállalkozói tevékenység folytatására irányuló önálló jogi személyiséggel felruházott konzorciális (közvállalati) gazdasági együttműködés a várostérségi kooperációkhoz. Ilyen közös közfeladat-ellátásra irányultak többek között az önkormányzati vízi-közmü vagy csatornatársulások. 21 polgármester sorolta az eszközt az 1. helyre (10,7\%); 23-an a 2.; 30.-an a 3.; 43 fő a 4; 40 településvezető az 5. és 35 településvezető az utolsó 6 . helyre pozícionálta. 


\section{$\underline{\text { A várostérségi közpolitikai eszközök országos értékelése }}$}

Az 1. helyre való sorolás megoszlása (pozitív lista):

1. Agglomeráció önkormányzati tanács: 46 db 1. helyezés

2. Agglomerációs pénzügyi alap: $30 \mathrm{db} 1$. helyezés

3. Közös önkormányzati konzorciumok: $21 \mathrm{db}$ első helyezés

4. ÖNET nagytérségi, regionális szintü kiterjesztése: $20 \mathrm{db} 1$. helyezés

5. Városkörnyéki gazdasági kapcsolatok (klaszterek): 16 db 1. helyezés

6. Speciális agglomerációs tananyag: $14 \mathrm{db} 1$. helyezés.

A 6. helyre való sorolás megoszlása (negatív lista):

1. Közös önkormányzati konzorciumok: $35 \mathrm{db} 6$. helyezés

2. Agglomerációs önkormányzati tanács: $33 \mathrm{db} 6$. helyezés

3. Speciális agglomerációs tananyag: $31 \mathrm{db} 6$. helyezés

4. ÖNET nagytérségi, regionális szintü kiterjesztése: 29 db 6. helyezés

5. Agglomerációs pénzügyi alap: $24 \mathrm{db} 6$. helyezés

6. Városkörnyéki gazdasági kapcsolatok (klaszterek): $19 \mathrm{db}$

Közpolitikai eszközök megítélése térségi és önkormányzati jogállás alapján:

Az országos tapasztalatok mellett néhány térségi-regionális specifikumot érdemes kihangsúlyozni. Amíg az önálló kétszintü agglomerációs tanács a közép-magyarországi régióban volt a legkevésbé kívánt - abban a térségben, ahol éppen a BAFT révén akár még beszélhetünk valós empirikus tapasztalatokról! -, addig az önálló agglomerációs pénzügyi alap egyértelmüen itt aratta a „legnagyobb sikert” a kérdöívet kitöltő településvezetőknél. A regionális ÖNET gondolata Dél-Alföldön volt a leginkább megosztó (legtöbb 1. és 6 . pozíció). A speciális agglomerációs tudásanyag a Dél-Dunántúlon kapta a legnagyobb támogatást, ennek talán köze van ahhoz, hogy itt már az 1980-as évek végén, 1990-es évek elején kiterjedt szakmai projektek, kezdeményezések indultak a regionalizmus (bottom-up) jegyében. ${ }^{202}$ A klaszterszerü gazdasági kezdeményezések javaslat a legerősebb polgármesteri támogatást a közép-dunántúli polgármesterektől kapta. A közös közszolgáltatási és fejlesztési célú önkormányzati konzorciumok a rendkívül szétaprózott településszerkezetű Nyugat-

\footnotetext{
202 A Magyar Tudományos Akadémia Regionális Kutatások Központja Pécsett több mint két évtizede a regionális és helyi önkormányzati kutatások fontos hazai központja - bövebben lásd a Pálné Kovács Ilona által szerkesztett „,A politika új színtere a régió” c. tanulmánykötetet! [Pálné, 2009].
} 
Dunántúlon nyerték a legtöbb pozitív értékelést, a legkevesebbet, pedig a Budapest és agglomerációs térségét magába foglaló Közép-Magyarországon.

A települési önkormányzati jogállás szerinti szintetizálásra alaposan rányomta a bélyegét a községek, nagyközségek túlnyomó aránya a kutatási mintánkban. Érdemes azért megemlíteni, hogy a két „legnépszerübb” eszköz, az önálló agglomerációs tanács illetve pénzügyi alap kiemelkedően magas támogatást kapott a járásszékhely városok polgármestereitől.

\section{V.8.7 A szabadon kifejtős kérdéshez érkezett válaszok összesítése}

A kutatási kérdőív utolsó kérdése így hangzott: VI. Milyen további fontos beavatkozást, megoldást igénylö problémákat érzékel a nagyváros és városkörnyéki települések közötti kapcsolatok alakulása és fejlesztése szempontjából? - ezzel a polgármesterek szabadon kifejthették véleményüket a kutatási témáról. A VI. kérdés kitöltése fakultatív volt - 36 esetében érkezett értékelhető kifejtős válasz.

A 36 db kifejtős választ a következő települési önkormányzati megoszlás jellemezte:

- 5 db járásszékhely városi önkormányzat;

- 6 db városi önkormányzat;

- $\quad 2$ db nagyközségi önkormányzat

- 23 db községi önkormányzat.

A $36 \mathrm{db}$ szabadon kifejtett válasz térségi megoszlása a következők szerint alakult: NyugatDunántúl 9 válasz; Dél-Alföld 5 válasz; Dél-Dunántúl 4 válasz; Észak-Alföld 5 válasz; ÉszakMagyarország 3 válasz; Közép-Dunántúl 7 válasz; Közép-Magyarország 3 válasz. Ha pedig a $36 \mathrm{db}$ válasz megyei összevetését tekintjük, aktivitás szempontjából érdekes módon 2 kisebb területü megye emelhető ki: a nyugati határvidéken található Vas megye $5 \mathrm{db}$, valamint az ország délkeleti csücskében lévő Békés megye $4 \mathrm{db}$ válasszal.

\section{$\underline{\text { A szabadon kifejtős válaszok tartalmi szintetizálása: }}$}

A szabadon kifejtős válaszoknál láthatóvá a kistelepülési polgármesterek kritikus, esetenként nyíltan nagyváros-ellenes attitűdje. A válaszok közel kétharmadánál volt érzékelhető, néhány esetben meglehetősen direkt megfogalmazás közepette. A város versus vidék konfliktus többször visszatérő nyelvpolitikai kontextusa az alárendelt viszony kifejezés, ami persze nem közjogi, hanem sokkal inkább a napi anyagi-gazdasági lehetőségek, az információ, a politikai lobbierő és a különböző fejlesztési forrásokért folytatott egyenlötlen 
verseny negatív véleményezésében nyilvánult meg. Többször visszatérő elem, szófordulat volt a „,nagyvárosok elszívják a fejlesztési forrásokat a kistelepülések elöl”, valamint a „városok erőből és önzö módon politizálnak” a környező (főleg községek) rovására. A „,falvak elsorvasztása" nagyon direkt szókapcsolat azonban csak $1 \mathrm{db}$ válasznál fordult elő. A nagyváros - városkörnyéki települések kapcsolatokról pozitívan mindössze egy dél-dunántúli községi polgármester nyilatkozott.

Néhány válaszban a város-vidék kontextus racionális tartalmi keretben - akár negatív, akár pozitív előjel nélkül - jelent meg, ezek a „,közös gondolkodás és partneri viszony”, valamint a „,helyi közfeladatok, közszolgáltatások térségi szintü (nagyváros, város és városkörnyék) megosztásának és megvalósitásának” fontosságát hangsúlyozták ki. Az országos politikai- és kormányzati kapcsolatoknak való direkt kitettség, kiszolgáltatottság gondolata mindössze 1 $\mathrm{db}$ válasz esetében vetődött fel.

Mintegy 4-5 db településvezetői vélemény kifejezetten a kistelepülési (községi, nagyközségi) saját források hiányát tartalmazta. Megfogalmazódott a helyi bevételek különösen a helyi önkormányzati adók - rendszerszerü megnövelése; a helyi adóknak térségi szinten való újraelosztása - kedvezve az alacsonyabb bevételü településeknek; a közösen ellátandó térségi feladatok jogszabályi megerősítése, pontosítása. Akadt olyan vélemény is, amely a különböző hazai és európai uniós fejlesztési forrásokhoz szükséges hazai önerő előteremtésének nehézségére panaszkodott. Ez a felvetés már számtalanszor előkerült különböző önkormányzati fórumokon, interjúkban, szakmai konferenciákon az elmúlt évtizedben. Csak nagyon kevés egyéb szakpolitikai felvetést $(4 \mathrm{db})$ találtunk a válaszok összegzése során, ezek érintették a vidéki úthálózat és közlekedés fejlesztésének igényét, a természeti értékek fokozottabb védelmét valamint a turizmusfejlesztés fontosságát.

Összességében megállapítható, hogy a nem nagyvárosi polgármesterek meglehetősen kritikusak a várostérségi települési kapcsolatok tekintetében. Több kooperációt és több lehetőséget igényelnek; a forráshiány pedig továbbra is része a már sokat emlegetett önkormányzati „konfliktuskonténernek”. 


\section{V.9 Összegző ábra és megállapítások}

Az alábbi ábra a XIX. század utolsó harmadától napjainkig összegzi a fontosabb magyarországi településhálózati- és várospolitikai folyamatokat, különös tekintettel az urbánus térségek vonatkozásában:

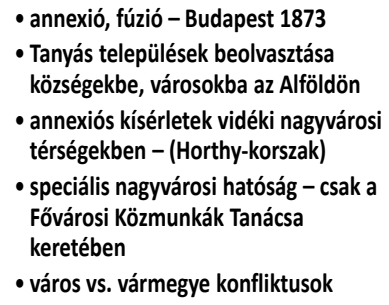

- annexió, fúzió - Budapest 1873

- Tanyás települések beolvasztása

községekbe, városokba az Alföldön

- annexiós kísérletek vidéki nagyvárosi

térségekben - (Horthy-korszak)

- speciális nagyvárosi hatóság - csak a

Fővárosi Közmunkák Tanácsa

keretében

- város vs. vármegye konfliktusok

XIX. század utolsó harmada -

a tanácsrendszer kialakulása (1950)

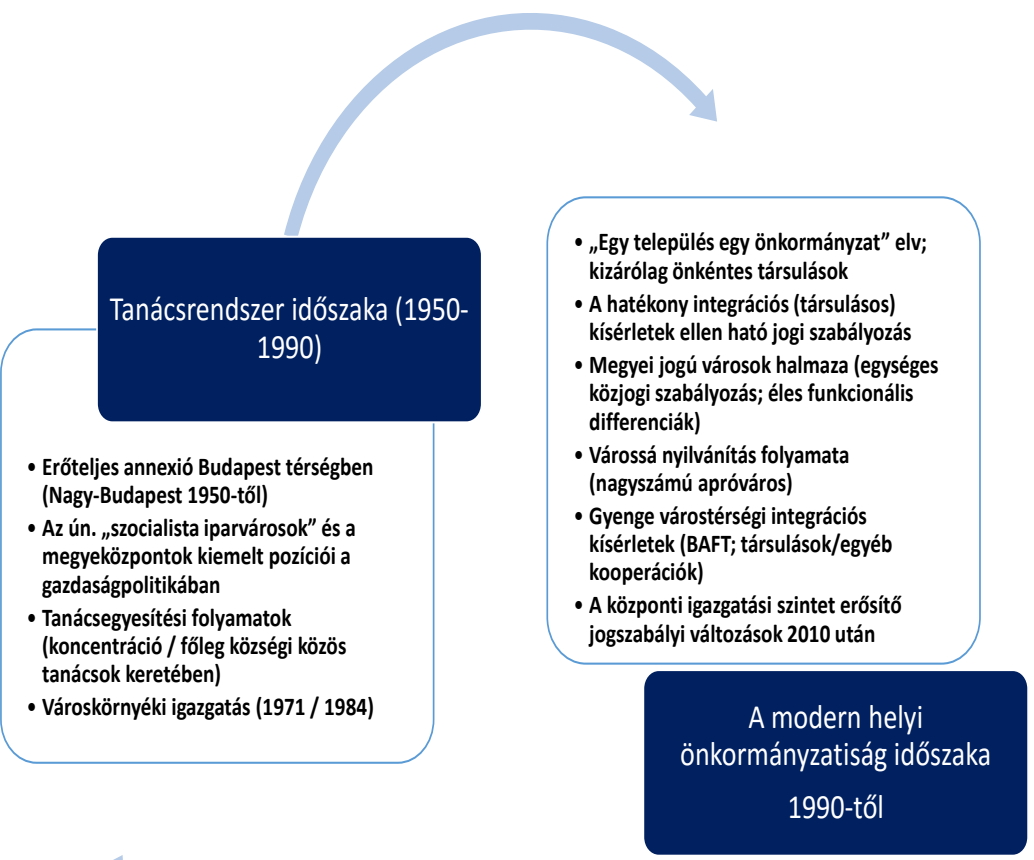

27. ábra: a hazai településhálózat- és várospolitika elmúlt másfél évszázada (saját szerkesztés)

$\underline{\text { Fontosabb időbeli tanulságok: }}$

1. A nagyvárosi folyamatokban sokáig a direkt közpolitikai government területszervezési eljárások (annexió, fúzió) voltak meghatározóak - pl. Budapest története - 1873; 1950; tanácsrendszer.

2. A (nagy)város versus (vár)megye konfliktus még a modern városfejlődés előtti időszakokból, maradt fenn egészen a rendszerváltás utánig. A nagyvárosok térségi feladatellátása sok szempontból a mai napig szabályozatlan, illetve a nagyvárosok potenciális kreatív kapacitásai (pl. humán erőforrás) sincsenek megfelelően kihasználva.

3. A tanácsrendszer centralizált központi döntéshozatali rendszerében Budapest és a megyeközpontok tervezési szempontból preferált helyzetben voltak. 
4. A tanácsrendszer koncentrált településpolitikai folyamatai után 1990 után települési mikroszinten egy decentralizált (az „egy település egy önkormányzat” szervezési alapelv - 1990-es Ötv.), a térségi szinteken azonban centralizált, sok tekintetben „fejnehéz” szisztéma vált dominánssá [gyenge megyei önkormányzatok; erős kompetenciákkal ellátott állami területi dekoncentrált szervek felső-közép (kvázi regionális NUTS2; megyei) és alsó-közép (korábban a kistérség most már a járásrendszer) szinten].

5. Budapest valamint a meghatározó vidéki nagyvárosoknál nem alakultak ki valóban integrált várostérségi igazgatási rendszerek, az akarat jobbára kimerült tervezésiterületfejlesztési kooperációkban, központilag támogatott modellkísérletekben illetve elszigetelt törekvésekben.

6. Az 1990-2012 között az önkormányzatokat érintő közjogi környezet (Alkotmány, Önkormányzati törvény, önkormányzati társulási törvény, Ttv. etc.) sok szempontból ellene hatott a nagyváros-térségi - de általában a városkörnyéki - igazgatási integrációs törekvéseknek - lásd az I. hipotézist, és annak bizonyitását!

7. 2010 után a kormányzati akarat, s vele a törvényhozói többség az erös állami ethosz nevében az állam és önkormányzatok közötti korábbi feladatmegosztás újragondolására törekedett - jelentős feladat- és intézménytranszfer történt az állami szektor irányába (közoktatás, fekvőbeteg-ellátás, számos szociális hatáskör, térségi korábban megyei önkormányzati - intézmények etc.).

8. A politikai valamint a negatív demográfiai (1981 óta regisztrált éves népességfogyás Magyarországon) folyamatok ellenére Budapest és a meghatározó vidéki nagyvárosok szuburbán-agglomerációs térségeiben az infrastrukturális és technikai fejlődéssel párhuzamosan egyre intenzívebbé válnak a várostérségi agglomerációs kapcsolatok. Az elmúlt évtized során a KSH kutatásai szerint jelentősen növekedett az agglomerációs övezetekbe sorolt városkörnyéki települések száma. 


\section{VI. Összefoglalás - hipotézisértékelés és modellkísérlet}

A disszertáció alapdilemmája a gazdasági, vonzáskörzeti szempontból egyre inkább funkcionális egészet alkotó nagyvárosi térségekben (nagyváros és szuburbán környezet) fennmaradt közigazgatási fragmentáció okozta napi problémák, működési anomáliák közpolitikai kezelése. A modern nagyvárosi kormányzás értelmezési tartománya a nagyváros és környező agglomerációs térsége, benne a szuburbán városkörnyék településeivel, helyi önkormányzataival. Mivel a globalizáció korában a gazdasági (termelési, szolgáltatói és fogyasztási szempontok szerint) és társadalmi (népességnövekedés etc.) fejlődési hangsúlyok egyre nagyobb mértékben az ún. nagyvárosi térségekre koncentrálódnak, ezért az elmúlt évtizedekben a kapcsolódó speciális közpolitikai tudás, ismeretek szerepe rendkívül felértékelődött. A témakör elméleti alapvetései mellett a nemzetközi dimenziók (az egységes nagyvárosi térségben való közpolitikai gondolkodás megjelenése, annak időbeli változásai és meghatározó földrajzi vetületei - Európa és Észak-Amerika) bemutatásával a cél éppen a témakör globális nemzetközi fontosságának a felvázolása volt. Európa - benne Magyarország - demográfiai folyamatai élesen eltérnek az amerikai kontinens és az egyre inkább a világgazdaság homlokterébe kerülő Ázsia népesedési trendjeitől, másrészt az urbanizáció volumene és térszerkezeti dimenziója (az öreg kontinens rendelkezik a leginkább policentrikus városhálózattal) jelentősen más, mint az említett kontinenseken. Ugyanakkor az urbánus térségek kiemelt gazdasági jelentősége, valamint a társadalmi folyamatokat leginkább dinamizáló képessége miatt alapvető fontosságú, hogy önálló diskurzusként hazánkban is megjelenjen az urbánus térségek közpolitikai kérdésköre. Ez a felismerés vitt annak az irányába, hogy a népességfogyás illetve a fejlett országokhoz képest némileg megkésett városfejlődés $^{203}$ ellenére - éppen a nemzetközi (benne hangsúlyosan a nyugat-európai) tapasztalatok ismeretében vizsgálni és kutatni kezdjem a várostérségi integrált közpolitikai kezdeményezések, kooperációk történetét. Ebből a szempontból kiemelt cezúraként alkalmaztam az 1989-1990-es politikai rendszerváltást, különösen a helyi közigazgatás demokratizálásának mozzanatát: a tanácsrendszer helyett a modern önkormányzati rendszer megteremtését. A közpolitikai, közjogi szabályozás, kezdeményezések bemutatása

\footnotetext{
203 Egyedül Budapest és térsége hagyta már maga mögött a modern városfejlődés klasszikus második szuburbanizációs stádiumát, s így már a dezurbanizáció és bizonyos szempontok alapján már a reurbanizálódás jeleit produkálva, miközben a többi nagyváros és övezete még jobbára a szuburbanizáció (agglomerálódás) szakaszban tart.
} 
önmagában rendkívül féloldalas a magyarországi urbanizáció közelmúltjának, jelenének domináns tendenciáinak - bemutatása nélkül. Ezen információk alapozzák meg a kutatási téma, s vele a vizsgált disszertációs hipotézisek objektív alapú (a rendelkezésre álló paraméterek, mint meghatározó input közpolitikai indikátorok) szükségességét. Különösen Budapest és térsége kapcsán indokolható valós problémafelvetésként az egységes agglomerációs szintű intézményesített közpolitikai kezelés hiánya. A lakosságszám, terület, gazdasági és társadalmi mutatók alapján önálló nagyvárosi térségként aposztrofált fővárosi agglomeráció esetében már az 1990-es években adekvát volt a felvetés: az elmúlt negyedszázad kurrens szuburbanizációs folyamatai (közel 200.000 Budapestről az agglomerációs településekre életvitelszerüen kiköltöző) pedig még inkább szükségessé teszik a Budapest és agglomerációja közötti kapcsolatok további intézményesítését. A vidéki nagyvárosaink (elsősorban a kiemelkedő megyei jogú városok) esetében a Központi Statisztikai Hivatal agglomerációs jellegü felmérései jelzik számunkra, hogy kevésbé látványos formában, de zajlik a vidéki nagyvárosok agglomerációs tereinek a bővülése, az ottani strukturált kapcsolatok intenzívebbé válnak. Az agglomerációs térségekben a szuburbán települések fejlődése, növekedése látványosabb és direktebb formában történik, mint a rurális övezetekben - lásd a hazai falukutatások eredményeit! Az 1990 utáni jobbára politikai motivációk által vezérelt expanzív városiasodás leginkább az agglomerációs községek, nagyközségek (különösen Pest megyében) esetében tekinthető indokoltnak, ezt a folyamatot az 1990 után fellendült szuburbanizációs folyamatok (kiköltözések; munkahelyi ingázás a nagyvárosba) táplálták. Ugyanakkor a disszertáció során bizonyosságot nyert az is, hogy a 23 megyei jogú várost gyakorlatilag csak közjogi szemszögből lehet közös halmazként értelmezni; funkcionális adottságok (lakosságszám, gazdasági teljesítmény és potenciál, magán- és közigazgatási intézményrendszer) alapján semmiképpen sem. Ez alapján egységes intézményesített agglomerációs közpolitikai megoldást (mint önálló agglomerációs tanács) csak meghatározott, a többi megyei jogú város közül kiemelkedő paraméterekkel (konkrétan a nagyváros lakosságszáma) és regionális spill-over hatókörrel bíró vidéki nagyvárosok esetében tartok elképzelhetőnek.

\section{VI.1 A disszertációs alapdilemma parlamenti, kormányzati környezete}

A disszertáció bevezetésében felvázolt hipotézisek értékelése előtt érdemes összefoglalni az országos „nagypolitika” (parlament és kormányzat) elmúlt negyedszázados 
viszonyát az urbánus térségek igazgatási integrálási (közigazgatási, közszolgáltatási, tervezési-szervezési) kérdéséhez.

A következő azonnal adódó kérdések:

a) Hogyan változott az egymást követő kormányok hozzáállása az agglomerációs igazgatási kérdéskörhöz?

b) Az önkormányzati rendszer 1990 utáni tapasztalatai miként alakították a kormányra kerülő politikai szereplők törekvéseit az önkormányzati kooperációk, együttmúködések kapcsán?

c) A 2/3-os parlamenti kodifikációs környezet, illetve az eredeti szabályozás adottságai (kötelező társulások hiánya; „egy település egy önkormányzat” elv) milyen mértékben determinálták a különböző kormányzati közpolitikai elképzeléseket, kezdeményezéseket?

d) Milyen dinamikával változott az állam versus helyi önkormányzatok kontextus megítélése, és hogyan vezetett el a 2010-2014 közötti parlamenti- és kormányzati ciklus jogalkotásában tetten érhető paradigmaváltásáig, amely alapjaiban strukturálta újra az állami és önkormányzati feladatellátás kereteit az előbbi javára?

Az 1990-ben elfogadott Helyi önkormányzatokról szóló 1990. évi LXV. törvény elfogadásához és módosításához az akkor hatályos Alkotmány [1949. évi XX. törvény] kétharmados parlamenti többséget írt elő, csak úgy, mint a később az örökébe lépő Magyarország helyi önkormányzatairól szóló 2011. évi CLXXXIX. törvényhez. Az 1990-es Ötv., mint az önkormányzatok számára irányadó alkotmányerejü, minősített többséget igénylő törvénybe a rendszerváltó parlament igyekezett „beszuszakolni” minél több kapcsolódó részletszabályozást, így az önkormányzatok alkotmányos jogállását tisztázó kérdések mellett olyan racionális, sokkal inkább hétköznapi kérdések is a törvény részévé váltak, mint például a helyhatóságok hitelfelvételi felső határa. Ez mindenképpen komoly alkotmányos törvényi védelmet biztosított a frissen létrejött önkormányzati szektornak, de egyfajta kodifikációs nehézségi tényező is volt, ami a későbbiekben komoly tehernek bizonyult - különösen a 2000-es években, amikor már tisztán lehetett látni a rendszer kodifikációs anomáliáit, viszont nagypolitikai (kormány-ellenzék) konszenzus híján az önkormányzati reform „lógva maradt a levegőben”. Az 1990-es eredeti törvényhozás során elöállt „,kegyelmi állapotnak” - amelyben sikerült konszenzusra jutnia az akkori vezető kormánypártnak, az MDF-nek a legnagyobb ellenzéki parlamenti erővel, az SZDSZ-szel - hamar vége szakadt, és egyre nagyobb erővel kulminálódott a politikai pártokat élesen megosztó országos nagypolitikai, parlamenti 
konfliktus és szembenállás. Az 1994-1998, illetve a 2010-2015 időszakokat nem számítva ${ }^{204}$ a kiegyensúlyozott parlamenti viszonyok következtében a helyi önkormányzati rendszer érdemi változtatására, racionalizálására a kiélezett (értsd: egyszerü parlamenti többséggel vagy éppen kisebbségi parlamenti jelenléttel - 2008-2010 - bíró kormányok!) - országgyülési politikai arányok között egyszerűen nem nyílott mód. ${ }^{205}$ Nem véletlen, hogy az eredeti kodifikációt követően az Ötv., valamint az önkormányzati választási törvény [1990. évi LXIV. törvény] későbbi kétharmados módosítása $(1994,1997)$ valamint az új törvények elfogadása (önkormányzati választási törvény 2010-ben, Mötv. 2011-ben) mögött sosem nagypolitikai (kormány-ellenzék) kiegyezés állt, hanem sokkal inkább a minősített parlamenti többséggel rendelkező kormányok „nyers akarata és erőfölénye”. A politikai környezet tekintetében annyi különbség azért adódott az 1994-es módosítás és a 2010-2011-es újrakodifikálások között, hogy amíg a Horn-kormány időszakában a kormányon lévő koalíciós felek (MSZP és SZDSZ) között sok tekintetben éles szakmapolitikai véleménykülönbségek domináltak egészen a ciklus végéig, 1998-ig (lásd többek között az új Alkotmány elfogadásának parlamenti kudarcát 1995-ben!) -, addig a 2010-ben hatalomba lépett második Orbánkormány (2010-2014) sokkal egységesebb Fidesz-KDNP politikai hátországának köszönhetően, lényegében a saját szája íze szerint alakíthatott az önkormányzati rendszeren. Az 1994-es törvénymódosítások elsődlegesen a választási rendszert érintették - [1994. évi LXII. tv.] - (minden polgármester közvetlen választása, valamint az egyfordulós szisztéma bevezetése), illetve az Ötv. 1994-es „kiegyenlítése” is sokkal kisebb mértékü volt [1994. évi LXIII. tv.] a 2011-es kodifikációhoz képest. Így olyan, akkor már régóta szajkózott szakértői javaslatok nem tudtak érdemben a „kodifikációs napirendre kerülni” 1990-2010 között, mint a kötelező igazgatási, szolgáltatási társulások vagy a látványosan erősebb megyei önkormányzati kompetenciák. Csak a dezintegrációs törekvéseknek szabtak némiképp határt a - pl. 300 fős limit meghatározásával új község létrehozása esetén. ${ }^{206} \mathrm{Az}$ 1990-es demokratikus, de túlzottan fragmentált szabályozás „,vadhajtásait” nem sikerült lenyesni, így

204 1994-1998 a Horn-kormány (MSZP-SZDSZ), 2010-2015 között a második és harmadik Orbán-kormány önmagában rendelkezett a parlamenti helyek több mint 2/3-val, önmagában alkotmányozó többséget alkotva.

${ }^{205}$ Ilyen „kiélezett” körülmények között a leginkább átfogó érdemi módosítási koncepciója a 2006-ban választást nyert Gyurcsány Ferenc miniszterelnök és második kormányának volt, ami a megyei önkormányzatok helyére regionális önkormányzatokat hozott volna létre, de a 2006 nyarán a rendkívüli nyári parlamenti ülésszakban benyújtott törvényjavaslat-csomagot vita nélkül utasította el a Fidesz vezette parlamenti ellenzék.

206 Érdemes megjegyezni, hogy az elnéptelenedő aprófalvak igazgatási problémáinak egységes kezelésére a Belügyminisztériumban már az 1990-es években született törvényjavaslat az ún. „csatlakozó községek” elnevezés alatt, amely azon apró településeket érintette volna, amelyek lakossága nem tud saját képviselőtestületet választani az Országgyülés döntése alapján egy másik kijelölt települési önkormányzathoz csatlakozna, és annak részévé válna helyi önkormányzati joghatóság szempontjából; a javaslat végül nem került a parlament elé. Kara Pál: Helyi önkormányzati rendszerünk értékei, fejlesztési lehetőségei II. (in: Magyar Közigazgatás 1998/11. szám) 645. pp. 
nem történt továbblépés a kötelező társulások vagy a városok térségszervező szerepkörét megerősítő irányokba.

Az 1994-es Ötv. módosítás során a kétharmados kormányzati többség a parlamentben nem tudta, nem akarta kihasználni a lehetőséget, hogy érdemben racionalizáljon az önkormányzati rendszeren, így a törekvés jobbára bizonyos kormányzati- és egyéb szakértői szinteken maradt meg - a koalíciós partnerek az MSZP és az SZDSZ közötti konszenzus hiányában! 1996-ban a közigazgatás korszerüsítéséért felelős kormánybiztos Verebélyi Imre részletes vitaanyagot bocsátott a nyilvánosság elé, amely többek között ismét elöhozta - ugyan az „egy település egy önkormányzat” elv következetes fenntartása mellett - de az apró települések számára kötelező körjegyzőségek, valamint a kötelező önkormányzati társulási jogintézmény törvényi megvalósítását. Verebélyi erőteljesebb közjogi differenciálást sürgetett az eltérő méretü, lakosságú települési önkormányzatok kötelező feladatellátása kapcsán: kerüljön közvetlen törvényi kimondásra, hogy a nagyobb lakosságú és teljesítőképességü helyhatóságok több nevesített kötelező feladatot lássanak el - direkt és erőteljes differenciált hatáskör-telepités javaslata! A vitairat eleme volt a felvetés, hogy bizonyos önkormányzati feladatokat körzeti kompetenciaként a megyei jogú városok láthassanak el városkörnyéki jelleggel. A kormánybiztos egyúttal a megyei önkormányzatok és a fővárosi önkormányzat kompetenciakörét is bővíteni javasolta [Verebélyi, 1996, 213-218. pp.]. A Verebélyijavaslatcsomag azonban érdemben már nem került a parlament asztalára 1994-1998 között.

Az első Orbán-kormány (1998-2002) előzetes helyi közigazgatási választási elképzelései között deklarációként szerepelt a regionális és kistérségi közigazgatás mellett a városkörnyéki közigazgatás. Ugyanakkor az 1998-as kormányprogram már nem számolt az önkormányzati kompetenciák újraszabályozásával, bár szóba került a közszektoron kívülre történő „kiszervezéses” feladatellátás (contracting out) erősítése - ennek jegyében született meg 2000-ben a ma is hatályos háziorvosi rendszer - [2000. évi II. törvény az önálló orvosi tevékenységről]. ${ }^{207}$ Viszont a várostérségi igazgatással kapcsolatban semmilyen hivatalos kormányzati stratégia, de még csak javaslat, elgondolás sem született.

Az első Fidesz kormányt követő kétciklusos szociálliberális kormányzás (2002-2010) időszak nagy részében Lamperth Mónika felügyelte kormánytagként az önkormányzatokat (2002-2006 a Belügyminisztérium, 2006-2007 között az Önkormányzati és Területfejlesztési Minisztérium élén). A disszertáció során már esett szó az IDEA kormányzati munkacsoport tevékenységéről, amely Lamperth minisztersége időszakában a közigazgatás

207 Kara Pál: Javaslat az önkormányzati és az államigazgatási feladat- és hatáskörök felülvizsgálatára (Vitaanyag) (in: Magyar Közigazgatás 1999/1-2. szám) 2-5. pp. 
megreformálásán (konkrétan az államszervezet decentralizáciált átalakításának előkészítésén) dolgozott, és számos szakértői anyag, konferencia született a kezük alatt. A 3 IDEA kabinet (regionális, kistérségi, finanszírozási) gondozásában készült tanulmányokat átböngészve láthatóvá válik, hogy a városok igazgatási szerepköre elsődlegesen az alsó-közép szintü kistérségi feladatszervezési koncepciók révén merült fel. A nagyvárosi kontextus kifejezetten Budapest és agglomerációja - lásd az IDEA Budapest tanulmánykötet 2005-ben! - kapcsán jelent csak meg. A megyei jogú nagyvárosok önálló vonzáskörzeti igazgatási dimenziója nem kapott komoly hangsúlyt az IDEA tevékenysége során. Nem véletlen, hogy 2005-ben a Helyi Önkormányzatok Napján, a magyar önkormányzati rendszer 15 évét értékelve Lamperth Mónika a tárca legfontosabb önkormányzati issue-jának a többcélú kistérségi társulások erősítését és további terjesztését nevezte meg. [Lamperth, 2005, 385-388. pp.]. Ugyanakkor mégis ez az időszak - a BAFT 2005-ös megújítása [2005. évi LXIV. tv.], illetve a többcélú társulásokhoz kapcsolódó modellkísérletek - jelentette az önálló nagyvárosi agglomerációs térségi igazgatás megteremtésének irányába tett leginkább érdemi lépéseket az elmúlt negyedszázadban Magyarországon.

A 2010-ben hatalomra lépett második Orbán-kormány az állam és közigazgatásszervezés teljesen más útját választotta, mint az elődei. A 2006 óta kialakult permanens politikai válságot ${ }^{208}$ tetézte a 2008 végén kirobbanó gazdasági és pénzügyi világválság, majd az átmeneti Bajnai-kabinet (2009-2010) válságkezelő intézkedéseit követően a 2010-es választásokon a Fidesz-KDNP európai összehasonlításban is rendkívül komoly választói támogatást, s vele politikai felhatalmazást kapott a 2010-2014 parlamenti és kormányzati ciklusra. A kormányzat a 2002-2010 közötti balliberális kabinetek által többé-kevésbé következetes, a központi államot szükitö felfogása (közfeladatok kiszervezése a magán- és civilszféra számára - privatizáció, contracting-out, PPP projektek, piacnyitási kezdeményezések) helyett éppen annak megerősítését, a központi kompetenciák felértékelését s mindezzel egy teljesen új politikai-közpolitikai ,igazodási környezet” megvalósítását tüzte ki célként a különböző gazdasági és civil stakeholderek, de a helyi önkormányzatok számára is. Az ambiciózus célokat a 2/3-os parlamenti többség alapozta meg a kormányzat számára. Nemzetközi megközelítésben a 2000-es évek második fele, de különösen a 2008-ban

${ }^{208}$ Gyurcsány Ferenc miniszterelnöknek, még 2006 nyarán Balatonöszödön az MSZP frakció előtt elmondott informális felszólalásának felvétele 2006 szeptemberében, az általános önkormányzati választások előtt került napvilágra. Országos méretủ tüntetésekre és máig vitatott eseményekre került sor (MTV székház ostroma; rendőri beavatkozás október 23-án), miközben a kormányoldal és az ellenzék meghatározó ereje a Fidesz-KDNP közötti viszony és kommunikáció a mélypontra esett. A megtépázott legitimációjú miniszterelnök 2009 tavaszán - a már hónapok óta tomboló gazdasági világválság hatására „dobta be a törülközőt”, utódját Bajnai Gordon szakminisztert az MSZP és SZDSZ frakciók konstruktív bizalmatlanságon keresztül választotta Magyarország miniszterelnökének a parlamentben. 
kezdődött gazdasági világválság - és a kapcsolódó központi kormányzati válaszlépések (bankmentő-csomagok etc.) -, az állam egyfajta reneszánszát hozták el a politikai, közpolitikai térben. Az ún. neoweberianus állam (Neo Weberian State - NWS) a fejlett nyugati országokban a XX. század utolsó évtizedeire meghatározó neoliberális államfelfogás és új közmenedzsment (New Public Management) vezérelte kormányzati praktikumot éles kritika alá véve jutottak el sokan a klasszikus weber-i állam megújításának koncepciójához [Pollit-Bouckhaert, 2004]. Az állami feladatellátás, intézményi és tulajdonosi pozícióinak kiterjesztése és megerősítése meghatározó sorvezetőként funkcionál 2010 óta a kormányzat gondolkodásában. ${ }^{209}$ Teljesen világos, hogy a központi hatalom decentralizációja - értsd: $a$ helyi önkormányzati autonómia és kompetenciák erösitése - alapvető irányait tekintve nem esik egybe ezzel a nyíltan nyíltan felvállalt és gyakran kommunikált államfelfogással. Az erős és hatékony központi állam ethosza hivatalos kormányzati szintre kerülve határozta meg a 2010 utáni központi jogalkotás (törvények és rendeletek) jellegét. A disszertáció behatóan foglalkozik az elmúlt évek különböző kapcsolódó kodifikációs vonatkozásaival - új Alaptörvény; Mötv. 2011-ben; járások kialakítása; kurrens ágazati törvények; átalakuló területfejlesztési intézményrendszer -, hogy az állam versus önkormányzatok viszonyában bekövetkezett lényegi változások a disszertációs témakör (a nagyvárosi térségek önkormányzati kapcsolatai és az agglomerációs feladatellátás szempontjából is láthatóvá váljék.

\section{VI.2 A disszertációs hipotézisek értékelése}

\section{VI.2.1 Disszertációs hipotézis a nem megfelelő szabályozási környezet hatásairól}

I. hipotézis: Magyarországon az 1990-ben a törvényalkotó által létrehozott helyi önkormányzati rendszer fragmentált jellege és a különböző kooperációkat nem megfelelően ösztönző szabályozás negatív hatással volt az elmúlt negyedszázad különböző nagyváros-térségi (agglomerációs szintü) közpolitikai folyamatokra. Ezt csak bizonyos fáziskéséssel igyekezett a politika és a jogalkotás különböző eszközökkel orvosolni - pl. negatív forrásszabályozás, differenciált hatáskörtelepítés, az addigiaknál hatékonyabb önkormányzati társulási jogintézmények megteremtése.

\footnotetext{
${ }^{209}$ Ez a kormányzati felfogás tükröződik a kormányzat 2011-ben elindított hivatalos közigazgatás-fejlesztési programjában a Magyary Zoltánról elnevezett Magyary Programban - bővebben: www.magyaryprogram.kormany.hu
} 
Az I. hipotézis alappremisszája, hogy az 1990-ben megszületett önkormányzati szabályozási környezet - minden kimutatható pozitív jogalkotói szándék ellenére - nem ösztönözte megfelelően a gazdasági szempontból egyre inkább funkcionális egységként működő, de igazgatásilag fragmentált várostérségekben a társult közös önkormányzati feladatellátást. A hipotézis bizonyítását a disszertációs kutatások során a szabályozási, közpolitika-alkotás valamint az alkalmazási, közpolitika-végrehajtás szakaszok során tapasztalt közpolitikai kudarctényezök [Hajnal, 2008] feltárásában gondolom, ezek a következők:

1. Az önkormányzati társulások tekintetében 1990-től a mai napig nem született külön a nagyvárosi térségekre, mint egységes agglomerációs terek igazgatására vonatkozó szabályozási formula, speciális többcélú föderatív agglomerációs tanácsi jogintézménnyel a fókuszban. Habár történtek progresszív kezdeményezések, mint a rövidéletü Budapesti Agglomerációs Fejlesztési Tanács (BAFT) vagy a két nagyvárosi kistérségi igazgatási modellkísérlet (különösen a miskolci) a 2000-es években, de ezek nem okoztak komolyabb paradigmaváltás az agglomerációs issue tekintetében. A 2004-ben törvényalkotás révén létrehozott többcélú kistérségi társulási jogintézmény alkalmas keret lehetett volna, amennyiben születik egy speciális differenciált agglomerációs változata az urbánus térségekre vonatkozólag, de ez elmaradt és a nagyvárosok csak a szükséges mértékben vették ki a részüket a folyamatban.

2. 1990-2012 között az önkormányzati társulások (leszámítva egy körjegyzőségi passzust - 1000 lakos alatt kötelező csatlakozásról) ${ }^{210}$ kizárólag önkéntes alapon jöttek létre. Kötelező önkormányzati társulási jogintézmény megalkotására pedig nem mutatkozott minősített 2/3-os parlamenti jogalkotási akarat egészen 2010-ig. ${ }^{211}$ Az alkotmányerejü országgyülési többséggel rendelkező második Orbán-kormány az Alaptörvénybe foglalta a kötelezö önkormányzati társulás lehetőségét [Alaptörvény, 34. cikk, (2)], és élve az alkotmányos lehetőséggel az ún. közös önkormányzati hivatalokba „kényszerítette” a 2000 lakos alatti kisközségeket - [Mötv. 85.§ (1)]. A mostani önkormányzati szabályozás egyetlen kötelező társulási jogintézménye azonban kifejezetten a kistelepülésekre lett „szabva”, amit bizonyít, hogy a KSH 2014-es helynévkönyve szerint a 2014. január 1.-én országosan müködő 749 közös

\footnotetext{
${ }^{210}$ A kisközségek „önfejüségét” jelzi, hogy sok érintett aprófalu a törvényi kötelezettség ellenére igyekezett önállóan működtetni a polgármesteri hivatalt.

${ }^{211}$ Még akkor sem, amikor a kormányzat alkotmányerejủ többséggel rendelkezett a Tisztelt Házban, 1994-1998 között az első MSZP-SZDSZ koalíció időszakában.
} 
önkormányzati hivatalból mindössze $3 \mathrm{db}$ müködött megyei jogú városi székhellyel: Szeged, Szekszárd és Veszprém. ${ }^{212}$

3. Az önkéntes társulásos jogintézmények különböző típusait egymással párhuzamosan alkalmazták a települések - még a többcélú kistérségi társulások megalakulását követően is. Egyfajta „társulási káosz” volt érzékelhető, ugyanazon települések több önkéntes társulásban is szerepet vállaltak (kistérségi társulások, körjegyzőség, közös intézményfenntartás). A nagyvárosi térségekben az intenzív spill-over kölcsönhatásokon alapuló települési önkormányzati kapcsolatok indokolják, hogy egy speciális tartalmi és eljárási szabályokon alapuló integrált föderatív modell váltsa fel a jelenleg még mindig rendkívül diffúz (egymás mellett párhuzamosan alkalmazott társulásos modellek) viszonyokat.

4. A megyei jogú város - megyei önkormányzat, valamint a Budapest fóváros - Pest megye viszonyrendszerek alulszabályozott (így a mai napig adós maradt a jogalkotás a két önkormányzati típus közötti alapos és egyértelmü tisztázásával) és bizonyos szempontból ambivalens (nagyvárosok lakossága nem szavazhat a megyei közgyülésekre) jellege. A megyei önkormányzatok 2011-es közjogi „profiltisztítása” (direkt kompetenciaszúkítése) alkalmat jelenthetett volna a nagyvárosok agglomerációs feladatellátásának kibővítésére, helyette az állami hatáskörök gyarapodtak.

5. Budapest valamint a legnagyobb megyei jogú városok illetve azok agglomerációs övezetei a különböző gazdasági, társadalmi és intézményi (benne a szolgáltatási spillover) paraméterek tekintetében jelentős mértékben elkülönülnek a többi urbánus térségtől. Ez szintén indokolja a speciális önálló szabályozást. Ugyanakkor más oldalról ez bizonyosan felveti a megyei jogú városok jelenlegi egységes csoportjának közjogi-alkotmányos „megbontását”, akár önálló elnevezéssel kiemelve a valódi regionális hatókörü megyei jogú városok szükebb csoportját az Alaptörvényben valamint a Mötv.-ben - ehhez ugyanakkor nagyon komoly politikai ,elszánásra”, parlamenti akaratra volna szükség!

6. A differenciált hatáskör-telepítés lassú inkrementális kompetencia-delegálási gyakorlat következetes alkalmazása révén a rendszerváltás óta eltelt közel hat és fél parlamenti ciklus alatt a valós különbségekre reflektáló, megfelelően strukturált önkormányzati -

${ }^{212}$ A 3 megyei jogú város mellett 129 városi, 41 nagyközségi és 576 községi székhellyel működő közös önkormányzati hivatal 2014-ben - Magyarország közigazgatási helynévkönyve 2014. január 1. (KSH, Budapest, 2014, 24. pp.) 
benne agglomerációs - feladatrendszer kialakítható lehetett volna. Ennek elmaradása szintén az átfogó és gyors kodifikációra épülő speciális nagyváros térségi szabályozás alternatíváját erősíti.

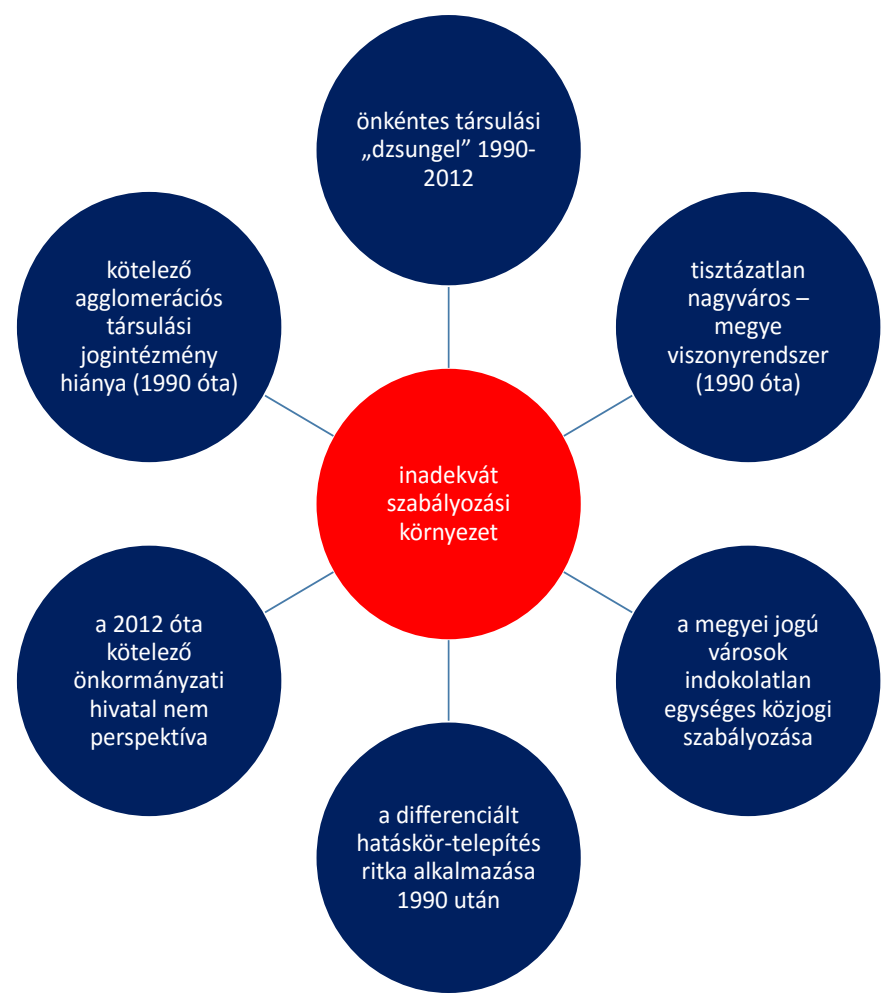

28. ábra: az inadekvát szabályozásról szóló hipotézis bizonyitása (saját szerkesztés)

\section{VI.2.2 Disszertációs hipotézis az agglomerációs feladat- és intézményrendszerről}

II. hipotézis: a kiemelkedő magyarországi nagyvárosi térségeknél (javasolt lehatárolás: Budapest + a 100.000 fős lakosságot meghaladó megyei jogú városok és környező térségek) meghatározott feladat,- hatáskörökkel felruházott föderatív kétszintü agglomerációs önkormányzati tanácsok - mint kötelező önkormányzati társulások létrehozásával a feladatellátás minőségét tekintve hatékonyabb és gazdaságosabb várostérségi kormányzás volna megvalósítható az önkormányzati szolgáltatási területen, mint a jelenlegi széttagolt illetve eseti kooperációs viszonyok közepette.

A II. hipotézis alappremisszája, hogy a kiemelkedő népességü hazai nagyvárosi agglomerációs térségekben az ország egyéb térségi, település-hálózati folyamataihoz viszonyítva olyan szintű dinamizmus és intenzitás tapasztalható, amely felveti meghatározott 
önkormányzati feladatok-, és közszolgáltatások szabályozott agglomerációs szintre való telepítését. A disszertáció nemzetközi fejezeteiben esett szó arról, hogy a fejlett országokban (különösen Nyugat-Európában) az elmúlt évtizedekben a nagyvárosi térségek igazgatási fragmentációját a szuburbán önkormányzatok autonómiáját tiszteletben tartó föderatív megoldásokkal igyekeztek orvosolni, elvetve a korábbi időszakok során alkalmazott durva településszervezési megoldásokat, mint az annexiós vagy fúziós megoldások. Az elmúlt évek centralizációs irányú jogalkotása és államszervezeti változásai ellenére szakmapolitikai tekintetben szükségesnek tartom az agglomerációs igazgatási kérdéskör politikai napirenden (policy agenda) tartását. Legerősebb érvnek az integrált intézményesített várostérségi kapcsolatoknak - különösen a kétszintü föderatív agglomerációs tanácsok - a fejlett országokban való közvetlen preferálását tekintem. Magyarországon az 1990-ben kialakított önkormányzati rendszer az „egy település egy önkormányzat” elv nevében a települési önkormányzati autonómia messzemenő tiszteletére épült, és ez az alapelv a mai napig meghatározó elem. Ezt a tendenciát visszaigazolják az elmúlt 25 év településeket érintő területszervezési döntései, a városok, nagyvárosok nem törekedtek a községek erőszakos „elnyelésére” - a statisztikák fúziókat, annexiókat nem ismernek. Ebből fakadóan a kétszintű föderatív megoldásnak más alternatívája (annexió, fúzió) fel sem merült a modellalkotás során.

A hipotézis bizonyítását az a) különböző városhálózati kutatások, $b$ ) az érintett nagyvárosok saját önkormányzati intézményi és a telepített állami szervek, az egyéb regionális kiterjedésű spill-over szerepkörök, c) a mintaként szolgáló nemzetközi empirikus példák (külföldi agglomerációs struktúrák), valamint d) a disszertációhoz kapcsolódó empirikus kutatás bizonyos tapasztalatai képezik, ezek a következők:

1. Budapest országos szempontból kiemelkedő demográfiai, gazdasági és intézményi pozíciókkal bír. A különböző köz- és magánszolgáltatások terén az agglomerációs térségén jóval túlmutató regionális illetve országos, sőt bizonyos vonatkozásokban nemzetközi hatókörü spill-over hatások. Mindezek valamint a teljes budapesti várostérség tekintetében rendkívül fragmentált igazgatási paraméterek (tagolt fővárosi önkormányzati modell - 23 kerület / 80 db agglomerációs település, közte megyei jogú várossal - Érd, járásszékhely jogú és számos városi jogú településsel) egyértelmüen indokolnak a fővárosi agglomeráció méretét ${ }^{213}$ és strukturális jellegét

\footnotetext{
${ }^{213}$ A 2014-es agglomerációs KSH anyag szerint a fövárosi agglomerációhoz tartozott az ország területének 15\%a valamint az ország összlakosságának 27\%-a, mintegy 2,7 millió ember-Magyarország településhálózata 1. Agglomerációk, településegyüttesek (KSH, Budapest, 2014) 15. pp.
} 
alapul vevő föderatív agglomerációs tanács intézmény szükségességét - javasolt elnevezés: Budapesti Metropolisz Tanács. Talán a leginkább jellemzi a fővárosi agglomeráció gazdaságilag funkcionális egységét, hogy a KSH szerint 2013-ban a 80 szuburbán település foglalkoztatottjainak 63,8\%-a ingázott más településre (nagy valószínűséggel túlnyomó többségük Budapestre; de Pest megye agglomeráción kívüli településeken is $57,7 \%$ volt a nap mint nap ingázó munkavállaló - [KSH, 2014a, 30 . pp.].

2. A legalább 100.000 fös állandó lakosságszám egy olyan általános paraméter a hazai megyei jogú városok esetében, amely már feltételez komoly saját intézményrendszert, önkormányzati humánerőforrást, amelyek képesek érdemben megfelelően kiszolgálni a városkörnyéki községek lakosságát - javasolt elnevezés: Agglomerációs Tanács. Egyéb meglévő intézményi és szolgáltatási funkciók pedig alkalmasak a megyén belüli, valamint a megyei határokon egyértelmüen túlmutató spill-over hatások generálására. A magyarországi városkutatással foglalkozó szakértők is eme lakosságszám felett beszélnek valódi nagyvárosokról. Az elmúlt negyedszázadban a különböző jogszabályokban és kormányzati stratégiai dokumentumokban ${ }^{214}$ pólusvárosként vagy regionális központként definiált megyei jogú városok alkotják ezt a kört:

- Debrecen, Szeged, Pécs, Győr, Miskolc, Székesfehérvár - mind önálló regionális központok; Székesfehérvár, mint regionális társközpont szerepelt a kisebb Veszprémmel a közép-dunántúli NUTS2 régióban - ugyanakkor Székesfehérvár lakossága éppen 100.000 lakos körül jár, valamint a kapcsolódó KSH lehatárolások szerint élénk agglomerálódási folyamat a jellemző a Fejér megyei megyeszékhely térségében. ${ }^{215}$ - a felsorolt várostérségek esetében mindenképpen javasolt a kötelezö föderatív agglomerációs tanács létrehozása!

- A föderatív agglomerációs intézmény kialakításához javasolt vidéki megyei jogú városoknál az agglomerációs településekről ingázó aktív foglalkoztatottak aránya: debreceni nagyvárosi településegyüttes $60,8 \%$; szegedi nagyvárosi településegyüttes $60,4 \%$; pécsi agglomeráció $73,5 \%$; győri agglomeráció

${ }^{214}$ Országos területfejlesztési koncepciók; pólusprogram etc.

215 Amíg a 2003-as KSH lehatárolás még csak 13 városkörnyéki települést sorolt székesfehérvári településeggyüteshez, addig ez 2014-re már 35-re növekedett, a teljes agglomerációs térségi népesség is több mint 40 ezer lakossal gyarapodott. Magyarország településhálózata 1. - Agglomerációk, településegyüttesek (KSH, Budapest, 2014, 20. pp.) 
$72,2 \%$; miskolci agglomeráció $67,3 \%$; székesfehérvári nagyvárosi településegyüttes 72,0\% - [KSH, 2014a, 40-252 pp.].

- Két további megyei jogú város bevonása is felmerült: Kecskemét - habár a Bács-Kiskun megyei székhely lakossága meghaladja a 100.000 lakost, mindössze 8 települést (30.000 alatti lakossággal) kapcsoltak közvetlenül a város vonzáskörzetéhez a KSH szakértői 2014-ben; Szombathely lakossága 80.000 lakos alatt van, viszont 52 települést kapcsolt hozzájuk a KSH agglomerációs tanulmány ${ }^{216}$ - ezen várostérségek esetében nem javasolt a kötelezö föderatív agglomerációs tanács létrehozása!

3. A nemzetközi (európai) komparatív dimenzióban a már működő kétszintü föderatív agglomerációs tanácsok mintaként szolgálhatnak a feladatrendszer és a müködésistrukturális kérdésekben a vizsgált intézménytípusnak a kiemelt magyarországi nagyvárosi térségekre való modellezésénél - pl. várostérségi tömegközlekedés; gazdasági infrastrukturális- és humánszolgáltatások.

4. Az agglomerációs szintü kapcsolatok vizsgálatára fókuszáló, a polgármesterek percepciós véleményén alapuló empirikus kutatás segít abba az irányba tájékozódni, hogy a városkörnyéki (községek, városok, járásszékhely városok) településvezetök miként gondolkodnak a várostérségi kapcsolatok szükségességéről és napi megvalósulásáról, valamint az agglomerációs térségekben a kooperációk javítására javasolt közpolitikai eszközökröl, a következö tanulságokkal:

- Várostérségi kontextusban a formális önkormányzati intézményi kapcsolatok (a térségi önkormányzati politikai és apparátusi nexus) direkt preferálása.

- Várostérségi kontextusban a nem klasszikus intézményi megoldások governance eszközöknek (pl. civil és nemzetközi kapcsolatok; fejlesztési kooperációk; egységes várostérségi kommunikáció) - alulértékelése.

- Várostérségi kontextusban az integrált jellegü közpolitikai eszközök (mint agglomerációs tanács; önálló agglomerációs pénzügyi alap; regionális ÖNET) preferálása a városkörnyéki településvezetők részéről.

5. A kötelezően létrejövő Budapesti Metropolisz Tanács valamint a vidéki Agglomerációs Tanácsok mellett önkéntes agglomerációs tanács intézményi keret lehetőségének biztosítása a többi megyei jogú város és környező települések számára

${ }^{216}$ Magyarország településhálózata 1. - Agglomerációk, településegyüttesek (KSH, Budapest, 2014, 20. pp.); Magyarország közigazgatási helynévkönyve 2014. január 1. (KSH, Budapest, 2014, 26. pp.) 
az agglomerációs igazgatási tér hatékonyabb megszervezésére a társulásban résztvevő települési önkormányzatok szabad akaratából.

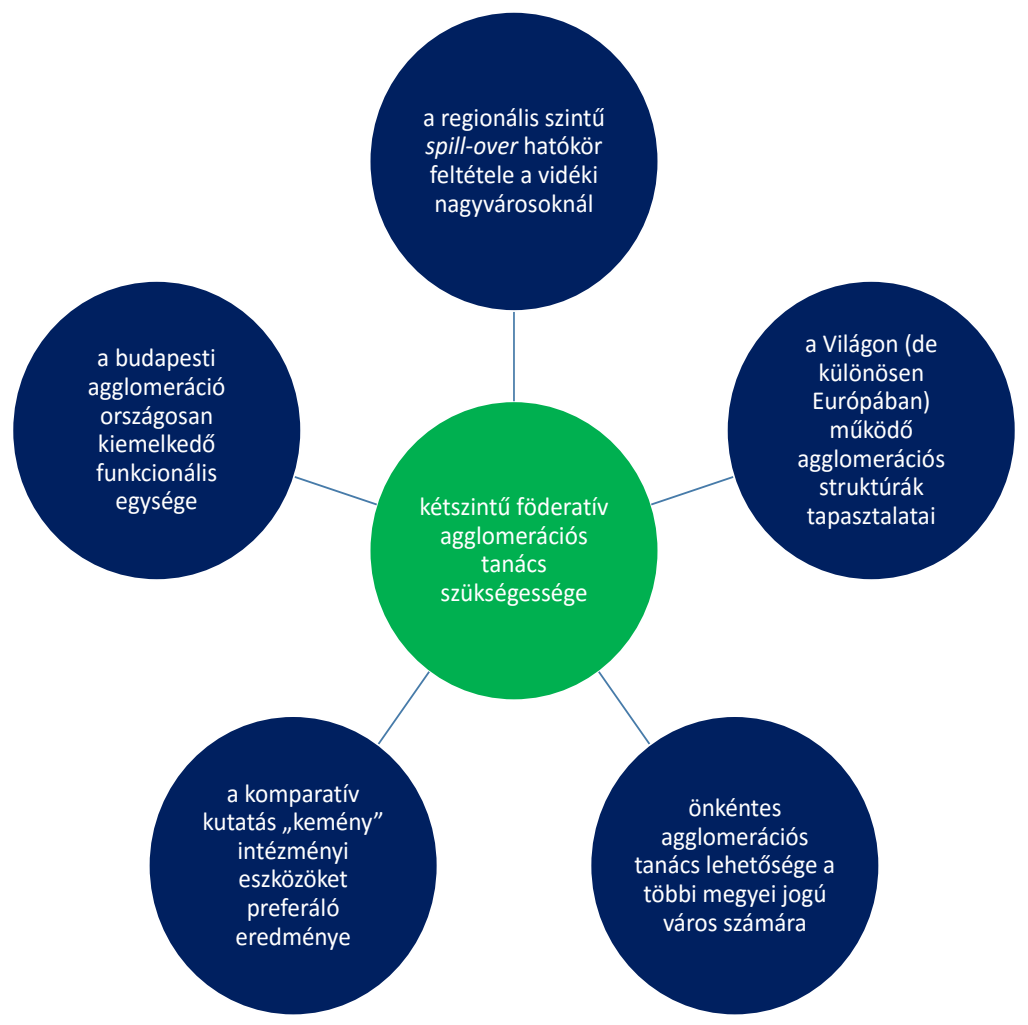

29. ábra: az agglomerációs tanács szükségességéröl szóló hipotézis bizonyitása (saját szerkesztés)

\section{VI.3 A modellkísérlet - struktúra és kodifikációs javaslat}

A Bevezetésben röviden már felvázolt kétszintü föderatív agglomerációs tanács intézményének továbbgondolása történik a következőkben. Az erős közjogi legitimáció érdekében önálló - lehetőleg 2/3-os országgyülési többséghez kötött - sarkalatos törvény jelenthetné az új intézmény (Budapesti Metropolisz Tanács; vidéki Agglomerációs Tanácsok) közjogi alapját. Mivel az Alaptörvény lehetővé teszi a kötelezö önkormányzati társulás lehetöségét [Alaptörvény 34. cikk (2)]. -, megvalósulás esetén, akár az intézménytípusnak az Alaptörvénybe való belefoglalása is elképzelhető. ${ }^{217}$

Az intézménytípus föbb paraméterei:

- Speciális kötelező agglomerációs önkormányzati társulás - tanulva az önkéntes társulások kudarcaiból, meghatározva azt, hogy az agglomerációs tanács

\footnotetext{
${ }^{217}$ A föderatív agglomerációs tanácsok rendkívül magas szintü közjogi legitimációja szempontjából, kifejezetten megfontolandó az Alaptörvénybe való belefoglalás.
} 
melyik más önkéntes társulási jogintézménnyel (pl. közös önkormányzati hivatal) volna összeférhető, és mely társulási jogintézményekkel nem. ${ }^{218}$

- Az agglomerációs tanács demokratikus legitimációja közvetett volna - a tanács tagjait nem a várostérség lakossága választaná, hanem az érintett önkormányzatok képviselőtestületei a lakosságszám arányában (és a müködéshez való anyagi hozzájárulás függvényében) delegálhatnának települési képviselő tagokat. Természetesen olyan belső arányok kialakítása ajánlatos, amely képes biztosítani a müködőképességet és csak minimális lehetőséget hagyna a „patthelyzet” számára.

- Kétszintü föderatív jelleg, amelyben az arányosság biztosítása alapvető a szavazás (lásd előző pont!) és a feladatellátás tekintetében. Tanulva a Tkt. ${ }^{219}$ hibáiból - pl. a társulási tanácsokban 1 település 1 szavazattal rendelkezett, és csak a tagönkormányzatokon múlott, hogy lakosságszám vagy az anyagi hozzájárulás alapján differenciálták a szavazati arányokat - [2004. évi CVII. tv. $6 . \S(1-2)]$.

- Szükséges a saját anyagi források biztosítása, amely több elemből tevődhet össze: az érintett önkormányzatok arányos hozzájárulása; költségvetési támogatás - mint normatív állami hozzájárulás / átengedett központi adó; saját agglomerációs-várostérségi adó - lehetöleg a saját bevétel (önkormányzatok hozzájárulása, önálló agglomerációs adó, pénzalap) minél nagyobb arányának a megteremtése javasolt!

- A minél erősebb „civil kontroll” biztosítása érdekében javasolt meghatározott delegálás alapján a várostérség meghatározó stakeholder csoportjainak közvetlen bekapcsolása a metropolisz / agglomerációs tanács közpolitikai döntéshozatali folyamatába (policy making): a tanács szakmai bizottságaiban való közvetlen konzultációs részvétel biztosítása révén a döntés-előkészítő szakaszba (agenda setting) való „,becsatornázás”. 220

\footnotetext{
${ }^{218}$ Nem volna cél, hogy a nagyváros és térsége kizárólag csak ezt a speciális társult agglomerációs tanácsot müködtessen, de a funkcionális párhuzamosságok kikerülése érdekében fontos összehangolni az egyéb önkormányzati társulási lehetőségekkel.

219 2004. évi CVII. törvény a többcélú kistérségi társulásokról

${ }^{220} \mathrm{Az}$ önkormányzatok és a civil szektor egyébiránt is sok kívánnivalót hagy maga után - sok esetben a kapcsolatok teljes hiányáról vagy a korábbi nexusok egyértelmü romlásáról beszélhetünk. Ezt erősíti meg az empirikus kutatás civileket érintő része - II.6 és III.6. kérdések. Valamint a KSH 2015-ben publikált az önkormányzatok és a nonprofit szervezetek kapcsolatát egy 2012-es országos kutatási adatfelvétel alapján értékelő mühelytanulmány: e szerint a helyi önkormányzatok $24 \%$ semmilyen kapcsolatot nem müködtet civil szervezetekkel; a 2000-es évektöl jelentősen csökkent a helyi önkormányzatok által támogatott civilek köre és a
} 
- A Budapesti Metropolisz Tanács illetve a vidéki agglomeráció tanácsok (pl. Győr térségi Agglomerációs Tanács) területi lehatárolásának kérdésében (mely önkormányzatok alkossák a létrejövő tanácsokat) a kizárólagos jog a szakmai szervezeteket, elsősorban a Központi Statisztikai Hivatalt illetné, kizárva ezzel a direkt politikai motivációkat.

\section{Budapesti Metropolisz Tanács javasolt kompetenciaköre:}

A tartalmi kompetencia-lehatárolás a jelenlegi fővárosi önkormányzat kötelező feladatainak újraszabályozásán alapulna, hogy mely kompetenciák kerülhessenek az agglomerációs szintre ${ }^{221}$ - ehhez a Mötv. 23. § (4), mint a fővárosi önkormányzat nevesített feladatai jelentik a kapaszkodót - ahol a feladat továbbra is fóvárosi kompetenciaként kerül meghatározásra, természetesen az annak megfelelő kötelező települési hatáskör az agglomerációs övezetben a szuburbán települési önkormányzatoknál marad (pl. szociális ellátások):

a) törvényben vagy kormányrendeletben meghatározott kiemelt forgalmú vagy országos közúti közlekedésben fontos szerepet játszó fơútvonalak, sugár- és gyürüirányú közutak, kiemelt tömegközlekedési csomópontok, kiemelt közparkok és közterek kezelése, fejlesztése, üzemeltetése, valamint ezeken a területeken a közterületfelügyelet müködtetése, illetve a főváros teljes területén a forgalomtechnikai kezelői és üzemeltetői feladatok ellátása, forgalomszervezés - igazodva a nemzetközi tendenciákhoz javasolt az agglomerációs szintre telepítés (metropolisz tanács)!

a) A kerületek határain átnyúló településrendezés, terület- és településfejlesztés - mivel a föváros közigazgatási határain belül marad a feladat, ez maradhat fơvárosi kompetencia!

a) településtisztaság (közutak locsolása, síkosság-mentesítés) - közvetlen fơvárosi kompetencia!

b) szociális ellátások biztosítása; - közvetlen fơvárosi kompetencia!

c) állategészségügyi feladatok; - közvetlen fövárosi kompetencia!

d) az érintett kerületek véleményének kikérésével közutak, közparkok, közterek elnevezése - közvetlen fövárosi kompetencia!

támogatás összege - bövebben lásd! Sebestyén István: Az önkormányzatok és a nonprofit szervezetek kapcsolata, 2012 (KSH, Budapest, 2015)

${ }^{221}$ A kerületi önkormányzati hatáskörök természetesen maradnának a jelenlegi szintjükön, vagy esetleg a főváros versus kerület 
e) saját tulajdonú lakás- és helyiséggazdálkodás - a nemzetközi példák miatt is életszerü, hogy a lakás- és ingatlangazdálkodás bizonyos elemei, részhatáskörei a Budapesti Metropolisz Tanács szintjére kerüljenek!

f) fỏvárosi szintü sport és szabadidősport - javasolt a feladat telepitése a metropolisz tanácsi szintre!

g) közvilágítás biztosítása, köztemetők fenntartása, kéményseprö-ipari szolgáltatás biztosítása - közvetlen fóvárosi kompetencia!

h) helyi közösségi közlekedés biztosítása és müködtetése, valamint a föváros területén a parkolás feltételrendszerének kialakítása - igazodva a nemzetközi tendenciákhoz a feladatkör metropolisz szintre telepitése!

i) távhőszolgáltatás, ivóvíz-ellátás, szennyvízelvezetés, - kezelés és ártalmatlanítás (csatornaszolgáltatás), hulladékgazdálkodás - a felsorolt kompetenciák metropolisz szintre delegálása!

j) környezet- és természetvédelem, vízgazdálkodás, vízkárelhárítás - a felsorolt kompetenciák metropolisz szintre delegálása!

b) honvédelem, polgári védelem, katasztrófavédelem - a polgári védelem, katasztrófavédelem kérdése telepithetö agglomerációs szintre!

k) fővárosi helyi adóval kapcsolatos feladatok - továbbra maradjon a fóvárosnak saját adókivetési joga, de a metropolisz tanács megvalósulása esetén külön hatástanulmány kérdése volna az agglomerációs szint saját helyi adóval való megerösitése!

c) gazdaságszervezés és - fejlesztés, turizmussal kapcsolatos feladatok - megfontolandó az agglomerációs szintre való telepítés (metropolisz tanács)!

1) az országos szerepkörrel összefüggő kulturális szolgáltatás, különösen a nyilvános könyvtári ellátás biztosítása, közmüvelődési tevékenység támogatása; filmszínház, előadó-müvészeti szervezet támogatása - közvetlen fövárosi kompetencia!

m) a kiemelt kulturális örökség védelme - közvetlen fövárosi kompetencia!

n) a hajléktalan ellátás - közvetlen fơvárosi kompetencia!

o) a tulajdonában álló közterületek használatára vonatkozó szabályok és díjak megállapítása - közvetlen fövárosi kompetencia!

A Mötv. 23.§ (5) a fővárosi kerületi önkormányzatok nevesített hatáskörei: ezek vagy maradnak kerületi kompetenciában vagy esetleg a főváros vs. kerület kontextusban delegálhatóak lehetnének a főváros irányába (pl. parkolás-üzemeltetés), de ezen feladatok esetében az agglomerációs szintre való delegálás abszolút nem életszerü, s így elvetendő. 


\section{Agglomerációs Tanácsok javasolt kompetenciaköre:}

Mivel ez csak meghatározott vidéki nagyvárosokat érint, felvetődik a kérdés - ismerve eme településkör heterogén jellegét (Debrecentől Szekszárdig) -, hogy alkotmányos-közjogi szempontból javasolt volna újrastrukturálni a jelenlegi megyei jogú városi kört az Alaptörvényben és a Mötv.-ben egyaránt. Létrehozva ezzel egy a kiemelkedő regionális hatókörü intézményrendszerrel és spill-over funkciókkal bíró ún. kiemelt megyei jogú város / regionális hatókörü megyei jogú városok önálló közjogi csoportját (Debrecen, Szeged, Győr, Pécs, Miskolc, Székesfehérvár).

A tartalmi kompetencia-lehatárolás a jelenlegi települési önkormányzati kötelező feladatainak újraszabályozásán alapulna, hogy mely kompetenciák kerülhetnek agglomerációs szintre - ehhez a Mötv. 13. § helyi közügyek felsorolása jelenti a kapaszkodót:

a) területfejlesztés, területrendezés - igazodva a nemzetközi tendenciákhoz javasolt az agglomerációs szintre telepítés (agglomerációs tanács)!

b) településüzemeltetés (benne a köztemetők kialakítása és fenntartása, a közvilágításról való gondoskodás, kéményseprő-ipari szolgáltatás biztosítása, a helyi közutak és tartozékainak kialakítása és fenntartása, közparkok és egyéb közterületek kialakítása és fenntartása, gépjármüvek parkolásának biztosítása) - ezek, mint önkormányzati müködési alapfeladatok maradnának közvetlen helyi önkormányzati hatáskörben (nagyvárosi önkormányzat / városkörnyéki önkormányzat)!

c) a közterületek, valamint az önkormányzat tulajdonában álló közintézmény elnevezése - mint helyi önkormányzati alapfeladat (nagyvárosi önkormányzat / városkörnyéki önkormányzat!)

d) egészségügyi alapellátás, az egészséges életmód segítését célzó szolgáltatások - mint helyi önkormányzati alapfeladat (nagyvárosi önkormányzat / városkörnyéki önkormányzat!)

e) környezet-egészségügy (köztisztaság, települési környezet tisztaságának biztosítása, rovar- és rágcsálóirtás) - alapvetöen helyi önkormányzati feladat, de megfontolandó lehet bizonyos részhatáskörök agglomerációs szintre történö delegálása!

f) óvodai ellátás - alapvetően helyi önkormányzati kompetencia, de éppen a káros spillover hatások kivédése érdekében megfontolandó bizonyos tervezési részhatáskörök (pl. agglomerációs óvodakörzetek) agglomerációs szintre delegálása!

g) kulturális szolgáltatás, különösen a nyilvános könyvtári ellátás biztosítása; filmszínház, előadó-művészeti szervezet támogatása, a kulturális örökség helyi 
védelme; a helyi közmüvelődési tevékenység támogatása - helyi önkormányzati alapfeladat (nagyvárosi önkormányzat / városkörnyéki önkormányzat!)

h) szociális, gyermekjóléti és gyermekvédelmi szolgáltatások és ellátások - helyi önkormányzati alapfeladat (nagyvárosi önkormányzat / városkörnyéki önkormányzat!)

i) lakás- és helyiséggazdálkodás - nemzetközi példák bizonyitják, hogy bizonyos méret felett (többmilliós nagyváros) érdemes a kompetencia agglomerációs szintre való delegálása, de néhány százezres várostérségek esetén maradhat helyi önkormányzati kompetencia!

j) a területén hajléktalanná vált személyek ellátásának és rehabilitációjának, valamint a hajléktalanná válás megelőzésének biztosítása - helyi önkormányzati alapfeladat (nagyvárosi önkormányzat / városkörnyéki önkormányzat!)

k) helyi környezet- és természetvédelem, vízgazdálkodás, vízkárelhárítás, ivóvízellátás, szennyvízelvezetés, - kezelés és ártalmatlanítás (csatornaszolgáltatás) - a közfeladat közvetlen agglomerációs-várostérségi szintre való delegálása (agglomerációs tanács)!

1) honvédelem, polgári védelem, katasztrófavédelem, helyi közfoglalkoztatás - a polgári védelem, katasztrófavédelem kérdése telepithető agglomerációs szintre!

m) helyi adóval, gazdaságszervezéssel és a turizmussal kapcsolatos feladatok megfontolandó az agglomerációs szintre való telepités (agglomerációs tanács)!

n) a kistermelők, őstermelők számára - jogszabályban meghatározott termékeik értékesítési lehetőségeinek biztosítása, ideértve a hétvégi árusítás lehetőségét is $-e z$ maradna helyi önkormányzati hatáskörben!

o) sport, ifjúsági ügyek - biztonsággal delegálhatók agglomerációs szintre (agglomerációs tanács)!

p) nemzetiségi ügyek - helyi önkormányzati alapfeladat (nagyvárosi önkormányzat / városkörnyéki önkormányzat!)

q) közremüködés a település közbiztonságának biztosításában - a közvetlen helyi önkormányzati kompetencia megtartása javasolt!

r) helyi közösségi közlekedés biztosítása - javasolt az agglomerációs szintre, s vele az agglomerációs tanácsokhoz való feladatdelegálás (nemzetközi példák egyértelmüen ezt preferálják)!

s) hulladékgazdálkodás - javasolt az agglomerációs szintre, s vele az agglomerációs tanácsokhoz való feladatdelegálás!

t) távhőszolgáltatás - javasolt az agglomerációs szintre, s vele az agglomerációs tanácsokhoz való feladatdelegálás! 


\section{Egyéb hatásköri kérdések:}

Már sok szó esett az elmúlt évek parlamenti, kormányzati jogalkotásáról, amely keretében számos, 1990-töl önkormányzati feladat (intézmény) került át az állam központi minisztériumok, országos hatáskörü kormányhivatalok, központi hivatalok - vagy területi dekoncentrált intézményeihez. Több ágazatban a mai napig problémákat okoz az „átállás”, és bizonyos területeken egyszerüen nem bizonyított, hogy a közpolitikai hatékonyság (gazdaságos feladatellátás, eredményes végrehajtás, ügyfél-központúság) szempontjából eredményes átalakításról volt szó. Elméleti síkon a létrejövő és ideális esetben jól müködő agglomerációs tanácsok speciális „visszaszerződési” kontraktus keretében — láthatnának el ismételten bizonyos 2010 után „államosított” feladatokat - pl. közoktatási fenntartói, irányítói jogok visszaadása a komoly iskolavárosi tradíciókkal rendelkező nagyvárosokhoz kapcsolódó agglomerációs hatóságokhoz. Budapest és a kiemelkedő vidéki nagyvárosaink rendelkeznek azzal a felhalmozott saját tudással, erőforrással és kreatív-innovatív képességekkel, amelyek alkalmassá tehetik őket a jelenleginél szélesebb feladatellátásra. 


\section{1. számú melléklet}

\section{A hatékony nagyvárosi kormányzás lehetőségei Magyarországon az új önkormányzati törvény elfogadását követően}

\section{Tisztelt Polgármester Asszony / Úr!}

\section{Kedves Kolléga!}

A Települési Önkormányzatok Szövetsége (TÖOSZ) a Homo Oecologicus Alapítvánnyal (www.hoec.hu) való szakmai együttmüködés keretében "A hatékony nagyvárosi kormányzás lehetőségei Magyarországon az új önkormányzati törvény elfogadását követően" elnevezés alatt szakmai kutatást végez a nagyvárosok (megyei jogú város / főváros) és a városkörnyéki települések közötti önkormányzati, közszolgáltatási és egyéb (gazdasági, civil) kapcsolatai témában, kifejezetten az érintett önkormányzati döntéshozók véleményének megismerésével a fókuszban. A kutatás alapját egy olyan kérdőíves felmérés jelenti, amelynek kialakításában több a téma nemzetközi és hazai aspektusaiban jártas szakértő is részt vett. Napjaink egyik legizgalmasabb gazdasági, társadalmi és településpolitikai kérdése a nagyvárosok, városok és a környező települések kapcsolatrendszere, az egymásra gyakorolt hatások és a napi müködés során kialakult szimbiózisok: hazánkban különös aktualitást ad a témának az új önkormányzati törvény (2011. évi CLXXXIX. törvény), valamint egyéb szabályozó ágazati törvények, végrehajtási jogszabályok életbe lépése. Ezen változások hatásainak jobb megismeréséhez kérnénk az Ön segítségét, hogy személyes tapasztalatai és benyomása alapján töltse ki a kutatási kérdőívet az alábbi internetes linken:

\section{www.hoec.hu/kutatas_varosikormanyzas}

A kitöltés online és anonim (név és a konkrét település megnevezése nélkül) történik. A kutatási adatfelvételre 2014. március 3. és 2014. április 3. között kerül sor, ebben az időszakban kérnénk kitölteni a szakmai kérdőívet, amely kb. 15-20 percet vesz igénybe.

Amennyiben a kérdőív kitöltésekor problémája adódik, kérjük, jelezze azt az info@hoec.hu email címen. 
Tájékoztatnám továbbá a Tisztelt Kollégát, hogy a kitöltött kérdöívek feldolgozásából nyert kutatási eredményeket - kiegészítve egyéb a témakörhöz kapcsolódó tanulmányokkal - egy majdani tanulmánykötetben és szakmai konferencián kívánjuk prezentálni nemcsak a szűkebb szakmai közönség, hanem az önkormányzatiság iránt érdeklődő szélesebb közvélemény számára is.

Segítségét elöre is köszönjük!

A kérdöív kitöltése

Budapest, 2014. március 3.

Segítségét előre is köszönjük!

Dr. Zongor Gábor

fötitkár

TÖOSZ
Szabó Tamás

ügyvezető elnök

Homo OecologicusAlapítvány

I

I.1 Kérjük, adja meg a nemét!

Kérjük, válasszon egyet az alábbiak közül:

Oférfi

nő

I.2 Kérjük, adja meg a születési évét! *

Kérjük, csak számokat írjon!

19.

I.3 Kérjük, adja meg a legmagasabb iskolai végzettségét! *

Kérjük, válasszon egyet az alábbiak közül: 
alapfokú iskolai végzettség

szakiskolai végzettség

középiskolai végzettség, érettségi

felsőoktatási diploma (főiskolai BA, egyetemi MA)

doktori (PhD.) fokozat

I.4 Melyik megyében található az Ön által irányított település?

I,5 Melyik járásban található az Ön által irányított település? *

I.6. Mi az Ön által irányított települési önkormányzat típusa? *

Kérjük, válasszon egyet az alábbiak közül:

község

nagyközség

Oáros

járásszékhely város

megyei jogú város

Fővárosi Önkormányzat

fövárosi kerületi önkormányzat

I.7 Mekkora az Ön által irányított település lélekszáma? *

Kérjük, válasszon egyet az alábbiak közül:

1000 fö alatt

1000 - 4999 fö között 
5000 - 9999 fő között

10000 - 49999 fö között

50000 fö fölött

I.8. Hányadik ciklusát tölti Ön, mint települési polgármester? *

Kérjük, válasszon egyet az alábbiak közül:

1. polgármesteri ciklus

2. polgármesteri ciklus

3. polgármesteri ciklus

3.-nál több polgármesteri ciklus

II.

Az Ön megítélése szerint mennyire szükséges a nagyváros és városkörnyéki települések közötti kapcsolatoknál az alábbi tényezők?

Értékelje egy 1-5-ig terjedő skálán! (1 - egyáltalán nem szükséges; 5 - nagyon szükséges) A közbülső értékekkel árnyalhatja véleményét.

II.1 Átlátható és egyértelmű jogszabályi keretek (Alaptörvény, Önkormányzati törvény, egyéb kapcsolódó ágazati törvények és végrehajtási rendeletek)

Kérjük, jelöljön meg egy megfelelő választ minden felsorolt elem számára:

$\begin{array}{lllll}1 \text { - egyáltalán } & 2-\text { inkább } & & & \\ \text { nem } & \text { nem } & 3 \text { - közepesen } & 4-\text { inkább } & 5 \text { - nagyon } \\ \text { szükséges } & \text { szükséges } & \text { szükséges } & \text { szükséges } & \text { szükséges }\end{array}$


1 - egyáltalán 2 - inkább

nem nem 3 - közepesen 4 - inkább 5 - nagyon

$\begin{array}{llll}\text { szükséges } & \text { szükséges } & \text { szükséges szükséges } & \text { szükséges }\end{array}$

II.2. Térségi önkormányzati politikai (polgármesterek, képviselőtestületek, megyei önkormányzat) kapcsolatok

Kérjük, jelöljön meg egy megfelelö választ minden felsorolt elem számára:

$\begin{array}{llllll}1 \text { - egyáltalán } & 2-\text { inkább } & & & \\ \text { nem } & \text { nem } & 3 \text { - közepesen } & 4-\text { inkább } & 5 \text { - nagyon } \\ \text { szükséges } & \text { szükséges } & \text { szükséges } & \text { szükséges } & \text { szükséges } \\ & & 0 & 0 & 0\end{array}$

II.3. Országos kormányzati és parlamenti kapcsolatok (miniszterelnök és miniszterek, államtitkárok és kormánybiztosok, parlamenti képviselők)

Kérjük, jelöljön meg egy megfelelő választ minden felsorolt elem számára:

$\begin{array}{lllll}1 \text { - egyáltalán } & 2-\text { inkább } & & & \\ \text { nem } & \text { nem } & 3 \text { - közepesen } & 4-\text { inkább } & 5 \text { - nagyon } \\ \text { szükséges } & \text { szükséges } & \text { szükséges } & \text { szükséges } & \text { szükséges } \\ & 0 & 0 & 0 & 0\end{array}$

II.4. Folyamatos koordináció és kooperáció a térségi önkormányzati apparátusok (hivatalok, jegyzők, vezető munkatársak, ügyintézők) között.

Kérjük, jelöljön meg egy megfelelő választ minden felsorolt elem számára:

$\begin{array}{lllll}1 \text { - egyáltalán } & 2-\text { inkább } & & & \\ \text { nem } & \text { nem } & 3 \text { - közepesen } & 4-\text { inkább } & 5 \text { - nagyon } \\ \text { szükséges } & \text { szükséges } & \text { szükséges } & \text { szükséges } & \text { szükséges } \\ & 0 & 0 & 0 & 0\end{array}$

II.5. Együttmüködés a térségi önkormányzatok valamint a fővárosban/megyei jogú városban/járásszékhely városban található állami területi dekoncentrált intézmények (kormányhivatalok és egyéb szakigazgatási szervek) vezetői, hivatali dolgozói között 
Kérjük, jelöljön meg egy megfelelő választ minden felsorolt elem számára:

$\begin{array}{lllll}1 \text { - egyáltalán } & 2-\text { inkább } & & & \\ \text { nem } & \text { nem } & 3 \text { - közepesen } & 4-\text { inkább } & 5 \text { - nagyon } \\ \text { szükséges } & \text { szükséges } & \text { szükséges } & \text { szükséges } & \text { szükséges } \\ & & & & 0\end{array}$

II.6. A nagyváros és városkörnyéki települések civil szervezetei közötti kapcsolatok, együttmüködések

Kérjük, jelöljön meg egy megfelelő választ minden felsorolt elem számára:

1 - egyáltalán 2 - inkább

$\begin{array}{lllll}\text { nem } & \text { nem } & 3 \text { - közepesen } & 4-\text { inkább } & 5 \text { - nagyon } \\ \text { szükséges } & \text { szükséges } & \text { szükséges } & \text { szükséges } & \text { szükséges }\end{array}$

II.7 Európai uniós és egyéb nemzetközi kapcsolatok (testvérvárosi kooperációk; euroregionális együttműködések; közvetlen brüsszeli, európai uniós kapcsolatok)

Kérjük, jelöljön meg egy megfelelő választ minden felsorolt elem számára:

$\begin{array}{lllll}1 \text { - egyáltalán } & 2-\text { inkább } & & & \\ \text { nem } & \text { nem } & 3 \text { - közepesen } & 4 \text { - inkább } & 5 \text { - nagyon } \\ \text { szükséges } & \text { szükséges } & \text { szükséges } & \text { szükséges } & \text { szükséges } \\ & 0 & 0 & 0 & 0\end{array}$

II.8. Közös, a nagyváros és városkörnyéki települések együttmüködésén alapuló önkormányzati feladatellátás és közszolgáltatások

Kérjük, jelöljön meg egy megfelelő választ minden felsorolt elem számára:

\begin{tabular}{|c|c|c|c|c|}
\hline nem & nem & 3 - közepesen & 4 - inkább & - nagyon \\
\hline szükséges & szükséges & szükséges & szükséges & szükséges \\
\hline
\end{tabular}




$\begin{array}{lllll}1 \text { - egyáltalán } & 2-\text { inkább } & & & \\ \text { nem } & \text { nem } & 3 \text { - közepesen } & 4-\text { inkább } & 5 \text { - nagyon } \\ \text { szükséges } & \text { szükséges } & \text { szükséges } & \text { szükséges } & \text { szükséges } \\ & 0 & 0 & 0 & \end{array}$

II.9. Fejlesztési együttmüködések (tervek, projektmenedzsment, konzorciális kooperációk) a nagyváros és városkörnyéki települések között

Kérjük, jelöljön meg egy megfelelő választ minden felsorolt elem számára:

$\begin{array}{lllll}1 \text { - egyáltalán } & 2-\text { inkább } & & & \\ \text { nem } & \text { nem } & 3 \text { - közepesen } & 4-\text { inkább } & 5 \text { - nagyon } \\ \text { szükséges } & \text { szükséges } & \text { szükséges } & \text { szükséges } & \text { szükséges } \\ & 0 & 0 & 0 & 0\end{array}$

II.10. Agglomerációs, városkörnyéki típusú ügyekben a nagyváros és városkörnyéki települések lakosságának folyamatos tájékoztatása

Kérjük, jelöljön meg egy megfelelő választ minden felsorolt elem számára:

$\begin{array}{lllll}1 \text { - egyáltalán } & 2-\text { inkább } & & & \\ \text { nem } & \text { nem } & 3 \text { - közepesen } & 4-\text { inkább } & 5 \text { - nagyon } \\ \text { szükséges } & \text { szükséges } & \text { szükséges } & \text { szükséges } & \text { szükséges } \\ & 0 & 0 & 0 & 0\end{array}$




\section{III.}

Az Ön saját hivatali tapasztalatai alapján mennyiben segítik a napi gyakorlatban az alábbi tényezők a nagyváros és városkörnyéki települések közötti kapcsolatok minőségét?

Értékelje egy 1-5-ig terjedő skálán! (1 - egyáltalán nem segíti; 5 - nagyon segíti) A közbülső értékekkel árnyalhatja véleményét.

III.1. Átlátható és egyértelmü jogszabályi keretek (Alaptörvény, Önkormányzati törvény, egyéb kapcsolódó ágazati törvények és végrehajtási rendeletek)

Kérjük, jelöljön meg egy megfelelő választ minden felsorolt elem számára:

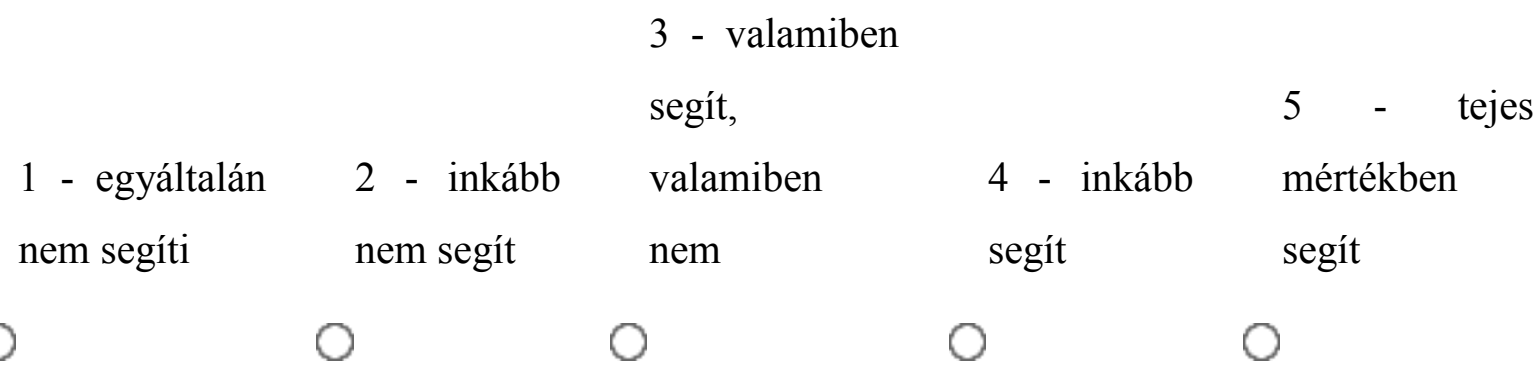

III.2. Térségi önkormányzati politikai (polgármesterek, képviselőtestületek, megyei önkormányzat) kapcsolatok

Kérjük, jelöljön meg egy megfelelő választ minden felsorolt elem számára:

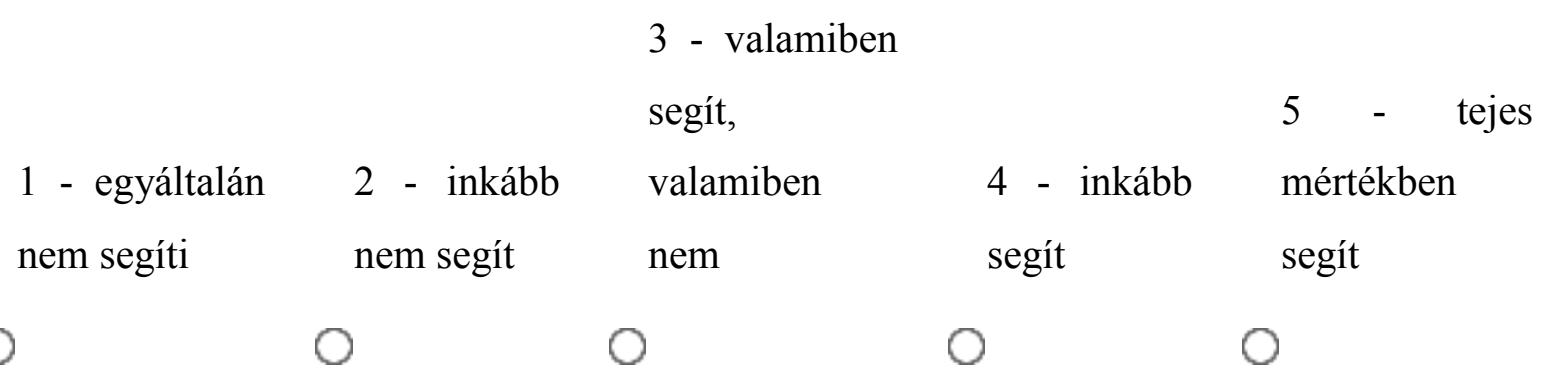

III.3. Országos kormányzati és parlamenti kapcsolatok (miniszterelnök és miniszterek, államtitkárok és kormánybiztosok, parlamenti képviselők)

Kérjük, jelöljön meg egy megfelelő választ minden felsorolt elem számára: 


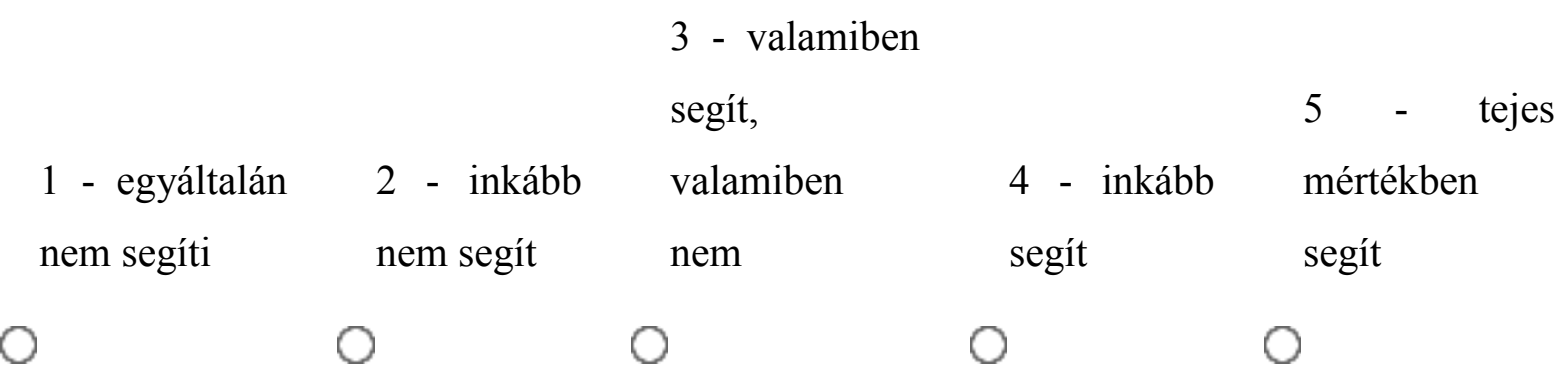

III.4. Folyamatos koordináció és kooperáció a térségi önkormányzati apparátusok (hivatalok, jegyzők, vezető munkatársak, ügyintézők) között

Kérjük, jelöljön meg egy megfelelő választ minden felsorolt elem számára:

\begin{tabular}{lllll} 
& \multicolumn{3}{c}{$\begin{array}{l}\text { - valamiben } \\
\text { segít, }\end{array}$} & 5 - tejes \\
1 - egyáltalán & 2 - inkább & valamiben & $4-$ inkább & mértékben \\
nem segíti & nem segít & nem & segít & segít \\
& 0 & 0 & 0 & 0
\end{tabular}

III.5. Együttmüködés a térségi önkormányzatok valamint a fővárosban/megyei jogú városban/járásszékhely városban található állami területi dekoncentrált intézmények (kormányhivatalok és egyéb szakigazgatási szervek) vezetői, hivatali dolgozói között

Kérjük, jelöljön meg egy megfelelő választ minden felsorolt elem számára:

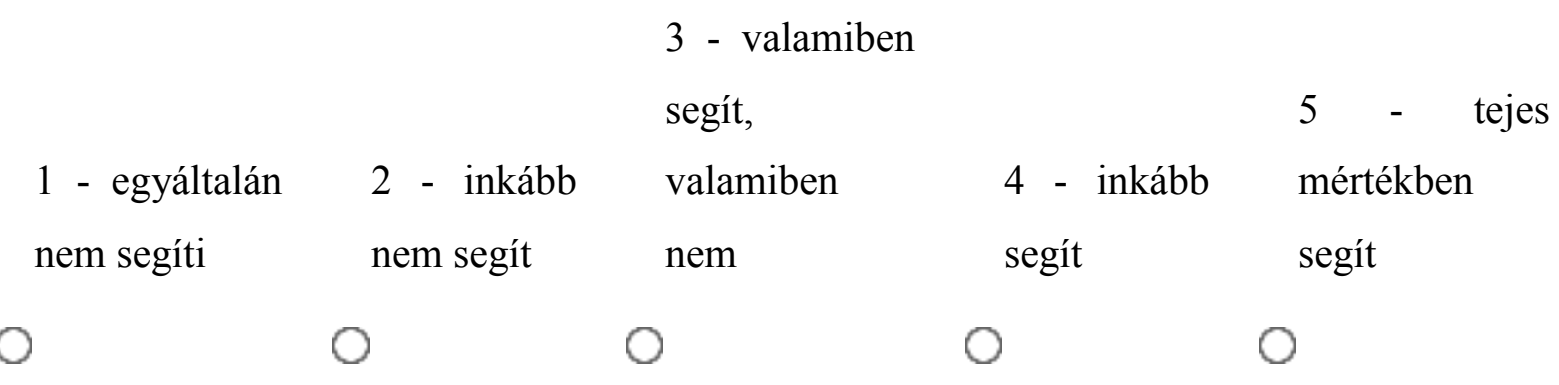

III.6.A nagyváros és városkörnyéki települések civil szervezetei közötti kapcsolatok, együttmüködések

Kérjük, jelöljön meg egy megfelelő választ minden felsorolt elem számára: 


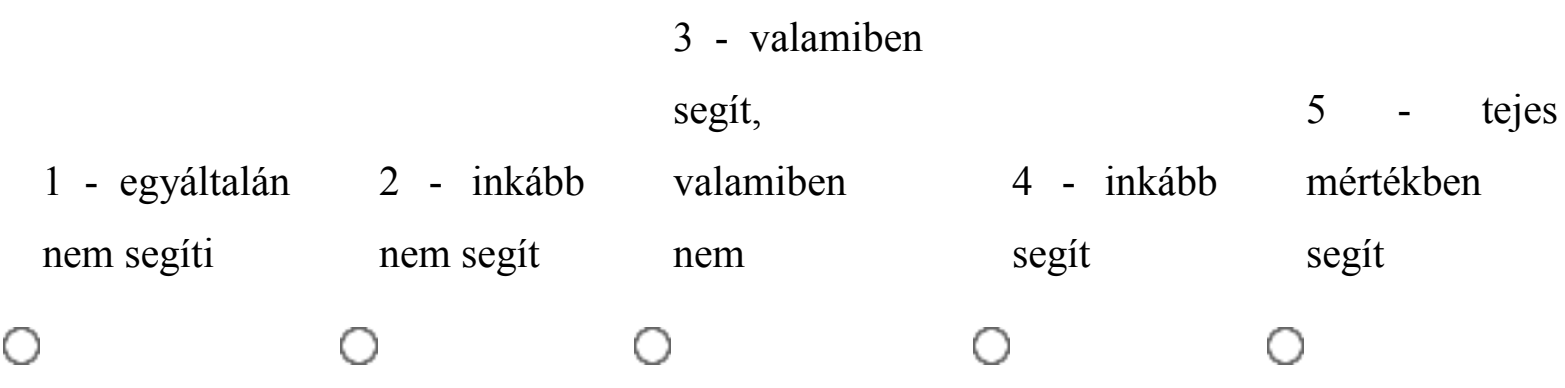

III.7. Európai uniós és egyéb nemzetközi kapcsolatok (testvérvárosi kooperációk; euroregionális együttműködések; közvetlen brüsszeli, Európai Uniós kapcsolatok)

Kérjük, jelöljön meg egy megfelelő választ minden felsorolt elem számára:

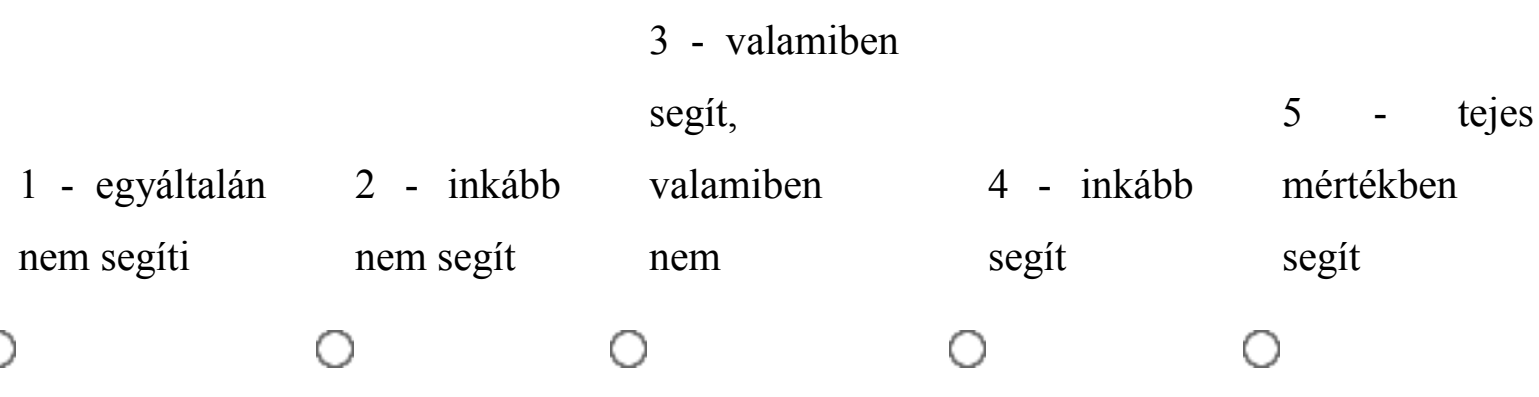

III.8. Közös, a nagyváros és városkörnyéki települések együttműködésén alapuló önkormányzati feladatellátás és közszolgáltatások

Kérjük, jelöljön meg egy megfelelő választ minden felsorolt elem számára:

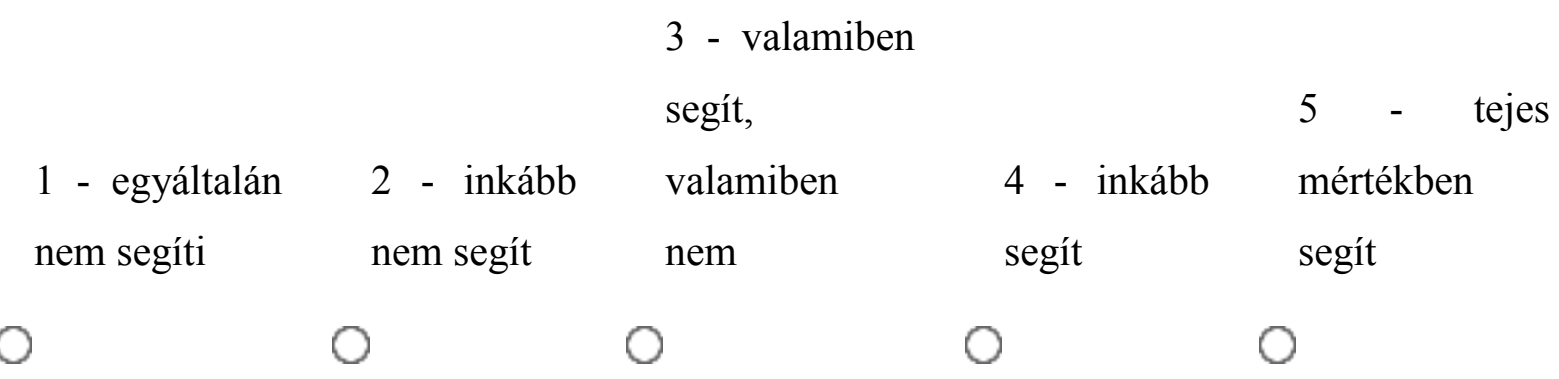

III.9. Fejlesztési együttmüködések (tervek, projektmenedzsment, konzorciális kooperációk) a nagyváros és városkörnyéki települések között

Kérjük, jelöljön meg egy megfelelő választ minden felsorolt elem számára:

\begin{tabular}{|c|c|c|c|c|}
\hline & & 3 - valam & & \\
\hline & & segít, & & $5-$ \\
\hline $\begin{array}{l}1 \text { - egyáltalán } \\
\text { nem segíti }\end{array}$ & $\begin{array}{l}2 \text { - inkább } \\
\text { nem segít }\end{array}$ & $\begin{array}{l}\text { valamiben } \\
\text { nem }\end{array}$ & $\begin{array}{l}4 \text { - inkább } \\
\text { segít }\end{array}$ & $\begin{array}{l}\text { mértékben } \\
\text { segít }\end{array}$ \\
\hline
\end{tabular}




\begin{tabular}{lllll} 
& \multicolumn{3}{c}{$\begin{array}{l}\text { - valamiben } \\
\text { segít, }\end{array}$} & 5 - tejes \\
1 - egyáltalán & $2-$ inkább & valamiben & $4-$ inkább & mértékben \\
nem segíti & nem segít & nem & segít & segít \\
& 0 & 0 & 0 & 0
\end{tabular}

III.10. Agglomerációs, városkörnyéki típusú ügyekben a nagyváros és városkörnyéki települések lakosságának folyamatos tájékoztatása

Kérjük, jelöljön meg egy megfelelő választ minden felsorolt elem számára:

\begin{tabular}{lllll} 
& \multicolumn{3}{c}{$\begin{array}{l}\text { - valamiben } \\
\text { segít, }\end{array}$} & 5 tejes \\
1 - egyáltalán & $2-$ inkább & valamiben & $4-$ inkább & mértékben \\
nem segíti & nem segít & nem & segít & segít \\
0 & 0 & 0 & 0 & 0
\end{tabular}

IV.

IV. Kérjük, a következő táblázatban tüntesse fel a települési közszolgáltatások és fejlesztési kooperációk területén más települési önkormányzatokkal közösen kialakított önkormányzati együttmüködéseket! (Több válasz is elfogadható)

Kérjük, jelöljön meg egy megfelelő választ minden felsorolt elem számára:

\begin{tabular}{|c|c|c|c|c|c|}
\hline & & & & fővárosi \\
\hline & & járásszék & megyei & fővárosi & kerületi \\
\hline & & hely & jogú & önkormán & önkormányz \\
\hline község & város & város & város & yzat & at \\
\hline
\end{tabular}

IV.1. Közös

önkormányz

ati hivatal

müködtetése

nincs válasz 
Kérjük, jelöljön meg egy megfelelő választ minden felsorolt elem számára:

$\begin{array}{cllll} & & & & \\ & \text { járásszék } & \text { megyei } & \text { fóvárosi } & \\ & \text { hely } & \text { jogú } & \text { önkormán } & \text { önkormány } \\ \text { község város } & \text { város } & \text { város } & \text { yzat } & \text { zat }\end{array}$

IV.2. humán

közszolgáltat

ás (oktatás,

egészségügy,

szociális,

kulturális

igazgatás)

nincs válasz

Kérjük, jelöljön meg egy megfelelő választ minden felsorolt elem számára:

\begin{tabular}{|c|c|c|c|c|c|}
\hline & & & & & fôvárosi \\
\hline & & járássz & megyei & fővárosi & kerületi \\
\hline & & ékhely & jogú & önkormány & önkormány \\
\hline község & város & város & város & zat & zat \\
\hline
\end{tabular}

\section{VI.3. Gazdasági}

közszolgáltatás

(tömegközleked

és,

energiaszolgált

atás,

hulladékszállítá

s, posta, víz és

szennyvíz-

szolgáltatás)

nincs válasz

Kérjük, jelöljön meg egy megfelelő választ minden felsorolt elem számára: 


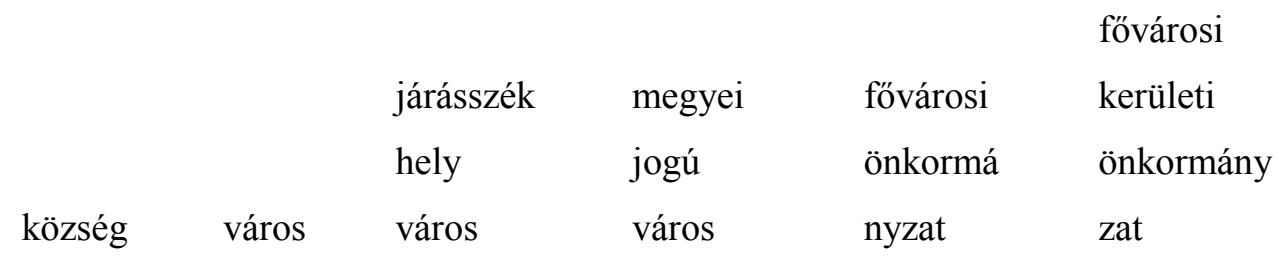

IV.4. Egyéb

hatósági

igazgatási

együttmükö

dés

nincs válasz

Kérjük, jelöljön meg egy megfelelő választ minden felsorolt elem számára:

\begin{tabular}{|c|c|c|c|c|c|}
\hline & & & & & fővárosi \\
\hline & & járásszék & megyei & fővárosi & kerületi \\
\hline & & hely & jogú & önkormán & önkormány \\
\hline község & város & város & város & yzat & zat \\
\hline
\end{tabular}

IV.5.

Fejlesztési

együttmúköd

és

(pályázatok,

beruházások)

nincs válasz

V. 


\section{Kérjük, alkosson sorrendet a nagyváros és városkörnyéki települések közötti kapcsolatok erősítéséhez ajánlott alábbi közpolitikai eszközökről?}

\section{Kérjük, válaszait 1-6 -ig terjedö fontossági sorrendben jelezze!}

Kérjük, írja ide a válaszait:

A. Agglomerációs / Városkörnyéki Önkormányzati Tanács: a nagyváros és városkörnyéki települési önkormányzatok közös részvételével létrehozott, önálló döntési feladat- és hatáskörökkel bíró önkormányzati jellegü szerveződés.

B. Nevesített agglomerációs, városkörnyéki pénzügyi alap: kifejezetten agglomerációs, városkörnyéki célokhoz rendelve - (forrása lehet az állami költségvetés elkülönített fejezete; átengedett központi adó; területi decentralizált forrás; közvetlen agglomerációs / városkörnyéki helyi adó).

C. Az Önkormányzatok Nemzeti Együttmüködési Tanácsának (ÖNET), mint a központi kormányzat és a helyi önkormányzatok közpolitikai konzultációs intézményének regionális, nagytérségi szintű kiterjesztése, ahol konkrét nagyvárosi-agglomerációs és városkörnyéki ügyek terítékre kerülnek.

D. Speciális közigazgatási, gazdasági és társadalmi agglomerációs, városkörnyéki tudásanyag, mint önálló modul (jegyzetek, tankönyvek, multimédiás kiadványok, önálló képzési tematika) a müködő köztisztviselői és kormánytisztviselői képzés, továbbképzés rendszerében.

E. A nagyváros és városkörnyéki települések gazdasági szereplöi közötti kapcsolatok intézményesített erősítése: a gazdasági klaszterek és klaszterszerü kezdeményezések támogatása; a minőségbiztosítás hatékonyabb hatósági érvényesítése a beszállítói és egyéb gazdasági jellegü kapcsolatok terén

F. Speciális, valamilyen közszolgáltatás vagy egyéb profitcélú gazdasági tevékenység biztosítására irányuló a nagyváros és városkörnyéki önkormányzatokat tömörítő önálló jogi személyiséggel felruházott konzorciális együttmüködés 
VI. Milyen további fontos beavatkozást, megoldást igénylő problémákat érzékel a nagyváros és városkörnyéki települések közötti kapcsolatok alakulása és fejlesztése szempontjából? Kitöltése nem kötelező!

Kérjük, írja ide a válaszát:

Köszönjük, hogy kitöltötte a kérdöívet. 


\section{2. számú melléklet:}

Empirikus kutatás - kérdốív II.1-10 és III.1-10.

A „szükséges” és „tapasztal” dimenziók térségi-regionális eredményei

Dél-Dunántúl

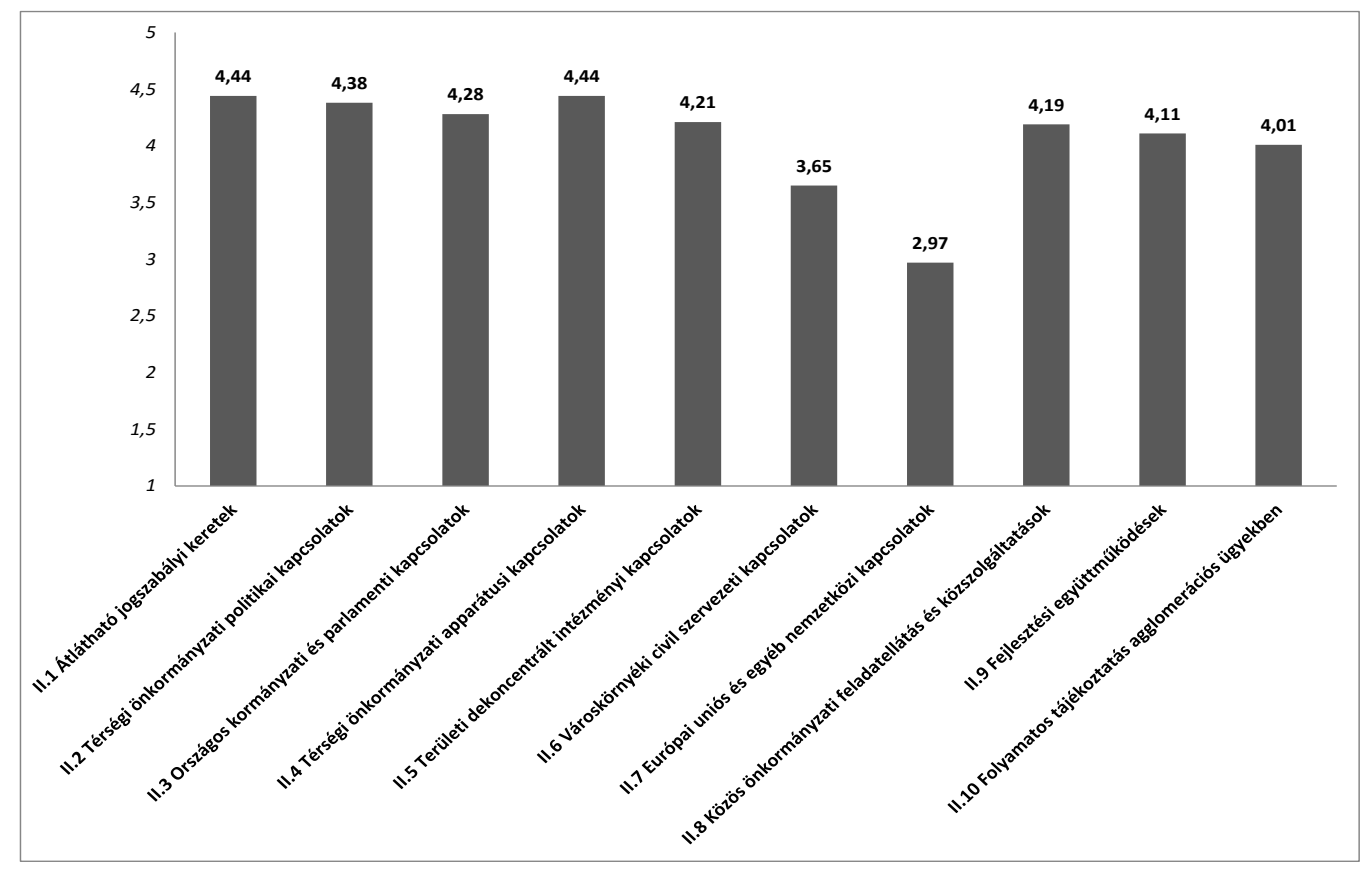

30. ábra: „szükséges” dimenzió a dél-dunántúli városkörnyéki településeknél (elemszám: 28 polgármesteri kérdöiv)

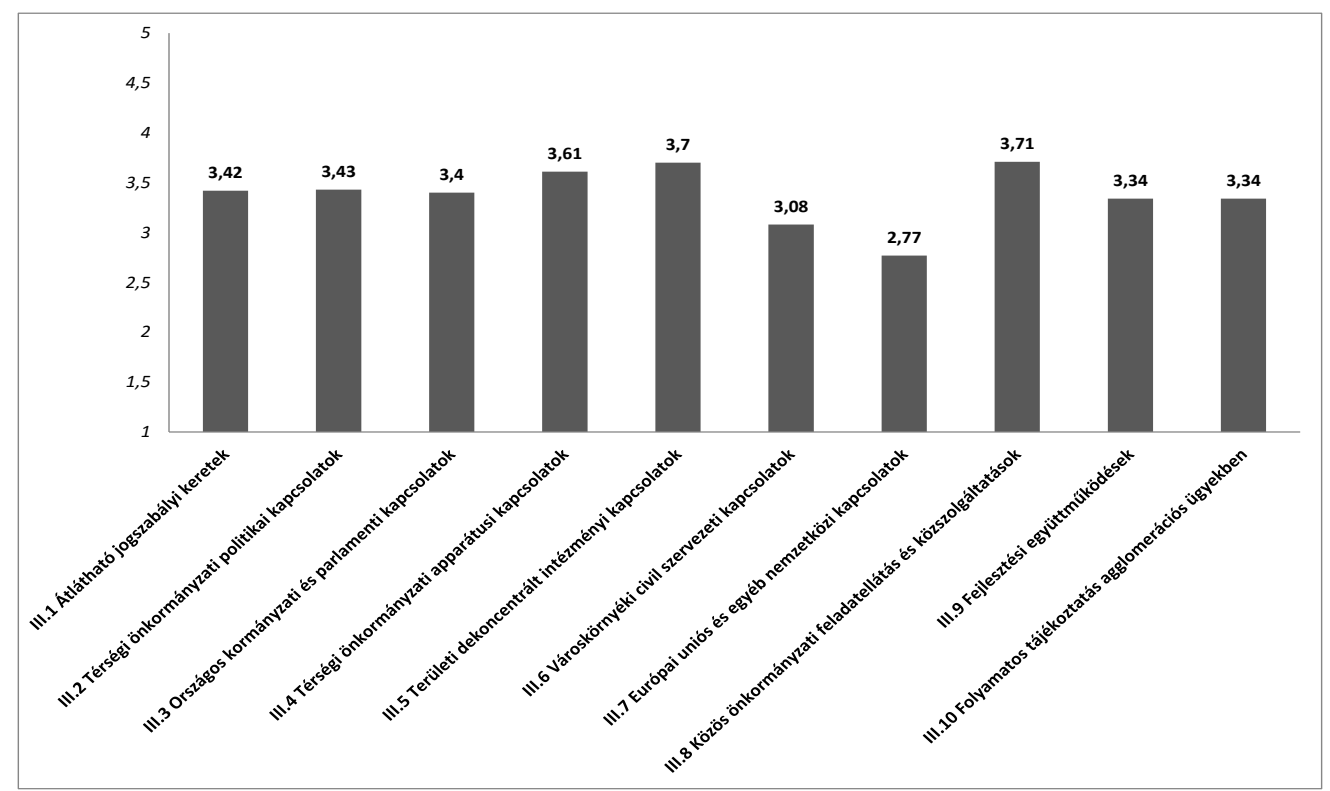

31. ábra: „tapasztal” dimenzió a dél-dunántúli városkörnyéki településeknél (elemszám: 28 polgármesteri kérdőiv) 
Dél-Alföld

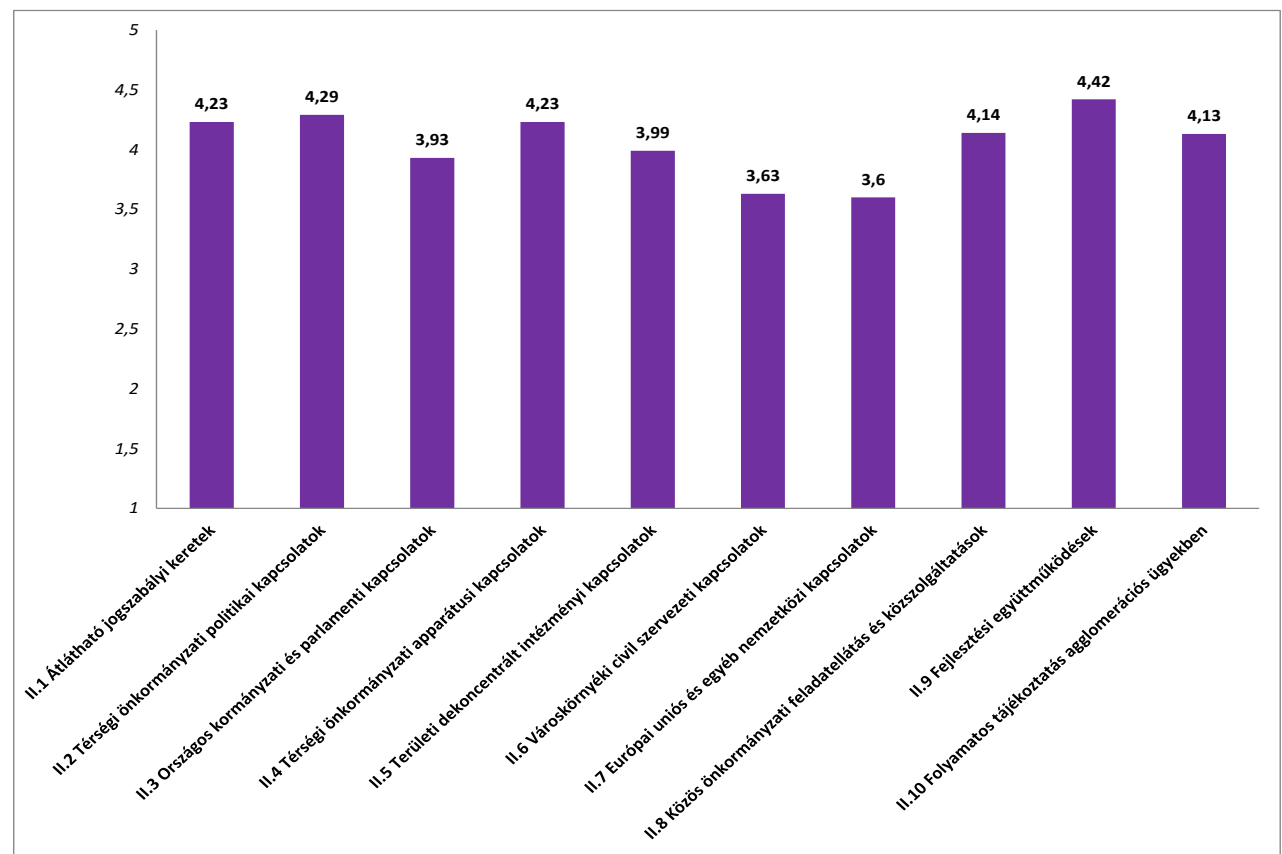

32. ábra: „,szükséges” dimenzió a dél-alföldi városkörnyéki településeknél (elemszám: 28 polgármesteri kérdöiv)

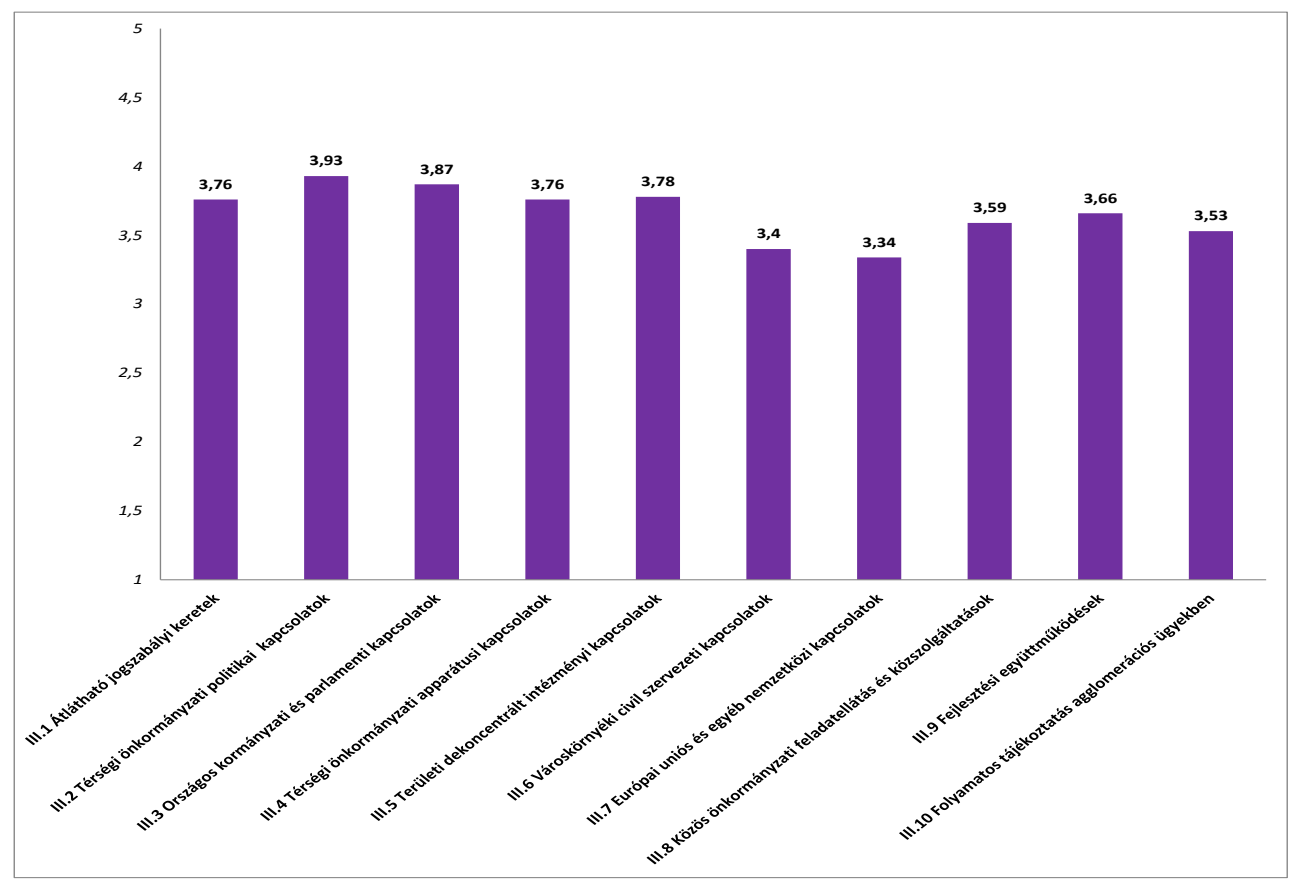

33. ábra: „,tapasztal” dimenzió a dél-alföldi városkörnyéki településeknél (elemszám: 28 polgármesteri kérdöiv) 
Észak-Alföld

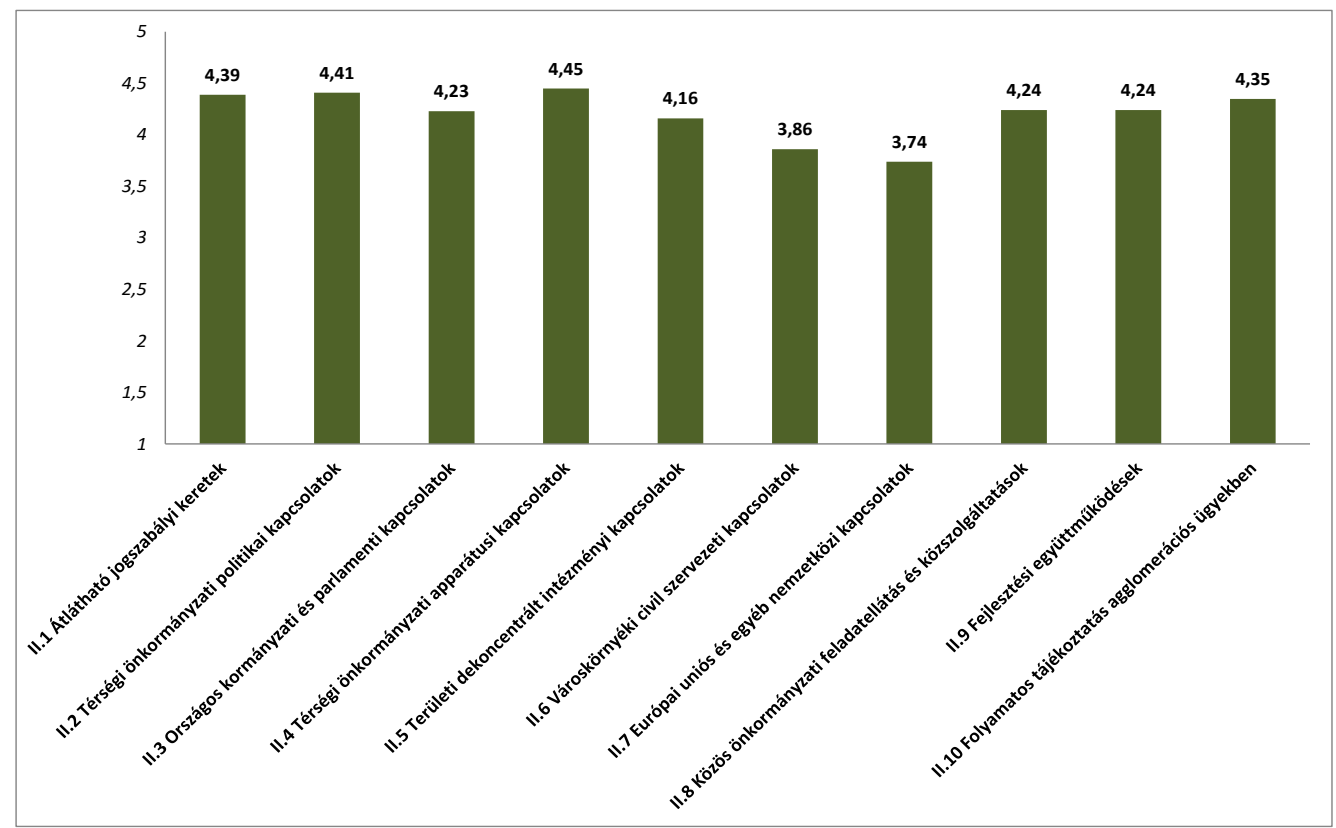

34. ábra: „szükségességi” dimenzió az észak-alföldi városkörnyéki településeknél (elemszám: 27 polgármesteri kérdöiv)

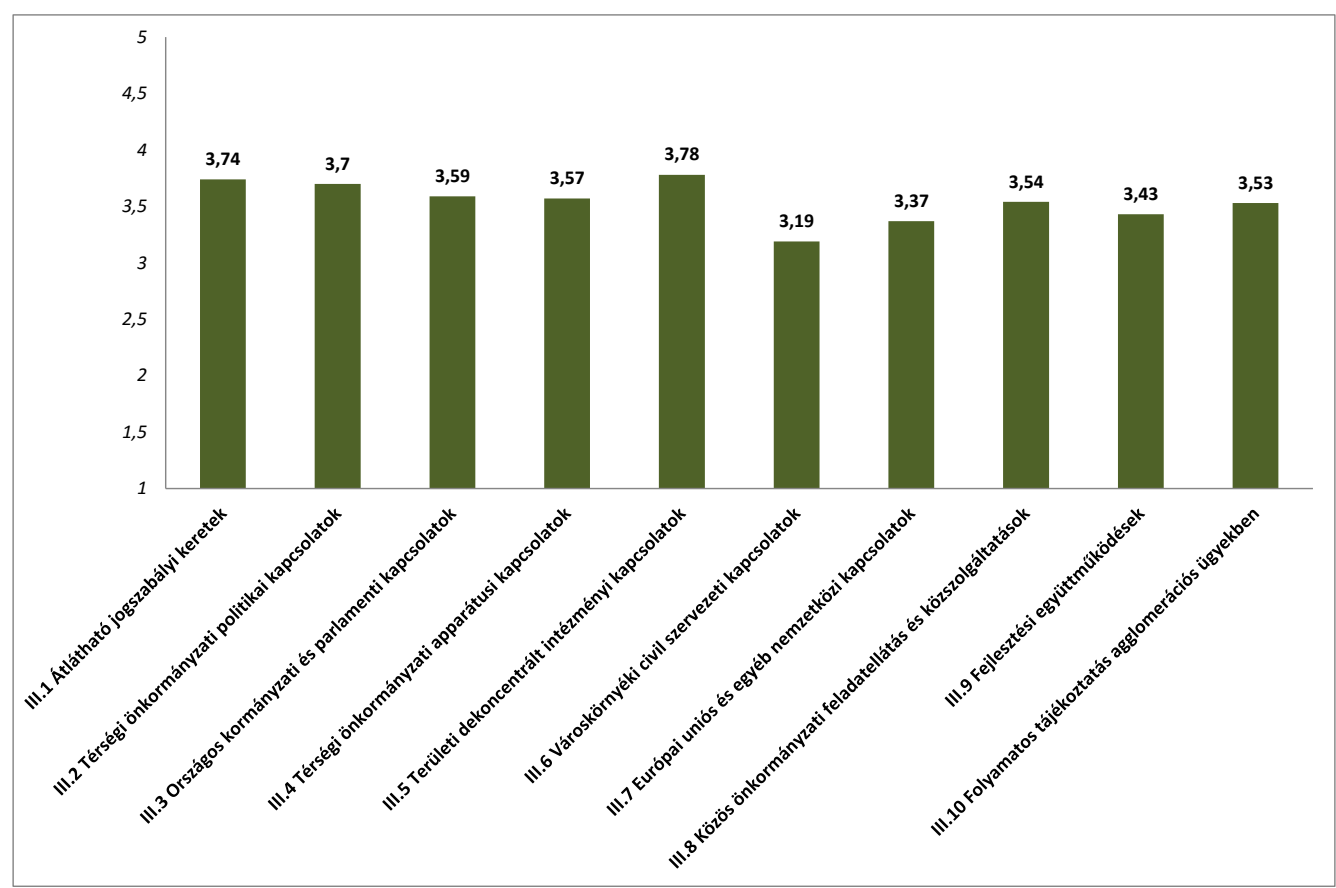

35. ábra: „tapasztal” dimenzió az észak-alföldi városkörnyéki településeknél (elemszám: 27 polgármesteri kérdöiv) 


\section{Észak-Magyarország}

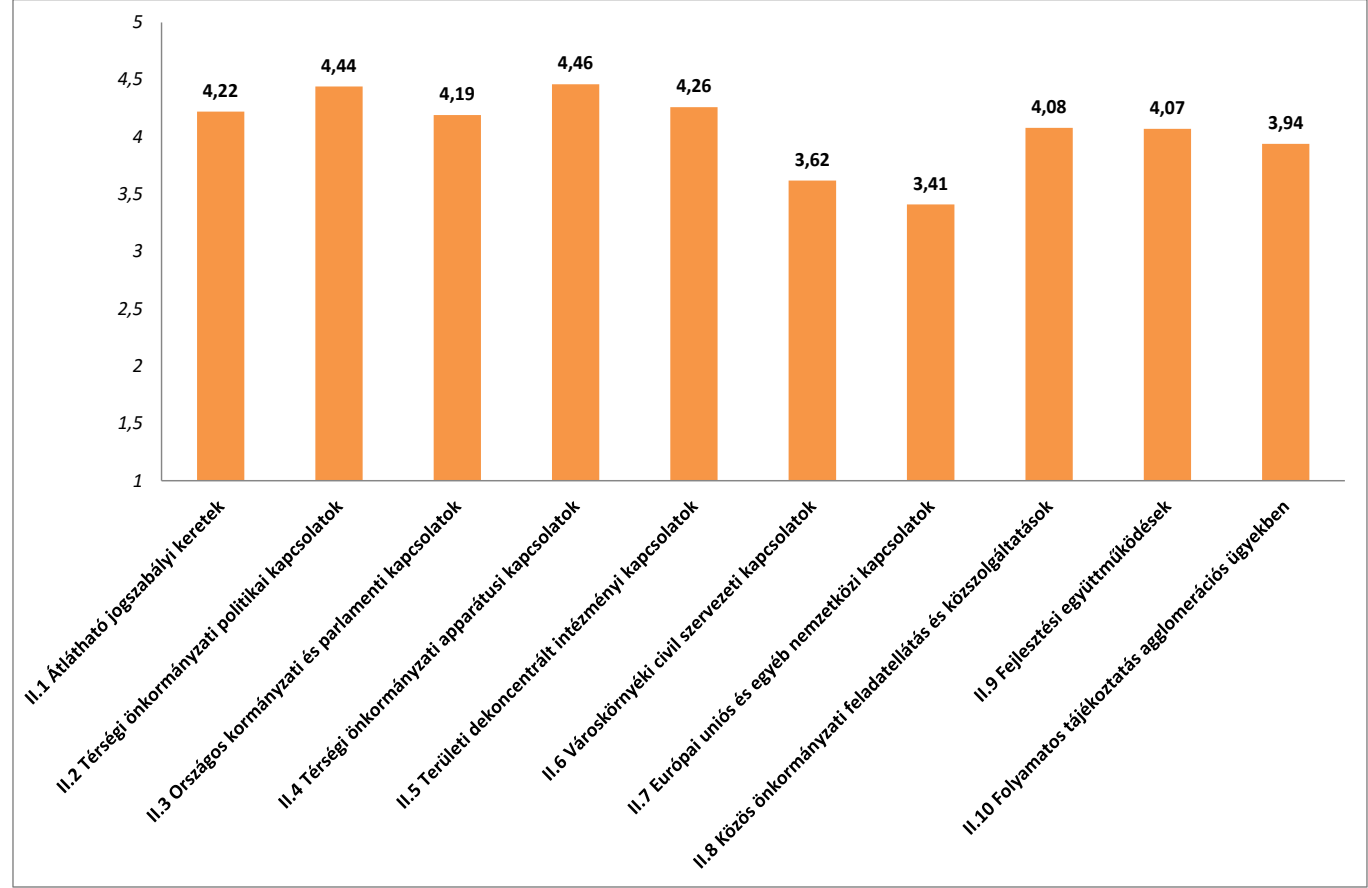

36. ábra: „szükségességi” dimenzió az észak-magyarországi városkörnyéki településeknél (elemszám: 45 polgármesteri kérdöív)

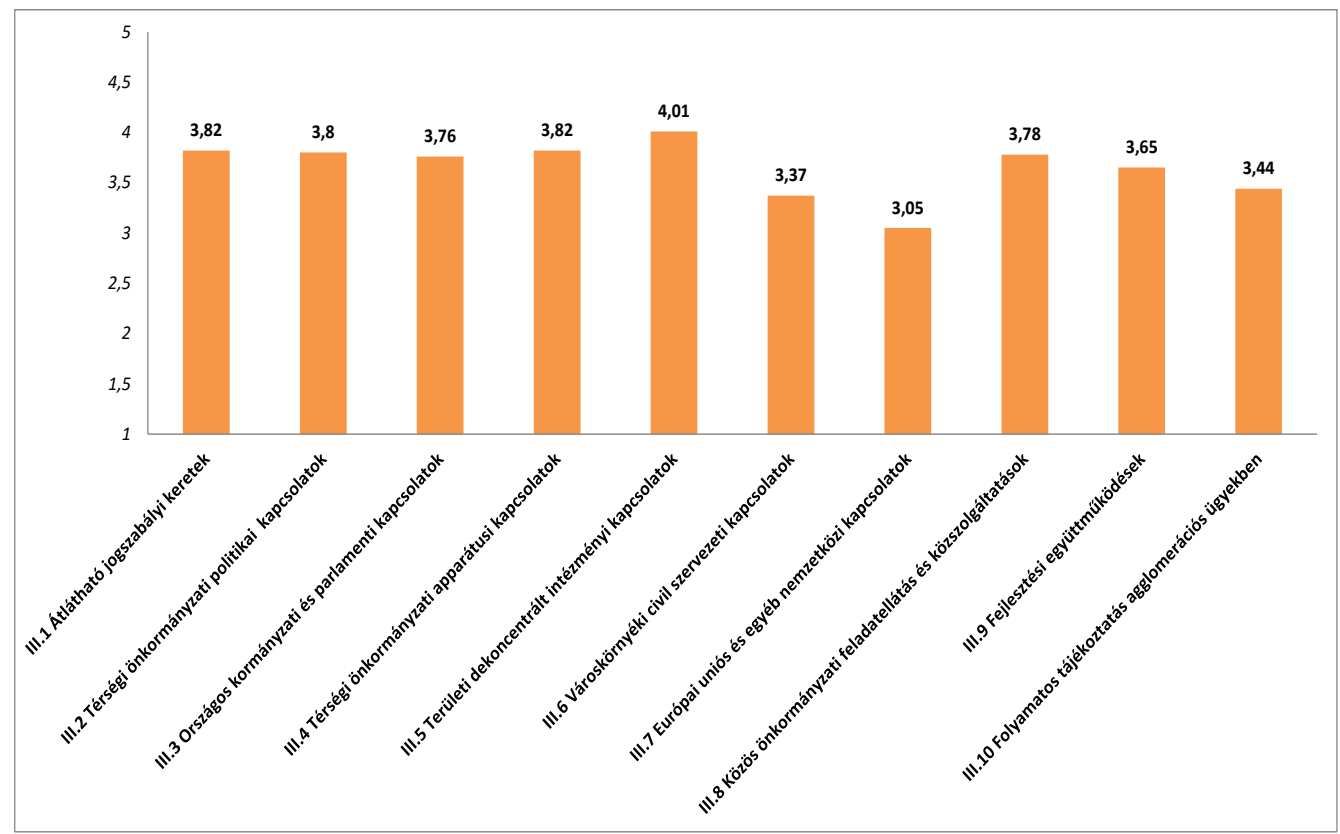

37. ábra: „,tapasztal” dimenzió az észak-magyarországi városkörnyéki településeknél (elemszám: 45 polgármesteri kérdőiv) 


\section{Közép-Dunántúl}

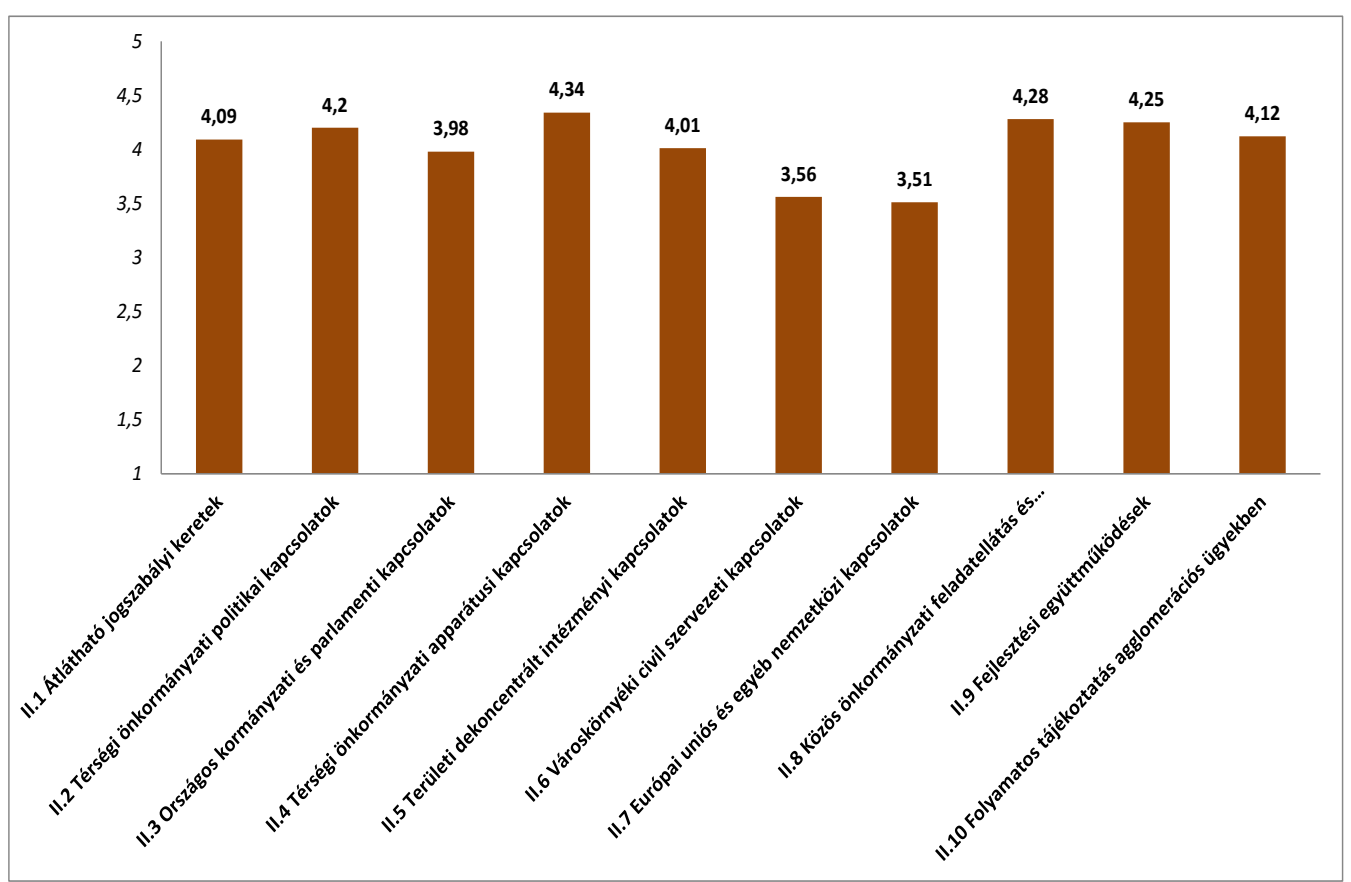

38. ábra: „,szükségességi” dimenzió a közép-dunántúli városkörnyéki településeknél (elemszám: 43 polgármesteri kérdöív)

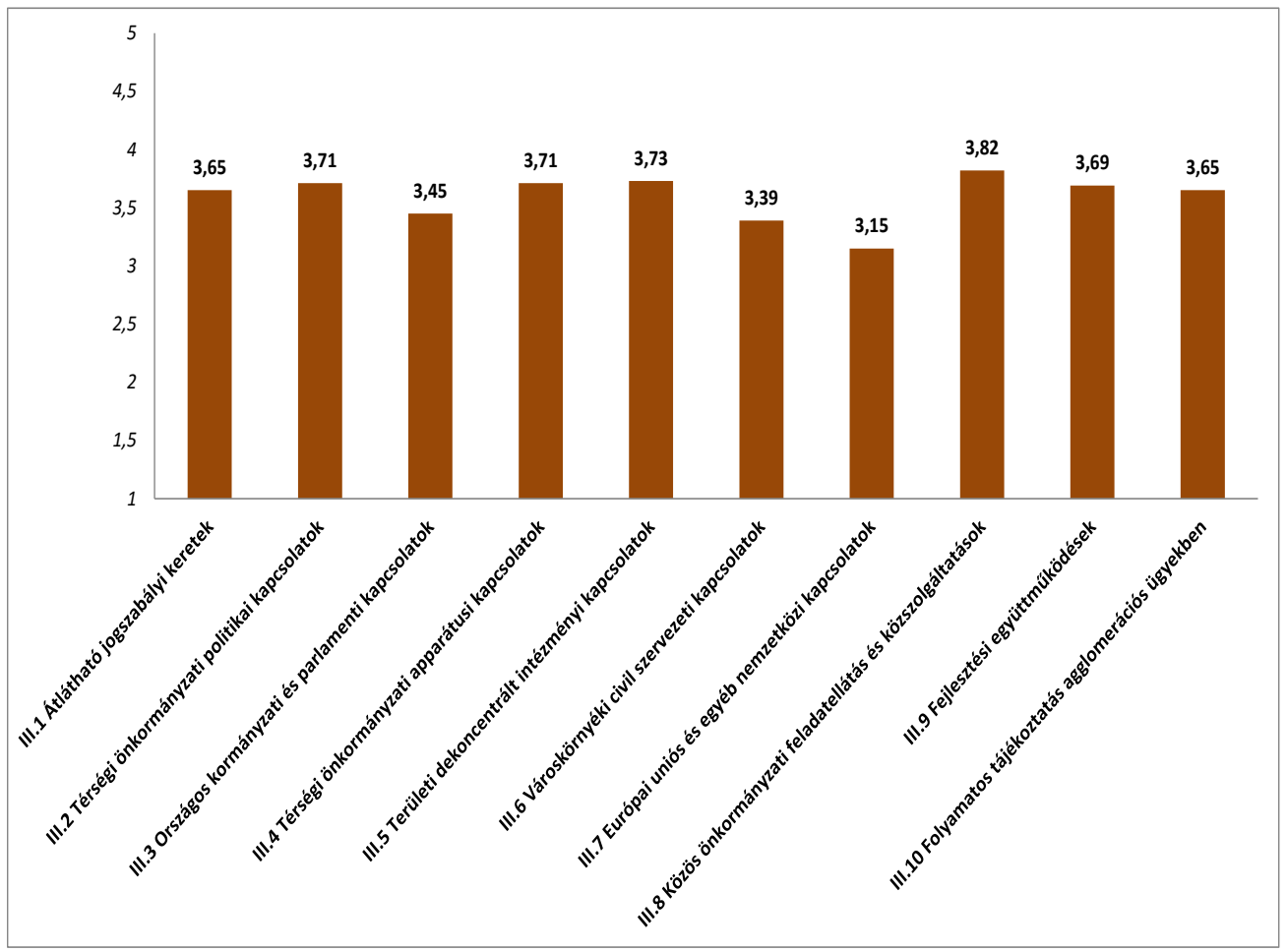

39. ábra: „,tapasztal” dimenzió a közép-dunántúli városkörnyéki településeknél (elemszám: 43 polgármesteri kérdöiv) 
$\underline{\text { Közép-Magyarország }}$

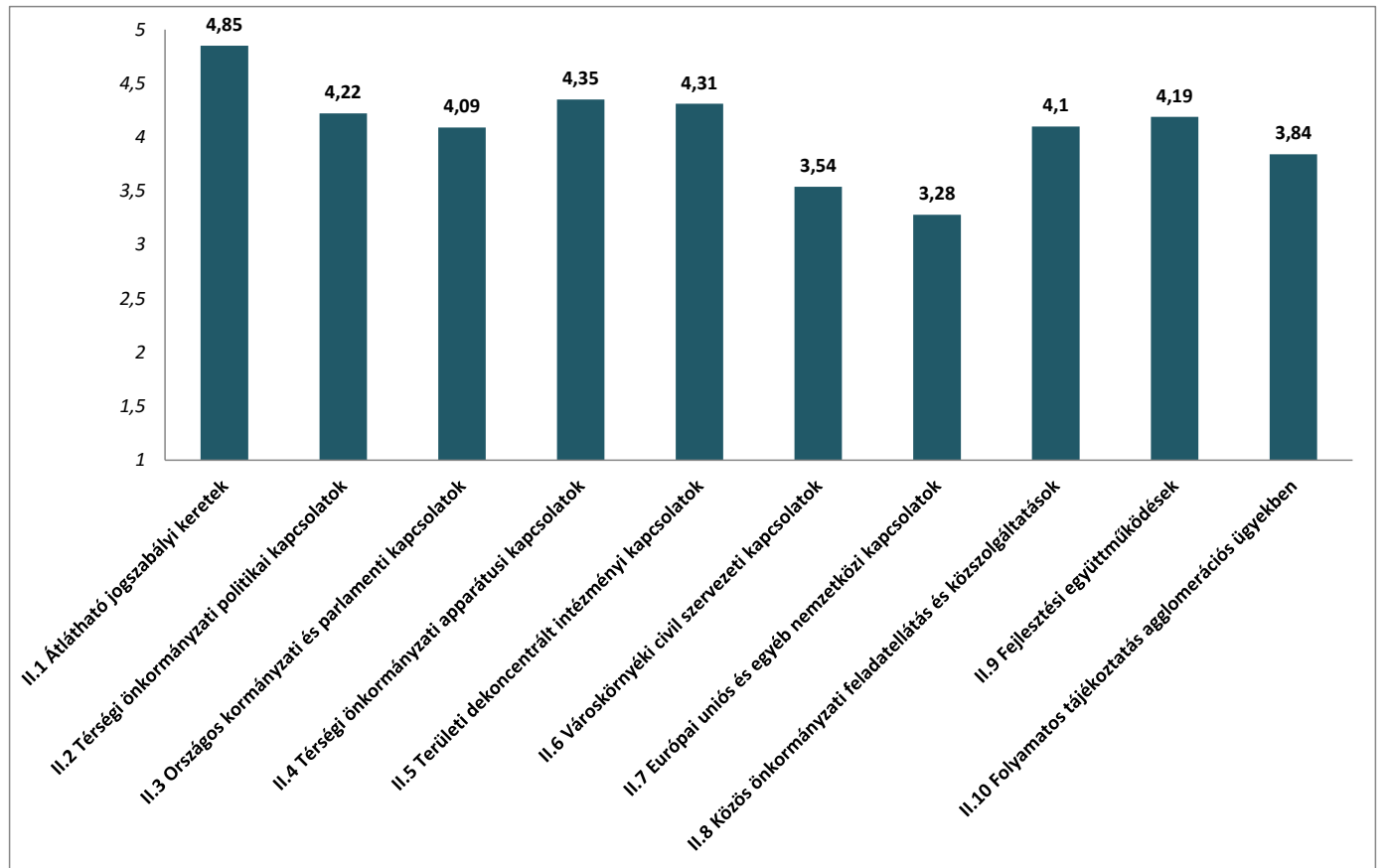

40. ábra: „,szükségességi” dimenzió a közép-magyarországi városkörnyéki településeknél (elemszám: 18 polgármesteri kérdöív)

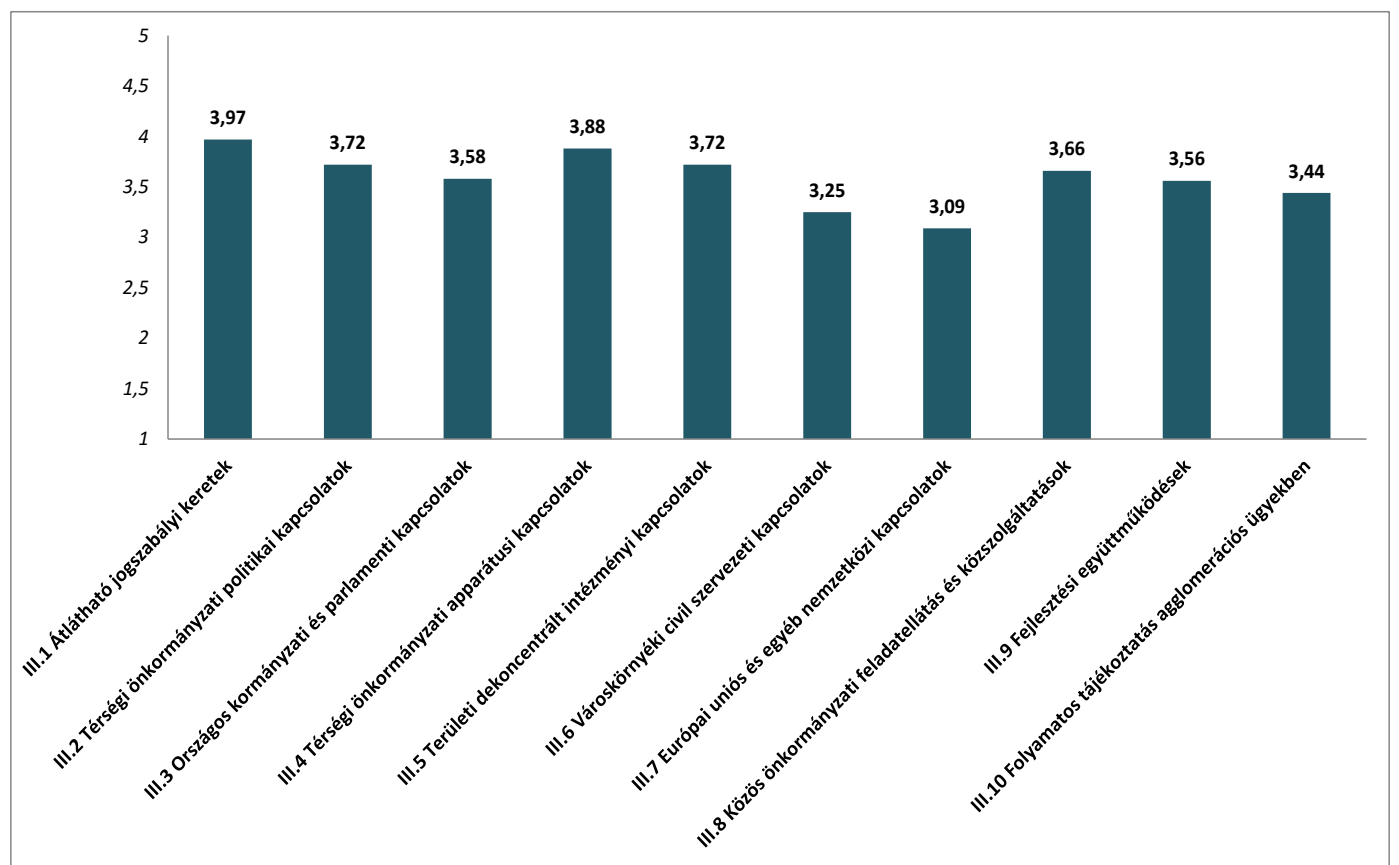

41. ábra: „tapasztal” dimenzió a közép-magyarországi városkörnyéki településeknél (elemszám: 18 polgármesteri kérdöív) 


\section{Nyugat-Dunántúl}

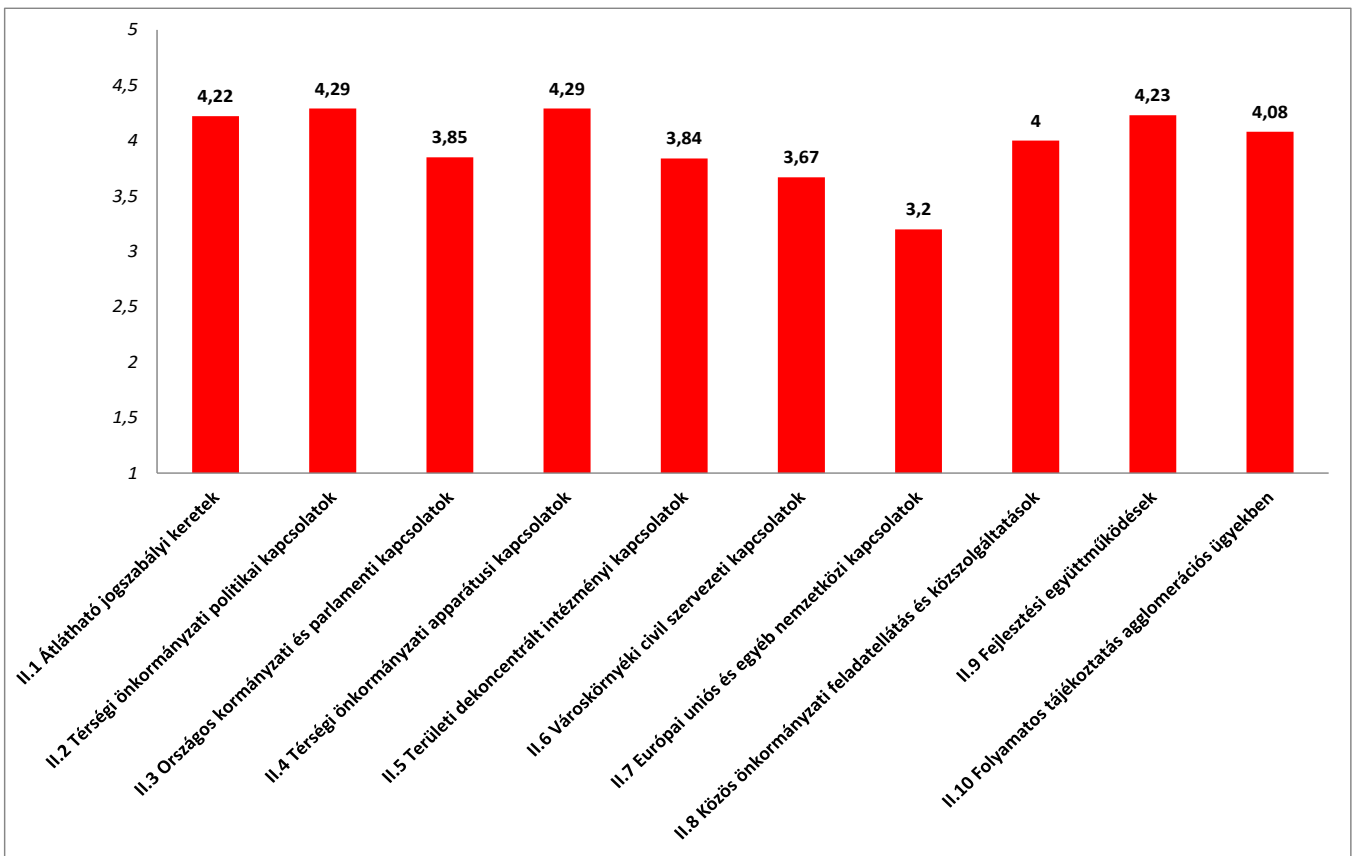

42. ábra: „szükségességi” dimenzió a nyugat-dunántúli városkörnyéki településeknél (elemszám: 51 polgármesteri kérdőív)

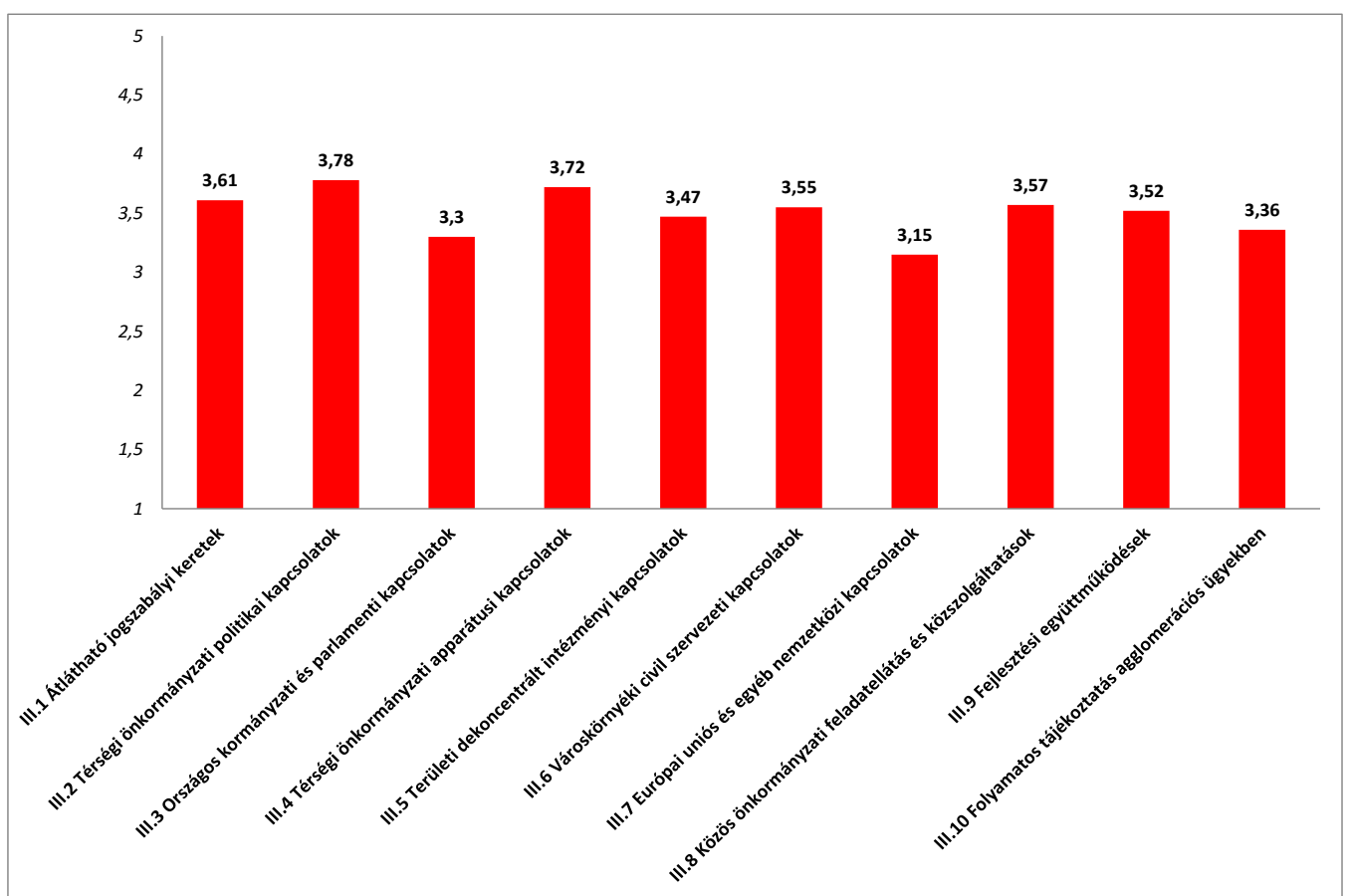

43. ábra: „tapasztal” dimenzió a nyugat-dunántúli városkörnyéki településeknél (elemszám: 51 polgármesteri kérdöiv) 


\section{Ábrák, táblázatok jegyzéke}

1. ábra: kettős konfliktuskonténer a nagyvárosi kormányzásban 14. pp.

2. ábra: az agglomerációs tanácsok elképzelt rendszere 21. pp.

3. ábra: az agglomerációs tanácsok elképzelt feladatköre 22. pp

4. ábra: az agglomerációs tanácsok szervezeti és müködése 22. pp.

5. ábra: a Világ lakosságának megoszlása városkategóriák szerint 2015-ben 25. pp

6. ábra: a metropolisz várostérségek kontinentális megoszlása 26. pp.

7. ábra: a közpolitikai koordináció egyes szintjei a nagyvárosi térségekben 49. pp.

8. ábra: ajánlott OECD közpolitikai alapelvek a várostérségi kormányzáshoz 51. pp.

9. az agglomerációs struktúrák Humes-Martin alapján 59. pp.

10. ábra: várostérségi eszközök Hamilton alapján 69. pp.

11. ábra: várostérségi eszközök Walker alapján 71. pp.

12. ábra: várostérségi eszközök Barlow alapján 73. pp.

13. ábra: a várostérségi kormányzás időbeli-történeti dimenziója 75. pp.

14. ábra: a kétszintủ várostérségi kormányzás közpolitikai modellje 90. pp.

15. ábra: globális és makroregionális tendenciák a várostérségi kormányzásban 91. pp.

16. ábra: városhierarchia a jogállás és a városkörnyéki spill-over függvényében 119. pp.

17. ábra: kutatási minta a települések lakosságszáma szerint 205. pp.

18. ábra: kutatási minta a települések jogállása szerint 206. pp.

19. ábra: a városkörnyéki kérdőívek megoszlása a települések lakosságszáma szerint 208.pp

20. ábra: országos „,szükségességi” dimenzió a városkörnyéki településeknél 209. pp.

21. ábra: országos „tapasztalati” „dimenzió a városkörnyéki településeknél 201.pp.

22. ábra: a városkörnyéki kérdőívek megoszlása NUTS2 régiók szerint 212. pp.

23. ábra: a városkörnyéki kérdőívek a települési jogállás szerint 215. pp.

24. ábra: „szükséges” dimenzió a községek, nagyközségek csoportban 216. pp. 
25. ábra: „tapasztalati” dimenzió a községek, nagyközségek csoportban 217. pp.

26. ábra: az ajánlott közpolitikai eszközök értékelésének komplex ábrázolása 219. pp.

27. ábra: a hazai településhálózat- és várospolitika elmúlt másfél évszázada 224. pp.

28. ábra: az inadekvát szabályozásról szóló hipotézis bizonyítása 235. pp.

29. ábra: az agglomerációs tanács szükségességéről szóló hipotézis bizonyítása 239. pp.

30. ábra: „szükséges” dimenzió a dél-dunántúli városkörnyéki településeknél 261. pp.

31. ábra: „szükséges” dimenzió a dél-dunántúli városkörnyéki településeknél 261. pp.

32. ábra: „szükséges” dimenzió a dél-alföldi városkörnyéki településeknél 262. pp.

33. ábra: „tapasztal” dimenzió a dél-alföldi városkörnyéki településeknél 262. pp.

34. ábra: „szükséges” dimenzió az észak-alföldi városkörnyéki településeknél 263. pp.

35. ábra: „tapasztal” dimenzió az észak-alföldi városkörnyéki településeknél 263. pp.

36. ábra: „szükséges” dimenzió az észak-magyarországi városkörnyéki településeknél 264. pp.

37. ábra: „tapasztal” dimenzió az észak-magyarországi városkörnyéki településeknél 264. pp.

38. ábra: „szükséges” dimenzió a közép-dunántúli városkörnyéki településeknél 265. pp.

39. ábra: „tapasztal” dimenzió a közép-dunántúli városkörnyéki településeknél 265. pp.

40. ábra: „,szükséges” dimenzió a közép-magyarországi városkörnyéki településeknél 266. pp.

41. ábra: „tapasztal” dimenzió a közép-magyarországi városkörnyéki településeknél 266. pp.

42. ábra: „szükséges” dimenzió a nyugat-dunántúli városkörnyéki településeknél 267. pp.

43. ábra: „tapasztal” dimenzió a nyugat-dunántúli városkörnyéki településeknél 267.pp.

1. táblázat: a londoni és párizsi adminisztratív, MUA és FUA lakossági adatok (2007) 31. pp.

2. táblázat: a várossá nyilvánítások száma 1990 után 125. pp.

3. táblázat: 2005. évben az 1 lakosra jutó átlagos önkormányzati bevétel 165. pp.

4. táblázat: a kutatási mintában az egyes NUTS2 régióknál alkalmazott statisztikai súlyok 205. pp. 


\section{Rövidítések jegyzéke}

ÁÉSZ - általános érdekű szolgáltatás

ÁGÉSZ - általános gazdasági érdekű szolgáltatás

BAFT - Budapesti Agglomerációs Fejlesztési Tanács

CGOs - Council of Governments

EU - Európai Unió (European Union)

FKT - Fővárosi Közmunkák Tanácsa

FUA - Functional Urban Area

mft - megyei területfejlesztési tanács

Mötv.- Magyarország helyi önkormányzatairól szóló 2011. évi CLXXXIX. törvény

MPOs - Metropolitan Planning Organizations

MUA - Morphological Urban Area

NET - Népköztársaság Elnöki Tanácsa

OECD - The Organization for Economic Co-operation and Development

OTK - Országos Településhálózat Fejlesztési Koncepció

Ötv. - A helyi önkormányzatokról szóló 1990. évi LXV. törvény

$\mathrm{rft}$ - regionális fejlesztési tanács

Tetv. - A területszervezési eljárásokról szóló 1999. évi XLI. törvény

Tftv. - A területfejlesztésről és területrendezésről szóló 1996. évi XXI. törvény

Tkt. - A többcélú kistérségi társulásokról szóló 2004. évi CVII. törvény 


\section{Felhasznált szakirodalom}

Ádám Antal [1994]: Észrevételek az önkormányzati reform néhány kérdésköréhez (in: Magyar Közigazgatás 1994/1. pp. 1-11.)

Agg Zoltán [1994]: Szabad demokrata vélemény a megyékről és az önkormányzatokról Beszélgetés dr. Wekler Ferenc országgyülési képviselövel (in: A lebegő megye - cikkek és tanulmányok, COMITATUS Könyv- és Lapkiadó, Veszprém, pp. 381-388.)

Agg Zoltán-Navracsics Tibor-Oláh Miklós [1994]: Hatalom, önkormányzat, autonómia Beszélgetés dr. Bihari Mihály politológussal (in: A lebegő megye - cikkek és tanulmányok, COMITATUS Könyv- és Lapkiadó, Veszprém, pp. 389-398.)

Agg Zoltán - Oláh Miklós [1993]: Polgármesterek véleménye az önkormányzati törvényröl (in: Magyar Közigazgatás 1993/5. szám pp. 307-315.)

Agg Zoltán [1990]: Hány járás - hány tartomány - hány megye? (in: Magyar Közigazgatás 1990/11. szám pp. 953-963.)

Ágh Attila [2008]: Az IDEA program a közigazgatási reform szolgálatában (in: IDEA és valóság - Az IDEA közigazgatás-korszerüsítési program négy éve, Közigazgatásfejlesztési Társaság, Budapest, 2008, pp. 9-32.)

Ágh Attila, [2006]: Magyarország az Európai Unióban - az aktív Európa-politika kezdetei (Századvég Kiadó, Budapest)

Ágh Attila - Somogyvári István szerk., [2006]: A közigazgatási reform új perspektívái (Stratégiai kutatások - Magyarország 2015 Új Mandátum Kiadó, Budapest)

Ágh Attila [2005]: Budapest, mint európai regionális föváros. (in: Budapest a Középmagyarországi régióban: A közös versenyképesség perspektívái. IDEA Budapest Kiadvány pp. 5-15)

Ágh Attila - Németh Jenő szerk. [2003]: Kistérségi közigazgatás - szakértői tanulmányok (Magyar Közigazgatási Intézet, Budapest)

Agnew, John, (2002): Making Political Geography (Arnold Press, Oxford, 2002) 
A helyi önkormányzati rendszer helyzetértékelése és továbbfejlesztésének irányai [Önkormányzati Minisztérium, 2008] (Önkormányzati Minisztérium, 2008. május)

Ahrend, R. - Schumann, A., [OECD, 2014b]: Approaches to Metropolitan Area Governance (OECD, Paris)

http://www.oecd-ilibrary.org/urban-rural-and-regional-development/approaches-to-

metropolitan-area-governance_5jz5j1q7s128-en\%3Fcrawler\%3Dtrue (Letöltés: 2014. december 10.)

Állami Számvevőszék [ÁSZ, 2014]: Jelentés a települési önkormányzatok társulásának és feladatellátásának ellenőrzéséről (Állami Számvevőszék 14194, 2014. október)

http://www.asz.hu/jelentes/14194/jelentes-a-telepulesi-onkormanyzatok-tarsulasanak-esfeladatellatasanak-ellenorzeserol/14194j000.pdf

Állami Számvevőszék [ÁSZ, 2009]: Pénzügyi kockázatok az önkormányzati rendszerben (ÁSZ, Budapest, 2009. január) Vigvári András tanulmány http://www.asz.hu/tanulmanyok/2009/penzugyi-kockazatok-az-onkormanyzatirendszerben/t272.pdf (Letöltés: 2013. május 30.)

Állami Számvevőszék [ÁSZ, 2008]: Jelentés a települési önkormányzatok többcélú kistérségi társulásainak a közszolgáltatások és területfejlesztési feladatok ellátásában betöltött szerepének ellenőrzéséről (Állami Számvevőszék 0817, 2008. július) http://www.asz.hu/jelentes/0817/jelentes-a-telepulesi-onkormanyzatok-tobbcelu-kistersegitarsulasainak-a-kozszolgaltatasok-es-teruletfejlesztesi-feladatok-ellatasaban-betoltottszerepenek-ellenorzeserol/0817j000.pdf (Letöltés: 2014. február 20.)

Balázs István [1996]: A város és körzete együttmüködésének szervezeti lehetöségei (in: KÖOSZ-MJVSZ-MKI: Város és vonzáskörzete Szerk.: Szabó Gábor, ÖNKORKÉP, Budapest pp. 107-119 pp.)

Balducci, A.-Kunzmann, K.R.-Sartori F. [2004]: Towards Creative City Region Governance in Italy and Germany

http://www.tandfonline.com/doi/abs/10.1080/02513625.2004.10556886?journalCode=rdsp20 (Letöltés: 2012. október 2.)

Bálint Lajos - Gödri Irén [2015]: Belföldi vándorlás (in: Demográfiai portré 2015 - Jelentés a magyar népesség helyzetéről KSH Népességtudományi kutatóintézet, Budapest, pp. 171- 
186.) http://demografia.hu/kiadvanyokonline/index.php/demografiaiportre/issue/view/532 (Letöltés: 2015. augusztus 11.)

Barabás Zoltán - Tiba Zsolt [1995]: A föváros közigazgatásának továbbfejlesztése (in: Magyar Közigazgatás 1995/4. szám pp. 193-202.)

Barlow, I.M. [1991]: Metropolitan government (Routledge, London)

Barna Orsolya-Haszonicsné Ádám Mária-Kiss Ferenc-Tátrai Tünde [2009]: Közbeszerzési és tervpályázati fogalom- és iratmintatár (TL-Média Kft., Budapest)

Bartke István [Bartke, 1985]: A vonzáskörzetek gazdasági (társadalmi) tervezése (in: A vonzáskörzetek gazdasági és közigazgatási kérdései - Nemzetközi Tudományos Konferencia, Pécs, 1983. november 1-3., MTA Regionális Kutatások Központjának Dunántúli Tudományos Intézete, Pécs pp. 21-36.)

Bekényi József - Gyergyák Ferenc [2013]: Közös önkormányzati hivatalok megalakulása, a jelenleg még önálló polgármesteri hivatalok, körjegyzöségek átalakulásának folyamata közös hivatallá (in: Új Magyar Közigazgatás, 2013/1. pp. 38-41.)

Bekényi József [2005]: A helyi önkormányzatok többcélú kistérségi társulásáról (Magyar Közigazgatás 2005/11.pp. 660-664.)

Bekényi József - Bércesi Ferenc - Németh Jenő [2003]: A kistérség fogalma, funkciói, intézményrendszere (elözetes koncepció - Vitaanyag) (in: Magyar Közigazgatás 2003/4. pp. 194-209.)

Beluszky Pál - Győri Róbert [2004]: Fel is út, le is út... Városaink településhierarchiában elfoglalt pozícióinak változásai a 20. században (in: Tér és Társadalom, 2004/1. szám, pp. 141.) http://epa.niif.hu/02200/02251/00015/pdf/EPA02251_Ter_es_tarsadalom1855.pdf (Letöltés: 2015. március 8.)

Beluszky Pál - Síkos T. Tamás, [2007]: Változó falvaink (MTA Társadalomkutató Központ, Budapest)

Beluszky Pál [2002]: A magyarországi városhálózat átformálódása 1990 után (in: Regionális fejlődés Európában és Magyarországon Miniszterelnöki Hivatal Stratégiai Elemző Központ, Budapest, pp. 53-77) 
Beluszky Pál - Győri Róbert [1999]: A magyarországi városhálózat és az EU-csatlakozás (Tér és Társadalom 1999.) http://tet.rkk.hu/index.php/TeT/article/view/510/1017 (Letöltés: 2015. március 8.)

Beluszky Pál [1985]: A vonzáskörzet-kutatás néhány kérdése (in: A vonzáskörzetek gazdasági és közigazgatási kérdései - Nemzetközi Tudományos Konferencia, Pécs, 1983. november 1-3., MTA Regionális Kutatások Központjának Dunántúli Tudományos Intézete, Pécs,)

Bércesi Ferenc [2002]: A kistérség helye és szerepe a közigazgatás rendszerében (in. Magyar Közigazgatás 2002/9. szám pp. 522-540.)

Bércesi Ferenc - Csefkó Ferenc - Horváth Gyula - Iváncsics Imre - Pálné Kovács Ilona [1991]: Nagyvárosok sajátos problémái az önkormányzati modellben (in: Magyar Közigazgatás 1991/1. szám 50-63.pp.)

Bernek Ágnes, [2010]: Geopolitika és/vagy geoökönómia - A 21. század világgazdasági és világpolitikai folyamatainak összefüggései (in: Geopolitika a 21. században, Zsigmond Király Főiskola - L'Harmattan, Budapest, pp.31-64.)

Bernek Ágnes, [2006]: A helyek hálózatától az áramlások hálózatáig (in: Artner Annamária - Bernek Ágnes - Csiki Anita - Farkas Péter - Schottner Krisztina: Globalizáció, tőkekoncentráció, térszerkezet - Harsányi János Főiskola - MTA Világgazdasági Kutatóintézet, Budapest pp. 71-82.)

Bevir, Mark [2007]: Encyclopedia of governance (Thousand Oaks, California: Sage Publications)

Borsi Balázs-Viszt Erzsébet [2010]: A kreativ és kulturális ágazatok (CCI) szerepe és növekedési lehetöségei a Budapest Metropolisz Régió gazdaságában (GKI, Budapest)

Boudville, Jacques [1966]: Problems of Regional Economic Planning (Edinburgh University Press, Edinburgh)

Bozsó Péter [1990]: A tanácsok müködése a többpártrendszerben (in: Magyar Közigazgatás 1990/7. pp. 647-656.) 
Brenner, Neil [2003]: Metropolitan institutional reform and the rescaling of state space in contemporary Western Europe (SAGE Publications, London) http://sociology.as.nyu.edu/docs/IO/222/2003.Brenner.EURS.pdf (Letöltés: 2012. február 10.)

Brezinski, Zbigniew [1999]: A nagy sakktábla (Európa Könyvkiadó)

Budapest 2030 Hosszú távú városfejlesztési koncepció [2013] (BFVT Kft. - Budapest Főváros Városépítési Tervező Kft.)

http://budapest.hu/Documents/varosfejlesztesi_koncepcio_bp2030/BP2030.pdf

Castells, Manuel, [2005]: A hálózati társadalom kialakulása (Gondolat-Infonia, Budapest)

Cities for citizens [OECD, 2001] (OECD, Paris)

http://www.ocs.polito.it/sostenibilita/dwd/oecd_gov-2001.pdf (Letöltés: 2012. március 9.)

Csapó Tamás - Kocsis Zsolt [2008]: A várossá válás reformja (in: Területi Statisztika 2008/6. Sz., Központi Statisztikai Hivatal, Budapest pp. 645-646.) http://www.ksh.hu/docs/hun/xftp/terstat/2008/06/csapo_kocsis.pdf (Letöltés: 2014. július 15.)

Csapó Tamás [2002]: A megyei jogú városok regionális funkciói (in: Területi Statisztika 2002/3. sz., Központi Statisztikai Hivatal, Budapest pp. 228-252.)

Csefkó Ferenc [2000]: A települések differenciált hatásköri rendje kialakitásának elvi alapjai (in: Magyar Közigazgatás 2000/2. pp. 66-82.)

Csefkó Ferenc [1992]: A megyei jogú város és a megyei önkormányzat közötti kapcsolatok (in: Magyar Közigazgatás 1992/11. pp. 689-694.)

Csefkó Ferenc [1991]: A települési és a megyei önkormányzatok (in: Magyar Közigazgatás 1991/3. pp. 227-235.)

Csomós György [2008]: A régióközpontok terminológiája (Szolnoki Tudományos

Közlemények XII., Szolnok, 2008)

http://tudomany.szolnok-mtesz.hu/kulonszamok/2008/cikkek/csomos-gyorgy.pdf (Letöltés: 2013. augusztus 7.)

Csörgits Lajos [2010]: Összefoglaló a Megyei Jogú Városok Szövetségének I. féléves közgyüléséről (Új Magyar Közig 2010/6-7. pp. 98-105.) 
Definition of the Functional Urban Area for the OECD metropolitan database [OECD, 2013]: (OECD, Paris) http://www.oecd.org/gov/regional-policy/Definition-ofFunctionalUrban-Areas-for-the-OECD-metropolitan-database.pdf (Letöltés: 2015. január 11.)

Delbó Márta [2005]: A kistérségi modellkisérletek tapasztalatai (in: Modellkísérletek a közigazgatás fejlesztésében Az ún. „pilot projektek” határai elméletben és gyakorlatban PPKE, JÁK, Pázmány Press, 2013 szerk: Gerencsér Balázs Szabolcs pp. 205-219) https://jak.ppke.hu/uploads/articles/227518/file/modellkiserletek_kotet.\%20_0515pdf.FINAL. pdf(Letöltés: 2015. augusztus 6.)

Demographia World Urban Area [2015]: 11th Annual Edition:2015:01 http://www.demographia.com/db-worldua.pdf (Letöltés: 2015. május 3.)

Demszky Gábor [1993]: A nagyvárosok közigazgatása, Budapest közigazgatása (in: Magyar Közigazgatás 1993/8. szám pp. 488-492.)

Déry Attila [1995]: A Fövárosi Közmunkák Tanácsa (1870-1948) (EPA Budapesti Negyed 9. 1995/3) http://epa.oszk.hu/00000/00003/00008/dery.htm (Letöltés: 2015. május 8.)

Domokos László [2012]: Kockázatok a müködésben és növekvö eladósodás a magyarországi önkormányzatoknál

http://www.asz.hu/publikaciok/2012/kockazatok-a-mukodesben-es-novekvo-eladosodas-amagyarorszagi-onkormanyzatoknal-az-allami-szamvevoszek-ellenorzeseinektapasztalatai/psz201202165.pdf (Letöltés: 2015. augusztus 22.)

Dowding, Keith - Feiock, Richard [2012]: Intralocal Competition and Cooperation (in: Mossberger, K.-Clarke, S.-John, P.: The Oxford Handbook of Urban Politics, University Press, Oxford, pp. 29-50.) DOI:10.1093/oxfordhb/9780195367867.001.0001

Dövényi Zoltán [Dövényi, 2007]: A belső vándormozgalom néhány sajátossága Magyarországon (in: A társadalmi földrajz világa Szerk.: Kovács Csaba - Pál Viktor Szegedi Tudományegyetem Gazdaság- és Társadalomföldrajz Tanszék, Szeged pp.133-147.)

Dudás Ferenc - Sárosi Magdolna - Virág Rudolf [1998]: Önkormányzati együttmüködés és társulás (Közgazdasági és Jogi Könyvkiadó, Budapest) 
Enyedi György [2011]: The Stages of Urban Growth (in: Urban Sprawl in Europe edited by: Szirmai Viktória, Aula Kiadó, Budapest, 2011, pp. 45-62.)

Enyedi György, [1996]: Regionális folyamatok Magyarországon az átmenet időszakában (Hilschler Jenő Szociálpolitikai Egyesület, Budapest)

Enyedi György [1991]: Fordulópont elött a magyar falu (in: Magyar Közigazgatás 1991/8. szám pp. 729-734.)

Erdei Ferenc [1977a]: A magyar város (Akadémiai Kiadó, Budapest)

Erdei Ferenc [1977b]: Településpolitika, közigazgatás, urbanizáció (Akadémiai Kiadó, Budapest)

\section{European Spatial Development Perspectives, ESDP [1999]}

http://ec.europa.eu/regional_policy/sources/docoffic/official/reports/pdf/sum_en.pdf (Letöltés: 2012.december 10.)

\section{Evaluation Report of the Territorial Agenda of the European Union [2011]}

http://www.vati.hu/territorialagenda/HTML/Docs/05_TA\%20EVAL\%20REPORT_FINAL.pdf (Letöltés: 2015. június 26.)

Farkas Edit [2001]: Körzetközponti igazgatás, az okmányiroda müködésének tapasztalatai (in: Magyar Közigazgatás 2001/10. pp. 626-631.)

Feiock, Richard [2004] Editor: Metropolitan Governance - Conflict, Competition, and Cooperation (Georgetown University Press, Washington D.C.)

Feitl István [2011]: Tanácsrendszer, tanácsigazgatás, településfejlesztés 1956 után.

(in: Megértő történelem. Tanulmányok a hatvanéves Gyarmati György tiszteletére.

L’Harmattan Kiadó, Budapest, 2011, pp.369-382. )

Filep Bálint [2014]: A nagyvárosok az európai és a magyar területi politikában (Publikon Kiadó, Pécs-Győr)

Finta István [2008]: Az önkormányzati jogállás és a településközi kapcsolatok aktuális kérdései (in: Közigazgatási Szemle 2008/3-4. pp. 55-63.) 
Finta István [1996]: A megyei jogú városok településrészi önkormányzatainak jogi szabályozása és müködési tapasztalatai (in: Magyar Közigazgatás 1996/3. szám pp. 154-164.)

Florida, Richard [2005]: Flight of the Creative Class (Harper Business, New York)

Florida, Richard [2002]: The rise of the Creative Class (Basic Books, New York)

Florida, Richard [1995]: Towards the Learning Region (University of Toronto; New York University

http://www.creativeclass.com/rfcgdb/articles/1995-Futures-Toward_the_Learning_Region.pdf (Letöltés: 2012. március 30.)

Forgács Imre, [2009]: Mégsem éjjeliőr? (Osiris Kiadó, Budapest)

Fürcht Pál [2009]: Sok a helyi önkormányzat Magyarországon!? (in: Új Magyar Közigazgatás 2009/3. szám pp. 43-47.)

Fürcht Pál [2003]: Kistérségi koncepció (in: Magyar Közigazgatás 2003/3. pp. 129-138.)

Fürcht Pál [1994]: Körjegyzöségi modell (in: Magyar Közigazgatás 1994/4. szám pp. 193202.)

Fürcht Pál [1992]: A körjegyzöségek müködésének föbb tapasztalatai (in: Magyar Közigazgatás 1992/12. szám pp. 724-731.)

Gazsó István-Kovács Róbert-Perger Éva-Schneider Gábor-Szegvári Péter-Vigvári András-Zsugyel János [2008]: A nagyváros és környéke a kistérségi rendszer szempontjából I. (KSH Területi Statisztika, 2008. szeptember Budapest, pp. 524-543.) http://www.ksh.hu/docs/hun/xftp/terstat/2008/05/gazso.pdf (Letöltés: 2015. április 11.)

Germuska Pál [2002]: A szocialista városok létrehozása (in: Századvég, 2002/2. pp. 49-73.) http://www.terport.hu/webfm_send/523 (Letöltés: 2015. május 5.)

Getimis P.-Heinelt H.-Sweeting, D. edited by [2006]: Legitimacy and urban governance (Routledge, London)

Gottman, Jean [1961]: Megalopolis - The Urbanized North-eastern Seaboard of the United States (Twentieth Century Fund, New York) 
Gravier, J-P. [1947]: Paris the French desert (Flammarion, Paris English 1972)

Günther Béla [1991]: A megyei önkormányzatok szerepe a területi igazgatásban (in: Magyar Közigazgatás 1991/12.pp. 1112-1121.)

Hajdú Zoltán [2007]: A település- és településhálózat-fejlesztési politika „nagypolitikai” összefüggései Magyarországon az államszocializmus időszakában (in: A társadalmi földrajz világai Szerk.: Kovács Csaba-Pál Viktor, Szegedi Tudományegyetem Gazdaság- és Társadalomföldrajz Tanszék, Szeged, 2007, pp. 173-180.)

Hajnal György [2008]: Adalékok a magyarországi közpolitika kudarcaihoz (KSZK ROP 3.1.1 Programigazgatóság, Budapest)

Hall, Peter - Pain, Kathy, [2006]: The Polycentric Metropolis - learning from megacityregions in Europe (Earthscan, New York)

Halmosi Péter [2010]: Kockázatok az önkormányzati hitelfinanszírozásban (in: Fejlesztés és finanszírozás 2010/1. Magyar Fejlesztési Bank pp. 23-31.)

Hamilton, David [1999]: Governing Metropolitan Areas: Responses to Growth and Changes (Garland, New York)

Hardi Tamás [2012]: Györ, Miskolc és Pécs agglomerációja a vidéki szuburbanizációban (in: Az agglomerációk intézményesítésének sajátos kérdései - Három magyar nagyvárosi térség az átalakuló térben Szerk.: Somlyódiné Pfeil Edit, Publikon Kiadó, Pécs, pp. 15-42.)

Harvey, David [1985]: Globalization and the spatial fix (McMillan, London)

file://D:/Downloads/gr2_01_Ess02\%20(2).pdf (Letöltés ideje: 2013. szeptember 8.)

Harvey, David [2001]: The Geopolitics in Capitalism (Routledge, New York)

Hatodik jelentés a gazdasági, társadalmi és területi kohézióról 2014 (Európai Bizottság, 2014)

http://ec.europa.eu/regional_policy/sources/docoffic/official/reports/cohesion6/6cr_hu.pdf (Letöltés ideje: 2015. június 8.) 
Healy, Patsy, [2004]: Creativity and Urban Governance (Policy Studies 2. pp. 87-102.] http://www.tandfonline.com/doi/abs/10.1080/0144287042000262189 (Letöltés: 2012. január 26.)

Hegedüs József, [2008]: A nagyvárosi kormányzatok és az önkormányzati rendszer (in: Tér és Társadalom: Városi kormányzás 2008/1. szám, Budapest, pp. 59-75.) http://epa.oszk.hu/02200/02251/00030/pdf/EPA02251_Ter_es_tarsadalom2309.pdf (Letöltés: 2013. március 9.)

Hencz Aurél [1973]: Területrendezési törekvések Magyarországon - Az államigazgatási jogi szabályozás aspektusából (Közgazdasági és Jogi Kiadó, Budapest)

Hódir Erzsébet - Varga Tibor [2002]: Az önkormányzati társulások és együttmüködés tapasztalatai Zala megyében (in: Magyar Közigazgatás 2002/1., pp. 32-38.)

Hoffman István [2011]: A helyi önkormányzatok társulási rendszerének föbb vonásai (in: Új Magyar Közigazgatás 2011/1. szám pp. 24-34.)

Hoffmann István [2009]: Önkormányzati közszolgáltatások szervezése és igazgatása (ELTE Eötvös Kiadó, Budapest)

Hooghe. L. - Marks, G. [2001]: Multi-level Governance and European Integration (Rowman \& Littlefield, New York)

Horváth Gyula [2007]: Régióközpontok Európában (in: Magyar Tudomány 2007/6) 704720. pp. http://epa.oszk.hu/00600/00691/00042/pdf/704-720.pdf (Letöltés: 2014. augusztus 10.)

Horváth M. Tamás szerk., [2013]: Kilengések - Közszolgáltatási változások (DialógCampus, Budapest-Pécs)

Horváth M. Tamás [2007a]: A helyi önkormányzatok kapacitáskeretei (in: Nézetek és látszatok - Decentralizáció a pénzügyi környezet szemszögéből - szerk.: Horváth M. Tamás Közigazgatási Olvasmányok, KSzK ROP 3.1.1 Programigazgatóság, Budapest, pp. 15-38.)

Horváth M. Tamás szerk. [2007b]: Piacok a fötéren - helyi kormányzás és szolgáltatásszervezés (KSZK ROP 3.1.1 Programigazgatóság, Budapest) 
Horváth M. Tamás [2005]: Közmenedzsment (Dialóg-Campus, Budapest-Pécs)

Horváth M. Tamás [2002]: Helyi közszolgáltatások szervezése (Dialóg-Campus Kiadó, Budapest-Pécs)

Horváth M. Tamás [1995]: Az önkormányzatok közötti együttmüködés keretei és problémái (in: Magyar Közigazgatás 1995/10. pp. 570-576.)

Humes, Samuel - Martin, Elieen, [1961]: The Structure of Local Governments throughout the World (University Press, Cambridge)

Hünnemeyer, Vanessa R. [2011]: Urban regeneration by large-scale urban projects: Case studies from Budapest and Liverpool (in: Metropolitan Regions in Europe Edited by Szrimai Viktória - Heinz Fassmann, pp. 54-82.)

IDEA és valóság - Az IDEA Közigazgatás-korszerüsítési program négy éve [IDEA, 2008] (Kádár Krisztián szerk., Közigazgatásfejlesztési Társaság, Budapest)

Illés Iván [2005]: Önkormányzati finanszírozás és adózás nemzetközi összevetésben [in: Félúton - Tanulmányok a helyi önkormányzatok finanszírozási rendszerének továbbfejlesztési lehetőségeiről - szerk.: Vigvári András (TÖOSZ - BM-IDEA kiadvány, Bp. 2005, pp. 21-46.)

Imre Miklós [1994]: Szempontok az építésügyi igazgatás reformjához (in: Magyar Közigazgatás 1994/3. szám pp. 129-145.)

Isard, Walter [1956]: Location and Space-economy. A General Theory Relating to Industrial Location, Market Areas, Land Use, Trade, and Urban Structure (MIT Press, Cambridge and Wiley, New York)

Ivády Gábor [2010]: Müködésképtelen történet (Index, 2010. január 6.)

http://index.hu/velemeny/jegyzet/2010/01/06/mukodeskeptelen_tortenet/ (Letöltés ideje: 2015. augusztus 10.)

Iváncsics Imre [1985]: A városkörnyéki igazgatás szerepe a területfejlesztésben (in: A vonzáskörzetek gazdasági és közigazgatási kérdései- Nemzetközi Tudományos Konferencia, Pécs, 1983. november 1-3. MTA Regionális Kutatások Központjának Dunántúli Tudományos Intézete, Pécs, pp. 277-284.) 
Jelentés a pénzügyi stabilitásról [2012. április] Magyar Nemzeti Bank')

https://www.mnb.hu/letoltes/jelentes-penzugyi-stabilitas-201204-hu.pdf (Letöltés: 2015. augusztus 3.)

Jenei György [2005]: Közigazgatás-menedzsment (Századvég Kiadó, Budapest)

Józsa Zoltán [2004]: Konszolidáció vagy fragmentáció (Magyar Közigazgatás 2004/11. pp. 681-693.)

Kaiser Tamás - Ágh Attila - Kis-Varga Judit szerk. [2006]: A régiók Magyarországa I-II. (MTA-MEH Budapest)

Kaiser Tamás szerk. [2006]: Hidak vagy sorompók? - A határokon átívelö együttmüködések szerepe az integrációs folyamatban (Új Mandátum Kiadó, Budapest)

Kálmán Judit [2005]: Urbanizációs, dezurbanizációs folyamatok a fejlett Világban tendenciák (in: Válogatás a Nemzeti Fejlesztési Hivatal fejlesztéspolitikai háttértanulmányaiból Nemzeti Fejlesztési Hivatal, Budapest, pp. 49-84.)

Kara Pál [1999]: Javaslat az önkormányzati és az államigazgatási feladat- és hatáskörök felülvizsgálatára (Vitaanyag) (in: Magyar Közigazgatás 1999/1-2., pp. 2-7.)

Kara Pál [1998]: Helyi önkormányzati rendszerünk értékei, fejlesztési lehetőségei (in: Magyar Közigazgatás 1998/10. pp. 577-581.)

Kara Pál [1996]: A város és vonzáskörzetének szervezeti, strukturális lehetöségei (in: KÖOSZ-MJVSZ-MKI: Város és vonzáskörzete Szerk.: Szabó Gábor, ÖNKORKÉP, Budapest, 1996 pp. 93-106.)

Kovács Katalin-Somlyódiné Pfeil Edit szerk. [2008]: Függőben - Közszolgáltatásszervezés a kistelepülések világában (Közigazgatási $\quad$ Olvasmányok $\quad$ KSZK $\quad$ ROP 3.1 .1 Programigazgatóság, Budapest)

Kéki Zoltán [Kéki, 2000]: A települések differenciált hatásköri rendje kialakitásának elvi alapjai II. (in: Magyar Közigazgatás 2000/3. pp. 157-165.)

Kemenszky Sándor [Kemenszky, 1993]: Önkormányzatok ellenörzési társulása (in: Magyar Közigazgatás 1993/8. pp. 481-487.) 
Kovács Katalin [2010]: Társulási vagy megszünési kényszer: Közoktatás-szervezés a többcélú kistérségi társulásokban (Tér és Társadalom 2010/4. szám) http://epa.oszk.hu/02200/02251/00041/pdf/EPA02251_Ter_es_tarsadalom3554.pdf (Letöltés: 2014. december 3.)

Kovács Róbert - Vigvári András [2009]: Látlelet a községi önkormányzatok pénzügyi helyzetéröl (in: Új Magyar Közigazgatás 2009/5. pp. 26-35.)

Kovacsics József [1990]: Hozzászólás az önkormányzati reformhoz (in: Magyar Közigazgatás 1990/9. szám pp. 831-838.)

Kökényesi Józef [1996]: A városkörnyéki igazgatás gazdasági alapkérdései (in: KÖOSZMJVSZ-MKI: Város és vonzáskörzete Szerk.: Szabó Gábor ÖNKORKÉP, Budapest pp. 159181.)

Krugman, Paul [1991]: Geography and Trade (Leuven University Press, Leuven, Belgium and MIT Press, Cambridge)

Kunzmann, Klaus R. [2004]: An Agenda for Creative Governance in City Regions (The Planning Review, Volume 40, Issue 158, 2004 Special Issue: Creative Governance in City Regions pp. 5-10.)

http://www.tandfonline.com/doi/abs/10.1080/02513625.2004.10556887 (Letöltés: 2012. április 5.)

Kübler, Daniel-Walti, Sonja [2000]: Metropolitan Governance and democracy: How to evaluate new tendencies? (Paper prepared for the 28 th ECPR Joint Sessions of 294 Workshops, University of Copenhagen, 19 April 2000; workshop no. 20 "Democracy from below")

http://ecpr.eu/Filestore/PaperProposal/3ab8c1e6-e917-46fe-a68d-079ff2345f3f.pdf (Letöltés: 2012. január 22.)

Lábadyné Csaba Anikó [2004]: A nagyvárosi kistérség szerveződésének speciális vonásai (BM IDEA, Budapest) http://www.terport.hu/webfm_send/371 (Letöltés: 2015. május 9.)

Lamperth Mónika [2005]: Helyi önkormányzati rendszerünk 15 éve (in: Magyar Közigazgatás $2005 / 7$ pp. 385-388.) 
Lasuén, José Ramón [1969]: On Growth Poles (Urban Studies. 2. pp. 137-161.)

Lefévre, Christian [2010]: The improbable metropolis: decentralization, local democracy and metropolitan areas in the Western world (Análise Social vol. XLV, 2010, 623-637. pp.) http://analisesocial.ics.ul.pt/documentos/1292287671R2dEY4xs1Gc79ED2.pdf (Letöltés: 2011. december 6.)

Lefévre, Christian [1998]: Metropolitan government and governance in Western countries (International Journal of Urban and Regional Research, 22: 9-25. pp.)

http://onlinelibrary.wiley.com/doi/10.1111/1468-2427.00120/abstract (Letöltés: 2011. december 6.)

Lengyel Imre - Rechnitzer János [2004]: Regionális gazdaságtan (Dialóg-Campus, Budapest-Pécs)

Lengyel Imre - Rechnitzer János szerk. [2002]: A hazai építôipar versenyképességének javitása: klaszterek szerepe a gazdaságfejlesztésben (RégióArt, Győr)

Lengyel Imre [2003]: Verseny és területi fejlödés: térségek versenyképessége Magyarországon (JATEPress, Szeged)

Lentner Csaba [2014]: A magyar önkormányzatok adósságkonszolidációja (in: Állami Számvevőszék, Pénzügyi Szemle) http://www.asz.hu/penzugyi-szemle-cikkek/2014/amagyar-onkormanyzatok-adossagkonszolidacioja/lentnercs-2014-3-m.pdf (Letöltés: 2015. július 9.)

\section{Lille Action Program 2000}

http://www.bmvi.de/SharedDocs/EN/Anlagen/lille-action-programme-november2000.pdf?_blob=publicationFile (Letöltés: 2014. nove,ber 5.)

Lipcsei Charta a fenntartható európai városokról 2007 (magyar szöveg) http://www.vati.hu/files/sharedUploads/docs/FVR/FVR_2008_2.pdf (Letöltés: 2013. február 1.)

Lóránt Zoltán [1999]: Az önkormányzati gazdálkodás időszerü kérdéseiröl az 1998. évi zárszámadás számvevői ellenőrzésének „,tükrében” (in: Magyar Közigazgatás 1999/9., pp. 491-500.) 
Lóránt Zoltán-Somogyiné Legény Mária-Bukva Anna [2002]: Az önkormányzatok költségvetési kapcsolatai 1991-2001 között az Állami Számvevőszék ellenőrzései tükrében (in: Magyar Közigazgatás 2002/6. pp. 360-370.)

Magyarország településhálózata 1. - Agglomerációk, településegyüttesek [KSH, 2014a] (Központi Statisztikai Hivatal, Budapest) http://www.ksh.hu/docs/hun/xftp/idoszaki/mo_telepuleshalozata/agglomeracio.pdf (Letöltés: 2015. május 12.)

Magyarország közigazgatási helynévkönyve 2014. január 1. [KSH, 2014b] (Központi Statisztikai Hivatal, Budapest, pp. 101-104.) http://www.ksh.hu/docs/hun/hnk/hnk_2014.pdf (Letöltés: 2015. április 27.)

McKinsey Global Institute [2012]: Urban world: Cities and the rise of consuming class http://www.mckinsey.com/insights/urbanization/urban_world_cities_and_the_rise_of_the_co nsuming_class (Letöltés: 2012. augusztus 24.)

McLuhan, Marshall [1968]: War and Peace in the Global Village (Bantam, New York) Megyei jogú városok [KSH, 2012] (KSH, Budapest) http://www.ksh.hu/docs/hun/xftp/idoszaki/regiok/veszpremmjv10.pdf (Letöltés: 2014. október 17.)

Mező Ferenc, [2007]: Térelemzések a geopolitikában (in: Tér és Társadalom, 2007/2. szám, Budapest, 1-22. pp.) http://www.epa.oszk.hu/02200/02251/00027/pdf/EPA02251_Ter_es_tarsadalom2207.pdf (Letöltés: 2014. július 25.)

Mitchell-Weaver C.-Miller, D.-Deal R. Jr, [2000]: Multilevel Governance and Metropolitan Regionalism in the USA (Urban Studies, Vol. 37. No. 5-6, pp. 851-876.) http://usj.sagepub.com/content/37/5-6/851.full.pdf+html (Letöltés: 2012. február 2.)

M. Kiss József - Horváth Tamás szerk. [1996]: Aréna és otthon (Politikai Tanulmányok Intézete Alapítvány, Budapest) 
Nedovic-Budic, Zorica-Tsenkova, Sasha-Marcuse Peter [2006]: The Urban Mosaic of Post-socialist Europe (in: The Urban Mosaic of Post-socialist Europe, editors: Tsenkova Sasha - Nedovic-Budic, Zorica Springer pp. 3-17.)

Nelson A.C. - Foster K. [1999]: Metropolitan governance structure and income growth (Journal of Urban Affairs, Vol.21, No.3. pp. 309-324.) http://onlinelibrary.wiley.com/doi/10.1111/0735-2166.00019/pdf (Letöltés: 2012. június 20.)

Németh Sándor [2009]: Mintha-városból mintavárost! (Területi Statisztika, KSH Bp. 2009/január 8-19. pp.) http://www.ksh.hu/docs/hun/xftp/terstat/2009/terstat0901.pdf (Letöltés: 2014. szeptember 8.)

Németh Zsolt [1994]: Településszövetség az önerös kistérségi területfejlesztésért (in: Magyar Közigazgatás 1994/8. pp. 482-488.)

Norris, Donald - Phares, Don [2011]: U.S. metropolitan governance: from formal structure to the sataus quo? - Discussion points (the conference on Regional Governance of Public Administration, University of Victoria, Richmond, May 27-28., 2011) http://www.uvic.ca/hsd/publicadmin/assets/docs/LGI/RegGovConf2011/Norris_Phares_ppt.p df (Letöltés: 2013. január 5.)

Ohmae, Kenichi [1995]: The End of the Nation-State: the Rise of Regional Economies (Simon and Schuster Inc. New York)

Osborne, David - Hutchinson, Peter [2006]: A kormányzás ára (Horváth \& IFUA, Budapest)

Pallai Katalin szerk. [2003]: Budapest-modell-egy liberális várospolitikai kísérlet (Nyílt Társadalom Intézet Alapítvány, Budapest)

Pálné Kovács Ilona [2012]: Megyék új szerepben (in: Új Magyar Közigazgatás 2012/7-8. pp. 20-24.)

Pálné Kovács Ilona [Pálné, 2008a]: Helyi kormányzás Magyarországon (Pécs Dialóg Campus Kiadó, Budapest - Pécs, 2008)

Pálné Kovács Ilona [2008b]: Az új várospolitika kormányzási filozófiája (in: Tér és Társadalom: Városi kormányzás 2008/1. szám, Budapest 45-57. pp.) 
Pálné Kovács Ilona [2008c]: Régiókkal és nélkülük (in: IDEA és valóság - Az IDEA közigazgatás-korszerűsítési program négy éve, Közigazgatásfejlesztési Társaság, Budapest, 2008, pp. 53-76.)

Pálné Kovács Ilona [2006]: A középszint reformjának nehézségei (in: Magyar Közigazgatás 2006/3-4. tematikus különszám: A központi igazgatás és a helyi önkormányzati igazgatás 15 éve pp. 223-231.)

Parkinson, Michael [2005]: Urban Policy in Europe - Where have we been and where are we going? (in: Antalovsky E.-Dangschat, Jens S.-Parkinson, Michael: European Metropolitan Governance: Cities in Europe - Europe in Cities (Liverpool John Moores University and Vienna University of Technology pp. 7-32.)

http://urbact.eu/sites/default/files/cities_in_europe.pdf(Letöltés: 2012. április 19.)

Parr, John B. [1999]: Growth-pole Strategies in Regional Economic Planning: A Retrospective View 1. (Urban Studies, 1999, vol. 36. 1195-1215. pp.)

http://usj.sagepub.com/content/36/7/1195.short (Letöltés: 2012. május 28.)

Perger Éva [2008]: Nagyvárosi térségek - kistérségek, Nagyvárosi funkciók-kistérségi szerepek (Helyi Obszervatórium LRMI Local Monitoring) http://www.terport.hu/webfm_send/4010) (Letöltés: 2015. június 9.)

Perger Éva [2004]: A föváros és ,környéke” régiónként való értelmezése, a „,központi” régió problémája (in: A regionális politika közigazgatási feltételei Horváth M. Tamás szerk. IDEA - Magyar Közigazgatási Intézet, 2004, pp. 213-254.)

Perger Éva [1994]: A fövárosi közigazgatási reform a regionális kutatások tükrében (in: Magyar Közigazgatás 1994/12. szám pp. 745-750.)

Péteri Gábor [Péteri, 2007]: Decentralizáció: akadály vagy lehetőség? (in: Nézetek és látszatok - decentralizáció a pénzügyi környezet szemszögéből szerk.: Horváth M. Tamás KSZK ROP Programigazgatóság, Budapest, pp. 39-66.)

Petrétei József-Tilk Péter [2005]: Az önkormányzati társulások és a kistérségek néhány alkotmányjogi kérdése (in: Magyar Közigazgatás 2005/3. szám, pp. 129-141.) 
Pintér Sándor [2000]: Egy évtized mérlege - a jövő kilátásai (in: Magyar Közigazgatás 2000/5. pp. 260-263.)

Pitti Zoltán [Pitti, 2005]: Az önkormányzatok pénzügyi finanszírozásának a modernizációja (in: Félúton - Tanulmányok a helyi önkormányzatok finanszírozási rendszerének továbbfejlesztési lehetőségeiről Szerk.: Vigvári András, Budapest, 2005, pp. 47-70.)

Pollit, Christopher - Bouckaert, Geert, [2004]: Public Management Reform: A Comparative Analysis: New Public Management, Governance and the Neo-Weberian State (University Press, Oxford)

Porter, Michael [2000]: Location, Competition and Economic Development: Local Clusters in a Global Economy (University Press, Oxford, 2000)

Porter, Michael [1998]: Clusters and the New Economics of Competition (Harvard Business Review)

Progressive Governance - Progressive Governance - International Conference tematikus különszám (Európai Tükör, Budapest, January, 2004)

Putnam, Robert D. [1993]: Making Democracy Work: Civic Traditions in Modern Italy (Princeton University Press, Princeton, 1993)

Rétiné Böhm Éva - Rigó Rozália [2001]: Győr-Moson-Sopron megyei helyzetkép az átalakitott gyermekvédelmi szakellátások területén (in: Magyar Közigazgatás 2001/11. pp. 693-700.)

Rhodes, R.A.W. [1992]: Policy networks in British government (Clanderon Press, Oxford)

Salet, Willem-Thornley, Andy-Kreukels, Anton [2003]: Institutional and spatial coordination in European metropolitan regions (in: Metropolitan Governance and Spatial Planning Edited by Salet-Thornley-Kreukels Spoon Press, New York-London, 2003 pp. 319.)

Sassen, Saskia [2002]: Global networks, linked cities (Routledge, New York)

Ságvári Bence - Dessewffy Tibor [2006]: A kreatív gazdaságról - Európa és Magyarország a kreatív korban (DEMOS Magyarország kiadványa, Budapest)

http://www.varosrehabilitacio.net/new/pdf/kreativ_gazdasag.pdf (Letöltés: 2014. október 17.) 
Sebestyén István [2015]: Az önkormányzatok és a nonprofit szervezetek kapcsolata 2012 (Központi Statisztikai Hivatal, Mühelytanulmányok 7.) http://www.ksh.hu/docs/hun/xftp/idoszaki/pdf/muhelytanulmanyok7.pdf (Letöltés: 2015. június 20.)

Simmie, James (Edited by) [2001]: Innovative Cities (Spon Press, London - New York)

Sió László [1998]: Iskolafenntartó társulások (in: Magyar Közigazgatás 1998/11., pp. 664683.)

Somlyódiné Pfeil Edit, [2011]: Az agglomerációk jelentőségének változása az államszervezés és a városi kormányzás szempontjából (in: Tér és Társadalom 2011/3. szám, Budapest, pp. 27-59.) http://tet.rkk.hu/index.php/TeT/article/viewFile/1876/3790 (Letöltés: 2013. augusztus 23.)

Somlyódiné Pfeil Edit [Somlyódiné, 2009]: A befejezetlen reform - a kistérségi közigazgatási rendszer értékei és dilemmái (in: Új Magyar Közigazgatás 2009/1. szám pp. 3343. pp.)

Somlyódiné Pfeil Edit, [2008]: A városi térségek a közigazgatási struktúra és a „governance” keresztmetszetében (in: Tér és Társadalom: Városi kormányzás 2008/1. szám, Budapest, 27-43. pp.) http://tet.rkk.hu/index.php/TeT/article/view/1154/2305 (Letöltés: 2015. március 9.)

Somlyódiné Pfeil Edit [2005]: Városok az átalakuló közigazgatási rendszerekben és a területi politikában (in: Magyar Közigazgatás 2005/4. pp. 193-203.)

Somlyódiné Pfeil Edit [Somlyódiné, 2003a]: Önkormányzati integráció és helyi közigazgatás (Dialóg-Campus Kiadó, Budapest-Pécs, 2003)

Somlyódiné Pfeil Edit [2003b]: A városok helye és szerepe a kistérségi közigazgatás rendszer kialakulásában (in: Magyar Közigazgatás 2003/7. pp. 413-423. pp.)

Somlyódiné Pfeil Edit [2002]: Látlelet a megye alatti közigazgatási térről (in: Magyar Közigazgatás 2002/10. pp. 619-630.)

Somlyódiné Pfeil Edit [2001]: A településhálózat fejlesztésének helye az önkormányzati rendszer jövőjében (in: Magyar Közigazgatás 2001/3. pp. 146-150.) 
Somlyódiné Pfeil Edit [Somlyódiné, 1994]: Gondolatok a településközi kapcsolatok ösztönözhetőségéröl (in: Magyar Közigazgatás 1994/2. pp. 117-119.)

Somlyódiné Pfeil Edit [1991]: Önállóság és egymásrautaltság a Baranya megyei kistelepülések szemszögéböl (in: Magyar Közigazgatás 1991/8. pp. 750-755. pp.)

Somlyódiné Pfeil Edit [1990]: A kisközségek az önkormányzattá válás útján (MTA Regionális Kutatások Központja, Pécs, 1990)

Somlyódiné Pfeil Edit-Faragó László [1991]: Önkormányzati társulások (in: Magyar Közigazgatás 1991/11. szám pp. 1003-1010.)

State of the World's Cities 2010/2011 [2012]: (UNHABITAT, London 2012) http://mirror.unhabitat.org/pmss/listItemDetails.aspx?publicationID=2917\&AspxAutoDetect CookieSupport=1 (Letöltés ideje: 2012. május 9.)

State of the World's Cities 2008/2009 [2010]: (UNHABITAT, London 2010) http://mirror.unhabitat.org/pmss/listItemDetails.aspx?publicationID=2562 (Letöltés ideje: 2012. május 9.)

Stumpf István [2008]: A „szuperkapitalizmus” válsága, avagy erös állam és társadalmi kiegyezés (Közigazgatási Szemle 2008/3-4. szám, Magyar Közlöny Lap- és könyvkiadó, Budapest, pp. 16-23.)

Szabó Gábor [1995]: Város és vonzáskörzete önkormányzati aspektusból (in: KÖOSZMJVSZ-MKI: Város és vonzáskörzete Szerk.: Szabó Gábor ÖNKORKÉP, Budapest, 1996 pp. 7-55.)

Szabó István [2014]: Önkormányzati feladatellátási modellek a megyei jogú városok önkormányzatainál (in: Polgári Szemle 2014/október)

http://www.polgariszemle.hu/?view=v_article\&ID=491 (Letöltés ideje: 2015. április 30.)

Szabó Lajos [2012]: A második önkormányzati törvény új vonásai (in: Új Magyar Közigazgatás 2012/4. pp. 28-45.)

Szabó Lajos [1994a]: A középszint az önkormányzati törvény módositása tükrében (in: Magyar Közigazgatás 1994/12., pp. 721-726.) 
Szabó Lajos [1994b]: Az önkormányzatok társulásai (in: Magyar Közigazgatás 1994/3. pp. 146-153.)

Szabó Tamás [2015]: A várossá nyilvánitás kérdésköre 2015 után - az elmúlt negyedszázad kapcsolódó folyamatainak értékelése (kézirat - várható megjelenés - in: Új Magyar Közigazgatás 2015/december)

Szabó Tamás [2014]: Nagyvárosi térségek, mint globális „,vonatkozási pontok” (in: Kultúra és Közösség 2014/3. pp. 39-52.)

Szabó Tamás [2009]: KÖEF a mérlegen - közpolitikai elemzés a Kormány- Önkormányzatok Egyeztető Fórum müködéséröl (in: Politikatudományi Szemle, 2009/3. sz. pp. 112-131.)

Szaló Péter [1999]: A területfejlesztés intézményrendszerének kiépitése és jövőbeli feladatai (in: Magyar Közigazgatás 1999/1-2., pp. 8-17.)

Szanyi Miklós [2008]: A versenyképesség javitása együttmüködéssel: regionális klaszterek (Napvilág Kiadó, Budapest)

Szegvári Péter [2015]: Egy volt fövárosi föjegyzö sajátos nézőpontú visszaemlékezései (in: A magyar önkormányzatok 25 éve - visszaemlékezések, adatok és tények a magyar önkormányzatiság történetéböl szerk.: Zongor Gábor, Települési Önkormányzatok Országos Szövetsége, Budapest, pp. 347-362.)

Szekeres Antal [2011]: A megyei jogú városok lehetséges helye a megújításra szoruló helyi önkormányzatok rendszerében (in: Új Magyar Közigazgatás 2011/10. pp. 34-35.)

Szente Zoltán [2007]: A fơvárosok jogállása Európában (in: Nemzetközi Közlöny KözépKelet Európai Közigazgatási Folyóirat 2007/1. pp. 5-27. pp.)

Szép László-Klonkay Zoltán [1996]: Az épitésügyi hatósági tevékenység gyakorlati problémái (in: Magyar Közigazgatás 1996/2. pp. 98-103.)

Szigeti Ernő [2010]: A körjegyzőségi rendszer térszerkezeti jellemzői (In: Közigazgatástudományi Közlöny, 2010/1. szám pp. 41-64.)

Szigeti Ernő [2008]: Az állami közigazgatás területi szervezetrendszerei térszerkezetének változásai (in: Közigazgatási Szemle 2008/2. pp. 43-55.) 
Szigeti Ernő [2003]: A régiók és a régióközpontok térszerkezeti alternativái (Budapest, IDEA, Magyar Közigazgatási Intézet) http://www.terport.hu/webfm_send/340

Szigeti Ernő [2002]: Község, város, jogállás (Magyar Közigazgatási Intézet, Budapest)

Szigeti Ernő [1996]: A községalakitások múltja és jelene (in: Magyar Közigazgatás 1996/9. pp. 513-527.)

Szigeti Ernő [1994]: A körjegyzöségek területi struktúrája (in: Magyar Közigazgatás 1994/10. szám pp. 609-619.)

Szilágyi Dániel - Gerse József [2015]: Fokról-fokra a települési lépcsőn - Társadalmigazdasági különbségek a település-hierarchia szintek között Magyarországon (in: Területi Statisztika, 2015/2.) http://www.ksh.hu/docs/hun/xftp/terstat/2015/02/szilagyi_gerse.pdf

Szirmai Viktória [2011]: Urban Sprawl in Eurpe: An Introduction (in: Urban Sprawl in Europe: Simiralities or Differences? szerk. Szirmai Viktória, Aula Kiadó, Budapest pp. 1544.)

Szücs Jenő [1983]: Vázlat Európa három történeti régiójáról (Magvető Kiadó, Budapest, 1983)

Szüdi János [2008]: A többcélú kistérségi társulás szerepe a közoktatásban (in: Közigazgatási Szemle 2008/1.pp. 53-64.)

\section{Territorial Agenda of the European Union 2020 [2011]}

http://ec.europa.eu/regional_policy/hu/policy/what/territorial-cohesion/ (Letöltés ideje: 2015. június 9.)

The OECD Metropolitan Governance Survey [OECD, 2014a]: (OECD, Paris) - Ahrend, R.Gamper C. - Schumann A.

http://www.oecd-ilibrary.org/urban-rural-and-regional-development/the-oecd-metropolitangovernance-survey_5jz43zldh08p-en (Letöltés: 2015. január 7.)

The Governance of Metropolitan Regions - European and Global Experiences [2011]: Workshop on the „Governance of Metropolitan Regions in Federal Systems” - Brussels, 2021 June 2011 (Forum of Federations The Global Network on Federalism - European Union Comitee of The Regions 
The reform of metropolitan governance [OECD, 2000] - Policy Brief (OECD, Paris) http://78.41.128.130/dataoecd/3/17/1918016.pdf

Tilk Péter [2011]: A helyi önkormányzatok az Alaptörvényben (in: Új Magyar Közigazgatás 2011/6-7. pp. 21-29.)

Torba Nándor [2008]: Kistérségi társulások főbb jellemzői (in: Közigazgatási Szemle 2008/1. pp. 73-83.]

Tosics Iván [2011]: Governance challenges and models for the cities of tomorrow (Metropolitan Research Institute, Budapest) http://ec.europa.eu/regional_policy/sources/docgener/studies/pdf/citiesoftomorrow/citiesofto morrow_governance.pdf (Letöltés: 2014. október 15.)

Tosics Iván [2008]: Nagyvárosi kormányzás: A város és környéke együttmüködése külföldi példák és hazai relevancia (in: Tér és Társadalom: Városi kormányzás 2008/1. szám, 3-25. pp.) http://tet.rkk.hu/index.php/TeT/article/view/1153/2303 (Letöltés: 2014. június 9.)

Tóth Tamara [2010]: A középszint az „önkormányzás hajnalán” (in: Az állam és jog alapvető értékei II. - A Széchenyi István Egyetem Állam- és Jogtudományi Doktori Iskola konferenciája szerk.: Smuk Péter, Győr pp. 227-230.) httpp://doktiskjog.sze.hu/downloadmanager/download/nohtml/1/id/.../m/3620 (Letöltés ideje: 2015. május 19.)

Tózsa István - Jószai Attila - László László [2010]: Stratégiai településirányitás (Polgármester Akadémia, TÖOSZ, Budapest)

Travers, Tony [2005]: Governance for metropolitan sustainability (OECD International Conference, 13-14 October 2005, Montreal)

http://78.41.128.130/dataoecd/52/63/35565616.pdf (Letöltés: 2013. november 26.)

Vadál Ildikó [Vadál, 2009]: A területi államigazgatási szervezetrendszer regionalizálásának dilemmái (in: A politika új színtere a régió szerk.: Pálné Kovács Ilona, Pécsi Tudományegyetem Interdiszciplináris Doktori Iskola, Budapest-Pécs, 2009, pp. 47-64.)

Walker, David B. [1987]: Snow white and 17 Dwarfs: From Metro Coorporation to Governance (National Civic Review, pp. 14-28.] 
http://www.researchgate.net/publication/229566151_Snow_White_and the_17_Dwarfs_Fro m_Metro_Cooperation_to_Governance [DOI: 10.1002/ncr.4100760104]

Wallerstein, Immanuel [1983]: A modern világgazdasági rendszer kialakulása. (Gondolat, Budapest)

Városfejlesztési kézikönyv - második, javított kiadás [2009. január] (Nemzeti Fejlesztési és Gazdasági Minisztérium) http://www.terport.hu/webfm_send/3989 (Letöltés: 2014. augusztus 9.)

Vass Géza [1993]: A középszintü önkormányzás hatályos jogrendszerünkben (in: Magyar Közigazgatás 1993/9.pp. 537-543.)

Verebélyi Imre [Verebélyi, 2009]: Válságban a magyar középszintü közigazgatás, quo vadis? '(in: Új Magyar Közigazgatás 2009/1. pp. 1-5.)

Verebélyi Imre [1996]: A kormányzás és a közigazgatás reformjának tervezete - részletes vitairat (in: Magyar Közigazgatás 1996/4. pp. 193-229.)

Verebélyi Imre [1995]: A helyi önkormányzati rendszer fejlödésének föbb irányai (in: Magyar Közigazgatás 1995/2. pp. 65-77.)

Verebélyi Imre [1993]: Kis vagy nagyméretü alapszintü önkormányzatok (in: Magyar Közigazgatás 1993/4. szám pp. 193-205.)

Verebélyi Imre [1987]: A tanácsi önkormányzat (Közgazdasági és Jogi Könyvkiadó, Budapest, 1987)

Weis, Carol H., [2005]: Értékelés (Országos Közoktatási Intézet, Budapest)

Wekler Ferenc [1993]: Az önkormányzás fejlesztési irányai (in: Magyar Közigazgatás 1993/11. pp. 656-665.)

Vigvári András [2007]: Vakvágányon? Szempontok és adalékok az önkormányzati vagyongazdálkodás elmúlt tizenöt évének értékeléséhez (in: Vigvári András szerk. A családi ezüst - tanulmányok az önkormányzati vagyongazdálkodás témaköréböl (KSZK ROP Programigazgatóság, Budapest pp. 15-30.) 
Zongor Gábor szerk. [2015]: A magyar önkormányzatok 25 éve - visszaemlékezések, adatok és tények a magyar önkormányzatiság történetéböl (Települési Önkormányzatok Országos Szövetsége, Budapest)

Zongor Gábor [2012]: Kétségek és kérdések az új önkormányzati rendszerrel kapcsolatban (in: Új Magyar Közigazgatás 2012/7-8. pp. 1-2.)

Zongor Gábor-Agg Zoltán [1994]: Önkormányzat és közigazgatás - Beszélgetés Boross Péter belügyminiszterrel (in: A lebegő megye - Cikkek és tanulmányok, COMITATUS Könyv- és Lapkiadó, Veszprém, pp. 369-380.)

Zongor Gábor [1991]: A szétdarabolt megye (in: Magyar Közigazgatás 1991/6. pp. 545553.) 